ELIANA MARIA ORMELEZI

\title{
INCLUSÃO EDUCACIONAL E ESCOLAR DA CRIANÇA CEGA CONGÊNITA COM PROBLEMAS NA CONSTITUIÇÃO SUBJETIVA E NO DESENVOLVIMENTO GLOBAL: UMA LEITURA PSICANALÍTICA EM ESTUDO DE CASO
}

Tese apresentada à Faculdade de Educação da Universidade de São Paulo como requisito parcial para a obtenção do título de Doutora em Psicologia e Educação.

Orientadora: Profa. Dra. Elcie F. Salzano Masini

São Paulo 2006 


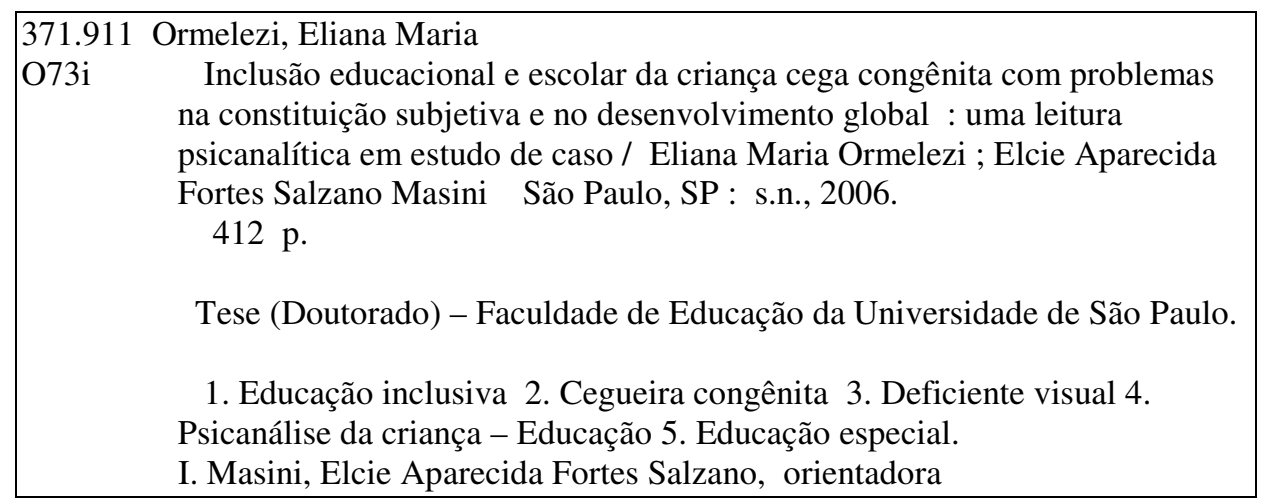

Ficha Catalográfica elaborada pelo Serviço de Biblioteca e Documentação da FEUSP 


\section{ELIANA MARIA ORMELEZI}

Inclusão educacional e escolar da criança cega congênita com problemas na constituição subjetiva e no desenvolvimento global: uma leitura psicanalítica em estudo de caso. Tese apresentada à Faculdade de Educação da Universidade de São Paulo como requisito parcial para a obtenção do título de Doutora em Psicologia e Educação.

Orientadora: Profa. Dra. Elcie F. Salzano Masini

Aprovada em

de 2006.

\section{BANCA EXAMINADORA}

Profa. Dra. Bernadete Gatti

Pontifícia Universidade Católica

Profa. Dra. Leny Magalhães Mrech

Universidade de São Paulo

Profa. Dra. Maria Cristina Machado Kupfer

Universidade de São Paulo

Profa. Dra. Rosângela Prieto

Universidade de São Paulo

São Paulo 
Ao Marcelo, Cris, Elaine, Marcão, Rosângela, Paulinho, Fernando... e Sílvio (in memorian); À Thaís, Camila, João, Gabriel, Marquinho, Marco Aurélio, Gustavo, Cássio, Samuel, Priscila, Fúlvia, Paloma, Talita e a tantos outros que, ao longo de vinte e seis anos de trabalho, me deram a certeza de que ali, onde muitas vezes parece não haver nada, somente pelo desejo e suposição de que um sujeito existe, um sujeito poderá advir... 


\section{AGRADECIMENTOS}

Especialmente à minha orientadora Profa. Dra. Elcie F. Salzano Masini pela competência e entusiasmo com que me acompanhou neste trabalho, pautando-se, com toda delicadeza, pelo rigor dos procedimentos científicos sem furtar-se à dimensão da relação humana. Por ter lançado questões essenciais, com o mais profundo respeito pelas minhas opções teóricas. Pelo apoio em tantos outros momentos de minha trajetória profissional.

Às crianças e mães que participaram desta pesquisa pelo consentimento em revelar, tão generosamente e com tanta sinceridade, suas histórias de vida e suas existências.

À Laramara, particularmente à Profa. Mara O. Campos Siaulys, e a todos os profissionais que nesta instituição acolheram e possibilitaram o desenvolvimento deste trabalho. Por lançar desafios, disseminar conhecimento e assumir compromissos para o desenvolvimento da área da deficiência visual.

À Profa. Dra. Leny Magalhães Mrech, ao Prof. Dr. Leandro de Lajonquière, à Profa. Dra. Maria Cristina Kupfer e ao Prof. Dr. Esteban Levin, pela disponibilidade que tiveram em ouvir e dirimir dúvidas acerca dos fundamentos da Psicanálise no encontro com a Educação.

À Profa. Dra. Bernadete Gatti pelas valiosas contribuições apresentadas no Exame de Qualificação.

À Profa. Dra. Mercè Leonhardt Gallego pela colaboração na revisão da literatura e parecer sobre a relevância desta pesquisa.

Ao $\mathrm{CNPq}$ pela concessão da bolsa de estudos, apoio essencial para viabilizar o desenvolvimento desta pesquisa.

Às amigas Fernanda Vilhena Mafra Bazon e Lívia Maria Villela de Mello Motta pela leitura crítica e cuidadosa que fizeram deste trabalho.

À Denise, ao Ney e à Renata pelos trabalhos técnicos de transcrição, filmagem e revisão. 
A todos os educadores de escolas públicas e privadas, de instituições especializadas e famílias que comigo vêm discutindo e buscando caminhos para a inclusão da criança com deficiência visual na escola.

Aos meus pais e irmãos por todo o apoio e carinho com que sempre me acompanharam e torceram por mim.

Ao Paulo meu companheiro de todos os momentos por dividir inquietações, positivar cada etapa vencida neste trabalho e compartilhar a esperança no amanhã.

À minha filha Fernanda por ser capaz de compreender minhas ausências, acompanhando e respeitando minha jornada.

A Deus, por fazer-me instrumento e tornar tudo isto possível. 
“... duas lições deixaram profunda impressão em mim: que jamais devemos nos fatigar de considerar os mesmos fenômenos repetidas vezes (ou de nos submeter aos seus efeitos) e que não devemos nos importar com depararmos com a contradição de todos os lados, de vez que tenhamos trabalhado com sinceridade.” FREUD 
“_ Tia, diz-me qualquer coisa, tenho medo porque está tão escuro.

_Para que te serviria isso se tu não podes ver-me? _ Não faz mal: desde que alguém fale, há claridade.” Freud (Três Ensaios sobre a História da Sexualidade) 


\section{RESUMO}

ORMELEZI, E.M. Inclusão educacional e escolar da criança cega congênita com problemas na constituição subjetiva e no desenvolvimento global: uma leitura psicanalítica em estudo de caso, 2006. Tese de Doutorado. Faculdade de Educação da Universidade de São Paulo.

Esta Tese tem como objeto de estudo a criança cega congênita com problemas na constituição da subjetividade e do desenvolvimento e sua inclusão educacional e escolar. É composta por um estudo de caso de um menino cego, no período em que ele se encontrava com cinco e seis anos de idade, com o objetivo de conhecer as especificidades dessa criança no modo como se instauraram os graves problemas de desenvolvimento, identificando singularidades e condições nas quais ela manifesta possibilidades de tornar-se sujeito e desenvolver-se, viabilizando também a inferência em relação a outras crianças cegas que mostram problemas semelhantes, sem compará-las à criança vidente. Além desse estudo apresentamos o levantamento de dados de outros dois casos para corroborar a análise e reflexões do primeiro. Estudar essa problemática, com o foco no âmbito educacional, poderá colaborar com os educadores na criação de condições necessárias à efetiva participação dessas crianças no contexto escolar. As referências teóricas que apóiam este trabalho estão pautadas em conceitos fundamentais da Psicanálise que abrem perspectivas para pensar essa criança, tais como as noções de corpo para além do dado orgânico na implicação da constituição de sujeito e a noção de olhar constituinte do sujeito, capaz de ver a criança além da deficiência. A abordagem da Psicanálise com a Educação, as especificidades da Educação Especial com foco na deficiência visual e os debates acerca dos paradigmas que atravessaram a Educação Especial até a Educação Inclusiva também deram suporte teórico à questão estudada. Os procedimentos metodológicos adotados foram a observação participativa da criança em atividades em uma instituição especializada e a entrevista com a mãe. Para análise dos dados foi adotado o método de Análise de Discurso em três níveis, a saber: 1) das condutas, falas, emoções, expressões corporais e modos próprios da criança; 2) do discurso de sua mãe; e 3 ) da inter-relação dos elementos significativos do discurso da mãe e das manifestações da criança. Os dados obtidos nesta pesquisa confirmam que a cegueira não é fator determinante nos desvios e comprometimentos no desenvolvimento, apesar de ter valor fundante na estruturação psíquica. A criança que nasce cega tem plenas condições de constituir-se sujeito, bem como de desenvolver-se. Mas ela poderá ter seu caminho impedido dependendo de como seus pais se sentirem afetados em sua fantasmática acerca da cegueira. São as dificuldades na 
interação mãe-bebê que poderão causar problemas para essa criança se desenvolver. Sua cegueira pode ser um limite ao desenvolvimento e à constituição, mas não a causa de possíveis desvios. É a preocupação com a inclusão educacional e escolar que dá sentido a este mergulho junto à mãe e à criança que estudamos para compreender o conflito referente à deficiência que se instala na família, o qual se estende a toda sociedade, da qual a escola é uma parte fundamental.

Unitermos: crianças cegas com problemas graves no desenvolvimento; cegueira; inclusão escolar; distúrbios globais de desenvolvimento; problemas na constituição da subjetividade; Psicanálise e Educação. 


\section{ABSTRACT}

ORMELEZI, E.M. Educational and school inclusion of the blind chills with problems on the subjective constitution and on the development: a psychoanalytic lecture of a study case. Thesis of Doctoral Degree. Faculty of Education. University of São Paulo. São Paulo.

This thesis concerns a congenital blind child with problems in his subjective constitution and development. It is a case study of a blind boy between five and six years old. It has the objective of studing the specific characteristics of this child and how he develops his severe problems of development, identifying singularities and conditions that he manifests. This research permits comparison with other blind children with similar problems, without comparing them with sighted children. In addition, we discuss the data of two other cases, to confirm the analysis and reflection about the first one. This study, in educational perspective, can aid teachers create the necessary conditions to the effect participation of these children in the school ambient. The theoretician references that support this research are based on the fundamental concepts of Psychoanalysis that open perspectives to think about this child, notions of the body, (not only the organic body) the subjective constitutions, the recognition of the subject beyond of the deficit. This research is supported by Psychoanalysis and the Education approach, the specific characteristics of Special Education that refers specially to the blind and the debates of the paradigm that crossed the Special Education until the Inclusive Education supports this research. The methodological procedure adopted were the participative observation of the activity of the child in the specialized institution and an interview with the mother. The data analysis used the analysis of discourse in three levels: 1) the attitude, the speech, the emotions, the body expression and the particular ways of the child be in the world; 2) the discourse of the mother; and 3) the interaction between the meaningful elements of the mother's speech and the manifestations of the child. The obtained data of these research confirms that the blindness is not a determinative factor on the problems of development, but it has a structural value on the psychic structure. The child that born blind has all the conditions to be a subject and to develop; however the child's development can be difficult, depending upon how the parents feel affected about blindness. But she can find difficult in her development depending how the parents be afected about the blindness. Difficultties in the relationship between mother and child may cause problems for the development of the child. Blindness can be a limit on development, but not the cause of the problems. It's the concern about the child entering the school and social environment that 
explains our motivation of this study - the relationship of mother and child to understand the conflict about the handicap inside the family, that can be extend to all society, and to school, which is an important part of the life of the child.

Keywords: Blind child with severe problems in the development; blindness; inclusion; global development disorders; problems at the constitution of subjectivity; Psychoanalysis and Education. 


\section{SUMÁRIO}

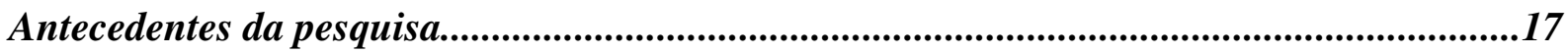

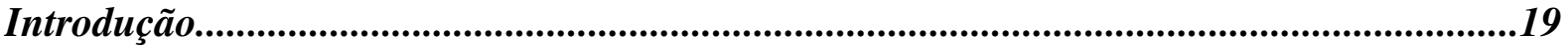

Capítulo I. Discutindo e contextualizando o tema da Inclusão educacional e escolar da criança com deficiência...................................................................................................

1. Raízes históricas e os paradigmas da Educação Especial e da Educação

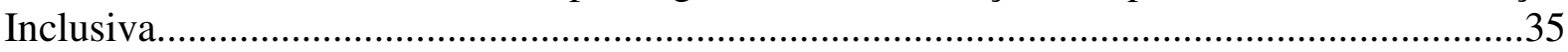

1.1. O nascimento da Educação Especial a partir de um modelo médico de tratar e

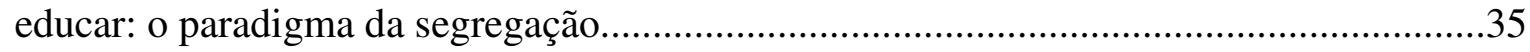

1.2. Os movimentos de ruptura do século XX e o paradigma da integração........................38

1.3. A emergência do paradigma da inclusão social como sustentação da Educação

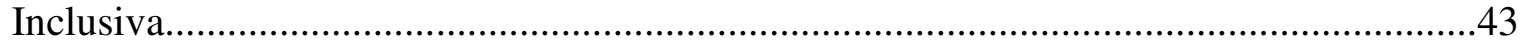

1.3.1. Os conceitos de deficiência e a proposta de diálogo entre as disciplinas............50

1.3.2. A escola e o professor no contexto da Educação Inclusiva................................56

1.3.3. Posição e atuação da família........................................................................67

1.3.4. O papel da instituição especializada na área da deficiência como parceira na construção da Educação Inclusiva...........................................................................73

Capítulo II. Definindo e refletindo sobre o universo da cegueira e dos "distúrbios globais

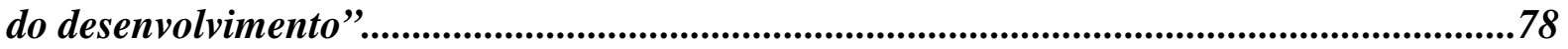

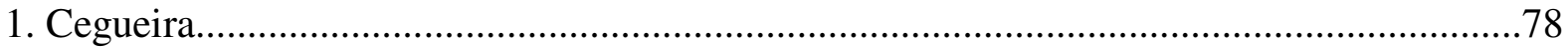

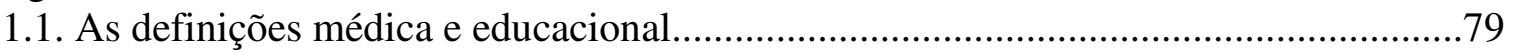

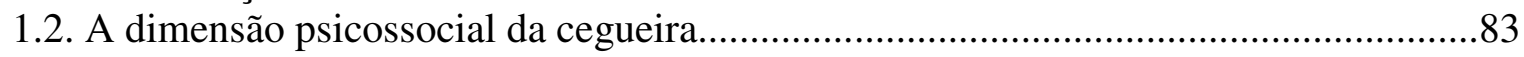

1.3. Cegueira congênita: estruturação psíquica, desenvolvimento e a noção de constituição

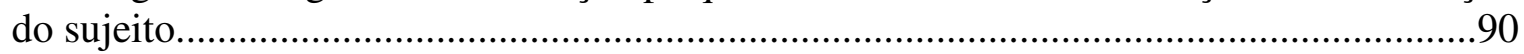

1.3.1. As noções de desenvolvimento e de constituição do sujeito...........................100

1.3.2. A relação mãe-bebê com cegueira: o impacto, as representações imaginárias e o

risco de não se instalarem as funções materna e paterna...........................................105

1.3.3. O corpo-organismo e o corpo-imagem...........................................................111

1.3.3.1. O estádio do espelho: de que espelho se trata na criança cega?............116

1.3.4. A construção do "eu" na criança cega congênita..............................................127

2. Distúrbios globais de desenvolvimento / Problemas graves na constituição

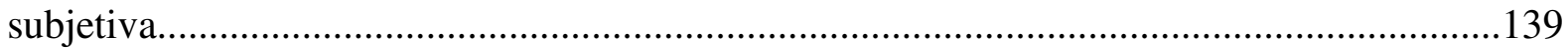

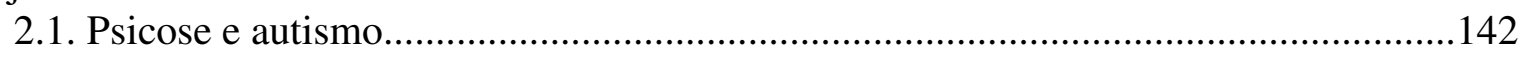

2.1.1. As especificidades da estruturação cognitiva e das aprendizagens na psicose e

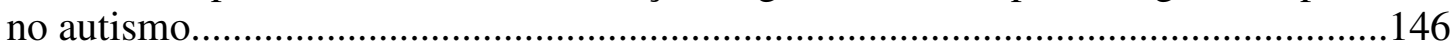

3. Cegueira e comprometimentos na constituição subjetiva e no desenvolvimento................150

Capítulo III. Construindo um espaço de trabalho da Psicanálise com a Educação: a inclusão educacional e escolar das crianças cegas com comprometimentos na constituição subjetiva e no desenvolvimento.............................................................................155

1. Conceitos fundamentais do referencial psicanalítico....................................................157 
2. Significantes que permeiam a Educação na perspectiva da Psicanálise: criança, escola,

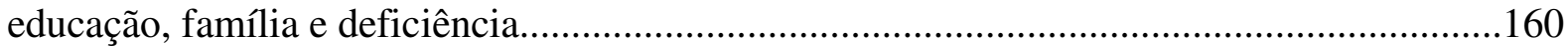

2.1. As implicações da Psicanálise para a Educação......................................................163

3. Integração / Inclusão: caminhos possíveis na escolarização da criança cega com comprometimentos na constituição subjetiva e no desenvolvimento....................................165

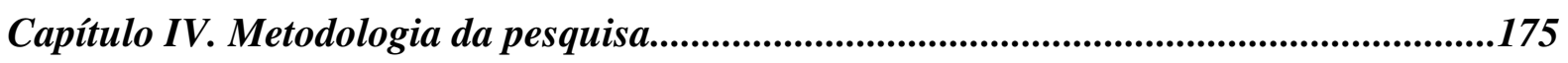

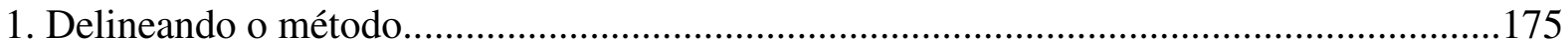

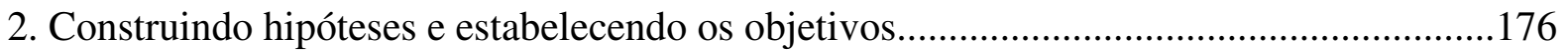

3. A escolha e a identificação dos sujeitos e da instituição especializada..............................178

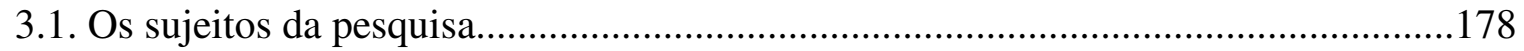

3.2. Caracterização da instituição especializada: local de realização da pesquisa............181

4. Fontes, procedimentos e instrumentos de coleta e registro de dados..................................182

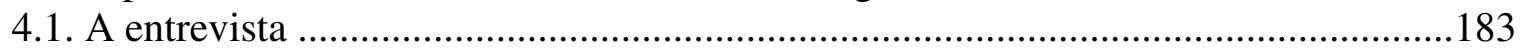

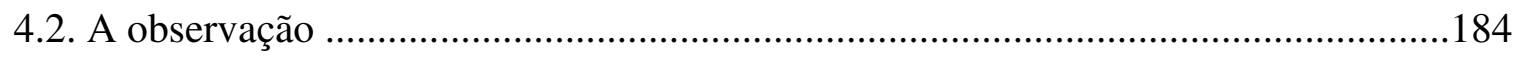

5. Procedimentos de análise e interpretação dos dados ........................................................186

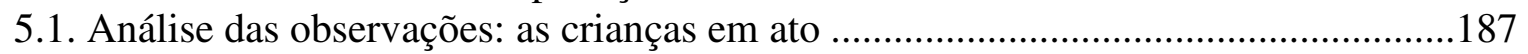

5.2. Análise das entrevistas: uma "análise de discurso" no discurso das mães................ 189

5.3. Análise da inter-relação dos discursos das mães e as manifestações das crianças....190

Capítulo V. Estudo de caso: análise e interpretação dos dados..........................................191

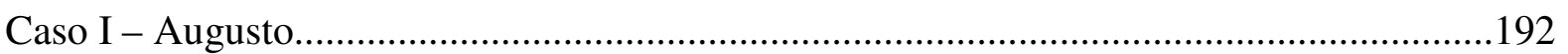

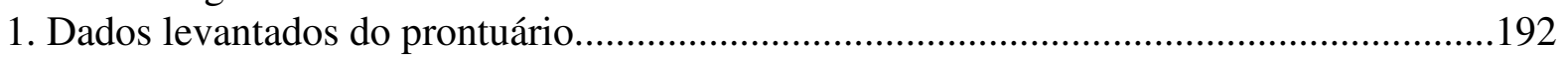

2. Análise das observações: a criança em ato - Dados levantados na observação participativa:

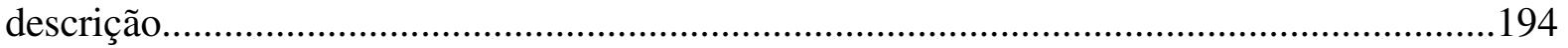

2.1. Análise interpretativa dos dados relativos a Augusto $-1^{\mathrm{a}}$ etapa..............................200

2.1.1. Formas de perceber, explorar, relacionar-se, compreender e expressar-se no

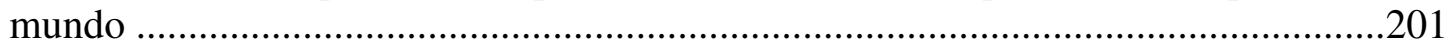

2.1.2. Manifestações de comprometimentos na constituição subjetiva e no

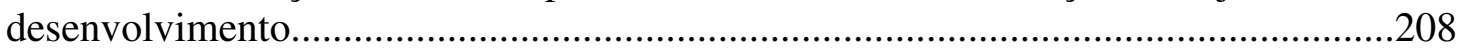

2.1.3. Manifestçãoes de pontos de abertura para a constituição subjetiva e o

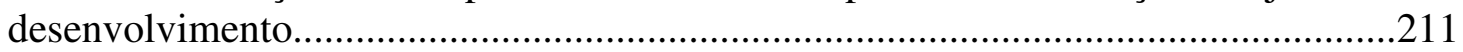

3. Análise da entrevista: uma "análise de discurso" no discurso da mãe.............................218

3.1. Análise interpretativa dos dados relativos à mãe de Augusto $-1^{\mathrm{a}}$ etapa...................218

3.1.1. A reação ao diagnóstico, os primeiros anos de vida de Augusto e outras

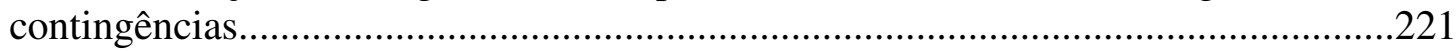

3.1.2. Relação mãe-criança: representação e sentimentos em relação ao filho e o que

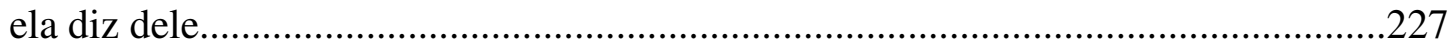

3.1.3. Representação, sentimentos e atitudes em relação à cegueira.........................230

3.1.4. Reação e sentimentos em relação à agressividade do filho...............................232

3.1.5. Como a mãe se mostrou - lugar que ocupou, como se sentiu...........................235

3.1.6. A mudança de olhar da mãe e a possibilidade de saída de Augusto do lugar de deficiente: a busca da instituição especializada, os apoios médico e psicológico e a

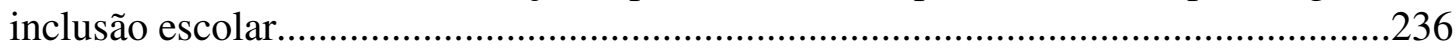

4. Análise interpretativa dos dados relativos a Augusto e à mãe - $2^{\mathrm{a}}$ etapa..........................237

5. Reflexões sobre a inter-relação dos elementos do discurso da mãe com as manifestações de Augusto. 
Caso II - Vivian.

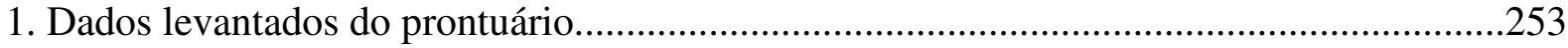

2. Análise das observações: a criança em ato - Dados levantados na observação participativa:

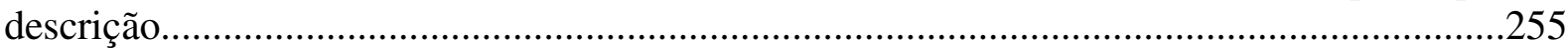

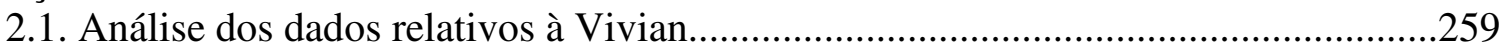

3. Análise da entrevista: uma "análise de discurso" no discurso da mãe..............................261

3.1. Análise dos dados relativos à mãe de Vivian...........................................................261

4. Análise dos dados relativos à inter-relação dos elementos do discurso da mãe com as

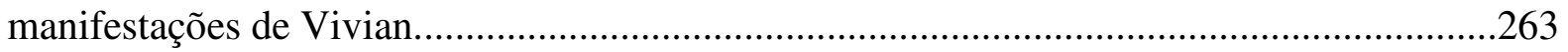

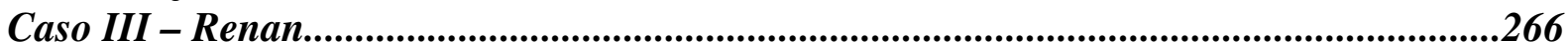

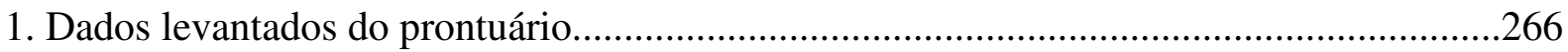

2. Análise das observações: a criança em ato - Dados levantados na observação participativa e

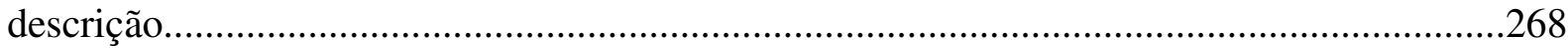

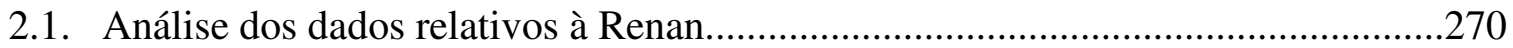

3. Análise da entrevista: uma "análise de discurso" no discurso da mãe...............................272

3.1. Análise dos dados relativos à mãe de Renan.......................................................272

4. Análise dos dados relativos à inter-relação dos elementos do discurso da mãe com as

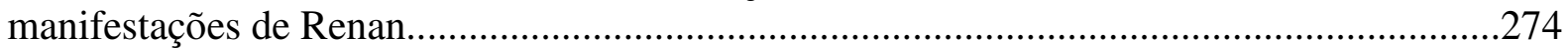

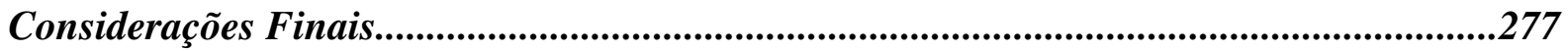

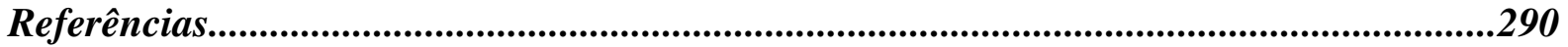

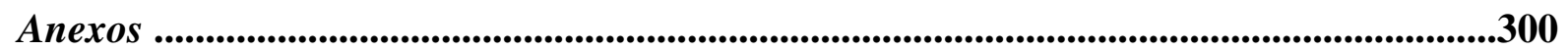

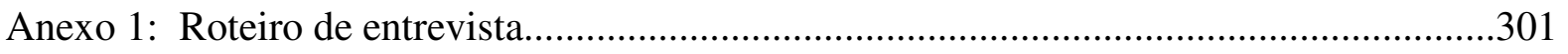

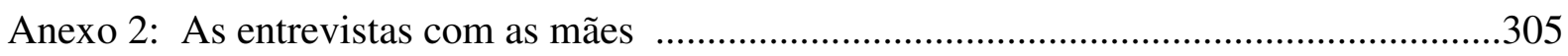

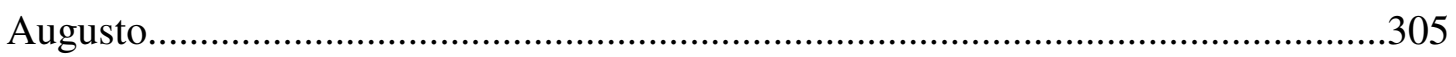

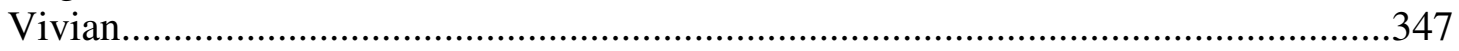

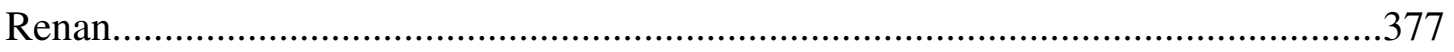

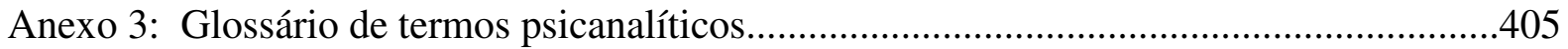

Anexo 4: Carta de informação ao responsável pelo sujeito da pesquisa e Carta de

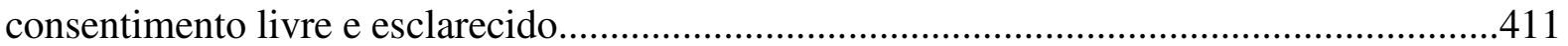

Anexo 5: Parecer de especialista acerca do tema da pesquisa..............................................412 


\section{Lista de Tabelas e Quadros}

\section{Capítulo I:}

Quadro 1: Quadro Geral da CIF

\section{Capítulo II:}

Tabela 1: Definição da CID-10 sobre visão cegueira

Tabela 2: Definição da CID-10 sobre visão subnormal.

\section{Capítulo IV:}

Quadro 1: Caracterização do sujeito

\section{Capítulo V:}

Quadro 1: primeiro encontro com Augusto

Quadro 2: segundo encontro com Augusto.

Quadro 3: terceiro encontro com Augusto.

Quadro 4: temas e elementos significativos identificados nos dados do prontuário e nas observações.

Quadro 5: temas e elementos significativos identificados na entrevista com a mãe de Augusto...

Quadro 6: a posição de Augusto na rede discursiva da mãe................................................246

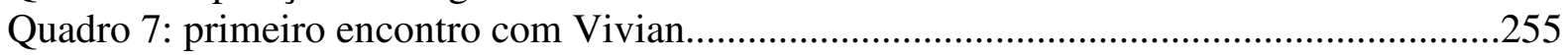

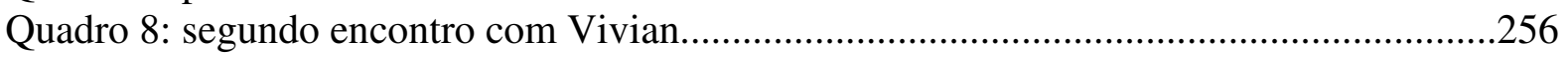

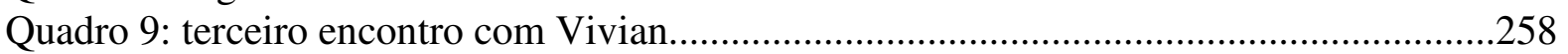

Quadro10: temas e elementos significativos identificados nos dados do prontuário e nas observações.

Quadro 11: temas e elementos significativos identificados na entrevista com a mãe de

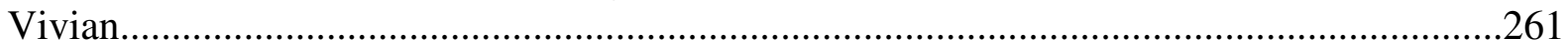

Quadro 12: a posição de Vivian na rede discursiva da mãe................................................263

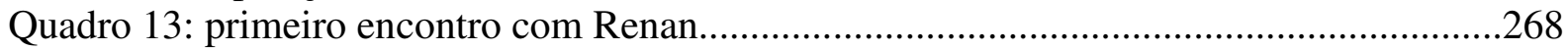

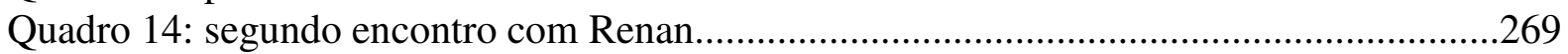

Quadro 15: temas e elementos significativos identificados nos dados do prontuário e nas observações.

Quadro 16: temas e elementos significativos identificados na entrevista com a mãe de Renan...... 


\section{ANTECEDENTES DA PESQUISA}

Em minha trajetória profissional de vinte e seis anos de trabalho na área da deficiência visual, como psicóloga educacional e clínica, deparei-me com muitas crianças e jovens que, além da deficiência visual, apresentam problemas graves no desenvolvimento, sem danos neurológicos comprovados. Identificamos nessas crianças e jovens comprometimentos na constituição da subjetividade e, portanto, na linguagem, na organização da experiência afetiva e cognitiva, nas interações sociais e no processo de aprendizagem.

Diante disso, a primeira questão que se apresentou foi: “como pode a criança, na ausência da visão, perceber/apreender/conhecer o mundo e organizá-lo mentalmente no processo de aprendizagem e desenvolvimento?" E em seguida: "a cegueira pode comprometer o desenvolvimento global da criança?”

Estas duas indagações levaram-me a desenvolver as pesquisas no Mestrado e agora no Doutorado.

No Mestrado, tratar a questão inicial do meu trabalho com crianças cegas - "Os caminhos da aquisição do conhecimento e a cegueira: do universo do corpo ao universo simbólico" - e pesquisar o processo de formação de conceitos me pareceu relevante na medida em que este é, talvez, o mais complexo dos níveis da aprendizagem e do desenvolvimento por caracterizar-se por funções cognitivas de abstração e generalização. A partir daí poderia, mais tarde, dar continuidade à pesquisa no estudo dos comprometimentos que muitas crianças cegas apresentam nesse processo.

A formação de conceitos na criança que não enxerga, bem como a implicação da linguagem no processo, constituiu-se o objeto de estudo da pesquisa de Mestrado, pois, no atendimento às crianças com deficiência visual, observava que para algumas crianças cegas havia um impedimento na transcendência da experiência concreta, na significação do vivido, em suma, no acesso à função simbólica e que, quando a palavra do mediador da sua aprendizagem se fazia significativa, algo se iluminava no mundo interno delas, operando uma transformação na organização psíquica.

Ao proceder ao levantamento bibliográfico identifiquei uma lacuna nesse campo de pesquisa científica no que diz respeito a abordar a questão buscando o referencial do cego, sua própria maneira de aprender, como parâmetro para sua educação. 
Investiguei então as peculiaridades dos caminhos trilhados pelo cego na aquisição do conhecimento, perguntando sobre suas percepções, imagens mentais e formação de conceitos, para compreender "como a função simbólica é instaurada na ausência da visão”. Estudar o modo como o cego que nunca enxergou constrói o conhecimento; conhecer a sua maneira de perceber o mundo e organizar as experiências vividas na interação com ele - ou seja, como se dá sua estruturação cognitiva -, ao mesmo tempo em que trouxe contribuições para a educação de pessoas com deficiência visual, pode oferecer subsídios também à compreensão de crianças que apresentam distúrbios no processo de entrada para a linguagem e de construção da função simbólica.

Esse estudo levou-me a confirmar a hipótese de que a cegueira em si não se configura como impedimento à estruturação psíquica. Ao entrevistar adultos cegos congênitos, os dados levantados evidenciaram que, na ausência da visão, há uma forma peculiar no contato com o mundo que deverá ser descoberta e estruturada no entrelaçamento do organismo com a cultura e nas interações e desejos humanos mediados pela linguagem, que oferecem condições para a organização perceptiva e cognitiva na construção do conhecimento.

Essa constatação reiterou a questão: "o que ocorre, então, com uma parcela significativa de crianças cegas congênitas que fica 'barrada' na possibilidade de tornar-se sujeito e desenvolver-se plenamente? Quais os fatores imbricados nessa realidade?”

A pesquisa no Mestrado fez, portanto, o recorte de estudo das relações da cegueira com as funções cognitivas, indicando a necessidade de enveredar pelos caminhos simbólicos do não-ver em relação à constituição do sujeito para compreender a problemática apresentada acima. Ou seja, a lógica do percurso de estudo foi conhecer as especificidades da cegueira na construção da representação simbólica para depois focalizar, na investigação do Doutorado, a análise dos impedimentos na constituição da subjetividade da criança cega congênita e dos graves problemas em seu desenvolvimento. 


\section{INTRODUÇÃO}

É alto o índice de crianças com comprometimentos associados a uma deficiência, tanto no Brasil como em outros países. No caso das crianças cegas essa realidade também se apresenta e a literatura especializada a comprova. Essa contingência define o objeto de estudo deste Doutorado: a criança cega congênita com problemas na sua constituição de sujeito e no seu desenvolvimento e sua inclusão educacional e escolar.

As questões das quais partimos e que nortearam o trabalho foram: "O que ocorre, então, com uma parcela significativa de crianças cegas congênitas que fica 'barrada' na possibilidade de tornar-se sujeito e desenvolver-se plenamente?" e "Quais fatores estão imbricados nessa realidade?” A partir dessas indagações, levantamos as seguintes hipóteses:

- não é a ausência da percepção visual o fator determinante nos transtornos da constituição subjetiva e do desenvolvimento global, apesar da cegueira ter valor fundante na estruturação psíquica;

- o fator determinante dos problemas graves de desenvolvimento nas crianças cegas congênitas é a interação prejudicada entre mãe e bebê que compromete sua constituição de sujeito.

O estudo de caso e a análise de discurso foram as abordagens metodológicas escolhidas pela natureza do problema estudado e, para sua investigação, procedemos ao levantamento de dados de três casos de crianças cegas congênitas com comprometimentos no desenvolvimento, nas idades entre cinco e nove anos, realizando uma busca nos registros em prontuários, observações participativas e entrevistas com as mães. Todos os casos foram abordados nas seguintes etapas:

- caracterização do histórico de vida dos sujeitos;

- descrição com comentários das observações de atividades;

- apresentação dos dados das entrevistas com as mães;

- assinalamento dos elementos significativos organizados por temas.

$\mathrm{Na}$ etapa de análise interpretativa, optamos pelo aprofundamento de um dos casos estudados, que foi realizada em três níveis, a saber:

- análise das condutas, falas, emoções, expressões corporais e modos próprios de estar no mundo das crianças cegas congênitas a partir de observação participativa;

- análise dos discursos das mães a partir do instrumento de entrevista; 
- análise da inter-relação dos elementos significativos do discurso das mães e das manifestações das crianças.

O foco desta pesquisa é educacional, não clínico, voltado para as condições necessárias à inclusão educacional e escolar da criança cega congênita com problemas na sua constituição de sujeito e no seu desenvolvimento. É a preocupação com a sua inserção escolar e social que vai dar sentido a este mergulho junto às mães e às crianças que estudamos para compreender o conflito referente à deficiência que se instala na família, estendendo-se também a toda sociedade, da qual a escola é uma parte fundamental.

Nessa perspectiva, a pesquisa tem como principal objetivo conhecer as especificidades dessa criança no modo como se constituíram os graves problemas de desenvolvimento, identificando singularidades e condições nas quais ela manifesta possibilidades de subjetivação e de desenvolvimento, possibilitando também a inferência em relação a outras crianças que mostram problemas semelhantes. A compreensão dessa problemática poderá propiciar a sistematização de dados que fornecerão subsídios aos educadores para criar condições necessárias à participação dessas crianças no processo de inclusão na escola.

O trabalho com crianças com deficiência situa-nos no universo da diversidade e nele procuramos compreender o ato educacional e sua ética a partir da possibilidade da convivência com as diferenças e, portanto, a importância de condições que incluam, e não excluam, as pessoas, na perspectiva de um dia termos uma "educação para todos", respeitando as singularidades e as necessidades próprias de cada um.

Crianças cegas com problemas graves no desenvolvimento global são aquelas que, além da limitação de ordem visual, mostram comprometimentos tais como: atrasos nas aquisições funcionais e dificuldades de ordem simbólica que prejudicam ou impedem a formação do "eu" e a aprendizagem - e ainda apresentam realizações intelectuais, estrutura de linguagem e padrões de comportamento atípicos (referência a si mesmo na terceira pessoa do singular, repetição de palavras ou frases ouvidas e aparentemente desconexas e sem sentido, balanceios do corpo, movimentos repetitivos de auto-estimulação, uso dos objetos com o fim de auto-estimulação e não pela função do mesmo).

Essas crianças podem aparentar deficiência mental, embora apresentem algumas qualidades cognitivas preservadas como indicadores de inteligência. São muitas vezes diagnosticadas como psicóticas, autistas, deficientes mentais ou com disfunção psiconeurológica. 
Neste trabalho é adotado o referencial psicanalítico segundo a concepção apresentada por Kupfer (1997) sobre as crianças com transtornos graves de desenvolvimento como:

(...) crianças cuja posição na rede da linguagem, cuja inscrição no registro do simbólico apresentam falhas ao ponto de ficar comprometida a sua constituição subjetiva, sua relação com o outro e sua circulação no campo social: psicóticas, autistas, sindrômicas ou algumas portadoras de deficiência para quem tais falhas simbólicas acabam por se instalar (Ibid., p.57).

De fato essas crianças parecem estar fora de toda ordem estabelecida pela linguagem ${ }^{1}$; não estão em sintonia com o mundo circundante; não se relacionam com as pessoas. Seus pais, clínicos e educadores não sabem o que fazer diante delas: a família, com o impacto do nascimento de um filho com deficiência e a falta de orientação adequada... os profissionais, pelas dificuldades técnicas e teóricas sobre o diagnóstico diferencial e a intervenção apropriada. Em ambos os casos, a perplexidade diante do diferente, daquele cuja principal dificuldade é a relação com o outro.

Neste trabalho assumimos para os "distúrbios globais de desenvolvimento", a designação de problemas na constituição subjetiva e no desenvolvimento, conforme Filidoro $(1997 ; 2005)$.

Se as crianças apenas com deficiência visual já fazem parte de uma parcela da população que muitas vezes fica segregada ou excluída do sistema regular de ensino, como também de outras instituições, por apresentar necessidades especiais decorrentes da deficiência, aquelas que têm outros comprometimentos associados à cegueira representam um problema humano e social ainda mais grave e pouco discutido no âmbito da Educação.

O objeto deste estudo está, portanto, atrelado a uma questão paradoxal que é falar de lugar social, quando é justamente da circulação no campo social, como refere Kupfer (1997), que essas crianças das quais falamos estão excluídas. Excluídas não só pelas contradições sociais e relacionais frente à diferença entre os seres humanos, tão discutidas e não resolvidas, mas também por questões de estruturação psíquica.

O que é preciso saber, então, sobre essas crianças para sua inclusão na escola? O que de sua existência é preciso conhecer e como elas nos mostram seu modo de perceber, compreender e se relacionar com o mundo de coisas, pessoas e acontecimentos? Como

\footnotetext{
${ }^{1}$ Linguagem no sentido psicanalítico de que o sujeito se constitui na rede de significantes instaurada na relação com o outro em um processo inconsciente. “(...) o inconsciente é da ordem da estrutura... é estruturado como linguagem... os elementos que apresenta são os mesmos da linguagem...” (MRECH, 1999 p.134).
} 
interagem, como se expressam e como se movimentam no tempo e no espaço? Como organizam a libido, as emoções e a vida mental? Que significantes podem ser identificados e que possíveis significados podem ser atribuídos a cada uma delas em sua história pessoal? Estas questões trazem imbricados os elementos que procuramos conhecer neste trabalho.

É evidente que a imagem e o conceito que o cego vai adquirir de espaço, ou de tamanho e formas serão dados pela sua disposição perceptiva, que não é visual, mas é auditiva, tátil, olfativa, cinestésica e cenestésica. Mas há um aspecto a partir do qual ele encontra-se com o vidente - o da linguagem... o da cultura... - e esse é um ponto que parece ser fundamental, pois permite refletir sobre a dimensão na qual a constituição de sujeito se coloca para além da diferença sensorial, apesar de marcada por ela.

Sabemos também que a visão é o sentido da apreensão do mundo de forma direta, global e à distância. Na sua ausência, há uma reorganização de toda a estrutura mental que possibilitará ao cego adquirir conhecimento sobre o mundo. Muitas crianças cegas congênitas evidenciam a força dessa complexa reestruturação psicológica em razão da atividade do organismo que visa a um maior desenvolvimento do tato ou da audição, mas principalmente de uma reorganização em virtude da possibilidade do cego comunicar-se na experiência social. Assim, podemos concluir que o significado de compensação presente na cegueira é de ordem sócio-psicológica, como denominou Vygotsky em seus trabalhos sobre defectologia na década de 20 do séc. XX (Cf. VYGOTSKY, 1993).

Na pesquisa de Mestrado constatamos que o corpo marca as diferenças perceptivas para o cego no mundo de videntes, e a dimensão do social e da cultura os unem como elementos estruturantes na constituição dos aspectos mais universais do tornar-se humano. $\mathrm{O}$ homem, como ser de linguagem, tem acesso ao mundo dos significados compartilhados em determinado contexto, permitindo, assim, a apreensão da realidade por intermédio dos símbolos criados pela cultura. Essa constatação no Mestrado amplia a noção de percepção para além do dado sensorial e a noção de corpo para além do dado orgânico, pois muitas crianças cegas congênitas mostram que há uma integração das percepções, buscando de forma dinâmica a melhor maneira de interpretar o que é dado no mundo. Por outro lado, a presença marcante dos adultos, membros da família que fazem parte da vida da criança, passado o impacto de receberem um filho cego, ao conseguirem tocá-la, acarinhá-la, falar com ela e olhá-la como um semelhante, deram-lhe condições para constituir-se como sujeito e compartilhar, com outros representantes da cultura, o mundo de coisas, eventos, sentimentos e palavras. 
Outra constatação foi que corpo, linguagem, cultura e afetividade dialeticamente medeiam a aquisição do conhecimento. A vivência perceptiva não se dá isolada do contexto social. Tampouco a linguagem atua fora da relação afetiva na qual o corpo é seu receptor e guardião.

Na perspectiva vygotskyana, a psicogênese do sujeito centra-se na dimensão sóciohistórica do ser humano mediado pela linguagem, marcando a transcendência do biológico ao universo simbólico. Assim, cegos e videntes constituem-se enquanto sujeitos a partir do corpo significado nas interações com o mundo para construir a possibilidade de substituir o real pelas representações que podem fazer dele a partir do sensível e da linguagem. Essa condição permite ao cego pautar-se pelo mundo que ele percebe e também ultrapassá-lo na aquisição do conhecimento de objetos, situações e acontecimentos, podendo até imaginar coisas jamais vivenciadas. Desde que nasce, a criança cega, assim como a que enxerga, está mergulhada na cultura, na qual o corpo e a palavra se encontram na constituição do sujeito. É a linguagem que permite compartilhar sentidos. É na relação humana que os significantes e significados circulam.

Refletindo, então, sobre a possibilidade do bebê cego constituir-se como sujeito a partir das sínteses alcançadas na pesquisa de Mestrado, surgiu a questão: "O que ocorre com a criança cega que fica paralisada nessa possibilidade se não há impedimento, nesse sentido, essencialmente proveniente da cegueira? E em que momento e dimensão da estruturação psíquica e do processo de desenvolvimento?"

A questão se amplia da seguinte forma: "de que maneira as relações iniciais ficam afetadas pela presença da cegueira na sua dimensão psicossocial, podendo impedir o acesso da criança ao simbólico e, portanto, à sua constituição de sujeito, levando-a a um desenvolvimento global prejudicado?”

A constituição da subjetividade na criança cega é, portanto, foco de estudo desta pesquisa de Doutorado, pois esse aprofundamento levará a reflexões importantes para a compreensão dos problemas graves no desenvolvimento global freqüentes na cegueira.

A literatura especializada na área da deficiência visual se divide - como fazem as teorias na proposta de conhecer a dimensão psicológica do ser humano - na tarefa de compreender, ora o funcionamento cognitivo, ora a dinâmica afetivo-emocional influenciados pela ausência da visão. Predominam, porém, os estudos acerca dos aspectos cognitivos fundamentados no referencial piagetiano, e dos aspectos afetivo-emocionais no enfoque 
psicanalítico, os quais abordam comparativamente cegos e videntes. Em relação ao desenvolvimento global da criança cega, tais estudos se dividem quanto às posições em relação aos fatores causadores de perturbações associadas à cegueira.

Para alguns (Cf. AMIRALIAN, 1985, 1997; PERAITA, 1992; FRAIBERG e ADELSON, 1977; BURLINGHAM, 1965; FRAIBERG e FREEDMAN, 1964; SANDLER,1963; WILLS, 1970, entre outros), a ausência da visão é considerada um fator preponderante no desenvolvimento da criança. Para outros (Cf. VYGOTSKY, 1993; MASINI, 1990; LEONHARDT, 1992; CANTAVELLA, 1998), o enfoque centra-se fundamentalmente na diferença de universos e formas singulares de aprender.

Burlinghan (1965), Sandler (1963), Fraiberg (1977-1981), Fraiberg e Freedman (1964), Fraiberg e Adelson (1982), entre outros, consideram que a criança cega tem seu desenvolvimento atrasado em relação à vidente porque a visão permite desenvolver competências e habilidades que a audição, o tato e os outros sentidos não o farão nem na mesma medida, nem no mesmo tempo. Esses estudos discorrem sobre dificuldades para o desenvolvimento na cegueira: em habilidades para alcançar a noção do todo; na mobilidade que favorece o teste da realidade; na percepção de deslocamento de objeto, profundidade, distância, tamanho, formas, posições, detalhes e movimento; na exploração do ambiente; na formação do conceito de objeto; na diferenciação eu-outro; na restrição das experiências significativas e relações consigo e com o outro, caracterizando-se no atraso de aquisições motoras e cognitivas. Tais afirmações poderiam nos levar a pensar que, em razão disso, as relações afetivas iniciais podem ficar comprometidas, prejudicando os laços sociais, podendo provocar um fechamento da criança sobre si mesma, ocasionando sérios problemas na sua constituição de sujeito e bloqueando seu desenvolvimento.

Todavia, estudos de outros pesquisadores (Cf. LEONHARDT, 1992; LEONHARDT e CANTAVELLA, 2002) apontam dificuldades do bebê cego na relação com os pais nos estágios primitivos da vida, no estabelecimento das relações objetais, comprometendo seu desenvolvimento global e sustentam que, se essas crianças fossem bem "estimuladas" - o que significa que os adultos deveriam apresentar-lhes o mundo, proporcionar-lhes experiências significativas, encorajá-las na locomoção, ajudá-las no reconhecimento de si mesmas - não teriam atrasos ou, pelo menos, estes poderiam ser reduzidos.

Todos os estudos mencionados acima, e particularmente os estudos psicanalíticos acerca da cegueira e da estruturação psíquica constituem uma importante contribuição e são abordados em profundidade na fundamentação teórica e na análise dos dados desta pesquisa. 
A grande maioria desses trabalhos, porém, comparam crianças cegas com crianças videntes e este, sem dúvida, não é o melhor caminho para conhecê-las, pois estudam a criança cega a partir do referencial da visão e concluem por atrasos no desenvolvimento das crianças cegas em todas as suas aquisições psicomotoras, cognitivas e sociais.

No Brasil, somente os estudos de Masini (1990), sobre o modo próprio de perceber e relacionar-se do cego, e seu artigo "A educação do portador de deficiência visual: perspectivas do vidente e do não-vidente, de 1994, discutem procedimentos de análise para conhecer o cego na construção da sua singularidade.

Ao proceder à revisão da literatura especializada na área da deficiência visual fizemos um levantamento junto à Biblioteca tradicional do Instituto de Psicologia da USP e via Internet. A busca pela Internet foi realizada através do Sistema Integrado de Bibliotecas da USP, que permite a consulta virtual em todas as suas bibliotecas; do Banco de dados bibliográficos da USP (Dédalus); da Base de dados de citações bibliográficas (web of Science); da Base de dados especializada em Psicologia (Psycinfo); dos sites de pesquisa científica Scielo, Periódicos Capes, Biblioteca Virtual de Psicologia e Bireme; de organizações nacionais e internacionais especializadas na prestação de serviços à pessoa com deficiência visual e produção de conhecimento na área; dos web sites de busca; correios eletrônicos trocados com profissionais da ONCE (anexo 5); além de catálogos de editoras e livrarias.

Os verbetes utilizados na busca, que se referiram ao tema de modo direto, foram os seguintes: "cegueira e distúrbios globais do desenvolvimento", "cegueira e autismo", "cegueira e psicose", "cegueira e formação do "eu", "crianças cegas e a formação do ego", "psicologia da cegueira", "deficiência visual e desenvolvimento", "desenvolvimento e crianças cegas", "cegueira congênita e desenvolvimento". Na maior parte das consultas os verbetes não foram localizados.

Muitos dos artigos encontrados - os mais diretamente ligados ao tema do desenvolvimento da criança cega congênita e possíveis desvios - referiram-se a estudos datados de 1950 a 1989 (Cf. CUTSFORTH, 1950; LOWENFELD, 1950; BLANK, 1957, 1958; OMWAKE e SOLNIT, 1961; SANDLER, 1963; FRAIBERG e FREEDMAN, 1964; NAGERA e COLONNA, 1965; BURLINGHAN, 1965; FRAIBERG e ADELSON, 1973; FRAIBERG, 1977; LAMBERT, 1980; OBIAKOR e STILE, 1989) e outros mais recentes, de 1990 a 2002 (Cf. LEONHARDT, 1992; OCHAITA e ROSA, 1995; AMIRALIAN, 1997; BROWN, 1997; LEONHARDT et al., 1999; LEONHARDT e CANTAVELLA, 2002), 
baseados na linha desenvolvimentista piagetiana ou na linha psicanalítica de Winnicott, sendo que os estudos psicanalíticos de Fraiberg e Freedman, 1964; Fraiberg, 1973-1977; Fraiberg e Adelson, 1982; Sandler, 1963; Blank, 1957-1958 e Burlinghan, 1965, foram os que mais estudaram a criança cega congênita com desvios na aquisição da função simbólica interrelacionada à formação do "eu".

Estudos brasileiros de grande contribuição para a área são os de Masini (1990; 1994; 2002) que trata do perceber e relacionar-se do cego, baseados no referencial da fenomenologia da percepção de Merleau-Ponty; Amiralian (1997), em uma visão psicanalítica da cegueira, aborda os temas do diagnóstico e do desenvolvimento da personalidade do cego; Ormelezi (2000), que estudou a formação do universo simbólico no cego, fundamentando no pensamento de Vygostsky e de Wallon em relação à mediação da linguagem e da afetividade na construção da cognição; Bruno (1993-1997-2005), Salomon (2000) e Sialulys (2006), com ênfase na intervenção precoce e nos aspectos pedagógicos do trabalho com a criança com deficiência visual. Outro trabalho que merece ser citado é o de Boato (2003), que discute formas de intervenção pedagógica, no referencial walloniano, em deficientes visuais com deficiência mental associada, além da contribuição de Rocha (1987) e Haddad et al. (2001) quanto ao conhecimento médico oftalmológico acerca das definições, patologias, necessidades e recursos especiais na deficiência visual.

Os estudos psicanalíticos citados anteriormente têm contribuído para a compreensão da psicodinâmica da cegueira abordando os aspectos da relação mãe-bebê cego, do desenvolvimento psicossexual na formação do ego, como também as dificuldades psicossociais vividas nesse percurso, mas são em número infinitamente menor em comparação àqueles que abordam os aspectos cognitivos. E, como já foi dito, em sua grande maioria partem do padrão visual como base de comparação entre cegos e videntes.

A relevância científica deste trabalho está na busca de partir do próprio referencial do cego, de trazer as concepções da psicanálise lacaniana no entendimento da questão da constituição da subjetividade e do desenvolvimento no bebê cego e pela tentativa de preencher uma lacuna nesse campo de estudo, pois, ao proceder ao levantamento bibliográfico, não foram encontrados estudos sobre o tema proposto nesta pesquisa.

Em consulta a especialistas da Organização Nacional dos Cegos Espanhóis (ONCE), agência reconhecida mundialmente no desenvolvimento de ações e fomento à pesquisa científica na área, a Profa. Dra. Mercè Leonhardt Gallego emitiu um parecer (anexo 5) 
indicando que o tema proposto neste Doutorado é de suma importância dada a escassez de trabalhos no assunto abordado.

Este estudo, portanto, pretende contribuir para o avanço do conhecimento sobre o tema para aqueles que convivem com essas crianças - familiares, educadores. Define-se na perspectiva da ética da convivência efetiva da diversidade na sociedade.

Como já vimos, o objetivo principal é conhecer algumas especificidades da criança cega com problemas na constituição subjetiva e no desenvolvimento global para oferecer subsídios ao educador no processo de inclusão dessa criança na escola. É, no entanto, relevante frisar que estamos cientes dos impasses para alcançar esse objetivo conforme posto a seguir:

- a Declaração de Salamanca/Espanha (1994) - documento de divulgação dos resultados da Conferência Mundial sobre Necessidades Educativas Especiais e Inclusão - e outros documentos apresentados nos encontros mundiais subseqüentes - Guatemala (1999), Dakar/Senegal (2000), Sapporo/Japão (2002) e Madrid/Espanha (2002), também contemplam a educação das crianças com problemas graves de desenvolvimento no contexto da educação para todos;

- há uma dificuldade enorme em viabilizar essa possibilidade, uma vez que a concepção vigente de escola ainda é aquela onde a criança é avaliada por seu desempenho.

Não obstante esse impasse, o objetivo desta tese permanece considerando que o lugar da escola não pode ser apenas o de transmissão de conhecimento, desvinculado do lugar social que ela representa em nossa cultura. Nesse sentido frisamos que a motivação inicial e a relevância social desta pesquisa reside no âmbito da inclusão educacional e escolar dessas crianças.

É importante ainda ressaltar que o objeto deste estudo - a criança cega congênita com problemas na constituição subjetiva e no desenvolvimento global e sua inclusão educacional e escolar - impõe a necessidade de um suporte teórico que possa sustentar as diversas especialidades que atuam nessa área com a perspectiva de focalizar o sujeito além da deficiência e que ali está em vias de se constituir.

As disciplinas das Ciências da Educação, e outras envolvidas no atendimento das crianças cegas com outros comprometimentos associados, fazem exigências que ultrapassam 
seus referenciais teóricos específicos que, de modo geral, fragmentam as concepções de sujeito e de desenvolvimento.

A Psicanálise - centrada na questão do sujeito, um sujeito que está além da deficiência, e na educação com função subjetivante - oferece fundamentos para a transdisciplinaridade, no sentido de um conhecimento que ultrapasse a especificidade de cada disciplina ao ajudá-las na compreensão da trama na qual estão enredadas crianças e famílias. Seu encontro com a Educação pode oferecer ao educador uma leitura e uma escuta que lhe possibilitem uma intervenção pedagógica atenta às singularidades dessas crianças, bem como, o encontro com outros profissionais, a clareza do atendimento à família e do encaminhamento à escola.

Esta pesquisa tem como pano de fundo a constituição do sujeito e o desenvolvimento infantil e é ele que precisa ser diferenciado em suas várias abordagens teóricas. A que nos interessa aqui é aquela que marca "o lugar e tempo do sujeito e não do organismo", como aponta Jerusalinsky (1988, p. 39). Ou seja, o universo simbólico da estruturação psíquica que está além do universo do orgânico, embora marcado por ele. Para esse autor:

(...) se o desenvolvimento depende de um processo maturativo, a constituição de um sujeito não depende para nada dele. E mais, tal processo maturativo faz limite para esse sujeito, porém não o condiciona nem o determina. (...) há crianças paralíticas cerebrais que nunca manejarão bem a pinça manual, nem caminharão; ou mielomelingocélicos que nunca chutarão uma bola, ou cegos que nunca alinharão a cabeça com sua visão inexistente, e nem por isso serão menos sujeitos de desejo que outras crianças que gozam de todas as habilidades corporais. É verdade que tais acidentes do desenvolvimento colocam uma série de obstáculos à estruturação psíquica e, em seus efeitos traumáticos, podem pô-la em questão. Mas também é certo que não é do corpo, mas da simbolização que nele se opere (a partir mesmo de suas primeiras falhas) que depende esta estruturação psíquica. Este processo depende do Outro que, desejante da criança, engendrou-a ou adotou-a para que ocupe um lugar em sua cadeia significante (Ibid., p. 44).

Esta colocação nos faz refletir sobre a relativização do orgânico sobre o psíquico na constituição subjetiva, considerando-o como suporte e campo do psíquico. A conquista da família, do educador e dos especialistas é olhar para um corpo marcado por uma deficiência, o qual precisa receber as condições adequadas para desenvolver-se, mas conseguir acreditar que ali um sujeito de desejo pode advir.

É importante fazer referência ao fato de que os conceitos de desenvolvimento, sujeito, registro simbólico, real e imaginário, significante e significado, imagem, palavra, desejo, 
função materna e função paterna, entre outros, constituem a base do campo de conhecimento da Psicanálise e têm delineamentos muito particulares nessa teoria. Eles foram devidamente explicitados na teorização da pesquisa e se converteram nos pilares que se apresentam como uma compreensão possível para as crianças cegas congênitas que ainda não podem se colocar como sujeitos e "falar em nome próprio" (KUPFER, 1997, p. 55).

Em síntese, o quadro teórico de fundamentação deste trabalho foi sustentado pela Psicanálise de Freud (1914; 1923) e Lacan (1978; 1987), nas leituras que fizeram Mannonni (1977; 1981), Jerusalinsky (1989), Mrech (1999), Kupfer (1989; 1997; 2000), Lajonquiére (1997), Laznik (1998), Levin (2002; 2005), entre outros, na apresentação dos conceitos fundamentais da Psicanálise lacaniana implicados nos impedimentos à constituição subjetiva e nos problemas graves de desenvolvimento (incluindo crianças com deficiência) e no processo de inclusão educacional e escolar. Em relação às questões das especificidades da cegueira nos guiamos pelos estudos de Masini (1990; 1994; 2004), e ainda Guirado (1995) sobre Psicanálise e Análise de Discurso, que é o método de análise desta pesquisa.

Estruturamos este trabalho em cinco capítulos.

Por ser o foco deste trabalho a inclusão educacional e escolar da criança com deficiência, no capítulo I abordamos as raízes históricas e os paradigmas que perpassaram a Educação Especial até a Educação Inclusiva, para contextualizar a discussão desde as estruturas e concepções que vêm regendo o sistema educacional ao longo da sua história, até a legislação, parâmetros e recomendações para a inclusão escolar da criança com deficiência. Foram tratados os fundamentos sobre a inclusão educacional e escolar dessas crianças nos seus pressupostos filosóficos e de trabalho a ser construído pela família, escola e comunidade com base na Constituição Brasileira (Cf. BRASIL, 1988), na Lei de Diretrizes e Bases (1996), nos Parâmetros Nacionais Curriculares da Educação Especial (1999), nas produções intelectuais sobre a prática das universidades e instituições especializadas do Brasil, bem como nas recomendações internacionais desde a Declaração de Salamanca, em 1994.

Neste enfoque discutimos o papel e a função da escola, as concepções de educação e a modalidade da Educação Especial, com as concepções de deficiência que foram se transformando ao longo da história. Procurando trazer à discussão o tom de uma abordagem interdisciplinar e comprometida com as exigências do momento educacional e social, discutimos o papel da escola e do professor hoje, bem como da família e da instituição especializada na área da deficiência na construção da Educação Inclusiva. 
No Capítulo II adentramos o universo da cegueira e dos chamados "distúrbios globais de desenvolvimento", uma vez que o trabalho trata da inclusão educacional e escolar da criança cega congênita com comprometimentos na constituição subjetiva e no desenvolvimento global. Assim, no campo da cegueira, explicitamos as definições médica e educacional, enfatizando a dimensão psicossocial, na qual situamos os transtornos na estruturação psíquica e muitas das dificuldades da inclusão escolar para além das especificidades da deficiência. Discorremos sobre a estruturação da vida psíquica na presença da cegueira nas vivências mais primitivas de constituição do sujeito na relação mãe-bebê, tal como o estádio do espelho com a formação da imagem corporal e da instância do "eu". Discutimos as noções adotadas neste trabalho referentes a desenvolvimento e constituição do sujeito, corpo-organismo e corpo-imagem, olho e olhar, e necessidade, demanda e desejo. Nesse mesmo capítulo, tratamos do campo dos problemas da constituição subjetiva, especificando os quadros da psicose e do autismo em suas particularidades de funcionamento cognitivo e de aprendizagem, para, em seguida, tratar do que é específico na cegueira quando associada a comprometimentos na subjetivação e no desenvolvimento.

O capítulo III retoma a questão da inclusão educacional e escolar, agora centrando na criança cega congênita com problemas na constituição subjetiva e no desenvolvimento global, propondo um trabalho da Psicanálise com a Educação. Para isso, convida o educador a entrar nesse campo de conhecimento, definindo alguns de seus conceitos fundamentais, tais como sujeito, inconsciente, significante, significado, outro e Outro, desejo, entre outros. E nesse mesmo enfoque psicanalítico discorre sobre os significantes que permeiam a educação: criança, escola, educação, família e deficiência.

O capítulo IV tratou da pesquisa na sua construção metodológica, desde o delineamento dos objetivos e hipóteses até a definição dos instrumentos e procedimentos de coleta e análise de dados.

No capítulo V, realizamos a apresentação e análise dos casos estudados, com base nos registros de prontuário, observações dos sujeitos e relatos das mães nas entrevistas, o assinalamento dos elementos significativos organizados por temas e ainda o aprofundamento de análise interpretativa de um dos casos com reflexões à luz do referencial teórico desta tese.

Por último, nas Considerações Finais, articulamos os dados analisados com os objetivos, hipóteses e questões que instigaram e nortearam a pesquisa, fazendo referências às suas contribuições, limites e abertura a novas investigações. 


\section{CAPÍTULO I - DISCUTINDO E CONTEXTUALIZANDO O TEMA DA INCLUSÃO EDUCACIONAL E ESCOLAR DA CRIANÇA COM DEFICIÊNCIA}

O presente capítulo apresenta o estado da questão sobre a inclusão educacional e escolar da criança com deficiência, resgatando as raízes históricas e os paradigmas da Educação Especial e da Educação Inclusiva. Discute os conceitos de deficiência desde os modelos médico e educacional e propõe a interdisciplinaridade na abordagem do assunto. Discute também o papel da escola e do professor, bem como a atuação da família e da instituição especializada na parceria com a escola para a construção da Educação Inclusiva.

O cenário mundial hoje em termos de políticas educacionais nos países signatários da Declaração Mundial sobre a Educação para Todos, aprovada na Conferência Mundial realizada em Jomtien - Tailândia/1990 -, aponta para uma escola capaz de realizar a inclusão de todas as crianças. Propõe o respeito às diversidades de toda ordem - biológicas, étnicas, culturais, sociais e psicológicas - garantindo a universalização do ensino básico com qualidade. Mas a escola tem conseguido realizar isso? E efetivamente inclui a quem? Quem são as crianças que têm ficado excluídas do processo de escolarização? Um contingente imenso de crianças que estão dentro da escola ou evadidas porque "não aprendem" - crianças cujo universo cultural e modo próprio de viver e aprender são difíceis de ser compreendidos pela escola.

Historicamente, ao longo do século XIX as crianças com deficiência começaram a ser tratadas em instituições especializadas, quer de orientação clínica, quer educacional. Mas para elas a escola comum, ainda hoje, é um espaço pouco acessível, um caminho a ser construído e essa realidade revela a identidade de uma sociedade - refletida na família e na escola - que se pauta pela homogeneidade, por estereótipos e preconceitos fortemente enraizados nas crenças sociais como formas alienadas do saber, o que significa um saber prévio que não leva em conta o sujeito - que não é visto além da sua limitação no organismo. Uma transformação dessa realidade deverá implicar a existência de paradigmas marcados por conceitos, crenças e valores de aceitação da diversidade humana. Nesse sentido fica claro que, ao falarmos de educação escolar inclusiva como uma das faces da inclusão social, não convocamos apenas a escola a (re)significar seu papel, mas toda a sociedade (Cf. MRECH, 1999).

A inclusão das crianças com deficiência na escola comum é fruto do momento sóciohistórico que vivemos. O tempo é marcado por e marca os processos históricos e sociocultural 
vividos nas relações entre seus protagonistas e as instituições que representam. Exige mudanças da sociedade: uma revisão do lugar social que cada um ocupa, inclusive do ponto de vista econômico e político, para sobrevivência do próprio sistema. É dever estar atento às resistências que, como diz Mrech (1999), diminuem o status científico e teórico-prático desse mais recente paradigma apresentado à Educação. Não pode correr o risco de converter-se apenas em mais uma reforma educacional superficial e inócua.

Muitas vezes nos equivocamos ao considerar que práticas anteriores no atendimento à criança com deficiência no espaço escolar poderiam tratar-se de inclusão, mas com outra designação - no caso a de integração - como se apenas houvesse mudado de nome ao longo do tempo. Porém, um nome/significante não surge sem uma demanda, um desejo que o prepara e dá curso a uma história, criando-a e recriando-a incessantemente. Mudar nomes em decorrência de movimentos sociais, não é criar modismos - embora muitas vezes esses nomes se desgastem antes mesmo de serem assimilados - mas é mudar conceitos, valores, atitudes, instituições, no sentido da conseqüência de mudanças de paradigmas como refere Kuhn (1978) acerca das revoluções científicas e sociais. Somos responsáveis pelas mudanças que nós mesmos engendramos diante das necessidades que vivemos.

O tema inclusão escolar em geral exige essa responsabilização porque trata a todo o momento de tomada de posições. É preciso, então, discuti-lo contornando-o e olhando-o sob vários ângulos, tentando escapar do risco de cair no esvaziamento de seus sentidos, como o faz a sociedade toda vez que é chamada a tratar de seus problemas mais contundentes. Pois, nesses casos a sociedade tende a negar o problema, ampliando tanto sua discussão, que o generaliza e o dilui justamente pela dificuldade de enfrentá-lo, enfraquecendo o debate e mascarando as soluções. Como generaliza, não vê o específico de cada grupo social e não se compromete com as causas que geraram sua exclusão, sendo que os aspectos fundamentais da inclusão - vale dizer social, pois inclusão é, antes de tudo, inclusão social - são justamente ver o individual no coletivo e considerar as diferenças dentro do princípio da igualdade para propor programas, estratégias e recursos que atendam suas particularidades.

Ao generalizar, no caso específico da criança com deficiência, desaparecem a Educação Especial e os recursos próprios e imprescindíveis ao atendimento das necessidades específicas decorrentes da deficiência. Na Educação Inclusiva, ao pensar o geral, temos que nos ver com cada um dos sujeitos do processo (o aluno com deficiência, a família, os alunos sem deficiência, os professores, os técnicos e outras pessoas da escola) e, ao considerar o particular, temos que vê-lo novamente no coletivo, pois muito do que podemos considerar 
individual deve ser lançado ao coletivo para que não nos enganemos com as velhas formas discriminatórias.

A inclusão educacional e escolar é um processo de responsabilização de todos na aceitação e na forma de abordagem da diversidade - sociedade civil, governamental e a própria pessoa com deficiência. Esta, lesada por uma condição social injusta, acostumada à comiseração e ao abandono, ou ao esforço pessoal de atender à demanda social de superação diária das suas dificuldades, experimenta, via de regra, um sofrimento psíquico provocado pela vivência de não fazer parte e não ter voz própria, adquirindo uma desvalorização de si mesmo e uma postura também de não responsabilização e posicionamento frente à discriminação.

A demanda de que a pessoa com deficiência execute atividades previstas por um referencial padrão resulta em avaliações regidas pelas idéias da incapacidade e do déficit, ficando a pessoa sempre em defasagem no seu desempenho. Há também uma idéia generalizada sobre as pessoas com deficiência, o que facilita o aparecimento dos estereótipos que regulam as relações na sociedade contemporânea.

Como diz Mrech (1999), na sociedade atual a imagem está acima do sujeito - a sociedade do estereótipo favorecendo as estruturas de alienação no saber. Estas se constituem em "sistemas simbólicos pelos quais a sociedade fornece aos sujeitos um código geral de ações predeterminadas - formas do saber estereotipado que perderam o efeito de possibilitar um contato real entre os sujeitos" (p. 35). É uma sociedade que exclui as diferenças e a singularidade, onde imperam a semelhança, o grupo e a padronização de comportamentos, atitudes, crenças e ideais; formas de ver o mundo a partir de concepções prévias de como as pessoas devem pensar e agir, de acordo com os modelos, gerando preconceito e não deixando falar a verdade dos sujeitos, construindo a exclusão.

A transição para uma nova visão que inclua a todos deverá passar por uma transformação coletiva de verdadeira abertura para estar disponível àquele e àquilo que se apresenta, sem formas prévias de julgamento e não recear aproximar-se para conhecer e situar-se na busca das possibilidades. Inclusão educacional e escolar é primeiramente uma mudança de olhar e de atitude de toda a comunidade sobre a deficiência ou qualquer outra diferença entre os seres humanos que ali estão.

Particularmente no processo de escolarização da pessoa com deficiência, a inclusão escolar não pode ser o simples ingresso do aluno na classe comum, sem apoio especializado 
para ele e para os professores no atendimento às necessidades específicas e sem o trabalho coletivo de solidariedade e respeito nas relações interpessoais que deve implicar todas as pessoas da escola. É preciso que as pessoas possam aprender umas com as outras, apesar de seus modos diferenciados de construir o conhecimento e adquirir habilidades e competências. É preciso apostar nas possibilidades e descobrir caminhos que levem cada aluno ao aprendizado; é necessário também investir em si e nas pessoas para realização do seu potencial e valorizar seu repertório cultural; é preciso exercitar a reflexão constante sobre a prática pedagógica que viabilize ao aluno a próxima zona de desenvolvimento (Cf. VYGOTSKY, 1984). É absolutamente necessário ousar na criação de novas formas de abordagem do aluno, de estratégias de aula e do conteúdo no ato de ensinar e aprender. No caso do aluno com deficiência, como frisou esse autor em seus estudos sobre defectologia (o estudo das deficiências), é preciso buscar caminhos alternativos e prover recursos especiais.

Tudo isso está ao alcance da escola, mas essa prática inovadora, que atenderia às necessidades de quem a freqüenta hoje, ainda é difícil, pois depende de uma decisão de abertura pessoal, de uma ética e de questões ideológicas, políticas e econômicas anteriores às estratégias pedagógicas.

É importante destacar ainda que a questão da inclusão educacional e escolar das crianças com deficiência nasceu no final do século XX no cerne das preocupações da Educação Especial, quer seja pela segregação sofrida por essas pessoas na sociedade, quer pelo não atendimento às suas necessidades específicas decorrentes da própria deficiência. Partindo da Educação Especial como lugar legítimo dessa discussão, faz-se necessária uma exposição sobre o conceito filosófico, as raízes históricas e o surgimento aí nesse campo como objeto que foi passando, como diz Bourdieu (1989), de um problema privado a um problema público e se transformando numa luta científica de um lado e política de outro.

Mas um assunto tão complexo, que não impressione apenas como carta de intenções e princípios (Cf. DIBET, 2004), remonta também à própria história da Educação em nossa sociedade e exige uma discussão acerca dos significantes inscritos nela: educação, escola, criança, família e também os conceitos de deficiência que foram se alterando ao longo do tempo. Assim, é preciso discutir sobre o que é educar na família e na escola; as origens sóciohistóricas da escola que temos (como se estruturou, para quem ela foi pensada e a quem ela serve); que concepção de criança advém daí; e o que dizer da criança com deficiência nesta sociedade, nesta escola e nesta família. 


\section{AS RAÍzES HISTÓRICAS E OS PARADIGMAS DA EDUCAÇÃO ESPECIAL E DA EDUCAÇÃO INCLUSIVA}

$\mathrm{Na}$ história da humanidade foram várias as formas de entendimento, tratamento e atitudes assumidas pela sociedade leiga e científica em relação às pessoas com deficiência ou com transtornos psíquicos. Da sentença de morte na Antigüidade à explicação e proteção divinas da Idade Média, ao atendimento à saúde e à educação na Modernidade, à defesa do direito humano de respeito à diversidade - ainda permeada por imagens fantasiosas que na maioria das vezes se sobrepõem à pessoa - e à luta pela interdisciplinaridade na atualidade, a questão da deficiência vem avançando nos últimos dez anos mais do que em séculos. É importante compreender essas passagens que levaram ao nascimento da Educação Especial e bem mais tarde à Educação Inclusiva.

\subsection{O nascimento da Educação Especial a partir de um modelo médico de tratar} e educar: o paradigma da segregação

É somente no final do século XVIII e começo do século XIX, na Europa, que surgem as instituições especializadas, dando início à educação das pessoas com deficiência, após terem sido por longo tempo asiladas. Tais instituições se caracterizaram pelo caráter assistencialista e pelo modelo médico de atendimento que reduzia ao orgânico a questão da deficiência, modelo este assumido também nas concepções inatistas, condutistas e psicométricas da Psicologia, bem como da Educação, perdurando até meados do século XX (Cf. MASINI, 1993).

A história da Educação Especial é uma história de "encontros entre tratamento e educação das crianças especiais”, como diz Kupfer (2001, p. 41). Podemos afirmar que, embora tenha havido sempre o predomínio do campo médico sobre os campos psicológico e educativo, ao se pensar o tratamento se enveredou pelas estratégias do educar; e quando se passou a educar, descobriu-se que se estava tratando. Do que se trata quando educamos veremos em um capítulo posterior.

A Educação Especial nasceu dentro da experiência médica, com grande preocupação diagnóstica, o que levou os especialistas da época a estabelecerem as primeiras classificações 
no campo da deficiência/doença mental e ao mesmo tempo orientar métodos educacionais. Com o passar do tempo, essa modalidade da Educação sofreu as influências das mudanças teórico-práticas da Psicologia, do advento da Psicanálise e sua aplicação e das correntes filosóficas contemporâneas que impulsionaram deslocamentos nas concepções da relação homem-mundo, criança-escola (Cf. KUPFER, 2001).

Os médicos-professores responsáveis pelo início dos tratamentos e métodos educativos das crianças com deficiência, entre eles Esquirol, que diferenciou confusão mental ligeira, loucura e idiotia (nomenclatura da deficiência mental na época); Seguin, que ampliou a categoria de idiotia para imbecilidade e debilidade mental, definindo suas etiologias, defendendo a importância do diagnóstico médico e introduzindo a idéia de indivíduo educável; e ainda Itard, que não concordando com o diagnóstico de idiotia dado a Victor (o “selvagem de Aveyron"), fez sua avaliação e lançou os princípios de como educar o deficiente mental (Cf. MASINI, 1993).

Por esses exemplos vemos que o avanço do conhecimento científico e de outras produções da cultura é cunhado na transgressão de quem se abre para o novo e assim descobre caminhos importantes para o entendimento e construção de novos paradigmas.

Kupfer (2001), reportando-se à história da Psiquiatria, também faz referência a esse especialista em surdos-mudos que, ao tomar para si a incumbência de educar uma criança mesmo quando esta tinha sido desacreditada em sua capacidade para aprender e conviver em sociedade, acreditou que ensinava Victor a se tornar humano e supunha que ali havia um sujeito. Considerou que a criança era idiota por não ter tido a convivência social, pois fora abandonada no bosque, e não que fora abandonada por não se adaptar à vida social. Considera-se que está presente nesse início da Psiquiatria Infantil a possibilidade da educação da criança com transtornos graves de desenvolvimento decorrentes do trabalho de Itard (apud MASINI, 1993): uma linha voltada ao adestramento e outra à humanização.

Porém, nem o mais revolucionário extrai do nada sua obra e não há ciência nem educação neutras.

Itard já era fruto de um novo ideal educativo que vinha se instaurando desde o século XVII, com o surgimento da escola e de um novo conceito de infância, para atender aos anseios de uma nova classe social: a burguesia. Ideal este presente até hoje - disciplina, proteção, segregação (Cf. KUPFER, 2001) - que atende uma elite econômica e política, sobre o que falaremos mais adiante. 
Dando curso à história da Educação Especial, paralelamente aos asilos - lugar de alimentação e abrigo, mas também de abandono para os deficientes, idosos e doentes - as crianças com deficiência começaram a ir para as escolas segregadas, o que representou um avanço na época, pois, além de serem tratadas, a sociedade passou a reconhecer que elas também poderiam ser produtivas e escolarizadas. Baseadas na classificação médica das crianças por tipo de deficiência a partir de parâmetros orgânicos e constitucionais, agrupandoas somente entre iguais, desconsiderando inclusive as diferenças individuais, surgiram no século XIX as escolas especiais para cegos, para surdos, para deficientes mentais. Foi instituído o paradigma da segregação que será levado até a década de 60 do século XX e não restrito apenas à escola. De acordo com Silva (1987), muitas instituições especializadas nas várias deficiências surgiram nessa época para promover habilitação e reabilitação, esporte e lazer especiais, oficinas ocupacionais protegidas, tudo que os deficientes "não podiam" realizar entre as pessoas comuns da sociedade.

A perspectiva da educação para cegos surge nessa época com a primeira escola de cegos - o Instituto Real dos Jovens Cegos de Paris - criada por Valentin Haüy em 1784, que desenvolveu um sistema de escrita dos caracteres comuns em relevo. Em seguida, em 1834, Luis Braille, um jovem cego, criou um sistema muito mais eficiente de escrita e leitura por pontos em relevo - o sistema Braille. Tal sistema foi o primeiro instrumento de independência das pessoas cegas e as escolas foram surgindo por toda Europa e Estados Unidos (Cf. LOWENFELD, 1950).

No Brasil, tivemos a influência européia na educação das pessoas cegas, por meio de um jovem cego, José Álvares de Azevedo que, ao retornar de seus estudos no Instituto de Paris, passou a ensinar Braille à filha de um médico da Corte Imperial. Por intermédio deste e do Barão do Rio Bonito, Álvares de Azevedo é recebido pelo Imperador D. Pedro II, a quem demonstrou a técnica que permitia aos cegos ler e escrever. O episódio ficou marcado com uma frase célebre de D. Pedro II: “a cegueira (...) quase já não é uma desgraça”, levando o imperador a inaugurar, em 1954, a primeira escola de cegos no Brasil - o Imperial Instituto de Cegos, hoje Instituto Benjamin Constant (LEMOS, 2000 p. 13).

Na primeira metade do século XX foram criadas outras escolas, no mesmo sistema de internato: o Instituto São Rafael (1926 - Belo Horizonte), Instituto Padre Chico (1928 - São Paulo), Instituto de Cegos da Bahia (1929 - Salvador), Instituto de Cegos do Ceará (1934 Fortaleza), Instituto Santa Luzia (1941 - Porto Alegre) e Instituto de Cegos Florisvaldo Vargas (Campo Grande - 1957) (). 
A análise do paradigma da segregação revela sua sustentação em um olhar lançado sobre o distúrbio, a doença, a deficiência - o modelo médico sobre o qual teceremos maiores comentários adiante.

Em outras áreas também se encontra reproduzido o mesmo histórico sustentado pelo mesmo modelo. Masini (1993), resgatando a história da Psicopedagogia, nos remete ao surgimento também, entre os anos 40 e 60 na França, dos Centros Psicopedagógicos (na realidade médicopedagógicos) para atender a crianças com problemas escolares e com distúrbios de comportamento, cuja ação do educador permanecia embasada no diagnóstico médico e nos testes de inteligência muito valorizados na Psicologia da época.

\subsection{Os movimentos de ruptura do século $\mathrm{XX}$ e o paradigma da integração}

Um pouco antes, no início da década de 30, com a veiculação de um novo saber - a Psicanálise - iniciam-se vários tratamentos para crianças psicóticas. E é nos anos 40 que Maud Mannoni (1973), psiquiatra e psicanalista, inicia um trabalho com "esses seres a que se dá o nome de anormais, pervertidos ou loucos" a partir de uma formação essencialmente prática e impelida por um saber que ela denomina inconsciente ao explicar que o iniciou antes mesmo do ensino universitário. Vinte anos depois deflagra uma "abertura para a antipsiquiatria" (p. 11), assumindo, como ela mesma declara, uma leitura estritamente lacaniana da Psicanálise.

Mas Mannoni já tinha um caminho próprio antes de encontrar Lacan e conseguiu fazer do encontro da Psicanálise com a Educação um dos marcos da história da educação das crianças com transtornos graves no desenvolvimento. De sua experiência em uma instituição médico-pedagógica, na qual percebia que a Psicanálise estava também se institucionalizando (no sentido de fechamento), passou à experiência de uma instituição aberta (estourada, como a chamou), cuja prática foi inspiradora de outros "lugares de vida" (Ibid.). Sobre isso trataremos em capítulos posteriores.

Por essa trajetória de ruptura com um modelo médico na Educação de crianças e jovens com deficiência, psicóticos ou com outros desajustes, por colocar amplamente o debate sobre o encontro da Psicanálise com a Educação, é que Mannoni é considerada uma das grandes referências quando se considera que a Psicanálise está na raiz da Educação Inclusiva. Fundamentalmente porque a Psicanálise subverteu a noção de sujeito psíquico. O sujeito é 
uma construção social para além do seu organismo e não está circunscrito à cognição. A Psicanálise vem justamente introduzir um conceito que leva a Ciência a pensar em um sujeito que se encontra em outra instância que não na consciência - o conceito de inconsciente. A Psicanálise referida por Mannoni, ao mostrar a existência do inconsciente nos processos psíquicos, questiona as proposições médico-pedagógicas impostas à compreensão da infância e da deficiência (Cf. MRECH, 1999).

Assim, Mannoni (1981) vai estruturar seu trabalho baseada nesse pressuposto fundamental, buscando a criança nos dramas familiares e no discurso e olhar dos pais sobre ela. Diz a autora acerca do trabalho com a criança com deficiência mental ou aquelas desviadas em sua constituição de sujeito:

Para mim não se trata de encontrar uma nova causa do atraso, e também não se trata de fazer um diagnóstico mais rigoroso. Esforçome muito simplesmente por ir além duma etiqueta que foi o ponto de partida da cristalização da angústia familiar... Não procuro reintroduzir uma classificação diferente. Antes, pelo contrário, limitome, partindo dum veredicto, a pô-lo em causa... A pergunta que faço a mim mesma não é: será débil ou não? É antes da ordem seguinte: que há de perturbado ao nível da linguagem (na relação mãe-filho) que se exprime por uma via afastada, paralisando o indivíduo no estatuto social que lhe foi conferido, paralisando a mãe no papel que ela se atribuiu a si própria? (Ibid., p. 40-41).

A autora revelou ainda que "a criança com deficiência é muito maior que o quadro clínico onde nós tentamos encaixá-la” (MRECH, 1999, p. 5).

Ao fazermos referência à Psicanálise de Lacan e aos estudos de Mannoni acerca da deficiência mental e da psicose, vamos nos aproximando do referencial teórico que será o fundamento deste trabalho, o qual discutiremos no capítulo que abordará a criança cega com problemas graves na constituição de sujeito e no desenvolvimento.

Após a II Guerra Mundial, o mundo encaminhou uma ampla discussão sobre direitos humanos, resultando na Declaração dos Direitos Humanos, em 1948, pela Organização das Nações Unidas (ONU) e em movimentos sociais de vários segmentos com a participação massiva do meio universitário. Iniciados na França dos anos 60 e disseminados por todo o mundo, esses movimentos, ao pregarem direitos civis e educativos a todas as pessoas, revelaram o caráter reacionário da Educação até então baseada em processos elitistas e 
estigmatizadores. Faz-se necessária em um novo tempo uma nova escola. Nasce então uma Pedagogia revolucionária denominada Pedagogia Institucional (Cf. MRECH, 1999).

Em Paris, como nos grandes centros da América Latina, nessa época a escola já dava sérios sinais de problemas como o analfabetismo crescente e rendimento escolar baixo. Os representantes da Pedagogia Institucional, Vasquez e Oury, em 1967, passaram a denunciar de um lado a escola e de outro os centros medicopedagógicos que, em seus métodos tradicionais de avaliar, testar e rotular, criavam sistemas aos quais o aluno deveria submeter-se silenciosamente, ou reeducar-se caso "desobedecesse", para estar de acordo com o que a sociedade esperava dele, não permitindo que sua voz fosse ouvida e o contexto da escola analisado. Os autores trouxeram para a Psicologia e a Educação questionamentos importantes que se consagraram como marcos teórico-práticos no tratamento e na educação daquelas crianças que não se adaptavam à escola e à sociedade, às quais médicos, psiquiatras e psicólogos recomendavam métodos especiais. Eles propuseram tirar a Pedagogia do lugar ingênuo de reprodutora da situação socioeconômica e cultural dominante e apropriar-se do rigor que a levaria ao status de ciência (Cf. VASQUEZ e OURY, 2001).

A Pedagogia Institucional revelou, portanto, o caráter da escola como "um incomparável instrumento de pressão ideológica" (Ibid., p. 12), a cisão entre teoria e prática e a falta de responsabilidade de ver-se como uma instituição que já não atendia à clientela que a freqüentava.

Neste contexto, um grupo intitulado Situacionistas Internacionais, inspirados em autores como Lacan na Psicanálise e Wallon na Psicologia, cunharam um novo conceito em Educação: o de situação. Este tratou de não mais considerar o sujeito isolado do contexto social e da situação na qual está colocado, entendendo que esta pode favorecer ou não o seu desenvolvimento. Este grupo foi muito importante na Revolução de Maio de 1968, que levou a todo o mundo "uma nova forma de ver a cultura e a Educação" (MRECH, 1999, p. 6), reforçando também a visão da Pedagogia Institucional.

Enquanto isso, nessa famigerada década de 1960, a Educação das pessoas com deficiência ainda vivia o seu modelo segregado das escolas especiais, sobre as quais também incidiram descontentamentos. Os reflexos dos avanços no conhecimento sobre a saúde mental e as deficiências e dos movimentos sociais de questionamentos sobre a Educação Geral, descritos acima, atingiram a Educação Especial provocando mudanças de ordem conceitual, administrativa e legislativa. Surgiu nos países nórdicos, se estendendo por toda Europa e Américas, fundamentalmente discutido pelas organizações representativas da deficiência 
mental, o conceito de normalização. Este pretendeu tirar a pessoa com deficiência da situação de isolamento e tornar sua vida diária o mais próxima possível das condições consideradas habituais em uma determinada sociedade ou meio social (Cf. NIRJE, 1969).

A partir daí a Educação Especial começa a trilhar um caminho em uma direção mais socializante. É o paradigma dos anos 70 - o da integração - que viria a "inserir as pessoas portadoras de deficiência nos sistemas sociais gerais como a escola, o trabalho, a família e o lazer" (SASSAKI, 1997, p. 31).

Este representou um avanço para a educação das crianças com deficiência, abrindo as escolas regulares para sua integração na sala de aula comum. Mas essa inserção acabou por ser parcial, pois estava condicionada às possibilidades dos alunos, sendo eles quem deveriam se adaptar à estrutura da escola e estar preparados para integrar-se a ela. Sustentava-se, mais uma vez, na forma seletiva, deixando em salas separadas - as salas especiais - os que não se colocavam no padrão de desempenho exigido. Acabou sendo regido pelo princípio da normalização no sentido desvirtuado. Este paradigma ainda responsabilizou os deficientes por seus próprios problemas, um modelo cujo foco permaneceu na deficiência, no déficit. Nesse modelo, quem sabe do que lhe falta é o especialista e a pessoa com deficiência não é ouvida (Ibid.).

O paradigma da integração, portanto, permaneceu atrelado à concepção "funcionalista de educação que entende a formação do homem como sendo determinada pela sociedade já estruturada, à qual ele deve adaptar-se" (MASINI, 1993, p. 15).

Esse paradigma cruzou em seu tempo com um outro movimento social dos mais importantes no século XX: a luta antimanicomial, pela desinstitucionalização das pessoas com doença mental. Sua atitude política era devolver à sociedade e à família a responsabilidade de propiciar-lhes uma vida mais digna na convivência em ambientes comuns a todas as pessoas, tratando a doença mental não só como um quadro psicofisiológico, mas como algo cunhado no social. Esse movimento viria provocar fundamentalmente uma reestruturação nas instituições, obrigando-as a verem-se com essa questão (Ibid.). Portanto, o princípio da normalização está implicado também nessa luta e se cruza com a desinstitucionalização das pessoas com deficiência das escolas residenciais e dos asilos.

Porém, o que vai estourar o paradigma da integração social é justamente o conceito de normalização por ter se desvirtuado como já foi explicitado acima. Mas está em curso na 
década de 80 um outro princípio que procurou avançar nessa conquista: o mainstreaming. Esse termo significa:

(...) levar os alunos com deficiência o mais possível para os serviços educacionais disponíveis na corrente principal da comunidade... "pode ocorrer em classes regulares, durante o almoço, em matérias específicas (como música, artes e educação física) e em atividades extracurriculares" (SASSAKI, 1997, p. 32).

Todos os princípios adotados até aqui para efetivar a integração do aluno com deficiência na escola regular representaram tentativas de ações que buscassem cada vez mais coerência e efetividade na direção de mudar as concepções e as formas estigmatizadoras de tratar a questão da deficiência. Todavia, só lograram êxito com aquelas crianças e jovens que conseguiam acompanhar os currículos e as atividades escolares comuns sem que a escola tivesse que se modificar.

Certamente, se tivermos uma visão histórica, a sociedade teve avanços significativos na luta pelos direitos da pessoa com deficiência, incluindo a sua participação no sistema educacional regular. Porém, não foram suficientes para acabar com a discriminação em relação a elas e lhes proporcionar a participação plena nesta sociedade, inclusive no espaço educacional e escolar.

Ainda de acordo com Sassaki (1997), a integração social:

(...) consistiu no esforço de inserir na sociedade pessoas com deficiência que alcançaram um nível de competência compatível com os padrões sociais vigentes. A integração tinha e tem o mérito de inserir o portador de deficiência na sociedade, sim, mas desde que ele esteja de alguma forma capacitado a superar as barreiras físicas, programáticas e atitudinais nela existentes. Sob a ótica dos dias de hoje, a integração constitui um esforço unilateral tão somente da pessoa com deficiência e seus aliados (a família, a instituição especializada e algumas pessoas da comunidade que abracem a causa da inserção social), sendo que estes tentam torná-la mais aceitável no seio da sociedade (Ibid., p. 34).

Essa mesma forma de ver e se posicionar frente às pessoas com deficiência e suas necessidades se deu no contexto educacional escolar. 
No Brasil, a integração educacional escolar das pessoas cegas tem início com a criação, em 1946, da Fundação para o Livro do Cego no Brasil, hoje Fundação Dorina Nowill para Cegos, pioneira na impressão do livro em Braille, no atendimento em reabilitação e na luta pela entrada de pessoas cegas na escola pública. Foi também a primeira a qualificar professores especializados para atuar no sistema comum do ensino regular público e integrar os alunos cegos. Assim, serão criadas as chamadas salas de recursos (1950 em São Paulo, na Escola Estadual Caetano de Campos e 1957, no Rio de Janeiro). Seguiram-se na própria Caetano de Campos os cursos em nível de Magistério para formação de professores especializados em deficiência visual até 1971 (Cf. LEMOS, 2000). Após alguns anos, aguardando regulamentação, tais cursos passaram a ser ministrados em nível superior em toda a América Latina. Assim, a formação passou a ser uma habilitação dos cursos de Pedagogia instalados na década de 70 na UNESP de Marília e na Faculdade do Carmo, em Santos e na década de 80 na USP, em São Paulo e na Faculdade de Educação do Paraná.

Hoje, no Estado de São Paulo, resta apenas o curso da UNESP, deixando uma grande lacuna nessa formação, lacuna esta que as instituições especializadas têm procurado suprir.

\subsection{A emergência do paradigma da inclusão social como sustentação da}

\section{Educação Inclusiva}

Em 1981 a ONU lançou o Ano Internacional das Pessoas Deficientes, cujo tema foi a participação plena na sociedade e igualdade de oportunidades, fazendo com que alguns segmentos da sociedade (as pessoas com deficiência e seus familiares, profissionais especializados, acadêmicos, legisladores), em muitos países do mundo, viessem a mudar o enfoque da luta pelos direitos da pessoa com deficiência à participação efetiva na sociedade: que a sociedade se adaptasse às pessoas com deficiência e não estas a ela. As conquistas avançaram a partir dessa discussão levando, no final dos anos 80, à emergência do conceito de inclusão aplicado a sistemas sociais fundamentais como a saúde, a educação, o trabalho e o lazer na vida da pessoa com deficiência (Cf. SASSAKI, 1997).

Particularmente no campo da Educação, em 1983 a ONU reafirmou tais ideais no Programa Mundial de Ação Relativo às Pessoas com Deficiência, cujo preceito era o de que toda sociedade deveria incorporar no planejamento geral e na estrutura administrativa medidas que viabilizassem a educação das crianças e jovens com deficiência no sistema 
escolar comum. Esse mesmo preceito estará embutido na Declaração Mundial de Educação para Todos aprovada pela ONU em 1990 na Conferência Mundial que ocorreu em Jomtien, na Tailândia, em um contexto de preocupação com as taxas cada vez maiores de repetência e evasão escolar em todo o mundo (Cf. SASSAKI, 1997).

O impacto desse paradigma na inclusão educacional e escolar se traduz pela universalização do acesso de todos à educação básica como um direito; pelo compromisso da melhoria da qualidade do ensino que atenda à diversidade e às necessidades específicas de cada pessoa dentro da escola; pela eliminação de preconceitos e estereótipos em relação aos grupos excluídos do processo educativo - população de rua, das periferias urbanas e zonas rurais, migrantes, indígenas, minorias étnicas, raciais e lingüísticas, pessoas com qualquer tipo de deficiência. Esse documento, dos mais importantes no século XX, resgatou o que já estava previsto no relatório da UNESCO de 1968, o qual estabelecia a proposta educacional mundial de educação para todos. Essa política mundial culminou na Declaração de Salamanca, na Espanha, em 1994, particularmente no que diz respeito às pessoas com deficiência (Cf. MRECH, 1997).

Essa declaração, representando 88 governos (sendo o Brasil um dos seus signatários) e 25 organizações internacionais, proclamou princípios de direitos à educação para crianças, jovens e adultos com deficiência; congregou governos a estabelecerem leis, políticas e orçamentos e a adotarem práticas que garantissem educação inclusiva e escolas inclusivas, a partir de uma pedagogia centrada no aluno, oferta dos recursos e apoios especiais voltados às necessidades específicas decorrentes de cada deficiência e formação continuada de professores, além das parcerias imprescindíveis com os serviços especializados e as famílias na avaliação, nas escolhas e na tomada de decisões conjuntas sobre a escola e as ações mais apropriadas. Assim, os pais passaram a assumir as responsabilidades sobre o processo educacional de seus filhos em cada momento de suas vidas. A Declaração introduziu ainda, no contexto dessa estrutura, o termo "necessidades educacionais especiais" que se refere a:

(...) todas aquelas crianças ou jovens cujas necessidades educacionais especiais se originam em função da deficiência ou dificuldades de aprendizagem. Muitas crianças experimentam dificuldades de aprendizagem e portanto possuem necessidades educacionais especiais em algum ponto durante a sua escolarização. Escolas devem buscar formas de educar tais crianças bem-sucedidamente, incluindo aquelas que possuam desvantagens severas (UNESCO, 1994, p. 3). 
E também as idéias de que a Educação Especial assume que:

(...) as diferenças humanas são normais e, em consonância com a aprendizagem de ser adaptada às necessidades da criança, ao invés de adaptar a criança às assunções pré-concebidas a respeito do ritmo e da natureza do processo de aprendizagem. (...) e de que uma pedagogia centrada na criança é benéfica para todos os estudantes e, conseqüentemente, à sociedade como um todo. A experiência tem demonstrado que tal pedagogia pode consideravelmente reduzir a taxa de desistência e repetência escolar... e garantir índices médios mais altos de rendimento escolar (UNESCO, 1994, p. 4).

A Declaração de Salamanca propõe ainda como aspectos fundamentais para a mudança de paradigma o trabalho de envolvimento das universidades, da mídia e da comunidade em geral e fala sobre o mérito das escolas inclusivas:

(...) não reside somente no fato de que elas sejam capazes de prover uma educação de alta qualidade a todas as crianças: o estabelecimento de tais escolas é um passo crucial no sentido de modificar atitudes discriminatórias, de criar comunidades acolhedoras e de desenvolver uma sociedade inclusiva (UNESCO, 1994, p. 3).

Sassaki (1997) conceitua a inclusão da pessoa com deficiência de forma ampla como inclusão social que atinge a todos os sistemas sociais em um processo que requer uma relação de reciprocidade entre a sociedade e a pessoa. Ou seja, um processo pelo qual "a sociedade se adapta para poder incluir as pessoas com necessidades especiais e estas se preparam para assumir seus papéis na sociedade" (p.41).

Certamente, não há como restringir a questão da inclusão apenas a um campo ou outro, uma vez que implica em mudança de paradigma, ou seja, de sistemas de crenças e valores que norteiam atitudes, além de exigir suportes materiais, administrativos e legais. Isso justifica, como diz Mrech (1999), que muitas vezes, ao tratarmos da educação inclusiva, o fazemos de modo geral dentro do conceito de inclusão.

Essa forma de abordar o tema traz implicações positivas quando consideramos que Educação é um sistema social permeado de todas as contingências sociais mais amplas; e negativas quando fazemos a discussão se perder no turbilhão dos problemas sociais gerais como já foi mencionado no início deste capítulo. 
Tratemos, então, um pouco mais do paradigma da inclusão para depois situar a Educação Inclusiva.

O paradigma da inclusão provoca um deslocamento na sociedade sobre a forma de ver as dificuldades de uma pessoa com deficiência como um problema só dela e de sua família. Assim, a sociedade assume sua responsabilidade, reconhece a singularidade de cada um e aprende com as diferenças; não põe em primeiro plano a deficiência, mas a pessoa que tem necessidades específicas; não cobra sua normalização, mas encontra caminhos para que ela desenvolva seu potencial e a valoriza de acordo com suas formas próprias de realização; torna-se mais humana e solidária - uma sociedade para todos -, pois exige que as pessoas e os sistemas nos quais estejam engajadas trabalhem constantemente nos seus mecanismos comportamentais enraizados que escondem preconceitos e visões estereotipadas. A inclusão exige a ética de atentar sempre para dissolver as barreiras de comunicação, de atitudes preconceituosas, de ambientes físicos não adaptados e recursos de apoio não disponíveis e, no caso do compromisso com todas as minorias excluídas, fazer cumprir as leis e declarações de defesa dos direitos humanos.

Ao defender essa posição corremos o risco de sermos considerados românticos e ingênuos, mas é preciso deixar claro que "ninguém mais vai ser bonzinho na sociedade inclusiva”, como alerta Werneck (1997), no título de seu livro acerca do tema da inclusão. Ou não é somente uma questão de ser "politicamente correto" como ressalta Mrech (1999, p. 22).

Uma mudança de paradigma implica muitas mudanças sociais, políticas, econômicas e científicas que vão sendo empurradas, ao mesmo tempo que preparam o mundo para as novas formas de vida como as que a sociedade contemporânea exigiu das estruturas e sistemas e que trouxe, por todo o movimento sócio-histórico relatado até aqui, uma nova condição para a pessoa com deficiência.

A Educação Especial neste panorama está sendo convocada a ocupar outra posição e precisa rever seu papel e sua atuação.

Mantoan (1997) situa o paradigma da inclusão no campo da Educação da seguinte forma: 
noção de inclusão institui a inserção de uma forma mais radical, completa e sistemática. $\mathrm{O}$ vocábulo integração é abandonado, uma vez que o objetivo é incluir um aluno ou um grupo de alunos que já foram anteriormente excluídos; a meta primordial da inclusão é a de deixar ninguém no exterior do ensino regular, desde o começo. As escolas inclusivas propõem um modo de se constituir o sistema educacional que considera as necessidades de todos os alunos e que é estruturado em virtude dessas necessidades. A inclusão causa uma mudança de perspectiva educacional... (MANTOAN, 1997, p. 145).

Note-se que, mais uma vez, ao se falar de inclusão, agora focada na escola, ainda se fala de incluir todos e não só os alunos com deficiência. Mas a educação inclusiva virou sinônimo de educação dos alunos com deficiência. É comum ouvirmos nas escolas a expressão "um aluno de inclusão", referindo-se a um aluno com deficiência, quando no paradigma da inclusão a pessoa não é mais tratada como deficiente e sim como uma pessoa que apresenta necessidades educacionais especiais e necessidades específicas decorrentes da deficiência. $\mathrm{O}$ termo necessidades educacionais especiais tem sido mal interpretado no sentido de correspondente à deficiência, sendo que qualquer aluno pode apresentar em algum momento uma necessidade especial, uma particularidade, para aprender.

Vamos nos ater ao foco deste trabalho: a inclusão educacional e escolar da criança ou jovem com deficiência, mas vale a pena explicitar um pouco mais o termo necessidades educacionais especiais.

Alguns autores como Bautista (1997), Gallargo e Gallego (1993), Giné (1987), com o livro da Reforma do Sistema Educativo da Espanha, tratados em Ide (1999), discutem o termo necessidades educacionais especiais e o definem, reposicionando também o conceito de Educação Especial, da seguinte forma:

(...) necessidades educacionais especiais como ajudas pedagógicas específicas necessárias para atingir os fins da educação, associando estas ajudas aos recursos humanos, materiais e técnicos, procedentes dos fins educativos... termo mais amplo, geral e propício à integração escolar, fazendo eco às necessidades permanentes ou temporárias dos alunos, não sendo pejorativo... Apresenta relatividade conceitual admitindo, como origem das dificuldades de aprendizagem e/ou desenvolvimento, uma causa não só pessoal, mas também escolar ou social... ao se referir ao currículo, o faz ao currículo do sistema educativo para todos os alunos, fomentando as adptações curriculares... E a Educação Especial deixa de ser uma educação para um tipo específico de aluno, mas é sim um conjunto de recursos humanos e materiais colocados à disposição do sistema educativo regular para que este possa responder de forma adequada às 
necessidades que, de forma transitória ou permanente, possam apresentar alguns dos alunos (IDE, 1999, p. 7-8).

Hoje, após uma década da Declaração de Salamanca, vemos nos Estados Unidos, Europa e América Latina, experiências difundidas que apontam avanços significativos, porém muito ainda há que se caminhar para que a inclusão da pessoa com deficiência na escola revele êxitos, principalmente nos países mais pobres. Não basta, é óbvio, a criança ou jovem estar dentro da escola comum, mas é preciso que eles efetivamente façam parte do ambiente físico e relacional, bem como possam usufruir plenamente dos processos sócio-educativos veiculados neste ambiente. Um ambiente cada vez menos restritivo à possibilidade de desenvolvimento desses alunos.

O Brasil passou também por todos os modelos de atendimento à pessoa com deficiência, desde as Santas Casas de Misericórdia e os asilos às primeiras escolas especiais na época ainda da regência de D. Pedro II, no final do século XIX, seguindo os moldes europeus e depois o norte-americano, durante a proposta integradora nas escolas comuns e públicas, com grandes educadores especialistas analisando e vivenciando os movimentos que levaram muitos de nós a aceitar hoje o desafio da educação inclusiva. A Constituição Brasileira de 1988 reza sobre os direitos da pessoa com deficiência à educação; as leis, as diretrizes e parâmetros curriculares para a Educação Especial são avançadas e essa constitucionalidade favoreceria a realização das mudanças necessárias para ancorar o novo modelo; os serviços especializados, localizados nos grandes centros, cumprem, em pequena escala na proporção deste país, a função do atendimento às necessidades específicas referentes à deficiência, do apoio à família, da capacitação de professores e do apoio ao projeto de inclusão da escola; as universidades formam profissionais e desenvolvem pesquisas e projetos na comunidade com alcance restrito; os órgãos governamentais em nível de secretarias e ministérios cumprem parcialmente o estabelecido na legislação em função das dificuldades de um país de grandes dimensões físicas e heterogeneidade cultural, falta de planejamento e má administração do orçamento. Mais uma vez é preciso enfatizar que é precária, e cada vez mais rara, a formação de professores especializados - o que leva à falta de apoio especializado dentro das escolas e também nos serviços especializados - e a capacitação em serviço dos professores do ensino comum. O preconceito é muito arraigado e a sociedade do estereótipo prevalece. 
Masini (2003) revela dados sobre as tentativas de inclusão escolar do aluno com deficiência no Brasil entre os anos de 1998 e 2002, constatando que:

(...) a Educação não propicia a inclusão sem transformações no contexto das escolas, ao matricular de forma indiscriminada, sem realizar estudos sobre as condições específicas para o atendimento da criança com deficiência e sem o preparo dos professores (...) a escola aceita, mas não se modifica (Ibid., p. 3).

Tais dados nos levam a refletir sobre o fato de que a inclusão educacional e escolar só será feita de modo gradual e depende de mudanças estruturais, pois os problemas vividos pela escola hoje acentuam as dificuldades da inclusão de todos os alunos e, em particular, do aluno com deficiência. Muitas vezes ouvimos nas escolas que "o problema não é o aluno cego, ou deficiente físico... o problema maior do professor são dez ou doze alunos por sala que não aprendem', chegando à quarta série sem estar alfabetizados. São copistas, mas não entendem o que lêem”. Sabemos hoje que esta situação não é privilégio do Brasil.

É preciso destacar ainda que já conhecemos no Brasil algumas ações educacionais inclusivas de grande valor. O Projeto Escola Viva do MEC documentou em vídeo algumas delas (no Rio Grande do Norte, Ceará e Bauru, no Estado de São Paulo, entre outras). Nas visitas que fazemos a escolas da rede municipal e estadual da cidade de São Paulo e municípios vizinhos também encontramos algumas escolas que estão realizando trabalhos consistentes nessa direção. Porém, representam experiências de importância local, mas incipientes ainda do ponto de vista de políticas públicas e práticas eficazes e consolidadas. Os problemas de formação dos professores, de recursos necessários à deficiência visual e de atitudes de não aceitação ainda são muito fortes.

Vale a pena ressaltar um trecho da Declaração de Salamanca (Cf. UNESCO, 1994) que denuncia a contradição entre o que se deseja e a realidade que temos hoje, mas que também anuncia uma convicção, uma utopia no sentido de algo que está em nenhum lugar (Cf. FERREIRA, 1986), mas que nem por isso nunca estará:

Princípio fundamental da escola inclusiva é o de que todas as crianças devem aprender juntas, sempre que possível, independentemente de quaisquer dificuldades ou diferenças que elas possam ter. Escolas inclusivas devem reconhecer e responder às necessidades diversas de seus alunos, acomodando os estilos e ritmos de aprendizagem e 
assegurando uma educação de qualidade a todos através de um currículo apropriado, arranjos organizacionais, estratégias de ensino, uso de recurso e parceria com as comunidades. Na verdade, deveria existir uma continuidade de serviços e apoio proporcional ao contínuo de necessidades especiais encontradas dentro da escola (UNESCO, 1994, p. 5).

A tendência em política social durante as duas últimas décadas tem sido a de promover integração e participação e de combater a exclusão. Inclusão e participação são essenciais à dignidade humana e ao desfrute e exercício dos direitos humanos. Dentro do campo da educação, isto se reflete no desenvolvimento de estratégias que procuram promover a genuína equalização de oportunidades. Experiências em vários países demonstram que a integração de crianças e jovens com necessidades educacionais especiais é melhor alcançada dentro de escolas inclusivas, que servem a todas as crianças dentro da comunidade. É dentro deste contexto que aqueles com necessidades educacionais especiais podem atingir o máximo progresso educacional e integração social. Ao mesmo tempo em que escolas inclusivas provêem um ambiente favorável à aquisição de igualdade de oportunidades e participação total, o sucesso delas requer um esforço claro, não somente por parte dos professores e dos profissionais na escola, mas também por parte dos colegas, pais, famílias e voluntários. A reforma das instituições sociais não constitui somente uma tarefa técnica, ela depende, acima de tudo, de convicções, compromisso e disposição dos indivíduos que compõem a sociedade (Ibid., p. 4).

A escola inclusiva, portanto, suscita questões de mudanças muito profundas da sociedade. Assim, discutir inclusão educacional e escolar para as pessoas com deficiência implica discutir ainda o conceito de deficiência de acordo com os modelos médico e social, bem como discutir questões sociais mais amplas que atingem a escola e seu papel neste contexto da sociedade atual. Implica discutir, fundamentalmente, que escola e que professor temos hoje, discutindo sob um outro enfoque essa "utopia" de uma escola mais justa e solidária que atenda a todos e a cada um em sua singularidade, o que faremos mais adiante.

\subsubsection{Os conceitos de deficiência e a proposta de diálogo entre as disciplinas}

As conceituações teórico-práticas nas áreas de conhecimento que estudam a questão da deficiência nem sempre encontram consenso nas definições, terminologias e abordagens utilizadas entre os especialistas. Tais divergências, ou diferenças, dificultam a veiculação de 
informações e a compreensão e aplicação dos conhecimentos desenvolvidos nesse campo. Isso ocorre com o conceito de deficiência que veio sofrendo transformações nas áreas da saúde e da educação de acordo com as demandas sociais e científicas de cada momento histórico.

$\mathrm{Na}$ área da Saúde, as doenças foram catalogadas e codificadas, de acordo com o modelo etiologia - patologia - manifestação, pela Organização Mundial da Saúde (OMS) que, em 1920, organizou a Classificação Internacional das Doenças (CID). A cada revisão tal classificação foi se alterando até passar a fazer referência, em 1948, às doenças que poderiam vir a se tornar crônicas, às evolutivas e irreversíveis, como também colocar em questão, em 1970, o modelo que não considerava as conseqüências de tal classe de doenças, levando, em 1976, a uma nova conceituação - International Classification of impairments, disabilities and handcaps: a manual of classification relating to the consequences of disease (ICIDH). Esta só foi traduzida em 1989 - a Classificação Internacional de Deficiências, Incapacidades e Desvantagens: um manual de classificação das consequiências das doenças (CIDID). Assim, unificou-se em muitos países um referencial para o diagnóstico, avaliação e tratamento médico e de reabilitação, como também serviu de parâmetro para fins de seguro social, saúde ocupacional e concessão de benefícios (Cf. MASINI et al., 2000).

Essa classificação representou um avanço por levar especialistas a debater o assunto e propor a adoção de uma linguagem comum, mas não homogênea, que unificasse as terminologias para conceituar as deficiências, considerando de forma objetiva sua abrangência, os graus de intensidade, como cada pessoa é particularmente afetada e, principalmente, pela tentativa de considerar de forma mais interativa as relações entre a deficiência, suas limitações e sua desvantagem no âmbito social. Porém, essa classificação ainda permaneceu atrelada ao modelo médico de doença, centrando no indivíduo a deficiência sem considerar as condições do meio que o afetam; fazendo prevalecer a força do diagnóstico do médico sobre o de outros profissionais, da família e da própria pessoa com deficiência; não discutindo em profundidade a dimensão social da deficiência - preconceitos e barreiras físicas e atitudinais - que o conceito de desvantagem tentou propor (Ibid.).

Além dessa, foi apontada uma outra crítica sobre a CIDID - a de não distinguir limitação funcional e incapacidade - pois "uma dada limitação funcional pode ser considerada ou não incapacidade, dependendo do contexto cultural" (MASINI et al., p. 101). O trabalho de classificação das doenças e deficiências sempre procurou cumprir o objetivo de conhecer e deixar claras e mais precisas às conceituações para fins científicos, informacionais, de 
diretrizes para políticas públicas, implantação de serviços, diminuição de preconceitos e estigmas. Mas alguns grupos organizados de pessoas com deficiência se preocuparam com as classificações que ainda permaneciam centradas demais na incapacidade sem aprofundar o debate sobre as contingências ambientais que promoviam ou intensificavam tais incapacidades.

Dessa forma, foi aprovada pela OMS em 2001, e traduzida no Brasil em 2003 para vigorar a partir de 2004, uma nova classificação que representa a revisão da CIDID e, portanto, mais um avanço na área da deficiência, embora não só aplicável a ela: a Classificação Internacional de Funcionalidade, Incapacidade e Saúde (CIF) (Cf. OMS, 2004).

Trata-se de um sistema aplicado à saúde e aos estados relacionados a ela, cujos domínios são "descritos com base na perspectiva do corpo, do indivíduo e da sociedade" (Ibid., p. 7). Vejamos sua apresentação geral na tabela abaixo:

Tabela 1: Quadro Geral da CIF

\begin{tabular}{|c|c|c|c|c|}
\hline & \multicolumn{2}{|c|}{ Parte1: Funcionalidade e Incapacidade } & \multicolumn{2}{|c|}{ Parte 2: Fatores Contextuais } \\
\hline Componentes & $\begin{array}{c}\text { Funções e Estruturas } \\
\text { do Corpo }\end{array}$ & $\begin{array}{l}\text { Atividades e } \\
\text { Participação }\end{array}$ & Fatores Ambientais & Fatores Pessoais \\
\hline Domínios & $\begin{array}{l}\text { Funções do Corpo } \\
\text { Estruturas do Corpo }\end{array}$ & $\begin{array}{l}\text { Áreas virtuais } \\
\text { (tarefas, ações) }\end{array}$ & $\begin{array}{l}\text { Influências externas } \\
\text { sobre a } \\
\text { funcionalidade e a } \\
\text { incapacidade }\end{array}$ & $\begin{array}{l}\text { Influências internas } \\
\qquad \text { sobre a } \\
\text { funcionalidade e a } \\
\text { incapacidade }\end{array}$ \\
\hline Constructos & $\begin{array}{l}\text { Mudança nas funções } \\
\text { do corpo (fisiológicas) } \\
\text { Mudança nas estruturas } \\
\text { do corpo (anatômicas) }\end{array}$ & $\begin{array}{c}\text { Capacidade } \\
\text { Execução de tarefas } \\
\text { num ambiente padrão } \\
\text { Desempenho/Execução } \\
\text { de tarefas no ambiente } \\
\text { habitual }\end{array}$ & $\begin{array}{c}\text { Impacto facilitador } \\
\text { ou limitador das } \\
\text { características do } \\
\text { mundo físico, social e } \\
\text { atitudinal }\end{array}$ & $\begin{array}{c}\text { Impacto dos } \\
\text { atributos de uma } \\
\text { pessoa }\end{array}$ \\
\hline $\begin{array}{l}\text { Aspectos } \\
\text { Positivos }\end{array}$ & $\begin{array}{c}\text { Integridade funcional e } \\
\text { estrutural }\end{array}$ & $\begin{array}{c}\text { Atividades } \\
\text { Participação }\end{array}$ & Facilitadores & Não aplicável \\
\hline $\begin{array}{l}\text { Aspectos } \\
\text { negativos }\end{array}$ & Deficiência & $\begin{array}{l}\text { Limitação da atividade } \\
\text { Restrição da } \\
\text { participação }\end{array}$ & Barreiras & Não aplicável \\
\hline
\end{tabular}

Fonte:OMS, 2004, p.14. 
A CID-10 (décima revisão/1989, em vigor a partir de 1993) proporciona o diagnóstico de doenças, perturbações ou outras condições de saúde e deve ser complementada pelas informações sobre funcionalidade fornecidas pela CIF. Uma não substitui a outra (Cf. OMS, 2004). Em relação à deficiência passa-se a considerar seus aspectos físicos, psicológicos e sociais: o indivíduo com alteração na estrutura ou nas funções do corpo em interação com os fatores contextuais (pessoais e ambientais).

Portanto, a CIF lança um novo olhar sobre a deficiência, considerando o impacto que uma mesma doença, ou deficiência, tem sobre cada pessoa em seu contexto particular de vida (Cf. REVISTA NACIONAL DE REABILITAÇÃO, 2002). Sua redação é pormenorizada e sua grande abrangência explicita a complexidade das interações que propõe entre os domínios, constructos e componentes relativos à funcionalidade e à incapacidade.

$\mathrm{Na}$ área da Educação, o conceito de deficiência sofreu toda a influência do modelo médico, e teve como referencial, tanto no paradigma da segregação quanto no da integração, a visão clínica orientando a prática pedagógica pela comparação do aluno com deficiência com aqueles ditos normais. O modelo médico se define pela ênfase na deficiência como um problema da pessoa em conseqüência de fatores orgânicos que se busca tratar com objetivo de cura ou adaptação. Enfim, um modelo que não permite ao professor ver cada um na sua particularidade: dificuldades e potencialidades pautadas em sua história e cultura. Socialmente esse modelo leva a uma imagem sobre a pessoa com deficiência de um ser dependente, incapaz, isento de responsabilidades, diminuído e de menor valor (inclusive foram usados termos como invalidez, em português, e disminuído e minus valido em espanhol). Leva o professor a isolar o aluno com deficiência em sala especial, ou no currículo simplificado e separado dos outros alunos na sala comum; tira-o das festas, dos passeios e das aulas de Educação Física alegando motivos protecionistas ou falta de adequações físicas, materiais e pessoal especializado. Tudo isso sempre vem em primeiro lugar e não as tentativas de relação e comunicação entre pessoas para encontrar estratégias pedagógicas e construir recursos.

Já no modelo social há o reconhecimento da limitação imposta pela deficiência, mas o impedimento maior está na sociedade que não cria condições para que essa pessoa realize as suas capacidades. O paradigma da inclusão é pautado pelo modelo social, o qual busca reconhecer a pessoa como ela é, com as especificidades da deficiência em questão que precisam ser atendidas, mas acima de tudo como um sujeito único tecido no ambiente social. Nesta concepção, todos se responsabilizam pela possibilidade da participação efetiva do 
deficiente na sociedade, promovendo atitudes e ambientes menos restritivos e menos preconceituosos, construindo - com o aluno, sua família e os especialistas - as adaptações curriculares necessárias. Nessa concepção, a sociedade deve reconhecer que ela cria problemas para as pessoas com necessidades especiais, fazendo com que elas fiquem em desvantagem no desempenho de papéis sociais em função de:

(...) ambientes restritivos; políticas discriminatórias e atitudes preconceituosas que rejeitam toda forma de diferenças; discutíveis padrões de normalidade; objetos e outros bens inacessíveis do ponto de vista físico; pré-requisitos atingíveis apenas pela maioria aparentemente homogênea; quase total desinformação sobre necessidades especiais e sobre direitos das pessoas que têm essas necessidades; práticas discriminatórias em muitos setores da atividade humana (SASSAKI, 1997, p. 47).

É uma questão ideológica que exige mudança de atitude e de mentalidade, levando a mudanças sociais, as quais, politicamente, tratam de numa questão de direitos humanos.

Os modelos médico e social da deficiência são citados sempre em contraposição, mas gostaríamos de trazer um outro enfoque sobre essa discussão. Nesse sentido é importante distinguir modelos e saberes. Quando se diz modelo médico não se está fazendo referência ao campo de saber da Medicina ou ao profissional médico, tampouco se está negando o valor e a importância ímpar desse campo de conhecimento prático e teórico. É evidente que ao longo da vida as pessoas com deficiência necessitam do saber médico que atenda suas necessidades e lhes auxilie nos recursos que melhorem sua qualidade de vida, sem falar na importância de um diagnóstico preciso sobre o aspecto orgânico para que se prescrevam as terapêuticas adequadas. Mas o saber médico é diferente de modelo médico, pois que "modelo" significa aqui paradigma e não é exclusivo da área da Medicina, podendo orientar também profissionais da Educação. Como saber se busca a contribuição, como modelo se questiona a postura da medicalização, da patologização da deficiência que faz com que o sujeito seja a deficiência.

Em contrapartida, temos o profissional da Medicina que nem sempre é aquele que se pauta por um modelo médico de atendimento. Spinelli (2002), médico foniatra, especialista em deficiência auditiva, propôs: 
(...) uma medicina participativa, interdisciplinar, que se propõe a atuar junto a terapeutas e educadores (...) reconhece que o bem-estar psíquico e social depende apenas parcialmente de da sanidade orgânica e de capacidades funcionais preservadas. Tal medicina coloca seu olhar, para além de doenças e de seqüelas, na valorização da história das pessoas afetadas e familiares e no estudo de questões específicas à condição que particulariza essas pessoas... próprias de suas condições prévias e circundantes (...) a medicina que volta sua atenção também à condição funcional que tem sua gênese em processos patológicos terminados... (SPINELLI, 2002, p. 209-213).

Esse autor identifica o médico como o profissional que contribui "no campo da cura e da terapêutica medicamentosa e cirúrgica, no diagnóstico correto o mais cedo possível" (Ibid., p. 209), mas que também atua interdisciplinarmente junto às áreas que atenderão as necessidades fora do campo médico.

Vietzsman (2002), oftalmologista, especialista em baixa visão, fala do papel do médico diante da deficiência:

A classificação clínica tem prevalecido para o médico, sem levar em conta outros dados, porém é imprescindível resgatar a questão para a instância sociocultural (...) Enquanto o oftalmologista tratar apenas o problema ocular, limitado às doenças do olho, (...) estará muito longe de modificar a deficiência visual que resulta dessas alterações (Ibid., p. 219).

Esses modelos são ditados pelas concepções filosóficas que permeiam as ciências e as tradições culturais, tal como a definição de paradigma, ditada por Kuhn (1978). Para esse autor, um paradigma é um modelo, um conjunto de valores, crenças, convicções, conceitos, saberes e práticas que uma comunidade científica partilha e que apresenta ao mundo com base em uma dada visão da realidade, que por sua vez é construída a partir de um tipo de pensamento.

Na realidade, a simples oposição entre os modelos médico e social não faz avançar o conhecimento e as práticas na busca das soluções dos problemas científicos e sociais. Mas a polarização em um determinado momento faz as rupturas necessárias que levam em seguida à busca da síntese tratando dialeticamente as duas perspectivas. O caminho não é o de passar de um modelo para outro, mas de promover uma interação entre eles para superar a dicotomia e fazer a passagem propondo o diálogo entre as disciplinas. Procurar a contribuição de cada área sobre o entendimento do fenômeno, onde cada uma possa olhar o ser contextualizado no 
corpo, na história, no tempo, ou seja, o ser humano na sua elaboração pessoal e no seu contexto de vida. A CIF baseia-se na integração desses dois modelos opostos e "tenta chegar a uma síntese que ofereça uma visão coerente das diferentes perspectivas de saúde: biológica, individual e social" (OMS, 2004, p. 22), envolvendo várias áreas de conhecimento.

Assim, estamos assumindo a proposta da interdisciplinaridade - ao aproximar e opor, complementar, negar e ampliar conhecimentos - como um melhor caminho para o desenvolvimento das ciências que objetivam o entendimento da complexidade das relações do homem em todas as suas dimensões vividas no cotidiano.

Nesse sentido, não há supremacia de uma disciplina sobre a outra. Tampouco há uma somatória de saberes onde cada disciplina vê uma parte do fenômeno estudado e mais: um fenômeno isolado. Ao contrário, propõe-se um empreendimento comum que convoca a pluralidade de perspectivas e leituras, promovendo o enriquecimento mútuo com a convivência da heterogeneidade sempre orientado pela ética da busca de soluções para os problemas (Cf. JAPIASSU, 1976).

$\mathrm{Na}$ história das ciências, Santomé (1998) resgata a justificativa política, social e científica da interdisciplinaridade como resposta às necessidades que levaram à mudança de paradigma na forma de abordar os problemas sociais. Essa articulação nos remete à CIF como uma resposta à construção do paradigma da inclusão e este como uma resposta possível da pós-modernidade às questões da deficiência.

\subsubsection{A escola e o professor no contexto da Educação Inclusiva}

Se o ambiente do qual estamos falando neste trabalho é o da escola, e particularmente a escola pública que é, ou deveria ser, a escola para todos, é preciso perguntar de que escola falamos, quem são os professores que ali estão e o que desejam eles e a comunidade escolar como um todo na proposta da escola inclusiva.

É comum cometermos novamente o erro de polarizar a discussão elegendo um elemento da rede de significações, rede esta que promoveu durante tantos anos a exclusão daquele que não se enquadrava no padrão ideal posto pela escola. É sabido que a escola reproduz o cenário macrossocial e este tem apontado contradições acentuadas no que diz 
respeito às relações humanas e institucionais desde o discurso e as leis até a realidade do cotidiano.

Os professores são fruto de uma formação fragmentada que não contribui para uma compreensão mais abrangente do aluno e da situação de escolarização. Os Parâmetros Curriculares Nacionais/98 do Ministério da Educação, com os preceitos da política da igualdade, da ética da identidade e da estética da sensibilidade - ou ainda os pilares do aprender a aprender, aprender a fazer, aprender a ser e aprender a conviver - ainda não foram assimilados e em muitas escolas nem sequer estudados pela equipe de professores para análise e crítica.

Os professores pedem explicações e métodos que respondam às necessidades das inúmeras crianças que "não aprendem", embora estas não tenham deficiência mental ou distúrbios de aprendizagem na sua grande maioria. E no caso da deficiência costumam considerar esse aluno como "mais um" e não "um" em particular como parte integrante do grupo. Falam que estão abertos e que aceitam, pois é um direito e todos deverão ser acolhidos, mas... que não foram capacitados para isso e não se sentem preparados.

A escola não pode mais recusar a matrícula do aluno com deficiência, que está assegurada como um direito pela lei e pela Constituição Brasileira (Cf. BRASIL, 1988) e, nesse caso, os professores pedem suporte técnico que vise à sua instrumentalização sobre as necessidades específicas desse aluno decorrentes de sua deficiência. Por exemplo, na deficiência visual: o sistema de leitura e escrita do cego, o braille; as técnicas de orientação e mobilidade que facilitam a autonomia e a independência no ambiente físico da escola; a definição, os indicadores de identificação e os recursos ópticos no caso da baixa visão; as adaptações no ambiente arquitetônico; e as adaptações táteis ou de ampliação dos materiais didáticos para que o aluno tenha acesso aos espaços físicos, bem como à informação escrita do conteúdo previsto no currículo que a escola deve cumprir.

$\mathrm{Na}$ prática, identificamos por parte dos professores, ou diretores e coordenadores das escolas, preocupações pontuais e de caráter pragmático para resolver os obstáculos que julgam os mais difíceis. Raramente, porém, identificamos a preocupação com as barreiras atitudinais, as relações de interdependência e parceria, ou o comprometimento com a mudança de ordem pessoal e coletiva diante da deficiência/diferença, ou ainda a disposição para rever posições, programas pedagógicos, metodologias e sistemas de avaliação que levem em conta tempos de aprendizagem e estilos cognitivos diferentes de todos os alunos. 
Fazendo uma análise mais aprofundada não podemos deixar de considerar que o professor faz parte de um grupo que quase não é escutado e quando é, isso acontece em uma estrutura autoritária. A legislação e as diretrizes da educação brasileira são avançadas, mas muitos professores se queixam de que são impostas pelas esferas governamentais superiores e que atingem diretamente o dia-a-dia do professor que é aquele que lida com a educação. Não se pode afirmar isso, pois a Lei de Diretrizes e Bases da Educação Nacional (LDB), de 1996 foi discutida durante anos em nível nacional. Não é um decreto-lei. Foram discutidas regionalmente, localmente. Não saiu da cabeça de um legislador. E as diretrizes também não. Estas foram trabalhadas por educadores. O que é difícil sim é pôr em prática. O que é imposto de cima para baixo sempre é uma política específica de um governo, quer federal, estadual ou municipal. Um governo pode querer privilegiar um tipo de coisa como o ciclo básico, a progressão continuada... Isto se pode dizer que veio de um grupo pensante específico, mas a lei não. E por todo o histórico até aqui apresentado não se pode dizer que as mudanças vieram de cima para baixo.

Por outro lado também encontramos professores que respondem às queixas de colegas alegando que os educadores que acompanharam as mudanças da Psicologia da Educação nos últimos trinta anos, por exemplo as concepções acerca da inteligência, não se surpreenderam com a inclusão do aluno com deficiência na sala comum do ensino regular. Também advogam estes, com clareza, que a inclusão não é apenas desse aluno, mas de todos.

Porém, entre a legislação e a realidade da escola há um descompasso. É nesse dia-adia que temos encontrado professores desmotivados, desacreditados, desistindo da Educação, por não conseguirem se situar diante dos novos paradigmas da pós-modernidade e sua formação não dá indicadores para fazer do ato pedagógico um ato sobre a verdade do sujeito. Na Pedagogia, como na Psicologia e outras áreas da Saúde, não se formam profissionais para dar conta do que ocorre com os sujeitos e sim para fazer a aplicação das teorias que explicam uma criança abstrata, fora da história. “... o que estaria levando os professores e os especialistas a apresentarem prática imprecisa e teorização pouco elaborada?”, indaga Mrech (1999, p. 6).

A questão é que mudar leis só não basta, é preciso haver mudança de mentalidade, uma mudança cultural. A mudança da escola depende muito das mudanças sociais. Porém estas estão atreladas à ordem política e econômica que só legislam em benefício próprio. A história da educação mostra isso. A escola está dentro de uma estrutura social maior que precisa mudar, mas a educação escolar vai convivendo e tentando responder ao que brota 
como demandas sociais antes dessa mudança essencial. O dinamismo das necessidades sociais é intenso e a mudança da escola é lenta, pois que além das mudanças estruturais citadas acima, necessita também da mudança das pessoas, o que implica no trabalho com limites emocionais. Entre outras questões, a inclusão escolar da criança ou jovem com deficiência é difícil porque envolve mudança de valores enraizados nas pessoas. Então seguimos perguntando: quem é esse professor? Como podemos ouvir suas necessidades e angústias e instigá-lo ao desejo de saber? Como acompanhá-lo na descoberta de que não serão teorias e técnicas apenas que aplacarão sua angústia de não saber, possibilitando a ele perceber que é a busca das ações que trabalha para que toda criança na escola tenha o sentimento de pertencimento, de ocupar nela um lugar social? Ou seja, como perceber que a inclusão escolar está muito mais voltada às atitudes e relações humanas no saber sobre os sujeitos e suas singularidades, embora também seja preciso saber sobre o específico da deficiência mesmo sem tornar a cada professor um especialista?

Essa reflexão nos obriga a delinear o contexto da escola para a qual foi formado este professor. É preciso entender as condições sob as quais a escola se estruturou, a que e a quem ela serve e foi pensada. Isso nos ajudará a pensar a inclusão educacional e escolar sob uma outra ótica.

Trata-se de que a organização e a evolução da educação escolar se desenvolve de forma a atender aos interesses das camadas sociais que estão representadas nas estruturas do poder político e econômico. Portanto, a forma como esses poderes se originam e se modificam ao longo do tempo tem implicação direta na formação e no papel da educação escolar. A escola nasceu para ser mediadora e transmissora da cultura, o que também possibilita criação, mas teve como função mais contundente a perpetuação das ideologias dominantes e das estruturas sociais sustentadas por essas ideologias, enfim um contexto sóciopolítico que acaba por se refletir na legislação educacional, na estrutura do sistema educacional e sua forma de administração e no conteúdo a ser transmitido (Cf. ROMANELLI, 1978).

Não faremos aqui uma explanação aprofundada da história da educação no Brasil, dada a abrangência e complexidade que sua análise requer das relações de dependência que estabelece com os conceitos de cultura, sociedade, demandas sociais, desenvolvimento e estruturas de poder. Mas assinalaremos alguns pontos-chave de sua construção e desenvolvimento que ajudarão a compreender o momento atual e a discussão sobre a inclusão escolar. 
A escola pública brasileira foi condicionada pela forma como se desenvolveu o processo de estratificação social, de detenção do poder, de adoção do modelo europeu de cultura letrada, privilegiando-se o acadêmico na formação daqueles que queriam manter ou conquistar um determinado universo cultural e status social e para aqueles que mostravam determinadas condições intelectuais de desenvolvimento. Até 1920, seguiu a origem da pedagogia dos jesuítas (as letras, a filosofia, a música e a matemática) e tinha a função de formar uma elite pensante que assumia os quadros da política e da administração pública. Havia equilíbrio entre educação e desenvolvimento: o que a escola oferecia como recursos humanos estava de acordo com a demanda social e econômica, ou seja, os fatores sóciopolítico-econômico-culturais se mantinham em equilíbrio. Mas a partir de 1930, mudam a ordem econômica (industrialização), social (urbanização) e política, fazendo com esse complexo entre em desequilíbrio e a sociedade passe a fazer outras exigências em relação à escola: outra formação de recursos humanos para atender a nova economia, setores médio e populares pressionam o sistema educacional a expandir-se. Foram gerados aí problemas estruturais cada vez mais crescentes, pois a expansão foi de um ensino que já não correspondia às necessidades nem da economia nem do público que passou a freqüentar a escola. Uma expansão até então nunca vista, mas que encontrou barreiras como a pequena oferta, o baixo rendimento e a discriminação social. Isso se deu pelas divergências entre as classes dominantes na estrutura de poder tanto na política quanto na economia e isso é evidente nas legislações do ensino, que se fez contraditória por tentar conciliar os interesses das facções das elites, acabando por atender a mais conservadora. Disso resultou para o ensino, antes apenas para a aristocracia, uma estrutura rígida, seletiva e socialmente discriminatória, favorecendo o ensino acadêmico em detrimento do técnico-profissionalizante. Assim, a escola se mantinha em um modelo antigo e não atendia as necessidades da expansão econômica, deixando marginalizada boa parte da população. Essa dinâmica atendia à lógica dos interesses políticos de dominação e das elites econômicas que passaram a pressionar o Governo a estabelecer um sistema paralelo de formação de mão-de-obra que elas mesmas controlariam (SENAI/SENAC), o que ocorreu a partir de 1946. Esse sistema interessava politicamente por manter um nível técnico alto, mas um nível baixo de escolarização. Nos anos 50 e 60 , com a entrada de capital estrangeiro no país e com o impulso do capitalismo, a influência e dominação norte-americana, a escola deixa de valorizar o conhecimento acadêmico, mas em termos de qualidade e democratização na prática não fez nem uma coisa nem outra. Com a abertura da escola pública - a democratização do ensino - passam a ser abaladas as formas aprendidas e a ideologia vigente. O poder público não conseguiu resolver 
a crise que se refletiu na Universidade e a Lei de Diretrizes e Bases da Educação Nacional mais uma vez atendeu aos interesses políticos e não sociais ou até mesmo econômicos. Durante o governo militar a educação mergulhou em uma crise mais acirrada pela nova política e novo modelo econômico de dependência externa, ficando relegada pelas duas forças da estrutura de poder com acordos internacionais. Porém contava com um nível de politização de professores e alunos que passaram a pressionar para uma expansão do ensino. Mas aí também se manipulou para atender a interesses internos e externos da burguesia empresariado, classe média e militares - expandindo o capitalismo, ainda que o Brasil se mantivesse na periferia desse processo, o que pagará mais tarde com um custo social enorme, e a modernização do ensino que tirou da Universidade sua autonomia e força de mobilização social e política (Cf. ROMANELLI, 1978).

Há muitos fatores importantes que não estão sendo mencionados, mas para não nos alongarmos mais, damos um enorme salto na história. Passamos a fazer referência a uma época marcada por muitas lutas sociais contra o regime totalitário militar até o início do processo de redemocratização do país no final dos anos 80, já quando as ditaduras não interessavam mais política e economicamente, interna ou externamente, com o retorno do governo civil. O setor educacional encontra-se absolutamente arrasado. Nos anos 80 e 90, a globalização absolutamente favorecida pelo desenvolvimento tecnológico nunca antes visto, mudando mais uma vez a ordem mundial política e econômica de uma sociedade do conhecimento e acirrando as desigualdades sociais, deixa a escola mais marginalizada, com uma defasagem mais contundente entre educação e desenvolvimento, uma escola sem nenhuma qualidade de ensino e nenhuma perspectiva de mobilidade social para a população que a freqüenta.

No panorama da escola pública brasileira continuamos a conviver com os mesmos problemas há décadas: alta evasão e repetência, baixo rendimento, baixo investimento, ausência de políticas de formação e baixa remuneração dos professores, promoção dos problemas de aprendizagem. Os dados quantitativos sobre a escolarização mostram o grau de seletividade e exclusão da população no ensino elementar, como mostra Shirahije (2000) na seguinte exposição:

(...) o relatório sobre o Desenvolvimento Mundial, do Banco Mundial de 1989, aponta o Brasil entre os dez países de maior Produto Nacional Bruto e o $106^{\circ}$ em evasão escolar no $1^{\circ}$ Grau (...) apenas $27 \%$ das crianças que ingressam na primeira série concluem essa 
etapa no Brasil (...) e 32\% no Estado de São Paulo (Helene, 1990); em 1986 , os índices de reprovação na $2^{\mathrm{a}}$ série do $1^{\circ}$ grau era de $30,45 \%$ nas escolas públicas paulistas e 7,59\% nas escolas particulares (SEADE, 1999) (...) maioria das crianças reprovadas ou que se evadem (...) é proveniente das camadas mais pobres...; o aluno brasileiro permanece em média oito anos e meio na escola (Ribeiro, 1992), mas apenas três entre cem ingressantes concluem o ensino elementar sem repetência; a defasagem série-idade aumenta ao longo do processo de escolarização de tal forma que em $198670 \%$ dos alunos de $8^{\mathrm{a}}$ série encontrava-se fora da idade real para o mesmo período (SEADE, 1989) (...) em 1995 o UNICEF realizou pesquisa em que o Brasil alcançou o quarto pior desempenho do ensino... (SHIRAHIJE, 2000, p. 17).

Como essa escola poderá então assumir, hoje, como uma belíssima meta, a incumbência de incluir a todos? Abrir um espaço para abarcar, considerar e aprender a trabalhar uma clientela que continua social e economicamente fora da ordem mundial? Esta conjuntura vai tocar diretamente o professor, tendo ele também sofrido os reflexos dessa história em sua própria formação. Há um grau de alienação grande por parte da escola e dos professores sobre o papel e a função da educação escolar, mas não se pode jogar toda a responsabilidade para a escola e para o professor, como se fosse uma questão de receber bem ou mal o aluno que hoje a freqüenta, incluindo o aluno com deficiência, pois há o contrapeso dessa origem sócio-histórica da escola, uma vez que o sucesso das práticas pedagógicas e das experiências internas à instituição educacional está submetido a fatores externos dos quais os educadores muitas vezes não se dão conta. Por isso a inclusão escolar não pode ficar restrita a experiências pontuais e dependentes de um professor entusiasta e bem intencionado. Quando falamos que a inclusão é uma questão de trabalho com a singularidade do sujeito não estamos deixando de nos posicionar politicamente frente aos obstáculos.

Para Mazzotta (2000), a inclusão escolar é mais uma questão política e ideológica, de direitos humanos e de uma sociedade mais justa, do que uma questão científica e tecnológica.

Dubet (2004), ao propor a questão "o que é uma escola justa”, não discute incluir o que e a quem, mas discute princípios que se aplicam também à inclusão escolar das crianças com deficiência. $\mathrm{O}$ autor tenta sair desse vazio do discurso que já está gasto e conceituar filosoficamente o que é essa justiça que está por trás dessa idéia de incluir a todos na escola. Afirma a legitimidade do desejo que temos de justiça e igualdade de oportunidades na escola, mas propõe uma discussão ética sobre a complexidade do conceito e a ambigüidade que pode gerar quaisquer das definições assumidas no discurso. Parte do princípio que todas as esferas da sociedade geram desigualdades: a escola, a economia, a cultura, a política, sendo que uma 
reflete na outra. Um exemplo que podemos introduzir a partir disso é a ocorrência da deficiência por causas de falta de provimento de saúde básica para a população mais pobre do país, falta de serviços de atenção precoce, falta de orientação familiar, dificuldades de acesso à educação, falta de apoio específico da deficiência para a aprendizagem e conseqüentes defasagens na escolarização.

Evidentemente, como diz o autor, todas as formas de desigualdades deverão ser enfrentadas e combatidas, e aqui tratamos da escola, mas convida a avaliar o "sentido e o alcance das políticas escolares" (DUBET, 2004, p. 5), assumindo a posição de que a igualdade de oportunidades e as formas de desenvolvê-las têm limites muito precisos e é fundamental que se reconheça isso para que se adotem práticas consistentes. $\mathrm{O}$ autor afirma, e nós corroboramos por toda a história da educação que relatamos anteriormente, que desde a aristocracia até a democracia em todo o mundo, o que continua pesando nas desigualdades escolares são as desigualdades sociais.

O sistema da meritocracia (desenvolvimento e ascenção por mérito) embutido na democracia, o ideal de que um dia poderemos todos ser competitivos, pretenso substituto da condição do nascimento na classe social favorecida, mostrou-se um engodo porque abrir a escola para todos (o que aumentou o nível de escolarização da população, embora já vimos que no Brasil isso não significou aumento da qualidade do ensino e ascenção social $)^{2}$, efetivamente não significa oportunidades iguais, uma vez que os mais favorecidos socialmente continuaram a ter vantagens no sistema competitivo pelo qual a escola e todas as instituições são regidas em nossa sociedade e isso não é senso de justiça (Ibid.). Mais uma vez cabe a consideração para as pessoas com deficiência que passaram a freqüentar a escola comum desde o final dos anos 50.

Dubet (2004) ainda refere que "todas as pesquisas mostram que a escola trata menos bem os menos favorecidos" (p. 542). Aqui reside um mecanismo perverso do princípio da meritocracia em relação ao fracasso escolar, que desloca o critério da injustiça social, pois leva a crer que a culpa do fracasso está na pessoa que não aproveitou a oportunidade dada. Do ponto de vista pessoal sabemos o que acontece: autodesvalorização, desmotivação, problemas de aprendizagem, comportamentos destrutivos etc., endossando as desigualdades sociais. Esse modelo de educação também gera problemas pedagógicos, pois nele se supõe que todos são iguais e estão no mesmo nível de competitividade, ou seja, os conteúdos e metodologias não

\footnotetext{
${ }^{2}$ Parênteses nosso
} 
levam em conta as diferenças individuais e culturais. No Brasil os estudos de Patto (1990) mostram isso com muito rigor, clareza, lógica e patriotismo, se podemos dizer assim.

A contribuição de Dubet (2004) está ainda em uma aparente contradição, qual seja, a aceitação dessa máxima da democracia que é a igualdade entre todos, mas como uma "ficção necessária": o mérito como a única forma de produzir "desigualdades justas, legítimas" (Ibid. p. 544) . Poderíamos inferir: o singular e cada sujeito. Para isso temos que ter uma garantia estrutural: a do acesso de todos à escola. Além disso, sabermos dos limites do sistema meritocrático e que a escola sozinha não vai construir a sociedade justa.

Dentro dessa perspectiva a escola, ciente das desigualdades reais, deve elaborar formas de compensá-las, formas eficazes e centradas no aluno: a chamada discriminação positiva, ou ações afirmativas, correspondentes aos objetivos traçados de acordo com as necessidades do aluno (quotas, preparação específica, maior tempo para a aprendizagem, mais atividades culturais etc.). Essa proposta coincide com a da inclusão escolar da pessoa com deficiência no que diz respeito às adaptações curriculares ${ }^{3}$, sejam de acesso ao currículo ou dos elementos do próprio currículo (objetivos, conteúdo, avaliação e temporalidade), pois que a escola não pode mais oferecer o mesmo do mesmo jeito para todos e esperar o mesmo resultado de todos. A homogeneidade não é mais o caminho da educação, paradoxalmente a uma sociedade de massa. Tais ações podem ser nada se não forem representativas da filosofia da escola e não fizerem parte do seu plano político pedagógico. Mas também não podemos perder de vista que estamos lidando com resistências das elites dentro do próprio sistema educacional e que as ações educativas têm influência limitada na dinâmica das desigualdades escolares (Cf. DUBET, 2004).

Outra forma de promover justiça social é a garantia à população desfavorecida de recursos mínimos de proteção e de aquisições de competências elementares (aquelas que todos precisam adquirir ao final da escolaridade obrigatória) (Cf. DUBET, 2004). Segundo Rawls (1987 apud DUBET, 2004), isso pode ser pensado no contexto escolar do seguinte modo:

(...) a justiça de um sistema escolar pode ser medida pelo modo como trata os mais fracos e não somente pela criação de uma competição pura (...) ela considera que as desigualdades são aceitáveis, ou mesmo

\footnotetext{
${ }^{3}$ Adaptações curriculares são respostas educativas que devem ser dadas pelo sistema educacional, de forma a favorecer a todos os alunos e, dentre estes, os que apresentam necessidades educacionais especiais - MEC Projeto Escola Viva - 2000.
} 
justas, quando não pioram as condições dos mais fracos (DUBET, 2004, p. 546).

Falar em justiça na escola sem poder garantir a justiça depois da escola é profundamente incômodo, pois estamos o tempo todo voltando ao ponto de que não há justiça social e, portanto, não há igualdade de oportunidades e então podemos perder o sentido do trabalho educacional escolar. Em nosso dia-a-dia de trabalho, com dados empíricos, mas não menos significativos, temos visto experiências de escolas que se colocaram como esforço supremo fazer aquilo que é seu papel por excelência: a responsabilidade pela alfabetização de todas as crianças até a $4^{\mathrm{a}}$ série do Ensino Fundamental, ao passo que na escola particular que atende outra camada social, essa alfabetização está concluída com êxito na $2^{\mathrm{a}}$ série. $\mathrm{O}$ que acontecerá lá na frente? Haverá oportunidades iguais no mercado de trabalho? Teríamos que seguir abordando muitos outros aspectos sobre o que é uma escola eficaz e justa, mas não é nosso foco tal aprofundamento. Podemos concluir apenas por este momento que a escola pública de massa se pauta por esse princípio meritocrático que produz o fracasso de muitos. Uma escola justa, para Dubet (2004), seria aquela que, se não pode fazer a justiça social, não trata mal aqueles que apresentam dificuldades nas aquisições das competências exigidas, que não os humilha, que não os fere em sua dignidade, que não os estigmatiza nem desvaloriza, mas que os conhece, apóia e confia. Aquela que acredita e defende o seu papel educativo e compromissado em pôr ao alcance dos alunos os bens culturais e ainda promover o aluno a um lugar social na comunidade escolar, pois o papel de instrução apenas não responde a essa população que "não é 'adepta' dos valores da escola" (Ibid., p. 552) - aquela que se preocupa também com a utilidade do que vai ensinar.

Em meio a essa realidade estão os alunos com deficiência. Estes, também membros das camadas mais pobres da população para quem as desvantagens sociais da falta de serviços de apoio e recursos específicos, bem como os comprometimentos decorrentes da deficiência, multiplicam as dificuldades na escolarização e imprimem uma dupla estigmatização. A eles a escola deve acolher como aos outros com a mesma responsabilidade posicionando-se diante de um sujeito que é uma pessoa com seu modo próprio de aprender, com suas necessidades específicas, que devem ser conhecidas e apoiadas no contexto escolar. A criança ou jovem com deficiência visual está dentro desse contexto.

Outro aspecto a ser considerado na realidade da escola é a formação do professor. Essa educação que se propõe inclusiva implica um professor que saiba trabalhar com a diversidade 
de pessoas e culturas, com currículos diversificados e com as adaptações que se fizerem necessárias, criativo em suas estratégias, aberto a mudanças, capaz de se aproximar do aluno sem idéias pré-concebidas, que esteja disposto a trabalhar suas resistências, medos e desejo de saber.

Durante muitos anos tivemos a Educação Comum de um lado e a Educação Especial de outro. O professor especializado na área da deficiência permaneceu dentro de algumas poucas escolas, das regiões mais centrais do Brasil, na rede estadual de ensino, desde o final da década de 50, mas esteve isolado no seu saber técnico atendendo ao aluno com deficiência em salas especiais ou de recursos. Assim, não aprendeu a trabalhar na Educação Comum, a pensar a educação de forma mais global. O professor da Educação Comum, por sua vez, não aprendeu a trabalhar com o aluno com deficiência, pois este era responsabilidade do professor especializado. Ele, então, não aprendeu a pensar as especificidades e buscar estratégias e metodologias de ensino para responder a elas como respostas educativas - e não caritativas em regime de exceção - e ver que isso é de responsabilidade de todo o sistema educativo. Para ambos - especialista e generalista - uma formação fragmentada acerca do conhecimento e do ser humano e baseada em uma criança teórica e não real. Além disso os cursos de formação de professores - Pedagogia, Psicologia e licenciaturas - lidam apenas com conteúdos intelectuais e os entraves que o professor vai viver no dia-a-dia de sua profissão são feitos de conteúdos afetivo-emocionais que muitas vezes ele não discrimina e projeta nos alunos e seus familiares, na equipe de profissionais da escola ou na estrutura e sistema de ensino. Isso não quer dizer que ele não tenha razões concretas para isso. Como refere Mrech (1997):

(...) de longa data os professores têm sido invalidados na construção do seu desejo. É dado a eles, por um sistema altamente pervertido, condições mínimas de trabalho. Da mesma forma que eles foram tratados como objetos pelo sistema educacional, eles passaram a se tratar (...) o professor não consegue lidar com aquilo que ele não sabe. Assim como não consegue lidar com os problemas de construção do saber dos alunos. O que acaba levando o professor a atribuir suas dificuldades ao outro (...) São os outros que não sabem. São os outros que deveriam saber para ensiná-lo a trabalhar melhor (Ibid., p. 8).

Mas os professores precisam encontrar novos sentidos para o seu fazer educativo e ajudar a escola a encontrar novos rumos e novas convicções. 
Ainda que no dia-a-dia desse fazer educativo nas instituições especializadas, nas escolas regulares ou especiais, bem como nas ações compartilhadas com as famílias e as próprias pessoas com deficiência, quando parecemos perder o horizonte ao mergulharmos no mais absoluto específico do sujeito que demanda a partir da trama em que foi tecido, podemos buscar algumas respostas para a afirmação e a questão propostas por Confúcio (s/d): “... a saída é pela porta. Por que ninguém quer usar esse método?"

É importante ainda ressaltar em termos de escola para todos os alunos, deficientes ou não, a necessidade de voltar a atenção máxima às políticas para a Educação Infantil e ao trabalho com a família. Essas duas ações associadas podem ser a base para uma escolarização mais ajustada.

\subsubsection{Posição e atuação da família}

Sabemos que a família, em suas diversas formas de organização e dinâmica, é o primeiro núcleo afetivo, social e cultural da criança, responsável por sua constituição como ser humano e sua inserção nas instituições sociais. As relações e conhecimento de mundo da criança são ampliados à medida em que ela participa da comunidade onde vive, incluindo a escola.

A Declaração de Salamanca nas linhas de ação previstas na perspectiva comunitária da Educação Inclusiva indica a participação da família como uma parceira no processo de atendimento às necessidades educacionais especiais, afirmando que a inclusão social e escolar depende das atitudes inclusivas dentro dela. Para isso recomenda a provisão de informações claras e urgentes aos pais, bem como o envolvimento deles como parceiros ativos na tomada de decisões, na participação das atividades da escola, no acompanhamento das atividades para casa, apoiando a aprendizagem dos filhos. Não só a escola deveria se guiar por ações compartilhadas com a família para o desenvolvimento e implementação de programas e políticas de direitos, mas também os governos e os serviços especializados para a avaliação conjunta com a aquisição de competências paternas que apóiem o processo de desenvolvimento de seu filho (Cf. UNESCO, 1994).

Além disso, as famílias e as próprias pessoas com deficiência são um dos principais agentes dessa mudança na sociedade ao defenderem seus direitos, dividirem responsabilidades e compreenderem a condição dinâmica da deficiência em seus aspectos individuais e sociais, 
dimensionando suas possibilidades e necessidades, trabalhando-se em relação aos sentimentos e expectativas em relação ao filho e dimensionando ainda a responsabilidade da escola.

Dubet (2004) quando propõe a reflexão acerca do trabalho pela construção de uma escola mais justa que educará a todos independentemente do desempenho escolar, conclama as famílias a participarem da vida da escola. No Brasil, vemos nessa direção os Programas "Escola da Família" (rede estadual de São Paulo) e "Escola Aberta" (rede municipal de São Paulo).

Abordando então a questão das relações família-escola, historicamente constatamos que a escola sempre afastou a família do processo educacional, com rótulos carregados de valores depreciativos em relação à má condução da educação dos filhos. A família, por sua vez, autorizou a escola na transmissão do conhecimento científico e esquivou-se da participação no processo educativo escolar. Não obstante esse impasse, é necessário considerar e explicitar que o lugar da escola não pode ser apenas de transmissão de conhecimento, desvinculado do lugar social que ela representa em nossa cultura. Sabemos também que a escola sozinha não dará conta da transformação que almejamos. As condutas que negam isso não favorecem uma relação de construção, não permitem estabelecer metas e propor ações e atitudes conjuntas na conquista de objetivos comuns para o desenvolvimento da criança ou jovem escolar.

Percebemos em nossa prática de assessoria às escolas no processo de inclusão das crianças com deficiência visual e múltipla deficiência que tanto a escola quanto a família se restringem às formas tradicionais de relação. A escola convida a família para reuniões gerais de pais, ou individuais quando algo com o aluno não vai bem; ou para as festas comemorativas da escola. A família vai à escola para fazer reclamações (e aqui não vamos tecer considerações acerca da pertinência ou não de tais queixas), atender aos chamados e convites, ou poucas participam da Associação de Pais e Mestres com a função básica de angariar fundos para suprir necessidades materiais da escola.

Hoje, no cenário da inclusão, a expectativa é de que o envolvimento da família no processo educativo escolar seja o de fazer escolhas e tomar decisões conjuntas sobre situações cruciais para a vida da criança na escola e na família e de cooperação nas atividades escolares. A escola aberta à família e a família envolvida responsavelmente na vida escolar de seu filho formariam uma forte parceria na qual todos ganham: os pais adquirem competências para auxiliar a criança ou jovem, os professores passam a conhecer o universo cultural do aluno e 
compreendê-lo melhor; e este se sentiria reconhecido e mais seguro com maiores chances na construção do conhecimento e na participação efetiva na vida escolar e, acreditamos, social.

Mas há dois aspectos que precisam ser melhor considerados em relação à família e à escola. Faremos isso tecendo um paralelo entre elas naquilo que na sociedade contemporânea afetou a ambas para, em seguida, considerar um desdobramento: o da família da pessoa com deficiência.

Já foi feita referência neste mesmo capítulo à história da educação situando a escola em relação às mudanças que sofreu em sua função sócio-educativa a partir da demanda social feita a ela e o descompasso em relação ao desenvolvimento e sua dependência das estruturas de poder político e econômico. Cabe ainda fazer menção às mudanças sociais que, a partir da metade do século XX, mudaram o mundo ocidental - cada vez mais urbano desde essa época - em termos de valores e costumes, afetando o valor simbólico de poder e autoridade instituído até então. Em relação à família essas mudanças geraram, não sem dificuldades, novas formas de organização e relações, mas, no caso da escola, esta permaneceu na estrutura e dinâmica antigas, gerando novo descompasso nas relações sociais (Cf. LIMA, 2005).

Essas duas instituições, até a metade do século XX, sofriam as influências em suas relações internas de um modelo de sociedade marcado pela racionalidade, pela tradição, pela moral, com seus limites bem claros, com pouco espaço para questionamentos e transgressões (mesmo em meio a insatisfações), cuja autoridade nas relações pessoais era representada pelas figuras do pai e do professor que se estendia para o poder da Escola e do Estado. A partir dos anos 60 esse mundo "masculino, adulto e racional" começa a ruir porque a modernidade só fez aumentar "as desigualdades sociais, a criminalidade, o sofrimento, a miséria, a fome" (Ibid., p. 2). Eclodiram movimentos sociais de contestação, podendo destacar-se aqueles representados pelas camadas médias: 1) o movimento jovem nas vertentes político-estudantil e existencial. O primeiro, que pretendia mudar o mundo e o da contra-cultura, que pretendia mudar os costumes, 2) o movimento das mulheres, que lutaram para sair da dependência e obediência ao mundo masculino, ascendendo ao mercado de trabalho, rompendo com o modelo de casamento e de família até então vigentes. Essas transformações geraram mudanças sociais mais amplas: as instituições se fragmentaram e perderam a coesão. Assim, família e escola, que antes eram regidas pelos mesmos ideais, crenças e valores, onde o poder do pai na família garantia o poder da escola e outras instituições, agora não sustentavam mais o discurso da modernidade (Ibid.). 
Nesse curso da história, vivemos hoje uma pós-modernidade de "desconstrução das referências simbólicas", um alheamento social, um descrédito total das instituições sociais de forma geral, uma falta de perspectiva para o futuro. Ou seja, um contexto social sem referências fixas, esse caos aberto a novas possibilidades na recriação de seus "registros sob novos signos" (LIMA, 2005, p. 3).

Essa análise poderia nos levar a pontuar a família e a escola, mundos nos quais as relações interpessoais são intensas, como forças potenciais na transformação que deverá suceder? Como irão se posicionar as crianças e os jovens nesse mundo que destituiu o poder patriarcal, exacerbou a figura do jovem, inverteu, subverteu e desmontou valores? A família está se refazendo, reposicionando papéis em novas redes de relações entre seus membros, mas a escola continua da mesma forma tradicional que não atende mais à infância e à juventude que as mudanças sociais descritas acima fizeram surgir. Continua na forma linear e homogênea de lidar com o conhecimento, não aproveita nem articula a pluralidade de culturas e universos que se apresentam no seu espaço. Os discursos parecem novos, mas não sustentam uma prática nova, pois muitas vezes são verbalizações de avanços teóricos, técnicos e científicos ainda não incorporados ao cotidiano (Ibid.).

Para os alunos com necessidades educacionais especiais essa escola também não encontra meios de proporcionar as oportunidades para seu pleno desenvolvimento e, mais uma vez, a família sobrepuja a escola na capacidade de buscar alternativas e acreditar nas possibilidades de seu filho. Elas também fazem parte dessa instituição que se modificou a partir das mudanças sociais do século XX, mas há peculiaridades em relação a outras famílias. Ter um filho com deficiência o que significa? O que provoca na estrutura familiar?

Sua vivência inicial é marcada por um processo de luto - a perda do filho esperado cuja elaboração é lenta, permeada de sentimentos de culpa, raiva e confusão. Em geral esse processo é desencadeado por um diagnóstico que leva às etapas de intensa reação ao choque, à perda e à privação. É comum uma vivência de depressão seguida de mecanismos de defesa como o de negação, passando um longo tempo na busca da cura, auto-comiseração, revolta, até chegar ao reconhecimento e aceitação, para depois iniciar a intervenção terapêutica e mais tarde o investimento em educação/socialização. Trata-se da experiência profunda de uma ferida narcísica (que fere o ego), com vivências de depressão e finalmente a elaboração com a reconstituição do ego e a construção de uma nova imagem e um novo sonho para seu filho. Muitas mães, ou pais, podem passar por todas essas etapas, como podem paralisar-se em uma 
delas. Isso depende da estrutura de personalidade e das relações afetivas anteriores ao nascimento de um filho com deficiência (Cf. LAMBERT e WEST, 1980).

A partir daí a dinâmica estabelecida no contexto familiar, que se estenderá para o contexto social mais amplo, dar-se-á de pelo menos duas maneiras na atitude dos pais: como superproteção ou como negação das limitações. A primeira delas impede experiências que favoreçam o desenvolvimento, carrega uma idéia de incapacidade e insuficiência que podem levar a pessoa com deficiência a desenvolver grande dependência, passividade e atitudes hostis frente ao mundo. A outra impõe intensa pressão pelo desempenho, alta carga de ansiedade, provocando agressividade, manipulação e grande dependência do objeto externo na tentativa de atender ao desejo dos pais (Ibid.).

O nascimento de um filho com deficiência vai alterar ainda mais a rotina da família e a vida do casal e dos irmãos.

Essas vivências são comuns na experiência das famílias onde nasce uma criança com deficiência, mas os múltiplos arranjos da estrutura existente serão determinantes no que virá a se desenrolar favoravelmente ou não ao desenvolvimento dessa criança e à vida da família. Muitas mães ficam sós, são abandonadas por seus maridos, deixam de trabalhar para cuidar do filho por suas necessidades freqüentes de hospitalização e muitas terapias (no caso da múltipla deficiência) e vão se fechando para a vida pessoal e passando a só existir para o filho. Outras absorvem o impacto e conseguem retomar a própria vida. Se o casal tiver uma união harmoniosa e os papéis homem-mulher, pai-mãe estiverem mais consistentes, encontrarão apoio mútuo e isso será resolvido de maneira mais saudável. Nesse caso se revela uma grande força acompanhada de companheirismo e atitudes confiantes para encontrar os caminhos que virão favorecer o desenvolvimento da criança.

Porém, são absolutamente freqüentes os casos em que o pai desaparece, quer concreta, quer simbolicamente. Aqui, neste último caso, vemos um tipo de família afetada pela perda do lugar masculino na rede de relações familiares. Muitas vezes isso está camuflado e, na emergência de um filho com deficiência, vem revelar a estrutura frágil do casal.

Mas em todos os tipos de dinâmica e estrutura familiar não escaparão à vivência do preconceito dentro da família nuclear, da família de origem ou de outros grupos sociais aos quais pertencem: trabalho, clube, igreja, vizinhança etc. e, novamente, cada família terá seu próprio modo de reação e seu próprio tempo de elaboração dos sentimentos provocados pela situação de grande sofrimento psíquico que a vivência do preconceito provoca. Algumas 
reagem agressivamente, outras com resignação, outras ainda procuram esclarecer as pessoas. Mas todas acabam por se imbuir de coragem e luta para transformar, de um jeito ou de outro, a situação de dificuldade. Saíram do anonimato e passaram a conhecer e defender o direito de seus filhos de serem vistos como pessoas além da deficiência, primeiro por elas mesmas, e depois pela sociedade. Assim defendem o direito ao atendimento na saúde, na educação, no transporte, no lazer e no trabalho. Geralmente quem faz essa ruptura e busca ajuda são as mães, mas vem crescendo nas instituições especializadas e nas escolas a presença de pais que cada dia mais sustentam essa posição.

Nesses parágrafos, nos permitimos lançar mão de dados empíricos de nossa prática profissional em educação, na qual percebemos, ao longo de mais de vinte anos, que as famílias muitas vezes viram usurpados seus direitos e temiam diante da figura de autoridade do médico, do especialista, do diretor da escola, ou não confiavam que suas demandas poderiam ser atendidas, mas hoje isso está mudando nesse grupo de famílias de crianças com deficiência. No contexto da educação escolar têm se colocado diante da escola como um parceiro a participar e ajudar a construir o processo. Essa atitude, porém, ainda é individualizada onde cada família luta pelo seu filho, por uma situação específica e pontual nem sempre tendo a visão de conjuntura com ações e posicionamentos mais pró-ativos capazes de gerar transformações mais amplas que possam atingir a situação de modo global que venha a beneficiar a todos e mudar o cenário. Por exemplo, em uma escola onde há diversos alunos com deficiência, os pais poderiam se organizar para ações inclusivas mais amplas na comunidade escolar como um todo e não apenas se concentrarem nas necessidades particulares de seus filhos.

Acompanhando a inclusão de crianças e jovens com deficiência visual e múltipla deficiência na escola, quando sentamos juntos em uma mesa de negociação com a família e a escola, verificamos que as famílias hoje vêm se mostrando conscientes das questões sociais que envolvem a deficiência e também conhecedoras das necessidades de apoios para o processo de aprendizagem e desenvolvimento de seus filhos. Assim, muito têm a contribuir para o processo de escolarização deles e de outras crianças. A escola ganharia em utilizar a competência das famílias para realizar esse trabalho, mas não tem desenvolvido estratégias para inseri-las no contexto educativo escolar, não as vê como parceiras.

A experiência profissional (não podemos descartá-la, ainda que sem tratamento científico para tais dados) nos põe diante também de famílias que não participam da escola, não aceitam os chamados, não aceitam a avaliação sobre as dificuldades do filho apontadas 
pela escola e os encaminhamentos feitos pela equipe pedagógica. Há casos em que a hipótese de deficiência, ou outros comprometimentos na aprendizagem, é levantada pela primeira vez pela escola e a família nega. Essa atitude nos leva novamente ao pensamento de que muitas vezes o entrave maior à inclusão social e escolar dessas crianças está no contexto familiar e nas particularidades da relação do casal de pais.

Há que considerar ainda uma diferença entre as famílias de crianças apenas deficientes visuais (que têm mais condições de autonomia tanto na vida prática como nos estudos) e aquelas de crianças que, além da deficiência visual, apresentam comprometimentos graves de desenvolvimento. As primeiras admitem e concordam que a escola inclusiva é a melhor opção para seus filhos. Já as outras (como vimos no caso estudado nesta pesquisa) ainda pensam que a escola especial trataria muito melhor as necessidades específicas da deficiência, pois apresentam uma realidade de poucas crianças por sala de aula, professores especializados e estrutura física e de recursos materiais mais apropriados. Porém, tais escolas são muito dispendiosas e por isso inacessíveis à maioria das famílias, ou não têm número suficiente de vagas. Mas quando as famílias tomam a decisão de levar seus filhos à escola comum e viver uma experiência positiva ou fazer de tudo para conquistá-la, passam a confiar e testemunhar as contribuições que essa escola pode trazer.

\subsubsection{O papel da instituição especializada na área da deficiência como} parceira na construção da Educação Inclusiva

No caso do aluno com deficiência, seu processo de escolarização necessita ainda contar com outro parceiro no atendimento às necessidades educacionais especiais: a instituição de atendimento especializado. Esta, cuja função é de complementação e suplementação educacional voltada aos apoios e atendimentos às especificidades da deficiência, também participa, junto à escola e à família, da elaboração de um plano de trabalho conjunto, além de oferecer-lhes apoio psicossocial no processo de inclusão do aluno, trabalhando na capacitação de professores, na mudança de atitudes, conceitos e valores que permeiam as relações humanas na família e na comunidade escolar.

Na prática, essa proposta tem se mostrado efetiva quando as condições que requerem estão ocorrendo nas seguintes ações junto à escola: 
- Políticas: parceria da instituição com as Coordenadorias e Diretorias de Ensino das redes públicas de ensino; participação na elaboração do Plano Político Pedagógico da escola;

- Técnicas: participação da instituição em reuniões técnicas de professores e coordenadores para orientações específicas; cursos, oficinas e palestras; discussão de caso e análise das adaptações curriculares;

- Sócio-educativas: escuta de professores sobre suas angústias, dificuldades, temores, fantasias, desejos, ansiedades e conquistas; trabalho com os grupos de alunos sobre o tema da diversidade;

- Operacionais: reuniões de avaliação para tomada de decisão e estabelecimento de metas; elaboração do Plano de Trabalho da criança ou jovem (e nesse caso o jovem também participa), definição de responsabilidades etc.

Já vimos neste capítulo que a igualdade de oportunidades para a aprendizagem escolar precisa ser garantida pela escola, mas no caso do aluno com deficiência deverá começar muito antes nos serviços de atenção precoce e desde a Educação Infantil, como forma de assegurar um melhor desenvolvimento e orientação à família.

Pela Declaração de Salamanca (Cf. UNESCO, 1994), a instituição especializada na área da deficiência, quer governamental, quer organização da sociedade civil, tem o papel de implementar tal declaração sobre princípios, política e prática em Educação Especial. Estas instituições devem ser centros de recursos para atendimento direto às necessidades específicas decorrentes da deficiência e apoio especializado às escolas inclusivas na identificação das crianças com deficiência, capacitação de profissionais, acesso a materiais e equipamentos específicos.

Cabe aqui uma observação: em nossa prática de assessorar escolas comuns no processo de inclusão de crianças com deficiência visual e múltipla deficiência deparamo-nos com as necessidades educacionais de muitas crianças além daquelas que apresentam alguma deficiência.

Ouvir a escola talvez seja o primeiro passo para a realização de uma proposta de Educação Inclusiva, respeitando o professor e promovendo situações nas quais possam falar de suas dúvidas, aflições, desejos, fantasias e demandas, fazendo emergir conteúdos fantasmáticos a respeito de situações educativas diversas, incluindo o aluno com deficiência e o significado desta. Sabemos que a questão da inclusão escolar não se esgota nas políticas 
públicas, mas se encerra especialmente em algo localizado em cada professor ou membro da escola, pois as ideologias externas, assim como os preconceitos e estigmas são passados pela fala e pela linguagem e internalizados de modo que as pessoas não se dão conta e isso só vem à tona quando posto na fala novamente em busca de um saber sobre o sujeito.

Da mesma forma os profissionais da instituição especializada são acometidos pelo processo de alienação, tendo eles, também, que se dispor a uma revisão pessoal de conceitos e imagens às quais estão colados, sobre os quais agem e se sustentam, tendo medo de mexer neles para não abalar suas crenças e posições. Os profissionais especializados em geral têm sua formação baseada no modelo médico, o qual submete o sujeito à deficiência e o processo de ensino-aprendizagem à patologia, tendo sempre como parâmetro de comparação a criança normal.

O trabalho da instituição especializada será então o de lidar com os preconceitos e suas imagens entranhadas; conceber a educação e o processo de ensino-aprendizagem como algo dinâmico a ser construído e voltado para o que há de singular em cada escola, em cada cultura e em cada um dos sujeitos envolvidos; pensar com a escola um plano de ação que a prepare para a entrada das crianças com deficiência; analisar o projeto político-pedagógico e sugerir adaptações necessárias de acesso ao currículo e em seus elementos: objetivos, conteúdos programáticos, metodologias, sistemas de avaliação e temporalidade; disponibilizar conhecimento técnico especializado sobre as especificidades da deficiência (Cf. MEC, 1999).

Será preciso também resgatar no próprio sistema de ensino regular o professor especializado que, desde a década de 60, atua em salas de recursos e salas especiais (hoje salas de apoio com designações distintas a depender da esfera estadual ou municipal) visando agora não só à instrumentalização do aluno com deficiência, mas também ao professor da sala comum e toda a comunidade escolar. Esse professor ficou por anos isolado em uma ação fragmentada e descolada da construção do conhecimento de forma integrada e coletiva.

Apesar dessa abordagem estar prevista nos Parâmetros Curriculares Nacionais da Educação Especial - Adaptações Curriculares e Estratégias para a Educação de Alunos com Necessidades Educacionais Especiais de 1999 -, percebemos ainda algumas resistências por parte das escolas e das Coordenadorias ou Diretorias de Ensino para aceitar essa atuação por parte das instituições especializadas.

Há muitas contradições ainda a serem explicitadas na legislação e na assimilação do novo paradigma da inclusão para que teoria e prática estejam mais afinadas e a parceria 
Educação Comum e Educação Especial possa realmente se efetivar em benefício daquilo que realmente importa - a educação para todos.

Já o trabalho da instituição especializada junto à família, além de tratá-la como parte integrante com atuação efetiva nesse processo dentro da escola, deve incumbir-se de uma outra linha de ação. Quer seja uma instituição clínica, quer seja educacional, não poderá deixar de fazer a escuta dessa família para identificar as imagens vinculadas à deficiência, o lugar da criança no discurso proferido pelos pais, seus sintomas e significações, criando espaços de fala cujo efeito terapêutico será percebido pela mudança de posição da criança na estrutura familiar. Como diz Oliveira (1996), referindo-se ao trabalho com pais na Escola Terapêutica Lugar de $\mathrm{Vida}^{4}$, ao falar de suas histórias, os pais têm a possibilidade de reconstruí-la, de ressignificá-la, reconhecendo-se e implicando-se naquilo que tem a ver consigo. Não se trata de um trabalho de análise ou psicoterapia de grupo, apesar de ter efeito terapêutico, pois que as famílias quando procuram uma instituição o fazem para seus filhos. Se houver demanda de trabalho pessoal, este deverá ser indicado para atendimento na comunidade.

Quando uma família procura uma instituição, ou um profissional, para atender seu filho "com problemas" supõe que há um Outro, que tem o saber que ela não tem. Está estabelecida a transferência que será o elemento chave desse trabalho. A instituição, via de regra, funciona como o terceiro que se interpõe entre a criança e a mãe, provocando a separação que até então não pôde ser feita.

O trabalho de escuta dos pais, em geral em grupos nas instituições, permite que estes se escutem e se confrontem com as diferenças. A princípio se justificam iguais na dor e se confortam na medida em que aplacam seu sofrimento por um visgo de catarse, até voltar para casa e continuarem repetindo seus sintomas. O profissional atento trabalha para que saiam dessa alienação e, aos poucos, as pessoas começam a perceber que, embora seus sintomas pareçam os mesmos, cada uma delas é diferente e suas significações são diferentes. Assim, passam a se responsabilizar no lugar de se culpar.

Quando falam dos filhos - de seu nascimento, o momento do diagnóstico, suas desconfianças sobre a deficiência, os comprometimentos que se deram em seu desenvolvimento, os tratamentos que fazem, a escola que desejam para eles, o que fazem e o

\footnotetext{
${ }^{4}$ Instituição voltada ao atendimento de crianças psicóticas e autistas, de orientação psicanalítica e sediada no Instituto de Psicologia da USP
} 
que deixam de fazer, suas perguntas etc. - os pais têm a oportunidade de refazer a história e reposicionar os filhos nos seus discursos.

Para Oliveira (1996), é necessário:

(...) produzir uma virada na posição da criança na estrutura familiar... relançá-la na série significante (...) as intervenções com os pais possibilitam mudança na posição que a criança ocupa: ela pode ser deslocada da posição de objeto para significante (Ibid., p. 42).

Sem o trabalho com os pais, que também envolverá aspectos informativos por parte de profissionais da equipe técnica, não lograremos a participação da família na escola em caráter de responsabilização por sua parte.

Neste capítulo, resgatamos a história da Educação para conhecer o momento sóciopolítico-histótico do nascimento da escola no intuito de situar os aspectos mais significativos que nos permitiram abordar a questão da inclusão educacional e escolar das crianças com deficiência.

No próximo capítulo, trataremos do universo da cegueira e dos "distúrbios globais de desenvolvimento" a fim de contextualizar o objeto de estudo desta pesquisa. 


\title{
CAPÍTULO II - DEFININDO E REFLETINDO SOBRE O UNIVERSO DA CEGUEIRA E DOS “DISTÚRBIOS GLOBAIS DE DESENVOLVIMENTO”
}

\begin{abstract}
Neste capítulo abordaremos a questão da cegueira e dos "distúrbios globais de desenvolvimento" para tratar da criança cega congênita com problemas graves no desenvolvimento. Assim, partiremos das definições médica e educacional de cegueira e sua dimensão psicossocial, adentrando o universo da estruturação psíquica do bebê cego nas suas primeiras relações objetais. Abordaremos o impacto para a mãe, suas representações simbólicas e os riscos para a constituição subjetiva do bebê. Para esta compreensão discutiremos as noções de desenvolvimento e constituição do sujeito, no referencial psicanalítico, discorrendo sobre cegueira como algo dado no real do corpo, mas com valor simbólico, portanto fundante do sujeito. Nessa perspectiva, trataremos das noções de corpo como organismo e corpo como imagem, refletindo sobre como a criança cega constrói a imagem especular e o "eu". Em seguida, definiremos a nomenclatura "distúrbios globais do desenvolvimento", justificando a designação assumida neste trabalho "problemas na constituição subjetiva e no desenvolvimento" para situar as crianças cegas congênitas com comprometimentos associados da ordem da subjetivação e do desenvolvimento.
\end{abstract}

Ao abordarmos neste estudo questões referentes a algumas crianças cegas com problemas no desenvolvimento iniciamos por explicitar as definições médica e educacional da cegueira, bem como sua dimensão social e peculiaridades, especificando ainda as formas de aquisição congênita e adquirida.

\section{CEGUEIRA}

Objetivamente, a cegueira é classificada dentro do quadro de referência da deficiência visual, caracterizando-se por uma limitação de ordem sensorial no órgão da visão, o que ocasiona um modo específico de percepção e organização do mundo. O valor atribuído à idéia de limitação é dado pelo fato de a visão ter um papel fundamental na apreensão do mundo, porém, diante das pessoas cegas, nos surpreendemos com a capacidade humana de buscar outras formas de sensibilidade para constituir a vida psíquica. Como diz Gregory (1979), a percepção vai além da experiência dos sentidos; ela busca, de forma dinâmica, a melhor interpretação do que lhe é apresentado. E Merleau-Ponty (1971) nos faz lembrar que: 
Ver é, por princípio, ver mais do que o que se vê (...) O sensível não é feito somente de coisas. É feito também de tudo o que nelas se desenha, mesmo no oco dos intervalos, tudo o que nelas deixa vestígio... (MERLEAU-PONTY, 1971, p. 81).

\subsection{As definições médica e educacional}

A partir de estudos realizados sobre as diversas definiç̧ões de cegueira encontradas em muitos países, a OMS (Organização Mundial da Saúde), em 1972, propôs normas para esta conceituação e para a uniformidade dos valores de acuidade visual, aprovando aquela adotada por Lowenfeld (1950).

Passou-se a considerar a cegueira, do ponto de vista médico e quantitativo, quando a acuidade visual menor que $20 / 200^{5}$, no melhor olho, após a possibilidade máxima de correção óptica e tratamentos, significando que aquilo que uma pessoa que enxerga normalmente pode ver a 200 pés, o cego enxerga até 20 pés. São denominados cegos também aqueles indivíduos cujo campo visual é restrito a um ângulo menor que 20 graus (visão tubular), ainda que possam ter acuidade normal nessa região, pois ficam impedidos da principal função dada pela percepção visual: a capacidade de captar o ambiente físico na sua totalidade.

De acordo com a $10^{a}$ revisão da Classificação Internacional das Doenças e Problemas Relacionados à Saúde (CID-10) da OMS (1993), é considerada cega a pessoa que tem acuidade visual abaixo de 20/400 (categorias 3, 4 e 5 de graus de comprometimento visual). Para fins legais de concessões de benefícios ou isenções, considera-se cegueira a "acuidade visual corrigida menor que 20/200 no melhor olho ou campo visual menor que 20 graus" (HADDAD et al., 2001, p. 12).

A tabela abaixo mostra os dados da OMS (1993):

\footnotetext{
${ }^{5}$ Medida em pés. 20 pés equivalem a 6 metros
} 
Tabela 1: Definição da CID-10 sobre cegueira

\begin{tabular}{|c|l|l|}
\hline $\begin{array}{c}\text { Graus de comprometimento } \\
\text { visual }\end{array}$ & \multicolumn{1}{|c|}{ Mcuidade visual com a melhor correção possível } \\
\hline 3 & $\begin{array}{l}\text { Mínima igual ou maior que: } \\
1 / 20(0,05) \\
20 / 400\end{array}$ & $\begin{array}{l}1 / 60 \text { (capacidade de contar } \\
\text { dedos a } 1 \mathrm{~m}) \\
1 / 50(0,02) \\
5 / 300(20 / 1200)\end{array}$ \\
\hline 4 & $\begin{array}{l}1 / 60 \text { (capacidade de contar } \\
\text { dedos a } 1 \mathrm{~m}) \\
1 / 50(0,02) \\
5 / 300\end{array}$ & \begin{tabular}{l} 
Percepção de luz \\
\hline 5
\end{tabular} \\
\hline & $\begin{array}{l}\text { Ausência da percepção de } \\
\text { luz }\end{array}$ \\
\hline
\end{tabular}

Fonte: OMS, 1999.

O quadro da deficiência visual abrange também o que se denomina, na terminologia mais recente, baixa-visão, definida nesses termos como acuidade visual residual menor que 20/70 e maior ou igual a 20/400 (categorias 1 e 2 de graus de comprometimento visual), no melhor olho, após a máxima correção, utilizando-se o mesmo referencial citado acima para compreensão dessa medida oftalmológica. Vejamos abaixo a tabela da OMS (1993):

Tabela 2: Definição da CID-10 sobre visão subnormal

\begin{tabular}{|c|l|l|}
\hline & \multicolumn{2}{|c|}{ Acuidade visual com a melhor correção possível } \\
\hline $\begin{array}{c}\text { Graus de comprometimento } \\
\text { visual }\end{array}$ & \multicolumn{1}{|c|}{ Máxima menor que: } & Mínima igual ou maior que: \\
\hline 1 & $6 / 18$ & $6 / 60$ \\
& $3 / 10(0,3)$ & $1 / 10(0,1)$ \\
& $20 / 70$ & $20 / 200$ \\
& $6 / 60$ & $3 / 60$ \\
2 & $1 / 10(0,1)$ & $1 / 20(0,5)$ \\
& $20 / 200$ & $20 / 400$ \\
\hline
\end{tabular}


Fonte: OMS, 1999.

Ainda na década de 1970, avanços da prática educacional e clínica resultaram em uma definição e classificação funcional com base na eficiência da visão, e não na acuidade visual que determinava que uma pessoa era cega quando, na realidade, ela utilizava seu resíduo visual de várias formas, fosse para as atividades da vida diária, ou mesmo para a escrita e a leitura em tinta tipo ampliado na maioria das vezes. Essa concepção educacional provocou uma mudança significativa no enfoque da deficiência visual, estabelecendo a seguinte classificação:

- Cegos são aqueles que apresentam desde ausência total de visão (amaurose) até percepção de luz (distinguindo entre claro e escuro), ou projeção de luz (identificando a direção de onde vem a luz). A cegueira parcial - condição na qual a grande maioria dos cegos se encontra - permite que os indivíduos possam perceber vultos, claro escuro e contar dedos da mão a uma certa distância (Cf. ROCHA, 1987). Necessitam do sistema de escrita Braille e utilizam outros sentidos que não a visão para o conhecimento do mundo.

- Pessoas com baixa visão mostram a possibilidade de indicar a projeção de luz até onde a dificuldade visual limita seu desempenho, porém, utilizam a visão residual para a situação educacional, incluindo a leitura e a escrita em tinta, com ou sem recursos ópticos, e para as situações práticas da vida diária.

Em 1992 foi proposta a definição de funcionalidade da baixa visão, mas esta não foi incorporada à CID-10.

Nessa definição, a pessoa com baixa visão, ou visão subnormal, apresenta alterações na sua funcionalidade, mesmo após tratamento e/ou correção óptica, com acuidade visual inferior a 20/70 à percepção de luz; porém usa ou é potencialmente capaz de usar a visão para o planejamento e/ou execução de uma tarefa (HADDAD et al., 2001, p. 12).

Segundo os autores há outros dados interessantes sobre a estimativa da Organização Mundial da Saúde - OMS - de que no mundo hoje há cerca de 140 milhões de pessoas com baixa visão e 45 milhões com cegueira, sendo que $80 \%$ dos casos seriam evitados com 
sistemas de prevenção ou tratamento. E ainda que, em relação à infância, há cerca de 1.500.000 crianças cegas cujas causas principais são as doenças genéticas (congênitas ou perinatais), nos países desenvolvidos e as nutricionais e infecciosas, nos países em desenvolvimento. No Brasil, os estudos mostram que a toxoplasmose congênita e a catarata congênita, secundária à rubéola, são as causas mais encontradas (Cf. HADDAD et al., 2001).

O Conselho Internacional de Oftalmologia adotou a resolução de Sidnei, Austrália, 2002, sobre as definições de deficiência visual:

- Cegueira: somente em caso de perda total da visão e para condições nas quais os indivíduos precisam contar predominantemente com habilidades de substituição à visão;

- Baixa visão: para graus menores de perda de visão nos quais os indivíduos podem receber auxílio significativo por meio de aparelhos e dispositivos de reforço da visão;

- Visão diminuída: quando a condição de perda de visão é caracterizada por perda de funções visuais (como acuidade visual, campo visual etc.) em nível de órgão. Muitas dessas funções podem ser medidas quantitativamente;

- Visão funcional: descreve a capacidade de uso da visão pelas pessoas para as atividades da vida diária. Sendo que muitas dessas atividades podem ser descritas apenas qualitativamente;

- Perda de visão: termo geral, que compreende perda total (Cegueira) e perda parcial (Baixa Visão), caracterizada por visão diminuída ou perda de visão funcional (Cf. CONSELHO BRASILEIRO DE OFTALMOLOGIA, 2002).

Em relação às classificações de acuidade CID-10 e de funcionalidade ICIDH-2 (International Classification of Functioning, Disability and Health), a indicação dos especialistas é que ambas sejam consideradas de forma integrada, pois são complementares, de acordo com cada finalidade específica: discussão de casos, troca de informações e orientações técnicas. Evidentemente, para o educador, a atenção está colocada nas respostas educacionais que deverá encontrar para promover condições adequadas ao desenvolvimento, à aprendizagem e à inclusão educacional e escolar da criança cega (Cf. HADDAD et al., 2001).

Para o educador, também, é importante considerar a época de incidência da cegueira na vida da criança, o que leva a diferenças na estruturação psíquica e no desenvolvimento da criança cega. 
Segundo Lowenfeld (1950), cegueira congênita define-se pela aquisição desde o momento do nascimento até os cinco anos, alegando que até essa idade as imagens visuais não podem ser retidas, pois, de acordo com as idéias de Piaget (s/d apud AMIRALIAN, 1997) antes dos seis anos (período operatório) a criança só forma imagens estáticas e não transformacionais e isso não lhe permite representar ou antecipar processos desconhecidos da realidade vivida e nem evocar uma memória das impressões visuais. Amiralian (1997) objeta que esse parâmetro pode ser importante no aspecto cognitivo, mas não se pode esquecer do que representa a pulsão do olhar nas primeiras relações objetais e, acrescento: não se pode esquecer que o desenvolvimento cognitivo depende dessas relações.

Convém ainda frisar que a cegueira implica certamente questões que não estão restritas apenas ao aspecto orgânico, mas substancialmente às questões psicossociais que vão engendrar aspectos da subjetividade de quem a mostra como também daquele que a lê. Quer do ponto de vista orgânico, quer do ponto de vista da subjetividade, a mesma patologia e o mesmo quadro clínico, em pessoas diferentes, terão manifestações próprias a cada uma delas.

\subsection{A dimensão psicossocial da cegueira}

A dimensão psicossocial da cegueira implica atitudes e crenças referentes a um imaginário coletivo, ao longo da história da humanidade, que são reeditadas nos mitos familiares. Eles identificam o modo como o cego é visto por aqueles que enxergam e qual o lugar que ele ocupa no discurso instaurado, quer no âmbito pessoal, quer no social. Ser visto como coitado, pecador ou como sábio, como o que tem que ser o melhor, ou aquele sobre quem paira sempre uma dúvida em relação à sua capacidade, tudo isso repercutirá sobre o caminho de constituição e desenvolvimento psíquicos da pessoa cega que vive em um mundo construído pela visão, onde o ver é sinônimo de conhecer e tem um papel central na formação da pessoa e o olhar um papel preponderante na constituição do sujeito. Em capítulo posterior trataremos mais particularmente a questão da visão e do olhar, porém aqui faz-se importante refletir acerca dos significados do "ver" e da cegueira que marcam a pessoa cega em sua subjetividade a partir do lugar social que lhe é atribuído.

As representações sociais da cegueira regem as imagens, conceitos, sentimentos e significados acerca da cegueira e geram atitudes muitas vezes preconceituosas, influenciando sobremaneira as relações interpessoais, causando sofrimento psíquico e impedimentos à 
manifestação própria de cada ser, além de discriminação e exclusão. Ao pensar na cegueira, as pessoas costumam associá-la mais comumente às noções de escuridão, impossibilidade, solidão, tristeza, comiseração, ou ainda idéias de habilidades superdesenvolvidas. Assim, as pessoas projetam-se no cego, imaginando que se sentiriam dessa forma se fossem elas. Tais sentimentos dizem respeito aos estigmas e às formas estereotipadas de representação da cegueira.

Relatos de pais, professores e das pessoas em geral, em um primeiro momento evidenciam tais idéias. Assim muitas vezes são vistas as pessoas cegas. Outras vezes, quando há uma racionalização ou elaboração da experiência vivida, começam a advir idéias mais vinculadas à realidade de cada pessoa cega.

Vários estudiosos relataram o modo como os cegos e a cegueira foram vistos ao longo da história da humanidade. Vygotsky (1993) apresenta uma retrospectiva interessante para mostrar a passagem da visão popular sustentada, na Antigüidade e na Idade Média, por fundamentos religiosos e de um lugar místico dado a eles - a cegueira seria um grande infortúnio, um castigo dos céus ou uma dádiva divina. Superstições que faziam com que as pessoas temessem ou endeusassem o cego, considerado como uma pessoa predisposta à sabedoria e à iluminação por ter uma vida interior mais rica - a visão biológica e depois sócio-psicológica da ciência na Idade Moderna, na qual o misticismo dá lugar à experiência e ao conhecimento. É nesse período da história que começa a educação do cego - escolas especiais de ensino segregado e a escrita Braille - como marco de sua libertação.

$\mathrm{Na}$ contemporaneidade, as idéias populares e místicas sobre a cegueira ainda permanecem vivas, bem como o estigma e o preconceito. Nas ciências, as concepções positivista e humanista ${ }^{6}$ permeiam a interdisciplinaridade das práticas clínica, educacional e social com referenciais prioritariamente visuais. Nas políticas públicas, nas recomendações universais que regem os blocos das nações e na ação crescente do chamado terceiro setor discute-se o papel do cego em um panorama mais amplo da sociedade - direitos humanos, cidadania, exclusão, inclusão - no qual ainda convivem a exclusão, a segregação, a tentativa

\footnotetext{
${ }^{6}$ Positivismo: termo que designa várias doutrinas do séc. XIX que se caracterizam pela valorização de um método empirista e quantitativo, pela defesa da experiência sensível como fonte principal do conhecimento(...) e pela consideração das ciências empírico-formais como paradigmas de cientificidade e modelos para as demais ciências. Humanismo: atitude filosófica que faz do homem o valor supremo e que vê nele a medida de todas as coisas. (JAPIASSU e MARCONDES, 1991, p. 198 e124).
} 
de integração e a luta recente pela inclusão ${ }^{7}$. Trata-se de uma transformação sócio-políticoideológica, segundo a qual a sociedade é para todos, respeitando-se as diferenças, estabelecendo-se a equiparação de oportunidades de trabalho e estudo e a acessibilidade do cego a todos os bens produzidos pela sociedade.

Masini (1990), em seu trabalho de Livre Docência, mostrou como, num mundo definido pelo padrão visual de organização e funcionamento, as diretrizes e propostas educacionais curriculares também não contemplam a especificidade das pessoas cegas no seu modo de perceber, sentir, agir e relacionar-se no mundo. Assim, a autora faz perguntas do cotidiano que devem permear o pensamento dos educadores na busca de conhecer o universo da cegueira destituído, o máximo possível, das idéias pré-concebidas:

De que modo um aluno com deficiência visual encontra fora da sala de aula seus companheiros? Como ele adquire autonomia no ambiente escolar para ir à secretaria, diretoria, sala dos professores? Quais os recursos para ensinar-lhe a localização da Amazônia? É possível esse aprendiz ter noção de arranha-céu, via elevada, microscópio (...) horizonte? (MASINI, 1994, p. 25).

As respostas para todas essas perguntas podem ser simples quando há sensibilidade, disponibilidade e alguém se aproxima para ver quem é esse aluno, qual sua forma de apreender e compreender o mundo. Outras questões poderiam juntar-se a essas no que diz respeito aos aspectos psicossociais da deficiência, como por exemplo: como se sente o aluno cego no espaço escolar feito de e para videntes? Como se sente sempre que é esquecido para trás, pois bate o sinal e todos saem correndo? E quando não é convidado para o programa do final de semana? E quando é dispensado da aula de Educação Física porque o professor diz que não sabe o que fazer com ele? E ainda quando o professor lhe dá nota mesmo que ele não faça prova ou apresente trabalho só porque não sabe como fazê-lo escrever? Quantas vezes ele agüenta explicar que pode e quer fazer o que todos fazem, mas do seu jeito? E quando é chamado de cego (o que ele de fato é, mas que ganha uma conotação depreciativa quando é dita pejorativamente)? Quantas vezes, quando assume a deficiência, tem que responder: sou cego, sim, mas meu nome é "João"? E o que diríamos quanto a tudo que ouve em casa, na rua,

\footnotetext{
${ }^{7}$ Inclusão: atitude norteada pela crença no valor da diversidade humana que contempla diferenças individuais e efetua mudanças administrativas, ambientais e atitudinais da sociedade para a pessoa com necessidades especiais buscar seu desenvolvimento e exercer sua cidadania. (SASSAKI, 1997, p. 43 e 65).
} 
na escola e no trabalho que alude à desconfiança sobre sua capacidade? E quando tem que assumir sua bengala, seus recursos ópticos perante todos?

Bruno (1999), em sua pesquisa de mestrado, levantou com pais, professores e alunos representações sociais da deficiência visual - na interação e comunicação na vida familiar, escolar e social e constatou que inicialmente, a vivência dos pais é de luto e dor pela perda do filho idealizado, tristeza e medo. Medo do inusitado, da diferença, do desconhecido mas que, na medida em que se vai convivendo e criando o vínculo, outros sentimentos e imagens são construídos. Esses mesmos sentimentos foram relatados pelos professores (à exceção do luto), cujo medo de enfrentar a cegueira foi expresso, simbolicamente, pela preocupação em "dar conta do recado". A pesquisadora observou nos relatos que os conceitos acerca da deficiência visual sinalizaram uma dimensão humana e psicológica e não mais mística, apontando para uma sociedade apoiada no conhecimento científico, a qual esforça-se na direção de novas atitudes e posturas na convivência e aceitação do diferente. Identificou-se ainda que os discursos apontaram duas direções: uma indicando uma conotação negativa com base nos conceitos culturalmente cristalizados; a outra positiva, construída na constatação das possibilidades e experiências gratificantes mostradas pela pessoa cega e no tempo para elaboração dos sentimentos.

É importante considerar que, quando as pessoas chegam a esse nível de elaboração, geralmente já participaram de programas sócio-educativos nas instituições especializadas ou de trabalho psicológico pessoal, ou contaram com recursos internos próprios que a vida lhes tenha proporcionado. Ou já tiveram o tempo de perceber o potencial para desenvolver-se que as crianças cegas têm, pois ao acercarmo-nos delas passamos a conhecê-las e mudamos conceitos calcados em estereótipos sociais construídos pelo mundo visual, além do fato de que o debate sobre a questão da deficiência está hoje trazendo uma consciência maior sobre o assunto para toda a sociedade.

Se os conceitos, valores e padrões são forjados na cultura por uma determinada sociedade, essa mesma cultura é passível de transformação. A nosso ver, a pesquisa de Bruno (1999) reflete isso quando identificou nos relatos de pais e alunos que os sentimentos diante da deficiência não eram mais de revolta, negação, culpa, vergonha ou incapacidade, mas de indignação e impotência frente ao preconceito e ao descaso com que a sociedade trata a questão da diferença e as necessidades específicas da deficiência visual. E também em relação aos professores entrevistados que mostraram em algum grau uma mudança na representação social acerca da deficiência visual quando não focalizaram a questão no déficit, mas na 
dimensão humana de seus alunos cegos ao falarem das características de personalidade, bem como de suas potencialidades e habilidades diversas ou limitações e dificuldades.

Mas é importante também salientar que todas as vezes que recebemos nas instituições famílias de bebês que nasceram cegos ou de crianças que adquiriram a cegueira mais tarde, jovens e adultos nessa condição, ou ainda professores que recebem o aluno cego, ouvimos a reedição dos conceitos e sentimentos que a idéia de não enxergar evoca num primeiro momento e que certamente não vêm da razão. É aí que queremos trabalhar, pois que "na explicação racional (...), ocorre a "cisão entre o olhar e a palavra" (MASINI, 1994, p. 15).

Algumas representações populares, também encontradas na literatura, revelam associações ligadas ao olho e à cegueira identificadas nos estudos psicanalíticos de Blank (1957; 1971) e citados por Amiralian (1997). Tais significados inconscientes referem olho como órgão sexual, como órgão hostil e destrutivo; cegueira como castração e punição; e olho e visão como onipotência, além de vinculados a conflitos de inveja, exibicionismo e escopofilia. O autor ressaltou o papel preponderante da visão sobre o desenvolvimento psicossexual e do ego, bem como dos conflitos não resolvidos de escopofilia e exibicionismo, presentes na estruturação do psiquismo, que seriam responsáveis pelos processos de transferência e contratransferência que a cegueira provoca.

Em uma cultura onde a maioria é vidente, o olho e a visão ocupam um lugar primordial. Masini $(1990 ; 1994)$ fez uma revisão do pensamento filosófico sobre a questão do ver como conhecer, do conhecer sem ver, da visão como excelência da percepção e condição do pensamento, a partir das articulações de Bosi, Chauí e Novaes (1988) - filósofos contemporâneos brasileiros - na articulação dos pensamentos de Aristóteles, Descartes, Galileu, Santo Agostinho e Merleau- Ponty. Nessa construção teórica a autora percebeu que todas as filosofias acerca do ver e do olhar convivem nos dias de hoje estando presentes na concepção de mundo das pessoas e no valor dado à visão. Idéias e ideais nos quais prevalecem o modo visual de conhecer e pensar o mundo sem conseguir conceber outras formas de apreensão do mundo na ausência da visão. Estas concepções precisam ser desveladas cada vez que alguém fala para que idéias pré-concebidas acerca da cegueira tornem-se conhecidas e, portanto, passíveis de desconstrução e abertura para o sujeito que se apresenta com sua cegueira.

Leonhardt (1984) acrescenta, sob a dimensão cognitiva, que: 
A criança cega não é um vidente que carece de visão. Sua maneira de perceber o mundo, que ele mesmo elabora, não é igual à de uma criança normal privada da visão. A diferença apóia-se na organização original que ele opera em sua modalidade sensorial (...) Não existe na realidade uma compensação sensorial mágica com a utilização dos outros sentidos (...) Será, pois, fundamental conhecer essa outra forma de ser, esta alteração e aceitá-la: é a única maneira de não conceber a educação da criança cega como compensatória ou uma reeducação e sim como uma aproximação diferente, necessária para uma organização totalmente distinta da pessoa (LEONHARDT, 1984, p. $59)$.

Ormelezi (2000), em sua dissertação de Mestrado, estudou os processos de formação de conceitos em pessoas cegas congênitas, trazendo as idéias de Vygotsky para o campo de conhecimento acerca da cegueira, mostrando que o autor fala de uma compensação de outra ordem - a sócio-psicológica.

Nesse estudo, a pesquisadora expôs que, para Vygotsky (1993), as possibilidades compensatórias para o cego congênito, nessa dinâmica do funcionamento cerebral, serão definidas pelos significados e relações estabelecidos no mundo a partir da sua condição física, da resposta social que a cegueira provoca e da elaboração do indivíduo em novas respostas ao ambiente.

Nesse sentido, o autor ressalta que, no caso da cegueira, a origem da compensação não diz respeito a um maior desenvolvimento do tato ou refinamento da audição, como já foi dito, mas à possibilidade de comunicação do indivíduo e sua inserção na experiência social. $\mathrm{O}$ homem, como ser de linguagem, tem acesso ao mundo dos significados compartilhados no contexto em que está inserido, pois a apreensão do real, pelo sujeito, não pode se dar senão por meio dos símbolos criados pela cultura. Essa mediação da linguagem, nos termos de Vygotsky (1993), permite transpor para o mundo interno do sujeito a representação da realidade, fazendo com que ele realize sua capacidade humana de concretizar mentalmente as coisas do mundo, indo além das experiências sensorial, perceptiva e motora, integrando-as em um sistema simbólico. Essa concepção ajuda-nos a pensar na viabilidade da aquisição de conhecimento pelo cego sobre coisas jamais vivenciadas, e nos remete à questão de sua aquisição de representações mentais e conceitos sobre o mundo como sujeito do conhecimento. Assim, podemos concluir com o autor que o significado de compensação presente na cegueira é de ordem sócio-psicológica. 
Abordando o aspecto social por um outro enfoque, aquele das relações interpessoais, que são afetadas pela presença de qualquer deficiência, e que geram os verdadeiros problemas em relação a elas, passamos a observar as reações de busca de uma supercompensação, de um grande esforço, por parte do indivíduo portador de deficiência visual, para adaptar-se a um mundo preponderantemente visual. Segundo comentários de Vygotsky (1993), por um lado, esse esforço é vitorioso, transforma a deficiência em competência, e a fragilidade em força. Vitória essa exemplificada pelos estudos de Saunderson (apud VYGOTSKY, 1993) com cegos de nascença, a respeito do esforço destes para compreender geometria, ciência na qual a noção de espaço alcança níveis abstratos muito elevados. Por outro lado, o confronto com a deficiência pode resultar em uma tentativa frustrada de superação, ocasionando para a vida psicológica do cego uma posição defensiva e de baixa auto-estima. Entre essas duas formas de lidar com a deficiência frente às exigências da sociedade, existem muitos níveis de experiências de conquistas e fracassos. O que se evidencia para Vygotsky (1993), porém, é que a cegueira cria para o cego, como já vimos, um lugar social difícil, em uma sociedade que não aceita a deficiência, o defeito, o diferente e que, por isso, cria conflitos para a pessoa cega, tanto que ela não busca recuperar a visão, mas uma supercompensação para a superação constante da deficiência nessa ordem social.

Vygotsky (1993) interessou-se em compreender a generalidade do significado social e individual da condição da cegueira, bem como a singularidade dessa forma de viver sem o sentido da visão. Para ele:

Cegueira não é meramente a ausência da visão; a cegueira causa uma total reestruturação de todo o organismo e de toda a personalidade. A cegueira, criando uma nova e única matriz da personalidade, traz à vida nova força; criativamente muda tendências normais das funções e organicamente refaz e forma a mente do indivíduo. Portanto, cegueira não é meramente um defeito, uma falta, uma debilidade, mas em algum sentido é também a origem da manifestação das habilidades, um adicional, uma força, por estranha e paradoxal que essa idéia possa parecer (Ibid., p. 97).

Certamente a cegueira requer que sobre ela seja lançado um olhar mais abrangente que vá além das dimensões física e intelectiva e que contemple questões humanas mais complexas de ordem afetiva, ética e sócio-cultural. 
Nesse sentido, refletir sobre os significados atribuídos à cegueira é muito importante para a construção de um olhar/discurso que veja a pessoa cega sob o seu próprio referencial. Amaral (1994) expõe o seguinte:

O outro, o diferente, o deficiente, representa muitas e muitas coisas. Representa a consciência da própria imperfeição daquele que vê, espelha suas limitações e castrações. (...) representa também uma ferida narcísica em cada pai, em cada profissional, em cada comunidade. Representa um conflito não camuflável, não escamoteável - explícito - em cada dinâmica de interlocuções (AMARAL, 1994, p. 30).

\subsection{Cegueira congênita: estruturação psíquica, desenvolvimento e a noção de constituição do sujeito}

Os estudos psicanalíticos sobre a cegueira, em sua grande maioria oriundos da Inglaterra, Estados Unidos e Espanha, focalizam crianças cegas a partir do referencial das crianças videntes, quanto à estruturação psíquica e possíveis desvios de personalidade. São estudos que priorizaram a compreensão sobre a formação do ego enfocando alguns problemas nesse processo. Problemas esses advindos, segundo os pesquisadores, das peculiaridades da ausência da visão na apreensão do mundo e do que isso pode representar nas interações entre mãe e filho no começo da vida da criança, bem como no seu desenvolvimento psicomotor e cognitivo.

$\mathrm{Na}$ Inglaterra, os estudos dirigidos por Burlinghan (1965) na Hampstead ChildTherapy Clinic, datados desde a década de 40 com crianças de zero a onze anos, concluíram por atrasos no desenvolvimento da criança cega congênita em relação às crianças videntes. Isso se daria como conseqüência da ausência da visão ao: 1) restringir e alterar o teste de realidade, dificultando a diferenciação eu/não-eu, dando margem à fantasia e à negação da realidade; 2) impedir que as crianças sejam atraídas pelos objetos que a circundam e saiam a buscá-los, tendendo à imobilidade motora e das funções do ego, bem como à passividade e falta de espontaneidade; 3) inibir nas mães o prazer na relação e o comportamento de aprovação que costuma incentivar as crianças a repetirem suas experiências de sucesso em suas ações sobre o mundo. A autora observou ainda um período prolongado de dependência, uma certa fixação da libido na boca e inibição da agressividade pela dependência que tem do 
vidente. As crianças estudadas também mostraram mais medo de agressões externas, maior interesse por pessoas do que por objetos, poucas experiências e por isso menos conquistas do ego.

Burlinghan (1965) assinalou também que a voz e sua escuta não compensam a pulsão do olhar na relação mãe-bebê. Muitas mães das crianças estudadas mostraram não compreender os significados do silêncio e dos estímulos sonoros para a criança, a cada momento, interrompendo a quietude que pode estar sendo importante na atenção da criança, ou deixando-a à mercê da multi-estimulação sonora que só faz dificultar a discriminação do que é pertinente para a situação. Pela falta de impressões visuais e no caso de não ser incentivada a explorar e conhecer o mundo e diferenciar-se, corre o risco de deslocar a imobilidade do motor para funções do ego, além de um certo vazio na mente que será preenchido pela atenção às sensações do próprio corpo.

A autora observou ainda nessas crianças excelente memória e vocabulário, mas com palavras básicas da experiência sensorial, ou por imitação/repetição, muitas vezes sem significado, denotando uma verbalização por associação, pouca generalização, podendo confundir a palavra com a coisa e, ainda, uma frustração por não conseguirem entender as palavras usadas pelas pessoas significativas para elas. Embora a palavra também seja a possibilidade para a criança cega orientar-se e construir seu mundo conceitual e de significações, ela pode tornar-se mero verbalismo (Cf. BURLINGHAM, 1965). Aqui Amiralian (1997) adverte sobre o cuidado que devemos ter ao designar apressadamente como verbalismo, perseveração ou ecolalia determinada forma de expressão oral das crianças cegas, pois muitas vezes tais expressões refletem uma elaboração de conceitos que segue um caminho próprio do cego, reiterando autores como Anderson (1981) e Hall (1981).

Deutsch (1940 apud LEONHARDT, 1992) concordou com as afirmações de Burlinghan sobre as crianças cegas congênitas e acrescentou um outro aspecto: o caráter de satisfação rápida da curiosidade, desinteressando-se logo pelo ambiente, voltando à fantasia.

Sandler (1963) investigou aspectos de passividade no desenvolvimento do ego de bebês cegos percebendo que até os quatro meses seguiam um desenvolvimento semelhante ao dos bebês videntes e que a partir daí passavam a mostrar diferenças importantes. Ou seja, na passagem da primeira para a segunda fase oral (passiva e ativa respectivamente), têm a tendência de centrar-se em si mesmos e ficar passivos, sem mostra de luta para avançar na conquista das coisas. A primeira fase oral é marcada pela predominância da boca como órgão de prazer e exploração do mundo em todas as crianças. Na fase oral ativa a mão é que assume 
o papel de explorar sendo direcionada pela visão, impedimento para o bebê cego, ficando este atrasado nessa aquisição. Como a função exploratória da mão conduz à diferenciação do próprio corpo em relação ao mundo externo, para a autora decorre daí, no bebê cego, um desvio do ego que algumas vezes poderá ser revertido com uma "maternagem” adequada.

Este autor afirma ainda que a capacidade auditiva não compensa a falta da visão no que diz respeito à continuidade sensorial que faz com que a criança se mantenha vinculada aos estímulos do meio, sendo que o bebê cego fica privado disso, voltando-se para si mesmo iniciando uma estimulação auto-centrada. Conclui assim que a cegueira é responsável pelas deformações que sofre o ego nesse período de desenvolvimento (Cf. SANDLER, 1963).

Omwake e Solnit (1961 apud LEONHARDT, 1992) assinalaram dificuldades na psicanálise de uma criança cega com desvios de personalidade e a condução do tratamento que levou à recuperação. Essas dificuldades se caracterizaram pela estagnação no curso da libido e do ego, pelo desenvolvimento de um comportamento inibitório por causa da necessidade de conhecer o mundo tatilmente, pela desorganização ocasionada pela lembrança de experiências penosas nos três primeiros anos de vida e a pobreza de estímulos com falta de orientação e proteção. Quanto ao que levou o tratamento a um desenrolar satisfatório foi o fato do terapeuta ter assumido uma posição de referente perceptivo e uma compreensão da deficiência sensorial de ordem visual.

Wills (1970), por sua vez, destacou os períodos mais vulneráveis para o desenvolvimento do bebê cego. Eles se referem à fase mais precoce da vida do bebê na qual a mãe necessita de muito apoio para possibilitar que seu filho se desenvolva sem falhas no processo. Esse período é crucial, pois o bebê tem que investir libidinalmente em seus objetos e organizar suas vivências. Esses estágios são caracterizados pela autora conforme o que segue:

- Período maior que o bebê cego precisa para localizar brinquedos e apanhá-los a partir de pistas sonoras. Isso terá que lhe dar a noção da substancialidade dos objetos e incitar a passagem do interesse centrado no próprio corpo e no da mãe para o mundo externo;

- Um longo período no qual o bebê cego permanece apegado ao que lhe é conhecido e à rotina, ao que lhe dá segurança, o que pode levar a uma tendência de retorno e fixação no funcionamento de uma fase anterior sempre que algo o ameace; 
- E o último desses períodos, o das representações internas do objeto, da noção de conservação e permanência dele, que pode levar o bebê a uma certa fusão entre impulsos agressivos e libidinosos em relação aos objetos. É difícil para o bebê cego perceber que a mãe que satisfaz é a mesma que frustra se ele não tem a representação interna consistente da mãe.

Nagera e Colonna (1965) também estudaram o processo de estruturação do ego e das relações objetais em um grupo de crianças cegas congênitas de quatro a oito meses e observaram que algumas mostravam desenvolvimento semelhante ao das crianças videntes, enquanto outras apresentavam um desenvolvimento atípico dando a impressão de deficientes mentais. Os autores criticam os estudos que se baseiam em perfis de desenvolvimento de crianças videntes, levando a interpretação das peculiaridades da criança cega como se fossem crianças apenas sem visão.

Nos Estados Unidos, um outro grupo formado por psicólogos, educadores, médicos e assistentes sociais desenvolveu trabalhos de orientação psicanalítica com crianças cegas congênitas dos primeiros anos de vida à puberdade, trabalhos esses coordenados por Fraiberg (1977), em 1961, no Family Service of New Orleans e depois na Universidade de Michigan em 1963. Observaram, em um universo de 27 crianças cegas congênitas com os outros sistemas íntegros, 7 crianças com quadros comparáveis ao autismo das videntes e graves comprometimentos no desenvolvimento e 20 com desvios no funcionamento do ego e atrasos no desenvolvimento, sendo que as 17 crianças que ficaram cegas no primeiro ou segundo ano de vida se mostraram menos comprometidas. A metodologia utilizada era a observação dos bebês e das mães em situações de interação. Esses estudos também compararam crianças cegas com videntes (Cf. AMIRALIAN, 1997).

Fraiberg e Freedman (1964) reforçaram a observação de uma das causas de sérios problemas de desenvolvimento nas crianças cegas congênitas ser a falha na aquisição da autonomia da mão e a permanência da percepção e exploração do mundo fixada na boca, o que indica uma sobrecarga libidinal em uma única fonte de prazer implicando desvios na formação do ego. Essa fixação na boca vai impedir a mobilidade da qual depende a ampliação do conhecimento sobre os objetos. Essa restrição na mobilidade, por sua vez, pela falta do estímulo visual e também pela dificuldade vivida pela mãe para proporcionar outras oportunidades à criança, levará a um atraso na locomoção e esta à restrição das experiências que levam as crianças a fazerem as distinções entre o eu e o não-eu. 
Fraiberg também estudou com Siegel e Gibson, em 1966, a importância da discriminação auditiva na formação do ego das crianças cegas. Os autores detectaram que a coordenação autônoma ouvido-mão nas crianças videntes se dá por volta dos seis meses e nas crianças cegas ao final do primeiro ano de vida. E além disso, esta não proporciona a mesma qualidade da coordenação olho-mão, pois o som não confere substancialidade ao objeto nesse período da vida. Quando a criança é capaz de usar a pista sonora na busca do objeto é porque já abstraiu de experiências anteriores a existência desse objeto, ou melhor, já descobriu um mundo de objetos. Já formou o conceito de objeto. Para isso a criança cega precisa fazer um caminho mais complicado e que muitas vezes não é trilhado pelas dificuldades da mãe para dar-se conta disso, ficando a criança impedida de seguir seu desenvolvimento, o que é característico das crianças cegas congênitas que apresentam desvios de personalidade (Cf. AMIRALIAN, 1997).

Em outro estudo, de Fraiberg e Adelson (1982), também foram constatados atrasos quanto à capacidade das crianças cegas congênitas, sem qualquer outro comprometimento, de representarem a si mesmas, na linguagem e no jogo simbólico, como um objeto e os objetos como outras coisas, bem como no uso estável do pronome "eu". Enquanto as crianças videntes o fazem por volta de dois anos e meio a três, as crianças cegas chegam aos quatro ou cinco anos até adquirirem tal qualidade psíquica. Discutiremos isso mais adiante.

Lowenfeld (1981) chegou às mesmas conclusões de Burlinghan e dos outros estudiosos citados quanto ao atraso que as crianças cegas adquirem em seu desenvolvimento e estruturação psíquica com base na alegação de que esse atraso indica diferenças básicas em relação à criança que conta com a visão. Ou seja, reconhece ser mais significativa a experiência que tem uma representação visual do que a que tem por base uma abstração verbal como acontece para a criança cega, mas faz uma crítica à linha de pesquisa que propõe a compreensão da cegueira pela simples comparação com o referencial do vidente.

Nesse sentido, no Brasil, Masini (1990; 1994) é a pesquisadora e estudiosa da área da deficiência visual que mais destaca a questão ética de compreendermos as especificidades da cegueira em seus caminhos perceptivos singulares na construção das estruturas mentais e significações no conhecimento do mundo que devem ser buscadas no referencial das próprias pessoas cegas.

Outra contribuição no estudo da cegueira foi dada pelo psicanalista Blank (1957) ao tratar os distúrbios de personalidade evidenciando os significados inconscientes de olho como órgão sexual na trilogia olho/boca/genital; como órgão hostil e destrutivo; e os significados 
inconscientes de cegueira como punição e castração. E ainda, em outro trabalho, discute a vinculação inconsciente entre olho/visão e onipotência e a presença do olho na inveja, cobiça, exibicionismo e escopofilia.

É interessante notar que essas associações referentes ao significante olho/olhar também estão presentes nas concepções populares e literárias sobre a cegueira, concepções estas que levam freqüentemente a atitudes contraditórias na sociedade: ora de superproteção e caridade, ora de uma crença em poderes especiais, ora de uma crença em expiação de culpa.

Para Blank (1957) tais atitudes e concepções são universais, dada a importância que a visão ocupa no desenvolvimento psicossexual e do ego e pela existência de conflitos de exibicionismo e escopofilia mal elaborados pelo ser humano durante toda a vida. Assim, a cegueira desencadeia em todos nós movimentos inconscientes de transferência e contratransferência nas relações. $O$ autor também ressalta que na cegueira congênita os distúrbios de personalidade dizem respeito mais às dificuldades na interação mãe-bebê, pela ambivalência de sentimentos e atitudes e pelas representações inconscientes já mencionadas do que à falta da visão em si.

Na Espanha, Leonhardt (1992) e Cantavella (2002) desenvolvem um trabalho substancioso no Serviço de Atenção Precoce Joan Amades do Centro de Recursos Educativos para Deficientes Visuais da Organização Nacional de Cegos.

Leonhardt (1992) em seus primeiros estudos observou a relação mãe-bebê desde os primeiros dias ou meses de vida constatando que algumas crianças cegas congênitas, se comparadas às que enxergam, apresentam desenvolvimento mais lento, são mais passivas, sem curiosidade pelo entorno, com inibição do impulso de exploração, necessitando continuamente de um ego-auxiliar para impulsioná-las na realização de qualquer ação ou atividade. Também constatou que a única atividade espontânea era a auditiva, mas com grande seletividade, pois se os estímulos que invadem continuamente o ambiente as desagradassem, mostravam pouca tolerância em relação aos mesmos, acabando por desorganizarem-se internamente, reagindo com as mãos nos ouvidos, ou isolando-se. Em geral, os atrasos no desenvolvimento resultavam da pobreza das interações e relações mãebebê e também com outras pessoas. Embora estas últimas fossem difíceis pela simbiose da relação da criança com a mãe. Chamava a atenção da pesquisadora o fato de que algumas crianças manipulavam as pessoas como se fossem objetos e a comunicação estabelecida não consistia em um diálogo, mas em um monólogo, aparentemente caótico, repleto de repetições 
de ordens, palavras soltas que denotavam desejos e necessidades básicas e de pedidos de objetos significativos aos quais estavam fixadas.

Essas crianças também mostravam um certo prazer na repetição de proibições, da linguagem ecolálica, aparentemente sem sentido, de cantilenas sem fim (como slogans de programas de rádio, por exemplo, por sua sonoridade). Em relação ao corpo, uma constância: a mão aderida a um objeto (geralmente pequeno e com sons) com fim de auto-estimulação (e não de uso do objeto em si), como se fosse um apêndice de seu corpo (sendo as partes da cabeça as mais escolhidas para essa estimulação). A qualquer momento, por um estímulo inesperado, podem sentir-se transbordar, como que ficando sem contorno, e submergir em uma crise de choro e irritabilidade. Nessa situação os pais ficam confusos e impotentes, sem poder entender o que se passa com seu filho (Cf. LEONHARDT, 1992).

Leonhardt (1992) também chama a atenção sobre outros transtornos que apresentam algumas crianças cegas congênitas, aos quais chama de núcleos psicóticos. Nestes as condutas que se apresentam são:

- Ausência ou falhas no desenvolvimento da linguagem;

- Fobias e crises intensas de pânico ou destruição;

- Dificuldades na discriminação entre os pensamentos e a realidade externa;

- Estagnação ou regressão do desenvolvimento cognitivo;

- Ausência da noção de identidade pessoal;

- Estereotipias motoras e verbais de caráter autosensorial.

Ao observar as alterações na relação entre pais e crianças, retoma as colocações de Wills na referência à instalação do núcleo do conflito que vai generalizando-se a todas as etapas do desenvolvimento da criança cega. Em seu trabalho com pais, Leonhardt vai propor ajudá-los na elaboração do conflito, do luto e da ansiedade para que não desviem as energias mentais disponíveis e possam usá-las na construção do vínculo e das competências para educar seu filho que nasceu cego. Se esse trabalho não é feito precocemente, a energia será direcionada para reprimir os conteúdos penosos que estão vivendo e paralisam-se. Até cerca de seis meses os pais de qualquer criança precisam mobilizar essa energia, principalmente a mãe, para converter-se na figura permanente que ajuda a criança a organizar-se, pois esta precisa um eixo, uma referência no mundo para adquirir uma "segurança básica" que lhe garante a existência e a prepara para que possa suportar, progressivamente, frustrações e 
adaptar-se ao princípio da realidade. O papel da mãe (a função materna) é também o de favorecer as identificações. Esse papel da mãe é chamado de maternagem e para explicitar esse conceito a autora cita Shaffer (1977), que define maternagem pelo envolvimento dos cuidados físicos, especialmente na alimentação, no desmame e na higiene, pois influenciarão a personalidade posteriormente; das atitudes que permeiam a relação (proximidade / distanciamento, calorosa / fria, permissiva / restritiva, responsiva / inerte etc.); da mediação naquilo que a criança precisa para desenvolver-se (seleção de estímulos ambientais); e da interlocução.

Ou seja, a maternagem é parte da interação na qual mãe e filho devem adaptar-se mutuamente, sincronizando suas respostas com o fim de regular a relação em um fluxo constante, onde a reciprocidade e a capacidade da mãe para saber "o que", "como" e “quando" responder é o que estabelecerá e manterá o diálogo e a previsibilidade de resultados (Cf. LEONHARDT, 1992).

A autora defende que a criança cega pode ser um ente ativo, capaz de conduta organizada e espontânea e de estabelecer relações objetais, ainda que necessite de ajuda para isso. Recorrendo à idéia de Winnicott de que todo ser humano tende ao isolamento e defende sua integridade interna quando se sente ameaçado, devendo encontrar elementos que lhe assegurem isso, como, por exemplo, que os seus compreendam suas necessidades de amor, sua expressão de agressividade e ambivalência. Se a mãe é capaz disso, torna-se uma imagem coerente para seu filho, viabilizando a construção de um ego independente dela, desenvolvendo seu esquema corporal e a representação da realidade externa, adquirindo uma certa estabilidade interior. Para que esta função materna seja levada a cabo, é necessário que a mãe (na maioria das vezes é a mãe, ou então um outro adulto que cumpra essa função) possa ser ela mesma, estar viva e conseguir identificar-se com seu filho por meio dos gestos e das mudanças que ele vai mostrando. É preciso que a mãe garanta uma continuidade e uma estabilidade que ajudarão na previsibilidade do comportamento dela, ajudando na integração da personalidade; que faça com que a criança sinta que ela vive e que pode aplacar seus impulsos até que consiga existir separada da mãe. Essas vivências satisfatórias fazem com que a criança preste atenção à realidade externa e confie nela. Assim, poderá, na ausência da satisfação, criar um objeto que lhe satisfaça ilusoriamente, germe da função simbólica. Ao passo, que quando essa função materna falha, observamos na criança desvios de personalidade com bloqueio na formação do símbolo, irritabilidade geral, problemas na alimentação, problemas no ritmo e no sono e ainda somatizações (Ibid.). 
Como pudemos perceber, Leonhardt centra os problemas do desenvolvimento de algumas crianças cegas nas falhas da função materna, o que dificulta as interações mãe-bebê. Assim, tece novas considerações acerca dos estudos apresentados por Burlinghan, Sandler, Fraiberg e outros.

Sobre os trabalhos de Burlinghan ela comenta que a maioria deles é de grande sensibilidade na compreensão dos comportamentos das crianças cegas, mas que, por outro lado, não leva em conta as singularidades de cada criança e principalmente as especificidades da cegueira, além da condição descrita acima de dificuldades expressivas das mães com seus filhos cegos em fase bem precoce de suas vidas, ocasionando possíveis falhas na função materna.

As observações dos bebês cegos reiteram as idéias de Winnicott de que quando a mãe não consegue adaptar-se a esse filho, ele é levado à submissão, sendo um "ser falso" que reage às exigências do meio. $\mathrm{O}$ "ser verdadeiro" sucumbe e não emergem o gesto espontâneo e a idéia pessoal. Só o "ser verdadeiro" produz o sentido de ser real. Ainda assim, Burlinghan destaca os problemas da imobilidade motora que se desloca para as funções do ego e do vazio mental que leva o bebê cego a centrar a atenção no próprio corpo. Burlinghan não dá atenção às capacidades dos bebês cegos, localizando-os somente nas falhas de mobilidade. Não reconhece que, se este desenvolver as capacidades que lhe são próprias na percepção do mundo por outros caminhos, não haverá vazio na formação do ego, porque partirá desde o princípio de sua forma própria de existir e estar no mundo e, a partir dela, poderá desenvolver-se plenamente como o fazem as crianças videntes na utilização de outras habilidades (Cf. LEONHARDT, 1992).

E sobre o esforço que Sandler, Fraiberg e colaboradores fizeram para mostrar que o atraso motor das crianças cegas se devia às dificuldades de preensão e para alcançar e pegar objetos a partir da pista sonora, Leonhardt (1992) reforça a capacidade precoce da criança cega para coordenar mão-ouvido; para separar-se da mãe e ver a si como outra pessoa; para representar mentalmente o espaço e os obstáculos contidos nele, ainda que seja trabalhoso para ela que depende de lidar com o medo do vazio e depende da força de um ego-auxiliar que é a mãe para dar-lhe segurança. Depende da qualidade da interação que essa mãe vai poder permitir-lhe, se puder ultrapassar as dificuldades de ser mãe de um bebê cego, identificar-se com ele e reconhecê-lo como seu filho.

Leonhardt (1992) assinala que muitos bebês e crianças cegas que observou e que tinham uma boa coordenação mão-ouvido, não podiam adquirir uma autonomia motora, pois 
esta só era possível quando as condições de relação com a mãe estavam garantidas. Para reforçar sua convicção recorre às idéias de Tustin (1987) de que na relação mãe-bebê, as necessidades da criança são as mais importantes e as da mãe são relativas. No caso da mãe do bebê cego (o que gera um contexto confusional), é comum as necessidades da mãe superarem as do filho, fazendo com que ele se sinta eliminado, isolado, excluído do mundo e das pessoas. Seu mundo fica rígido e vazio e a consciência de eu e não-eu ficará apagada. Ou se fundem com o não-eu ou o ignoram. Não usará objetos de forma transicional e comunicativa (não formando símbolos), mas de forma confusional e autista, gerando um auto-centrismo, com a libido fixada e uma aparência de deficiência mental.

Leonhardt (1992) também fez uma articulação acerca das estereotipias (condutas repetitivas e aparentemente sem sentido) que observou surgirem tão cedo nas crianças cegas (por exemplo o apertar os olhos - 'ceguismos' foram detectados em bebês entre os cinco e sete meses). Em outro grupo de crianças de 0 a 10 anos, foi confirmada a hipótese de que, ao sentirem-se muito exigidas ou controladas, necessitando manter um alto grau de atenção em situações difíceis de serem percebidas na totalidade, ou que solicitassem um ritmo de atividade muito rápido, surgiam estereotipias motoras, ceguismos ou atividades parasitárias também estereotipadas.

Também foi constatado pela pesquisadora o aparecimento de ceguismos nas situações nas quais a criança começa a perceber que sua deficiência lhe dificulta o acesso a experiências e informações visuais (por exemplo compartilhando situações com o vidente nas quais se faz menção ao mundo visual). Esse comportamento pode denotar dificuldades na adaptação e aceitação da deficiência. Pode ainda recorrer a comportamentos sociais estereotipados em situações de excitação e surpresa, e pode recorrer a estereotipias motoras em situações de tensão emocional, de frustração e de ansiedade. Assim como, o cansaço e a inibição de movimentos podem provocar estereotipias do tipo motor. A auto-estimulação, forma grave de estereotipia pela fixação em estímulos sensoriais como fonte de prazer, são induzidas pela ausência ou fragilidade de vínculo, isolamento, separações constantes e duradouras, falta de sincronia do bebê com a mãe (dificuldade por parte da mãe de compreender as necessidades do bebê no exato momento em que ele as apresenta). Também favorecem essas condutas os medos, reais ou não, as circunstâncias vividas como perigosas ou como agressão ao mundo interno. E, por fim, a não-oferta de recursos adequados para o desenvolvimento motor e cognitivo, o que entrava a evolução e provoca a regressão a comportamentos primitivos nos 
quais as estereotipias ocupam quase todo o tempo de vigília da criança (Cf. LEONHARDT, 1992).

Os estudos de orientação psicanalítica apresentados anteriormente constataram atrasos no desenvolvimento de crianças cegas congênitas nos primeiros anos de vida, as quais, após esse tempo de vida inicial, seguiram o curso do desenvolvimento atingindo os níveis previstos para a média das crianças videntes sem comprometimentos de qualquer natureza. Estudaram também crianças cegas congênitas que, apesar de terem intactos os outros sistemas físicos e neurológicos, ficaram comprometidas em seu desenvolvimento cognitivo e relacional. Esses estudos explicam os atrasos e problemas no desenvolvimento como decorrentes da ausência da visão, ou seja, como ela compromete a percepção do mundo, a mobilidade e a organização mental do mesmo.

Leonhardt (1992) em seus estudos assume outra postura: procura compreender essas crianças a partir das especificidades da cegueira na apreensão que o recém-nascido vai fazer do mundo e, principalmente, das singularidades da relação mãe-bebê que possibilitarão ou não a constituição de sujeito e o desenvolvimento.

Para ampliar a discussão sobre as falhas na estruturação do psiquismo - na constituição de sujeito mais propriamente falando - e os problemas de desenvolvimento que algumas crianças cegas congênitas podem adquirir, procuraremos sair da concepção desenvolvimentista, ainda que os autores a seguir não tratem especificamente das questões da cegueira.

Esta discussão certamente passa pela questão de como se pode articular Psicanálise com a idéia de desenvolvimento.

\subsubsection{As noções de desenvolvimento e de constituição do sujeito}

$\mathrm{Na}$ perspectiva psicanalítica o que está posto é a questão do sujeito e sua estrutura. Este se constitui, não se desenvolve. O desenvolvimento propriamente dito depende de um processo maturativo do organismo e na constituição do sujeito não há essa dependência. Assim, quando falamos em desenvolvimento, estamos dizendo que o que se desenvolve são as funções e não o sujeito, pois este corresponderá a uma estrutura contingente da simbolização e historicização desse corpo, como ser cultural e social que é. 
Essa dimensão simbólica, a dimensão psíquica especificamente humana, parte dos mecanismos fisicobiológicos de que o organismo é capaz e os organiza em sistemas específicos (o perceptivo, o motor, o fonatório, os adaptativos). São eles os representantes do corpo físico, sendo o representante entre o psíquico e o somático chamado de pulsão. É por meio dos representantes da pulsão (que correspondem às entradas e saídas do corpo) que esse corpo será erotizado e carregará nele a marca do significante que lhe será lançado pelo olhar, pelo toque, pela voz, enfim pelo que pulsa de desejo nas relações intersubjetivas. Dentro da concepção psicanalítica, portanto, a maturação do corpo físico pode limitar o sujeito, mas não pode determiná-lo, pois sua subjetivação não depende de que sustente a cabeça, ande, fale, tenha controle muscular de esfíncter ou coordenação motora fina. Há crianças com graves comprometimentos neuromotores que nunca poderão andar, ou crianças cegas que não contarão com a visão para alinhar a cabeça, mas que poderão se constituir como sujeitos de desejo (Cf. JERUSALINSKY, 1989)

Assim, dentro desse referencial, consideramos que os impedimentos no desenvolvimento podem se colocar como obstáculos à estruturação da vida psíquica, mas também é certo que não é propriamente desse corpo físico que se trata nessa estruturação, mas do que será simbolizado dele. Essa simbolização depende do Outro, pois a insuficiência do filhote do homem para poder sobreviver e ser o faz depender dele, do desejo que o anima lançado sobre esse filhote. O Outro é um conceito lacaniano para designar o social, a cultura e a linguagem que são os indicadores constitutivos do sujeito. Isso se dá dessa forma porque esse Outro (encarnado nos pais ou quem os substitua na função que têm como representantes da cultura, na qual todo ser humano é forjado), desejante da criança, engendra para ela um lugar em sua cadeia significante. Essa criança suportará no corpo as marcas que seus pais precisam traçar para que eles também se sustentem como sujeitos ao identificarem-se com o filho (Ibid.).

A captura do corpo por parte de uma cadeia significante o ordena em um olhar, escutar, dirigir-se, receber, entregar etc., onde as funções (...) ou princípios perceptivos cedem lugar a esse ordenamento simbólico do corpo, operado por um Outro, que rearma esse corpo em uma posição imaginária (Ibid., p. 23).

Desse modo, a Psicanálise dimensiona a relação entre desenvolvimento e constituição subjetiva, entendendo que o desenvolvimento depende do aparato e do funcionamento 
neurofisiológico, mas também do "tratamento que o Outro na posição materna outorgue aos estímulos internos que assediam a criança", ou seja, "para que se opere o desenvolvimento (...) existe a necessidade de que "a mãe signifique no campo da linguagem (dimensão especificamente psíquica) o que o bebê manisfesta em suas variações tônico-musculares" (Ibid., p. 22). Quando vemos os bebês passarem à ação explorando o mundo ao seu redor, o que observamos não é um desenvolvimento que se fez meramente pelo automatismo biológico, ou pelos estímulos do meio, mas identificamos aí as marcas simbólicas que afetaram o funcionamento do corpo produzindo os efeitos da estruturação que descrevemos (Cf. JERUSALINSKY, 1989).

Ao nascer e durante seu desenvolvimento, a criança encontra um mundo e uma cultura formados pelos outros, seus semelhantes, que irão conferir-lhe ou não a possibilidade de ter um lugar próprio designado a ela. Esta, por sua vez, tem uma função na fantasmática ${ }^{8,9}$ da família: os pais projetam-se na criança, remetendo-se à sua infância e seus mitos familiares. A partir daí, e mesmo antes do nascimento, a criança vai estruturar-se com base no desejo dos pais e assim serão marcadas as posições simbólicas de mãe-pai-filho.

O Outro que espera a criança nascer, a deseja e espera dela amor, logo procura saber sobre ela e tem três dúvidas fundamentais e subjetivantes: se nasceu bem (saúde/doença, normalidade), se é menino ou menina (identidade sexual, a marca fundamental da diferença) e com quem se parece (reconhecimento, identificação familiar). O Outro pressupõe um sujeito, o antecipa, o põe no cenário do mundo e na cena da vida, o interroga como se ele soubesse e fala com ele como alguém que ele ainda não é, mas que poderá ser pelo fato de assim o suporem e desejarem. Fala com ele como um sujeito de desejo. O nascimento, então, mais que uma herança genética, traz uma herança simbólica. Esta sim faz nascer o sujeito, por meio do campo do Outro, enodando estrutura e desenvolvimento. Muitas vezes, no caso da criança que não nasce bem, ou seja, nasce com alguma deficiência, os pais não são impelidos a interrogar sobre a identidade sexual e a identificação familiar. A deficiência pode assumir, assim, toda a identidade (Cf. LEVIN, 2002).

\footnotetext{
${ }^{8} \mathrm{O}$ conceito de fantasma é fundamental para desvelar a realidade psíquica da criança e dos pais, pois possibilita uma aproximação do modo como se constituíram, dos sentidos que foram atribuídos às suas ações, o que foi visto, vivido e ouvido nas relações (Cf. MRECH, 1999).

${ }^{9}$ Fantasma para a Psicanálise é "um roteiro imaginário em que o sujeito está presente e que figura, de maneira mais ou menos deformada pelos processos defensivos, a realização de um desejo inconsciente. O fantasma se constitui a partir das coisas vistas e ouvidas" (KAUFMANN, 1996, p. 196).
} 
Há primazia do significante ${ }^{10}$ sobre o organismo na constituição da subjetividade, como mostrou Lacan (1985). Mas como se inscreve no corpo o significiante? Como o universo simbólico toca o biológico para constituir o sujeito? Há uma permeabilidade biológica ao significante (Cf. Jerusalinsky, 1989). O sujeito se constitui e as estruturas físicas e mentais se desenvolvem respondendo ao que o Outro lhe demanda. Por isso o corpo responde ao significante que "é sempre significante da falta no Outro" (KAUFMANN, 1996, p.473) e que pelo campo da linguagem é inscrito. O corpo humano é subjetivado nas relações intersubjetivas $\mathrm{e}$ as inscrições dos representantes de objeto ${ }^{11}$ não vêm previamente determinadas geneticamente, mas serão construídas simbolicamente. A criança brinca e elege objetos que lhe farão imaginar ali o objeto faltante (a mãe) para dar conta, na fantasia, de sua insuficiência e do mundo que lhe foi antecipado na estrutura, consolidando seu lugar de sujeito (Cf. JERUSALINSKY, 1989).

Nesse sentido, voltamos a indagar sobre a constituição subjetiva e o desenvolvimento quando algo no real do corpo não responde porque há, em algum nível, uma insuficiência orgânica e não simbólica. Nesses casos, a estrutura pode tropeçar em um corpo danificado que $(\ldots)$

(...) opõe a resistência de sua imaturidade ou déficit, impondo-lhe, assim, os limites de sua inscrição. Esses limites serão os da relativa capacidade de um sistema nervoso, conforme o nível de sua maturidade ou de sua integridade fisiológica, para oferecer a essa estrutura o material comportamental para expressar sua inscrição. Nesse sentido, no relativo à estrutura psíquica, a maturação ou integridade neurofisiológica operam como Real, já que o significante

\footnotetext{
${ }^{10} \mathrm{Na}$ lingüística de Saussure "o significante é a representação psíquica do som tal como nossos sentidos o percebem, ao passo que o significado é o conceito a que ele corresponde." Lacan subverteu essa relação significante/significado afirmando a supremacia do significante sobre o significado. Assim, "o significado do significante não é um conceito delimitável no interior do campo lingüístico propriamente dito, ele é o desejo. Lacan, nos Escritos, refere que 'o significante vai consistir na estrutura sincrônica do material da linguagem' e o significado vai regê-lo 'historicamente'. Um significante remete sempre a outro significante, formando a cadeia de significantes que se desdobra no tempo e engendra o sujeito. Lacan postulou que 'o significante representa o sujeito para outro significante' e "será num outro tempo que poderemos ter acesso ao significado”(KAUFMANN, 1996, p. 472 e 473).

11 “A noção de objeto é encarada em psicanálise sob três aspectos principais: A) Enquanto correlativo à pulsão, ele é aquilo em que e por que esta procura atingir o seu alvo, isto é, um certo tipo de satisfação. Pode tratar-se de uma pessoa ou de um objeto parcial, de um objeto real ou de um objeto fantasmático. B) Enquanto correlativo do amor(ou do ódio), a relação em causa é então a da pessoa total, ou da instância do ego, com um objeto visado também como totalidade (pessoa, entidade, ideal etc.). C) No sentido tradicional da filosofia e da psicologia do conhecimento, enquanto correlativo do sujeito que percebe e conhece, é aquilo que se oferece com características fixas e pensamentos, reconhecíveis de direito pela universalidade dos sujeitos independentemente dos desejos e das opiniões dos indivíduos" (LAPLANCHE e PONTALIS, 1985, p. 407).
} 
mantém sua primazia mesmo quando a criança não pode ainda fazer uso dele (Ibid., p. 46).

A criança com deficiência é de qualquer modo marcada com os significantes da cultura onde nasce, mas é preciso reconhecer as dificuldades que isso implica e os riscos da não inscrição desses significantes, por isso o trabalho precoce de atenção a essas crianças e suas mães é fundamental.

No caso da cegueira congênita sem comprometimentos de ordem neurológica, sabemos que muitas crianças nessa condição se estruturam psiquicamente e se desenvolvem plenamente, mas que também existem aquelas que encontram muitas dificuldades no caminho, desde paralisarem-se na constituição até dificuldades instaladas em vários níveis do desenvolvimento.

Falar da constituição de sujeito na criança cega congênita implica falar de vulnerabilidades e de um dado crucial que oferece para essa criança o risco (risco e não destino, em nosso entender) de ficar sem lugar, isto é, excluída do campo do significante por ficar sem a vivência do que o olhar da mãe propicia como "oportunidade de se colocar na perspectiva do Outro para olhar a si mesma" (JERUSALINSKY, 1989, p. 49).

No início da vida, as pulsões - olhar, toque, voz - por meio do que o Outro invocará o bebê, são indicadores do lugar de sujeito. A pulsão do olhar situa-se no olho da mãe que a criança vai captar e dele será feito seu lugar primitivo de sujeito. A criança cega congênita vai substituir a carência da visão atendendo ao chamado do Outro pela sua voz. Mas para Jerusalinsky (1989), corre o risco de ser um falante precoce que poderá transformar a fala em fala vazia, ou seja, fala do outro e não sua, podendo ainda estruturar-se como Outro sem mediação simbólica, abrindo-se aí uma brecha para a psicose, uma vez que não tem "olhar para oferecer à demanda de seus pais" (p.49). Assim, a especularização pode virar espelhamento, tornando-se ela a própria imagem sem representação, ocupando um lugar de objeto para seus pais (Ibid.).

Vimos então como a constituição do sujeito e a sincronicidade da simultaneidade estrutural com a maturação psiconeurológica vai fazer surgir o desenvolvimento que dá conta da estrutura que é formada a priori e antecipada na linguagem (Ibid.). Por isso a supremacia do significante sobre o organismo. 
A pergunta que insiste é se esta criança que nasceu com a marca de uma diferença - no caso a cegueira - que a afasta do que é reconhecido como normalidade, sendo que esta última faz tornar logo o ser nascente um semelhante, poderá tornar-se um sujeito de desejo.

A realidade da cegueira impõe, de fato, aos pais e à criança que nasce um caminho de grande complexidade a ser trilhado na possibilidade dessa constituição e na adaptação ao que é específico da ausência da visão na construção do conhecimento do mundo. Ultrapassar o impacto e vencer a frustração e a angústia até conseguirem identificar-se com seu bebê e proporcionar-lhe crescimento e educação é para os pais uma tarefa bem difícil, porém viável se forem ajudados nessa travessia.

\subsubsection{A relação mãe-bebê com cegueira: o impacto, as representações imaginárias e o risco de não se instalarem as funções materna e paterna}

Muitos já se dedicaram a escrever sobre a vivência das famílias que recebem uma criança com deficiência como um choque provocado pela quebra da idealização do filho esperado em relação ao filho que nasceu, o que vai afetar a função materna que se colocaria em curso. Trata-se de uma vivência de luto pela perda do filho desejado e o total desconhecimento desse que chegou. Os relatos são de perda do terreno conhecido e de não saber com ele se relacionar, ficando paralisada sem poder "ler" e responder às manifestações desse ser que lhe provoca estranheza fazendo acordar muitos de seus fantasmas (dela mãe), além de desmontar o sonho, os sentimentos e as fantasias acerca desse filho, construídos durante a gravidez e até muito antes dela .

O desejo materno costuma dar conta do vínculo entre mãe e bebê fazendo com que ela construa o cenário para o olhar, o brincar, a libidinização corporal, a alimentação e todos os cuidados e costumes de sua cultura montando a cena que constituirá psiquicamente essa criança. Mas quando o bebê tem uma deficiência, vemos que tudo isso pode ficar perturbado, inclusive pela dificuldade do bebê em registrar e responder ao que lhe é invocado pela mãe, gerando um profundo desencontro.

É possível refazer o encontro, e muitas mães o fazem até mesmo sem a ajuda de profissionais, mas é preciso frisar que não pode haver demora, com o risco de que a ineficácia da instituição da função materna e da adaptação mútua entre mãe e bebê gerem problemas graves para a constituição subjetiva e o desenvolvimento da criança. 
O momento do diagnóstico é particularmente difícil, feito de muita dor e extrema ansiedade e comumente não é feito de uma maneira sensível pelos profissionais. Mas também os momentos de mudanças a cada fase na vida da criança (como desmamar, deixá-la com outras pessoas, tirar a fralda, entrar na escola) são marcados por crises profundas.

Os sentimentos gerados podem ser de distanciamento sem necessidade de olhá-lo, acarinhá-lo ou de falar-lhe; um misto de raiva, pena e culpa é experimentado, bem como um desejo inconsciente de morte para o filho pode às vezes advir. Também pode gerar uma projeção da causa da deficiência nos outros. Crises de choro e irritação, como também manifestações depressivas, como já vimos, ou de recolhimento com sua dor, além de confusão sobre sua identidade, um ferimento profundo em seu ego e fantasias das mais aterradoras acerca da deficiência (Cf. LEONHARDT, 1992; FRAIBERG, 1977; WILLS, 1970; BRULINGHAM, 1965).

Algumas mães sentem-se fracassadas, com desejo de renúncia à maternidade, além de ver seu filho como um prolongamento dela e como um produto defeituoso, o que a faz sentirse diminuída, envergonhada e com receio das opiniões dos outros. Sentem-se, às vezes, decepcionadas com a aparência física do filho. Alguns pais melhor posicionados socialmente sentem-se mais afetados em sua ferida narcísica, bloqueando as energias que precisariam mobilizar para estabelecer o vínculo com o bebê e acabam por perceber a criança como uma parte deles que querem negar (Cf. LEONHARDT, 1992).

É preciso lembrar que todos esses sentimentos são inconscientes e custam a ser reconhecidos e expressados.

São também conhecidas as fases pelas quais os pais passam na elaboração desses sentimentos e do luto desde o estado confusional dos primeiros momentos, aflição e ansiedade; busca do filho perdido (o que pode durar meses ou até anos); desorganização e desespero, evoluindo para a negação, rejeição, superproteção, para finalmente entrar em um grau maior ou menor de reorganização e aceitação (Cf. BLANK, 1957).

Vamos aqui situar algumas vicissitudes no caso do nascimento de um filho cego, pois já tratamos da dimensão psicossocial da cegueira em item anterior deste mesmo capítulo.

Os mitos familiares sempre são fortes elementos na história que antecipa a criança na rede simbólica que se fará presente na sua constituição de sujeito. Sobre a criança cega ficam acrescidos os mitos e as representações imaginárias acerca dessa deficiência em particular. 
Alguns pais de crianças cegas se projetam nos filhos como se eles mesmos vivessem a cegueira, ou seja, de acordo com suas impressões e fantasias: medo da escuridão, tristeza, dor, insegurança, dependência, incapacidade, isolamento. Essas idéias denotam uma imagem negativa acerca de cegueira.

Cutsforth (1950) apontou que o impacto que a família sofre ao saber do diagnóstico de cegueira é muito grande, podendo desencadear a separação do casal ou até transtornos psicopatológicos. Lairy e Covello (1975) observam que há uma tendência ao exagero nas reações que não condiz com as limitações que realmente a deficiência implica. Os autores explicam que as reações dos pais frente à cegueira do filho correspondem ao valor simbólico que ela representa para eles e à estrutura de suas personalidades anterior ao nascimento desse filho. Na relação da mãe com seu bebê cego são observadas dificuldades no contato, um incômodo e pesar por não haver troca entre ela e o bebê pela via do olhar; um não saber como brincar com ele, o que oferecer-lhe e como mostrar-lhe o mundo; não compreender o que ele lhe mostra nos gestos e nos sons. Na ausência da visão a relação se paralisa.

Algumas mães relatam que não aceitavam os brinquedos que seus bebês ganharam ao nascer, pois não viam como poderiam usá-lo; que experimentam grande frustração por não serem vistas por seus filhos; que sentem uma profunda tristeza por seus filhos nunca poderem ver as belezas do mundo. Outras tendem a negar tais sentimentos assumindo um discurso de que esse filho foi sua maior benção e trouxe-lhe mudanças cruciais em sua vida. Em algumas mães essa posição é a expressão de sua elaboração, de um aprendizado contínuo em uma relação prazerosa, resgatando sua vida pessoal. Já em outras leva à fixação em um mecanismo de defesa e uma relação simbiotizada com seu bebê que impede sua constituição e desenvolvimento. Outras encontram aceitação pela crença religiosa. E outras continuam arrastando pela vida afora a criança como um peso que lhe tirou a vida que tinha antes e que não pode mais fazer nada a não ser cuidar dessa criança "coisificada".

Em todos os casos, frente à deficiência, se há uma recusa a viver o luto e o pesar, a adaptação será superficial e a capacidade afetiva e emocional serão prejudicadas, levando a um fechamento e diminuição na disponibilidade para as relações, com aumento da força dos mecanismos de defesa.

A primeira crise de adaptação que se refere à negação parcial ou total do diagnóstico é acompanhada da necessidade de confirmação do diagnóstico, pois os pais tendem a não acreditar, cogitam erro médico ou outras causas para a suspeita do problema visual. Iniciam uma peregrinação por diversos médicos na busca de um milagre. Mais tarde, com a certeza do 
diagnóstico, passam a viver uma avalanche de sentimentos e emoções: culpa, depressão e problemas familiares permeados de outras vivências (negação, hostilidade, ressentimento, angústia, rejeição, frustração, desejo de morte ao filho, instabilidade e insatisfação emocional, superproteção, interrupção do desenvolvimento da criança, transtornos em outros membros da família). Dependendo da forma como se resolverem em maior ou menor grau esses conflitos internos, dar-se-ão as posições adaptativas da etapa seguinte: positiva com aceitação realista da deficiência e suas limitações, ou ainda uma aceitação precária, com relativa adequação. Negativa com constantes crises emocionais e sem aceitação da realidade. Ou desintegrativa com separações do casal e problemas psicopatológicos em algum membro da família (Cf. CANTAVELLA, 1988 apud LEONHARDT, 1992). Na posição negativa encontramos a rejeição. A depressão vivida pela mãe vai dificultar sua percepção sobre seu bebê e suas respostas às mensagens dele, ficando fechada às necessidade de amor e relação dele, sem vida e sem possibilidade de corresponder-lhe. O bebê, em decorrência dessa conduta, pode deixar de buscá-la, ficar passivo e voltar-se para seu próprio corpo ou objetos inanimados, podendo constituir transtornos graves de personalidade e desenvolvimento. Há pais que só vêem no filho a deficiência, desenvolvendo, assim, condutas superprotetoras que o privam das experiências comuns da vida, cortam a espontaneidade e os interesses e em nada favorecem sua autonomia e independência. Essas condutas, em geral, estão associadas a sentimentos de culpa e rejeição. Nesses casos a mãe mostra uma necessidade de manter a criança dependente dela, pois assim está pagando sua culpa. Em nada podemos comparar essa conduta com a proteção necessária a algumas crianças com outros comprometimentos além do visual e que de fato necessitam de apoios muito especiais por parte dos pais. Outra conduta dos pais que expressa a não aceitação da deficiência é a negação. Estes fazem de tudo para mostrar a si mesmos e aos outros que seu filho é como todas as crianças. Nestes casos o fazem para diminuir o sentimento de culpa que carregam sem se dar conta. Esses pais podem impedir o desenvolvimento das potencialidades do filho por não perceberem as necessidades que têm decorrentes de sua deficiência e criar inseguranças, insatisfações e desânimo por uma alta exigência feita a ele. Observamos também a rejeição encoberta. Os pais vivem a cegueira como uma desgraça, mas tentam driblar a culpa e a hostilidade que sentem tentando compensar com demonstrações exageradas de amor e sacrifício. Mas a rejeição também pode ser, em alguns casos, manifesta. A negligência, a hostilidade, a irritação pela responsabilidade com a criança às vezes é consciente, o que os faz justificar atos e atitudes e ainda culpar outros por seus problemas e dificuldades. A criança sente que não é querida e sabe que é sentida como um peso; não desenvolve sentimento de pertença e de segurança, podendo 
desenvolver, sim, condutas sociais negativas e agressivas, isolando-se (Cf. LEONHARDT, 1992).

Nessas condições todos os momentos a serem vividos pela criança serão de transtorno para mãe e filho ou protelados: o desmame, o tirar as fraldas, a alimentação, o deixar o quarto dos pais.

\begin{abstract}
A personalidade da mãe, sua organização interna, suas primeiras relações com o bebê cego, põem em marcha mecanismos profundos, medos encobertos; o feito de conhecê-los pode ajudá-la no processo terapêutico, assim como criar, refazer, ampliar ou melhorar as relações com seu bebê (LEONHARDT, 1992, p. 30).
\end{abstract}

A vida não é estática, há um contingente enorme de possibilidades que mudam uma dinâmica e iniciam uma transformação; a reação da própria criança, uma pessoa que lance sobre ela um olhar que lhe possibilite saídas, uma instituição que leia suas necessidades e a dos pais e lhes arranque da inércia e os potencialize.

Ainda cabe ressaltar que as crises de incerteza, insegurança e medo vividas no período inicial retornam a cada momento de mudança que a vida vai introduzindo: a escola, as amizades, o momento da consciência da deficiência por parte da criança, a adolescência, a exclusão social mais ampla. Porém, a cada uma delas os pais poderão estar mais fortalecidos se puderem ver o que já viveram até aí e aprender com isso. Aprender o quê? Fundamentalmente a se relacionar com seu filho.

Os pais de crianças cegas necessitam de orientações para que possam apoiá-las nas necessidades específicas que têm e proporcionar-lhes experiências significativas do mundo, que serão as oportunidades para a realização de suas potencialidades. Eles precisarão ser escutados em sua dor e em suas defesas para reconhecer os fantasmas que os assombram a respeito da cegueira e da ferida narcísica e poder ver aquilo que da cegueira salta como forma singular de estar no mundo para que ressurja a possibilidade da relação pais-bebê e se instituam as funções materna e paterna.

Em outras palavras, vimos quanto o nascimento de uma criança com deficiência custa aos pais instaurar essa criança na cadeia significante deles. Quanto custa dar a ela um lugar no mundo. Quanto custa refazer seu desejo e reencontrar a criança, reconhecendo-a como filho. Vimos como a emergência de algo no corpo da criança - neste caso a cegueira - oferece-lhes 
uma imagem que faz acionar mecanismos psicológicos que os impedem ou dificultam viver a relação.

Mãe é a que cumpre a função materna: dar sustentação ao seu bebê para a segurança afetiva; tocá-lo de forma a libidinizar seu corpo; mostrar-lhe o mundo e lançá-lo para além da relação com ela; interpretar seus gestos, introduzindo-o na linguagem.

No exercício dessa função, uma mãe sustenta para o bebê o lugar do Outro primordial, o que significa dizer que antecipa nele uma existência subjetiva, desenhando o mapa libidinal que recobrirá seu corpo pelo gesto, pelo toque e pelas palavras. Não é uma questão de volição, mas vai se construindo em um dia-a-dia de minuciosos reconhecimentos mútuos entre mãe e bebê (Cf. KUPFER, 2001).

(...) a relação mãe-bebê opera sobre um universo de grande complexidade que começa com o equipamento material com o qual a criança vem ao mundo e termina no entorno social (...) somente o encontro mãe-bebê poderá permitir que um bebê faça uso de seu equipamento, inteiramente inoperante se não houver quem o pilote. Mais que isso, esse equipamento sequer existirá se não houver quem o construa. Assim, poderemos estar diante de um equipamento defeituoso, que uma mãe poderá "saber" pilotar, enquanto outras ali sucumbiriam. Poderemos estar diante de um equipamento completamente inoperante e uma mãe não poderá humanizá-lo de jeito nenhum, em que pesem seus esforços. Falhou a função materna, não porque a mãe não tivesse condições de exercê-la, mas porque seu bebê não podia absorvê-la (Ibid., p. 50).

O essencial da função materna é a libidinização do corpo. Portanto, se tal função e o desejo maternos forem inoperantes, não se constituirá a imagem corporal e poderá advir o autismo infantil precoce. Também poderão haver falhas no estádio do espelho ${ }^{12}$, o que resultará nos traços autistas. A função materna opera de modo a fazer a passagem do biológico para o mundo humano da linguagem, do sentido. O que não pode faltar: o olhar e o desejo da mãe sobre essa criança para que haja uma inscrição em uma filiação e a conseqüente constituição de sujeito (Ibid.).

É possível fazer a articulação sobre as dificuldades de algumas mães com seu bebê cego ao nascimento quanto a essa construção subjetiva e especularização. É difícil para elas reconhecerem-se e identificarem-se com eles e dar sentido à sua existência, vivendo, assim, um certo esmorecimento para exercer a função materna. Elas se encontram com grandes

\footnotetext{
12 Tema que será tratado em item subseqüente neste mesmo capítulo.
} 
dificuldades para investir libidinalmente o corpo do bebê. Se uma mãe que desejou seu filho, ao estar diante da cegueira dele, não conseguir dizer "Filhinho bonitinho da mamãe! É a cara do papai, heim?!", ou algo parecido que o lance em uma filiação e o reconheça e se reconheça nele e ele a reconhecer-se nesse "espelho" que ela oferece, haverá dificuldades para que a vida psíquica se institua.

Quanto à função paterna, que nos primeiros meses de vida do bebê é geralmente desempenhada pela mãe (ou quem a substitua), esta tem o desígnio de dar um basta à relação onipotente da mãe com o bebê - necessária no início da vida do bebê, mas prejudicial se não evoluir para a separação - fazendo a entrada de um terceiro e instaurando uma falta constitutiva, retirando a criança do papel de objeto total da mãe e marcando a entrada no simbólico como ser em quem algo falta e falta no Outro que o deseja (Cf. LEVIN, 2002).

A mãe é a que oportuniza a posição paterna se esta se encontra nela. Esta posição então oportuniza a função materna que deseja o filho para que este deseje. Se isso transcorre dessa maneira, a mãe instaura um espaço entre ela e o filho e abre a porta para um terceiro que por sua vez faz circular o desejo em direção a outros (Ibid.). Às vezes, se a mãe não instaura esse percurso, isso se dá pela entrada da sabedoria de uma avó, do amor de um irmão, às vezes da visada de uma instituição de atendimento especializado, que vêm estabelecer uma relação verdadeiramente humana ao provocar essa ruptura. A ausência ou falhas na função paterna pode abrir caminho para os traços psicóticos. Algumas vezes, à criança que nasce cega fica suspensa a possibilidade de inscrição simbólica por estar a mãe impossibilitada de ensejar essa função.

Isso também pode se dar pela rejeição que sofre a criança por parte do pai real (Cf. JERUSALINSKY, 1989). Mas novamente insistimos que a vida é dinâmica e sempre é possível, na infância principalmente, fazer o que não pôde ser feito antes.

\subsubsection{O corpo-organismo e o corpo-imagem}

Vimos como na relação mãe-bebê a função de libidinização do corpo é essencial na instauração do psiquismo. Vimos também como essa função "manca" quando o corpo do bebê é um corpo que traz em si algo de inesperado/desconhecido/"defeituoso", como a cegueira. 
É certo que a ausência da visão, uma marca no real do corpo, pode restringir o conhecimento do mundo, ficando as crianças cegas desde o nascimento prejudicadas, muitas vezes, no desenvolvimento de suas habilidades motoras, perceptivas e de formação do ego. Queremos, porém, chamar atenção para a ênfase dada pelos psicanalistas ingleses e norteamericanos à primazia da visão na construção da vida psíquica e do desenvolvimento. Assim, os aspectos da imobilidade e atraso motor nas crianças cegas congênitas sempre tiveram grande ênfase nos estudos sobre o seu desenvolvimento, não levando em conta o sujeito que habita, ou não habita esse corpo.

Nesse sentido, pensamos ser importante ressaltar que problemas no corpo físico, como as deficiências e síndromes, podem fazer limite ao desenvolvimento e à constituição de sujeito, mas não são a causa desta última. E também que é preciso relativizar os limites do orgânico na constituição do sujeito, pois, nesse sentido, o corpo físico, no caso da deficiência, não é a causa, mas o limite e aquele que provoca conseqüências "de ordem fantasmática tanto para o sujeito infantil como para seus pais" a ponto de produzir falhas nessa constituição (KUPFER, 2001, p. 59).

Parece-nos importante, assim, considerar a questão sob um prisma que nos leve além do campo da materialidade do corpo, da estimulação de habilidades e competências físicas e que nos proponha pensar a questão da constituição da subjetividade que se faz ao mesmo tempo que o desenvolvimento, mas que de certa forma o precede no desejo. Que nos proponha entender a relação entre o aspecto motor e a subjetividade orientando o trabalho, tanto clínico quanto educacional, com essas crianças e mães do seguinte modo:

O enodamento do desenvolvimento corporal com a estrutura subjetiva é o campo privilegiado da interdisciplina. Recordamos que o sujeito se constitui e se institui; não se desenvolve, mas se estrutura. Em troca, o corpo se constrói e se desenvolve, matura e cresce. A infância transita por esse inefável caminho onde o enodamento entre a constituição subjetiva e o desenvolvimento psicomotor marca um trajeto balizado por particularidades, onde o sujeito infantil toma a palavra e se apropria de seu corpo. Consideramos que é "em" e "por" estes pontos de encontro entre estrutura e desenvolvimento que a interdisciplinaridade tem sua origem e sua fundamentação em nosso campo de trabalho (LEVIN, 1996, p. 20).

Jardim (1996) nos diz que, quando olhamos para uma criança, olhamos para sua história e, sendo assim, vemos o corpo em uma dimensão simbólica e não só orgânica. Por 
que simbólica? Porque para a Psicanálise o sujeito que habita o corpo da criança é produto da linguagem e o corpo é um corpo erógeno (libidinizado); é uma construção significante. E “o sujeito advém de uma operação que vai do corpo à imagem, da imagem à palavra e da palavra ao desejo" (JARDIM, 1996, p. 73).

Assim é com a criança cega também. Mas vejamos a distinção entre as dimensões do corpo como organismo e do corpo como imagem.

Desde que nasce, o corpo do bebê é "habitado por palavras, imagens, cores, sons, vozes, toques, ritmos, texturas, símbolos" (LEVIN, 2005, p. 84); por uma canção que o embala, um carinho e um olhar que o particulariza. Todos elementos relacionais que envolvem o corpo em sua materialidade, mas que não são o órgão, o elemento da carne. Também não se referem à deficiência se houver uma. Ao contrário, referem-se a alguém que habita o corpo-organismo instaurado em uma cena e um cenário simbólico que confirmam sua origem e seu lugar de filho. Ao se inventar a cena, a criança passa a existir nela por essa poética do corpo, por sua representação nela, por sua imagem. O real do corpo dá lugar à sua imagem na constituição do sujeito.

Este "verdadeiro" enodamento do corpo no real (como corpo-órgão a ser investido, inscrito ou emoldurado), do corpo no imaginário (terá de constituir-se em imagem do corpo para re-conhecer-se e representar-se) e do corpo no simbólico (ao "submergir-se" e besuntarse na linguagem) irá configurar o itinerário estruturador da infância que, como tal, possui um limite determinado pelo percurso adolescente (LEVIN, 2002, p. 19).

O corpo precisa entrar em uma cena e um cenário simbólico propostos pelo Outro para ser "habitado pela poética da representação" e, portanto, subjetivado (Ibid., p.106). É nesse encenar do corpo no espaço simbólico ficcional que a criança se representa e tece sua história.

$\mathrm{O}$ nascimento de um filho remete os pais à sua própria história subjetiva e mito familiar que permeiam o desejo sobre o recém-nascido estruturando-o como sujeito. É uma realidade mítica, na qual o casal tomará a criança pondo em curso as funções materna e paterna, como já vimos. Ao assumirem tais lugares simbólicos - de pai e mãe - a criança assumirá o de filho. O nascimento do filho/sujeito, portanto, não coincide com a hora em que saiu da barriga de sua mãe, assim como o corpo-organismo não corresponde ao corpoimagem. A vida psíquica é delineada por uma herança simbólica e não genética e é isso que é 
posto em cena no cenário que precede o sujeito e que está além do corpo físico. Estrutura e desenvolvimento se enodam e configuram pontos de encontro nos quais o sujeito terá de reconhecer-se e afirmar-se. Assim, a imagem corporal é uma apresentação (inconsciente) do corpo. Marca de uma unidade imaginária do corpo, mas também de uma posição simbólica; e o esquema corporal é uma representação (pré-consciente) da imagem do corpo, do corpo no espaço. Ele advém e se ressignifica quando a criança (apoiada na imagem do seu corpo) começa a distinguir entre ela e seu reflexo. Se não houver imagem, não haverá esquema (Ibid.).

E o que ocorre com essa ficção originária, que supõe na criança um sujeito, que recobre o corpo-organismo com a investidura do desejo traduzido nas formas da cultura, tão absolutamente essencial à construção de sua imagem corporal para representá-la, quando se trata de uma criança com deficiência, ou seja, algo no corpo "não saiu bem”?

Nesses casos observamos nos relatos de mães, incluindo as desta pesquisa, que geralmente a deficiência toma conta de toda a fantasmática dos pais, de toda a cena, adquirindo identidade própria. Não há mais criança, nem menino ou menina (diferença sexual/identidade) e tampouco filiação (identificação) que são as premissas subjetivantes. No caso da criança cega, para algumas mães e pais, o mito da impossibilidade na presença da cegueira invade tudo e barra de fato qualquer possibilidade de ver a criança além disso. $\mathrm{O}$ corpo com uma deficiência quando olhado somente pela deficiência não é habitado pelo sensível e fica ocupado pelos mitos populares ou pelo discurso técnico-científico (é quando ouvimos mães que identificam seus filhos não pelo nome próprio, mas pelo nome da patologia causa da deficiência e conhecem mais as definiçõos médicas do que à criança). Nas duas formas, não vêem a criança, vêem somente a cegueira.

Levin (2005), ao considerar a sexualidade como o que confere ao ser humano a identidade e a diferença, indica que tais aspectos na criança com deficiência ficam atrelados à deficiência, anulando nos pais o querer saber sobre a criança e instaurando um querer saber sobre a deficência e seus efeitos. A imagem corporal passa a representar a deficiência e a sexualidade fica restrita à genitalidade. Quando se fala de um sujeito se fala de um sujeito sexuado e o saber da mãe sobre ele também é sexuado, pois que ela é mãe para um menino ou para uma menina. Dessa origem estruturante que irá inseri-la na cultura a criança não se lembrará, mas será representada por ela.

A primeira imagem corporal de um bebê é dada pelo Outro. Ele se vê como é visto. Trata-se de um momento estruturador e alienante ao mesmo tempo para posterior 
diferenciação. Depois passa a representar sua imagem e a imagem do Outro nos objetos transicionais, objetos que ensejam uma presença na ausência garantindo assim a continuidade/descontinuidade da mãe e dela criança, para, aos poucos, não precisar mais desses objetos concretos, introjetando-os e sustentando-se sozinha e representando-se por meio do brincar e de sua imagem constituída. Assim, a criança...

Vai criando e construindo suas próprias versões de seu corpo, da sua motricidade, do seu desenvolvimento, de seus pais, da sua história, quando começa a brincar e bisbilhotar pelo mundo que ativamente a circunda e ao qual ela, por sua vez, circunda (LEVIN, 2005, p. 197).

Pode acontecer que algumas crianças com deficiência não estruturem a imagem pelo que foi exposto até aqui, ficando presas à sua organicidade e deficiência e não se diferenciando/singularizando. Mas também pode se dar o fato da criança ter construído a imagem do corpo, mas não conseguir colocá-la em cena e usá-la. Assim, congela-se na imagem repetindo a cena infinitamente, configurando-se as estereotipias e empobrecendo o universo representacional.

Isso é comum nas crianças com deficiência mental. Nas crianças com comprometimentos neuromotores severos, a imagem pode se constituir, mas é questionada pela impossibilidade do uso do corpo no desenrolar da cena. Já no autismo e na psicose a imagem do corpo não se estrutura, como já foi exposto anteriormente (Cf. LEVIN, 2005)

No caso das crianças cegas congênitas como se dá a construção da imagem corporal?

Já ressaltamos a importância de uma "instância do olhar" - que não é o olho ou a visão - e que "na ou pela presença do olhar materno" (Cf. BARATTO, 2000, p. 50) carregado de desejo, olhar que olha o sujeito na criança, essa instância cumpre uma função constituinte da imagem corporal e estruturante do sujeito. O sujeito é produto do desejo materno, que por sua vez é o olhar do Outro. Se o Outro como olhar estiver ausente, não cumprirá a função de libidinização do corpo e de suas funções, não haverá "espelho" e, portanto, imagem corporal, promovendo transtornos na subjetivação..

Para compreender essa estruturação, recorreremos ao estádio do espelho elaborado por Lacan (1998) nos anos de 1953 e 1954, via pela qual estabeleceu uma distinção entre o ver e o olhar. 


\title{
1.3.3.1. O estádio do espelho: de que espelho se trata na criança cega?
}

Identificar-se com sua imagem como referência de seu corpo, passar a outras identificações, diferenciar-se do outro, ascender ao simbólico são os ganhos da construção especular.

Trata-se do tempo na vida do ser humano ainda bem pequeno no qual ele formará uma imagem de seu corpo que será refletida pelo espelho e, portanto, dada na exterioridade e da qual deverá ter um retorno do Outro que, além de refleti-la também irá refratá-la, ou seja, confirmar que a imagem é dela dando-lhe, assim, consistência. Uma imagem falsa, pois que a imagem não é o real. A criança irá reconhecer primeiro o outro e depois, pela confirmação deste, irá reconhecer-se. Passará à imitação diante do espelho e então à identificação e à diferenciação em relação ao outro. Dessa vivência, da imagem de um semelhante, surgirá o “eu” especular. Primeiro será uma imagem construída no Outro (materno), seu espelho. Uma imagem que será reconhecida primeiro como "ele" (que ali está no espelho) para depois ser assumida como "eu” (sou eu lá). Um verdadeiro enigma!

Lacan (1998), subsidiado pelos estudos anteriores de Wallon sobre o estádio do espelho na estruturação psíquica - marcando uma diferença na perspectiva da Psicanálise em 1949 escreveu:

\begin{abstract}
A assunção jubilatória de sua imagem especular por esse ser ainda mergulhado na impotência motora e na dependência da amamentação que é o filhote do homem nesse estágio de infans, parecer-nos-á, pois, manifestar, numa situação exemplar, a matriz simbólica em que o (eu) se precipita numa forma primordial, antes de objetivar na dialética da identificação com o outro e antes que a linguagem lhe restitua no universal, sua função de sujeito (LACAN, 1998, p. 97).
\end{abstract}

Não se trata, portanto, para a Psicanálise do espelho concreto, como em Wallon, mas do "espelho" que o Outro será para a criança ao dar-lhe a imagem e também a posição simbólica. Metáfora da virtualidade representacional do ser humano, o espelho representa uma dialética entre o olho e o olhar na formação da imagem. Para o bebê, então, o primeiro espelho é o olhar da mãe no qual ele está. Imagem dada pelo Outro na exterioridade. Ficção do encontro do corpo - imaginariamente unificado - e da imagem, institui o "eu", construindo também o esquema corporal como representação do corpo no espaço. Mas nessa fase do 
espelho, como já dissemos, a criança não só se reflete na imagem, mas também é refratada: executa um gesto postural de virada sobre seu eixo, fazendo com que a mãe (geralmente a mãe) que a segura no colo, lhe confirme, por meio do desejo, do olhar e da palavra, que aquela "criança"-imagem que ali está refletida é ela. A criança vira e confirma no Outro a sua existência. E no olhar a transmissão de que sua mãe deseja essa imagem, está ali e a ama. Assim é que o bebê assume essa imagem refletida como sua e se identifica com ela. Aos poucos, vai ganhando consistência enlaçando a motricidade com sua existência especularizada. É assim que vai reconhecer-se a partir do outro (Cf. LEVIN, 2002).

A imagem do corpo transforma-se em operador que funda e institui as peripécias e a estruturação subjetiva da criança. (...) se a criança não tiver configurado a sua imagem corporal, não poderá brincar. Isto porque, para conseguir estruturar um espaço de ficção onde encenar as suas representações, a criança precisa apoiar-se numa imagem a partir da qual possa desdobrar-se e desconhecer-se para brincar do que não é (...) Brincando a criança se representa e contesta a sua realidade para criar outra, desconhecimento originário, que vai the permitir colocar-se em cena utilizando a sua imagem corporal. Sem ela não há espaço ficcional possível para criar a encenação de sua atividade representacional e simbólica (Ibid., p. 106).

O estádio do espelho se dá em três tempos estruturais:

O primeiro momento é quando mãe e bebê se refletem no espelho e o bebê apreende a imagem como se fosse um outro real (registro imaginário). O segundo momento já é marcado pela discriminação da imagem, levando-o a perceber e diferenciar o outro real de sua imagem (processo de identificação). Nesse momento o bebê vira-se e busca o Outro encarnado na mãe como referência e esta o confirma dizendo que aquele da imagem é ele. E no terceiro desses momentos, o bebê não só diferencia a imagem como acaba reconhecendo que é sua imagem, seu próprio corpo (Cf. BASTOS, 2003).

Tanto Freud quanto Lacan consideraram o estádio do espelho como um momento fundante do sujeito. Um tempo no qual a criança bem pequena ainda (o infans, como se refere Lacan, etimologicamente aquele que não fala) irá identificar-se com uma imagem de corpo inteiro dada primeiro na exterioridade e que vai resultar em uma antecipação do "eu". Antecipação "precipitada por uma armadilha de identificação espacial, que faz com que uma imagem retalhada do corpo tenha uma forma ortopédica de sua totalidade no espelho" (JARDIM, 1996, p. 74). 
Baratto (2000), sobre o estádio do espelho, vai dizer:

Esse tempo de especularização, de pura reflexão identificatória na imagem do semelhante, requer ainda um tempo imediatamente segundo, no qual esta imagem encontrará no significante o suporte que se apresenta como a possibilidade de estabilização e captura da imagem real enquanto parcialidade posta nos significantes. Tempo necessário de desdobramento da imagem real para as imagens virtuais, de deslocamento do olhar do Outro daquela para esta; o sujeito não está no corpo, não está na imagem real, mas nos significantes que o representam em termos simbólicos. A imagem tendo seu suporte no significante, lança o sujeito numa relação transferencial ao Outro. O imaginário do sujeito deve-se à sua posição no simbólico como lugar que valida, num ato de reconhecimento, aquilo que ele vê (BARATTO, 2000, p. 54).

E sobre o olhar, a autora elucida que:

A importância do olhar de reconhecimento reside no fato de circunscrever, demarcar um desejo que se dirige ao sujeito, e em que o Outro se põe a enunciar palavras que portam notícias sobre aquilo que ele vê, sendo toda a cadeia de significantes que assim se estabelece (...) e que vem dar consistência ao imaginário do corpo, articulando-o nos três registros: real, simbólico e imaginário (Ibid., p. $54)$.

\section{Concluindo:}

Para metaforizar a via de passagem de um "fora" para um "dentro", Lacan acrescenta ao esquema óptico o espelho plano que representa o estádio do espelho (...) Neste, a imagem real se desdobra, translada, da imagem imediata para as mediatas, introduzindo entre o sujeito e sua imagem a mediação da palavra, e é no nível desta que se situa agora para o sujeito sua imagem, na qual o desejo do Outro veiculado pela palavra se faz demanda endereçada ao sujeito. Momento de passagem de desejo no Outro para desejo do Outro (Ibid., p. 54).

Aqui nos perguntamos mais uma vez pela criança cega congênita. Como vai ela passar pelo estádio do espelho, formar sua imagem corporal e resultar na formação do "eu”? Se o espelho é uma metáfora da imagem corporal, então o bebê cego também pode formá-la e 
certamente a forma, embora alguns possam viver um certo desvio nessa estruturação, como mostram alguns estudos que comentaremos mais adiante.

É também interessante mencionar aqui a pesquisa de mestrado realizada por Ormelezi (2000), na qual estudou a formação de conceitos de coisas não acessíveis aos sentidos da audição, tato e olfato, como lua, estrela, nuvem e espelho na ausência da visão, entrevistando cegos congênitos adultos acerca do tema a partir de suas lembranças de infância. Quando perguntados sobre o conceito de espelho como objeto concreto no qual se forma a imagem, esperando obter respostas ancoradas no conceito científico do qual todos tinham total conhecimento, estes escolheram outro caminho em suas respostas. De suas lembranças emergiram associações do conceito de espelho com o corpo e sua imagem na consciência que tinham de ser um "eu", remetendo-se diretamente à vivência do sentir e tocar o próprio corpo e ser tocado, tocar o corpo do outro, bem como ser capturado pela voz do outro. Embora não fosse o foco do trabalho, estes dados surgiram como significativos e ilustram o que tratamos aqui.

Aprofundando a questão e como mais subsídios à nossa articulação teórica recorremos à Lacan (1985) no Seminário Livro 11 de 1964 onde trata a questão da "esquize do olho e do olhar", fazendo referência à obra de Merleau-Ponty - desde A fenomenologia da percepção até $O$ visível e o invisível - da seguinte maneira:

A Fenomenologia nos remetia então à regulação da forma, à qual preside não apenas o olho do sujeito, mas toda a sua espera, seu movimento, sua tomada, sua emoção muscular e também visceral em suma, sua presença constitutiva, mostrada no que se chamam sua intencionalidade total. (...) As vias pelas quais ele nos levará não são apenas da ordem da fenomenologia do visual, pois elas chegam a reencontrar - aí está o ponto essencial - a dependência do visível em relação àquilo que nos põe sob o olho do que vê. Ainda é dizer demais, pois esse olho é apenas a metáfora de algo que melhor chamarei o empuxo daquele que vê - algo de anterior ao seu olho. $\mathrm{O}$ que se trata de discernir, pelas vias do caminho que ele nos indica, é a pré-existência de um olhar - eu só vejo de um ponto, mas em minha existência sou olhado de toda parte (Ibid. p. 73).

Lacan (1985) ressalta que se trata de um "ver" ao qual estamos submetidos desde a origem, factível na condição humana, e que não se trata o caminho do sujeito propriamente de passar entre o visível e o invisível, mas de uma "esquize" (fenda) entre o olho e o olhar na 
qual irá se manifestar a pulsão escópica. No ver, algo escorrega, escapa à visão, é transmitido e isso é o olhar.

Lacan (1985) segue falando sobre o olhar em outro trecho no qual, em nossa opinião, ao mesmo tempo que questiona, elucida:

O olhar de que se trata é mesmo presença de outrem enquanto tal. Mas é de se dizer que, originalmente, é na relação de sujeito a sujeito, na função da existência de outrem como me olhando, que percebemos o de que se trata no olhar? Não estará claro que o olhar só intervém na medida em que não é o sujeito nadificante, correlativo do mundo da objetividade, que se sente surpreendido, mas o sujeito se sustentando numa função de desejo? Não será justamente porque o desejo se instaura aqui no domínio da "voyura" que podemos escamoteá-lo? (...) o domínio da visão foi integrado ao campo do desejo (LACAN, 1985, p. 84).

Nessa construção na qual trava diálogo com Merleu-Ponty, o autor mais uma vez faz alusão a ele para referir que a visão não vem do corpo, mas do que ele chama a carne do mundo ${ }^{13}$, e, assim, chega à idéia do olhar como "avesso da consciência”.

Para Lacan (1985), ao contrário de Wallon, a consciência de si não existe, uma vez que o "ver-se vendo-se" (p. 75) é uma ilusão. Ilusão absolutamente necessária na constituição, mas que faz o olhar suprimir-se. Tudo que é de mais significativo na constituição do sujeito não é da ordem da consciência. O sujeito, e nem mesmo o "eu”, podem ser abarcados por ela. O sujeito é o sujeito do inconsciente e parte dessa instância psíquica chamada "eu" também é inconsciente.

É do senso comum a expressão "olho, mas não vejo" e é uma constante na fala de algumas mães de crianças cegas, cujo diagnóstico não veio logo ao nascimento, que elas

\footnotetext{
13 Descrita por Merleau-Ponty em “O Visível e o invisível” em 1960 (a propósito de tempo, espaço, movimento) como segregação, dimensionalidade, continuação, latência, imbricação - depois interrogar novamente os fenômenos-questões: eles nos reenviam a percebedor-percebido (...) meu corpo é feito da mesma carne que o mundo (é um percebido) e que para mais essa carne de meu corpo é participada pelo mundo, ele a reflete, ambos se imbricam mutuamente (o sentido a um tempo auge de subjetividade e auge de materialidade) (...)

Masini (2005) contribui com nosso entendimento dessa expressão afirmando que Merleau-Ponty mostra que é preciso sentir de alguma maneira para poder constituir-se e que esta estrutura advém de uma carne. Assim, para constituição como sujeito da criança cega é necessário aproximar-se de seu corpo e da experiência que ela tem através dos sentidos de que dispõe, de maneira total e não fragmentada. O corpo próprio de cada um está no mundo.
} 
olhavam e não viam nada, pois que da dialética do ver e do olhar, entre o visível e o invisível, há algo que é suprimido, algo que cai, algo de que é matéria prima a estrutura do sujeito.

É do evangelho a frase "eles têm olhos para não ver", "para não ver que as coisas têm a ver com eles, que elas os olham" (LACAN, 1985, p. 106).

Em relação à cegueira e à visão, Lacan se refere a Diderot em sua Carta sobre os cegos para uso dos que vêem mostrando o que o filósofo considerou que "de tudo que a visão nos entrega do espaço, o cego é capaz de dar conta, de reconstruir, de imaginar, de falar" (Ibid., p. 91). Mas Lacan objeta que:

(...) essa conotação deixa totalmente escapar o que seja a visão. Pois o espaço geometral da visão - mesmo incluindo aí essas partes imaginárias de dentro do espaço virtual do espelho (...) - é perfeitamente reconstrutível, imaginável, pelo cego. O de que se trata na perspectiva geometral é apenas demarcação do espaço, e não da visão. O cego pode muito bem conceber que o campo do espaço que ele conhece, e que ele conhece como real, possa ser percebido à distância e simultaneamente. Trata-se para ele apenas de apreender uma função temporal, a instantaneidade. A dimensão geometral da visão não esgota, portanto, e longe disso, o que o campo da visão enquanto tal nos propõe como relação subjetivante original (LACAN, 1985, p. 86; 91).

Não nos estenderemos na complexidade desse assunto que Lacan dissecou extensa e profundamente nos convidando a visitar a filosofia de Descartes em sua dióptrica, a geometria, as artes visuais na descoberta da perspectiva, fundamentando a idéia de que é do campo do desejo que se trata e não do campo do visual quando nos propomos a falar do ver e do olhar na formação da imagem corporal e na constituição do sujeito. Vamos apenas procurar entender do que ele fala quando afirma que a visão não se esgota na dimensão geometral do espaço e apreensão deste no tempo pela qualidade da instantaneidade, mas a visão tem também uma dimensão subjetivante. E repete: "o olhar não é o olho". O olhar está além do olho; há um anteparo entre um e outro, que é a mediação de outrem. Em função desse anteparo surgem os mais diversos efeitos: contorno, opacidade, deformações, fragmentação, difusão (LACAN, 1985, p. 89).

Por essa linha Lacan nos dá a parecer, se não nos equivocamos, que ao mesmo tempo em que ele deixa claro que o olhar não é o olho e que a visão não se esgota na capacidade do órgão visual, ele também parece salvaguardar a primazia da pulsão do olhar que passa pelo 
campo do olho. "Olho como signo de um investimento libidinal, mais que o órgão suporte da vista" (LAZNIK, 1998, p. 32). A essa altura temos que confessar um certo incômodo aqui, talvez provocado menos pelo pensamento de Lacan do que pela possível incompreensão de seu texto, mas que nos põe a argumentar que o autor não considerou a referência perceptual própria do cego e sua capacidade de apreensão da experiência além da materialidade, pois na apreensão do espaço, por exemplo, não há apenas a dimensão geometral. Certamente a experiência da visão não é dada apenas pela percepção do espaço enquanto tal. Ficamos aqui com a idéia de Lacan já apresentada do olhar como desejo e presença do Outro.

Estamos relacionando essas idéias ao que nos interessa para pensar a criança cega congênita em sua constituição subjetiva a partir da função do olhar. $\mathrm{O}$ mundo, inclusive o visual, para o cego é experimentado sem a visão traduzindo formas singulares de percebê-lo e relacionar-se com ele. Esse mundo de pessoas, objetos, situações e eventos que carregam em cada experiência perceptiva marcas humanas vividas com, pelo e no corpo. Um corpo como nos propõe pensar Masini (1994):

O primeiro objeto cultural é o corpo do outro como portador de uma experiência humana. Não é um simples fragmento do mundo, mas o lugar de uma certa elaboração, de um certo horizonte. Através de seu corpo vivo, que tem a mesma estrutura do meu, sei que e como o outro se serve de objetos familiares. Cada corpo - sistema único tem em comum com os outros o estar engajado num mundo físico e cultural como vivente. Cada um é a vida aberta que não se esgota em certo número de funções biológicas ou sensoriais (Ibid., p. 88).

Para Laing (1963) uma idéia que nos remete a pensar sobre o "ser olhado" da criança cega é que no ser humano:

A necessidade de ser notado não é, certamente, apenas uma questão visual. Estende-se à necessidade geral de ter a presença endossada ou confirmada por outrem, a necessidade de ser reconhecida a existência total (Ibid., p. 132).

Assim, pensamos que o espelho também para o cego é dado pelo olhar do Outro, assentado nesse corpo materno, que veicula um olhar que não passa pelo visual, mas sim pelo desejo. “A apreensão do olhar no olhar de outrem (...) não é a experiência fundamental do 
olhar (...) mas a apreensão do olhar na direção do desejo", daquilo que o Outro vê e deseja (LACAN, 1985, p. 88). É aí nessa experiência que o sujeito é capturado.

Em texto de 1905 sobre a origem da angústia infantil, em Três ensaios sobre a sexualidade, Freud (1996) escreve sobre um menino de três anos que roga à tia:

"Titia, fale comigo! Estou com medo porque está muito escuro." E a tia respondeu: "De que lhe adianta isso? Você não pode mesmo me ver." "Não faz mal", respondeu o menino, "quando alguém fala fica mais claro" (Ibid., p. 312).

A fala desta criança nos faz pensar no sentir-se olhado e poder sentir a presença do Outro no outro, sem ver, podendo "o ouvir" ser mensageiro da confirmação de uma presença que lança um olhar que garante a existência. É curioso que muitas mães de bebês que nascem cegos, não falam com eles, não tocam neles, não brincam, não conseguem ser essa presença e confirmar-lhes a existência.

Dolto (1984), embora conceitue de modo diferente ao de Levin $(2002 ; 2005)$ a questão do esquema corporal, definindo-o como a experiência cinestésica do corpo de fato, própria da espécie humana e igual para todos os indivíduos dessa espécie, também reconhece que é possível à criança cega formar a imagem do corpo mesmo que seu corpo-organismo (para ela esquema corporal) esteja “danificado" pela ausência da visão, pois, para a autora, a imagem corporal não está no visual.

Jerusalinsky (1989), como já vimos, alerta para o risco do bebê cego, a quem vai faltar no olho o testemunho do olhar da mãe, ficar excluído da confirmação de que é ele, seu filho. Ao nosso ver, o autor fala de risco e não de impossibilidade e Kupfer (2001) se refere à metáfora do espelho de Lacan, segundo ele mesmo o primeiro tempo na constituição do sujeito, "a partir do desejo ou do olhar materno" (p. 49). Essa conjunção ou que marcamos e cujo valor semântico designa exclusão, mas também alternativa, indica a possibilidade do bebê encontrar o Outro não no olho da mãe, mas em outras formas de contato e retorno - sua voz e seu toque a invocá-lo e transmitir-lhe o desejo por ele, confirmando-o na rede simbólica.

Jerusalinsky (1989) ainda fala do risco da pulsão da voz não ter o mesmo valor subjetivante da pulsão do olhar, desviando e fazendo com que o bebê se assuma como Outro sem distância simbólica (psicose). Fala da criança cega com comprometimentos na 
constituição subjetiva e no desenvolvimento, aquelas que apresentam traços autistas ou psicóticos.

Vimos que quando há uma impedimento de instauração do estádio do espelho, advém o autismo infantil e quando esse impedimento se dá na entrada para o simbólico, estamos diante da psicose infantil. No caso do estádio do espelho o que ocorre em cada uma dessas formações na estruturação psíquica pode ser descrito da seguinte forma:

(...) se a criança apenas se refletisse no olhar, na gestualidade, ou no corpo materno, sem se refratar (...), ficaria colada em sua imagem (que é a do Outro, de quem não poderia diferenciar-se); a criança estaria, assim, trilhando a senda do narcisismo e da psicose infantil. Se a criança não se afastasse da pura imagem não haveria reflexo, nem ela se refrataria em outra posição. Sendo assim, o espelho não cumpriria a sua função cênica e se manteria indefinidamente no especular, sem diferenciação possível. A função paterna ficaria elidida, fora da cena. Pura imagem especular sem interdição. Sem terceiridade. Puro reflexo, sem terceira instância, a criança ficaria sem refração simbólica e sem imagem virtual. Criança e espelho seriam um. Presa à sua imagem, a criança se completa com ela indefinidamente, sendo um com ela e nela (LEVIN, 2002, p. 112113).

(...) se no momento em que a criança virasse para confirmar a sua imagem, o Outro não estivesse ali, ou não a referisse à sua imagem, e sim a uma posição de coisa sem qualquer caráter afetivo, ela ficaria refratada em uma posição de objeto sem se refletir em imagem nenhuma: restaria à criança apenas seu corpo como coisa, navegando no terreno pré-especular e pré-pulsional, próprio do autismo infantil (...) o espelho não funcionaria como tal, mas como uma muralha que refrata a imagem no real e, ao fazê-lo, fragmenta-a em uma realidade fractal (Ibid., p. 112-113).

Para Levin (2002), o mistério da imagem corporal reside no fato de que a imagem, embora apareça dando unidade ao corpo, antes percebido por partes, não é completa. Está em falta, o que deflagra o desejo. Desejo de descobrir, de perceber, de verificar, de encontrar algo nunca possível. Por isso as crianças passam tanto tempo na infância brincando com o espelho: fazendo caretas e micagens, buscando-se atrás dele, conferindo a imagem de quem está com ele no espaço real...

Mesmo que haja uma "desconfiança" em relação à formação da imagem na criança cega pela via da voz, observamos muito um prazer lúdico que as crianças cegas mostram ao 
brincarem com o eco em garagens, recipientes fundos como canecas e outras situações ou objetos que se prestam ao fim de ser esse veículo de ressonância, de retorno. O que pode falhar também aí é a presença de alguém que confirme sua existência e não a deixe à mercê de uma experiência vazia, sem nome, no puro retorno do eco - quer por reflexão, quer por refração, para usar a metáfora dos mesmos fenômenos físicos usados para descrever a visão.

Muito já discorremos sobre a pulsão do olhar, por isso vamos aqui ressaltar o toque e a voz como padrões indicadores da estruturação psíquica e do desenvolvimento psicomotor. Indicadores estes que são mais significativos da criança cega congênita na formação da imagem corporal (prejudicada no visual e na mobilidade).

O toque junto a toda cena veiculada na relação humana com sua história e desejo - o toque do Outro (materno) - é capaz de levar as reações tônicas do bebê ao estatuto de “diálogo tônico libidinal”, o qual dará solidez ao eixo postural e à imagem do corpo, do que se desdobrará o movimento e, então, o gesto. No toque há um intocável que, como um cenário estrutura a "superfície libidinal do corpo e do diálogo tônico" (LEVIN, 2002, p.120). Sem imagem do corpo, o toque não será veículo da libido, não tocará afetivamente a criança, apenas encostará em um organismo. No toque poderá haver também um excesso de investimento libidinal, ficando a criança sem contorno, bloqueada na constituição subjetiva. Ao contrário, a mãe ao tocar e falar e procurar conhecer seu bebê, dar-lhe-á ao corpo o contorno necessário estrutural. Sem história e desejo (o cenário), “o toque deixa de ser referente e referência corporal subjetiva..." (Ibid., p. 122) de desejo e reconhecimento.

A voz, outro indicador do enodamento entre desenvolvimento psicomotor e estruturação da imagem corporal - a voz que carrega afeto, sedução, vínculo - veicula o desejo. À sua modulação, o bebê irá responder com a boca, movendo-a "(como um espelho)", retornando (como imagem) um som, "um eco virtual", desejando imitar a musicalidade "do encontro com o Outro" (Ibid., p. 122). Sons de reconhecimento que se complexizarão nos balbucios e fonemas até as palavras sempre que encontrar a confirmação de sua existência no diálogo íntimo com o Outro (materno) que irá enredá-lo em uma série de significantes. Se falhar a formação da imagem corporal, esse diálogo vocal não existirá e perpetuarão os gritos, os sons inarticulados, a ecolalia, as palavras soltas e vazias.

Trata-se aqui do encontro do corpo com a linguagem no qual ele responde pelas impressões das sensações internas orgânicas (cenestesia) e da percepção dos movimentos musculares, peso e posição dos membros (cinestesia). O corpo responde à voz que guia e orienta seus movimentos. A imagem corporal construída pela voz que se fará palavra e se 
distanciará do corpo pela capacidade da simbolização. A voz também veicula o desejo do Outro (Ibid.).

Para Dolto (1991):

(...) não há somente o espelho plano, há sobretudo o espelho que o outro é para nós. E, particularmente este outro, primeiro personagem visto no nascimento por um ser humano; ou ainda as primeiras palavras escutadas nas primeiras horas da vida como ecos de um espelho sonoro (DOLTO, 1991, p. 43).

Assim temos que o olhar, o toque e a voz estruturam a imagem corporal e estimulam o desenvolvimento psicomotor porque libidinizam o corpo quando há desejo do Outro. A motricidade será orientada pela imagem corporal, portanto. Porque entre o sensível e o motor interpõe-se uma marca, a marca do desejo, a libidinização, a representação, uma cena, o espelho, o espaço simbólico, a cultura.

Se a motricidade não for orientada pela imagem corporal, se converterá em estereotipias (ações sem representação) e cairá no espaço sem fronteira e diferenciação. A motricidade, por sua vez, se tornará gestualidade e por ela, ao contrário, simbolicamente invocará o olhar, a voz, o toque do Outro que irá refleti-lo e confirmá-lo na cena (Cf. DOLTO, 1991).

Além desses indicadores, ainda temos $o$ não, a denegação e a dor que confirmam a imagem corporal. Explicando melhor:

O gesto negativo (com a cabeça, a postura ou o som) afirma o uso do corpo e da linguagem num universo significante onde ela começa a reconhecer-se. (...) Desse modo, a negação afirma a imagem da criança num status simbólico. (...) Uma criança que não for constituída por uma imagem não conseguirá negar-se para se afirmar e sem essa negação afirmativa, não poderá gerar um espaço de ficção onde recusar e recriar uma nova realidade corporal, afim de reconhecer-se fora do corpo, ou seja, em sua imagem.

A denegação permite que a criança (...) sem perceber o que está fazendo, pois está brincando (...) ponha em jogo sua verdade inconsciente mediante o espaço ficcional e artificial que criam denegando a realidade ao brincar. (...) Sem imagem do corpo não há possibilidade de a criança negar e ficcionalizar a sua realidade.

A ausência do registro corporal da dor, tanto no que se refere aos limites do corpo (em relação ao esquema corporal) quanto à ausência do registro do medo, do risco ou do perigo de dano corporal, resulta 
em tamanha diluição dos limites da criança, que conota a nãoestruturação da imagem (LEVIN, 2002, p. 128-129).

Cremos ter exposto até aqui elementos suficientes à reflexão sobre as crianças cegas congênitas quando não constituem a imagem corporal. Analisaremos alguns casos neste trabalho. Vejamos agora como essas crianças constroem o "eu".

\subsubsection{A construção do "eu” na criança cega congênita}

A trajetória a ser cumprida pela criança, desde o nascimento, na constituição de sua subjetividade a partir do Outro, a coloca primeiro em posição de alienação ${ }^{14}$, da qual até certo ponto irá se libertar no momento em que se apropriar da linguagem. Desde que nasce, e antes disso, ela está inserida na ordem simbólica da cultura como objeto, para depois situar-se aí como sujeito. Essa entrada no universo simbólico (entrada para a linguagem) será acompanhada de uma "organização fonemática da realidade" (MANNONI, 1977, p. 77) - os esboços de significação das vivências de experimentação da realidade no exercício constante da diferenciação: estar e não estar com o outro, ter conforto e desconforto, ir e vir, aparecer e desaparecer, para só então pôr em funcionamento a diferença eu-outro e o pronome pessoal "eu" e seus referentes me, mim, comigo, meu, minha.

É pela identificação com a imagem do outro que o bebê (entre os seis e dezoito meses) no estado ainda impotente, sem coordenação motora, se antecipa imaginariamente em uma unidade corporal. Uma forma alienada de ser no outro, objetivando-se a si mesmo em uma imagem que ele chamará de "eu". Uma imagem ancorada no reconhecimento do Outro materno (Cf. BASTOS, 2003).

Lacan (1985) considera alienada porque se trata de uma falsa imagem e não de sua própria imagem. "O que vai ser projetado e introjetado pela criança é a imagem que refletirá o olhar do outro, o desejo e as expectativas dos pais em torno dessa criança” (BASTOS, 2003, p. 132). A criança aprende a reconhecer seu próprio corpo e seu desejo por intermédio do outro e depois diferencia-se dele. Esse processo de diferenciação eu-outro é fundamental na constituição do sujeito.

\footnotetext{
${ }^{14}$ Para se tornar humano, terá que ser primeiro objeto do desejo do Outro para depois separar-se dele e tornar-se um sujeito desejante.
} 
$\mathrm{Na}$ fase do espelho constitui-se o primeiro esboço do "eu" pela imagem do seu semelhante em um registro imaginário. Tal registro é caracterizado por essa relação com a imagem dada pelo outro e pela relação dual. De modo bem simplificado, esperando não colocar de modo simplista, podemos escrever o seguinte: somos seres de linguagem, faltantes e desejantes. Buscamos respostas para questões existenciais como quem somos, de onde viemos e para onde vamos. Nessa dimensão do humano a mãe é um ser faltante e portanto quer o que a complete, ou seja, em termos psicanalíticos, o falo imaginário. Na relação da mãe com seu bebê ela vai querer que este a complete. O bebê, por sua vez, é um ser dependente de amor, proteção e alimento. Seu desejo é ser o objeto do desejo da mãe. Assim, estabelece-se a dualidade: mãe quer ser completada na sua falta fundamental e bebê quer ser tudo para a mãe, inaugurando o primeiro tempo do complexo de Édipo (Cf. BASTOS, 2003).

Se por um lado a fase do espelho, da relação dual, do registro imaginário é fundamental, a questão do sujeito é exatamente ultrapassar esse momento e aceder ao registro simbólico. Assim passará para o segundo tempo do Édipo, no qual a criança deixará de ser o objeto de completude da mãe, já que a vivência da completude era imaginária. Será necessário que um terceiro se interponha na relação dual, instaurando a mediação simbólica, fazendo com que a criança possa situar-se a si mesma e aos outros, ordenar o mundo de pessoas e objetos. Nesse segundo tempo vai surgir a lei como metáfora desse terceiro, como o representante da lei: o pai que vem privar a mãe de seu objeto fálico (o bebê) e o bebê do objeto do seu desejo (a mãe). Essa é a metáfora que Lacan (1999) chamou Nome-do-pai. Para que o pai atue e seja aceita a lei, é preciso que a sua palavra seja autorizada pela mãe para que ele seja legitimado como o representante da lei. Se não é mais a criança quem tem o falo para completar a mãe, agora ela supõe que é o pai que o tem. Essa vivência de frustração e castração resulta para a mãe, simbolicamente, que ela não tem o falo e, de modo análogo, para o bebê que ele não é e não tem o falo, ele é um sujeito. Surge assim como singular, como subjetividade. A partir daí, adentrando o terceiro tempo do Édipo, o pai é quem supostamente tem o falo, deslocando o objeto de desejo da mãe para o pai e não mais o filho (Cf. BASTOS, 2003).

Antes de prosseguirmos é importante ressaltar a diferença entre "eu" e "sujeito".

O "eu” é uma construção imaginária, como já vimos, advindo da relação especular na diferenciação eu-outro. "É gerado pelo Outro, é produto do insconsciente e entre eles existe uma construção de linguagem (...) sendo que a confirmação do que se é vem do Outro" (Ibid., 
p. 136). O sujeito é o sujeito do inconsciente, cindido pela linguagem, constituindo-se quando da entrada no simbólico.

Revertendo para o nosso interesse neste trabalho, a construção do "eu" nas crianças cegas congênitas, Fraiberg e Freedman (1964) dão ênfase ao fato de que dificuldades na mobilidade no espaço lhes confere entraves no conhecimento do mundo, na conseqüente oportunidade de testar a realidade e, portanto, na distinção entre o eu e o outro. Sandler (1965), por sua vez, aponta que com freqüência observamos nos bebês cegos um desvio na formação do ego, quando se fixa no estado de indiferenciação entre o "eu" e o "não-eu" próprio do narcisismo primário, momento no qual a libido (grosso modo energia psíquica pulsional) é investida em si mesmo para depois passar ao investimento das relações objetais (narcisismo secundário) ${ }^{15}$.

Para Freud (1996) em Sobre o narcisismo: uma introdução (1914):

O desenvolvimento do ego consiste num afastamento do narcisismo primário e dá margem a uma vigorosa tentativa de recuperação desse estado. Esse afastamento é ocasionado pelo deslocamento da libido em direção a um ideal do ego imposto de fora, sendo a satisfação provocada pela realização desse ideal. Ao mesmo tempo, o ego emite as catexias ${ }^{16}$ objetais libidinais. Torna-se empobrecido em benefício dessas catexias, do mesmo modo que o faz em benefício do ideal do ego, e se enriquece mais uma vez a partir de suas satisfações no tocante ao objeto, do mesmo modo que o faz, realizando seu ideal (Ibid., p. 106)

Como a maioria das pessoas se vale do olhar nas relações, como um sinalizador na comunicação de pensamentos, emoções e feedbacks diversos - acompanhado ou não da expressão oral - algumas mães de bebês cegos não conseguem estabelecer o con(tato), ficando interrompida a relação com lacunas de respostas da mãe sobre as ações do bebê, dificultando prazer e o investimento libidinal sobre o mundo objetal. Nesses casos ocorre uma fixação no auto-erotismo, tendendo a libido a ficar apenas no próprio corpo.

Segundo Fraiberg e Freedman (1964), as crianças cegas congênitas que apresentam problemas no desenvolvimento mostram a tendência a permanecer centradas na boca como órgão de percepção e prazer, não passando à autonomia da mão na busca dos objetos e

\footnotetext{
${ }^{15}$ As relações objetais consistem no modo de relação do sujeito com o mundo de pessoas e coisas, resultado complexo da organização psíquica e da apreensão fantasmática do mundo (LAPLANCHE e PONTALIS, 1985).

${ }^{16}$ Investimento da libido
} 
tampouco ao prazer de descobri-los no mundo. Para os autores, a libido centrada no corpo sem investimento dos objetos é causadora de distorções na formação do ego. Eles relatam alta incidência de desvios, cujo quadro clínico se assemelha ao autismo nas crianças videntes, mas também com significativas diferenças. Referem ainda uma parada no desenvolvimento com "congelamento" da personalidade no nível da primazia da boca e indiferenciação eu-outro, destacando como crítico o período dos nove aos dezoito meses, embora haja evidência de um grande número de crianças cegas congênitas para quem esse quadro não se estabelece. Por essa razão os autores, obviamente, concluem que outras modalidades sensoriais podem substituir a visão no processo de formação do ego, mas se perguntam como se dão tais substituições e como acontecem os desvios. Apontam para o fato de que toda teorização sobre a formação do ego se baseia na visão e para as vulnerabilidades no desenvolvimento precoce que podem levar a falhas adaptativas e desvios no ego, mas sem a devida explicação.

Estudando crianças cegas congênitas - desde os primeiros meses de vida até a puberdade - com desvios na formação do ego, constataram, independentemente da idade, uniformidade nos seguintes comportamentos: desinteresse por brinquedos ou objetos que não sejam para gratificação de suas necessidades ou estimulação da boca; permanência da boca como órgão primário de percepção, exploração e discriminação, além de qualidades de agressão e erotismo; uso raro das mãos na exploração que até podem ser usadas para se alimentar, por exemplo, mas não mostram autonomia em si mesmas; podem cravar as unhas, agarrar, morder e beliscar as pessoas sem noção de que elas possam sentir dor; repetição de frases estereotipadas; referência a si na terceira pessoa do singular; ausência dos conceitos de permanência e constância de objeto e da diferença sexual. O balançar é similar às crianças videntes autistas, mas a falha adaptativa da mão não. As crianças cegas com boa integração do ego ou com desvios mostram desenvolvimento motor semelhante até perto de nove meses, ficando as desviantes atrasadas após essa idade. Em suas histórias encontram-se mães que relataram sentimentos de culpa e depressão em relação à cegueira de seus filhos e falhas no oferecimento de estímulos e no contato afetivo. As crianças com desvio na formação do ego mostram problemas no desenvolvimento a partir do primeiro ano de vida, entrando para o segundo, parecendo estagnado no terceiro ano. A independência da locomoção aos quatro ou cinco anos parece provocar um certo efeito sobre todo o desenvolvimento (Cf. FRAIBERG e FREEDMAN, 1964).

Os autores ressaltam que as especulações sobre danos neurológicos não foram fortes para dar sustentação à etiologia nesses casos estudados, bem como nos casos de videntes 
autistas. Embora tenham sido suscitadas causas neurológicas nas crianças com retinopatia da prematuridade, as pesquisas não mostraram diferenças significativas entre elas e as crianças cegas congênitas por outras causas, afastando a hipótese dos desvios na formação do ego em função de dano neurológico. Relatam ainda pesquisas com crianças com cegueira adquirida que mostram desvios menos acentuados em relação às cegas congênitas. Concluem os estudiosos a partir das pesquisas que os desvios encontrados em algumas crianças cegas estão associados à cegueira total e congênita e uma história de pouca estimulação e problemas na relação afetiva nos primeiros meses de vida, com a ressalva de que a cegueira desde o nascimento em si não é predisposição para o desenvolvimento desviante, já o fator de problemas na relação afetiva sim. Alertam que, se os sinais patológicos são precoces, pode-se trabalhar para um desenvolvimento favorável a partir de uma abordagem educacional e terapêutica com a criança e a família (Cf. FRAIBERG e FREEDMAN, 1964).

Esses estudos concluem ainda que há uma fragilidade nas crianças cegas congênitas em relação à construção do ego no que diz respeito à aquisição do conceito de objeto, como citamos acima. Tal aquisição - como mostrou Freud (1988) em 1920, no jogo de escondeesconde (Fort- Da), representando o significante da ausência que vai dar à criança os pontos de referência na identificação com a mãe e no reconhecimento de si mesmo - ficaria comprometida pela ausência da visão. A aquisição do conceito de objeto depende de sucessivas vivências com este aparecer e desaparecer, estar aí e já não estar, um aqui e um lá, de recobrir e procurar, chamar o objeto perdido e trazê-lo de volta.

O papel da visão na construção do objeto já vimos que é importante, pois à criança cega a experiência pode ficar fragmentada e descontinuada. Depois de sua locomoção independente fica mais provida de referências espaciais para, a partir de sua percepção, acompanhar o objeto no seu deslocamento no espaço, na investigação, descoberta e reconhecimento. Mas outras pistas e formas de contato e respostas das pessoas precisam existir para que a criança cega não perca essa experiência.

O "objeto humano" tem que prover o máximo de experiências a ela. Onde uma modalidade sensorial não pode substituir a visão como receptor à distância e um organizador do conjunto das percepções, a mãe e outros altamente investidos conduzem o principal peso de ensinar uma criança cega sobre a permanência dos objetos e através das suas próprias pessoas oferecer as possibilidades de sintetizar e unir essas impressões. Onde as catexias dos objetos humanos e dados sensoriais não visuais estabelecem um objeto estável de representação da criança cega, as idas e vindas da mãe, a localização desta por pistas 
audíveis, e depois sua busca por significados da mobilidade da criança, levarão todas as crianças cegas ao conceito de mãe que existe mesmo quando perdem o contato com elas (FRAIBERG e FREEDMAN, 1964, p. 135).

É certo que a audição pode referir a criança cega apenas a certas classes de objetos e o tato não pode indicar-lhe a localização dos objetos com os quais ela perdeu o contato. É certo também que as crianças cegas mostram interesse restrito aos objetos inanimados que não tenham som, ou cheiro, pois estes é que podem dar indícios dos objetos em movimento. Por essa razão, a mãe e outros adultos necessitam estar atentos na promoção das experiências significativas. Esses recursos são compensatórios da falta de informação disponível para a criança cega para que possa integrar as experiências perceptivas. Mas quando a relação mãebebê está afetada pela cegueira, tais possibilidades se fecham, provocando falhas adaptativas no conceito de objeto, na diferenciação eu-outro e na formação do ego. Algumas mães relatam não terem colocado seus bebês no chão deixando-os livres e estimulado-os a engatinhar, a manipular objetos, a explorar o ambiente, por exemplo. Também se referem a um sentimento de estranheza com o bebê com o qual não conseguiu travar um diálogo. Observa-se que quando as oportunidades são oferecidas, com a presença afetiva, e as crianças começam a explorar o mundo mais ativamente, a linguagem oral se amplia e ganha em qualidade. Ao contrário, na criança cega se a imobilidade motora toma conta e sua força pulsional fica auto-centrada, invariavelmente na boca, os impulsos agressivos e libidinais ficam indiferenciados, prejudicando a constituição da imagem corporal, esquema corporal e formação do ego (Cf. FRAIBERG e FREEDMAN, 1964).

Os estudos mostraram duas linhas de investigação, a saber:

1. Cegueira como uma barreira de comunicação entre mãe e criança com demandas sobre as capacidades adaptativas da mãe;

2. Cegueira como impedimento durante as fases críticas da formação do ego com demandas sobre as capacidades adaptativas da criança (Ibid., p. 152).

Em relação à primeira linha de investigação sobre as crianças cegas com problemas na formação do ego, havia mães que eram hábeis na tarefa de educar seus outros filhos, mas falharam com seus bebês cegos, pois, quando o contato pelo olhar e pelo sorriso não pôde se dar, o diálogo foi truncado e não conseguiram outras formas de comunicação. O sentimento 
de estranheza se somava ao desespero e depressão. Algumas ainda se mostraram bem sucedidas com esses mesmos filhos, mas antes do diagnóstico. Ao passo que as mães das crianças cegas que não mostravam desvios, tiveram uma qualidade de verdadeira relação humana com seus bebês nos momentos mais precoces de suas vidas. Em se tratando da segunda linha de investigação citada acima, o que se constatou foi que a cegueira cria riscos em determinados pontos do desenvolvimento do ego. Por exemplo da permanência da boca como zona erógena e órgão de percepção. Mesmo as crianças cegas "sadias" mostraram aquisição da autonomia da mão com prevalência desta sobre a boca aos quase dois anos de idade e para que isso ocorresse precisavam de alguém, pois tal aquisição requer uma mudança de direção elaborada que não será guiada pela visão. Algumas crianças cegas com problemas no desenvolvimento passam a usar a mão de modo similar ao que faz a boca: arranham, agarram, apertam, beliscam os objetos inanimados e humanos como um frenesi para capturar e possuir o objeto, além das falhas adquiridas no desenvolvimento motor que impediram a criança de adquirir novos padrões de mobilidade na exploração do mundo. Até que a criança cega adquira independência na locomoção, não experimenta totalmente a separação (Cf. FRAIBERG e FREEDMAN, 1964).

Mas os autores levantam uma hipótese: se a cegueira tem levado um grupo de crianças a falhas adaptativas, deve haver um correlato na forma dos problemas específicos de adaptação no desenvolvimento de todas as crianças cegas. Passam então a relatar o estudo de caso de T., a quem acompanharam dos cinco meses e meio aos dois anos e meio. Observaram que se tratava de uma criança que respondia seletivamente à voz da mãe com sorriso e alegria e sua cegueira não era impedimento para os vínculos humanos. Já aos oitonove meses ela discriminava entre sua mãe e um estranho pela audição e pelo tato, na presença de quem dava mostras de ansiedade (Ibid.).

Nesse sentido, os pesquisadores concluem que a mãe de T. conseguiu ajudá-lo a usar as capacidades perceptivas não visuais que o levaram a formar a imagem da mãe porque o objeto foi catexizado. Seu desenvolvimento motor não mostrava problemas. Perto de um ano, porém, houve uma certa regressão no desenvolvimento de T., o que é observado em muitas crianças cegas congênitas nesse período. T. não mostrava interesse pelos brinquedos e outros objetos que não a mamadeira e a chupeta. Aparentava contentamento em estar no chão passivamente, com o rosto para baixo, sorrindo levemente "para si mesma" por longo tempo. Esses comportamentos provocaram em sua mãe ansiedade, irritação, desconcerto e frustração e ela já não podia ver os progressos que ele fazia. Quando a mãe estimulava T., ele ficava 
alegre e excitado, mas ela desistia e só pensava que ele não olhava normalmente para ela (Ibid.).

Os autores avaliam que neste período se deve levar em conta os impedimentos que se relacionam direta ou indiretamente à cegueira e os impedimentos relacionados às dificuldades da relação mãe-criança, embora ambos se reforcem mutuamente. T. estava dependente da estimulação e quando não a tinha caía em um vácuo e retornava à experiência proprioceptiva, eroticamente estimulante. Mas começou a reclamar quando estava de bruços. Foi quando sua mãe comprou um andador. Assim, ele passou a atender aos seus chamados e chegava a ela pela voz, alcançando o objeto desejado no espaço e já podia recuperá-los quando perdia o contato físico com eles e as pistas sonoras já não eram sempre necessárias (Cf. FRAIBERG e FREEDMAN, 1964).

O trabalho foi centrado na interação entre a mãe e T. Quando T. estava com um ano e meio eles haviam resgatado a relação. Nessa época ele já explora o ambiente, alcança objetos e os conhece pela língua, lábios e dedos. Escolhe o que quer, belisca quando é frustrado, morde para demonstrar amor e brincadeira, imita a fala da mãe. A mobilidade independente favoreceu a separação da mãe, a distinção entre o eu e o outro, a construção do objeto. Os progressos geraram respostas positivas na mãe que geraram novas aquisições de T. (Ibid.).

A passagem para o interesse nos objetos inanimados, dependente da catexia dos objetos humanos, era lenta, mas seguia o mesmo caminho das crianças videntes e foi formando o conceito desses objetos, conforme os descobria na necessidade que tinha deles e na satisfação que lhes proporcionava. A percepção de totalidade foi adquirida pela mão que apoiava na discriminação e com ela também explorava o rosto das pessoas e as reconhecia. Esse uso saudável da catexia da zona pulsional para a percepção teve implicações importantes na formação do ego. Uma especificidade da cegueira, portanto, na visão dos pesquisadores, é o fato da mão manter um padrão associado à boca por um longo tempo. Aos dois anos, T. já havia passado da boca à autonomia da mão e já era capaz de interessar-se por objetos inanimados que não eram em si mesmos libidinalmente catexizados, ou seja, objetos que não eram ligados à satisfação ou auto-estimulação (Ibid.).

Certamente, em situações menos favoráveis, a criança cega pode não encontrar as soluções complexas para continuar o caminho de sua constituição de sujeito e desenvolvimento. 
Outro estudo que merece ser citado é o de Fraiberg e Adelson (1982), o qual tratou do desenvolvimento lingüístico de crianças cegas congênitas de zero a cinco anos. Neste estudo descobriram que nessas crianças a capacidade de representar a si mesmas, com o uso estável e flexível dos pronomes "eu" - "tu” e também no jogo simbólico, se apresentava com dificuldades, sendo adquirida em torno dos quatro a cinco anos. Essa evidência foi compreendida pelas pesquisadoras como um sinal de problemas quanto à formação do ego e do mundo de objetos e ainda da representação de si mesmo como um "eu" entre outros "eus". Ao mesmo tempo, as crianças mostravam avanços nas habilidades lingüísticas e aumento de vocabulário e estruturas sintáticas. Para as autoras, a cegueira impõe dificuldades na constituição da imagem e um sentido coerente do próprio "eu". Algumas crianças mostravam transtornos no desenvolvimento e outras adquiriram o conceito estável e uso flexível do "eu" por volta dos dois anos e meio, porém, só chegaram ao "eu" não sincrético" ${ }^{17}$ aos quatro cinco anos.

Como se explica isso? Não havia deficiência mental entre as crianças estudadas e nem comprometimentos neurológicos, segundo a informação das autoras.

Passaram, então, a observar as crianças no jogo simbólico e perceberam que elas não utilizavam o modelo da imitação da vida, no jogo imaginativo (o faz-de-conta, o brincar de ser outro e representar-se em uma boneca, por exemplo). Até cerca de três anos e meio-quatro não inventavam, sendo que as crianças videntes de dois anos e meio já o fazem. Em cada caso havia uma certa correspondência entre o jogo representacional e os pronomes de autoreferência "eu" e "me". Estes pareciam estar estritamente ligados à capacidade de representação simbólica. Aqui os pesquisadores referem mais uma especificidade da cegueira: carência de memória de imagens ocasionando atrasos nas aquisições dos conceitos de tempo, causalidade, auto-representação e de permanência de objetos. Foi entre os dois anos e meio e os quatro que os atrasos entre a linguagem e outros processos cognitivos se fizeram notar, pois que antes não havia diferença entre as crianças estudadas e crianças videntes em relação ao vocabulário, identificação da palavra-coisa e análise de frases e orações (Cf. FRAIBERG e ADELSON, 1982).

$17 \mathrm{O}$ "eu" sincrético está associado às formas verbais que expressam necessidade ou desejo e o "eu" nãosincrético se desprende da forma inicial e é usado criativamente em novas combinações. Este requer um alto nível de dedução: eu sou um "eu" para mim, tu és um "eu” para ti e ele é um "eu" para ele (ZAZZO, 1949 In: FRAIBERG e ADELSON, 1982) 
As pesquisadoras se propuseram a mostrar elementos da auto-representação que dependem, segundo elas, de uma organização sensório-motora coerente e intacta. Assim, observaram que aos dois anos uma das crianças estudadas apresentava vocabulário esperado nessa faixa etária; identificava pessoas da família; discriminava objetos pelo som e pelo tato e os nomeava, inclusive objetos novos para ela; usava frases de cinco palavras para expressar desejos e sentimentos, embora não fizesse novas combinações; usava com sentido a fala dos outros para situações proibitivas; mostrava certo nível de generalização de conceitos, regressão e confusão no uso dos pronomes pessoais; e não gostava de escutar histórias ainda que breves. Por este último traço, as pesquisadoras levantaram uma hipótese de que o início da linguagem nas crianças cegas seria diferente das crianças videntes, o que levaria a algumas incapacidades na representação simbólica. Aos três anos, K. começa a apresentar desvios na linguagem e na representação de si mesma no jogo simbólico; não contava histórias e nem respondia a perguntas feitas sobre uma contada; não inventava nada nas situações de brincadeiras livres ou dirigidas, nem descobria novas possibilidades, apesar de manter o interesse na atividade; não relatava algo que lhe acontecera; mostrava-se confusa e instável quanto aos pronomes eu-você; não era capaz de atribuir características humanas aos bonecos, animais e objetos (Cf. FRAIBERG e ADELSON, 1982).

Quando as pesquisadoras criaram cenas para provocar a entrada de K. no cenário, no simbolismo da brincadeira, ou seja, criaram condições apropriadas para incentivar K., ela começou a brincar, primeiro reproduzindo uma cena entre ela e a mãe, na qual fazia o papel e a fala das duas. Assim, já podia considerar-se como objeto e fazer-se de sujeito e objeto. Ainda não podia transpor para a boneca, fazer a projeção para que esta a representasse e ela representasse a mãe. Normalmente a criança que vê se imagina na boneca e a criança cega precisa fazer isso pela ação, pelos movimentos. Segundo as autoras, as crianças videntes alternam o jogo egocêntrico e o representacional, pondo-se a si mesmas e às bonecas nas cenas (Ibid.).

As pesquisadoras revelam a ambigüidade dos pronomes pessoal e possessivo (eu, me, mim, meu): ser um você para os outros e um eu para si mesma; eles serem vocês para ela e “eus" para si mesmos. Lembram que tais pronomes não delimitam o sujeito, mas são indícios do nível de desenvolvimento cognitivo conceitual. E, com base na abordagem piagetiana, explicam que a capacidade de K. para representar a si mesma no jogo é uma medida do nível de desenvolvimento conceitual e de representação mental, no qual o "eu" pode se considerar 
objeto e objetos podem representar o "eu". Concluem que K. não está atrasada e não corre perigo de autismo (Ibid.).

Em torno dos quatro-cinco anos, K. começou a representar-se a si mesma brincando com as bonecas e a linguagem tornou-se mais elaborada com estabilização do pronome "eu". Tinha um amigo imaginário e logo passou a contar seus sonhos. Passou a fazer perguntas sobre que dia estava e quis os dias da semana, tempos verbais no passado, reconstruir um fato ocorrido no dia anterior (Ibid.).

Fraiberg e Adelson (1982) mostraram que a aquisição do pronome pessoal vai além da forma gramatical. Está relacionada à constituição da auto-imagem e consideram uma proeza a criança cega congênita adquirir tal construção, ainda que de forma mais lenta do que a criança vidente. Ressaltam que a criança cega constrói por outros caminhos que levam mais tempo para se consolidar com coerência e estabilidade. Na criança cega, as experiências auditiva, vocal, cinestésica, locomotora lhe proporcionam a sensação de substancialidade e de autonomia do próprio corpo, mas vinculadas a uma experiência egocêntrica de seu corpo e não lhe permite chegar com facilidade ao conceito de si mesma como objeto, o que é condição para o "eu" não-sincrético.

As autoras reforçam a idéia de que a réplica da criança dada pelo espelho só a visão pode proporcionar e que a imagem no espelho é a imagem de si mesmo, experiência que falta ao cego congênito. Explicam, por essa razão, que a aquisição para ele se dá mais tarde, mas não explicam como se dá. É um caminho que o cego faz solitariamente, pois falta, às pessoas que estão ao seu redor, maior clareza sobre esse caminho e como acompanhá-lo. Vimos anteriormente como o retorno da voz, do eco, de uma gravação escutando a própria voz e a voz do outro, ou imitar personagens na construção de cenas e também jogos e brincadeiras corporais e de aparecer e desaparecer com o suporte da voz e do toque favorecem essas construções. Nesse estudo as pesquisadoras se propuseram a investigar a criança cega sem ultrapassar o referencial do vidente. Também não avaliaram no processo de estruturação da função simbólica e do "eu" as condições apropriadas ou não do contexto de vida da criança (Cf. FRAIBERG e ADELSON, 1982).

Por todo o aporte teórico trazido neste trabalho temos que retomar a concepção de que há especificidades na forma de existir da criança cega, com seus caminhos próprios para perceber e relacionar-se no mundo, não podendo ser comparada com a criança vidente. Ao mesmo tempo, o espelho é uma metáfora e a imagem é uma ilusão, precisando a criança, para se tornar sujeito, ter e fazer uso de sua imagem, sendo posicionada no simbólico. Por fim, a 
cegueira não pode ser pensada isoladamente, pois ela vai provocar na mãe certas dificuldades para estabelecer a relação com seu bebê e reconstruir um sonho para ele, instaurando o desejo, incitando o curso da libido em seu corpo, cunhando um lugar de filho para ele. Nessa linha não estamos de acordo com os estudos que se baseiam na cegueira em si como impedimento à constituição da imagem corporal e da formação do "eu” e da função simbólica. Ao nosso ver a questão não pode ser reduzida a falhas adaptativas pela ausência da visão.

De acordo com Levin (2002):

A criança somente pode constituir-se num único espelho que, como vimos, primeiro é construído no Outro (materno), em terceira pessoa, para depois se afirmar na primeira pessoa do singular. A criança estrutura a linguagem e a imagem corporal partindo da posição do Ele para a do eu. Sem Ele (Outro), o eu não poderia espelhar-se cenicamente. É a cena do espelho (no seu excesso) o que modifica a criança prazerosamente, e não um processo evolutivo ou de adaptação ao mundo. (...) o espelho como um cenário no qual, acordado, ele se desdobra. Existe na ficção do encontro entre o corpo e a imagem. A criança "nega" seu corpo para confirmar-se em sua imagem e a partir dela irá ressignificá-lo instituindo seu eu e construindo o esquema corporal como representação do corpo em espaço. Cada criança em cena constrói e é constituída por seu espelho, em frente e verso de duplicidade e desejo (LEVIN, 2002, p. 104).

A ênfase dada ao desenvolvimento motor atrasado na criança cega em relação à vidente, suas dificuldades para explorar o ambiente e dirigir-se aos objetos dispostos nele, se baseiam na concepção de cegueira como impedimento que leva a falhas adaptativas ao mundo e conseqüentes transtornos na construção do "eu". Por não ver, não mostra interesse e prazer na descoberta do mundo que a circunda.

Mas entre o sensório e o motor existe a cena que é uma inscrição, uma marca e a experiência de satisfação, o prazer que a criança experimenta ao se locomover, não está propriamente na motricidade e sim nessa cena que dá forma às suas representações - "O sensório-motor como gesto significante e espelho de representações internas" (LEVIN, 2002, p. 177). Pensamos que o olhar sobre o orgânico muitas vezes impede pais, educadores e terapeutas de ver o que a criança põe em cena.

É essa imagem desejante cedida por esse Outro (materno) que permitirá à criança refletir-se não no seu desenvolvimento muscular, tônico ou funcional, mas num lugar impossível de tocar (...), 
imperceptível aos sentidos (...) é uma posição subjetiva que insiste e consiste real, imaginária e simbolicamente. (...) que o Outro reflete e refrata em cada olhar, em cada gesto amoroso, o que insiste e investe o bebê não em organismo de uma espécie, mas em sujeito de seu próprio e singular destino. (...) gerando seu próprio estilo e seu próprio corpo (...) o que é próprio do seu corpo, um nome e uma imagem (LEVIN, 2002, p. 195).

Não desconhecemos a importância da organicidade e esta, no olhar do Outro, tantas vezes ocupa o lugar da criança negando-lhe a dimensão subjetiva. Nosso foco é olhar para a criança cega, e particularmente a criança cega com problemas na constituição da subjetividade e no desenvolvimento na possibilidade de simbolizar-se.

(...) encontrar nessa pura presença orgânica uma pista, uma cena que permita avistar uma ilusão, uma ficção. A ilusão antecipatória de um sujeito permite antecipar (...) uma ausência, uma dialética ente o visível e o invisível, entre o órgão e a imagem, entre o aspecto motor e o gesto, conferindo outra consistência imaginária e simbólica à realidade imposta (LEVIN, 2002, p. 199).

\section{DISTÚRBIOS GLOBAIS DE DESENVOLVIMENTO / PROBLEMAS GRAVES NA CONSTITUIÇÃO SUBJETIVA}

Como ocorre no campo da deficiência, há intrincadas discussões que buscam estabelecer uma terminologia de referência para fins de uniformidade no diagnóstico, tratamento e comunicação entre profissionais da área quando se tenta uma categorização nosográfica para os quadros clínicos das desordens psíquicas infantis que comprometem o desenvolvimento.

Tornam esse caminho difícil à discussão epistemológica e as concepções teóricas de um lado e as posições político-ideológicas de outro.

Ao longo dos anos, encontramos diversas nomenclaturas para os transtornos infantis: problemas emocionais graves, problemas de desenvolvimento, transtornos graves de desenvolvimento, distúrbios de comportamento, graves distúrbios de desenvolvimento para designar, na maioria das vezes, a psicose infantil e o autismo. 
Em 1994, a Associação Americana de Psiquiatria publicou o Manual de Diagnóstico e Estatística das Perturbações Mentais em sua $4^{\mathrm{a}}$ edição - o DSM-IV - que adotou a nomenclatura "distúrbios globais do desenvolvimento" (Cf. APA, 1994).

As classificações internacionais - CID 10 - Classificação Estatística Internacional das Doenças e Problemas Relacionados à Saúde (Cf. OMS, 1993), e DSM IV - Manual de Diagnóstico e Estatística das Perturbações Mentais - (Cf. ASSOCIAÇÃO AMERICANA DE PSIQUIATRIA, 1994), consideram como "transtornos invasivos de desenvolvimento", um transtorno global de desenvolvimento que abarca os transtornos autista, de Rett, desintegrativo da infância, de Asperger e transtorno invasivo de desenvolvimento sem outras especificações (Cf. BALLONE, 2002). Enfim, uma gama imensa de quadros clínicos, de etiologias diversas.

A caracterização dada pelo DSM IV pela APA (1993) indica:

(...) prejuízo severo e invasivo em diversas áreas do desenvolvimento: habilidades de interação social recíproca, habilidades de comunicação, ou presença de comportamento, interesses e atividades estereotipados. Os prejuízos qualitativos que definem essas condições representam um desvio acentuado em relação ao nível de desenvolvimento ou idade mental do indivíduo (BALLONE, 2002).

Ao contrário do que se deu com a classificação das deficiências pelo conceito de funcionalidade com base no critério social, a classificação "distúrbios globais de desenvolvimento" não representou avanço, pois apenas descreve a manifestação sintomática dos quadros sem a compreensão da etiologia, estruturação e diversidade dos mesmos.

Apresentando uma preocupação mais compreensiva desses quadros e com uma tradição das linhas psicodinâmicas temos a Classificação Francesa dos Distúrbios Mentais pouco conhecida entre nós (Cf. ASSUMPÇÃO, 1997).

Para Assumpção (1997), citando Gilbert (1990), na visão psiquiátrica, o conceito atual dos distúrbios globais de desenvolvimento decorrem de diversas etiologias e se caracterizam por:

(...) deficit social, visualizado pela inabilidade em relacionar-se com o outro, usualmente combinado com déficit de linguagem e alterações de comportamento. (...) em alguns quadros específicos, podemos 
ainda observar retardo no desenvolvimento neuropsicomotor ou mesmo perda de funções anteriormente adquiridas (Ibid., p. 104).

Para a área da deficiência poderíamos pensar que houve um ganho na adoção da terminologia "distúrbios globais de desenvolvimento", pois passou a considerar, além da psicose e do autismo, aqueles quadros de deficiências e síndromes associados a problemas na constituição de sujeito. No caso da criança cega, muitas vezes confundimos sua maneira singular de apreender o mundo com quadros de deficiência mental ou autismo. Mas na opinião de Lajonquière (1997), uma variedade tão ampla de quadros clínicos sob a mesma categoria de "distúrbios globais de desenvolvimento" acabaria por encobrir a psicose e o autismo.

O diagnóstico diferencial é de grande complexidade por se tratar de crianças cujo organismo está em desenvolvimento e cujas redes sociais estão se formando podendo ser passíveis de alteração.

Acreditamos avançar com a visão da psicanálise apresentada por Kupfer (1997) para se referir às crianças com "graves distúrbios de desenvolvimento" como:

(...) crianças cuja posição na rede da linguagem, cuja inscrição no registro do simbólico apresentam falhas a ponto de ficar comprometida a sua constituição subjetiva, sua relação com o outro e sua circulação no campo social: psicóticas, autistas, sindrômicas ou algumas portadoras de deficiência para quem tais falhas simbólicas acabam por se instalar (Ibid., p.57).

Em outra referência literária a autora se refere de maneira ainda mais precisa sobre quem são essas crianças: "psicóticas, com traços autistas, pós-autistas e crianças com problemas orgânicos associados a falhas na constituição subjetiva” (Ibid., p. 83).

Os psicanalistas que se dedicam ao estudo e trabalho nessa área têm utilizado essa nomenclatura, como também transtornos graves, ou ainda graves problemas de desenvolvimento e problemas na constituição de sujeito, mas quase sempre acabam se referindo à psicose e ao autismo.

Efetivamente, para a Psicanálise, são crianças para quem falhou a educação no sentido da ação do social que constitui o sujeito. Não foi possível à criança usufruir do convívio social 
pelas dificuldades em fazer laço social, "seja pela fantasmática parental, seja pelos limites do corpo, seja por injunções sociais" (KUPFER, 2001, p. 40).

Notemos que a Psicanálise sai da abordagem médica e se refere a falhas na estruturação psíquica da ordem do social, na medida em que o insconsciente é social. Parte do que é fundante nos distúrbios de desenvolvimento de forma a compreender processos e existências humanas na sua constituição subjetiva e não apenas descrever sinais caractereológicos. Essa é uma distinção importante que nos leva a adotar neste trabalho a designação "problemas graves na constituição subjetiva”, como o faz Filidoro (2005).

\subsection{Psicose e autismo}

As conceituações de psicose e autismo também têm um histórico e as divergências ou nuances de diferenças de abordagens entre correntes psiquiátricas e psicanalíticas se fazem presentes. Da vertente médica as explicações são de falhas de base neurológica. Da vertente psicanalítica entende-se como falhas ocorridas por uma relação patogênica entre mãe-bebê. Sem deixar de considerar a possibilidade de descobertas que possam surgir na Medicina e em outras áreas, vamos nos concentrar na direção da Psicanálise, pois nos interessa a questão da constituição do sujeito. A Psicanálise hoje define autismo e psicose como dois quadros distintos (e não o autismo como uma forma de psicose como fazia antes), caracterizando, portanto, as diferenças entre essas formações psíquicas que comprometem a constituição de sujeito.

Para alguns psicanalistas lacanianos (Cf. MANNONI, 1987; JERUSALINSKY, 1993; KUPFER, 2001; LEVIN, 2002), no autismo há "falha" da função materna e na psicose há "falha" da função paterna. O que isso significa?

Vejamos que não se trata da mãe e do pai reais que cuidam, se relacionam, sentem e desempenham seu papel social, mas de uma função inconsciente no funcionamento psíquico dos mesmos. Assim, na função materna, cada mãe, levada pelo desejo, vislumbra uma existência subjetiva para o bebê. Uma existência ainda inexistente, mas que se constituirá exatamente porque essa mãe a supõe. Com seu toque, seu olhar, sua voz, gestos e dizeres, no cotidiano onde vai nascendo um reconhecimento mútuo entre ela e o bebê, ela dá curso ao 
investimento libidinal que recobre o corpo do bebê, fazendo-o desaparecer como carne sob essa rede por ela tecida e que fará surgir pelo desejo ou pelo olhar dela, como imagem corporal que o faz reconhecer-se. Assim, nessa função materna, a mãe sustenta o lugar de Outro primordial para seu bebê (Cf. KUPFER, 2000).

Entendemos que o universo sobre o qual a relação mãe-bebê opera é muito complexo. Se não for colocada em exercício a função materna que leva o ser humano do universo do corpo ao universo simbólico pelas redes sociais e se o encontro mãe-bebê não se der por essa via de significação, algo da ordem da constituição da subjetividade ficará comprometido. Falamos de encontro, pois trata-se de uma adaptação mútua nessa relação.

É esse encontro que vai construir e pôr a funcionar o equipamento com o qual a criança nasce. Assim, podemos ter uma mãe que sustenta um lugar para esse filho na rede significante, mesmo ele tendo um equipamento "defeituoso" e outras mães que não conseguiriam. Ou ter um bebê totalmente inoperante, que por mais que a mãe se esforce ela não consegue torná-lo humano. De todo modo falhou a função materna porque mesmo a mãe tendo condições de colocá-la em curso, o bebê pode não conseguir absorvê-la. Os efeitos da falha no desejo ou função materna podem ser de autismo precoce com a ausência de imagem corporal pela não libidinização do corpo. E falhas na especularização, levando à ocorrência de traços autistas associados a outros comprometimentos patológicos (Cf. KUPFER, 2000).

Desse modo, quando as trocas entre mãe e bebê falham, por uma razão que não é da volição e da consciência, ficando perdidas as percepções de um sobre o outro, rareando os contatos significativos - nos quais ambos se reconhecem mutuamente e alimentam a interação - surgem precocemente os primeiros traços do autismo.

No autismo, há ausência de inscrição e a criança está excluída do olhar da mãe. O objeto de desejo da mãe está fora do seu olhar. E qualquer demanda para o autista, ele a recebe como demanda de exclusão. As estereotipias que caracterizam seu comportamento como algo sem sentido e que insiste em uma presença inerte, que não se dirige a nada nem a ninguém, são respostas a essa demanda do Outro que é de exclusão (Cf. JERUSALINSKY, 1993).

Por ser algo que se instala no encontro entre mãe e filho, não há culpa, mas, como indica o trabalho dos psicanalistas, há responsabilidade pelo destino da subjetividade dessa criança. Esta responsabilidade faz com que uma mãe, ao querer saber sobre sua relação com seu filho, possa, nas palavras de Kupfer (2000): 
(...) resgatar o que não pôde acontecer quando seu filho era ainda um bebê, seja porque ele não facilitou as coisas por ser, por exemplo, cego, surdo, ou hipotônico, seja porque ela vivia um momento em que se encontrava "apagada" para o exercício da função materna (p. 9).

O autista está excluído da linguagem, ou seja, da corrente de significações e é uma existência sem sujeito. Na psicose infantil, por sua vez, há presença da mãe desejante, mas onipotente, que impede que se opere a função paterna. A função paterna é aquela que leva significantes que funcionam como "pontos de basta, articuladores, pontos nodais dos feixes de cadeias significantes necessárias à constituição do sujeito" (Ibid., p. 12). É ela que tira o sujeito para fora da simbiose com o desejo da mãe, impedindo que ele permaneça como seu objeto de completude: seu falo.

Na psicose infantil o sujeito fica aprisionado ao desejo da mãe, como objeto dela, e não constitui seu desejo. Entra na linguagem, no mundo das significações, mas fica alienado no discurso dos pais e precisa se separar dele para falar em nome próprio e se constituir. Há inscrição do sujeito, mas não pode haver consequiências na função significante. E de acordo com Stevens (1996), “a criança psicótica está inscrita na linguagem mesmo quando (...) não se inscreve como sujeito na palavra" (p.60).

Para Mannoni (1987), ele não entra na situação triangular. E podemos dizer, não há sujeito castrado. O Outro não se estrutura como barrado. É todo, absoluto. E tudo é uma grande completude, sem corte e sem contorno, sem entrada no simbólico, sem consistência.

A criança psicótica ou fica totalmente absorvida por um auto-erotismo, ou fica totalmente absorvida por uma alterização absoluta (Cf. JERUSALINSKY, 1993).

Para designar como se estrutura a psicose infantil, Lacan (1966) utilizou o termo foraclusão do significante Nome-do-Pai, significante primordial que instaura o sujeito do desejo. Existe um tempo na infância para passar pela metáfora paterna e se não passar, fica foracluído, fica suspenso e não passa mais.

Na psicose infantil o significante Nome-do-Pai não pode exercer sua função e deixa “um ‘furo’ no campo das significações” (KUPFER, 2000, p. 13).

É importante ressaltar que, para alguns psicanalistas (Cf. JERUSALINSKY, 1993; CALLIGARIS, 1989), as psicoses infantis devem ser consideradas como não-decididas, uma vez que a estruturação subjetiva se dá ao longo da infância em vários tempos de ordenação 
psíquica. Para Calligaris (1989), só se poderia falar em foraclusão da função paterna, depois de passar pelo tempo da latência e chegar à puberdade. Antes disso a criança está em formação. Isso nos dá a possibilidade de realizar um trabalho de desalienação dessa criança, que é capaz de fazer laço social, ao contrário da autista.

Para Jerusalinsky (1993), a mãe da criança psicótica a prende em seu corpo e a vive como seu objeto e nada desse filho escapa ao seu olhar. Na ausência de consistência do significante Nome-do-Pai, a criança não se separa da mãe e fica sem poder ser outra coisa que não seu objeto.

É importante ainda precisar que não se constituem como sujeitos de desejo e estão presas a "cadeias de gozo" e as significações de seus comportamentos escapam às interpretações que possamos fazer sobre o seu sentido.

Algumas articulações de Mrech (1999) explicam que a criança:

(...) repete porque não está conseguindo sair desse processo, porque não consegue encontrar outra forma de gozar (...) repete algo que ainda não conseguiu elaborar (...) faz porque aquilo tem um determinado sentido, porque se encontra presa em cadeias das quais não consegue sair (Ibid., p. 116-117).

Observemos nessas colocações mais um conceito fundamental da obra de Lacan que muito nos aproxima dessa outra forma de compreender o mecanismo de funcionamento psíquico no modo de existir dessas crianças. Trata-se do conceito de gozo para Lacan:

(...) modalidade de funcionamento do sujeito (...) não é o gozo do prazer que se obtém através do orgasmo (...) é uma outra satisfação obtida através do inconsciente, através da linguagem e da fala, frente a algo onde o sujeito não deveria estar sentindo prazer. É por isso que Lacan fala de uma outra satisfação (...) que não serve para nada, mas que mantém o sujeito atado às suas cadeias (...) Um prazer inconsciente que emerge na manutenção da inércia (...) que se encontra vinculado à libido fixada, fazendo com que o sujeito repita sempre os mesmos contextos, as coisas da mesma forma. Ou que queira sempre mais, e acabe obtendo o pior (MRECH, 1999, p. 132).

E mais: 
(...) Quando a criança se aproxima de um brinquedo para brincar, já está aparelhada com formas estruturadas de pensar e de saber. Durante muito tempo os psicanalistas acreditaram que bastava o sujeito saber o sentido e os significados das suas ações para mudar. $\mathrm{O}$ problema é muito maior: estamos presos às cadeias de gozo - formas de gozar padronizadas - das quais não conseguimos nos desvencilhar, nem saber o sentido. (Ibid., p. 116).

Em suma, há algo com essas crianças que não sabemos exatamente o que seja e vamos procurá-lo em suas manifestações.

\subsubsection{As especificidades da estruturação cognitiva e das aprendizagens na psicose} e no autismo

Para a Psicanálise, a relação entre os processos mentais e o sujeito do inconsciente é dada considerando o bebê no início da vida quando recebe "inscrições psíquicas", marcas que os representantes da cultura - em geral seus pais - farão para torná-lo humano. Cada inscrição psíquica regerá uma "longa e indefinida série de novas inscrições que se desdobrarão no tempo em conexão com a primeira". Essa marca inicial estará presente em todas as suas ações na vida. A aprendizagem não está predeterminada, mas será regida a partir dessa inscrição primordial e para fazer os deslocamentos dessa marca terá que "desenvolver as estruturas mentais" (KUPFER, 2001, p. 108).

As crianças com problemas graves na constituição subjetiva, que mostram condições para aprender, embora com dificuldades, apresentam um desenvolvimento psicomotor e cognitivo atípico, pois parecem ter adquirido competências em determinadas áreas cognitivas e em outras não. Muitas vezes são confundidas com deficientes mentais. Vejamos como se organizam mentalmente e como aprendem para que os educadores tenham subsídios para organizar o trabalho escolar junto a elas.

É evidente que as falhas na estruturação subjetiva têm conseqüências para o desenvolvimento das estruturas cognitivas e para a aprendizagem, pois estas estruturas e o próprio processo de construção delas levam a formas peculiares de funcionamento e organização que afetam a aprendizagem. 
Na experiência de Filidoro (1997), algumas regularidades nesse processo podem ser descritas em relação às crianças psicóticas, como o fato de chegarem a constituir estruturas mentais de modo a alcançar o nível das operações concretas. Atingem as operações lógicas, porém de modo incompleto. A autora nunca constatou que jovens atingissem o nível do pensamento formal pela impossibilidade de generalização que apresentam. Conseguem atingir o nível pré-operatório da classificação e seriação, mas têm muitas dificuldades para construir as noções de conservação, identidade e permanência de objeto, construções essas que ficam comprometidas pelas falhas na constituição do "eu" e da subjetividade. Filidoro (1997) indica ainda falhas em três dimensões da cognição: na estrutura, no funcionamento mental e nos procedimentos para solução de problemas.

$\mathrm{Na}$ dimensão da estrutura do pensamento nas crianças psicóticas que revelam a dificuldade de construção de certa estabilidade do mundo há três fatores contingentes:

(...) os esquemas de ação ou representativos perdem sua função estruturante - a de atribuir significações à realidade a partir do jogo entre assimilação e acomodação; os esquemas coordenam-se com muita dificuldade ou não conseguem coordenar-se com outros esquemas; produzem-se falhas nos processos de integração de esquemas (FILIDORO, 1997, p. 124).

Há também falhas no funcionamento mental que se caracterizam pela seguinte dinâmica:

(...) 1) defeitos nas formas de equilibração: assimilação dos objetos aos esquemas e acomodação destes aos objetos - assimilação e acomodação recíproca entre sub-sistemas - assimilação de um subsistema a uma totalidade (integração) e acomodação desta ao subsistema (diferenciação); 2) as perturbações não operam provocando desequilíbrios e/ou os desequilíbrios não são fonte de regulações e compensações (Ibid., p. 130-132).

E por fim, as falhas de procedimentos e estratégias:

(...) as ações se encadeiam de próximo a próximo (...) conhece a seqüência dos passos, mas perde vista a finalidade; o procedimento ocupa o lugar do fim; produzem-se falhas nos encadeamentos temporais (Ibid., p. 134-135). 
Os professores precisam conhecer em cada criança como ela está nessas formas de organização e funcionamento cognitivo: como pensa, como propõe resolver os problemas que se apresentam, quais são suas hipóteses sobre os objetos de conhecimento. Aproximar-se da criança para conhecer seu modo próprio de aprender ou não aprender. Conhecer seu estilo cognitivo.

Para entendermos de que se trata o estilo cognitivo, Kupfer (2001) retoma o pensamento de Lacan sobre o termo estilo como "a marca de um sujeito em sua singular maneira de enfrentar a impossibilidade de ser"; é do sujeito "a marca do seu desejo"; o modo de "obturação da falta no Outro" (p. 129) resultando nas estruturas da neurose, psicose e perversão E sobre estilo cognitivo:

(...) a peculiar relação de um sujeito com um particular objeto, o conhecimento.Tal relação trará as marcas de seu estilo como sujeito na relação com o Outro. Tal estilo se construirá nos sucessivos encontros com os objetos de conhecimento, moldando os próprios objetos e determinando, no mesmo processo, os padrões de relação com os outros encarregados de apresentar esses objetos, ou seja, seus mestres (KUPFER, 2001, p. 129).

Kupfer (2001) concorda com as colocações de Filidoro sobre as falhas na estrutura e no funcionamento cognitivo dos psicóticos, apenas salienta que vemos também crianças psicóticas que mostram um funcionamento cognitivo adequado e, às vezes, superior. Portanto, não devemos generalizar as condições acima para todas as crianças psicóticas, embora uma grande parte delas mostre essa forma de funcionamento cognitivo na tentativa de construir algum conhecimento sobre a lógica existente no mundo.

Encontramos psicóticos que, para "defender o sistema de pensamento das invasões devastadoras do real"18, estão sempre fazendo coisas que os identifique, e outros que alimentam a capacidade de raciocínio lógico, criando assim um sistema fechado de pensamento, que possa gerar alguma metáfora de sustentação simbólica, substituindo parcialmente o significante Nome-do-Pai, permitindo algum nível de circulação social (JERUSALINSKY, 1997, p. 85-86).

\footnotetext{
${ }^{18}$ Para Lacan o registro do real é distinto da realidade material, concreta, diz respeito ao real do inconsciente, o qual não é passível de apreensão direta, mas somente por meio do simbólico (Cf. MRECH, 1999)
} 
Para Jerusalinky (1997), os psicóticos podem mostrar inteligência, mas "morrem na praia" porque não conseguem entrar no simbólico ${ }^{19}$, ou seja, na cadeia de significantes - na articulação entre eles, mais que ser capaz de uma significação fixa para cada significante em particular.

Outra característica do modo próprio do psicótico em relação ao conhecimento diz respeito ao que Freud tratou sobre a curiosidade, dizendo que o que a incita como necessidade de conhecer é uma curiosidade anterior: a curiosidade sexual que em última instância é perguntar/saber sobre a cena primária, sobre a cena da relação sexual que deu origem à vida. Ao psicótico falta essa curiosidade primordial, mas é possível "promover curiosidades parciais, fragmentárias" que permitam a essa criança que se constituiu como sujeito, mas que está fora do simbólico, aprender coisas. Esse "conhecimento" tem alcance restrito, pois não pode ser generalizado, mas é uma forma de administrar as coisas do mundo. São pontos de referência, uma série de significações construídas para poder interpretar situações, ainda que de extensão limitada. Assim, o educador deve saber dessa dinâmica de funcionamento cognitivo nos psicóticos para estar sempre engendrando metáforas de ordenamento do mundo (JERUSALINSKY, 1997, p. 86).

Para a criança autista, o que se pode dizer sobre seu funcionamento mental e sua estrutura cognitiva?

Cremos que pouco ainda se sabe sobre as formas enigmáticas de expressão dos autistas. Encontramos aqueles como que apagados para a vida, encerrados em um mundo de estereotipias e sem linguagem, como também são conhecidos os casos descritos na literatura psiquiátrica como autistas de "bom rendimento", ou seja, aqueles com linguagem e inteligência. Uma inteligência centrada, em geral, em um único objeto de conhecimento como são os casos de autistas com excelente memória para decorar a lista telefônica, mas que não se estende a outras áreas e tampouco flexibiliza o pensamento dentro dessa mesma área: os números, no caso do exemplo citado.

\footnotetext{
${ }^{19}$ O termo 'simbólico', um dos registros do aparelho psíquico, é usado por Lacan em duas direções diferentes e complementares: a) para designar uma estrutura cujos elementos discretos funcionam como significantes ou, de um modo mais geral, o registro a que pertencem tais estruturas (a ordem simbólica); b) para designar a lei que fundamenta esta ordem: assim Lacan, pela expressão pai simbólico ou Nome-do-Pai, tem em vista uma instância que não é redutível às metamorfoses do pai real ou imaginário que promulga a lei (...) o significante lingüístico tomado isoladamente não possui qualquer ligação interna com o significado; não remete para uma significação senão por estar integrado num sistema significante caracterizado por oposições diferenciais" (LAPLANCHE e PONTALIS, 1985, p. 624-625).

O símbolo para Lacan é compreendido como significante (KAUFMANN, 1996, p. 476).
} 
Shichida (1993 apud KUPFER, 2001) descreve um modo de funcionamento mental do autista com predominância do hemisfério direito do cérebro, o que define um funcionamento sintético, global e não analítico. As crianças têm esse sistema no início da vida e depois fazem uma passagem para o hemisfério esquerdo, coisa que o autista, supostamente para a neurologia, não faria. Esse modo de funcionamento permitiria habilidades impressionantes, porém Kupfer (2001) posiciona essa expressão chamada de inteligência como “desvitalizada”, dessubjetivada, sem sentido e inócua na produção do laço social.

O que os autores apontam sobre a (des) organização cognitiva das crianças psicóticas e autistas corrobora com nossas vivências com crianças cegas com problemas na constituição subjetiva que apresentam problemas no desenvolvimento cognitivo.

\section{CEGUEIRA E COMPROMETIMENTOS NA CONSTITUIÇÃO SUBJETIVA E NO DESENVOLVIMENTO}

A especificidade da cegueira na apreensão do mundo e a singularidade das relações estabelecidas entre mãe e filho são nossos pontos de referência neste trabalho. A ausência da visão, como já mencionamos, define para a criança uma forma peculiar de apreensão do mundo que regerá seu desenvolvimento, mas não sua constituição subjetiva. Esta dependerá da maneira como sua mãe conseguirá ou não reconhecê-la como um filho além de sua deficiência.

Retomemos, então, a questão colocada: "de que maneira as relações primitivas ficam afetadas pela presença da cegueira na sua dimensão psicossocial (no sentido de que a subjetividade é forjada no social pelo Outro encarnado no adulto, em geral a mãe) podendo impedir o acesso da criança a simbólico e, portanto, à sua constituição de sujeito, levando-a a um desenvolvimento global prejudicado?"

Para abordar essa questão é fundamental lembrar que as trocas humanas primitivas ficam dificultadas para a mãe quando nasce seu bebê cego. Este impacto pode tolher o contato e o diálogo mãe-bebê provocando a falta da presença que sustenta a criança neste momento e isso pode retardar suas impressões e expressões do/no mundo, comprometendo o acesso às representações deste no plano psíquico. Vimos que se engendra aí um imaginário acerca da cegueira e a vivência da perda do filho idealizado que não permitem que a mãe veja e faça o 
essencial: deseje esse filho e refaça seu sonho. Algumas mães sucumbem e ficam paralisadas não conseguindo ensejar para seus bebês cegos um mundo de significações.

Mesmo não sendo pela cegueira ou não tendo lesões neurológicas que dificultem a apreensão do mundo e respostas a ele, embora muitas patologias que causam a cegueira possam deixar outras seqüelas, estamos diante de dificuldades da mãe para sustentar uma posição que marque essa criança na rede simbólica e possibilite ao sujeito constituir-se. A cegueira em si, organicamente falando, não representa impossibilidade na estruturação do psiquismo, mas a não subjetivação de algumas crianças cegas passam pelo significado que assume na fantasmática de cada mãe e em que medida e de que forma elas vão poder olhar ou não para seu bebê; permitir ou não a realização da função paterna; lidar ou não com seus fantasmas. Lembremos que o sujeito é feito daquilo que "o desejo e o discurso dos outros recortam historicamente no seio de uma cultura e inscrevem num organismo mais ou menos maltratado" (Cf. SAAL e BRAUNSTEIN, 1980; JERUSALINSKY, 1988 apud LAJONQUIÈRE, 1994, p.319).

Além disso a mãe necessita perceber qual é a maneira que seu bebê irá conhecer o mundo e se relacionar com ele, pois a cegueira indica caminhos perceptuais distintos na organização mental e instrumental para sua ação na vida. A maneira pela qual essa criança e seus pais vão enfrentar, de um modo absolutamente particular, sua realidade de estar no mundo sem a visão marcará a singularidade da estruturação subjetiva. O sujeito advém pelo discurso dos pais e para que este opere "depende em parte da permeabilidade que o constitucional e o maturativo lhe ofereçam desde o plano biológico" (Cf. JERUSALINSKY, 1989).

Não propomos neste trabalho tratar a relação da cegueira com o autismo ou a psicose, pois que tal diagnóstico entre as crianças sempre foi difícil, não menos que para as outras crianças certamente, mas esse diagnóstico, por sua imprecisão na infância e, pela especificidade da cegueira, é temerário, se podemos dizer assim. O rastreamento da literatura especializada feita nesta pesquisa mostrou ausência de estudos sobre as diferenças de quadros de autismo e psicose associados à cegueira.

Não descartamos a importância do diagnóstico diferencial na condução dos tratamentos, porém estes não devem reforçar a cristalização da criança na posição de incapacidade e nulidade que ela já se encontra. $\mathrm{O}$ dispositivo analítico propõe tirar a criança desse engessamento que muitas vezes o diagnóstico impõe quando leva em conta somente o 
orgânico e caractereológico que acabam por justificar as práticas de treinamentos e adaptações sem levar em conta o sujeito.

A discussão sobre os distúrbios sempre esteve atrelada a uma separação artificial entre os fatores orgânicos e psíquicos, o que dificulta em muito a sua compreensão. Julgamos ter ultrapassado essa dicotomia assumindo que os transtornos graves de desenvolvimento e de constituição subjetiva resultam de uma complexa interação entre a vida do organismo e a social na fundação do sujeito.

Na proposição de Kupfer (1997) de que há graves distúrbios no desenvolvimento de algumas crianças "portadoras de deficiências para quem tais falhas simbólicas acabam por se instalar ${ }^{20}$, encontramos subsídios para fundamentação deste estudo: a criança cega congênita com problemas graves na constituição subjetiva e no desenvolvimento. Procuraremos nos remeter às condições nas quais as crianças cegas ficam expostas às dificuldades que os pais enfrentam na relação, como já mencionamos aqui.

Focalizar a criança cega com traços autistas ou psicóticos na perspectiva dos problemas graves na constituição subjetiva descortina horizontes de possibilidades - ao centrar a questão na singularidade e não na generalidade -, pois não a aprisiona em um diagnóstico fechado de autismo ou psicose.

Vimos no capítulo anterior como comparece o corpo na constituição do sujeito e também a função da metáfora do espelho. Aqui vamos ressaltar apenas que os comprometimentos do organismo - síndromes, deficiências físicas, sensoriais, mentais e as múltiplas deficiências - muitas vezes podem afetar gravemente tanto o desenvolvimento como a constituição do sujeito do desejo.

Nesse sentido concordamos com a visão dos psicanalistas que consideram que, nesses casos, o corpo físico não é a causa, mas o limite e também aquele que desencadeia a fantasmática da criança e dos pais, recaindo sobre a especularização (a formação da imagem corporal e a formação do eu especular) e produzindo falhas que são responsáveis pelos traços autistas, por exemplo.

O que afirmamos anteriormente sobre a função materna ser dada pelo desejo instituindo que ali tem uma criança - um sujeito que será assim-assim, que parecerá com tal pessoa, que fará os pais felizes, que veio na hora certa ou que não deveria ter vindo - mostra

\footnotetext{
${ }^{20}$ Itálico nosso
} 
que há um imaginário que atua e quando isso não pode marcar um bebê, introduzindo-o na linguagem, então nem um corpo são poderá abrigar um sujeito.

Vemos que para as mães de crianças com deficiência a dificuldade de reconhecê-las como filhos e reconhecer-se nelas, poderá levá-las a não exercer a função materna e o encontro mãe-bebê ficar prejudicado. Assim, um corpo "lesado" provocará dificuldades para a mãe se relacionar com ele. Isso vemos na relação de algumas mães de algumas crianças cegas.

À indagação "se os quadros de psicose e autismo na infância se assemelham àqueles apresentados por algumas crianças cegas, pois sempre os temos qualificado como traços de autismo ou psicose", poderemos apenas fazer referência a eles naquilo que se aproximam desses quadros ficando marcados como traços do fantasmagórico que impedem a constituição do sujeito.

Chamam atenção dados estatísticos americanos mencionados por Kupfer (2000) que indicam que a maior incidência de autismo infantil precoce é dada por aquelas crianças que apresentam os ditos traços autistas associados a outras patologias, o que reitera que a relação mãe-bebê na presença de uma deficiência da criança está sujeita a dificuldades. E ainda segundo a autora o mesmo se dá na psicose infantil, pois, para as crianças com deficiência, o estádio do espelho não se estruturou de modo adequado.

Façamos aqui um parêntesis para outro dado que Kupfer (2000) relata sobre uma categoria usada por Kanner (1997) denominada pós-autistas para indicar aqueles que conseguem uma saída, passando a estabelecer relação com um outro. Isso importa muito, uma vez que estamos falando de problemas que algumas crianças cegas apresentam quanto à sua constituição subjetiva e a possibilidade de seu resgate na via de sua inclusão educacional e escolar em um trabalho com pais e professores.

A Psicanálise, quando questiona a insipiência da categoria "distúrbios globais de desenvolvimento" para dizer da criança que não se constitui como sujeito ou tem falhas nesse processo, resgata-nos da querela dos diagnósticos e das sutilezas do debate.

Referimo-nos aos quadros de psicose e autismo para mostrar que existem falhas na constituição subjetiva que são assim denominadas. Tendo claras as definições de psicose e autismo elas poderão auxiliar nossa compreensão dos traços apresentados por algumas crianças cegas comprometidas na constituição subjetiva, identificando de que ordem são e que estrutura clínica os caracterizam. 
Assumimos, portanto, que há impasses na constituição subjetiva de algumas crianças cegas. Algo que está além da cegueira e que nos surpreende quando vemos que elas não brincam e não se encontram com o outro como as outras crianças, cegas ou não, o fazem; crianças que têm dificuldades para se situar a respeito do desejo.

Enfatizamos que o diagnóstico diferencial é importante e que a interdisciplinaridade é o caminho para o tratamento e a escolarização. Nesse sentido, Kupfer (2000) nos encoraja e nos faz ver que não estamos sós na construção desse trabalho. Ela indica que estudiosos vêm propondo uma outra abordagem de diagnóstico. Nesta, a pergunta a ser feita pelos psicanalistas e educadores não é pelas falhas orgânicas ou psicogênicas, mas "pela posição do sujeito no enodamento do simbólico, do imaginário e do real”. A pergunta à criança será, então, "por sua posição subjetiva diante do Outro" (Ibid., p. 17).

Dessa forma, diz a autora sobre os termos psicose e autismo, o que podemos adotar em relação às crianças cegas com falhas na constituição da subjetividade:

(...) ao invés de psicóticos (...) crianças postas em variadas posições, cujo eixo comum é uma falha no registro simbólico, ou seja, o Outro não se estruturou como barrado, o que resulta em uma variedade de manifestações fenomênicas. Ao invés de autistas (...) crianças para as quais é o registro do imaginário que não se estruturou de modo conveniente, provocando igualmente uma grande gama de manifestações "subjetivas". (...) no tratamento das falhas do imaginário, uma atenção à construção da imagem corporal. Nas falhas do simbólico, um reordenamento da relação da criança com o Outro para barrá-lo, ainda que de modo ortopédico (KUPFER, 2000, p. 17).

Este capítulo fez uma articulação dos fundamentos e definições acerca de cegueira e "distúrbios globais do desenvolvimento", assumindo o aporte teórico da Psicanálise na discussão das especificidades da criança que nasce cega em sua constituição de sujeito e em seu desenvolvimento.

No capítulo que segue, discutiremos, especificamente, a inclusão educacional e escolar da criança cega com problemas na constituição subjetiva e no desenvolvimento, propondo a construção de um trabalho entre Psicanálise e Educação. 


\section{CAPÍTULO III - CONSTRUINDO UM ESPAÇO DE TRABALHO DA PSICANÁLISE COM A EDUCAÇÃO: A INCLUSÃO EDUCACIONAL E ESCOLAR DAS CRIANÇAS CEGAS CONGÊNITAS COM COMPROMETIMENTOS NA CONSTITUIÇÃO SUBJETIVA E NO DESENVOLVIMENTO}

O foco deste capítulo provém de um duplo recorte do cenário amplo da inclusão social: o primeiro que se restringe à inclusão educacional e escolar; o segundo à inclusão educacional e escolar da criança cega comprometida na sua constituição de sujeito e no seu desenvolvimento global. Para desenvolvê-lo, apresentamos os conceitos fundamentais do referencial psicanalítico, incluindo aqueles que permeiam o universo educacional, para refletir sobre as implicações da Psicanálise para a Educação e os caminhos possíveis de encontro entre essas disciplinas.

Como diz Kupfer (2001), historicamente, o trabalho com a criança com graves distúrbios de desenvolvimento (incluindo aquelas com deficiência) sempre implicou tratamento e educação. Por esse motivo, nos capítulos I e II abordamos a questão da deficiência e da inclusão educacional e escolar com base nos referenciais da Educação Especial e da Medicina e também introduzimos a questão da constituição subjetiva no aporte teórico da Psicanálise para fazer uma leitura da cegueira associada aos transtornos de desenvolvimento.

No presente capítulo, portanto, focalizamos a proposta da interdisciplinaridade no contexto educacional propondo a contribuição do referencial psicanalítico na reflexão sobre as questões apontadas pela inclusão educacional e escolar e os significantes implicados nela: criança - escola - educar - família - educação inclusiva. Para isso vamos demarcar esse referencial teórico e prático no encontro com a Educação.

A Psicanálise, concebendo o homem como um ser que se tece no social, na cultura e na história, no diálogo com a Educação tem como principal contribuição caracterizar-se como um corpo de conhecimento sobre o não observável - o saber inconsciente - e não buscar na razão o sujeito, mas no campo da linguagem e do sentido. No que diz respeito às crianças com problemas no desenvolvimento, busca identificar o curto circuito que ocorreu na constituição subjetiva dificultando sua entrada na ordem simbólica, não permitindo o estabelecimento do laço social.

Sobre a expressão laço social explica Lajonquière (1997): 
Entre o adulto e a criança medeia um fragmento cultural (...) Quando ensinamos algo para uma criança (...) há o desejo do adulto e transmite-se uma lógica operativa (...) de um pedaço da cultura, um universal, um fragmento de liame social. (...) À medida que a criança "apre(e)nde" a amostra de laço, faz laço. (...) O que enlaça é o desejo do adulto, em posição de educador, mas também o próprio fragmento interativo transmitido. $\mathrm{O}$ que se transmite? Uma forma de colher batatas, de lavar a louça, de brincar (...) É como se se dissesse: "você não faz assim porque eu quero, você faz assim porque é dessa forma que todos devemos fazer se quisermos manter vivo esse pedaço de cultura" (LAJONQUIÈRE, 1997, p. 126).

$\mathrm{Na}$ transmissão da cultura, portanto, constroem-se as identidades, os seres semelhantes (não iguais), que trocam o mesmo universo como seres tornados humanos.

Neste trabalho, a Psicanálise se alia à Educação buscando pensar formas de educar essas crianças que ainda não se constituíram na sua subjetividade. Mas são crianças capazes de aprender e por isso elas devem ir à escola, a qual, com todos os dispositivos da cultura, poderá significar a possibilidade de construir ou resgatar o que falhou anteriormente: o chamado laço social.

Nessa perspectiva da relevância da escola para essas crianças e de uma educação orientada pela Psicanálise, é importante citar Kupfer (2001) quando defende que:

(...) preconizar a ida à escola (...) é mais que atender a um mandamento político que reza sobre os direitos do cidadão. Mais do que um exercício de cidadania, ir à escola (...) tem valor terapêutico. Ou seja, a escola pode contribuir para a retomada ou a reordenação da estruturação perdida do sujeito. Este alvo, que não consta da política inclusiva, é o diferencial presente no eixo da inclusão atravessado pela Psicanálise (Ibid., p. 96).

A inclusão educacional e escolar orientada pelo referencial da Psicanálise significa uma educação centrada no sujeito. Seus conceitos, assim como os significantes criançaescola-família-educar-educação inclusiva, precisam ser bem assimilados e explicitados para poderem ser compartilhados com os educadores. 


\section{CONCEITOS FUNDAMENTAIS DO REFERENCIAL PSICANALÍTICO}

Alguns conceitos na Psicanálise são fundamentais para a compreensão da estruturação psíquica. São eles: inconsciente - sujeito - Outro - desejo. Sujeito diz respeito ao inconsciente - a realidade psíquica que importa para dizer a verdade do sujeito. Não corresponde ao ego consciente mediador da realidade, nem à razão cartesiana que encerra aí a existência humana, nem ao organismo piagetiano. Sujeito é o sujeito do inconsciente, está além do ego e constitui-se na linguagem e por ela.

Quanto ao inconsciente, assim o define Lacan (1985):

O inconsciente são os efeitos da fala sobre o sujeito, é a dimensão em que o sujeito se determina no desenvolvimento dos efeitos da fala, em consequiência de que, o inconsciente é estruturado como linguagem (Ibid., p.142).

E sobre como o inconsciente se mostra:

(...) no sonho, no ato falho, no chiste (...) chama a atenção o modo de tropeço pelo qual eles aparecem. Tropeço, desfalecimento, rachadura. Numa frase pronunciada, escrita, alguma coisa se estatela. (...) Ali, alguma coisa quer se realizar - algo que aparece como intencional, certamente, mas de uma estranha temporalidade. (...) a surpresa (...) um achado (...) e uma vez que se apresenta é um reachado, e mais ainda, está prestes a escapar de novo (...) (Ibid., p. 30).

Articulando a noção de inconsciente, Bastos (2003) traduz as idéias de Lacan do seguinte modo:

(...) o saber independente do "Eu sei" (...) uma cadeia de significantes que se repete e insiste (...) é a estrutura da linguagem que incide sobre o sujeito e age à revelia da consciência. $\mathrm{O}$ sujeito do inconsciente fala e não sabe o que diz, pois há algo que se tece pelas palavras, além delas. (...) o inconsciente também é o discurso do Outro. Entre o eu e o outro (o semelhante) aparecerá o Outro, compreendido como o lugar da linguagem e do significante. Para além da relação imaginária entre o eu e o outro existe a relação simbólica e inconsciente entre o sujeito e o Outro (Ibid., p. 114-15). 
Para a Psicanálise a linguagem e a fala são os elementos primordiais constitutivos do sujeito. Este é enredado na cadeia de significantes. E a própria noção de inconsciente na leitura lacaniana é de que ele é estruturado como linguagem. Essa formulação desmitifica o conceito popular, e até de algumas abordagens psicológicas, de que o inconsciente é uma "caixa preta" na qual as "experiências traumáticas" ficaram guardadas intactas podendo ser acessadas por um processo terapêutico de "regressão". Expressões que ficaram populares certamente, mas que encobrem o conceito. $\mathrm{O}$ inconsciente não é individual, ele se constitui na história social do sujeito e, portanto, o transpassa. História forjada por uma infinidade de discursos e laços que produzem o sujeito. Como explica Calligaris $(1992 ; 1993)$ pautando-se na visão lacaniana, o inconsciente é:

(...) trans-subjetivo, ou seja, é a rede dos laços de linguagem e os discursos que nos organizam e pelos quais somos produzidos como sujeitos. A cena analítica, o consultório de um analista, é um lugar povoado por uma multidão indefinida. Desde que o sujeito fala, articula-se uma rede que se estende indefinidamente, da qual ele é feito (Ibid., p. 16).

Lacan subverte também a noção de linguagem, entendendo-a como "a trama mesma de que é feito o sujeito" na cultura pelos efeitos de fala na rede de significantes e de sentidos, e não como instrumento de comunicação.

Nessa noção de constituição do sujeito estão imbricados dois outros conceitos importantes: o (grande) Outro e o Desejo. O primeiro indica o lugar da linguagem, "o lugar em que se situa a cadeia do significante que comanda tudo que vai poder presentificar-se do sujeito, é o campo desse vivo onde o sujeito tem que aparecer" (LACAN, 1985, p.194). O Outro para o sujeito é um efeito dos significantes veiculados na estrutura familiar e na sociedade e cultura na qual está inserido. Não é uma entidade concreta (o Pai ou a Mãe). "O que há são os significantes que tecem as existências paterna e materna através das cadeias de significantes" (MRECH, 1999, p.77).

Reiterando o que ficou dito, o sujeito vai se fazendo, se constituindo, se estruturando psiquicamente na relação com o Outro, mais especificamente na "dependência daquilo que o Outro venha a simbolizar para o recém-nascido desvalido em sua capacidade de simbolizar" (KUPFER, 2001, p. 124). Outro que, desejante da criança, a faz ocupar um lugar em sua rede de significações importantes para si. 
O desejo, constituinte e estruturante do sujeito, é de início desejo do Outro. É algo que falta no Outro e também é efeito da linguagem. Se falta, então o desejo é sempre desejo de outra coisa, instaurando no sujeito um movimento de busca. Essa busca é de sentido, sentido este que é procurado de um significante a outro.

Para que o sujeito se constitua e vá se estruturando, é preciso haver o desejo do Outro sobre ele para que depois passe a desejar. O Outro demanda algo que deverá a princípio fazer com que a criança se coloque à disposição como objeto para poder saber sobre o desejo do Outro e também sobre um lugar possível para si. O que o Outro, encarnado no adulto, demanda e oferta da cultura e de suas representações fantasmáticas imprimirá na criança marcas dessa história às quais ela se alienará para ter seu lugar no mundo e tornar-se um semelhante. Mas, ao saber do desejo e da falta no Outro que lhe demandará sempre o que ele não poderá cumprir totalmente, ou estará perdido, irá defender-se de permanecer grudado no adulto para ser ele também um sujeito de desejo. Como atende parcialmente à demanda, sobra algo que marcará sua diferença.

Portanto, para se constituir como sujeito, para ter um lugar no mundo, o recém-nascido depende do desejo do Outro. Ou seja, o organismo tem que subjetivar-se (fazer advir um sujeito), entrar na rede do desejo. Assim o sujeito - para a Psicanálise sempre sujeito do inconsciente - se constitui.

Nas teorias psicológicas que implicam uma perspectiva dialética, como as de Wallon e Vygotsky, ao considerar a interação entre os aspectos biológico e social na construção da afetividade e da inteligência, o desenvolvimento é concebido como um modelo universal, dependente da maturação do organismo e que segue etapas previstas para a evolução da consciência na diferenciação cada vez mais apurada da relação eu-outro.

O ponto de vista psicanalítico implica uma concepção que é da ordem de algo estruturante dado pelo modo como a criança foi olhada, pensada, percebida, sentida, imaginada, fantasiada, aceita, recusada e o que foi dito sobre ela, ou seja, a partir da relação do sujeito com o Outro. A constituição diz respeito a um momento em que algo se marca, se inscreve e funda o sujeito posicionando-o na rede simbólica.

Assim, vimos a distinção entre desenvolvimento e constituição: o organismo se desenvolve, amadurece, cresce, se constrói. O sujeito não se desenvolve, mas se constitui, se estrutura. E a infância, como explica Levin (1996): 
(...) transita por esse inefável caminho onde o enodamento (tichè) entre a constituição subjetiva e o desenvolvimento psicomotor marca um trajeto balizado por particularidades, onde o sujeito infantil toma a palavra e se apropria de seu corpo. Consideramos que é "em" e "por" estes pontos de encontro entre estrutura e desenvolvimento que a clínica interdisciplinar tem sua origem e sua fundamentação em nosso campo de trabalho (LEVIN, 1996, p. 20).

\section{SIGNIFICANTES QUE PERMEIAM A EDUCAÇÃo NA PERSPECTIVA DA PSICANÁLISE:CRIANÇA, ESCOLA, EDUCAÇÃO, FAMÍLIA E DEFICIÊNCIA}

Antes de passarmos à referência psicanalítica de alguns significantes engendrados na concepção de educação é importante situar suas dimensões histórica e social em nossa cultura ocidental.

Áries (1981), em sua obra "História social da criança e da família", expõe a tese de que o universo infantil nem sempre foi como o consideramos atualmente, ou seja, o conceito de infância é um conceito que surge com a Modernidade. Durante a Idade Média a criança era vista como um pequeno adulto e só era cuidada por um período bem curto no início da vida após o qual passava a viver entre os adultos da comunidade e em outros ambientes que não o da família em um processo de sociabilidade que ele define como aprendizagem do "saberfazer e do saber-viver" ( $\mathrm{p}$. XIV). A família não tinha, portanto, essa função e não se formava, a priori, por laços afetivos. Estes se davam fora dela, mas por razões de sobrevivência nas necessidades cotidianas, conservação dos bens e da honra. Descortina um tempo depois da Idade Média no qual se originaram comportamentos e estruturas institucionais com as quais lidamos hoje quando falamos de educação. Foi somente a partir do século XVII que a família passa a se organizar por vínculos afetivos de responsabilidade pela criança e preocupar-se com sua educação - transmissão de valores e conhecimentos - que será realizada, desde então, por uma instituição chamada escola. A criança sai do anonimato, constituindo-se como uma instância significativa e se define como criança a partir do momento de tutela estendida e condicionada ao período que irá à escola.

A criança, para a Psicanálise, está além do escolar, contudo optamos por fazer alusão a essa passagem histórica para introduzir o momento no qual o significante criança é criado pelo discurso dos tempos modernos, passando a introduzir significações antes não existentes. Do ponto de vista psicanalítico a criança é considerada não só objeto 'real', suporte biológico de um desenvolvimento, mas também produto de um discurso (Cf. LACCADÉ, 1998). É 
como dizer que ela é falada pelo Outro, é efeito do desejo do Outro. Vai se estruturar de acordo com disposições fantasmáticas inconscientes e se constituirá como sujeito desejante, se puder deixar de ser objeto da mãe e entrar para a linguagem. A criança está inserida na estrutura e discurso social da família que a recebe e é efeito desse discurso, inclusive bem antes de nascer. A criança freudiana, como resgata Kupfer (2001), é assujeitada ao inconsciente, é sexual e permanece no adulto pela vida afora. E o inconsciente freudiano, como a autora retoma, é social, é cultural. O sujeito nasce do Outro que é a cultura.

A criança está inserida na estrutura social da escola também, outro meio de educar além da família e, portanto, outro discurso social que também deve ser escutado ao falar da criança. A escola, reconhecida socialmente pela família no seu papel de educar, é vista pela Psicanálise lacaniana como um lugar social que veicula um discurso social que fala sobre a criança e a família e sobre sua concepção de educar. Por isso também precisa ser escutada.

Sobre a posição e valor da escola na sociedade, Jerusalinsky (1997) nos brinda com uma belíssima referência sobre escolas para psicóticos, autistas ou deficientes mentais que, quando saem à rua para atividades, encontram na vizinhança uma receptividade e abertura para comunicar-se com eles, e isso ele justifica da seguinte forma:

A circulação por pequenas lojas e "botecos", e até mesmo por prédios e casas de vizinhos vai se tornando lentamente viável. A conquista de uma certa popularidade aparece em nome do fato de que "eles são os da escola aqui do lado", e não há dúvida que as reações seriam muito diferentes se se tratasse de "os do manicômio"; o significante, como sempre, pode ser decisivo. Porque escola é coisa de criança, no final das contas se esses meninos e meninas têm problemas mas estão na escola, seus atos viram artes. Se gritam demais, se se aproximam demais, pulam demais, comem demais, põem a mão onde não devem, são simplesmente meninos e meninas, seguramente o são porque vão à escola. Quem sai do manicômio não tem esse benefício na leitura social (Ibid., p. 91).

Nossa experiência compartilha dessa convicção, pois quando vamos ao parque, ao teatro e ao museu, ou à praia e ao restaurante com as crianças e jovens cegos e com problemas graves no desenvolvimento, muitas vezes nos acompanhando também os pais, percebemos que opera uma transformação geral neles porque estão no mundo como todos. O mesmo ocorre com os pais que muitas vezes se admiram com nossa "coragem" de estar com eles na rua e se nós o fazemos, então eles também podem fazê-lo, e nas pessoas que passam e se aproximam para perguntar ou conversar. Assim, a escola para essas crianças e jovens se 
expande para fora dos seus muros na tarefa de educar. Reiteramos a citação acima que a comunicação começa a se tornar possível e possível é, portanto, o laço social. Para Kupfer (2001), na perspectiva lacaniana, o discurso é condição para o laço social, vinculando estruturalmente aquele que fala ao Outro e educar é “(...) a prática social discursiva responsável pela imersão da criança na linguagem, tornando-a capaz por sua vez de produzir discurso, ou seja, de dirigir-se ao outro fazendo com isso laço social" (Ibid., p. 35).

Assim, o significante educar ganha o estatuto de subjetivação, ou seja, de tornar o ser um sujeito de desejo. Nas palavras de Lajonquière (1997):

(...) educar é tornar o ser um semelhante enquanto humano, mas um diferente como subjetividade; reconhecer o outro como nóssemelhantes e, ao mesmo tempo, como outro singular, diferente. E a educação é a articulação desse paradoxo, iludindo-se com a crença de que pode formatar alguém e trabalhar na homogeneidade, enquadrando-o conforme um modelo proposto. "Entre nossos pais e nós, há algo que permanece, bem como outra coisa que difere" (Ibid., p.118).

A família, segundo Lacan (1984), deve ser vista pelas relações sociais que forja, pelo papel preponderante na transmissão cultural e por reger os processos mais significativos da constituição da vida psíquica por meio dos organizadores aos quais Lacan chama de complexos.

No ato de educar, portanto, família e escola são seus agentes, os representantes da cultura, responsáveis na possibilidade de inscrever a criança no mundo, de transmitir-lhe marcas e a demanda social além do desejo, via discurso social. O que se aprende na educação escolar e familiar é mais que a apropriação de conhecimentos utilitários acumulados pela humanidade sobre o mundo e sobre modos possíveis de viver: aprendem-se saberes existenciais (Cf. LAJONQUIÈRE, 1997). Mas por que é inerente à educação reinscrever a diferença que já se encontra na origem? Porque o sujeito do desejo, alienado no Outro no início, vai responder à falta de uma maneira própria; porque tudo o que se transmite no ato educativo é veiculado no interior da linguagem e esta, na transmissão, é modificada, uma parte se repete e outra se perde, sendo modificada. São esses os saberes que forjam a existência e por isso são singulares.

Mas a escola que temos, por sua tradição (psico) pedagógica, define educação como o desenvolvimento de capacidades referentes a cada faixa etária, processo dependente da 
maturação biológica e dos instrumentos metodológicos do ensino. Assim, a própria escola produz seus excluídos, pois não educa para a diferença e sim para o igual, o padrão.

Frente a essa construção teórica, retomando a criança que estudamos neste trabalho - a criança que não tem sua existência sustentada pela lógica do desejo como estruturante da vida psíquica - perguntamos: como o educador deverá posicionar-se frente a ela para a possibilidade dela fazer-se semelhante, reconhecendo-se no outro por portar uma marca de pertencimento, de filiação, de identificação e então saber-se diferente? Quem será esse educador? E como lidar com o saber inconsciente no contexto educacional?

\subsection{As implicações da Psicanálise para a Educação}

É lícito que se coloque a pergunta "o que tem a Psicanálise a contribuir com a prática educativa, uma vez que ela é um campo de saber orientado para a prática clínica?” Freud se preocupou desde muito cedo em sua obra com a questão da Educação. A princípio pensando que a educação poderia evitar as neuroses se não reprimisse a sexualidade, mas logo percebendo que isso seria uma tarefa impossível tanto para a Educação quanto para a Psicanálise, pois as neuroses fundam a subjetivação. Passa então a considerar a educação como a herança social passada de geração a geração com poder subjetivante.

Indubitavelmente, a descoberta da sexualidade infantil e do inconsciente -constitutivos do sujeito - e da existência de um saber inconsciente independente da consciência que não pode ser ignorado, revolucionou as concepções psicológicas de desenvolvimento que determinam à Educação um saber absoluto e universal sobre o sujeito aportado na consciência. A Psicanálise se volta fundamentalmente à realidade psíquica singular, à escuta dos discursos instaurados em cada sujeito. Este pensamento levado à Educação implica levar em conta cada um: cada aluno, cada professor, cada pai e cada mãe. Não havendo saber absoluto e um único caminho para a criança se desenvolver, o professor pode se permitir não saber e buscar saber, colocar questões, aprender a perceber as formações inconscientes responsabilizando-se assim pelo ato educativo.

A introdução desse campo de saber teórico e prático na Educação pode operar mudanças se esta se apropriar dele. E a Psicanálise, indo à escola e dialogando com ela, muda também, pois se põe na escuta dos discursos que circulam nesse campo social e, para servir ao educador, obriga-se a encontrar outras formas de atuação. 
Mannoni (1977), ao edificar o trabalho educativo com crianças com graves transtornos na constituição psíquica, que inspirou outras escolas, procurou restringir o ato analítico naquele contexto, mas a formação psicanalítica de seus profissionais e seu dispositivo fizeram mais, como ela mesma acabou mostrando em seus livros. Mais porque ela percebeu que o conhecimento psicanalítico poderia iluminar o que se dá como objeto da educação e cunhou a expressão "clareagem" para identificar essa possibilidade de usar seus dispositivos na situação e nos ambientes educativos. Mas como fazer isso? A transmissão da Psicanálise ao educador pode ser feita - se ele assim o desejar - pelo estudo. Este pode provocar mudanças se, em seu trabalho com a criança, sentir-se instigado a saber dela de sua posição no caminho da constituição de sujeito e seus entraves. Encontrará uma via para a educação na Psicanálise, se perguntar-se sobre a criança e sobre si mesmo. Se assim for, o conhecimento será capaz de alterar "sua posição subjetiva", bem como traçar caminhos que abram possibilidades de alteração na criança com problemas na subjetivação e no desenvolvimento (Cf. KUPFER, 2001).

Os indicadores psicanalíticos contribuem para uma nova leitura da segregação e da inclusão educacional e escolar de modo a pensar segregação como exclusão do lugar social, do lugar dos ideais da sociedade; e conseqüentemente inclusão como a escuta da verdade do sujeito e o espaço de sua palavra/gesto/existência nessa sociedade.

Enfim, se a Psicanálise pode iluminar a Educação, é porque visa ao sujeito, e pensamos que a verdadeira educação inclusiva vai nessa direção também.

Nesse sentido importa considerar ainda o seguinte: partimos de uma lei, de uma questão jurídica que põe a norma, o que é importante sem dúvida. Mas há um problema: a lei é homogeneizante. Avançamos muito na Educação Especial, ao considerarmos hoje não mais crianças deficientes, mas crianças com necessidades educativas especiais, mas como categoria, mais uma vez, pode ocultar a cada criança em particular. A questão da inclusão escolar, colocada na perspectiva jurídica, está preocupada com uma questão de direito e a trata de forma objetiva. A Educação, em conformidade com essa perspectiva, faz o mesmo: trata a todas as crianças com necessidades educativas especiais do mesmo modo, incluindo aquelas com necessidades específicas decorrentes da deficiência. O sistema escolar, jurídico e a própria expressão "necessidades educativas especiais" apontam somente para as necessidades e não consideram o desejo (na concepção psicanalítica). Sobre este ninguém se pergunta. A Psicanálise propõe a inclusão educacional e escolar sob a condição de que se trabalhe com a subjetividade, pois sobre a normalização todos querem saber, sobre a diferença 
não. Não querer saber da diferença e do particular exclui alunos e professores. Na realidade, não se quer saber do mal-estar. Nesse sentido, podemos pensar, por exemplo, que se os professores resistem, é porque também são tratados como objeto. E quando pedem capacitação, não necessariamente estão mostrando desejo de saber. Assim, pode-se cumprir a lei sem que nada de educativo aconteça (Cf. VOLTOLINI, 2004).

A lei garante uma parte, o restante está por fazer e ainda corremos o risco de cair em uma velha repetição que vem se apresentando como um sintoma da Educação Especial:

(...) o inevitável retorno do recalcado, ou seja, o retorno disfarçado daquilo do qual nada queremos saber, apesar de nossas boas intenções. Aquilo que, nesta história do ideário educativo especial, não cessa de (não) se escrever é a impossibilidade de reduzirmos o sujeito do desejo a um "ser mais ou menos deficiente", um "ser portador de deficiências" ou "com necessidades educativas especiais" ou, simplesmente, a uma "sigla" a ser mexida com maior ou menor força de vontade, sensibilidade e carinho. O desconhecimento dessa impossibilidade está precisamente em causa na expulsão de crianças, com nome e sobrenome, das escolas, pátios e parques da vida (LAJONQUIÈRE, 2001, p. 48).

\section{INTEGRAÇÃO / INCLUSÃO: CAMINHOS POSSÍVEIS NA ESCOLARIZAÇÃO DA CRIANÇA CEGA COM COMPROMETIMENTOS NA CONSTITUIÇÃO SUBJETIVA E NO DESENVOLVIMENTO}

Aqui centraremos nossa exposição na educação veiculada na escola.

Se assumimos os constructos da Psicanálise lacaniana em relação ao milagre do laço social que nos torna humanos, nos constitui como sujeitos no aprendizado das formas do saber fazer e existir transmitidas pela cultura - dependendo, claro, de como se desenrola a história das relações estabelecidas na família onde chegamos - acreditamos que a escola para as crianças com transtornos na subjetivação e problemas no desenvolvimento é fundamental, pois representa uma possibilidade importante na conquista de um espaço de educação.

Nesse sentido é importante que citemos algumas experiências de escolas e instituições especiais de atendimento a essas crianças, como a escola de Bonneuil, de Mannoni desde 1969 (França), a partir do trabalho de Françoise Dolto, de Psicanálise com crianças; o Le Courtil (Bélgica) e a Pré-Escola Terapêutica Lugar de Vida (Brasil) desde 1989. O que é 
comum a todas é que são trabalhos atravessados pela Psicanálise e buscam fazer-se "lugares de vida". Já que a única forma do ser humano se constituir como sujeito é estar verdadeiramente na vida, nessas instituições se aposta totalmente nisso: no simples que há no cotidiano e na ampliação desse universo como a forma de mergulho na cultura. Cada uma a seu modo, em seu contexto sócio-cultural e tempos distintos, com formulações da Psicanálise lacaniana, vão se construindo e se revendo diante do que apresentam as crianças que nelas chegam e de um social que se transforma.

São experiências profícuas do encontro da Psicanálise com a Educação Especial, porém no cenário da escola comum esses trabalhos são pouco ou nada conhecidos e poderiam servir de referência para a Educação Comum nos aspectos que apontamos.

No caso das crianças cegas também comprometidas no desenvolvimento com quadros que se assemelham ao autismo ou à psicose, há muitas já incluídas na escola comum, mas não há relatos publicados ou pesquisas que mostrem o processo de forma mais sistematizada na sua orientação psicanalítica.

O porquê de toda criança dever ir à escola, inclusive as crianças com deficiência e com problemas no desenvolvimento, já foi exaustivamente defendido pelo valor que essa instituição tem em nossa sociedade e seu peso na possibilidade de constituir sujeitos. Mas por que ir à escola comum?

Ainda que na escola especializada, a escolarização esteja garantida e a via da inclusão possa estar presente - dependendo de como se trabalha e se pensa o sujeito e a deficiência - a escola comum ampliaria, em tese, a possibilidade de fazer laço, ou seja, da relação com o outro diferente, onde poderia advir um novo discurso social que aponte para a diferença ao mesmo tempo que acolhe como semelhante.

A política sobre a inclusão escolar da criança com deficiência na escola comum discute os princípios do direito da pessoa no acesso ao ambiente escolar e centra as preocupações objetivas na necessidade das adaptações curriculares, seja naquilo que garante acesso ao currículo ou naquilo que dispõem sobre os elementos curriculares. Precisa olhar o sujeito, pois a escola ainda é o lugar da criança na nossa sociedade, o que lhe dá o status de criança, e como tal pode ter uma força enorme no resgate ou no reposicionamento das subjetividades.

Nesse sentido, acreditamos no trabalho da Psicanálise com a Educação em que pese ela poder iluminar esse campo escolar social e também de apoios ao desenvolvimento 
cognitivo. E como propõe Kupfer (2001), fundadora da Pré-escola Terapêutica Lugar de Vida, se o encontro da Psicanálise com a Educação Especial é possível, é hora de propormos esse enlace à Educação Geral.

A instituição citada acima já tem publicado suas experiências na inclusão das crianças psicóticas e autistas na escola comum. Dados empíricos de outras instituições, inclusive aquela na qual esta pesquisa se realizou, já mostram possibilidades de inclusão de crianças cegas com problemas de desenvolvimento na escola comum. Essas experiências nos têm mostrado benefícios significativos na convivência dessas crianças com aquelas ditas normais consideradas pela Psicanálise como de estrutura psíquica neurótica. Alguns motivos expostos por Jerusalinsky (1997), referindo-se às crianças psicóticas na escola comum, reiteram a constatação desses benefícios: a identificação, a apreensão do repertório do grupo ajudando na simbolização, brechas de comunicação, parâmetros, norma, lei, e poderíamos acrescentar: reconhecimento social e mudança no olhar dos pais, da família e da comunidade onde vivem as crianças. Não há ainda, contudo, pesquisas científicas para corroborar o que na prática cotidiana os profissionais da Educação Especial de atendimento a essas crianças têm observado.

Assim como têm sido constatadas experiências positivas na entrada das crianças cegas com dificuldades na constituição subjetiva na escola comum, pelos motivos já expostos, também testemunhamos casos de crianças que sofrem o isolamento, ficando segregadas dentro da escola comum, pois os professores não sabem o que fazer com elas na estrutura existente. Isso não raro se dá com formas perversas de mantê-la na escola: freqüência de uma ou duas vezes por semana, saída antes do período terminar, freqüentar apenas a sala de recursos, ficar na sala sem fazer nada, não participar das festas e das aulas de Educação Física e de Artes, entre outras

Obviamente não se pode generalizar a indicação da escola comum para todas as crianças cegas com comprometimentos sérios em seu desenvolvimento. Certamente não podemos fazer a indicação de qual escola é a mais adequada para as crianças de que tratamos aqui - a escola comum ou a especial - mas podemos pensar em alguns critérios que auxiliem essa escolha, tais como: estudar caso a caso para evitar o encaminhamento indiscriminado, levar em conta a "opção" - desejo/necessidade - dos pais, estudar junto com a família as necessidades e potencialidades da criança, conhecer as condições da escola e então propor um trabalho de parceria que envolva a todos: família, escola, instituição/profissionais especializados. 
Na prática, em nosso país, outros elementos dificultadores entram em questão para essa opção. Há fatores como o das escolas especiais não darem conta da demanda de atendimento existente, deixando as crianças fora da escola por falta de vagas; ou essas escolas serem inacessíveis economicamente à grande maioria das famílias; a quase inexistência de instituições que atendem vários comprometimentos associados, como por exemplo a criança cega com deficiência mental, a criança cega com paralisia cerebral, a criança cega com problemas graves na constituição subjetiva e no desenvolvimento (aquelas com traços autistas ou psicóticos). A escola comum e pública - em tese a escola para todos - por sua vez, também enfrenta dificuldades, como vimos. Permanece, então, o enorme desafio de propor criar condições na escola comum para algo relativo à educação no sentido que vimos tratando aqui. Não se trata de propor uma reforma geral da Educação no viés do conhecimento psicanalítico, trata-se do acompanhamento caso a caso, a pendulação entre o geral e o particular dentro da escola, a contribuição da visão psicanalítica de criança, educação, escola e diferença.

Entram em jogo as idéias de normal e anormal, do igual e diferente e do lidar com tais concepções na escola, assim como na família. O trabalho com a escola deverá percorrer um caminho que aponte para o tratamento da questão no sentido da diferença e não da menos valia, como desde sempre nos ensinou Amaral (1994). Para essas crianças, e para todas, precisamos de uma escola que mude a sua concepção de educação e que acolha as diferenças.

Também contribui para nossa reflexão sobre a educação inclusiva a concepção de diferença no sentido que Kupfer (2005) discute na perspectiva psicanalítica da constituição do sujeito, ou seja, que diferença "não é um desvio da norma, mas surge dela, emerge a partir da lei” (p. 20); nasce da igualdade (semelhança), portanto. Estar na escola comum é ser supostamente igual a todos por estar lá e, por isso, poder ser diferente, único. Trata-se do singular surgindo do universal. A diferença como singularidade desde a constituição do sujeito. Para a criança cega com problemas nessa constituição há dupla diferença: aquela dada pela norma que define o desvio e a dada pela busca de constituir-se sujeito. A inclusão educacional e escolar poderia vir a ser, então, uma possibilidade de ver o sujeito além da deficiência orgânica.

Voltando à escola inclusiva, o que pode ela aprender com as experiências que relatamos sobre o atendimento às crianças cegas com impedimentos na constituição de sujeitos? O que pode ajudar a escola comum a propor vivências escolares que possam ter efeitos subjetivantes? 
A princípio qualquer atividade corriqueira pode ter esse potencial, pois são atividades da cultura a qual pertencemos. As atividades corriqueiras na escola são aquelas da leitura e escrita, dos números, de todas as artes, das brincadeiras e dos jogos, das histórias/contos/fábulas/parlendas, das experiências das ciências da natureza, das festas e passeios, da higiene e alimentação, da religiosidade e formação social, enfim toda manifestação da tradição cultural. Porque todas essas produções estão repletas de temas da vida e sem dúvida falarão da criança e ela se reconhecerá. E de todas essas vivências surgirão brechas por onde o educador poderá entrar e se comunicar com ela e provocar-lhe momentos de entrada no universo simbólico, ajudando-a a organizar-se na linguagem. Que o professor saiba "aproveitar e tirar partido de tudo o que de insólito surja (esse insólito que, pelo contrário, tem-se o costume de reprimir)" (MANNONI, 1977, p. 79).

Nesse sentido voltemos ao que Mannoni (1977) postula: que sejam mergulhados na cultura e não que desenvolvam habilidades antes de viver a vida cotidiana na família, na escola, na comunidade. Porque essa é a forma de fazer o laço, pois, "à medida que a criança 'apre(e)nde' a amostra de laço transmitida, faz laço (...), pois joga com as regras da cultura" (LAJONQUIÈRE, 1997 p. 126). Se há regras é porque não se pode tudo, algo vai faltar, algo não pode ser todo, apenas mais um. Isso é o que a criança com problemas na subjetivação não está construindo. Em uma expressão de Cazenave (1992) citada no texto de Filidoro (2005), na escola é possível a subjetivação porque é uma instituição que se "sustenta na proibição que faz possível o desejo" (Ibid.), desde que cumpra seu papel de garantir as leis que regem as relações, de conter atos fora da norma significando-os.

Lembremos que as famílias dessas crianças, como os professores, também têm dificuldades no estabelecimento dessa relação, quando o papel do adulto é justamente o de representante da cultura, daquele que diz sim e não, deseja e desmente a demanda, garantindo assim a existência de um terceiro veiculado pelos fragmentos de cultura. "O adulto precisa manter a cena que encena um laço" (LAJONQUIÈRE, 1997, p. 128). Fazer de conta, inventar um sonho, um como se fosse; continuar, mesmo quando a criança sai de cena e resgatá-la para dar-lhe contorno, fazer sentido dentro do instituído, ajudando-a a compor o que ainda não sofreu um ordenamento simbólico.

É preciso deixar claro que quando dizemos é preciso que a escola... é preciso que a família... queremos dizer que um trabalho é possível ali onde as dificuldades surgem diante de uma criança que não enxerga e que além disso se expressa de forma incompreensível para os 
pais e professores. Sabemos quanto essas instituições estão fragilizadas e esgotadas no mundo hoje e não podemos dizer-lhes simplesmente o que e como devem fazer.

Além disso, a escola não pode assumir esse trabalho sozinha, pois apesar de ser poderosa na circulação dos discursos sociais dos quais a criança com transtornos graves na subjetivação vai pegar o que lhe for possível, terá que ter o suporte de profissionais especializados. Já nos referimos anteriormente à responsabilidade da equipe interdisciplinar que está na instituição especializada no trabalho conjunto com a escola e a família. São profissionais, incluindo os psicanalistas e outros de disciplinas diversas e os especialistas da Educação Especial das pessoas com cegueira, trabalhando na conduta ética de escutar esses educadores e seguir a entrada da criança na escola para ajudar a fazer uma inclusão responsável.

Diante das experiências que já começam a ser construídas, de modo favorável na inclusão da criança cega com problemas na constituição subjetiva na escola comum, podemos identificar que as escolas que mostram maior potencial terapêutico são aquelas que aceitam refletir sobre sua prática colocando-se questões-problemas. Uma das questões colocada como um impasse pelos professores e que os deixa angustiados é a de como estão essas crianças em relação à aprendizagem. Em outras palavras: podem elas aprender? E isso significa apre(e)nder o conhecimento formal que é dado na escola, ser capaz de assimilar o currículo definido para cada série.

Filidoro (2005) comenta a esse respeito que as intervenções dos professores sempre produzem efeitos que não podem controlar. Quando estão passando um conteúdo é de muitos outros conteúdos que se está tratando ao mesmo tempo: a transferência que está em jogo, o ideal do eu, as identificações. "Na cena didática, está posta em jogo outra cena que escapa a todo planejamento" (p. 3).

Confiamos que os professores se apropriem disso e saibam que seus atos podem operar mudanças no psiquismo, pois falamos de crianças e jovens e estes podem ter a chance de refazer caminhos que não foram feitos. Isso se propõe em uma análise, mas se propõe fundamentalmente nas redes sociais quando se lhes permite viver. O processo educativo, portanto, e as aprendizagens orientadas para a construção de conhecimentos e saberes podem ser estruturantes. Note-se que sempre frisamos a possibilidade (o pode ter ou pode ser), mas isso não significa que a escola não possa ser uma experiência desastrosa. Por isso o cuidado do acompanhamento da escola pela equipe interdisciplinar e pela família. 
É preciso trabalhar para que o educador e saiba pôr a lei, não deixar a criança fechada repetindo o mesmo indefinidamente de maneira estereotipada e aparentemente sem sentido, propor atividades produtivas e não reprodutivas sem consonância com a vida, ser capaz de supor uma criança e não um nada, que se pergunte pelo que a criança sabe e é capaz e pelo que interessa a ela, que se pergunte o porquê dessa maneira da criança estar no mundo sem que busque aprisioná-la no diagnóstico, pois nem tudo, ou muito pouco pode ser explicado somente por ele. E mais: que ele saiba montar cenas e atividades, vivências que vão outorgar sentido às repetições e falas aparentemente desconexas, que aprenda que no fazer coisas a criança vai procurar representar a si mesma, que seja capaz de questionar as verdades da pedagogia condutista e entender que educar é constituir sujeitos (Cf. FILIDORO, 2005).

O trabalho com uma criança que não têm dentro de si a instituição no sentido da proibição, que joga tudo ou grita o tempo todo, ou bate a cabeça na parede, ou soca quem se aproxima, ou tira a roupa, ou se balança obedecendo a um determinado ritmo, ou repete vezes sem fim a mesma pergunta ou uma vinheta ou slogan de um programa de tv, que ainda não usufrui o convívio social retornando a ele falas e atitudes incompreensíveis, enfim uma criança com comportamentos desviantes que não se submete à lei, não é mesmo fácil. É preciso que o professor saiba que tais comportamentos estereotipados e repetitivos nos quais ela está fixada não são simplesmente "birras", "agressividade", formas de "chamar a atenção" ou de "irritar" alguém, ou modos próprios de um determinado quadro clínico genérico. É preciso que ele conheça as especificidades de cada criança, seu estilo de aprendizagem, sua maneira própria de usufruir do laço social, sua forma de existência. Precisa compreender que educar essa criança é procurar torná-la sujeito e não adaptá-la à "normalidade". E precisa ser ajudado a saber da posição que cada criança ocupa na estrutura discursiva dos pais.

Colli (1997) nos inspira e reitera nossas convicções de que:

A escolarização dessas crianças precisa estar lastreada no desejo do professor pois este, ao apontar seu desejo para o aprendizado da criança, supõe nela um sujeito também desejante e, portanto, capaz de aprender. Desta suposição das subjetividades é que poderão surgir as curiosidades que abrirão acesso ao sujeito em aprendizagem (Ibid., p. 140).

Escutar o professor e não recriminá-lo, respeitando-o na sua forma de trabalhar e naquilo que acredita ser certo, poderá ajudá-lo a se comprometer "com seu desejo e com os 
destinos desta criança" (COLLI, 1997, p.143). Na situação educacional escolar nos havemos então com outros dois conceitos psicanalíticos que subvertem a linguagem da Psicologia: saber e transferência.

O saber, assim como suas imagens e símbolos, de que fala a Psicanálise não é o conhecimento e não é uma entidade asséptica, isenta das relações que o tecem, mas é investido de energia psíquica, o que significa dizer que é erotizado e que, portanto, se encontra vinculado às cadeias de gozo. $\mathrm{O}$ conceito de gozo, no sentido lacaniano, diz respeito à modalidade de funcionamento psíquico do sujeito. Explicando melhor:

(...) não é o gozo do prazer que se obtém através do orgasmo (sentido tradicional da cultura). É o gozo obtido através da linguagem e da palavra. O gozo é uma outra satisfação... obtida através do inconsciente... da linguagem e da fala, frente a algo onde o sujeito não deveria estar sentindo prazer. É por isso que Lacan fala de uma outra satisfação... que não serve para nada, mas que mantém o sujeito atado às suas cadeias. Onde o sujeito goza, goza, sem parar. Um prazer inconsciente que emerge na manutenção da inércia. Um prazer inconsciente que se encontra vinculado à libido fixada, fazendo com que o sujeito repita sempre os mesmos contextos, as coisas da mesma forma. Ou que queira sempre mais e acabe obtendo o pior. O gozo enquanto libido fixada está ligado à pulsão de morte" (MRECH, 1999, p. 132).

A percepção, o conhecimento das coisas do mundo, a aquisição de conceitos do cotidiano ou científicos e um certo saber existencial são formados na relação com as modalidades de gozo passadas pelo meio social e familiar. Este é um avanço em relação às teorias cognitivistas da Psicologia e permite perceber que nada no sujeito é neutro, tampouco sua constituição cognitiva.

Nas palavras de Mrech (1999) a denominação lacaniana de transferência diz respeito a uma "elaboração de saber trazida pelo sujeito a partir da sua história pessoal" (p. 66) e ligada às modalidades de gozo que o aluno atualizará e repetirá nas suas outras relações e outros contextos na vida.

Para a emancipação humana e para o educador interessa a transferência de trabalho que "leva o sujeito a investir libidinalmente as coisas, a conseguir criar, a conseguir trabalhar, a ler, a escrever etc." (Ibid., p. 140). 
Embora a linguagem e a fala não possam dizer os sujeitos e suas histórias em toda a sua complexidade ou verdade - pois não é possível apreender todo o sentido e este sempre escapará - cabe a cada um, e inclusive ao professor, construir o saber por meio delas. Assim como cabe a cada um também se responsabilizar pelo seu gozo.

$\mathrm{Na}$ educação da criança cega com problemas graves no desenvolvimento por seus comprometimentos na constituição subjetiva, temos que considerar suas especificidades também no que diz respeito à sua organização cognitiva: como integra e organiza suas percepções, como pensa, qual seu estilo cognitivo, suas formas de aprendizagem.

Acerca do modo próprio do perceber e relacionar-se da criança cega, Masini (1990; 1993) questiona as afirmativas que localizam na visão o cerne da percepção e a base do pensamento, pois suas pesquisas sempre mostraram que as crianças cegas percebem o mundo de uma forma específica e assim desenvolvem o pensamento. Não há comparação com o vidente. É a especificidade de estar no mundo sem a visão no desenvolvimento das competências funcionais para lidar com o mundo. Em seu trabalho de formação de educadores, a pesquisadora realizou análises de currículos e propostas educacionais alertando sempre para este ponto de vista e para a idéia de que essas crianças, como outras, estão no mundo e têm toda possibilidade de desenvolver-se plenamente, se respeitadas no seu modo próprio de relacionar-se e de perceber com os seus próprios canais de percepção e que, se assim não for, poderão fechar-se para as experiências e adoecer. A partir deste pensamento propõe que o educador deve estar aberto e aproximar-se da criança cega, assim como de qualquer outra, para conhecê-la da maneira como ela se apresenta ao mundo - por meio da dialética e da síntese de suas percepções através de seu corpo e das relações com o outro permeadas do dado cultural da linguagem. Assim, com base na fenomenologia da percepção de Merleau-Ponty, a autora amplia as noções de corpo e de percepção, dando ao primeiro a dimensão de abrigo das ações e das palavras, como uma totalidade na dinâmica das relações com o mundo, e à segunda (também corporal, mas não como referência direta dos órgãos dos sentidos) a idéia de síntese integrada do vivido pelo corpo. Nesta perspectiva dialética, o movimento, a expressão do corpo no espaço já é carregada de sentido, pois é assim toda relação do ser no mundo. As significações estão expressas no corpo e este é consciência, pois sente e conhece, mas há também um saber do corpo que antecipa a consciência, a emoção, o conceito. Esse saber não é intelecção referente ao objeto do conhecimento, mas "um saber de si ao saber do objeto" (MASINI, 1994, p.87). 
No trabalho com os professores, Masini (1994) vai apontar para um modo de compreender o fenômeno buscando seus significados na maneira como ele se mostra, sem idéias pré-concebidas. Aproximar-se e estar aberto para o entendimento são características importantes no educador para compreender a si mesmo e ao aluno. Tal postura favorece a mudança do olhar, da atitude e da escuta de professores, alunos e familiares na compreensão do fenômeno humano na sua diversidade e, em particular, do ensino-aprendizagem e da escolarização das crianças cegas com problemas na constituição de sujeito.

As concepções apresentadas por Masini (1994) no capítulo anterior sobre o universo da cegueira: a especificidade de ser cego e a generalidade de ser humano, novamente o particular e o universal, são proposições fundamentais de reflexão para o educador que poderão possibilitar sua aproximação junto a esse aluno.

Não se pode pensar que ser cego é ser igual a todo mundo apenas sem o sentido da visão. Não é um extra-terrestre, certamente. Nessa discussão teríamos que nos remeter mais uma vez à questão da semelhança e da diferença. O educador tropeça ora tratando exatamente como a todos e esquecendo que ele não enxerga - e isso não é pouca coisa na objetividade do mundo - ora se excedendo nos cuidados que acabam por discriminar. Na realidade, a cegueira não provoca o problema de subjetivação da criança por seu dado orgânico, embora o sujeito esteja atravessado por ele na fantasmática dos pais. Se a criança cega estará prejudicada na sua constituição de sujeito dependerá de como foi recebida, olhada, pensada, falada. Dependerá enfim de sua história e lugar no discurso dos pais (Cf. ORMELEZI, 2000). Essa afirmação é muito importante no processo de inclusão educacional e escolar dessa criança, sendo que sempre paira no contexto familiar e da escola essa "mística" sobre a cegueira: a de que não é possível aprender e viver sem a visão. Nesse processo, pais e professores precisam ser escutados para lidar com essa representação da cegueira e com essa criança.

Encerramos este capítulo, deixando algumas articulações acerca do encontro da Psicanálise com a Educação na perspectiva de uma construção possível para a inclusão das crianças cegas com problemas na constituição da subjetividade e no desenvolvimento.

No capítulo IV trataremos dos aspectos metodológicos desta pesquisa. 


\section{CAPÍTULO IV - METODOLOGIA DA PESQUISA}

Neste capítulo apresentaremos a metodologia adotada na realização deste estudo, partindo das questões que levaram à formulação das hipóteses, à definição dos objetivos, à escolha dos participantes da pesquisa, bem como aos procedimentos para coleta e análise dos dados.

\section{DELINEANDO O MÉTODO}

O estudo de caso e análise de discurso foram as abordagens escolhidas para esta pesquisa pela natureza do problema estudado, a saber, a criança cega congênita com problemas na constituição subjetiva e no desenvolvimento global na perspectiva de seu processo de inclusão educacional e escolar.

Trata-se de uma pesquisa que busca os dados no contexto de vida dos sujeitos, na tentativa de vê-los em suas manifestações próprias e no modo como são vistos por suas mães. Foi desenvolvida em quatro etapas:

- Preparatória: levantamento de questões e conhecimentos acerca do tema, definição da problemática específica e da metodologia, seleção e caracterização do sujeito, caracterização do local, estabelecimento de contato com o sujeito, desenvolvimento dos instrumentos e procedimentos de coleta dos dados;

- Descritiva: busca sistemática de dados a partir dos prontuários, entrevista com as mães e observação das crianças em atividades;

- Interpretativa: assinalamento dos elementos significativos nas entrevistas e observações, organização por temas e análise;

- Reflexiva e teórica: discussão e articulação dos dados da análise à luz da teoria em um dos casos estudados.

Os instrumentos de investigação foram a entrevista com as mães e a observação participativa nas atividades das crianças, além da consulta à documentação existente na instituição na qual foi realizada a pesquisa. 
A análise consistiu em um primeiro momento em leituras de recortes e fragmentos: 1) das situações vividas pelos sujeitos nas atividades; e 2) dos elementos do discurso proferido por suas mães; 3) da inter-relação dos discursos das mães e das manifestações das crianças. Os recortes foram feitos de acordo com o que se mostrou significativo na escuta da pesquisadora como conteúdos importantes nesta pesquisa.

A análise de discurso da entrevista, bem como as observações, visaram pôr em evidência o que as mães entrevistadas mamifestaram sobre a visão que têm do filho cego e como agem frente a ele, e também como cada criança se manifesta em sua estrutura psíquica e singularidades na relação com o mundo. Os dados que revelaram cada uma das crianças e cada história familiar permitiram inferências e possíveis generalizações.

Os dados das entrevistas e das observações das crianças nas atividades foram inseridos na apresentação de cada caso para caracterização dos sujeitos.

Finalmente, a ética da pesquisa diz respeito a buscar saber da criança cega com problemas na constituição de sujeito e no desenvolvimento global por ela mesma e por aquele que ainda fala por ela, sem buscar o parâmetro de comparação com a criança vidente, respeitando-a nas suas peculiaridades, procurando identificar as suas possibilidades de tornarse sujeito.

\section{CONSTRUINDO HIPÓTESES E ESTABELECENDO OS OBJETIVOS}

Para os pais, os profissionais e as instituições em geral, a impossibilidade do ver confunde-se com a impossibilidade do existir, do aprender, do comunicar-se, do relacionar-se, do fazer parte, entrar para a cultura e tornar-se sujeito. Diante da presença de traços psicóticos ou autistas, da deficiência mental ou de comprometimentos sindrômicos associados à cegueira, vão centrar-se apenas nos problemas de desenvolvimento dessa criança. Quando consideramos, porém, a deficiência em sua dimensão social, quer no início da vida do bebê cego, quer um pouco mais tarde quando amplia a convivência no grupo familiar e comunitário e adentra o espaço escolar, percebemos significantes inconscientes que lhe são atribuídos e que dificultam a constituição do sujeito, os laços sociais e o desenvolvimento. 
Quando uma mãe relata que o filho que ela esperava morreu quando este nasceu (o bebê cego), e perguntamos quem é esse então que nasceu e ela responde que é um saco vazio, o que exatamente isso poderia significar?

Significaria que esse "sentimento" de quebra da imagem do filho esperado e idealizado, essa reação acerca da deficiência poderiam traçar o destino dessa criança fora da ordem simbólica? Significaria que a deficiência impõe a algumas mães uma barreira intransponível e a interação mãe-bebê, nesses casos, fica gravemente prejudicada a ponto da criança ter grandes prejuízos na constituição de sujeito e no desenvolvimento?

Diante do que foi exposto temos as seguintes hipóteses:

- Não é a ausência da percepção visual fator determinante nos transtornos da constituição subjetiva e do desenvolvimento global, apesar da cegueira ter valor fundante na estruturação psíquica;

- O fator determinante dos problemas graves de desenvolvimento nas crianças cegas congênitas é a interação prejudicada entre mãe e bebê que compromete sua constituição de sujeito.

Os objetivos estabelecidos nesta pesquisa foram os seguintes:

- Compreender como se constituem os graves problemas de desenvolvimento em algumas crianças cegas congênitas;

- Identificar as condições nas quais essas crianças manifestaram possibilidades de constituição da subjetividade e de desenvolvimento;

- Refletir sobre o que precisam saber os educadores sobre a forma de existir dessas crianças para criar algumas condições necessárias à sua participação no processo de inclusão na escola. 


\section{A ESCOLHA E A IDENTIFICAÇÃO DOS SUJEITOS E DA INSTITUIÇÃO ESPECIALIZADA}

\subsection{Os sujeitos da pesquisa}

A escolha do sujeito desta pesquisa seguiu três critérios fundamentais: 1) serem crianças cegas congênitas; 2) apresentarem problemas na constituição subjetiva e comprometimentos no desenvolvimento; 3 ) terem entre cinco e nove anos de idade.

Os dois primeiros critérios consistiram fatores complicadores do ponto de vista teórico. O primeiro deles é referente à retenção de imagens visuais. Conforme visto anteriormente, a definição adotada por Lowenfeld (1950) até a classificação da OMS em sua última revisão CID-10 (1993), considera que não há retenção das imagens visuais quando a perda ocorre até os cinco anos de idade. Essa definição, no entanto, não considera que a relação inicial mãe-bebê pode ficar afetada pela presença da cegueira e, portanto, a constituição de sujeito. Por tratarmos neste trabalho fundamentalmente dessa relação, optamos por crianças cegas desde o nascimento.

O outro critério - problemas na constituição subjetiva e no desenvolvimento global associados à cegueira - a princípio nos levou a pensar se deveríamos discriminar as patologias visuais que pudessem comprometer também as estruturas cognitivas além da visual, ou ainda síndromes que envolvem quadros clínicos muitas vezes desconhecidos ou processos de caráter regressivo com perdas de funções já adquiridas. Selecionar crianças sindrômicas ou com lesões cerebrais de alguma ordem poderia suscitar a conjectura de que os problemas no desenvolvimento estivessem diretamente ligados a esses quadros, ficando a dúvida se as manifestações eram características da síndrome ou resultantes de outros fatores. Embora estejamos considerando as questões de desenvolvimento e este, sem dúvida, está comprometido quando os danos neurológicos são evidentes, não nos preocupamos com isso, pois que nos interessa ver a criança que está aí para se constituir, pois estamos lidando com dois eixos: o do desenvolvimento e o da estrutura, sendo que o sujeito pode constituir-se apesar de uma organicidade prejudicada.

A faixa etária, compreendida entre as idades de cinco a nove anos, levou em conta que a criança cega congênita que se desenvolve sem impedimentos já evidencia isso em torno dos 
quatro anos e meio, conforme os estudos psicanalíticos encontrados no levantamento bibliográfico já citado.

Esta escolha justificou-se também pelo fato de que as complicações próprias da organização dessas crianças estudadas, adicionadas às mudanças decorrentes da puberdade como as mudanças hormonais que se refletem nas mudanças no corpo influenciando e alterando condutas e reações emocionais - implicariam na análise de outros fatores.

Além dos critérios estabelecidos, os sujeitos desta pesquisa apresentaram ainda a característica de pertencer à classe socioeconômica média-baixa, conforme indicadores estabelecidos na avaliação realizada pelo Serviço Social da instituição. São eles: renda familiar não superior a $\mathrm{R} \$ 70,00$ per capita, critério para receber o benefício de prestação continuada concedido pelo governo do Estado a toda família que tiver uma pessoa idosa ou portadora de deficiência; local e condições de moradia precários; dependência dos serviços públicos de saúde e educação; uso de transporte coletivo; desemprego; baixa escolaridade; quadro social agravado pelas condições econômicas precárias.

Os contextos de vida familiar e comunitária mostram uma rotina simples na qual a religião ocupa um lugar importante, com vivências escolares pobres e recentes, sendo que um dos sujeitos nunca havia freqüentado a escola na ocasião da entrevista. Suas histórias e quadros clínicos apresentam certa uniformidade no que diz respeito a alguns dos comportamentos citados abaixo que caracterizam os quadros de problemas graves na constituição subjetiva e no desenvolvimento, os quais se expressam em comportamentos que tangem a afetividade, a mobilidade, a função simbólica, a linguagem, a relação com o outro e os laços sociais, a imagem corporal e a construção do "eu" tais como:

- Comunicação verbal pobre: ecolálica, sem uso dos pronomes de referência do "eu" (eu, me, mim, comigo, meu, minha);

- Indiferenciação eu-outro;

- Relação descontextualizada com objetos inanimados;

- Prevalência da boca como zona libidinizada e como órgão de percepção e contato com o mundo;

- Rara autonomia da mão como órgão de percepção na exploração e conhecimento do mundo de objetos e pessoas;

- Pouca autonomia na orientação para mobilidade no espaço; 
- Falta de percepção dos deslocamentos dos objetos no espaço;

- Ausência do conceito de objeto e permanência deste;

- Maneirismos e formas primitivas de contato com as pessoas (como apertar, morder, agarrar), e com seu próprio corpo (como balançar, girar);

- Imagem e esquema corporal instáveis;

- Falta de interesse por objetos e brinquedos por suas características e funções, mas apenas para satisfação de necessidades ou estimulação do corpo (com primazia da boca);

- Ausência do jogo simbólico, incapacidade de projetar-se como um objeto entre outros objetos;

- Resistência a mudanças;

- Núcleos de inteligência preservados em determinadas áreas e lacunas em outras.

Os sujeitos estudados freqüentavam a instituição especializada semanalmente, integrados em um grupo de dez crianças, participando de atividades lúdicas, de arte e cultura, de interação social, comunicação e linguagem, de aprendizagens específicas de instrumentos e recursos relativos à deficiência visual como o Braille, o soroban, a orientação e mobilidade e habilidades para a autonomia e a independência nas atividades da vida diária.

Quanto às patologias da visão apresentadas pelos sujeitos e suas etiologias, as mesmas estão descritas na apresentação dos casos no capítulo V.

O quadro a seguir caracteriza os sujeitos participantes da pesquisa ${ }^{21}$ :

\section{Quadro 1: Caracterização do sujeito}

\begin{tabular}{|c|c|c|c|c|c|c|}
\hline Criança & Sexo & Idade & $\begin{array}{c}\text { Composição } \\
\text { familiar }\end{array}$ & $\begin{array}{c}\text { Escolaridade/ } \\
\text { Escola }\end{array}$ & $\begin{array}{c}\text { Deficiência/ } \\
\text { patologia }\end{array}$ & $\begin{array}{l}\text { Escolaridade/ } \\
\text { profiss. Pais }\end{array}$ \\
\hline Augusto & $\begin{array}{l}\text { Mas } \\
\text { c. }\end{array}$ & 6 & $\begin{array}{c}\text { Pais } \\
\text { separados e } \\
\text { duas irmãs } \\
\text { adolescentes }\end{array}$ & $\begin{array}{c}1^{\mathrm{a}} \text { Série / } \\
\text { Municipal }\end{array}$ & $\begin{array}{c}\text { Cegueira } \\
\text { congênita/ } \\
\text { Malformação } \\
\text { intra-uterina } \\
\text { ocular } \\
\text { bilateral com } \\
\text { alterações } \\
\text { retinianas e } \\
\text { microftalmia }\end{array}$ & $\begin{array}{c}\text { Pai - Ens. } \\
\text { Fund. } \\
\text { (incompleto) / } \\
\text { operário } \\
\text { Mãe - Ens. } \\
\text { Médio } \\
\text { (incompleto) / } \\
\text { do lar }\end{array}$ \\
\hline
\end{tabular}

\footnotetext{
${ }^{21}$ Os nomes utilizados para os sujeitos são fictícios.
} 


\begin{tabular}{|c|c|c|c|c|c|c|}
\hline Vivian & Fem. & 8 & $\begin{array}{l}\text { Pais e duas } \\
\text { irmãs jovens }\end{array}$ & $\begin{array}{l}2^{\mathrm{a}} \text { Série / } \\
\text { Municipal }\end{array}$ & $\begin{array}{c}\text { Cegueira } \\
\text { congênita/ } \\
\text { Sequiela de } \\
\text { Rubéola na } \\
\text { gravidez }\end{array}$ & $\begin{array}{l}\text { Ensino Fund. } \\
\text { (incompleto)/ } \\
\text { operário e do } \\
\text { lar }\end{array}$ \\
\hline Renan & $\begin{array}{c}\text { Masc } \\
.\end{array}$ & 9 & $\begin{array}{c}\text { Pais e um } \\
\text { irmão menor }\end{array}$ & $\begin{array}{c}3^{\text {a }} \text { Série/ } \\
\text { Municipal }\end{array}$ & $\begin{array}{c}\text { Cegueira } \\
\text { congênita/ } \\
\text { Amaurose } \\
\text { Congênita de } \\
\text { Leber }\end{array}$ & $\begin{array}{l}\text { Pai - Ens. } \\
\text { Fund. } \\
\text { (incompleto)/ } \\
\text { operário } \\
\text { Mãe - Ens. } \\
\text { Médio / } \\
\text { auxiliar em } \\
\text { escola }\end{array}$ \\
\hline
\end{tabular}

\subsection{Caracterização da instituição especializada: local de realização da pesquisa}

A pesquisa foi desenvolvida em uma organização da sociedade civil, filantrópica, de enfoque sócio-educativo, especializada no atendimento à pessoa com deficiência visual.

Fundada no ano de 1991, Laramara - Associação de Assistência ao Deficiente Visual - atende crianças, jovens e adultos com cegueira, baixa visão e deficiências associadas, bem como às suas famílias, promovendo um trabalho voltado ao desenvolvimento humano e à inclusão social. Seu modelo de atendimento é sócio-educativo, tendo como única área clínica os serviços de Oftalmologia e Ortóptica. Seu enfoque é sócio-cultural e sua abordagem ecológica.

Os grandes núcleos de concentração dos serviços oferecidos estão divididos em Avaliação, Atendimento e Inclusão Social. Os programas que compõem esses núcleos correspondem à complementação e suplementação educacional, atuando na especificidade da deficiência - diagnóstico, indicação e treinamento em recursos especiais ópticos e não ópticos e em sistemas, técnicas e tecnologias para a autonomia e independência das pessoas com deficiência visual - como também desenvolve ações nos contextos social e educacional mais amplos.

As áreas de atuação, além da área médica já citada, estão concentradas na Intervenção Precoce, Pedagogia, Psicologia, Serviço Social, Atividades Funcionais de Orientação e 
Mobilidade e Atividades da Vida Diária, Recreação e Lazer, Arte e Cultura. Essas áreas desenvolvem projetos e ações internas e externas à instituição que vão do atendimento direto ao usuário à capacitação de profissionais da área ou não, além dos serviços de apoio à inclusão social e escolar prestados à comunidade e ainda o desenvolvimento de materiais didático-pedagógicos especializados e de tecnologia assistiva.

Os atendimentos são realizados em grupos de dez crianças, em periodicidade semanal, aos quais os usuários são integrados após a avaliação e estudo de caso.

A família participa como elemento essencial do processo de avaliação e estabelecimento de metas em um plano de trabalho individual, sendo atendidas também em grupos de apoio psicossocial.

\section{FONTES, PROCEDIMENTOS E INSTRUMENTOS DE COLETA DE DADOS}

Após definição da problemática a ser investigada, a revisão da literatura e o estabelecimento dos critérios de seleção dos sujeitos, foi solicitada autorização junto à instituição especializada descrita acima para a realização da pesquisa.

Os sujeitos pesquisados fazem parte do setor de habilitação, o qual apresenta um universo de 450 crianças atendidas semanalmente. Destas, cerca de $70 \%$ têm baixa visão e $30 \%$ são cegas, sendo que aproximadamente $40 \%$ desse universo apresentam algum tipo de comprometimento associado à deficiência visual.

Os diagnósticos mais freqüentes para esses comprometimentos nessa instituição são caracterizados por: paralisia cerebral, deficiência mental ou atraso inespecífico, psicose infantil, autismo infantil, síndromes diversas, disfunção de integração sensorial e muitas crianças sem diagnóstico.

Tendo claros os critérios de eleição dos sujeitos, procedemos à realização de um levantamento junto aos profissionais do atendimento, a partir de uma explanação sobre o objeto e os objetivos da pesquisa.

Em seguida, passamos ao estudo dos prontuários para um mapeamento descritivo sobre os diagnósticos e outras especificidades dos casos. 
Os registros nos prontuários de cada criança com avaliações dos profissionais, relatos familiares e produções pedagógicas forneceram dados referentes à sua história de vida, patologia visual, aspectos familiares e de aprendizagens e desenvolvimento.

Após esse momento inicial, foi feita a consulta às famílias, seguida da apresentação de motivos e etapas a serem desenvolvidas, ao que elas assentiram, passando à assinatura do Termo de Consentimento Livre e Esclarecido.

A essa etapa seguiu-se o delineamento dos aspectos gerais e dos itens norteadores da escolha e do desenvolvimento dos instrumentos de coleta de dados, a ser realizada em dois momentos, a saber:

- Entrevista com as mães (parte semi-estruturada como depoimento e parte estruturada como anamnese) para levantamento da história de vida das crianças, da simbologia e dos sentimentos das mães em relação ao filho cego, identificando significantes que marcaram as crianças na constituição de sujeitos na relação mãefilho;

- Observações das crianças e interação com as mesmas registrando suas expressões corporais, linguagem verbal ou pré-verbal, interações sociais, padrões de comportamento e organização mental e afetiva, a serem registrados em fitas de vídeo para evidenciar as manifestações que as definem como crianças cegas com problemas graves no desenvolvimento.

\subsection{A Entrevista}

Optamos pela entrevista com a mãe dada a relação mãe-criança ser a primeira e fundamental relação na constituição do sujeito. Esta entrevista objetivou identificar características da relação mãe-criança dos primeiros anos até o momento presente.

A modalidade de entrevista escolhida foi a semi-estruturada, com proposituras amplas e abertas no início, permitindo que o entrevistado discorresse livremente sobre o assunto, possibilitando que conteúdos latentes pudessem vir à tona na reconstituição de lembranças e reconstrução de sentidos para as vivências relatadas.

Foi utilizado um roteiro básico e flexível que permitiu colher a informação imediata, esclarecer pontos relevantes e ainda adaptar ou inserir questões que não estivessem sendo 
abordadas. Por isso o instrumento serviu de guia para a entrevistadora. A primeira proposição aberta - "Fale-me sobre a história de seu (sua) filho (a)" - permitia que a partir dela outras poderiam ser ou não ser feitas, dependendo das informações serem ou não enunciadas espontaneamente. As perguntas do roteiro (Anexo 1) foram inspiradas na leitura de instrumentos padronizados de avaliação e intervenção no trabalho com crianças com deficiência, cujas referências constarão da Bibliografia. São eles:

- PEDI (Pediatric Evaluation of Disability Inventory - Inventário de Avaliação Pediátrica de Disfunção)

- Crescer: do nascimento aos três anos

- Avaliação e Intervenção em Multideficiência

- Escala Leonhardt de Desenvolvimento

Quanto à forma de registro das entrevistas, foi utilizada a gravação em fita de áudio, a qual mostrou-se adequada para captar as informações do modo como foram expressas, ficando a pesquisadora mais livre para acompanhar a fala e outras manifestações da entrevistada. Após cada entrevista, foi feita a transcrição da linguagem falada para a escrita, processo cuidadoso que não pode comprometer a riqueza de conteúdo e estrutura do que foi dito e o modo como foi dito: as repetições, a entonação, as figuras e outras formações de linguagem como metáforas, chistes, imitações, ironias, provérbios, entre outras que fazem do discurso algo que se constrói no momento mesmo em que alguém fala.

\subsection{A Observação}

O objetivo da observação das crianças estudadas foi conhecer como elas se mostravam no funcionamento pessoal e seus modos de estar no mundo e relacionar-se consigo mesmas, com pessoas, objetos e eventos, como também as manifestações de seus modos de organizar mental e afetivamente o mundo que as circundam e as respostas que elaboram frente às suas demandas e às demandas do ambiente no seu contexto de vida atual.

A observação não se constituiu como instrumento de avaliação do desenvolvimento desses sujeitos, o que levaria, na perspectiva desenvolvimentista, à comparação inevitável da criança cega com a vidente e seríamos levados a explicar os desvios pela ausência da visão como causa do comprometimento e atraso no desenvolvimento da criança cega. 
Adotamos a forma da observação participativa que tratou de corroborar os dados da entrevista com as mães e dos profissionais na descrição e identificação dos elementos que mostravam os desvios na estruturação psíquica dessas crianças cegas que ficaram barradas na constituição subjetiva e no desenvolvimento e não que se constituíram em um momento mais tardio e por outros caminhos de percepção e construção. Pretendemos conhecer para analisar, em situação, as manifestações que evidenciavam um impedimento, características dos problemas graves de desenvolvimento, que atingem, particularmente, a construção do "eu", de acordo com a definição apresentada no referencial teórico adotado neste trabalho. As observações puderam, ainda, iluminar aspectos relevantes da entrevista no momento da análise das mesmas.

Procuramos manter uma atitude aberta, sem idéias pré-estabelecidas, para captar as informações que se apresentaram na situação, sem a colocação de limites arbitrários, porém com atenção em alguns aspectos relevantes da expressão das crianças - no corpo e no movimento, na comunicação, nos vínculos e interações sócio-afetivas, nos sentimentos, no brincar, na percepção do mundo e nas noções de objeto e de referências do "eu" - os quais auxiliaram na discriminação dos indícios dos transtornos mencionados.

Para levantamento desses dados foram definidas as atividades da instituição às quais as crianças já estavam integradas e que oportunizaram observar as interações entre criançasadultos e crianças-crianças. Eram situações, ambientes, pessoas e objetos que elas conheciam e faziam parte da sua rotina na instituição. Algumas das atividades foram planejadas (com a intervenção do adulto: profissional ou familiar), outras de rotina (que aconteciam regularmente) e outras, ainda, espontâneas (iniciadas pela criança). Basearam-se fundamentalmente no contexto de brincadeiras e atividades funcionais para autonomia na vida diária.

As manifestações das crianças foram contextualizadas em relação à ocorrência no tempo - antes, durante e depois - e às características de determinados acontecimentos.

Quanto ao registro das observações, as mesmas foram relatadas de forma descritiva, com comentários sobre o visto e percebido nas diversas situações. Foram também gravadas em vídeo para que pudéssemos retornar à cena sempre que necessário elucidar dúvidas ou complementar dados. Foi usada uma folha-registro de observação contendo nome da criança, data, atividade, ambiente, pessoas envolvidas, tempo, materiais usados, além da descrição e comentários. 


\section{PROCEDIMENTOS DE ANÁLISE E INTERPRETAÇÃO DOS DADOS}

As fitas de áudio que registraram as entrevistas passaram pelo tratamento de transposição da linguagem falada para a escrita e as de vídeo foram descritas e reunidas às anotações feitas durante as observações, convertendo-se no material para análise e interpretação dos dados.

Para proceder à análise e interpretação a partir dos dados coletados nas entrevistas e nas observações, passamos à caracterização dos sujeitos e ao trabalho de identificação de marcas significativas no discurso das mães e nas observações das crianças, levantando aspectos de singularidades e regularidades a partir de recortes que os casos estudados convidaram a fazer, construindo arranjos por temas recorrentes para organização e sistematização desses dados e sua interpretação.

Foi delineado um processo de análise, conforme segue. Contudo, cabe aqui explicitar que, inicialmente, pensamos levar a cabo a proposta de interpretação dos três casos, mas o estudo do primeiro já demandou um trabalho de elaboração muito extenso e, devido ao limite de tempo para esse aprofundamento, bem como o volume e complexidade dos dados coletados, decidimos realizar esse nível de análise em apenas um dos casos. Os três casos se mostraram igualmente importantes para este estudo, porém o que foi interpretado justificou-se por ser um caso mais extremado, tratando-se de uma criança muito comprometida em seu desenvolvimento e organização interna e que, no espaço de tempo de um ano, pudemos acompanhar um giro no olhar e no discurso da mãe, bem como uma virada na organização interna e nos comportamentos manifestos pela criança. Este fato ilustrou a operação de uma mudança significativa que evidenciou pontos de abertura para a criança e que acenam como possibilidades de sua constituição subjetiva. Foi importante e necessário identificá-los e interpretá-los para serem discutidos no contexto educacional em que este estudo está inserido e com o objetivo que se propõe atingir junto aos educadores.

Assim, a análise consistiu em três passos:

- Assinalamento dos elementos significativos ${ }^{22}$ que emergiram em relação às crianças e às mães;

\footnotetext{
${ }^{22}$ Consideramos significativos os elementos que se destacaram como importantes para a análise
} 
- Arranjo por temas recorrentes em relação às crianças e às mãe;

- Inter-relação entre o discurso das mães e as manifestações das crianças.

Também foi utilizado um roteiro de análise dos dados das observações, cujos itens centraram a atenção em manifestações corporais, imagem corporal, uso da boca e da mão, maneirismos e expressões libidinais e agressivas; tipo de uso dos objetos (satisfação de necessidades/função); orientação e mobilidade no espaço; comunicação (intencional ou não verbal e não-verbal); fala (contexto - estrutura - conteúdo); discriminação eu-outro; uso dos pronomes de referência do "eu"; o "eu" na linguagem e no jogo simbólico; interações com pessoas (crianças e adultos) e objetos; laços afetivos; capacidade de separar-se de alguém ou de algo; jogo simbólico criativo; capacidade de brincar e imitar; nível de atividade; percepção e organização mental do mundo (função simbólica); cognição (compreensão, conceito e permanência de objeto); expressão emocional frente à frustração, medos e ansiedades ou contentamento; reconhecimento da emoção; fragilidades e defesas; resistências a mudanças; habilidades e competências; desejos e necessidades; respostas táteis, auditivas; tipos de apoios e ajudas de que necessitam.

A interpretação foi feita com base no referencial psicanalítico, o qual fornece instrumentos para análise de discurso e, além disso, foi a base de compreensão para as reflexões teóricas.

\subsection{Análise das entrevistas: uma "análise de discurso" no discurso das mães} (Anexo 2)

A análise do discurso proferido pelas mães nas entrevistas desta pesquisa foi baseada no referencial teórico da Análise do Discurso. Cabe, porém, explicitar de que Análise do Discurso vai se tratar: a Análise do Discurso conforme o recorte proposto por Guirado (1995).

A autora, apoiada nas idéias de Maingueneau (1989), que por sua vez revelam novas tendências na articulação que faz da Linguística com o pensamento de Foucault, propõe uma articulação entre a Análise do Discurso como disciplina do conhecimento inserida no âmbito da Linguística, e a Psicanálise como campo do saber autorizado a fazer análises de discurso.

$\mathrm{Na}$ sustentação que apresenta para sua proposição metodológica defende a possibilidade da apropriação, mas não aplicação direta, do modelo clínico da Psicanálise em 
outros espaços institucionais, inclusive o espaço acadêmico. Seu trabalho fundamental é a análise do discurso das instituições e de como o sujeito institucionalizado é marcado por isso e como o revela no seu próprio discurso. Nessa perspectiva propõe-se a "pensar o sujeito e a subjetividade no discurso em análise” (GUIRADO, 1995, p.12). Nesta pesquisa analisamos “como os sujeitos estudados se mostram enunciados nos discursos de suas mãse e como isso os constituiu ou não como sujeitos".

Sujeito, subjetividade, discurso, sentido, significante e significado, inconsciente, enunciado e enunciação, leitura e escuta, análise e outros referentes psicanalíticos ${ }^{23}$ compatíveis com a Análise do Discurso usados pela autora, numa articulação voltada à modalidade da pesquisa acadêmica, estão de acordo com o quadro teórico da Psicanálise lacaniana que sustenta esta pesquisa. Os mesmos exigem uma explanação aprofundada e foram tratados no capítulo específico da fundamentação teórica. Optamos por fazer referência a tais conceitos elaborando também um glossário (Anexo 4). Para isso, recorremos às próprias palavras de Guirado (Ibid.) na organização que fez do pensamento dos autores que elegeu para dispor sobre Análise do Discurso e Psicanálise, fora do consultório, e, segundo ela mesma, não incorrer em equívocos teóricos.

Feitas as considerações sobre o aporte teórico da abordagem metodológica de análise, passamos a descrever o tratamento que foi dado aos discursos das mães nas entrevistas. A análise propriamente dita das entrevistas foi dividida em três momentos. O primeiro deles tratou da transcrição das fitas gravadas em áudio seguido de um processo minucioso de assinalamento dos elementos significativos identificados nas construções de fala das mães, elementos esses que surgiram à pesquisadora pelo instrumento de sua escuta/leitura e que foram considerados importantes para esta pesquisa, a saber:

- na rede de encadeamento das idéias e nos seus cortes;

- na escolha, uso, função, valor, lugar e inter-relações dos termos na estrutura e funcionamento das falas.

Analisar os discursos significou interpretar, no sentido de identificar fantasias e desejos inconscientes, resistências, significações e sentidos que saltaram da história contada pelas mães. Histórias essas que fizeram a montagem de um discurso sobre suas vivências e relações com seus filhos com cegueira, num misto de lembranças, sentimentos, vínculos, lugares/posições, tempos e ações em um contexto particular que reflete um social mais amplo

\footnotetext{
${ }^{23}$ Ver glossário Anexo 3
} 
que atravessou suas vidas. Histórias que revelam o impacto da deficiência e o tempo de superação ou não superação, a representação simbólica da deficiência e a consciência ou não sobre o filho esperado versus o filho real.

Tratamos de analisar os discursos na medida que possibilitaram vislumbrar o "lugar que se vê ocupando aquele que nos fala, ainda que disto não fale (...) na estrutura discursiva, portanto, o desenho dos afetos" (GUIRADO, 1995, p. 94). E de compreender o "discurso enquanto lugar e cena (...) cena enunciativa (...) instância de enunciação em termos de lugares, visando enfatizar a preeminência do lugar social sobre os falantes que aí vêm se inscrever" (Ibid., p. 27).

Da entrevista foram assinalados os elementos significativos construídos nos discursos das mães como indicativos da posição subjetiva das crianças, orientando-se pelas seguintes questões:

- O que emergiu dos discursos das mães que enuncia o modo como essas crianças se manifestam no mundo?

- O que se mostrou significativo na relação inicial entre mãe e bebê?

- Que significados e sentidos emergiram dos discursos das mães em relação às crianças, à cegueira e à inclusão?

Por último, a produção de um texto analítico da entrevista pautado pela interpretação dos dados, ou seja, analisar o discurso é trabalhar com suas marcas significativas (o mesmo que elementos significativos, dito anteriormente), num arranjo por temas recorrentes, destacando trechos dos dizeres da mãe entrevistada que exemplifiquem tais interpretações para os múltiplos sentidos depreendidos de suas palavras.

\subsection{Análise das observações: a criança em ato}

$\mathrm{Na}$ análise das observações das crianças em atividades, tratamos suas manifestações identificando possíveis sentidos e significados para seus atos, falas e modos de relacionamento consigo e com o mundo de coisas, pessoas e eventos.

Foi dado um tratamento às marcas e aos traços significativos para esta pesquisa que emergiram das crianças, organizando-os em temas para análise dos aspectos constitutivos do 
complexo de comportamentos no que diz respeito ao corpo, à fala, à interação com objetos e pessoas, à afetividade, à função simbólica e à discriminação eu-outro.

Da observação foram levantados dados para caracterizar os quadros clínicos de problemas na constituição de sujeito e no desenvolvimento associados à cegueira nos sujeitos desta pesquisa e para estabelecer relações com os dados levantados nas entrevistas com as mães. As questões norteadoras no tratamento das observações foram:

- O que as crianças mostram que as caracterizam como tendo comprometimentos na constituição de sujeito e no desenvolvimento?

- Que significantes emergem de suas condutas e falas?

- Quais os possíveis significados para suas formas de estar no mundo?

- Que pontos de abertura são identificados?

\subsection{Análise da inter-relação do discurso das mães e das manifestações das crianças}

Além de conhecer as singularidades da existência e estruturação psíquica das crianças, neste nível de análise pretendemos um cotejamento entre o modo das crianças estarem no mundo e as significações apresentadas por suas mães nas entrevistas.

As perguntas que nortearam este momento da análise e que serão trabalhadas no capítulo V foram:

- As mães falam e as crianças atuam fora da ordem simbólica. Não puderam se constituir como sujeitos? Por quê?

- De que falaram as mães, qual o lugar dado a seus filhos cegos e como estes se mostram afetados pelas marcas que sobressaem nesse discurso?

O quarto capítulo, em suas cinco sessões, apresentou os fundamentos e justificativas da metodologia adotada nesta pesquisa, explicitando cada etapa do trabalho, bem como traçando os objetivos, identificando as fontes, os instrumentos e procedimentos de coleta e análise dos dados. O capítulo seguinte é dedicado à apresentação dos casos e à análise e interpretação. 


\section{CAPÍTULO V - ESTUDO DE CASO: ANÁLISE E INTERPRETAÇÃO DOS DADOS}

Neste capítulo tratamos do estudo de caso de um menino cego congênito com problemas na constituição subjetiva e no desenvolvimento. Dadas as contingências já explicitadas no capítulo anterior e às características deste caso, o mesmo foi escolhido para um tratamento mais aprofundado de análise. Esta se constituiu pela caracterização do sujeito, descrição das observações, entrevista com a mãe, assinalamento dos elementos significativos organizados por temas levantados nas observações e na entrevista e análise interpretativa à luz dos fundamentos teóricos que sustentam esta tese.

Esse estudo de caso foi organizado nas seguintes seções:

1) Dados levantados do prontuário;

2) Análise das observações: a criança em ato

Dados levantados na observação participativa: descrição;

2.1. Análise interpretativa dos dados relativos a Augusto $-1^{\mathrm{a}}$ etapa;

3) Análise da entrevista: uma análise de discurso no discurso da mãe

3.1. Análise interpretativa dos dados relativos à mãe $-1^{\mathrm{a}}$ etapa;

4) Análise interpretativa dos dados relativos a Augusto e à mãe - $2^{\mathrm{a}}$ etapa;

5) Reflexões sobre a inter-relação dos elementos do discurso da mãe com as manifestações de Augusto.

Em seguida apresentamos também outros dois casos, cujos dados levantados mostramse relevantes para corroborar a discussão e a análise interpretativa do primeiro. Estes, constituem-se das mesmas etapas citadas acima, não tendo passado pelo aprofundamento de análise interpretativa e reflexões teóricas.

Passamos a seguir à apresentação dos casos. 


\section{CASO I - AUGUSTO}

\section{DADOS LEVANTADOS DO PRONTUÁRIO}

A consulta ao prontuário teve a finalidade de levantar dados de identificação do sujeito e seu histórico de vida, bem como etiologia da deficiência, quadro clínico e de aprendizagem e desenvolvimento para posterior análise.

Idade: 5 anos no primeiro encontro e 6 anos no segundo e terceiro encontros

Sexo: masculino

Composição familiar: pais separados. Augusto mora com a mãe e três irmãs de 14,12 e 9 anos. O pai mora em outro Estado.

Nível de escolaridade e profissão dos pais: pai (Ensino Fundamental - operário); mãe (Ensino Médio - do lar)

Situação sócioeconômica: baixa renda

Tipo, etiologia e tempo de ocorrência da deficiência visual: cegueira congênita, com percepção de luz, por malformação ocular bilateral (microftalmia ${ }^{24}$, alterações retinianas difusas, olho direito menor que o esquerdo, olho direito com córnea com diâmetro diminuído). Na microftalmia há alteração das estruturas do olho como um todo.

História clínica (avaliações e diagnósticos psicológico, médico e pedagógico): diagnóstico médico aos 2 meses de vida. Deficiência visual total com estudo tomográfico computadorizado e ressonância magnética do crânio sem alterações significativas. Déficit no processo de aprendizagem e desenvolvimento, mas sem evidência de distúrbio neuropsicomotor. Atualmente conta com acompanhamento psicológico que levantou a hipótese de psicose infantil. Desde o nascimento a mãe observava malformação do olho direito confirmada pelo Serviço de Oftalmologia do hospital. Aos 4 meses foi atendido para avaliação oftalmológica e do desenvolvimento global na instituição que freqüenta hoje, mas a mãe só voltou a ela aos 4 anos de idade com a queixa de que ele estava muito desorganizado e agressivo. Mãe refere que não manteve o atendimento em idade precoce, pois estava em depressão e não agüentou levá-lo.

\footnotetext{
${ }^{24}$ Microftalmia é uma malformação congênita na qual o globo ocular é menor do que o normal. Pode ser definida como olho com comprimento axial menor que dois desvios padrões do normal. (OGASAWARA et al, http://www.abonet.com.br/abo/664s/casosclin01.htm)
} 
Contexto familiar: aos 4 meses de idade de Augusto a família estava muito desorganizada pela separação do casal, quando a mãe entrou e permaneceu dois anos em depressão e também precisou sair para trabalhar, ficando Augusto com as irmãs (na época com 8, 6 e 3 anos) que o deixavam sozinho, sem cuidados e sem conseguir controle sobre ele. Relacionamse bem com parentes paternos.

Vivência escolar e comunitária: nunca havia estado na escola à época da entrevista, pois a mãe evita levá-lo a lugares públicos (festinhas para as quais sempre é convidado na vizinhança, parques, shoppings, visitas e escola) por receio de suas agressões. Teve alguns atendimentos no antigo NAE - Núcleo de Atendimento Educacional, hoje Coordenadoria de Ensino da Secretaria de Educação do Município de São Paulo para preparar-se para a escola, mas isso não aconteceu. Atualmente, a mãe se diz consciente de que ele precisa de escola e aguarda vaga em EMEI - Escola Municipal de Educação Infantil. Após alguns meses da entrevista, Augusto foi para a escola, à qual se adaptou, e vem mostrando mudanças em seu comportamento. Além da escola e da vida em casa, gosta de ficar no portão e ir à casa dos vizinhos. Também vão a um clube e à igreja. A mãe nunca comemorou o aniversário dele com medo que agredisse as pessoas.

História de aprendizagem e de desenvolvimento: atendido na instituição desde os quatro anos, os dados do prontuário com relatos dos profissionais e da mãe fazem referência a um potencial de aprendizagem ao desenvolvimento de Augusto. Esses dados sugerem desenvolvimento motor adequado para a idade em todas as fases, linguagem atrasada e dificuldades de aprendizagem. Tem muita facilidade para decorar músicas. Mostra inteligência em alguns aspectos: perguntas que faz, nomes que inventa para pedaços de objetos, estratégias que usa para conseguir o que quer.

Quadro clínico: desde 1 ano, Augusto mostra um quadro de auto-agressão ao morder-se e também agressividade com as pessoas que se aproximam e lhe fazem carinho. A essa aproximação ele reage com socos, chutes e cabeçadas, machucando-as. A mãe o acha muito nervoso. Em 2004 tomou remédio para regularizar o sono e para "agressividade" (sic mãe). Ela suspendeu o do sono após melhora. A mãe diz que ele está desorganizado, seu comportamento agressivo se intensificou, as irmãs não conseguem contê-lo e que ele quebrou a casa toda. Interage com as pessoas ainda precariamente, pois está mais voltado para si mesmo, mas percebe o que se passa à sua volta e comunica-se oralmente dirigindo-se pelo nome às pessoas que conhece e fazendo perguntas sobre a natureza de algo que percebe e chama sua atenção. Vale-se muito da percepção auditiva na apreensão do mundo. Mostra-se 
atento e curioso sobre o que ouve. Ele consegue se envolver nas atividades propostas, realizando-as ainda de forma reprodutiva, sem criar, inovar, transformar a situação dada e também não inventa e não faz-de-conta nos jogos simbólicos. Sua linguagem ainda é pouco estruturada. Mostra formação de conceitos simples e poucas generalizações, contemplando mais palavras soltas e repetições do que encadeamento de idéias. Não tem uma fala propriamente sua e contextualizada, chamando-se mais pelo próprio nome, na terceira pessoa, aparecendo às vezes o pronome "eu" para referir-se a si mesmo apenas no que diz respeito a necessidades e satisfação (eu quero). Mostra compreender instruções simples que lhe são dadas: entrar, sentar, pegar, levantar, ir ao banheiro, comer e outras dessa natureza. Executaas, mas ainda é dependente nas atividades da vida diária, apesar de possuir habilidades e competências funcionais que não usa espontaneamente. Manipula os objetos mais pelo prazer e satisfação libidinal do que pela função dos mesmos, auto-estimulando-se na região da boca. Apresenta fala ecolálica (repetitiva). Em ambientes novos volta a se desorganizar e agredir.

Atividades freqüentadas na instituição: Pedagogia, Atividades recreativas, funcionais e motoras, Oftalmologia e Grupo de Apoio Psicossocial para a mãe.

\section{ANÁlISE DAS OBSERVAÇÕES: A CRIANÇA EM ATO DADOS LEVANTADOS NA OBSERVAÇÃO PARTICIPATIVA: DESCRIÇÃO}

Nesta seção apresentamos os dados referentes a Augusto nas atividades observadas pela pesquisadora. A estrutura das atividades foi mostrada em três quadros seguidos das descrições da situação de observação participativa para análise e interpretação dos dados.

Quadro 1: primeiro encontro com Augusto

\begin{tabular}{|l|l|l|l|l|l|}
\hline DATA & AMBIENTES & ATIVIDADES & PARTICIPANTES & TEMPO & MATERIAIS \\
\hline 3/9/04 & $\begin{array}{l}\text {-Sala de } \\
\text { atividades } \\
\text { pedagógicas }\end{array}$ & $\begin{array}{l}\text {-Encontro } \\
\text { para conhecer } \\
\text { Augusto }\end{array}$ & - Augusto & 40 minutos & $\begin{array}{l}\text { Caixa de } \\
\text { brinquedos mãe }\end{array}$ \\
- pesquisadora & $\begin{array}{l}\text { Prancha de } \\
\text { desenho } \\
\text { adaptada para } \\
\text { cegos - Massa }\end{array}$ \\
\hline
\end{tabular}




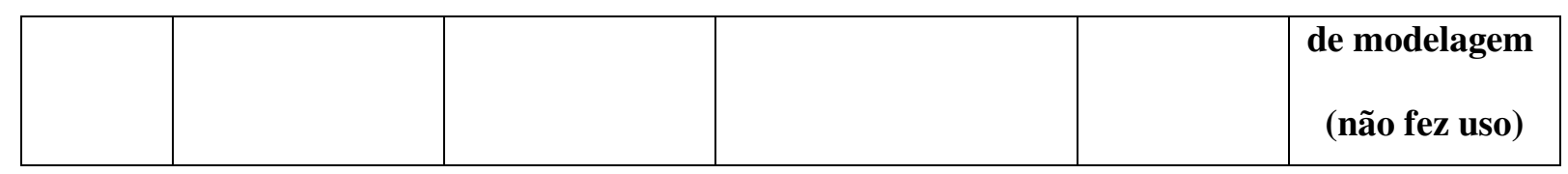

\section{Descrição:}

Augusto e sua mãe compareceram ao nosso encontro cujo objetivo foi explicitar o propósito desta pesquisa, consultar sobre sua participação e conhecer a criança. Augusto entrou e logo em resposta à saudação verbal e aproximação física tentou golpear a pesquisadora com a cabeça, gesto este impedido por sua mãe. Esta, então, começou a explicar que ele é assim mesmo e que isto a está deixando imensamente preocupada. Não pode confiar em deixá-lo um só instante com medo de que ele machuque as pessoas, pois assim acontece. Relatou que em casa, por exemplo, suas filhas estão no sofá, ou dormindo e ele chega e, sem mais nem menos, as agride com socos e cabeçadas que realmente as machuca tamanha é sua força. Ou então, ele vai à cozinha e começa a quebrar tudo. Enquanto sua mãe falava, Augusto andava ao redor da sala parecendo familiarizar-se com o ambiente ao qual vinha pela primeira vez. Em sua caminhada encontrou os armários e fez menção de puxar as portas. Novamente a mãe o deteve. A pesquisadora disse a ele que na sala havia uma caixa de brinquedos e sobre a mesa material para desenhar e massa para modelar, se ele quisesse usar. Augusto não respondeu, manteve-se inerte, parecendo não ter escutado e continuando a rodear a sala. Foi até a porta e começou a chutá-la. A pesquisadora aproximou-se e disse: é a porta da sala que você está chutando. Ele foi se aproximando, a mãe correu e a advertiu para que tomasse cuidado. Ele chegou perto e de fato tentou dar-lhe uma cabeçada. Ela afastou-se um pouco e disse que não o deixaria fazer isso, mas que podiam conversar, se quisesse. Ele não disse uma palavra em todo o encontro, mas começou a fazer sons de resmungo mostrando certa impaciência e contrariedade em estar ali. A mãe disse que ele estava cansado. A pesquisadora tentou mostrar os materiais a Augusto, mas ele os rejeitou. Ela disse então que já estavam encerrando e que ela iria vê-lo em outro momento nas suas atividades da piscina e outras. Ele saiu satisfeito e foi marcada a entrevista com a mãe.

Quadro 2: segundo encontro com Augusto

\begin{tabular}{|l|l|l|l|l|l|}
\hline DATA & AMBIENTES & ATIVIDADES & PARTICIPANTES & TEMPO & MATERIAIS \\
\hline $\mathbf{1 8 / 8 / 0 5}$ & $\begin{array}{l}\text { - Sala de } \\
\text { atividades }\end{array}$ & $\begin{array}{l}\text { - Saudação e } \\
\text { Roda de }\end{array}$ & -4 crianças & 2 horas & $\begin{array}{l}\text { Brinquedos e } \\
\text { bóias }\end{array}$ \\
\hline
\end{tabular}




\begin{tabular}{|l|l|l|l|l|}
\hline pedagógicas & conversa & - profissional de & \\
- Vestiário & - Orientação e & Educação Física & \\
- Piscina & Mobilidade & - pesquisadora & \\
& - Atividades da & - câmera & \\
& Vida Diária & & \\
& (vestir-se e & & \\
& higiene) & & \\
& - Atividades & & \\
& Aquáticas & & \\
& - Fechamento & & \\
\hline
\end{tabular}

\section{Descrição:}

Augusto veio da sala de espera acompanhado pela mãe. Vieram juntos com outras crianças e mães. Adentraram a sala e ele atendeu à instrução dada pela professora de Educação Física para sentar-se à roda. Mostrou-se receptivo e respondeu à apresentação que a profissional fez da pesquisadora e do câmera que faria a filmagem. Ele se manteve na roda com balanceios de corpo. Iniciaram uma conversa sobre o que fizeram na semana. Ele ouviu, mas não respondeu. Ao som de "A canoa virou" falando o nome de cada criança com movimentos corporais, Augusto soube os nomes dos amigos. Não cantou, mas se divertiu com os movimentos. Quando perguntado, por várias vezes, sobre o que havia trazido na mochila para ir à piscina, ele deu uma resposta de cada vez a cada pergunta repetida várias vezes: toalha, sunga, chinelo, pente. Ria eufórico. Ao saírem da sala, a mãe informou que esqueceu a bengala e lhe emprestaram uma. Ele ainda não mostrou autonomia na orientação no espaço, mas procurava a parede como referência e, quando solicitado, fazia o movimento de arco no chão com a bengala. No vestiário, usou o banheiro e puxou a descarga sozinho. Só precisou de apoio da mãe para a higiene. Ele a chamou, mas, quando ela o ajudou, ele disse: "Qué limpá sozinho!" Arrumou-se. A mãe o puxou pela mão e o levou para lavar as mãos. Abriu e fechou a torneira para ele e lhe ensinou a pegar o sabonete e a toalha. Ele consentiu e sorriu. A mãe o levou ao banco para vestir-se para a piscina. Ele mostrou iniciativa de tirar o blusão e a mãe o ajudou. Ele mostrou ser capaz de tirar toda a roupa e os sapatos iniciando a ação que precisou ser terminada pela mãe. Ele disse: "Tira!” e depois que ela o fez ele disse: “Brigado". Errou os chinelos e a mãe advertiu. A professora pediu que a mãe o deixasse 
descobrir sozinho, mas ela ficava ansiosa e fazia gestos apressados, antecipando-se. No caminho até a piscina, ela não lhe deu as pistas de referência para que se orientasse no espaço. A professora chamou e ele entrou na piscina pela escada onde foi deixado pela mãe. Uma das mães do grupo entrou também e lhe ofereceu bolas em uma cesta. Ele estava animado e mostrava prazer na atividade. Começou a jogar as bolas. A professora disse "não" e ele parou. Nesse momento as mães se retiraram. Foram a outro espaço para aprender Braille. A professora o levou para o outro lado da piscina para lhe apresentar o espaguete, mas ele voltou à cesta de bolas. Ela o chamou e ele respondeu "não", mas depois atendeu. Ela pediu para ele molhar o cabelo e ele veementemente disse "não". Ela insistiu e ele aceitou. Continuaram as brincadeiras na água, a professora se afastou dele para estar com as outras crianças e ele a chamou. Ela voltou e lhe deu a cesta. Ele ficou satisfeito brincando na borda. Parecia sentir-se mais seguro ali e gostava de estar mais isolado. Nesse momento a pesquisadora se aproximou e perguntou se estava bom na piscina e ele: na piscina de água? É. Tá bom aí? - Tá. Entra! - Eu não trouxe maiô. - Não? - Não. - Entra! - Outro dia.

As mães retornaram e ficaram olhando e conversando entre elas. A professora chamou para outra brincadeira: procurar as bolinhas na água e colocar na cesta. Augusto resistiu e largou a cesta. A próxima atividade foi bater pernas atravessando a piscina junto com os monitores. Ele pareceu aceitar, mas voltou para a borda dizendo: “aqui”. Ele mostrou preferência por estar sozinho, não interagiu com as outras crianças. Quando foi buscado para o exercício com a prancha, ele resistiu, mas depois fez e logo voltou à borda. A pesquisadora tentou uma conversa novamente, mas desta vez ele não respondeu. Passado mais algum tempo ele pareceu cansado e começou a gritar. A professora veio e fez de mãos dadas com ele o pulo de fora pra dentro da piscina. Ele foi, mas voltou para borda, querendo ficar sozinho. Uma criança o chamou, mas ele não respondeu e começou a emitir sons guturais. Aula encerrada, a professora o ajudou a subir a escada e a mãe o recebeu. No vestiário a mãe não esperou para que ele se vestisse sozinho, logo o aprontou e saíram. A pesquisadora disse "até logo" e ele primeiro respondeu "não" e depois se despediu.

Quadro 3: terceiro encontro com Augusto

\begin{tabular}{|l|l|l|l|l|l|}
\hline DATA & AMBIENTES & ATIVIDADES & PARTICIPANTES & TEMPO & MATERIAIS \\
\hline $25 / 8 / 05$ & $\begin{array}{l}\text { - Sala de } \\
\text { atividades } \\
\text { pedagógicas }\end{array}$ & $\begin{array}{l}\text { - Saudação e } \\
\text { Roda de } \\
\text { conversa }\end{array}$ & -4 crianças & 2 horas & $\begin{array}{l}\text { Livro de } \\
\text { história } \\
\text { adaptado }\end{array}$ \\
\hline
\end{tabular}




\begin{tabular}{|l|l|l|l|l|}
\hline & - Cadernos & - pesquisadora & & - Fantoches \\
táteis & - câmera & & \\
- Atividades da & & & \\
Vida Diária & & & \\
(Lanche) & - Retomada da & & \\
história do & & & \\
atendimento & & & \\
anterior e & & & \\
encenação & & & \\
\hline
\end{tabular}

\section{Descrição:}

A pedagoga encontrou as crianças na sala de espera. A mãe não trouxe a bengala novamente e também esqueceu o caderno tátil no qual deveria colar algum objeto que representasse algo significativo para Augusto durante a semana. Mãe se desculpou e argumentou que não sabia como fazer e que não incorporou ainda como hábito o uso da bengala. Enquanto isso, a pesquisadora o cumprimentou e o acompanhou até a sala rastreando a mão dele na parede como referência, chamando-lhe a atenção também para as sinalizações em Braille nas portas. Ele correspondeu quando ela pediu que dissesse "tchau" à mãe. Já na sala foi orientado a guardar a lancheira, mas se perdeu no espaço. A pedagoga antecipou o que ia acontecer no dia mostrando às crianças um "calendário" com objetos de referência de cada atividade que seria desenvolvida. Na roda cantaram a saudação da chegada falando os nomes de cada um na sala e tocando chocalhos. Ele não cantou, apenas passou o chocalho na boca incessantemente. Conversaram sobre a semana, mas ele não contou nada, apenas se auto-estimulava com o chocalho indo e vindo do queixo ao nariz e deste ao queixo. Hora de guardar os chocalhos e ele atendeu, mas se dispersou no caminho e a pedagoga deu-lhe novamente a instrução. Ele pegou a lancheira e ela disse-lhe que antes iriam trabalhar com os cadernos táteis que as crianças haviam trazido. Ela pediu que se sentasse e ele atendeu. Ela passou a lembrar da história da semana anterior e ele começou a imitar um choro (foi o que lembrou da história), mas não contou nada do enredo. Ele ficava muito com a cabeça baixa, agitando-se corporalmente. Continuando a história, a pedagoga perguntou o que tinha na casinha em que ficaram presos João e Maria, esperando a resposta "doce”, mas ele disse: 
"medo". A pedagoga não explorou esse conteúdo trazido por Augusto e continuou perguntando quem gostava de doce, ao que ele respondeu: "Augusto gosta de batata." Nesse momento tocou o telefone e Augusto imitou o som dizendo: "atende". A pesquisadora atendeu e anotou o recado. Ele quis ver levantando-se e dizendo: "vê". Ela mostrou-lhe o papel, passando sua mão sobre ele dizendo que não dava pra sentir porque não estava escrito em Braille.

Continuando a história, a pedagoga perguntou "quem salvou as crianças". Ninguém respondeu. Ela então contou que foi o papai que chegou e abraçou as crianças. Pediu que Augusto abraçasse a amiga e ele assim o fez. Em seguida, ele disse: "pegá o livro" e joga-o no chão. A pedagoga não comentou e trouxe os fantoches para representar os personagens da história. Augusto os pegou e arrancou as pernas. Ela pediu que ele os mostrasse ao colega e ele disse: “ó! vê!" E depois: “o João qué fazê cocô". A pedagoga perguntou quem mais queria. Ninguém respondeu e ela perguntou para cada um dizendo seus nomes e ele disse: "o Augusto qué". A pesquisadora o acompanhou ao banheiro. Ele usou o banheiro sozinho e na hora de lavar as mãos precisou de apoio. A pesquisadora bateu o pé no chão ao mesmo tempo pra ele saber onde estava a lata de lixo. Ele achou graça e imitou a batida sorrindo, então ela aproveitou e fez isso virar uma brincadeira. Voltou à sala rastreando a mão na parede, lembrando o nome de um profissional de uma das salas. Ao voltarem, enquanto as outras crianças ainda estavam no banheiro, a pesquisadora continuou o jogo de ritmos corporais que Augusto repetia com precisão e prazer na brincadeira. Ao retorno das crianças para a sala, tomaram o lanche. Augusto pediu: “Mã, ajuda!” A pedagoga explicou que a mãe não estava e que ela o ajudaria. Ele tomou sozinho o Danone com a colher. Augusto mostrou interagir com os adultos, mas nunca procurava as crianças. Terminaram o lanche e levaram os pratos para uma mesa. Hora do jogo de bola em círculo, sentados no chão, de pernas abertas para receber a bola. Cada um dizia "tô aqui" para ser localizado e localizar o lugar em que cada colega estava sentado e então escolher um deles para jogar a bola. Augusto escolheu a pesquisadora: “jogá pra Eliana”. Augusto pediu para rodar, pareceu cansado e começou a se agitar, bater palmas, fazer balanceios, sons guturais. Logo a pedagoga começou a avisar que estava acabando a atividade e encerraram cantando a canção de dizer "tchau". Na saída a pesquisadora fez uma colocação para a mãe de Augusto, dizendo que havia notado nos dois encontros que Augusto já não procurava agredir. Ela respondeu que depois da escola e da psicóloga ele havia melhorado muito e que em casa ainda fazia, mas com bem menos intensidade. 


\subsection{Análise interpretativa dos dados relativos a Augusto - $1^{\mathrm{a}}$ etapa:}

A análise relativa a Augusto foi baseada na consulta ao prontuário e nas observações realizadas em dois períodos com intervalo de um ano entre eles. Refere-se a dados de história de vida e quadro clínico, bem como a seu modo de apresentar-se ao mundo caracterizando-o como uma criança cega com problemas na constituição subjetiva e no desenvolvimento. Os dados da observação complementaram os do prontuário e vice-versa e não houve contradição entre eles. Os mesmos foram organizados em temas a partir dos elementos que emergiram como significativos, conforme o Quadro 4:

Quadro 4: temas e elementos significativos identificados nos dados do prontuário e nas observações

\begin{tabular}{|c|c|}
\hline TEMAS & ELEMENTOS SIGNIFICATIVOS \\
\hline $\begin{array}{l}\text { Formas de perceber, } \\
\text { explorar, relacionar-se, } \\
\text { compreender, e expressar-se } \\
\text { no mundo }\end{array}$ & $\begin{array}{l}\text { Com } 1 \text { ano começou a morder; nervoso; reagir com agressividade } \\
\text { à aproximação das pessoas e gestos de carinho: mordendo, dando } \\
\text { socos, cabeçadas e pontapés; } \\
\text { Com objetos: quebrando, desmontando, ficando só com um pedaço } \\
\text { e inventando um nome para o fragmento; } \\
\text { Exploração do objeto com a região da boca estimulando-se; } \\
\text { Interaçâo precária com adultos; saber o nome das pessoas e dirigir- } \\
\text { se a elas; não-interação com crianças de sua idade; linguagem } \\
\text { pouco estruturada, mais repetitiva, ecolálica; } \\
\text { Apreensão do mundo muito pela audição, pelo tato, pelo olfato e } \\
\text { pela boca com pouco uso das mãos; não explora e rejeita materiais } \\
\text { para conhecer, usa-os para estimular-se; } \\
\text { Passividade nas atividades de cuidados pessoais, esperando que a } \\
\text { mãe faça; tendência à fixação em objetos, palavras e movimentos } \\
\text { repetitivos; estereotipias; } \\
\text { Em situações incômodas, reação com gritos, resmungos, batendo, } \\
\text { não falando ou falando palavrão; } \\
\text { Diante de solicitações, primeiro recusar, dizer não, depois atender } \\
\text { e consentir, mas voltar ao seu querer. }\end{array}$ \\
\hline $\begin{array}{l}\text { Manifestações de } \\
\text { comprometimentos na } \\
\text { constituição subjetiva e no } \\
\text { desenvolvimento }\end{array}$ & $\begin{array}{l}\text { Isolado; até os } 4 \text { anos mais voltado para si mesmo; problemas na } \\
\text { relação com o outro; } \\
\text { Uso de objetos pelo prazer e satisfação libidinal e não pela função; } \\
\text { Problemas com a constituição da imagem corporal e formação do } \\
\text { "eu"; diferenciação eu-outro sem muita estabilidade e consistência; } \\
\text { falar de si na terceira pessoa do singular ou usar seu próprio nome } \\
\text { e não usar o pronome "eu" e seus referentes; saber que é ele, mas }\end{array}$ \\
\hline
\end{tabular}




\begin{tabular}{|c|c|}
\hline & $\begin{array}{l}\text { de forma difusa; } \\
\text { Problemas na função simbólica, jogo simbólico e funções } \\
\text { cognitivas; } \\
\text { Dependência nas atividades práticas e na orientação e mobilidade } \\
\text { no espaço, mesmo tendo capacidade; } \\
\text { Não brincar, usar somente fragmentos de brinquedos e outros } \\
\text { objetos para auto-estimulação; não inventar; } \\
\text { Não distinguir afetos; dificuldade em entender limites, preso às } \\
\text { suas necessidades e prazeres; não identificar nem falar de } \\
\text { sentimentos. }\end{array}$ \\
\hline $\begin{array}{l}\text { Manifestações de pontos de } \\
\text { abertura para a constituição } \\
\text { subjetiva e o desenvolvimento }\end{array}$ & $\begin{array}{l}\text { Após } 1 \text { ano do primeiro encontro: } \\
\text { Mudança no olhar da mãe sobre Augusto; a escola; a psicoterapia, } \\
\text { a neurologista; Buscar relacionar-se; tencionar comunicar-se e } \\
\text { responder a perguntas, ainda que muito insipientemente; } \\
\text { Diminuição sensível das agressões no contato com as pessoas; } \\
\text { Novas aprendizagens, como seguir instruções, formação de } \\
\text { conceitos, compreensão de perguntas, começando diálogo simples; } \\
\text { reconhecimento de objetos e noção de identidade, permanência e } \\
\text { conservação; curiosidade sobre o mundo, seu funcionamento e } \\
\text { ocorrências; aprender experimentando e perguntando; } \\
\text { reconhecimento de pessoas pela voz e associação com seus nomes; } \\
\text { inventar nomes para fragmentos de objetos; usando estratégias } \\
\text { para conseguir o que quer; discriminar objetos e pessoas; fazer } \\
\text { associações; } \\
\text { Desenvolvimento de competências psicomotoras e na mobilidade; } \\
\text { Brechas de comunicação pela música; ilhas de inteligência; } \\
\text { Envolvimento e permanência nas atividades; } \\
\text { Começar a projetar-se no objeto; começar a fazer escolhas; } \\
\text { Mobilidade independente em casa; } \\
\text { Conhecimento das partes do seu corpo e do corpo do outro; } \\
\text { Mãe confiante que ele pode aprender e procura ensinar; } \\
\text { Aos } 5 \text { anos está entendendo alguns limites ainda que não os queira } \\
\text { aceitar; } \\
\text { Aceitação de contato físico como abraço e beijo. }\end{array}$ \\
\hline
\end{tabular}

\subsubsection{Formas de perceber, explorar, relacionar-se, compreender e expressar-se} no mundo.

À época do primeiro encontro com Augusto ele mostrava em seu comportamento o que fora enunciado em seu histórico de vida e quadro clínico pelas falas de sua mãe e registrados pelos profissionais da instituição em prontuário: não falava, a não ser por uma fala repetitiva que não propunha abertura e tampouco manifestava interesse na relação com o 
outro e no diálogo. Auto-centrado, referia-se a si mesmo pelo próprio nome, passava um pedaço de papel na boca com movimentos repetitivos de auto-estimulação, andava pela sala conhecendo-a em toda a sua dimensão parecendo formar dela um mapa mental. Por momentos se detinha em algum móvel, explorava-o com as mãos para depois continuar rastreando ao largo da sala e também dirigindo-se à pesquisadora, quando a ouvia falando com sua mãe ou chamando por ele pelo nome ("o Augusto qué salgadinho”...). Fazia contato do modo que sabia: investiu na direção da pesquisadora com cabeçadas com um impulso tão forte que, se pegasse, machucaria quando ela fez menção de aproximar-me dele. Poderíamos dizer que era sua forma de fazer contato. Quando detido, dava socos e pontapés, mostrando defender-se para permanecer em seu modo conhecido de funcionamento, em seu gozo, ainda que aprisionado nele, poderíamos dizer.

A mãe ilustrou, nesse dia, as manifestações de agressividade de Augusto em casa:

(...) ele quebrou muito a minha casa, quebrou muita coisa, muito nervoso (...) E ele tem uma força enorme. $O$ tapa dele, dependendo do local que ele atinge, ele derruba um adulto. Ele bateu num rapaz, o rapaz lá vizinho nosso sabe que às vezes ele chega a agredir as pessoas, pegou ele assim sem esperar, bateu na parte íntima dele e o cara caiu no chão. Foi tão forte a pancada, que ele caiu. Ele tem o braço forte. O tapa dele machuca. Ele dá cabeçadas. Se você segurar a mão ele dá cabeçadas.

(...) quando ele era bebê, o pai fechava a mãozinha, começou a ensinar ele a dar soco...,

(...) tudo dele era, tanto era jogar, quebrar tudo, destruir... Televisão: se você deixar ele só, ele que jogar a televisão no chão, ele quebrou três TVs minhas. Quebrou quase tudo, assim, os eletrodomésticos (...) é que não foi comigo em casa, né? A televisão tava uma no quarto das crianças... elas lá na cama, conversando... ele vai, é de repente, é sem esperar, que ele vem e joga.

Percebemos também em nosso encontro que, quando ele tentou abrir um armário, quase quebrando, que essa era sua forma de conhecer e explorar. Mas vi também que havia explorado a sala sem quebrá-la e isso, de certa forma, contrariava a unanimidade do que era dito sobre ele. E a mãe usa o verbo no tempo passado para dizer:

(...) se antes ele visse uma porta assim no guarda-roupa, ele tenta abrir e força ela ao contrário, até soltar a porta do guarda-roupa. Então, assim, tudo o que você possa imaginar, ele tenta assim, de alguma forma, tirar do local, modificar...

Chama a atenção a interpretação da mãe sobre o quebrar como querer modificar e não agredir. Poderíamos pensar aqui em um traço de curiosidade, o que nos leva também a aludir a um prenúncio de desejo de saber. Mas sua curiosidade é satisfeita muito rapidamente e precisa da mediação de alguém para levar adiante o que poderia ser um conhecer e saber do 
objeto. Ele o modifica, mas ainda para a mesma finalidade de satisfação ligada à região da boca, com uma sobrecarga libidinal nessa fonte de prazer.

O mundo lhe chama atenção muito pelo que ouve, toca e cheira como referência de sua concretude e substancialidade, conhecendo-o predominantemente por esses canais de percepção, como é confirmado pela mãe:

O que ele pôr a mão... telefone, coisas assim... utensílios domésticos, tudo o que ele pôr a mão, a maioria, acho que noventa e cinco, noventa e nove vírgula nove ele sabe. Só alguma coisa que ele não pôs a mão mesmo, que ele nunca... é... ouviu.... E ele agora, tudo ele quer saber: o que que passa. Se passa uma moto, ele pára: que que é isso? Aí eu vou e falo: "É o barulho da moto". Aí ele vai memorizando. Quando eu saio com ele, ele sabe o que é que tá passando. Só no som ele já fala: "É o ônibus, é a moto", entendeu? Ele consegue, já, distinguir já os sons...

Se a irmã vai na ponta dos pés (...) ele escuta e vai correndo (...) às vezes ele acerta (o lugar que ela está) pelas risadas e às vezes ele... dá um cheiro assim... se ela tá de perfume, ele corre atrás e consegue localizar ela.

Tudo que ele vai pegar, ele cheira primeiro. Antes passa a mão pra ver o que que é e depois cheira... pela voz ele percebe tudo em volta.

Tato ele buscava quando ele queria se locomover, né? Balançava alguma coisa, algum som longe, ele escutava, ia até lá, pegava com a mãozinha, aí ele realmente sabia que era aquele som que eu fiz, entendeu?

Ele mostrava percepção do mundo ao seu redor pela repetição das atividades da vida diária, como a hora do banho, e esse é um sinal importante na noção da realidade externa:

O banho dele era sempre no mesmo horário... quando eu ultrapassava, atrasava dez minutos, ele já chorava, porque já sabia que já passou do horário...

Usa a audição desde bebê como um canal perceptivo fundamental em sua apreensão do mundo, o que foi um ponto forte em sua relação com a mãe, quando reconhecia sua voz e respondia a ela e hoje continua, como vemos neste relato:

Devido a ele escutar a voz, ele ria, você vê as reações do bebê, entendeu? "Mamãe tá aqui!" Então a hora que ele escutava a minha voz, ele já se jogava em direção à minha voz, pra vir pra mim... entendeu?

(...) Em direção dos sons ele sempre... se chegava assim perto da gente...

(...) ele percebe os sons, tudo. Passa um cachorrinho, algum conhecido assim, ele fala quem é

e... sempre. Pela voz, ele percebe tudo em volta.

Nesse tempo a invasão de estímulos sonoros lhe causava estresse, desorganizando-o internamente também, como é comum acontecer com as crianças cegas bem pequenas que se 
não tiverem a presença de alguém que lhes ajudem a discriminar esses estímulos e sentirem-se seguras, ficam mergulhadas neles sem poder construir internamente a representação dos mesmos.

\begin{abstract}
Quando bebê eu acho que ele teve muita dificuldade. Era muito som ao mesmo tempo, ele não conseguia distinguir de onde vinha. Eram pessoas que chegavam, pessoas que iam embora... (...) músicas barulhentas que, no começo, ele ficava agitado, daí ele não conseguia assimilar o som muito alto e também nem... muito assim, o som muito... Músicas muito agitadas deixavam ele nervoso... Até hoje.

(...) quando eu ligava a televisão, podia ser o que fosse: um som barulhento ou mais tranqüilo, ele não agüentava... Desligou... ele quebrou muitos sons em casa, ele não agüentava assimilar, né?! (...) Até mais ou menos um ano, um ano e meio atrás.
\end{abstract}

Ainda assim, Augusto diferenciava as pessoas da casa e as estranhas, o que indica que ele tinha noção de diferença :

\begin{abstract}
Eu acho que ele não tinha muito essa percepção, não, né? Mas, assim, das irmãs, que são as pessoas que tem um contato diariamente dentro de casa, ele sabia. Porque, pelo som, ele se jogava pra pessoa. Mas só as pessoas que ele via pouquíssimas vezes, ele segurava em mim, na minha mão, e não ia, entendeu? Como se percebesse que aquela pessoa era uma pessoa estranha, entendeu? Mas, os tios, que tinham contato com ele, a avó, ele se joga...
\end{abstract}

Essa discriminação das coisas do mundo pela audição apóia a criança cega no teste da realidade e os relatos mostram que Augusto o fazia, e que tinha possibilidade de perceber a presença/ausência da mãe para diferenciar-se dela. E, se ele era capaz de usar a referência sonora para se lançar ao mundo e buscar o que queria, é porque já havia em algum nível uma abstração de experiências anteriores no contato com a mãe e outros objetos, o que também o auxiliaria na formação do conceito de objeto, como também a pulsão da voz seria sua força para constituir-se. Mas algo parece ter se interrompido nesse percurso, pois com um ano, quando passou a morder, fixou a libido na boca até os quatro anos como forma primordial de contato, restringindo as experiências que levam ao conhecimento do mundo, à relação com o outro, à circulação social e, portanto, à diferenciação entre o eu e o não-eu.

Ele estava com dois anos quando sua mãe saiu para trabalhar fora, deixando-o com as irmãs que não cuidavam dele. Assim, ficava à mercê do ambiente, sem controle, sem contorno, sem limite, sem estímulos significativos para ele e sem segurança com a referência de alguém. Isso intensificou suas mordidas e outras investidas agressivas contra as pessoas e objetos. 
Ele começou a morder na hora que é a fase que começou a sair os dentes... uns seis... O primeiro dentinho saiu com cinco meses, o primeiro. Aí parou, aí começou a nascer o segundo, em diante os outros. Com sete, oito meses começou a vir em seqüência. E... aí começou (riso). Foi aí meus erros, porque se eu tivesse tratado ele como uma criança normal, talvez ele não me desse tanto trabalho como ele deu esses últimos anos, porque ele quebrou muito a minha casa, quebrou muita coisa, muito nervoso, devido eu ter que trabalhar...

(...) eu precisei trabalhar, e aí foi que começou a quebrar e agredir...

(...) em casa, por exemplo, as filhas estão no sofá, ou dormindo e ele chega e, sem mais nem menos, as agride com socos e cabeçadas que realmente as machuca tamanha é sua força. Ou então, ele vai à cozinha e começa a quebrar tudo.

(...) eu trabalhei quase dois anos, não, mais, dois anos e dois meses, que ele foi orientado por outras crianças, e eu muito cansada, acordava quatro horas da manhã pra ir trabalhar. Então, aí, foi o.... a fase que ele precisou de mim e eu não tava próxima a ele para orientar, pra ver onde tava errado. E mesmo, acho, que eu próxima, eu errei muito nos erros, né? Porque, quando eu fui normal, ah, isso não é certo, ah, isso é errado. Então você corrige. E por ser deficiente, eu achava que tudo pra ele tinha que ser daquele jeito, entendeu? Então foi o теи еrro.

E eu falo, eu cobro das minhas filhas, porque uma tinha doze e a outra tinha dez. Eu falo: "Filha, pelo amor de Deus, deixa a casa do jeito que tá, suja, só cuida dele, só dá atenção pra ele. Quando a mãe chegar, a mãe limpava”, entendeu? Mas elas dormiam tarde, acordavam tarde e ele, sem enxergar, acordava e saía destruindo tudo o que via pela frente.

Ele ficava sozinho... algumas horas ficava, porque... eu ia chorar, eu ia trabalhar chorando, porque eu pensava: "eu preciso trabalhar, né?” (choro) Difícil... (chorando muito) Eu precisava ir trabalhar, né, pra dar as coisas assim pra elas... O pai não soube me compreender (chorando). Foi difícil essa fase.

Entregava na mão de Deus e ia... Aí, quando eu vi que não agüentava mais, que não dava mais certo, que a minha filha mais velha tava saindo muito de casa, judiando do Augusto, não dava a refeição nada correta, né? Deixava ele dormir na hora errada, também. Ele não tinha horário pra acordar com ela, né? Às vezes eu chegava três horas do serviço, o Augusto já tava dormindo.

Também referiu-se às discussões permeadas de gritos que tinha com o marido, cenas agressivas às quais Augusto presenciava.

Sua agressão hoje parece também ser sua forma de ter um lugar no mundo e a usa para mostrar e obter o que quer - pois não sabe se comunicar de outro jeito - e quando não consegue satisfazer sua vontade imediata, não sabendo esperar, ainda com dificuldades em relação ao princípio de realidade. Encontramos no relato da mãe algo que expressa isso:

\begin{abstract}
Algumas vezes tem reação de agredir, quando o portão está fechado. Com o portão aberto, ele já não agride ninguém. Não sei porquê ele faz isso. Qualquer pessoa. Vai um vendedor, um menor, qualquer coisa... se aproximou muito, se não souber, ele agride com o portão fechado. Com o portão aberto, se você chamar: "Vamos passear?", ele vai com a pessoa...
\end{abstract}

Augusto vem demonstrando, desde os quatro anos, aproximadamente, a exploração de objetos por meio do tato e olfato, com maior interesse sobre o mundo. Toca as coisas e sabe o 
que são, mas percebemos que usa pouco as mãos para explorar e se valer dos objetos. Aliás, não mostrou interesse e não brincou com os objetos e brinquedos que havia na sala, em nosso primeiro encontro, mantendo-se fixado ao movimento de rodear a sala sem cansar, parecendo obter prazer naquela forma estereotipada e aparentemente sem sentido de estar lá. Não vinculava com o contexto e com as pessoas naquela situação.

Mas ele mostrou compreender o significado das palavras que lhe eram ditas, respondendo com ações e poucas palavras:

Pode entrar... (foi entrando na sala ao meu convite)

Entre e feche a porta, por favor. (puxou a porta de correr)

Venha cá sentar! (atendeu à mãe, aproximou-se dela e sentou)

Quer ir ao banheiro? (Qué)

Depois você vai comer salgadinho. Está na bolsa... (estendeu o braço)

Você já pode ir... (não levantou)

Vamos, Augusto?! (levantou-se ao chamado da mãe)

A mãe complementou, mostrando que ele tem alguns conceitos formados, sendo capaz de seguir instruções e orientar-se no espaço para sua mobilidade com independência:

Ó, eu tranquei o portão, porque tem que varrer a frente da casa lá. Aí eu falei: "Augusto, vai em direção à mamãe e me traz a vassoura, está próxima à porta da cozinha, na garagem. Não é pra entrar". Ele foi reto, pôs a mão na porta da cozinha. Aí eu falei: "Então, tá do outro lado". Aí ele foi, pegou a vassoura e me trouxe.

Além disso, nesse mesmo encontro, quando Augusto já se mostrava cansado, começou a resmungar, gritar e puxar a mãe. Isso mostrava que havia uma comunicação e, portanto, uma organização conceitual e acesso à função simbólica, ainda que não o fizesse por palavras. Isso corroborava o que tínhamos de informações sobre ele vindas do prontuário e dos profissionais da instituição. Na saída respondeu ao meu "até logo".

Um outro comportamento de Augusto que chama atenção diz respeito à sua relação com os objetos inanimados: não brinca com brinquedos e objetos inteiros com significados e funções próprias deles, mas retira pedaços ou quebra-os para obter deles fragmentos e inventa-lhes um nome (sílabas reunidas aparentemente sem sentido), fixando-se a eles, como contou a mãe:

Tem uma pecinha do... prendedor de cabelo da minha filha, ele é um formato igual a uma flor e ele é duro, o plástico, e aquilo é "izilo"... e fica "izilo", e se eu perder o "izilo", eu tenho que pegar e comprar outro lacinho de corta, entendeu? Então... Tem uma parte da vassoura, que é aquela parte de fora, azul, que é de plástico, ele desencaixa e fala que aquilo é “duiuiu”, e é “duiuiu”... Então são palavras que a gente não encontra e nem é, entendeu? Ele 
dá o nome nos brinquedos, e só sabe quem convive com ele... Ele põe nomes, assim, absurdos, e tem hora que até eu esqueço, entendeu?

Esse modo de Augusto construir concretamente seus objetos e apegar-se a eles nos remete ao relato da mãe sobre o período dele bebê, quando passou muito tempo ficando sozinho, centrando-se no próprio corpo e no corpo da mãe sem investir libidinalmente os objetos. Augusto hoje incorpora os objetos de acordo com sua realidade psíquica, mostrando relações objetais fragmentadas, as quais tenta nomear, representar, fazer adquirir significados próprios. Cria seus objetos como uma forma sofisticada de manter o investimento da libido em si mesmo, continuando a estimular-se com eles. O que a mãe relata sobre isso:

\begin{abstract}
Algumas coisas ele leva à boca e morde... algumas coisas ele brinca, fica esfregando, né? Embaixo do queixo, em cima do queixo, vai até assim no nariz assim e desce, sobe, e fica gesticulando esse gesto durante mais de meia hora. Se você deixar, ele senta, cruza as perninhas e fica fazendo esse movimento, esse gesto de debaixo do queixo até o nariz, ele fica descendo até... tem até um... tem até um pouquinho escuro embaixo assim do queixo, de tanto que ele faz assim esse movimento. E é tudo, é tudo, era um brinquedo, um pano, um papel... o que ele encontrar, ele pega o papel dobra em vários tamanhozinhos e fica fazendo esse mesmo movimento. Aí, aos poucos eu fui tirando, né? Chamando ele pra brincar, pra cantar uma musiquinha, pra ouvir um som, aí aos poucos, ele tá diminuindo mas, de vez em quando, ele ainda senta e faz esse movimento de novo...
\end{abstract}

Augusto mostra o que é comum em algumas crianças cegas quando têm dificuldades para passar da primeira fase oral (passiva) para a segunda (ativa), na qual a mão passa a ser preponderante na conquista do mundo, assim como o morder, por volta de um ano de idade, fase na qual também se estendeu por muito tempo, permanecendo em um estado confusional entre os impulsos agressivos e libidinais (Cf. SANDLER, 1963).

Até um ano mostrava-se ao olhar da mãe uma criança normal porque era "quietinho" e se desenvolvia bem no aspecto motor, ficando em pé no berço, levantando e se apoiando nos móveis, movimentando-se pela casa com o andador. Em sua motricidade mostra competências para realização de tarefas, as quais não faz, ficando em uma posição de passividade, esperando que a mãe faça para ele. Poderíamos pensar na passividade que a literatura da área indica como característica da criança cega que fica limitada para se lançar na experiência (Cf. BURLINGHAN, 1965). Mas o que isso significava em Augusto?

A mãe de Augusto só tinha olhos (preocupação) para seu desenvolvimento motor, como indicou em vários momentos da entrevista:

Ele era normal. Ele jogava um brinquedo, ele levantava do berço, em pé... tudo o que uma criança normal fazia, ele faz. Faz até hoje, entendeu? Mas, assim... ele não fazia nada 
anormal, pra você achar que era um deficiente. O problema dele era só que ele não via... entendeu? Aí eu busquei a ajuda da Laramara quando bebê por isso: pro engatinhar dele, entendeu?

(...) eu vim naquela preocupação: o engatinhar e o primeiro passo. Aí eu comecei a comprar andador, pra ele se proteger, pra não bater, porque é muito pequenininho, entendeu? Saber de coordenação motora, essas coisas... Assim... Eu nunca trabalhei, né?! Até esse tempo... Então me dedicava a ele e minhas filhas.

Ela parecia considerar que a normalidade de uma criança é dada pelo desenvolvimento motor corporal. Esqueceu-se da cena que se inventa para um filho ao colocá-lo no mundo. A cena, a representação, a presença da cultura, a linguagem que está oculta entre o sensório e o motor e que faz aparecer um corpo-imagem afetado pelo discurso do Outro, como a Psicanálise advoga em relação à constituição do sujeito. Assim é que Augusto mostra ter a competência motora, mas não faz nada com ela ainda. Pode ter um prelúdio de imagem do corpo e não usá-la porque ainda não há representação psíquica possível da vivência dessa motricidade, instalando-se um descompasso, que está de acordo com o que diz Levin (2000). Essa forma de pensar o "saber fazer" com o corpo, que depende do que o enseja - o desejo - é o que Burlinghan (1965) não dimensionou em seus estudos, responsabilizando a falta de iniciativa apenas à condição da falta do estímulo visual.

\subsubsection{Manifestações de comprometimentos na constituição subjetiva e no} desenvolvimento

A partir da primeira observação de Augusto começo a pensar sobre o modo dele conduzir-se na vida. Com a presença de uma estruturação psíquica insipiente, perto de seus seis anos, mostra-se excluído da ordem simbólica, mas lutando para aí inscrever-se com suas condutas agressivas que clamam por ser reconhecido em sua existência mergulhada em um mundo de sensações corporais com as quais permanece estimulando-se muitas vezes, mundo pouco simbolizado e pouco partilhado com outros.

Dessa forma, o modo peculiar como Augusto se apresenta ao mundo com sua cegueira, em sua família, sua casa, a vizinhança e a instituição que freqüenta... mostrando como é sua vida, como pensa, age, brinca e como vê o mundo, nos levou a dizer dele que é uma criança que teve problemas na instauração da vida psíquica, na constituição de sujeito, na entrada para a linguagem, no relacionamento com os outros, para diferenciar-se deles e fundar o seu "eu", fazer laço social, aprender e desenvolver-se nas competências funcionais e cognitivas, com diferenciação tênue entre o "eu" e o outro, um "eu" sem consistência ainda. 
Enfim, suas expressões no mundo refletem os impasses de sua subjetivação e seus problemas de desenvolvimento. Os trechos recortados de dados de prontuário e das observações e falas da mãe que foram citados ilustraram isso.

Em sua forma de brincar também mostra uma atitude estereotipada, como aparece em um relato da mãe:

O brincar tanto é assim, que eu te falei, o mesmo gesto passando no rosto. Às vezes eu sento junto com ele, mostro pra ele que é de rodar, tudo. $O$ brincar dele é mexendo, procurando e sempre gesticulando o mesmo gesto...

Ele também não inventa uma brincadeira de faz-de-conta, como continua sua mãe:

Não, não. Às vezes ele fala: “Augusto quer ir pra escola”. Aí, quando eu sei que ele quer escrever, eu dou papel e caneta e ele fica: rabisca, rabisca, rabisca a folha até... daqui a pouco, quando eu penso que ele tá... ou também ele se risca ou ele começa a amassar, dobra, dobra, dobra, quando tá fininho, começa a esfregar de novo...

Ele começou aos quase seis anos a brincar de bola, sentado, um jogando para o outro, e de esconde-esconde. Esta última brincadeira promove uma elaboração da ausência da mãe, o que incita a formação do conceito de objeto, sua permanência e conservação.

Identificamos em Augusto um traço que Levin (2002) aponta como indicador de problemas na constituição da imagem corporal, que é o fato da criança não sentir dor como evidência de uma evanescência do registro dos limites do corpo. Como relatou a mãe, ele só sente quando algo parece se interpor entre ele e a realidade externa de modo irremediável e capturá-lo fazendo-se significante, como vemos abaixo:

Sabe, e se machucar... e se chegar e machucar o pezinho, ele fala: "Está sangrando o pé”. Só que ele não sente dor, ele não chora e fala: "Ah, tá doendo", né? Pra ele sentir uma dor, chorar mesmo, é preciso o negócio ser feio mesmo. Aí... Que tipo de dor o faz chorar? Um tombo que ele não esteja esperando, que ele machuque mesmo...

É. Ele já chegou a cair duas vezes da escada, rolou a escada, foi só o susto, mas aí... chorou também...

É importante ressaltar que alguns marcos no início da vida de Augusto e alguns de seus traços e comportamentos já sinalizavam precocemente indícios desses comprometimentos: a estagnação do curso da libido com primazia do prazer na boca, o estado de confusão ente os impulsos agressivos e libidinais, o isolamento pela falta da referência do 
adulto como presença do Outro (materno), a fusão com a mãe até por volta dos quatro anos de idade, o relacionamento com as pessoas via agressividade.

Augusto ficou só, sem pai nem mãe, no início de sua vida. Que mundo lhe foi apresentado? Ou mundo algum? Já nos referimos ao seu isolamento no período dos dois aos quatro anos, quando sua mãe foi trabalhar e suas irmãs não o olhavam. Antes disso, porém, a presença da mãe não foi subjetivante, ou seja, não era um espelho para Augusto ver-se e não enunciava palavras sobre ele, não encarnou o Outro com seu desejo sobre esse filho, como veremos nos dados da entrevista com a mãe.

Quando perguntada na entrevista se Augusto tinha alguma noção de ser ele mesmo em relação aos outros para investigar em que medida apresentava uma consistência na formação do seu “eu", a mãe respondeu:

\footnotetext{
Aí você me pegou! Se ele consegue saber que ele é o Augusto? Eu acho que sim, porque às vezes ele fala: "O Augusto quer isso", entendeu? Às vezes ele pega um... uma mochila, aí ele fala: "Essa mochila é da Letícia”, da irmã dele, entendeu? Às vezes ele pega um certo objeto e ele fala de quem é o objeto, entendeu? Então, creio eи que sim.

(...) mais ou menos com cinco anos ele começou a.... eu comecei já a passar isso pra ele, né?

(...) ele sabe e percebe o que se passa à volta dele. Ele não é uma criança alheia...

(...) percebe os sons, tudo. Passa um cachorrinho, algum conhecido assim, ele fala quem é e... sempre. Pela voz, ele percebe tudo em volta.
}

Aos cinco anos Augusto ainda vê a si mesmo de forma alienada como se estivesse fora dele a sua identidade. Não introjetou a imagem. Essa passagem de uma "exterioridade" para uma interioridade" como Lacan mostrou na metáfora do espelho, na qual a criança se reconhece primeiro no Outro, no desejo que este lhe endereça e que vai ser lido como algo que esse Outro quer dele para depois reconhecer-se a si mesmo. Augusto sinaliza o momento em que está chamando-se pelo próprio nome ("o Augusto qué almoçar... o Augusto qué água com gelo... o Augusto qué batata frita... qué xixi”). Parece não ter incorporado sua imagem, pois o olhar de sua mãe como o Outro (materno) parece ter ficado não totalmente apagado, mas vacilante. Um olhar sem palavras que enunciassem quem era o Augusto, dirigindo-lhe mensagens de desejo de alguém que podia ver algo nele para que ele pudesse ver-se, estabelecendo a cadeia significante que o marcaria, primeiro como objeto do desejo da mãe, para depois ser sujeito do seu próprio desejo. O olhar da mãe de Augusto era um olhar que não podia se completar no ato de olhar, pois ela desmaiava. Ela ficava "cega", escurecia-lhe a vista e não podia vê-lo, pois somente via à sua cegueira. Um olhar que se interrompia e que 
não chegava à palavra da mãe sobre seu bebê. Não havia a mediação da palavra que diz do sujeito na constituição de sua imagem e que o lançasse na rede simbólica enlaçando-o como alguém que passa a fazer parte dessa família, dessa cultura. Aliás, o que a mãe de Augusto via era sua representação de cegueira: a dependência, a impossibilidade de vida, o nunca sair de casa. Mas hoje Augusto fica no portão e quer ir à casa dos vizinhos, como vimos.

Ainda sobre o "eu" de Augusto, este está se formando e ainda é um "eu" sincrético, denominação adotada por Fraiberg e Adelson (1982) em seus estudos sobre crianças cegas congênitas, ou seja, um “eu” ligado à consciência de necessidades apenas ("Augusto qué...”) e não deduzido do seu desdobramento na imagem especular.

Augusto, quando bebê, mostrou um desenvolvimento motor adequado para a idade e sua mãe conseguiu, apesar da depressão, fazê-lo utilizar suas capacidades perceptivas não visuais. Ele estava formando a imagem da mãe, pois a reconhecia pela voz e a diferenciava dos outros, mas, por volta de um ano, pareceu interromper esse caminho, como evidenciam as palavras de sua mãe:

\begin{abstract}
A hora que ele escutava a minha voz, ele já se jogava em direção a minha voz, pra vir pra mim... entendeu? Ele pegava, brincava normal. Se era chocalho, ele balançava, se era mordedor, ele levava à boquinha, muita coisa ele levava à boca. Toda criança na idade dele, primeiro leva a boca, né...

(...) bebê não deu muito problema, né? Ele era muito gorduchinho, todo mundo queria pegar, todo mundo tinha prazer em tirar foto com ele, todo mundo gostava demais dele. Todo lugar, no ônibus, queria pegar ele no colo, essas coisas, né, normais. Aí, quando ele começou a ter os dentes dele, começou a morder, essa fase de morder, eu achava que era normal, por ele ser cego... Foi aí um dos meus erros, também. Eu não soube... eu não soube assim... corrigir na hora que eu devia, fui deixando, ele foi mordendo, foi ficando agressivo... ele mordia só os outros... as pessoas.

Ele começou na hora que é a fase que começou a sair os dentes... uns seis... O primeiro dentinho saiu com cinco meses, o primeiro. Aí parou, aí começou a nascer o segundo, em diante os outros. Com sete, oito meses começou a vir em seqüência. E... aí começou (riso). Foi aí meus erros, porque se eu tivesse tratado ele como uma criança normal, talvez ele não me desse tanto trabalho como ele deu esses últimos anos, porque ele quebrou muito a minha casa, quebrou muita coisa, muito nervoso...
\end{abstract}

\title{
2.1.3. Manifestações de pontos de abertura para a constituição subjetiva e o
}

\section{desenvolvimento}

Como mostraram as descrições das observações de Augusto nas atividades da instituição e também o relato da mãe nessas situações, vimos, entre o primeiro encontro com ele e os outros, passado um ano, mudanças importantes em suas condutas e relações no 
mundo. Nas duas atividades observadas - uma no vestiário e na piscina, outra na sala de espera e na sala de atividades pedagógicas - ele mostrou aceitação na aproximação das pessoas e já não agredia as crianças e os adultos, mesmo interagindo pouco. Compreendia o que era dito e seguia as instruções, participava, apenas não tomava iniciativa. Ainda se isolava em alguns momentos, mas com poucos maneirismos (movimentos repetitivos próprios de crianças cegas), uma vez que estava mais integrado ao social e sua libido já era canalizada para os objetos.

Mas alguns sinais já se evidenciavam desde a entrevista com a mãe quando podíamos ver pontos de abertura para apostarmos em sua constituição subjetiva e desenvolvimento. Augusto é uma criança viva, anda pela casa, quer ficar no portão e conversar com os vizinhos, sair para a rua e ir à casa deles. Pede-lhes isso, como vemos na seguinte passagem relatada por sua mãe:

\begin{abstract}
Às vezes, ele repete o que as pessoas falam e às vezes ele consegue ter, tá começando a ter um diálogo, entendeu? Fazer perguntas, pedir alguma coisa. Passa vizinhos, chega no portão: "Oi, Augusto, bom dia!" e ele repete, entendeu, conversa. Ele... pela voz, a maioria das vezes, ele acerta as pessoas que são, fala os nomes, pede pra pessoa segurar no portão, porque segurar no portão ele apóia a mão dele em cima e não deixa a pessoa ir embora. Pra ele, todo mundo que chega próximo, ele dá a mão e ele fala: "Dá a mão pro Augusto". Não é pra mim, é pro Augusto e puxa a pessoa e segura aqui, e ele fala: "Segura aqui, qué assim”. E segura, e segura a mão dele por cima das mãos das pessoas, pras pessoas não irem embora, pra ficar lá com ele, entendeu?
\end{abstract}

Vemos nesse trecho a abertura de Augusto para a relação com o outro (como vimos nas atividades observadas na instituição), o início do diálogo, os conceitos aplicados à situação, a ampliação de seu universo familiar, o prazer voltado para a atividade e não apenas vinculado ao seu corpo na auto-erotização, embora ele ainda o faça sobremaneira. Um exemplo de diálogo foi o que ele teve com a pesquisadora quando ela se aproximou e perguntou se estava bom na piscina e ele:

--Na piscina de água? - É. Tá bom aí? - Tá. Entra! - Eu não trouxe maiô. - Não? - Não. Entra! - Outro dia.

Em uma das observações foi muito interessante o jogo sutil que experimentou com a pesquisadora: um jogo rítmico que ela iniciei como um chamado a Augusto. Ela batia os pés no chão em uma dada cadência e ele repetia, ou melhor, imitava e o jogo foi se tornando uma conversa. Mostrou inteligência, comunicação e relação com o outro. Mostrou também que seu mundo é rico se soubermos como evocá-lo. 
Nas atividades de observação participativa vimos então (e a mãe assinalou nessa situação) que ele está começando a brincar, pois ainda é freqüente apenas a auto-estimulação com os brinquedos ou outros objetos. Ela conta que "ele brinca de esconde-esconde (...) brinca de bola”. Quanto ao brincar de esconde-esconde, sabemos, desde Freud (em 1920), que representa o significante da ausência que levará à identificação com a mãe e reconhecimento de si mesmo com a construção interna do objeto. Muitas crianças cegas congênitas, como vemos em Augusto também, mostram uma fragilidade nessa construção. A literatura aponta a falta da visão como um elemento importante nessa dificuldade, mas não deixamos de frisar que não se trata da cegueira em si, mas daquilo que ela pode representar para a mãe da criança e que dificultará a relação.

Em relação à abertura de Augusto para o brincar, a mãe relata uma brincadeira que faz em casa, da qual gosta muito, e como é seu modo de brincar:

(...) Com bola. Às vezes, pra mim ficar mais próxima dele, ele fica na minha frente e fala que quer "assim". Aí ele quer que eu ponha as mãos por trás dele, segurando nos braços dele, pra na hora que a bola vir, eu já direcionar ele a agarrar a bola, entendeu? E ele ri pra caramba, quando a gente brinca assim. Ele gosta.

(...) Se eu deito no tapete, ele: "Vira, mamãe, vira”, aí eu viro. Quando eu viro, ele monta e fala: "Agora vamos, vamos brincar de cavalo". Aí eu começo a andar no tapete de quatro e ele morre de rir em cima de mim, entendeu? Assim ele brinca.

(...)Mas se pegar um bichinho, um ursinho, fazer de conta que é o nenezinho dele...

“dorme, nenê...” (...) fazer de conta que é... não...

É interessante notar como ele está sentindo prazer em algumas brincadeiras como se deu na terceira atividade observada:

A pesquisadora bateu o pé no chão ao mesmo tempo que falava pra ele saber onde estava a
lata de lixo. Ele achou graça e imitou a batida sorrindo, então ela aproveitou e fez isso virar
uma brincadeira. (...) ao voltarem, enquanto as outras crianças ainda estavam no banheiro, a
pesquisadora continuou o jogo de ritmos corporais que Augusto repetia com precisão e
prazer na brincadeira.

Ele agora não sente prazer apenas com os fragmentos de brinquedos ou objetos para auto-estimular-se, embora ainda o faça bastante. No jogo de bola vemos que começa a haver uma erotização do brinquedo bola. Ele pede o tipo de ajuda que precisa da mãe para agarrar a bola percebendo que a mãe consegue. Ao pedir para brincar de cavalinho com a mãe, Augusto mostra que é capaz de entrar no simbolismo da brincadeira. Ainda não é ele que se desdobra e brinca de ser outro (é a mãe o cavalo), nem se projeta no objeto para ser outro nele (como um ursinho ou uma boneca etc.). 
Por outro lado, quando a pedagoga encenou com fantoches a história de João e Maria que havia contado na semana anterior, ele começou a imitar um choro (foi o que lembrou da história), mas não contou nada do enredo. Quando ela perguntou o que tinha na casinha em que ficaram presos João e Maria, ele disse: “medo”. Foi capaz de responder à pergunta e projetar seu conteúdo interno.

E depois, passando do ato de arrancar as pernas do boneco e voltar a brincar podemos dizer da estereotipia (cena sem contexto, sem representação) ao esboço de imagem corporal - ele disse: "o João qué fazê cocô". A pedagoga perguntou quem mais queria. Ninguém respondeu e ela perguntou para cada um dizendo seus nomes e ele diz: "o Augusto $q u e ́$. Foi capaz de projetar-se mais uma vez e ver-se.

Augusto parece que começa a contar com uma imagem corporal, se não for assim, não terá como fazer essa operação, que é um desdobrar-se para poder brincar de ser outro. $\mathrm{O}$ brincar que representa pôr-se na cena, ser capaz de montar um cenário e aí estar com seus conteúdos imaginários e simbólicos encenando sua própria história. Como diz Mrech (1999), o brinquedo e o brincar não são neutros, eles se oferecem condensando essa história que a criança vive com outros objetos.

Fraiberg e Adelson (1982) explicam que, para a criança cega, é difícil imaginar-se no objeto representando-a, então precisa fazê-lo no movimento, como ensaia Augusto cada vez que brinca de cavalinho com a mãe.

Outra abertura de Augusto na via da constituição da sua subjetividade é ser capaz de usar o "não" ao que lhe demandam. Ele primeiro diz "não" para depois aceitar, como vimos na atividade da piscina, quando:

A professora o chamou para ir até ela e ele respondeu "não", mas depois atendeu. E também ao pedir que ele molhasse o cabelo e ele veementemente disse "não". Ela insistiu e ele aceitou. Na próxima atividade de bater pernas atravessando a piscina junto com os monitores, ele pareceu aceitar, mas voltou para a borda dizendo: "aqui".

A pesquisadora disse "até logo" e ele primeiro respondeu "não" e depois se despediu.

Para Levin (2002) essa capacidade de usar a negativa significa a confirmação da sua identidade, a capacidade de diferenciar-se do outro negando-o. Para o autor, só há essa possibilidade se houver imagem corporal constituída. 
Augusto sabe pedir o que quer, tanto para coisas relacionadas a necessidades, como outras, o que mostra uma passagem no terceiro encontro da pesquisadora com Augusto:

Tocou o telefone e Augusto imitou o som dizendo: "atende”. A pesquisadora atendeu e anotou o recado. Ele quis ver levantando e dizendo: "vê". Ela mostra-lhe o papel, passando sua mão sobre eles dizendo que não dava para sentir porque não estava escrito em Braille.

E mostra desejo de saber, fazendo perguntas sobre o que são as coisas e pessoas do mundo, os quais ainda não conhece, como conta a mãe:

\begin{abstract}
Ele pergunta: "O que que é isso?” Eu ri pra caramba anteontem, porque o tempo fechou e veio o trovão. Aí ele olhou e falou: "Mamãe, o que que é isso?" E eu tava com a TV ligada, não consegui escutar muito. Aí eu falei assim: "O que que você quer saber, Augusto?”. Aí, de novo, veio mais forte. "Que que é isso, mamãe?". Eu falei: "É o trovão”. Aí, ele abriu a porta da cozinha, saiu pra garagem, pra escutar de novo. A hora que veio mais forte, ele correu, mas ficou entre a cozinha e o outro pé na garagem, com medo de... Do barulho. Aí eu falei: "É a chuva e esse som, Augusto, é o trovão. Cê tá com medo?" Ele disse: "Tô". Falei: "Então fecha a porta”. Aí fecho. Mas ele insistia em abrir, foi até lá fora. Aí ontem choveu de novo, fez o trovão, ele não teve mais medo (rindo).
\end{abstract}

Já não agride tanto como antes, pois está conseguindo pôr na fala suas vontades e necessidades e sua agressão aparece quando quer conseguir algo, quando é frustrado, mostrando que agora há uma intencionalidade e auto-afirmação.

(...) ele sabe distinguir o que pode e o que não pode, o certo do errado. Ele sabe. Ele já compreende. Às vezes ele faz ou pra chamar a atenção ou quando ele você... quando ele quer algo que você não atende naquela hora. Por exemplo, às vezes a comida... só no refogar do alho, ele já sabe que é comida. "Augusto quer papá”, "Augusto quer almoçar", ele fala. Aí eu falo: "Eu estou fazendo, você aguarda?!". Ele: "Tá bom, eu aguardo”. Aí ele vai e senta. Aí eu falo: "Você aguarda só um pouquinho que já tá quase pronto". Aí, de repente, ele quer um Danone, uma bolacha. Aí eu falo: "Eu dou depois da comida, primeiro a gente vai almoçar". Aí, às vezes, ele sabe, entendeu?

Aí ele se joga, começa a fazer birra, quer bater na geladeira que ele já amassou, porque eu já falei, eu pus a mão dele e expliquei que ele amassou toda a minha geladeira. Aí ele vai em lugares que ele sabe que é errado, que não é pra ser feito. Ele vai lá e faz, só porque eu falei não pra ele naquele momento, entendeu? Às vezes ele se joga, às vezes as perninhas dele ficam toda roxa de ele ficar se jogando no chão, fazendo birra, porque eu falei não pra ele naquele momento. Mas, quando eu ando com ele no metrô, no ônibus, que ele fala: "Eu quero" ou "O Augusto quer um... uma coxinha", porque ele come muito lanche, aí eu falo: "você espera chegar na estação"... aí falo o nome da estação e ele espera quietinho, não dá trabalho nenhum. Mas algumas vezes em casa ele faz aquilo que não é pra fazer só pra chamar a atenção, porque ele quer naquele momento, você entendeu? E eu percebo que ele já sabe... Uma coisa é quando a criança não compreende, e ele já compreende. 
Augusto ouviu a história contada pela pedagoga e respondeu a uma pergunta dela de acordo com as idéias que está passando a construir em seu pensamento e nos diálogos e respostas que dá às situações práticas, está mostrando maior organização cognitiva com alguma generalização das experiências sobre o mundo que o cerca e sobre o que sente.

Além disso, está iniciando seu percurso de aquisição da escrita Braille e interessandose por isso. Para Kupfer (2001), um dos eixos no trabalho com crianças com problemas na subjetivação e no desenvolvimento é a escrita, por ser esta uma construção do significante, uma operação de linguagem, uma oportunidade de inscrever-se enquanto escreve. Um “exercício de 'letração', que ordena e reordena a partir da interpretação do Outro” (p. 109).

Nesse período de um ano entre o primeiro encontro com Augusto e os outros dois, algumas novidades fundamentais foram introduzidas em sua vida: a neurologista, a psicóloga e depois a escola. Estas fizeram diferença e nos fazem ver que todos funcionaram como um terceiro na relação fusionada que Augusto e a mãe mantinham. Reforçaram um ponto de basta no gozo, o que ela já havia começado a pôr desde que resolveu levá-lo para a instituição especializada, desta vez para ficar e fazer valer.

Laramara, a instituição especializada, colocou Augusto em contato com outros adultos e crianças, ajudando a construir seu mundo interno dando maior consistência ao conceito de objeto, com uma constância de atividades e organização de ambiente de trabalho que foi lhe dando maior noção de tempo, garantiu pessoas de referência para que se situasse frente a elas com maior segurança, ofereceu oportunidades e começou a descortinar o universo infantil dos brinquedos e brincadeiras, dos jogos corporais e simbólicos do faz-de-conta. Criou condições seguras para que explorasse os espaços com maior confiança e se percebesse neles com seu corpo, dando-lhe também uma extensão possível de conhecimento do ambiente com o uso da bengala. Introduziu a normatização institucional, que é fundamental na educação que leva em conta o sujeito na singularidade de sua constituição. $\mathrm{O}$ espaço institucional vislumbrou para Augusto um sujeito que ainda não estava lá e inseriu os significantes criança, brincar, aprender, escola, letra. E também uma descontinuidade nas atividades e pessoas que o estão ajudando a diferenciar-se e separar-se de sua mãe.

A neurologista, quando procurada, receitou um remédio para que Augusto ficasse mais calmo, mas também recomendou a escola. Assim legitimou, ao nosso ver, que a escola poderia ter um efeito terapêutico que ele necessitava, como indica Kupfer (Ibid.). Os três eixos apontados por essa autora na aposta de uma nova oportunidade de retomada da subjetivação e que definem um lugar de criança e de sujeito passam pela escola, pelo espaço 
institucional e pelo letramento e alfabetização. Para Augusto, eles também estão representando um lugar de criança e de capacidade. A entrada de Augusto na escola foi também reforçada pela instituição e por sua psicoterapeuta.

$\mathrm{Na}$ instituição, a mãe também encontrou um espaço de fala no Serviço de Psicologia e em grupos de apoio psicossocial, podendo expor seus sentimentos e fantasmática que circundaram os primeiros anos de sua relação com Augusto e ainda hoje a angustiam.

Freqüentar a instituição, que segue uma linha sócio-educativa, ou seja, promotora de educação - no sentido de função subjetivante - e a inclusão de Augusto na escola abriram a possibilidade dele freqüientar um espaço da cultura reservado às crianças e se deslocar de seu mundo cristalizado, provocando um ensaio de deslizamento pela linguagem como cadeia de significantes que se inscrevem no sujeito.

Augusto foi bem acolhido na escola e a ela adaptou-se muito bem, ampliando sua rede social e iniciando os primeiros contatos com o letramento de forma mais sistemática, com o apoio da instituição especializada para o sistema Braille.

As novas conquistas de Augusto provocaram mudanças expressivas tanto nele quanto em sua mãe, pois, quanto mais Augusto se esboça como sujeito, aprende e se desenvolve, mais ela muda seu olhar sobre ele, possibilitando o que antes não tinha tido condição de fazer: ter orgulho dele, vê-lo como criança capaz, reconhecê-lo como filho.

Cerca de oito meses após as observações, a pesquisadora teve a oportunidade de encontrar-se informalmente com Augusto ao vê-lo saindo de uma atividade dizendo à profissional: “G., eu vou faltar!”, quando queria dizer na saída: "Eu vou embora!” Atrapalhando-se um pouco com a adequação das palavras, na realidade comunicou-se contextualmente, pois ir embora é, para ele, em certo sentido, faltar, deixar uma ausência. Já começa a simbolizar e verbalizar espontaneamente, mostrando uma diferenciação mais consistente entre o "eu" e o outro e no uso mais estável do pronome eu.

Augusto mostra pontos de abertura para o mundo e para fazer laço social. Augusto é uma criança viva que explora o mundo com suas possibilidades. Ele vê o mundo do portão e faz contato com as pessoas que passam na rua; percorre os espaços dentro da casa com autonomia, como nos contou sua mãe: 
"Augusto, vai em direção à mamãe e me traz a vassoura, está próxima à porta da cozinha, na garagem. Não é pra entrar". Ele foi reto, pôs a mão na porta da cozinha. Aí eu falei: "Então, tá do outro lado". Aí ele foi, pegou a vassoura e me trouxe.

Também quer ir à casa dos vizinhos, expressa isso falando com eles, como podemos ilustrar em mais uma passagem:

Ele já chega e fala: "Izilda!", o nome da pessoa. Ele pronuncia o nome da pessoa que ele tá ouvindo a voz, ele já fala quem é, entendeu? Aí, assim que ele fala o nome da pessoa, ele fala: "O Augusto quer a Izilda". Ou então: "O Augusto quer entrar na casa da Izilda". Ele não usa "eu quero". A maioria das vezes, quando ele se desloca, assim, que ouve algum adulto, passa alguém na rua, ele vai e fala: "O Augusto quer passear com a Izilda. Vamos, Izilda, passear com ele, vamos, Izilda?”. Aí, a Izilda vai, pega na mãozinha e começa a rir, e fala: "O que que você quer, Augusto?". "Ah, Augusto quer passar com a Izilda. Sai de perto, mamãe, sai de perto!". Aí, quando tem alguém assim, ele manda eu embora, ele quer que eu saia de próximo dele. Aí eu vou e saio. Por quê? Pra não pôr ele pra dentro de casa.

Augusto tem uma leitura de mundo que chama muito a atenção, pois ele reage: agride, destrói para dizer que quer saber das coisas e quer ser visto, busca relacionar-se com as pessoas.

Onde ele aprendeu a agredir? Foi via pai. O pai foi presença. A mãe desejava o pai e isso marcou uma falta na mãe para Augusto, o que pode ter deixado de modo muito sutil um furo, uma brecha por onde podemos entrar e apostar na simbolização do seu mundo e da sua existência.

Vemos na literatura especializada e na prática empírica de nosso dia-a-dia profissional, o que se mostra também com Augusto e sua mãe no que diz respeito a retomar a relação, lançando um novo olhar de possibilidade sobre o filho quando ele começa a mostrar-lhe e ela começa a enxergar isso. Nesse ponto ela passa a supor que ali está um sujeito. Vejamos o que se passou com ela na relação com Augusto.

\section{ANÁLISE DA ENTREVISTA: UMA “ANÁLISE DE DISCURSO” NO DISCURSO DA MÃE}

\subsection{Análise interpretativa dos dados relativos à mãe de Augusto - $1^{\text {a }}$ etapa:}

Nesta seção iniciamos a etapa de interpretação dos elementos significativos que emergiram do discurso da mãe de Augusto na entrevista. 
Quadro 5: temas e elementos significativos identificados na entrevista com a mãe de

Augusto

\begin{tabular}{|c|c|}
\hline TEMAS & ELEMENTOS SIGNIFICATIVOS \\
\hline $\begin{array}{l}\text { A reação ao diagnóstico, os } \\
\text { primeiros anos de vida de } \\
\text { Augusto e outras contingências }\end{array}$ & $\begin{array}{l}\text { Problemas conjugais anteriores culminando em separação; muita } \\
\text { raiva da traição do marido e dele não estar presente; sentir muita } \\
\text { falta do marido; } \\
\text { Muito difícil, não agüentar a deficiência do filho, a separação do } \\
\text { marido e a desorganização da família ao mesmo tempo; } \\
\text { Depressão por } 2 \text { anos; } \\
\text { Diagnóstico de cegueira aos } 2 \text { meses; cirurgia no olho; busca de } \\
\text { intervenção precoce, mas não seguimento por estar depressiva; } \\
\text { Perplexidade, idéias de não merecimento e depois resignação; } \\
\text { sucumbir ao olhar para o filho; } \\
\text { Ausência ao sair para trabalhar fora; deixar Augusto com as filhas } \\
\text { mais velhas que não cuidavam dele; mas sempre tinha alguém } \\
\text { (tios, avó); } \\
\text { Superproteção e não correção dos comportamentos destrutivos do } \\
\text { filho; } \\
\text { Augusto começou a quebrar tudo quando a mãe saiu para } \\
\text { trabalhar; } \\
\text { Parada no trabalho para cuidar de Augusto; nova busca e } \\
\text { permanência no atendimento aos } 4 \text { anos; } \\
\text { A figura do pai: ensinar Augusto a dar socos quando era bem } \\
\text { pequeno; querer um filho homem; ver o filho e chorar; escrever } \\
\text { sobre seu amor por ele; sem contato atualmente; mistura da } \\
\text { relação com a esposa e o filho; culpabilização da mãe e depois } \\
\text { arrependimento por ter casos de cegueira em sua família; Augusto } \\
\text { não pergunta mais do pai; } \\
\text { As filhas mais velhas, irmãs de Augusto: agressividade dele com } \\
\text { elas; ele as pega de surpresa e as machuca; elas não conseguiam e } \\
\text { não conseguem contê-lo. Elas o deixam só e sem cuidados e } \\
\text { atenção. }\end{array}$ \\
\hline $\begin{array}{l}\text { Relação mãe-criança: } \\
\text { representação e sentimentos } \\
\text { em relação ao filho e o que ela } \\
\text { diz dele }\end{array}$ & $\begin{array}{l}\text { Não haver desejo específico para esse filho; } \\
\text { Desejo de normalidade; era normal, tudo normal, 90\% normal; } \\
\text { Não poder olhar pra ele, só chorar, faltar o ar, desmaiar; } \\
\text { Ao mesmo tempo perceber seu bebê, interpretar, nomear e atender } \\
\text { suas necessidades e demandas; ler suas necessidades, mas já } \\
\text { preenchê-las antes dele solicitar; } \\
\text { Ambivalência: era normal, mas não o tratou assim; } \\
\text { Cuidados, interação com Augusto no início (ficar junto, estimular, } \\
\text { conversar, passear, brincar, banho, mamadas, sol, treino com } \\
\text { lanterna), depois precisou da mãe para orientar e ela não estava, } \\
\text { foi trabalhar; } \\
\text { Abandono; } \\
\text { Convivência de Augusto com a depressão da mãe; } \\
\text { Só ver a deficiência e não a criança; deficiência justificando todos } \\
\text { os comportamentos e o atraso no desenvolvimento; ver o atraso, } \\
\text { mas não se importar; } \\
\text { Corrigir era judiar e não podia judiar de deficiente; por ser }\end{array}$ \\
\hline
\end{tabular}




\begin{tabular}{|c|c|}
\hline & $\begin{array}{l}\text { deficiente não precisava ensinar as coisas tão cedo; } \\
\text { Sentimentos de pena e culpa na mãe; superproteção } \\
\text { Precisar e permitir o vínculo com a avó e os tios; } \\
\text { Não conseguir impor limites, hoje consegue; dormir com o filho } \\
\text { até hoje; } \\
\text { Deixar Augusto fazer tudo que quisesse; } \\
\text { Dependência; } \\
\text { Bebê quietinho; choro por fome e outras necessidades; } \\
\text { Fazer tudo o que uma criança normal fazia do ponto de vista } \\
\text { motor; } \\
\text { Irritação e intolerância a muito barulho (até } 3-4 \text { anos), quebrando } \\
\text { o aparelho de som; } \\
\text { Apreensão do mundo muito pela audição, tato e pela boca com } \\
\text { pouco uso das mãos; } \\
\text { Reconhecimento da voz da mãe, sorrir e se jogar pra ela; } \\
\text { Não explorar e rejeitar materiais para conhecer, uso para auto- } \\
\text { estimulação; } \\
\text { Hoje: saber o que é errado, mas insistir; distinguir o certo do } \\
\text { errado, mas fazer de birra e pra chamar atenção; } \\
\text { Tendência à fixação em objetos, palavras e movimentos } \\
\text { repetitivos, estereotipias; } \\
\text { Em situações incômodas: gritar, resmungar, bater, não falar ou } \\
\text { falar palavrão; } \\
\text { Em situações novas e incômodas: voltar a agredir, quebrar objetos } \\
\text { ao ficar sozinho, ser contrariado, querer obter um pedaço do } \\
\text { objeto para estimular-se. }\end{array}$ \\
\hline $\begin{array}{l}\text { Representação, sentimentos e } \\
\text { atitudes em relação à cegueira }\end{array}$ & $\begin{array}{l}\text { Pensar que o filho iria sofrer, viver em um mundo escuro, sentir } \\
\text { falta da visão, não ter vida normal, ser sempre dependente dela, } \\
\text { ficar dentro de casa; } \\
\text { Depois pensou que o mundo dele é assim, então é normal pra ele. }\end{array}$ \\
\hline $\begin{array}{l}\text { Reação e sentimentos em } \\
\text { relação à agressividade do filho }\end{array}$ & $\begin{array}{l}\text { Viver assustada, medo, agonia, ansiedade, apreensão, ódio, } \\
\text { vergonha; } \\
\text { Impedimento da aproximação de pessoas, isolamento, não } \\
\text { promoção de eventos sociais; } \\
\text { Desistência de substituição do que o filho quebra, resignação; } \\
\text { Crença de que seus comportamentos destrutivos eram pela } \\
\text { deficiência; não correção e proibição; crença que vai passar; } \\
\text { Explicação da agressividade como reação do filho a muito } \\
\text { barulho, discussões do casal, ensinamento do pai e sua inércia; o } \\
\text { pai ensinava e ela não gostava. }\end{array}$ \\
\hline $\begin{array}{l}\text { Como a mãe se mostrou - lugar } \\
\text { que ocupou, como se sentiu }\end{array}$ & $\begin{array}{l}\text { Perceptiva, atenta e vinculada ao filho: percebeu logo a } \\
\text { deficiência; buscar logo ajuda, mas não prosseguir; sucumbir, } \\
\text { errar e superar; } \\
\text { Lugar de traída e mãe de deficiente; lugar da errada em relação à } \\
\text { não proibição aos comportamentos destrutivos do filho; a errada } \\
\text { como esposa; } \\
\text { Culpada por ter que sair pra trabalhar e deixar Augusto com as }\end{array}$ \\
\hline
\end{tabular}




\begin{tabular}{|c|c|}
\hline & $\begin{array}{l}\text { filhas que não cuidavam dele; } \\
\text { Movimentos de superação; } \\
\text { Aceitação após } 2 \text { anos ao ver que ele não tinha outras deficiências; } \\
\text { Ainda não o deixa fazer as coisas sozinho; sem paciência de } \\
\text { ensinar, impede seu crescimento; ansiedade e dificuldade para } \\
\text { ensinar na falta da visão; } \\
\text { Manter dependência: tirar a fralda aos } 5 \text { anos; dormir em sua } \\
\text { cama; não deixar comer sozinho. }\end{array}$ \\
\hline $\begin{array}{l}\text { A mudança de olhar da mãe e a } \\
\text { possibilidade de saída de } \\
\text { Augusto do lugar de deficiente: } \\
\text { a busca da instituição } \\
\text { especializada, os apoios médico } \\
\text { e psicológico e a inclusão } \\
\text { escolar }\end{array}$ & $\begin{array}{l}\text { A instituição fez ver que a deficiência não impede a vida; } \\
\text { Passou a ver as possibilidades de Augusto; } \\
\text { A neurologista e a psicóloga estão sendo muito importantes no } \\
\text { desenvolvimento do filho e trabalhando com a mãe; } \\
\text { Pensava que ele deveria ir pra escola especial; } \\
\text { Depois de estar na escola comum viu que não, percebeu sua } \\
\text { importância e benefícios. }\end{array}$ \\
\hline
\end{tabular}

\subsubsection{A reação ao diagnóstico, os primeiros anos de vida de Augusto e outras} contingências

O diagnóstico quanto à cegueira de Augusto foi realizado quando ele estava com um mês de vida e confirmado aos quatro meses. Sua mãe nos conta qual foi sua reação e o que ela viveu nos primeiros anos da vida dele:

(...) eu percebi que tinha algo diferente assim no olhinho dele desde a primeira mamada que ele foi... no hospital. Mas as médicas acharam que não. Por ser pequenininho, a retina tava normal. Aí, conforme ele foi desenvolvendo, o olhinho não foi desenvolvendo, ele continuava do mesmo tamanhinho. Tem um que é menorzinho, tem um outro que é um pouquinho maior. Mas a retina não foi formada, entendeu? Então, assim: ele nasceu com baixa visão e depois, aos poucos, foi perdendo... o pouco que tinha. Ele vê, assim, uma luz, mas muito longe. Não consegue distinguir de onde vem... entendeu?

Aí, como foi cesárea e eu sou meio molenga pra andar, com trinta dias o levaram pra mim no oftalmo e falaram que tava normal... Foi depois de uns dois, três meses que eu comecei a buscar mesmo, sabe? Fui na Faculdade de Medicina de São Paulo... procurei tudo que era de oftalmo aqui em São Paulo, e... vários lugares o diagnóstico era o mesmo, que ele tinha... má formação na retina... foi feita uma operação também no olho, entendeu? Então foi isso. Eu corri atrás, tentei...

(...) não foi só um diagnóstico. Nós andamos em vários oftalmos, escutamos a mesma coisa, o mesmo diagnóstico, entendeu? Aí, quando... aí tipo eu ia atrás, entendeu?

Foi difícil no começo pra mim, viu? Eu não conseguia entender...! A gente nunca acha que vai acontecer com a gente, sempre acha que é só com o outro, ou nunca acha que a gente merece, mas é aquele negócio, né?! Se Deus me deu ele assim, é porque eu tinha que cuidar dele assim. Foi difícil no começo... Aí depois eu superei, né? 
Fiquei dois anos depressiva, aí, depois consegui superar tudo. Porque foi logo... parte da visão do Augusto e depois eu tive também o problema com o meu ex-marido, aí foi tudo junto, eu não agüentei...

Nesse relato, chama a atenção o fato dela ter percebido tão cedo a deficiência de seu filho. Percebeu logo algo de errado nos olhos de Augusto, insistiu com os médicos que contrariavam o que ela era capaz de ver. Podemos pensar ser esse um sinal promissor de vínculo, mesmo tendo atravessado os percalços comuns às mães de bebês com deficiência. Mas, ao mesmo tempo, deixou que outros o levassem para a consulta com o especialista, o que vemos como uma certa ambigüidade de seu comportamento que aparecerá um pouco adiante: ora aparece como mãe zelosa e que se vincula, ora como mãe que não agüenta e abandona. Chama atenção também ela sempre referir-se à superação e resignação quando fala o quanto foi difícil, movimento que veio depois, como mostra o trecho abaixo:

Se Deus me deu ele assim, é porque eu tinha que cuidar dele assim. Foi difícil no começo... Aí depois eu superei, né?

Fiquei dois anos depressiva, aí, depois consegui superar tudo.

O início da vida de Augusto foi marcado por momentos difíceis na família, momentos de desorganização, especialmente para sua mãe, devido à separação do marido e à deficiência do filho. Como vemos no depoimento, esta situação provocou nela a entrada em uma depressão profunda, que viria a se prolongar por bastante tempo e que refletiu em Augusto no sentido das primeiras trocas afetivas na relação entre mãe e bebê. Foram dois anos nos quais ela vivenciou sentimentos de culpa, tristeza e não-aceitação, como relata:

Só chorava, olhava pra ele e passava mal... Às vezes faltava a visão, escurecia, caía a pressão, eu tinha que ir pro pronto socorro, entendeu? Aí, tinha que ligar pra família do... do pai dele, às vezes eu tinha que tomar medicamento, às vezes eu passava três, quatro, cinco dias sem conseguir dormir, só chorando... Ficou assim durante muito tempo.

Esse relato dos sentimentos gerados na mãe de Augusto pela cegueira do filho reitera o que estudiosos como Blank (1957), Lambert (1980), Leonhardt (1992), Amiralian (1997) e Cantavella (2002) mostraram em seus trabalhos acerca dessa vivência dos pais: fases de depressão (principalmente da mãe), narcisismo ferido do "porque eu" e do filho não-perfeito, assim como da culpa e ansiedade, passando à elaboração e evoluindo para atitudes de rejeição, superproteção ou aceitação. 
(...) olhava pra ele e passava mal...

(...) Começou a dar os primeiros passos, então eu, com medo, comecei a superproteger...

(...) Então, assim, eu falei: “Ah, não, meu filho é perfeito, tem saúde”, entendeu?

No início o sentimento foi de não-aceitação. Depois, o primeiro passo para a aceitação foi abrir-se para o mundo novamente - o que, por sua vez, abre o mundo para a criança -, deparar-se com outras crianças mais comprometidas e ver que Augusto tinha potencial para desenvolver-se, o que vai tornar-se mais forte após os dois anos de depressão e os quatro anos dele, quando começa a perceber suas possibilidades:

(...) quando você começa a sair, a ver outras pessoas e ver que a vida não é... só tem você que tá passando por aquele problema, que tem outras pessoas que às vezes têm até pior, aí foi quando eu passei a mais aceitar o Augusto, a ver que ele anda, ele fala, ele escuta. Então... e tem crianças que, infelizmente, você vê, que há uma certa dificuldade, paraplégico, às vezes fica em cima de uma cama vegetando, às vezes tem uma doença contagiosa... Então, assim, eu falei: “Ah, não, meu filho é perfeito, tem saúde”, entendeu?

Também sabemos que não foi propriamente o filho que ela rejeitou, mas a cegueira, da qual ela tinha medo e dificuldade para enfrentar, como veremos mais adiante, e como nos chamam atenção Leonhardt e Cantavella (1999) e também ela mesma em outro trecho da entrevista, reforçando e denegando de certa forma seus sentimentos:

Eu ñ̃a assimilei, nãa foi o fato dele ter nascido deficiente, e sim por tudo, entendeu? Não foi a cegueira do Augusto. Ajudou bastante? Ajudou, porque eu até então não tava preparada. Mãe nenhuma tá preparada, né?

A gente muda no momento. A gente não tá preparada... Se eu soubesse... que tinha parente na família do meu... do pai que tinha esse problema, talvez eu tivesse outra reação, entendeu? Mas, como na minha família não teve nenhum tipo de deficiência, nenhuma, então foi difícil no começo.

Em outro trecho, ela rememora os sentimentos de dor e revolta no início da vida de Augusto pelo impacto da deficiência do filho, mas principalmente pela falta do marido e da presença do pai que ela invoca como importante. Não dissocia os dois acontecimentos simultâneos e, quando olhava para Augusto, via os dois fatos:

Tinha raiva, né, do pai, de ter feito o que fez, né? Me traído. Aí ele é problemático, ele é doente, aí ele se afastou das crianças. A raiva que a gente tinha um do outro, ele descontou 
nas crianças, foi se afastar. Eu também tinha raiva dele, por não ser um pai tão presente, entendeu? Então é isso, é... no momento assim que você tá meio desanimada, você pensa muita bobagem, né?

(...) Se o pai tivesse do meu lado, talvez eu não tivesse passado tanta dificuldade, né? Mas aí eu já superei, faz tempo.

Podemos pensar que a falta do seu marido e pai de seus filhos indica que para essa mãe há um lugar importante dado ao homem e que ela o queria, o que vai marcar desde o início uma presença paterna veiculada pela mãe para Augusto, mas ela vai afastá-lo, vai causar um impasse, deixando esse lugar do pai vazio, desvalorizado por sua mágoa até seu afastamento total nos dias de hoje. Poderíamos também considerar que a perda que sua mãe viveu deixou marcas em Augusto nesse momento tão vulnerável de sua constituição de sujeito - momento de tornar-se o objeto do desejo da mãe para depois saber de seu próprio desejo mas esses dados só seriam levantados em uma análise, não podem aqui ser aprofundados.

Em outros trechos da entrevista, a mãe implica ao pai no que diz respeito a ela e à deficiência de Augusto da seguinte maneira:

\begin{abstract}
Olha, no começo assim, porque, devido às nossas brigas, ele quis me culpar, né? Primeiro ele falou pra mim que eu não era capaz de dar um filho perfeito pra ele, porque o sonho dele era ter um menino. Aí, depois que ele descobriu do Augusto, tudo... e veio descobrir que a causa veio dele mesmo, né? É hereditário, como eu já tinha te dito, é... foi dele mesmo a causa da cegueira, né? Pelo que foi constatado, entendeu? Aí ele passou a me pedir perdão, e passou a aceitar mais o Augusto, né? Falou que o Augusto, pra ele, é uma criança normal, que não tinha problema nenhum, tudo. Mas, devido a nossa crise dentro de casa e até fora, ele acaba descontando nas crianças um problema que é nosso. É onde eu acho que é o erro dele. Hoje, ele só tem falha como pai, entendeu? Eu não queria mais ele como marido, só queria que ele fosse bom pai. Nunca é tarde pra ele mudar. Mas ele não se conscientiza que tá precisando de ajuda e não sou eu que vou ajudá-lo, porque ele já tem outra mulher e tem mais um filhinho, entendeu? Mas sempre que ele vê o Augusto, ele chora muito. Chora que nem uma criança e, assim, de soluçar. Na frente, longe...
\end{abstract}

Ele escreve, ele só chora. Ele escreve falando que ama muito ele. Aí eu leio pro Augusto. Mas o Augusto não chama mais o pai, não lembra mais dele. Eu também não fico lembrando. Não sei se eu tô errada.

(...) quando ele era bebê, o pai fechava a mãozinha, começou a ensinar ele a dar socos, eu corrigia, corrigia, e o pai ensinando ele a ser agressivo. Não foi muito tempo. Não sei se isso ajudou ele a ser... mas era o pai falando que não... o pai falando que sim e eu falando que não, e eu pedindo, então eu não sei se isso ajudou. Mas isso já faz muito tempo... O pai começava a brincar: "ah, é macho, ah, é homem..."

Aos quatro meses, após passar por vários oftalmologistas e ter a confirmação do diagnóstico de cegueira, Augusto começou a ser atendido em um serviço de intervenção precoce especializado na área da deficiência visual - o que foi totalmente acertado - mas sua mãe não conseguiu manter o atendimento em função de seu estado depressivo. 
Ela alega que cuidava de Augusto nessa fase de depressão e também se justifica por sentir-se culpada:

\begin{abstract}
Em relação ao Augusto, quando eu estava deprimida, eu cuidava dele normal, eu não tentava passar pra ele a minha angústia. Mas, eu creio que, de alguma forma, ele acabou percebendo. Porque eu chorava muito... entendeu?

$E$ E, mas eu não chegava a gritar, nem maltratar, nem ele nem nenhuma das minhas filhas, não. A minha angústia era só de chorar, não querer sair, ficar isolada, não conseguia dormir, tinha falta de ar constante, entendeu? Aí, quando vinha aquela falta de ar muito forte que eu achava que eu ia desmaiar, ai minha filha mais velha ia, ligava e me levava pro prontosocorro. Não sei se o Augusto conseguiu guardar alguma coisa... dessa fase baixa aí que eu passei, mas, maltratar ele ou alterar o tom de voz, não sei... nunca... não... nunca passei isso pro Augusto.
\end{abstract}

Segundo Leonhardt (1992), a depressão vivida pela mãe da criança cega congênita dificulta-lhe perceber seu bebê e responder às suas demandas e ele, por sua vez, pode deixar de buscá-la e fechar-se em si mesmo.

Podemos dizer que não há, assim, um olhar de desejo que veiculará palavras que falam da criança e que libidinizam seu corpo, do que vai depender sua imagem corporal e sua motricidade colocada em ato, em cena, com sentidos de vida. São processos inconscientes que ditos teoricamente parecem ultrapassar uma possibilidade de compreensão, mas não é difícil admitir que a vivência de Augusto com a mãe nesse período de sua depressão dificultou sua constituição subjetiva e interrompeu seu desenvolvimento. A depressão dificulta a relação e torna difícil a inscrição do significante primeiro, que é um dizer sobre o filho, um dizer carregado de desejo.

A separação do marido que a traiu e foi embora, o que a fez sofrer muito, e a cegueira de Augusto ofuscaram seu olhar para o filho. Só pôde ver a deficiência dele: "Toda hora, só via essa imagem na minha cabeça, assim, sabe?"

A deficiência de Augusto no olhar da mãe acabou por encobrir o querer saber de sua sexualidade e filiação, como mostra Levin (2002) quando se refere às duas perguntas sobre um recém-nascido e que o levam a constituir-se, ter um lugar de filho e construir sua identidade. Essa duas indagações são: “é menino ou menina?" e “com quem se parece?”. Na realidade existe, segundo Levin (Ibid.), uma indagação anterior a essas: "nasceu bem?" Para esta, no que diz respeito a Augusto, já sabemos a resposta. 
Nesse período de depressão a mãe de Augusto não podia ver o filho cego, pois cada vez que olhava para ele, sentia-se muito mal, como ilustramos acima. Assim, Augusto ficou sem mãe nem pai.

Mas, apesar da depressão, a mãe de Augusto diz que o amamentou até mais de um ano, percebia suas necessidades, compreendia seus choros de fome, sono ou manha, estimulava-o com brinquedos sonoros (como havia sido orientada na vez que o levou à instituição especializada), brincava com ele, conversava, levava-o para tomar sol e passear:

(...) o seio ele mamou acho que até um ano... um ano e dois meses mais ou menos, ele mamou.

(...) já é o quarto filho, então você percebe quando é choro de manha, quando é choro de dor, quando a criança quer colo, entendeu?

(...) Brincar... mais coisas de som: chocalhos, né (...) passear, tomar solzinho... ia ensinando com a mãozinha pra ele... saber tocar, brincar...

Além disso, nesse período houve um ponto bastante positivo na história de Augusto que foi o de que "sempre havia alguém" com quem ela, e certamente Augusto, podiam contar: as irmãs e a família do pai (a avó e os tios), figuras que são importantes para ele, como registra a mãe:

(...) por eu descobrir a deficiência cedo, eu não esperava... ele nunca ficava só... ele nunca... devido a ter outras irmãs, ter tios por perto, ter a avó... Então ele nunca estava só. Então, assim... Nunca, nunca deixei ele num local sozinho por muito tempo, pra ele precisar e me chamar, entendeu? Sempre tinha alguém.

Esse "sempre tinha alguém" pode ter sido a salvação de Augusto em relação a não ficar totalmente isolado e ter uma pequena via de entrada do social, além do pai que nessa época o visitava.

A mãe relata outro momento muito difícil para ela e Augusto nos primeiros tempos de sua vida. Foi quando ela precisou sair para trabalhar. Augusto estava com dois anos e foi aí que começou a quebrar as coisas. Para Augusto tratou-se de um período no qual teve que ficar muito tempo sem a presença da mãe, ficando aos cuidados das irmãs que dele não cuidavam. Ficar com as irmãs representou a vivência de ser deixado só, sem atenção, à sua mercê, sem controle, quando ele precisava de cuidados, rotina, presença e ausência para diferenciar-se do outro, para ter contorno, para sentir-se seguro e organizar-se internamente. 
(...) eu trabalhei quase dois anos, não, mais, dois anos e dois meses, que ele foi orientado por outras crianças, e eu muito cansada, acordava quatro horas da manhã pra ir trabalhar. Então, aí, foi o... a fase que ele precisou de mim e eu não tava próxima a ele para orientar, pra ver onde tava errado.

As irmãs, tão pequenas, não puderam fazer a função da mãe, já que eram elas que ficavam com ele todo o dia quando a mãe saía para trabalhar. Não cuidaram dele nas necessidades básicas, não falaram, cantaram ou brincaram com ele, não lhe mostraram o mundo, nem lhe mostraram como viver. Esse período foi longo, durando até os quatro anos de Augusto. Ele assim se expressava:

(...) ele quebrou muito a minha casa, quebrou muita coisa, muito nervoso, devido eu ter que trabalhar... eu trabalhei quase dois anos, não, mais, dois anos e dois meses, que ele foi orientado por outras crianças, e eu muito cansada, acordava quatro horas da manhã pra ir trabalhar. Então, aí, foi o.... a fase que ele precisou de mim e eu não tava próxima a ele para orientar, pra ver onde tava errado.

E ele tem uma força enorme. O tapa dele, dependendo do local que ele atinge, ele derruba um adulto. (...) O tapa dele machuca. Ele dá cabeçadas. Se você segurar a mão ele dá cabeçadas.

(...) tudo dele era, tanto era jogar, quebrar tudo, destruir... Televisão: se você deixar ele só, ele quer jogar a televisão no chão, ele quebrou três TVs minhas. Quebrou quase tudo, assim, os eletrodomésticos (...) é que não foi comigo em casa, né? A televisão tava uma no quarto das crianças... elas lá na cama, conversando... ele vai, é de repente, é sem esperar, que ele vem e joga.

(...) pega as irmãs de surpresa e as machuca... elas não podem com ele.

Quando Augusto tinha quatro anos, julgando que ele estava precisando de ajuda e que aquela situação não poderia continuar, ela procurou novamente a instituição especializada e deu uma virada em suas vidas, como já foi antecipado nas referências a Augusto no item anterior.

\subsubsection{Relação mãe-criança: representação e sentimentos em relação ao filho e o}

\section{que ela diz dele}

Indagada sobre o que representou esse filho para ela, a mãe diz:

Mais um filho, né?! Uma bênção pra mim. Mas, assim.... é ... Eu não tava... não foi planejada a gestação dele, entendeu? Eu tive três meninas, eu ia fazer cesárea da terceira... aí meu ex-marido falou assim: "Não, deixa que eu faço a vasectomia". Aí eu fui na onda dele, no fim ele não fez, aí nós tivemos uma crise, ele saiu de casa, foi pra mãe dele, que eu pedi, depois disso ele voltou, foi só uma transa só, à noite, foi suficiente pra engravidar do Augusto. Então, assim... não tô falando pra você que ele não foi um filho bem-vindo. A hora que eu 
soube da gestação, tudo bem. Tratei a gestação como se fosse a primeira. Fiz pré-natal, tudo direitinho, sem problema nenhum.

A mãe relata que não havia desejo de um filho específico, só queria que viesse com “saúde e perfeição”. Ela diz em sua entrevista:

Não. Eu não parava pra... desejar um filho de olho azul, um filho branquinho, pretinho... Não! Achava que era um filho que eu tava tendo e... ia ter todo o meu carinho, como teve as outras... independente do... sexo, da cor, entendeu? Eu não cheguei a... a imaginar, não... a desejar ele de outra forma? Não...

Não, não, não, não... não me passou... Eu nunca... parei pra... desejar... A gente pede que venha pelo menos com saúde e com perfeição, mas se Deus deu, se Deus me deu ele assim, é porque eu tinha que ter ele assim, entendeu?

A quebra do filho esperado, "com saúde e perfeição" - o que podemos entender sem deficiência nesse caso, expressão do desejo de normalidade - jogou-a para o lugar do sentido para sua existência que a depressão provocou. Não havia expectativas para seu filho, olhar vazio de palavras, uma vez que era cego e que já não tinha seu marido com ela e este era o filho que seu marido desejava. Acabou-se como mulher capaz de dar um filho homem e perfeito ao marido, como ouviu dele em dado momento e, como mãe, por não poder olhar seu filho.

Ao mesmo tempo, ela diz que antes de ter fechado o diagnóstico, e mesmo depois, viao, e assim ele se mostrava para ela, como uma criança normal e ele relacionava-se com ele, apesar da depressão. O significado de normal para ela é traduzido pelo que segue:

Normal. Ele jogava um brinquedo, ele levantava do berço, em pé... tudo que uma criança normal fazia, ele faz... faz até hoje, entendeu? Mas, assim... ele não fazia nada anormal, pra você achar que era um deficiente. O problema dele era só que ele não via... entendeu? Devido a ele escutar a voz, ele ria, você vê as reações do bebê, entendeu? "Mamãe tá aqui", então a hora que ele escutava a minha voz, ele já se jogava em direção à minha voz, pra vir pra mim... entendeu? Conversar, passear, tomar solzinho... Um hábito normal como uma criança... entendeu? Tinha a hora do banho, tinha a hora das mamadas... desde bebezinho... o banho dele era sempre no mesmo horário... quando eu ultrapassava... atrasava dez minutos, ele já chorava, porque já sabia que já passou do horário...

Ele pegava, brincava normal. Se era chocalho, ele balançava, se era mordedor, ele levava à boquinha, muita coisa ele levava à boca. Toda criança na idade dele, primeiro leva a boca, né... Então sempre tinha esse cuidado de olhar se não tinha caído no chão, tudo, entendeu? Pra dar na mãozinha dele, pra ele num... Que a maioria das coisas ele leva à boca. Mas é normal...

A gente ficava junto, eu comprava muito brinquedo com sons, que saía musiquinha, aí eu ia ensinando com a mãozinha pra ele... saber tocar, brincar... Mais coisas de som: chocalhos, né? As irmãs tinham uns brinquedos, assim, de coordenação motora, com formas, né... 
quadrados, e tal... Então era mais esses lados, assim... mais de coordenação motora e som... musiquinha, mais tranqüila...

Ele ficava muito quietinho... entendeu? É... não dava trabalho, ele só chorava quando mamava, quando tinha fome pra mamar. Então, fora isso, então... hora do banho que ele gostava... até hoje ele gosta bastante de água, tomar banho... Se deixar ele toma mais de cinco banhos por dia, porque ele gosta muito de tomar banho. Então foi assim... Foi normal, não tinha dor, nem nada.

(...) ele brincava, tudo, né, se desse brinquedo, a reação dele era a de uma criança normal. Ele só não conseguia distinguir onde estavam as pessoas, entendeu? De onde tava vindo a voz, né? Sem me ver... entendeu? Mas, quando a gente conversava com ele, ele ria, ele escutava tudo direitinho.

(...) Normal. Engatinhava, queria subir escadas, ia pra cozinha. Eu tinha que ficar sempre atenta pra ele não se machucar, entendeu? Aí ele ia, quando encontrava a geladeira, colocava a mão na geladeira, ficava em pezinho na geladeira, entendeu? O que uma criança na idade dele fazia, ele também fazia.

Ao mesmo tempo em que fala de Augusto como uma criança normal, que cuidou dele do mesmo jeito que das suas filhas mais velhas, dá-se conta de que o tratou de modo diferente pela deficiência. E assim mesmo seria em relação às especificidades de conhecer o mundo sem a visão, mas o tratou diferente em relação à educação:

Se eu fui diferente... É.... é o meu erro, né? Por ser deficiente você acha que... deixar ele bater, deixar ele agredir, é porque é deficiente, entendeu? Na educação, no início, foi o meu erro.

(...) Começou a dar os primeiros passos, então eu, com medo, comecei a superproteger...

Engatinhava... Como eu tinha carrinho, às vezes eu colocava um som baixinho, deixava ele no carrinho, quando ele... ele ainda dava pra ficar no carrinho, porque ele sempre foi grandão. Às vezes eu tava lavando a louça, eu começava a conversar com ele, dava um brinquedo, o mordedor, quando tava saindo os dentes... Então, assim, o que eu tratava ele, eu tratei as outras, era igual. Não houve diferença. A diferença foi assim: eu achava que por ele ser... por ele não ter visão, eu superprotegia demais. Por eu não ter deixado ele ser mais independente, até hoje ele não come sozinho, já é um hábito: eu sento, e o Laramara tá puxando muito a minha orelha, porque já era para ele estar comendo só. Muita coisa... lanche, refrigerante... muita coisa ele toma e come sozinho. É só a comida que eu levo a colher na boca. E ele quer aprender, às vezes ele pede, e o hábito, o medo dele se sujar, tudo o local onde ele tá, eu acabo... fazendo, e tô errada... Eu dava pra ele... ele sabe o que é colher. Muita coisa ele toca a mão e sabe o que é que é... mas...

Eu achava que, devido à deficiência, eu tinha que cuidar, proteger ele. Foi um dos meus erros... quando eu fui normal, ah, isso não é certo, ah, isso é errado. Então você corrige. E por ser deficiente, eu achava que tudo pra ele tinha que ser daquele jeito, entendeu? Então foi o теи erro.

Ele saiu das fraldas com cinco anos. Porque eu pensei que, por ele ser deficiente.... eu não precisaria me preocupar em ensinar tão cedo. Eu achei que eu ia tá ajudando ele, que era tudo pra... tudo o que eu iria ensinar, por ser deficiente, eu achei que era assim. Eu achei que eu deveria retardar o ensinar, entendeu? Em vez de eu ensinar o mais cedo pra ele ser mais independente, eu retardei tudo. 
Em todos esses recortes do discurso da mãe de Augusto na entrevista, detectamos a passagem da rejeição inicial à superproteção, o que levou a momentos de contato e relação, mas uma relação que encobriu os sentimentos de culpa e não-aceitação que ela ainda vivenciava. Assim, superprotegendo, mantinha-o no lugar da impossibilidade que a cegueira representava para ela; mantinha-o dependente, impedindo sua entrada no mundo da cultura, retardando seu desenvolvimento, tornando-o seu objeto, construindo e devolvendo-lhe essa imagem de deficiente, como podemos ver em outros trechos:

Sei lá... Pela deficiência, eu fui colocando fralda, fralda... "Ah, ele é deficiente. Enquanto eu tiver saúde e Deus me der saúde, eu vou cuidar dele. Ele não precisa se preocupar em ir no banheiro tão cedo, por ser deficiente". Eu achava que, quanto mais tarde, melhor pra ele. Então foi aonde eu falo muito do meu erro, porque eu sei que eu errei bastante, mas... (rindo) nesse sentido, entendeu?

Deficiente pra mim é uma pessoa que depende do outro. Eu achava que era isso. Eu achava que o deficiente dependia, né? Por ele não enxergar, é... lógico, a gente tem como passar a ensinar coisas. Quando você enxerga, você tem estimulação da visão, cê tá vendo o que certo e o que é errado. Quem não enxerga, você tem que passar a ensinar e a falar e a usar o tato. E eu achava que não, que quanto mais cedo era bobagem, que eu poderia esperar mais, pra não judiar... tudo bobagem da minha cabeça. Tudo bobagem... pelo contrário, eu tava prejudicando ele. Acho que se eu tivesse pego com ele normal... Não, o Augusto tá normal pra mim, entendeu? Talvez ele hoje fosse uma criança bem mais calma e bem mais independente.

\subsubsection{Representação, sentimentos e atitudes em relação à cegueira}

Já fizemos referência anteriormente ao modo como a mãe de Augusto reagiu à deficiência dele: representações (idéias e imagens) e sentimentos que foram suscitados e que a levaram a deixá-lo em sua alienação do mundo e fora da ordem simbólica:

(...) mudança não houve não. Houve mais é ... proteção. Acho que foi o meu erro. Proteger ele demais... por achar que ser deficiente, né?! Sabe? Eu sobrecarreguei ele... assim: eu protegi demais, demais. Tudo era ele... então tudo o que ele fazia de errado eu achava que era por ser deficiente, eu tinha que concordar. Foi um dos meus erros... Entendeu? E isso influencia, porque se tu tem uma criança, só porque é deficiente tem que falar palavrão, tem que bater? Eu acho que não. Eu acho que educação ela é normal pra todos. Mas, aí, foi o meu erro, entendeu? Por achar que ser deficiente, tinha que deixar fazer o que queria, e não era bem assim...

Mais especificamente em relação ao significante cegueira vimos suas representações fantasmáticas que remetiam a outros significantes: o nada, a ausência de coisas, ausência de 
vida, confinamento, dependência dela para sempre, conforme vemos em seu relato na entrevista:

Eu achava que ele ia sofrer, eu achava que ele não ia ter uma vida normal como a nossa, eu achava que ele ia sentir falta da visão. Mas depois que eu fui percebendo que ele já nasceu assim, que o mundo dele é o mundo normal. Mas foi difícil no começo, entendeu?

Nossa! Eu achava que ele ia viver num mundo escuro! Toda hora, só via essa imagem na minha cabeça, assim, sabe? Achava que ele não ia ter uma vida normal, como eu já te falei... Achava que ele ia ficar uma criança... que ia depender de mim assim, que ia ficar dentro de casa... Falava: "Meu Deus!" Mas, não, depois que eu fui percebendo aos poucos que não é nada disso. É tudo paranóia (risos)...

Mais uma vez, fica ressaltado o fato de que ela só via a deficiência, não podia ver o filho. Via o nada, a dependência, a escuridão, o sofrimento que aprisionaria os dois para o resto da vida (em sua fantasmática). E assim, não libidinizava o corpo de seu bebê, não o promovia ao estatuto de guardião dos afetos e das palavras. Havia sim, momentos nos quais parecia envolvê-lo com toques, carícias, vozes, movimentos, brinquedos, mas estes não chegaram a ganhar força suficiente como elementos relacionais em um continuum de sustentação para a constituição do sujeito.

Tais elementos também não faltaram por completo, pois ela afirma que a cegueira não o impedia de mamar, sorrir para ela quando ouvia sua voz, desenvolver-se motoramente. Ainda que digamos que vê-lo "como uma criança normal" poderia ter sido um mecanismo para redimir-se do sentimento de culpa, essa idéia, dita a posteriori, é certo, pode ter operado em algum fragmento de relação e ter aberto o mundo para Augusto. Seria por isso, uma vez que as relações humanas não são estáticas, que se diz das crianças com problemas na constituição subjetiva e no desenvolvimento, que elas constroem focos de inteligência e contato com o mundo?

A mãe diz que esteve adormecida pela depressão e que acordou num dado momento: não podia ver a cegueira e paradoxalmente só enxergava isso, hoje enxerga as possibilidades de Augusto. Ela lhe ensina, apesar de nem sempre conseguir. Ainda acha as coisas difíceis sem a visão, fica ansiosa nos momentos nos quais ainda vê a cegueira na frente de Augusto.

Diante da cegueira ela paralisou e paralisou Augusto causando na relação impasses para a subjetivação dele. 


\subsubsection{Reação e sentimentos em relação à agressividade do filho}

A mãe de Augusto nos conta como ele começou a morder e tornar-se agressivo e como ela lidou com essas manifestações frente ao mundo:

(...) quando ele começou a ter os dentes dele, começou a morder, essa fase de morder, eu achava que era normal, por ele ser cego... Foi aí um dos meus erros, também. Eu não soube... eu não soube assim... corrigir na hora que eu devia, fui deixando, ele foi mordendo, foi ficando agressivo...

Eu cheguei já a corrigir de uns dois anos pra cá, mas eu acho que, não é que foi tarde, é que ele já se habituou naquela rotina de agredir e eu achava que era normal...

No início das mordidas, julgou normal como para qualquer criança, mas quando esse comportamento persistiu, ela entendeu que isso era o correto para uma criança cega. Se não fosse cego, se fosse uma criança normal, se ela o visse como "normal", uma criança sem deficiência, o teria corrigido. Julga ter errado por não corrigi-lo. Podemos ler: culpa-se por não tê-lo visto além de sua deficiência.

Ela explica ainda a origem e as causas de tal comportamento:

(...) quando ele era bebê, o pai fechava a mãozinha, começou a ensinar ele a dar socos, começou a ensinar a dar o dedinho do meio, e eu corrigia, corrigia, e o pai ensinando ele a ser agressivo. Não foi muito tempo. Não sei se isso ajudou ele a ser... mas era o pai falando que não... o pai falando que sim e eu falando que não, e eu pedindo, então eu não sei se isso ajudou. Mas isso já faz muito tempo... O pai começava a brincar: "ah, é macho, ah, é homem..."

(...) o pai influenciou muito. E aí junta a agressividade dele, que já deve ser por natureza, já deve ser um pouquinho nervoso, e o fato de não enxergar, de não conseguir distinguir de onde vinha os sons antes, quando ele era um pouco menor, hoje não; o pai ensinando agressividade, né?! Eu discutia muito com o pai, era só gritos e discussão. Ele também presenciou muito isso. Aí junta o pai ensinando, a gente discutia muito, aí som ligado, tudo, eu não sei se isso ajudou muito, contribui com que ele... Aí junta a agressividade dele, e eu achando que era correto, fui deixando, deixando...

A mãe localiza a agressividade de Augusto no pai, na dificuldade de discriminar os sons pela cegueira, no ambiente agressivo e na sua negligência por deixá-lo fazer. Assim justifica seus atos pela dificuldade de enfrentar os sentimentos que a deficiência do filho lhe representou, não deixando que ela considerasse suas peculiaridades para apreender e compreender o mundo, que dela exigiria um fazer mais atento e uma disponibilidade para ele que lhe foi difícil, como já vimos. Um fazer que, para constituí-lo em sua subjetividade, exigiria dela (Outro materno) presença e relação para não se tornar mecânico e vazio. Um 
fazer que exigiria palavras que portassem um dizer carregado de desejo sobre seu filho Augusto. Ela julga, assim, que errou como mãe e que, se seu marido estivesse com ela, teria sido mais fácil. Ela se convence de que errou por deixá-lo dependente dela. Diríamos que pôs em marcha o desejo inconsciente de deixá-lo dependente. Por que ela lhe teria dado esse lugar? Em suas próprias palavras temos:

Foi aí meus erros, porque se eu tivesse tratado ele como uma criança normal, talvez ele não me desse tanto trabalho como ele deu esses últimos anos, porque ele quebrou muito a minha casa, quebrou muita coisa, muito nervoso, devido eu ter que trabalhar...

(...) por ser deficiente, eu não tinha que corrigir, entendeu? Eu achava que, conforme o tempo, ia acabando... mas, não! Foi o meu erro.

Eu cheguei já a corrigir de uns dois anos pra cá, mas eu acho que, não é que foi tarde, é que ele já se habituou naquela rotina de agredir e eu achava que era normal...

Agredir tornou-se o gozo de Augusto e deste só viria a se livrar quando ela o visse de outra forma, pois a criança se vê como é vista. Ela diz: "ele já se habituou naquela rotina de agredir e eu achava normal".

A mãe localiza seus erros também pelas dificuldades que viveu com a ausência do marido:

Ele ficava sozinho... Algumas horas ficava, porque... eu ia chorar, eu ia trabalhar chorando, porque eu pensava: "eu preciso trabalhar, né?" (choro) Difícil... (chorando muito) Eu precisava ir trabalhar, né, pra dar as coisas assim pra elas... O pai não soube me compreender (chorando). Foi difícil essa fase. Graças a Deus, agora já passou... No começo foi... eu não tinha ódio, nem nada, nem descontava nele, no Augusto, não, nunca. Eu só falava: "Ai, meu Deus, quebrou mais outra coisa", e pronto. Hoje eu não compro nada, assim. O tempo que sobra, as minhas economias, eu guardo um pouco, pra quem sabe, daqui a alguns anos, quando o Augusto ficar menos agressivo, eu conseguir de novo.

Ela revela ainda sua angústia e o medo de deixar Augusto perto das pessoas por sua agressividade, evitando levá-lo aos lugares públicos (festinhas para as quais sempre é convidado na vizinhança, parques, shoppings, visitas e escola).

(...) quando ele cisma de querer sentar sozinho e eu tenho que ficar do lado dele. Eu já tenho medo. Eu ando vinte e quatro horas com medo de ele agredir as pessoas. Eu ando, assim, assustada. Então, tá assim: eu tenho que sentar do lado dele, e você sabe que às vezes no ônibus tem alguém idoso que precisa mais do que eu... e se eu ceder o lugar e ele machucar um idoso? Aí eu fico com esse medo e acabo sentando. Aí, se senta um casal na frente e começa a conversar e incomoda ele, ele... ou quer avançar nas pessoas que tá na frente ou que tá atrás, ou começa a falar palavrão.

(....... o medo dele machucar é tamanho, que eu acabo entrando no meio. Não sei se ele vai agredir ou não, mas eu já vou logo me prevenindo, me precavendo, não deixando ele se 
aproximar, entendeu? (rindo). Quando eu sei que a criança é uma criança como nós, que tem autodefesa, tudo, eu deixo, porque eu aviso, eu deixo. Porque a criança já sabe que ele tem esse lado dele... de repente, assim, do nada, ele agredir. Mas quando é uma criança que tem um certo problema mental ou tem uma certa deficiência que não tem como perceber que ele vai agredir, eu tenho que entrar no meio. Ou então eu aviso a mãe. Aí, cabe à mãe ou não. Mas que eu tô sempre ali protegendo, com medo, eu tô (rindo). Não sei se é exagero, mas infelizmente eu sou assim.

Esse medo a faz impedir Augusto de relacionar-se e conviver nos espaços sociais, tirando-o dessa circulação, antecipando-se sempre e interpondo-se entre ele e os seus semelhantes e, assim, sem que ela saiba, acaba impedindo-o de tornar-se humano.

Ela demorou a mergulhá-lo na cultura e vemos isso quando ela menciona que "nunca comemorou seu aniversário". Nunca comemorou seu nascimento nem para ela nem socialmente por medo que mostrasse sua inabilidade para o social, inabilidade que ela ajudou a construir.

Além disso, sua reação diante dos comportamentos destrutivos do filho mostra certa resignação dizendo confiar que um dia isso vai passar:

Eu chego e falo: "Ai, meu Deus, mais uma”. Aí falo: "Filho, não pode... você quebrou mais outra”, entendeu? Vou conversando. E eu falo, eu cobro das minhas filhas, porque uma tinha doze e a outra tinha dez. Eu falo: "Filha, pelo amor de Deus, deixa a casa do jeito que tá, suja, só cuida dele, só dá atenção pra ele. Quando a mãe chegar, a mãe limpava”, entendeu? Mas elas dormiam tarde, acordavam tarde e ele, sem enxergar, acordava e saía destruindo tudo o que via pela frente.

Ele quebrou tudo e eu não compro outra com medo dele quebrar de novo. Eu penso que essa fase vai passar logo... quando ele for, aos poucos... eu vou...

Mas ele quebra tudo. Então, assim, pratos... pratos eu tô com poucos em casa, tô sempre comprando, sempre repondo, porque se tiver um prato aí fácil, às vezes, né, ele... "mamãe acabou”. Aí ele me dá o prato, na minha mão, eu falo: "Vamos levar na pia”. Eu levo. Aí ele tá lavando louça junto comigo, né, lava copo, prato e algumas coisas que não é cortante. Mas algumas vezes, quando você descuida, deixa ele sozinho, o que tiver de quebrar, ele joga tudo no chão.

Novamente aparece a díade ficar sozinho/quebrar como significante na história da destrutividade de Augusto, um ato desesperado para ser visto e sustentado pelo Outro.

Ainda em relação à reação da mãe frente a esses comportamentos dele, ela mostrou ter dificuldades para dizer o que sente sobre isso. Apenas diz o que pensa:

Na hora em que ele destrói algo? O meu sentimento? Hoje eu não me incomodo mais com bem material. Antes eu queria ter a casinha arrumadinha, tudo no seu devido lugar, tudo arrumadinho. Depois que o Augusto nasceu, que ele começou a ter... quebrar tudo e eu precisei trabalhar, e aí foi que começou a quebrar... Se ele vê uma porta dessa aí antes... hoje eu não sei, né, porque ele... eu não dou mais tempo pra ele destruir nada, mas... se antes ele 
visse uma porta assim no guarda-roupa, ele tenta abrir e força ela ao contrário, até soltar a porta do guarda-roupa. Então, assim, tudo o que você possa imaginar, ele tenta assim, de alguma forma, tirar do local, modificar, eu não sei o porquê ele age desse jeito, entendeu?

O meu sentimento? Ah, eu explico pra ele o porquê que ele quebrou, que não podia...

Não sei! Que tipo de sentimento você acha... ah.... a minha reação de momento? Ah, eu penso que vai passar, eu penso que depois eu vou poder arrumar minha casa aos poucos de novo...

Raiva? Não. Eu já cheguei a dar uns tapinhas na mão dele, no bumbum, explicar pra ele que não podia, que não pode, que é errado, fecho, mostro o lado...

\subsubsection{Como a mãe se mostrou - lugar que ocupou, como se sentiu}

Por tudo que foi mostrado até aqui vimos que a mãe de Augusto mostrou-se perceptiva e zelosa, ao mesmo tempo em que o abandonou: percebeu logo sua deficiência, buscou ajuda precocemente, mas não seguiu o atendimento. Caiu em depressão e superou. Sentiu-se errada como esposa para o marido e como mãe para Augusto. Sentiu-se culpada por deixá-lo só. Rejeitou e depois passou a aceitá-lo. Ainda não o deixa fazer as coisas por si próprio para as quais ele se mostra capaz. Não o introduzia na vida e pensava que ser deficiente era estar fora mesmo, pelo menos julgava poder protelar seu tempo de entrada. Enfim, uma avalanche de sentimentos e de vivências provocadas pela experiência de ser mãe de uma criança com deficiência.

Depois de um período difícil no qual ocupou o lugar de mulher traída, abandonada pelo marido e mãe de deficiente, ficando dois anos em depressão e mais dois nos quais viveu uma grande angústia de deixar Augusto com as filhas para trabalhar, é que começou um movimento de libertação. Ela relata um pouco desses dois momentos da seguinte maneira:

Foi depois dos primeiros dois anos... Foi... devido eu ter ficado depressiva, eu não passei a raciocinar melhor, né? Tava com uma certa dificuldade. Depois que eu acordei. Aí eu trouxe ele pro Laramara... Houve um período que eu trouxe ele pro Laramara, quando bebê, né? Mas ele era tão bebezinho, né? E aí, surgiu uma vaga lá na Faculdade de Guarulhos, aí o Laramara falou: "Pode, você pode continuar levando ele lá, o efeito vai ser o mesmo". Aí eu levei. E devido à depressão que eu tive, eu não agüentei, comecei a faltar. Aí, ele perdeu a vaga lá, entendeu? Ele fez muitas amizades, inclusive com o psicólogo de lá... ele montou uma clínica... não... olha, ele quer que eu continue levando o Augusto, e eu, agora, não tá dando tempo, porque eu tenho minhas outras filhas em casa, tá numa fase muito difícil. Aí, eu não tô podendo... só venho pra cá, mas eu dou graças a Deus à Laramara, porque a Laramara tem me dado muito suporte. Muito bom a Laramara.

(...) Depois pensei que o mundo dele é assim, então é normal pra ele. 
Pra ele, é bom frisar, e não mais para ela. Já começa a poder vê-lo?

\subsubsection{A mudança de olhar da mãe e a possibilidade de saída de Augusto do lugar} de deficiente: a busca da instituição especializada, os apoios médico e psicológico e a inclusão escolar

Quando a mãe de Augusto sentiu-se capaz de investir em sua educação, ou seja, retomar o que não pôde fazer quando ele era bebê (olhá-lo, desejá-lo, torná-lo uma criança que fizesse parte do fazer e do dizer daquela família para fazer laço social), passou a buscar os atendimentos. Inclusive voltou à primeira instituição, a qual havia deixado em função de sua depressão. Aceitou e tentou cumprir as orientações e encaminhamentos dados. Ela julga que tais apoios têm sido fundamentais para fazê-la perceber melhor seu filho e aprender como auxiliá-lo nas necessidades específicas decorrentes da deficiência visual e na construção da infância.

Como já foi dito, ela é clara em afirmar que, depois da instituição, da neurologista e da psicóloga, Augusto e ela vêm se desenvolvendo muito. Em relação à escola tinha ressalvas, pois pensava que ele deveria ir à escola especial.

De início a mãe pensava que Augusto não poderia estar no espaço da escola comum no qual estão as crianças que não têm deficiência. Ainda pensava em seu filho deficiente, preso ao seu gozo que se sustentava nos comportamentos destrutivos e agressivos, que machucaria as outras crianças, merecendo estar restrito à escola especial, sem convívio no social mais amplo dado pela escola comum:

Eu achava que... quanto mais tarde ir pra escola, melhor, devido a essa agressividade dele. Eu tava esperando ele diminuir esse lado agressivo dele, com receio dele ir pra escola e agredir outras crianças, entendeu? Eu comecei a esperar, retardar um pouco a ida pra escola por esse motivo.

(...) achava que tinha que ir pra escola especial... O Laramara pediu que eu colocasse ele numa escola normal... no EMEI. Só que tô com uma certa dificuldade, porque tá assim: o bairro onde eu resido, o EMEI não está preparado pra aceitar o Augusto, porque a sala tem mais de vinte e oito crianças. Disse que a professora não está nem preparada e nem vai poder se dedicar ao Augusto, porque a escrita do EMEI é mais na lousa. E eles falaram que eu não posso pôr o Augusto numa escola, numa sala especial, porque o Augusto fala, anda e escuta. Estou com uma certa dificuldade... 
Incentivada pelos profissionais da instituição, começou a pensar na possibilidade da escola comum e regular para Augusto e arriscou, quando conseguiu a vaga na EMEI, ficando surpreendida com o resultado positivo da experiência.

Para ela, a instituição representou um início de mudança de olhar sobre a cegueira e sobre as possibilidades de seu filho quando, ouvindo outras mães e vendo outras crianças, pôde ressignificar os mitos de isolamento social, incapacidade e dependência da pessoa cega que tinha marcado sua relação inicial com seu filho. Também vislumbrou a idéia de que Augusto poderia estar na escola comum, simplesmente porque é uma criança. Viu profissionais que acreditaram no potencial de Augusto e o trataram como criança nas suas especificidades de ser cego com os apoios de que necessita para aprender a viver e a conhecer.

Em última instância, a mãe de Augusto, em um processo inconsciente, chegou a ponto de desejar outras coisas. Como Outro, quando ela diz que acordou, é como se ela dissesse para Augusto: "não era bem isso, meu filho, tem que ser outra coisa agora para a sua vida e para a minha”. Nesse momento sugere um movimento para Augusto diferenciar-se dela.

\section{ANÁLISE INTERPRETATIVA DOS DADOS RELATIVOS A AUGUSTO E À MÃE $-2^{\mathrm{a}}$ ETAPA}

É comum vermos mães de crianças com deficiência que, inconscientemente, procuram eternizar a infância dos filhos com medo que cresçam e assim fiquem, mãe e filho, mais expostos à sociedade, que vê o bebê e a criança pequena com mais condescendência e menos exigências de adequação social do que quando vão ficando crescidas.

Como explicita Leonhardt (1992) sobre o trabalho de Cantavella (1988) acerca das vivências psicológicas na relação mãe-bebê cego no início de sua vida, a negação parcial ou total que inicialmente leva os pais a uma peregrinação para a confirmação do diagnóstico, associada às fantasias sobre a cegueira, desencadeia os sentimentos mais profundos e dolorosos como os que levaram a mãe de Augusto a cair em depressão por um período muito longo. Essa vivência provocou um mecanismo de superproteção, ao qual ela se refere e que, para os autores, é uma conduta de pais que só vêem a deficiência do filho, impedindo-o de viver as experiências comuns da vida, de interessar-se pelo mundo e relacionar-se com o outro. São condutas superprotetoras de pais que subestimam a criança e que estão, 
geralmente, associadas à culpa e rejeição. Assim, mantêm a criança como seu objeto de desejo e não passam a desejar outras coisas, impedindo a geração de desejo na criança.

Retomamos um pensamento de Stevens (1996) que expressa essa relação que se mantém paralisada:

(...) tal mãe sacrifica-se sem cessar pelo seu filho, submetendo-se à sua violência e a todas às suas fantasias, suspendendo sua vida na presença da criança; entretanto, ela não cessa de queixar-se de seu sacrifício, enquanto que o sacrifício que se deverá buscar que ela faça é o de renunciar a esta posição de sacrifício (STEVENS, 1996, p. 62).

Embora um trabalho pessoal que opere nesse nível de profundidade proposto pelo autor citado acima só se possa lograr mais efetivamente em uma análise, queremos ressaltar que a mãe de Augusto esboçou um desejo de saída do lugar que vinha ocupando e reservando ao filho para cunhar uma nova posição. Ela mesma ensaiou um "basta" para aquela situação na qual estavam, mãe e filho, paralisados.

Retomando o que se passou nessa relação, um ponto que merece ser destacado é o de que a mãe relata que só podia ver a deficiência de Augusto, ou seja, ao seu corpo-organismo. Não podia ver o filho como alguém que habitasse esse organismo e, assim, não podia criar para ele uma história, um sonho, uma ficção que o fizesse viver. Na constituição do sujeito, o real do corpo precisa dar lugar à imagem corporal que passa a representar esse alguém e se somente é vista a deficiência, esta ocupa todo o lugar dessa criança, toda a sua identidade (Cf. LEVIN, 2002).

As vivências relatadas pela mãe de Augusto corroboram as idéias expressas por Levin (Ibid.) no que diz respeito aos transtornos em sua relação com ele até por volta de seus quatro anos de idade. As dificuldades na relação mãe-bebê são ilustradas pelas condutas oscilantes da mãe que protelaram os momentos de ruptura necessários para instaurar no corpo as marcas simbólicas e as aquisições funcionais: o desmame, o tirar as fraldas, a saída do quarto dos pais (o que até hoje não se deu no caso deste último), a entrada na escola. Quando a mãe é capaz de fazer os cortes, as proibições e as separações a cada etapa da vida de seu filho, ela favorece sua constituição de sujeito e seu desenvolvimento. A mãe de Augusto nos conta como ela protelava e ainda protela essa tomada de posição, para, inconscientemente, não "barrá-lo" (no sentido de não cortar a fusão mãe-filho), para que ele não deixasse de ser seu objeto, para que 
não se separasse dela. Ao mesmo tempo em que o queria ver crescer, também o queria pequenino.

Os estudos de Fraiberg e Freedman (1964), Fraiberg e Adelson (1982), Leonhardt (1992) e outros corroboram para o esclarecimento de que muitas crianças cegas congênitas podem ter o desenvolvimento interrompido, retomando a possibilidade de evoluir após os quatro ou cinco anos de idade. Vemos que se interrompe o curso da libido, passando a criança a não se interessar (catexizar) pelos objetos e centrar a libido em si mesma. Os autores vão concluir que essa parada não é dada pela cegueira, mas pelas dificuldades na relação mãebebê, embora possamos ressaltar que uma está implicada na outra pela fantasmática da mãe em relação ao sentido que a cegueira assume para ela.

Vimos no estudo que fizemos de Augusto que isso também foi constatado. Nesse período ele começou a morder e estagnar. É um momento crucial na constituição da imagem, na subjetivação e no desenvolvimento e depende da presença que a mãe será capaz ou não de sustentar. A mãe de Augusto não sentiu-se capaz nesse momento, devido à depressão, culminando um pouco mais tarde na saída de casa para trabalhar, só voltando a investir nele por volta de seus quatro anos, quando resolveu voltar à instituição especializada.

Ela ilustra isso quando diz que não o corrigiu: "Aí foi o meu erro... eu errei muito nos erros..., não corrigi... fui deixando, deixando", referindo-se às suas mordidas e outras condutas agressivas. Entendemos que corrigir seria colocar o ponto de basta que introduz a criança na cultura, que possibilita diferenciar-se. É como se o Outro nesse momento diria: Não pode fazer isso porque isso está fora do que todos nós fazemos. Para ser um de nós (como um humano), precisa fazer como nós.

Assim, a ambivalência no comportamento da mãe ao relatar sua história, suas lembranças, fantasias e desejos inconscientes, que foram cunhando lugares e posições para Augusto em seu discurso, mostrados na não proibição e na superproteção, não lhe permitiram educar Augusto no sentido psicanalítico exposto por Kupfer (2001) como "a prática social discursiva responsável pela imersão da criança na linguagem, tornando-a capaz, por sua vez, de produzir discurso, ou seja, de dirigir-se ao outro fazendo com isso laço social” (p. 35). O laço social, que é uma forma do adulto transmitir o desejo e um pedaço de cultura. Para Lajonquière (1997), educar é “(...) filiar o aprendiz a uma tradição existencial, permitindo que este se reconheça no outro" (p. 30). 
Nos exemplos que a mãe de Augusto nos deu em sua entrevista, textualmente ela nos conta que (...) "enquanto eu tiver saúde e Deus me der saúde, eu vou cuidar dele. Ele não precisa se preocupar em ir no banheiro tão cedo, por ser deficiente (...) quanto mais tarde, melhor pra ele”. Ela fazia e ainda faz por ele, dificultando-lhe a apropriação da prática social que faz laço.

Ainda hoje a mãe mostra certa negligência/resistência para favorecer seu enlace social, como vimos em uma das atividades que observamos: ela esqueceu a bengala, não fez o caderno tátil pedido para Augusto compartilhar com os colegas na atividade na instituição. Justamente este caderno tem a proposta de registrar com objetos, letras e outras marcas significativas no contexto da criança que historicizem sua vida no seu cotidiano na família.

Outro aspecto relatado pela mãe em sua entrevista diz respeito à relação que ela estabelece entre sua saída de casa para trabalhar, deixando Augusto praticamente sozinho com o início dos seus comportamentos destrutivos. E depois o parar de trabalhar, cuidar dele levando-o à instituição especializada, à neurologista, à psicóloga e depois à escola, com a diminuição de tal desordem. Antes, nem lhe fazia festinha de aniversário, como também não aceitava convites para levá-lo ao aniversário de outras crianças da vizinhança. Evitava em razão da agressividade dele, ela explica. Por vergonha, por não reconhecer-se nesse filho e identificar-se com ele, interpretamos nós.

A vivência de agressividade e ambivalência de sentimentos no bebê é parte de sua estruturação psíquica. Nesse momento do início da vida em que o bebê ainda está confundido com o outro, a agressividade pode ser uma forma de diferenciação. Pode também representar um ato da criança frente ao mundo ou ato sofrido por outra pessoa (Cf. BASTOS, 2003). No caso das crianças cegas congênitas a agressividade pode representar uma reação às dificuldades dos pais (principalmente da mãe) em aceitar o filho, com sentimento de rejeição e quadro de depressão, levando a criança ao isolamento e a condutas sociais atípicas e agressivas (Cf. LEONHARDT, 1992).

Na vida de Augusto vemos que, de fato, estas duas experiências se deram em relação à agressividade que perdurou tantos anos: uma como forma de diferenciar-se e atuar no mundo, além da "agressão" sofrida pela mãe, e outra como reação ao modo como a mãe viveu a deficiência do filho, a não aceitação, que a levou a permanecer em depressão por dois anos. Nas palavras da mãe: "auto-defesa”. Além disso, havia também a figura do pai que foi quem lançou sobre ele o desejo e viu-o em sua identidade sexual como menino e deu-lhe o reconhecimento de filho através do ato de dar socos. Como diz a mãe: "o sonho dele era ter 
um filho homem... (...) 'ah, é macho, ah, é homem!' (...) o pai sempre ensinando ele a dar $\operatorname{socos} "$.

Poderíamos levantar ainda a hipótese de que ele percebeu e expressou a raiva que a mãe confessou sentir do marido na ocasião da separação e do diagnóstico de cegueira e sua depressão. Ela denega que tenha descontado nele tais sentimentos, como é possível ver em sua fala:

(...) quando eu estava deprimida, eu cuidava dele normal, eu não tentava passar pra ele a minha angústia. Mas, eu creio que, de alguma forma, ele acabou percebendo. Porque eu chorava muito... entendeu?

(...) eu não chegava a gritar, nem maltratar, nem ele nem nenhuma das minhas filhas, não. A minha angústia era só de chorar, não querer sair, ficar isolada, não conseguia dormir, tinha falta de ar constante, entendeu? Aí, quando vinha aquela falta de ar muito forte que eu achava que eu ia desmaiar, aí minha filha mais velha ia, ligava e me levava pro prontosocorro. Não sei se o Augusto conseguiu guardar alguma coisa... dessa fase baixa aí que eu passei, mas, maltratar ele ou alterar o tom de voz, não sei... nunca... não... nunca passei isso pro Augusto.

(...)eu não tinha ódio, nem nada, nem descontava nele, no Augusto.

O termo descontar já expressa culpa e basta que ela tenha sentido. isso se expressou e Augusto percebeu.

Mas o interessante é que ele a reconhecia. Por sua voz que lhe conferia substancialidade como objeto na materialidade do mundo, possibilitando a construção do objeto e sua noção de permanência e lhe respondia com sorriso, jogando-se na direção dela. Isso nos faz ver que havia, em certa medida, um aparato com o qual Augusto contava e que tornaria possível a sua interação no mundo - a pulsão da voz:

Devido a ele escutar a voz, ele ria, você vê as reações do bebê, entendeu? "Mamãe tá aqui!" Então a hora que ele escutava a minha voz, ele já se jogava em direção à minha voz, pra vir pra mim... entendeu?

Alguns pontos saudáveis na relação da mãe com Augusto o salvaram do isolamento total. Mesmo deprimida ao longo dos dois primeiros anos de vida dele, só fazendo chorar, ela o amamentava, conversava e brincava com ele, incentivando-o a aprender coisas sobre o mundo à sua maneira: “Ah, a gente ficava junto (...) aí eu ia ensinando...”

Comprou-lhe um andador para que ficasse perto dela e pudesse explorar o espaço e vir quando ela o chamasse. Assim, ela fazia leitura das manifestações de Augusto, mostrando 
compreendê-lo de certa forma e intervindo para satisfazer suas necessidades e atender o que supunha serem suas demandas como mostram os trechos abaixo:

Quando saciava a fome dele, ele ficava quietinho porque ele não pegou chupeta, então... mas a hora que dava a fome, ele já começava a chorar e aí... a hora que eu pegava ele no colo que ele procurava o seio, eu já sabia que era fome, entendeu?

(...) fome, ele chora, né? Sempre chorou, quando bebê. E a sede... eu via ele pondo a lingüinha pra fora, ou então eu via que a boquinha tava um pouco seca, mas eu nunca esperava ele ter muita sede.

(...) às vezes, eu pegava um pouco no colo e, às vezes, eu falava: "Você quer colo?" E aí ele já sorria e me abraçava, quer dizer sim, entendeu? E algumas vezes, quando eu estava ocupada, que eu não tinha como segurar, eu colocava no andador, no carrinho, não tinha como você deixar uma criança chorando. Não é porque ele é cego.

Augusto, por sua vez, passou a demandar? Uma forma rudimentar foi sua agressividade para mostrar o que queria. Passou da necessidade ao desejo? Não inteiramente, se podemos dizer assim. Vemos o tempo todo que ele mostrava possibilidades, a mãe esboçava um movimento, mas não sustentou a rede simbólica. Não ofereceu a ele uma imagem consistente com a qual poderia identificar-se. Só via sua deficiência e a ausência do marido. O corpo-imagem de Augusto foi recoberto por essa dupla ausência: do marido (objeto de desejo da mãe) e da visão (representante para a mãe da impossibilidade de ser e de viver). Ambas as ausências representavam para a mãe uma perda insuportável que a fazia sucumbir cada vez que olhava para Augusto. Olhava com o olho e não podia ver. "Escurecia a vista, caía a pressão", como ela mesma relata.

Apesar dos pontos que se mostravam favoráveis para que Augusto tivesse sucesso em sua constituição, vimos que a relação com sua mãe atravessou dificuldades. Além dos trechos já citados sobre sua depressão e o modo como o olhava, ela conta que, quando ele era bebê, falava pouco com ele, não explicava nem dava significado para as coisas que aconteciam, nomeava-as apenas:

Quando bebê, não. Só o chocalho... é, o chocalho e o pianinho, né? Eu falava o que que era que dava sons, falava pra ele o que que era e ele ficava brincando, né?

Via em Augusto a diferença em relação às crianças que enxergam, pois ele usava mais a audição como referência dos acontecimentos e dos objetos do mundo ao seu redor. Percebia 
também que Augusto a reconhecia e a diferenciava de estranhos pelas vozes e que ele mostrava ser capaz de estabelecer vínculos humanos.

Em um dado momento, na entrevista, a mãe de Augusto misturou os tempos que o situam em sua vida, empregando no mesmo acontecimento o passado e presente. Esse lapso no tempo nos faz pensar em uma impressão que este caso nos tem suscitado: Augusto se traduz em alguns momentos por evidências de sua mudança na direção de constituir-se como sujeito e conquistas em seu desenvolvimento cognitivo, e outros nos quais expressa regressão ou permanência em comportamentos fixos e cristalizados. Essa forma de lidar com passado e presente parece indicar esse caminho de sua subjetivação que começa a permitir que ele faça em tempo diferente ao do que faria "normalmente". O trecho abaixo é indicativo dessa afirmação dos tempos:

Eu acho que ele não tinha muito essa percepção, não, né? Mas, assim, das irmãs, que é as pessoas que têm um contato diariamente dentro de casa, ele sabia. Porque, pelo som, ele se jogava pra pessoa. Mas só as pessoas que ele via pouquíssimas vezes, ele segurava em mim, na minha mão, e não ia, entendeu? Como se percebesse que aquela pessoa era uma pessoa estranha, entendeu? Mas, os tios, que tinham contato com ele, a avó, ele se joga...

... tudo o que uma criança normal fazia, ele faz.

Sobre a comunicação, a mãe fala de Augusto ter sido um bebê quieto, que se expressava pelo choro quando tinha fome, sono, dor ou outro incômodo e que isso fazia com que ela o visse como uma criança normal que apenas não enxergava. Sabemos que não é bem assim, pois não contar com o sentido da visão determina uma outra forma de estar no mundo, com outro equipamento perceptual e de organização mental, o qual exigirá alguém que compreenda isso e lhe corresponda no modo de lhe interpretar o mundo e proporcionar experiências significativas da vida para que possa constituir-se, dado que a relação mãe-bebê estará marcada por esse fato como vimos na entrevista com a mãe.

Por ele não enxergar, é... lógico, a gente tem como passar a ensinar coisas. Quando você enxerga, você tem estimulação da visão, cê tá vendo o que é certo e o que é errado. Quem não enxerga, você tem que passar a ensinar e a falar a usar o tato.

Nessa fala retomamos Masini (1990) quando defende que o "equipamento" da criança cega é distinto e em nada pode ser comparado ao da criança que enxerga. Assim, pensamos que na relação da mãe com seu bebê cego a sensibilidade dela de levar em conta as formas 
próprias do perceber que acionarão o relacionar-se e o agir dele sobre o mundo é que permitirão ao bebê fazer uso de seu equipamento e constituir-se.

A mãe parece compreender isso, mas houve dificuldade para fazê-lo:

E eu achava que não, que quanto mais cedo era bobagem, que eu poderia esperar mais, pra não judiar... tudo bobagem da minha cabeça. Tudo bobagem... pelo contrário, eu tava prejudicando ele. Acho que se eu tivesse pego com ele normal... Não, o Augusto tá normal pra mim, entendeu? Talvez ele hoje fosse uma criança bem mais calma e bem mais independente.

Vemos aqui reiterada a idéia da grande complexidade da relação mãe-bebê que Kupfer (2001) assinala quando fala de um encontro entre mãe e bebê que começa da seguinte maneira:

(...) com o equipamento material com o qual a criança vem ao mundo e termina no entorno social em que mãe e bebê encontram-se mergulhados. (...) somente ele (o encontro) poderá permitir que um bebê faça uso de seu equipamento, inteiramente inoperante se não houver quem o pilote. Mais que isso, esse equipamento sequer existirá se não houver quem o construa (Ibid., p. 50).

Vemos no caso de Augusto que ele mostrou possibilidades para absorver as coisas do mundo e humanizar-se, mas a fantasmática da mãe sobre a cegueira dificultou que ela pudesse exercer sua função de torná-lo humano.

Augusto, com seu equipamento, desde bebê mostrou indícios de sua força para a vida, como, por exemplo, ser guiado pela pulsão da voz, mostrando perceber a mãe, o que favoreceu a relação com ela e sua diferenciação do outro. Depois passou a reconhecer, pelas vozes, também as irmãs, a avó e os tios, estranhando aqueles que não faziam parte do cotidiano da casa.

Além das manifestações citadas acima, ele também se comunicava com outros movimentos corporais:

Em direção dos sons ele sempre... se chegava assim perto da gente, ele colocava o apoio, ele ficava em pé, entendeu?

Augusto continua seu percurso de constituir-se. A mãe diz, ainda, que ele hoje já conhece e nomeia as partes do corpo dele e dos outros: 
(...) porque eи ensinei...

(...) Às vezes ele quer ficar sempre sem roupa, sempre. Chega em casa, vai tirando tudo...

Mas apesar do contato e conhecimento do próprio corpo, ele ainda mantém uma fixação na boca como órgão de prazer e exploração do mundo, como ilustramos anteriormente.

Em certa medida a mãe o aceitou em sua forma de fazer contato - mordendo e batendo - e permitiu, inconscientemente, que ele se identificasse com essa forma. Apenas deixava, e isso era uma forma de não-relação, de não vê-lo, ou melhor, de só ver a deficiência porque ser deficiente, para ela, era isso. Agora percebeu que pode ser de outro jeito, pois ele entende o que se passa ao seu redor e o que lhe é dito:

(...) Sim, ele entende. Quando eu passo a conversar com ele, sim.

Em relação à figura do pai, para a mãe, como já vimos, ficou fora e permeada de ressentimentos e mágoas. Isso concretamente não representaria falhas na função paterna que poderia ser exercida pela mãe ou outros adultos. Mas o modo como essa mãe viveu a saída do marido de sua vida e a depressão decorrente desse fato e da cegueira de Augusto, causaram impasses no acesso de Augusto ao simbólico.

\section{REFLEXÕES SOBRE A INTER-RELAÇÃO DOS ELEMENTOS DO DISCURSO DA MÃE COM AS MANIFESTAÇÕES DE AUGUSTO}

Este nível da análise procurou cruzar os significantes que emergiram do discurso da mãe na entrevista como indicativos da posição que Augusto ocupou nessa rede discursiva. E também as manifestações de Augusto que se evidenciam como marcas desse mesmo dizer da mãe sobre ele na sua forma de viver.

Ao longo de toda a análise fomos mostrando essa inter-relação e possíveis sentidos para as vicissitudes da relação mãe-filho em sua aventura de procurar constituir um sujeito.

Recorremos à elaboração do quadro abaixo para melhor visualização desses dados que propõem uma possível interpretação do caso: 
Quadro 6: a posição de Augusto na rede discursiva da mãe

\begin{tabular}{|c|c|c|c|}
\hline \multicolumn{2}{|c|}{$\mathbf{M} \tilde{\mathbf{A E}}$} & \multicolumn{2}{|c|}{ CRIANÇA } \\
\hline $\begin{array}{c}\text { O QUE A MÃE FALA } \\
\text { DA CRIANÇA }\end{array}$ & $\begin{array}{c}\text { O LUGAR DADO } \\
\text { À CRIANÇA NO } \\
\text { DISCURSO DA MÃE }\end{array}$ & $\begin{array}{c}\text { O QUE A CRIANÇA } \\
\text { MOSTRA }\end{array}$ & $\begin{array}{c}\text { MARCAS DO } \\
\text { DISCURSO } \\
\text { DA MÃE NA } \\
\text { CRIANÇA }\end{array}$ \\
\hline $\begin{array}{l}\text { Era normal como outra } \\
\text { criança até um ano, } \\
\text { quando começou a } \\
\text { morder e, depois, a } \\
\text { agredir }\end{array}$ & $\begin{array}{l}\text { Normal } \\
\text { Deficiente } \\
\text { Agressivo }\end{array}$ & $\begin{array}{c}\text { Fixação do curso da } \\
\text { libido na boca } \\
\text { Agressividade }\end{array}$ & $\begin{array}{l}\text { Não libidinização do } \\
\text { corpo pela mãe }\end{array}$ \\
\hline $\begin{array}{l}\text { Não descontava nele a } \\
\text { raiva que sentiu do } \\
\text { marido e da deficiência } \\
\text { do filho }\end{array}$ & $\begin{array}{l}\text { Representante da } \\
\text { agressividade } \\
\text { reprimida na mãe }\end{array}$ & Agressividade & Raiva \\
\hline $\begin{array}{c}\text { Não podia olhar para } \\
\text { ele que só chorava e } \\
\text { desmaiava } \\
\text { Ficou dois anos em } \\
\text { depressão }\end{array}$ & $\begin{array}{c}\text { Vazio } \\
\text { Sem identificação } \\
\text { Deficiente } \\
\text { Isolamento }\end{array}$ & $\begin{array}{l}\text { Isolamento em si } \\
\text { mesmo } \\
\text { Auto-erotização } \\
\text { Fixação da libido } \\
\text { Não entrada na } \\
\text { linguagem } \\
\text { Estereotipia }\end{array}$ & $\begin{array}{c}\text { Não ser visto } \\
\text { Não ser reconhecido } \\
\text { Impasses na formação } \\
\text { da imagem corporal } \\
\text { (não ver-se) }\end{array}$ \\
\hline $\begin{array}{c}\text { Não desejou um filho } \\
\text { ideal, não desejava } \\
\text { nem esperava nada, era } \\
\text { mais um filho } \\
\text { Desejou um filho com } \\
\text { saúde e perfeição, o } \\
\text { filho homem para o } \\
\text { marido }\end{array}$ & $\begin{array}{l}\text { Mais um filho } \\
\text { Sem expectativa } \\
\text { Não perfeito }\end{array}$ & $\begin{array}{c}\text { Impasses na formação } \\
\text { da imagem, na } \\
\text { constituição subjetiva } \\
\text { e problemas no } \\
\text { desenvolvimento }\end{array}$ & $\begin{array}{c}\text { Sem desejo } \\
\text { Sem lugar na cadeia } \\
\text { significante da mãe } \\
\text { Fora da linguagem }\end{array}$ \\
\hline
\end{tabular}




\begin{tabular}{|c|c|c|c|}
\hline $\begin{array}{l}\text { Podia fazer tudo que } \\
\text { queria por ser } \\
\text { deficiente }\end{array}$ & $\begin{array}{c}\text { Deficiente } \\
\text { Poder tudo } \\
\text { Sem corte } \\
\text { Não ser barrado }\end{array}$ & $\begin{array}{l}\text { Morder - Bater - Dar } \\
\text { socos - Quebrar tudo } \\
\text { Fechado em si mesmo }\end{array}$ & $\begin{array}{c}\text { Poder tudo } \\
\text { Não ter falta } \\
\text { Não desejar } \\
\text { Não se constituir como } \\
\text { sujeito }\end{array}$ \\
\hline $\begin{array}{l}\text { Não corrigia Augusto } \\
\text { por ser deficiente e } \\
\text { seria judiar dele }\end{array}$ & $\begin{array}{l}\text { Deficiente } \\
\text { Coitado }\end{array}$ & $\begin{array}{c}\text { Agredir - Quebrar - } \\
\text { Falar palavrão } \\
\text { Pedir pra ter a } \\
\text { existência reconhecida }\end{array}$ & $\begin{array}{c}\text { Superproteção } \\
\text { Pena }\end{array}$ \\
\hline $\begin{array}{l}\text { Vai fazer tudo mais } \\
\text { tarde porque é } \\
\text { deficiente }\end{array}$ & $\begin{array}{l}\text { Deficiente } \\
\text { Atrasado }\end{array}$ & $\begin{array}{c}\text { Comprometimentos no } \\
\text { desenvolvimento } \\
\text { global }\end{array}$ & $\begin{array}{c}\text { Tornar-se sujeito mais } \\
\text { tarde }\end{array}$ \\
\hline $\begin{array}{l}\text { A cegueira significava } \\
\text { não ter uma vida } \\
\text { normal, ser dependente } \\
\text { da mãe, não sair de } \\
\text { casa, viver num mundo } \\
\text { escuro e sentir falta da } \\
\text { visão }\end{array}$ & $\begin{array}{c}\text { Dependência } \\
\text { Não ir a festas, fazer } \\
\text { aniversário ou ir à } \\
\text { escola aonde vão todas } \\
\text { as crianças } \\
\text { Não viver } \\
\text { Não se tornar sujeito }\end{array}$ & $\begin{array}{c}\text { Dependência da mãe } \\
\text { Expressar-se pela } \\
\text { agressividade } \\
\text { Isolamento }\end{array}$ & $\begin{array}{c}\text { Aprisionado na mãe } \\
\text { Objeto dela } \\
\text { Anormal } \\
\text { Isolamento }\end{array}$ \\
\hline $\begin{array}{l}\text { Começou a ver que ele } \\
\text { tinha outras } \\
\text { capacidades e que seu } \\
\text { mundo era aquele } \\
\text { Passou a corrigi-lo }\end{array}$ & $\begin{array}{c}\text { Capacidade } \\
\text { Possibilidade } \\
\text { Sujeito }\end{array}$ & $\begin{array}{c}\text { Desenvolvimento } \\
\text { cognitivo } \\
\text { Sublimação da } \\
\text { agressividade } \\
\text { Abertura para a relação } \\
\text { com o outro }\end{array}$ & $\begin{array}{c}\text { Aberturas para } \\
\text { subjetivação } \\
\text { Circulação social } \\
\text { Lugar na cadeia } \\
\text { significante da mãe }\end{array}$ \\
\hline $\begin{array}{l}\text { Aceitação } \\
\text { Superação } \\
\text { Vai passar }\end{array}$ & Capacidade & $\begin{array}{l}\text { Buscar relacionar-se } \\
\text { Querer saber } \\
\text { Fazer laço social }\end{array}$ & $\begin{array}{l}\text { Poder tornar-se uma } \\
\text { criança além da } \\
\text { deficiência } \\
\text { Sair da fusão com a } \\
\text { mãe para tornar-se }\end{array}$ \\
\hline
\end{tabular}




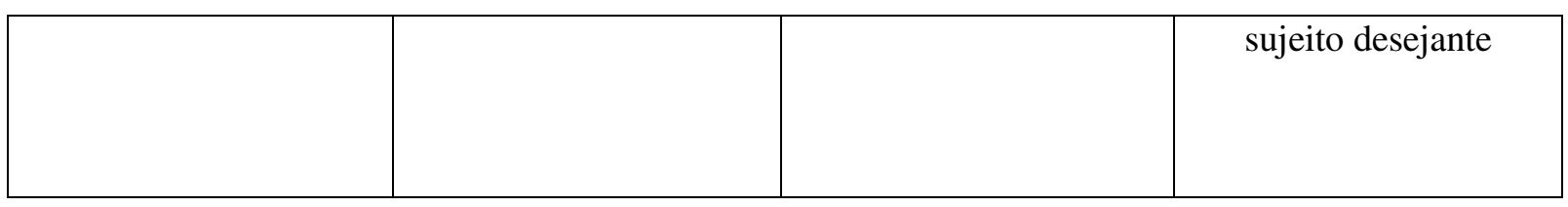

O quadro 6 mostra uma inter-relação dos conteúdos internos da mãe de Augusto, inconscientes na relação afetiva primitiva com ele, que se refletem no modo dele estar no mundo e responder aos significantes de sua mãe. Os sintomas de Augusto foram interpretados a partir dessa relação. São eles: morder, bater, quebrar, auto-centrar-se e ter movimentos estereotipados, isto é, sem representação. Não brincar, mas apenas auto-estimular-se com os brinquedos, ou seja, não representar a si mesmo na brincadeira, não ter consistência na construção do "eu". Não simbolização de experiências mais complexas, aprendizagens simples e dependência nas "atividades de vida autônoma" mesmo com capacidade para executá-las. Problemas na diferenciação eu-outro, linguagem pouco estruturada, além de pouca autonomia no uso da mão, fixação na boca, sinais de inteligência, resistência a mudanças e poucas interações sócio-afetivas.

Evidentemente não há uma correspondência linear, unívoca, porém há uma relação entre o que a mãe fala dele e o que ele manifesta em sua existência. Uma inter-relação dos significantes que emergem do seu dizer sobre ele e que se caracterizaram como marcas no corpo de Augusto, cunhando-lhe uma posição na cadeia de significantes da mãe a qual ele manifesta em sua forma de existir. De acordo com Jerusalinsky (1988), há uma primazia do significante do Outro sobre o organismo. Há uma "permeabilidade biológica ao significante" (Ibid., p. 44).

Quando, por exemplo, a mãe diz que não descontava em Augusto a raiva que sentia do marido, põe em pauta a enunciação de que havia raiva e vemos que ele se coloca no mundo como uma criança que morde e agride.

Quando ela diz que não podia olhar para ele que escureciam as vistas, caía a pressão e ela passava mal, a enunciação é que havia um olhar vazio, que não refletia nada, e o que temos é um impasse em Augusto na formação da imagem corporal, no reconhecimento de quem é ele.

Quando ela pensava que ser deficiente era fazer tudo mais tarde em termos de desenvolvimento, temos em Augusto uma criança com desvios e bloqueios no desenvolvimento. 
Estes significantes da mãe que apareceram em sua rede discursiva marcaram a criança.

Augusto viveu muitas das vicissitudes que os estudos sobre a criança cega mencionados neste trabalho apontam e que podem justificar suas dificuldades na constituição de sujeito e no desenvolvimento, como já vimos. São elas: a desordem na família e a separação do casal, o fechamento em si mesmo pela falta do olhar da mãe em sua depressão, levando-o a expressar por meio da agressão suas demandas, e a superproteção da mãe em relação a ele que só instauraram um lugar de dependência e hostilidade.

Mas a relação mãe-Augusto também deu mostras de abertura para fazer, em outro tempo, o que não pôde acontecer em idade precoce, não sem ônus certamente, mas a criança cega congênita mostrou possibilidades de constituir-se como sujeito e desenvolver-se (Cf. LEONHARDT, 1992) e vimos que isso está se abrindo para Augusto.

Sua mãe despertou o que ficou apagado em sua relação com ele quando não conseguiu levar a cabo sua função materna, o que ela tinha possibilidade de realizar, mas que, diante da perda do marido e da cegueira de seu filho homem, ficou afetada e não conseguiu também pôr em curso a função paterna e um projeto para ele na função de filho (Cf. LEVIN, 2002).

Augusto mostrou possibilidades para constituir-se e desenvolver-se, mas sua mãe teve dificuldades para ajudá-lo a trilhar esse caminho, desconhecendo as expressões e necessidades advindas das peculiaridades de criança que não contava com a visão para receber seu olhar, seu toque, sua voz. Foi difícil colocar-se como Outro (materno) representante da cultura, inventar um sonho para Augusto, uma cena na qual ele pudesse existir e ser visto além da deficiência.

Algo ficou perturbado na relação mãe-Augusto que o paralisou na posição de deficiente, dependente, agressivo, que viria a fazer tudo mais tarde e que podia fazer tudo o que quisesse sem correção/proibição porque precisava ser superprotegido. A atitude superprotetora que encobria a não-aceitação, o não-reconhecimento e o não-investimento nesse filho. E assim foi. Também paralisou a ela mesma no papel de mãe que atribuiu a si mesma (abandonada, traída, culpada, errada, que deixava estar, pois pensava ser assim que se passasse com uma criança com deficiência; resignar-se, pois se Deus deu assim, era assim que tinha que ser e cabia-lhe cuidar dele e pagar sua “culpa”).

Mas “ele era normal!" Até um ano ela o via normal. Depois mudou. Se ela diz que até um ano era normal, é porque depois deixou de sê-lo, quando passou a morder. Afinal, ser cego era não ter uma vida normal, era ser dependente da mãe (e ela aí o prendeu), não sair 
de casa, viver no escuro e sentir falta de ver. Por ser agressivo, ele não tinha comemoração de seu aniversário, nem ia às festas de outros na vizinhança (hoje ele quer ganhar o mundo pedindo para ir à casa de vizinhos), nem podia ir à escola e conviver com crianças. Ele era aquele que machucava as pessoas.

Há algo além do que é dito pela mãe, mas ela não tem consciência disso. "Ele era normal" e ela o via normal, mas ela só cita o aspecto motor como indicador de normalidade. Para ela ser criança e normal é aprender a usar bem o corpo-organismo (sentar, engatinhar, andar), mas quando ele começou a engatinhar, ela passou a "protegê-lo". Proteger de quê? Do mundo? Ele paralisou no uso do corpo, pois, mesmo tendo as capacidades motoras, não as coloca em ação porque não formou a imagem dele, não foi confirmado por sua mãe e, assim, não pôde reconhecer-se.

Vimos que Augusto teve "estímulos" para se desenvolver, pois sua mãe comprou brinquedos sonoros, seguindo a orientação dos especialistas. Tais orientações podem ter dito à mãe o que fazer para estimular uma criança que não enxerga, e ela as seguiu. O que ficou de fora foi um saber sobre como se relacionar com Augusto, seu filho, com uma presença materna que sustentasse sua relação com o mundo. Sua mãe não teve apoio para elaborar o luto, a angústia e a fantasmática acerca de seu filho. Por falta de apoio, não conseguiu enlaçar Augusto em seu desejo e na cultura. Cantava para ele, brincava com ele, mas, as respostas que ele lhe dava, ela não compreendia para poder apostar nele. Não agüentou e foi trabalhar. Abandonou-o em um momento crucial: o primeiro momento da constituição do sujeito, ou seja, o da formação da imagem corporal (o olhar da mãe, um olhar de reconhecimento, como o primeiro "espelho" da criança) que o representasse no e para o mundo e que culmina com a formação do "eu".

O que guiou nossa análise foram as perguntas que fomos levantando na leitura dos dados registrados: o que ocorreu que Augusto paralisou a partir do primeiro ano de vida, segundo os relatos que acompanhamos da mãe? Por que interrompeu seu percurso? Por que começou a se fixar no morder para sorver e absorver o mundo? Por que fixou a libido na boca? Por que antes a mãe o via normal? Quando ele paralisou, ela paralisou também: deixou de vê-lo normal e parou de investir em seu filho? A depressão é uma total falta de investimento e nessa fase da vida do bebê ele precisa de uma mãe viva.

Os estudos de Fraiberg e Freedman (1977), de Fraiberg e Adelson (1982) e de Wills (1970) mostram que esse momento é muito vulnerável para o desenvolvimento na ausência da visão, pois a criança tem que investir libidinalmente nos objetos, passando do interesse pelo 
próprio corpo e corpo da mãe para o mundo externo; ter segurança para enfrentar o que desse mundo o ameaça sem voltar a fases anteriores; ter condições para representar internamente os objetos, discernindo os impulsos agressivos dos amorosos, sendo que precisa formar uma imagem interna consistente da mãe por ser seu primeiro objeto. Concordamos com essas afirmações, entretanto ressaltamos o que Kupfer (2001) e Levin (2002), apontam no sentido de que o limite orgânico não é o que vai constituir o sujeito, mas pode dificultar pelo que causa na fantasmática parental.

Mannoni (1981) ressalta a idéia de que os sintomas das crianças devem ser procurados nos pais, principalmente na mãe, nos seus conteúdos inconscientes, esclarecendo (a partir desses conteúdos) a posição do filho na fantasmática deles para uma possível abertura para este. Buscamos na mãe, pois é nela que reside o destino do filhote do homem para tornar-se ou não sujeito, humanizar-se, tornar-se semelhante e diferente (Cf. LAJONQUIÈRE, 1997).

Sabemos pelos estudos acerca da cegueira, mencionados neste trabalho, (Cf. VYGOTSKY, 1993; LEONHARDT, 1992; ORMELEZI, 2000), que o caminho para a aprendizagem e o desenvolvimento da criança cega tem suas especificidades e que a ausência da visão não é impedimento, mas sabemos também, particularmente pelos estudos de Fraiberg e Adelson (1982) e Leonhardt (1992), que, se houver dificuldades na relação mãe-bebê e este não for olhado como uma criança para além de sua deficiência e não for incentivado a conhecer o mundo pelos seus canais de percepção, haverá vulnerabilidades e possibilidades de desvios na sua trajetória de constituir-se um sujeito e desenvolver-se plenamente.

Nessa fase a criança que não enxerga precisa de apoio para fortalecer as relações objetais e construir as referências do mundo, alçando um vôo maior, agora já com um ano: alcançar as coisas do mundo, experimentar-se nele, conhecer e interpretar acontecimentos, ter muitas experiências palpáveis e alguém que dê nome e contextualize tais vivências, dentro de uma relação consistente. Consistente porque esse alguém, esse Outro (materno) foi presente, lançando sobre ele um olhar de desejo e expectativas, introduzindo-o na cultura e na linguagem. Os estudos acerca das crianças cegas congênitas mostram que esse é um momento vulnerável se elas não contarem com isso (Cf. WILLS, 1970; LEONHARDT, 1992).

A depressão da mãe de Augusto não favoreceu, mas ela está mudando agora e sua singularidade e sua vida familiar guardam uma riqueza imensa a ser descoberta e, à medida que a mãe vai elaborando seus fantasmas, Augusto vai se libertando na direção da simbolização também. 
Se houve ou não desejo, olhar, não temos condições de afirmar categoricamente neste trabalho. Podemos dizer que houve um bebê insuficiente como todo recém-nascido para sobreviver sozinho e também como um bebê com uma limitação no corpo diante de um desejo e um olhar que podem ser questionados.

Parece que Augusto ficou a meio caminho de subjetivar-se e desenvolver-se. Nem total ausência, nem total presença das funções materna e paterna, causando impasses e deixando também pontos de abertura, mas que ainda o mantêm alienado na "verdade" da mãe.

Nesta seção do capítulo $\mathrm{V}$ apresentamos o estudo de caso que foi analisado em profundidade em todos os passos: 1) assinalamento dos elementos significativos que emergiram das manifestações de Augusto nas atividades observadas e do discurso da mãe enunciado na entrevista; 2) análise interpretativa desses dados em duas etapas; e 3) a análise da inter-relação da enunciação da criança no discurso da mãe e sua existência marcada por isso.

A seguir passamos à apresentação dos dados levantados em outros dois casos - caso II: Vivian e caso III: Renan - com a caracterização dos sujeitos, a descrição das atividades observadas e a montagem dos quadros que organizaram os dados significativos em relação às crianças, às mães e sua inter-relação, constituindo a análise preliminar para corroborar os dados encontrados no Caso I. 


\section{CASO II - VIVIAN}

\section{DADOS LEVANTADOS DO PRONTUÁRIO}

Os dados coletados no prontuário serviram para caracterizar o sujeito em seu histórico de vida, históricos clínico e de aprendizagem e desenvolvimento, dados familiares, bem como a etiologia de sua cegueira.

Idade: 7 anos no primeiro encontro e 8 anos no segundo e terceiro

Sexo: feminino

Nível de escolaridade e profissão dos pais: pai (6 ${ }^{\mathrm{a}}$. Série do Ensino Fundamental operário); mãe (5 . Série do Ensino Fundamental - do lar)

Situação sócio-econômica: baixa renda

Tipo, etiologia e tempo de ocorrência da deficiência visual: cegueira congênita, com percepção de luz, por seqüela de infecção congênita por citomegalovírus e rubéola. Microftalmia em ambos os olhos, mais acentuada no olho esquerdo (alteração da estrutura do olho como um todo e alteração de fundo de olho também). Enoftalmia (retração do olho para dentro). Esse quadro faz suspeitar de dano neurológico por ser infeccioso na fase intra-uterina, mas não há confirmação nos dados do prontuário, inclusive mãe refere que na ocasião do diagnóstico o parecer médico foi de que só foi afetada a visão ${ }^{25}$.

História clínica (avaliações e diagnósticos psicológico, médico e pedagógico): Deficiência visual total, no início com tênue percepção de luz. Logo após o nascimento foi detectada a microftalmia e aos 5 meses foi encaminhada para Oftalmologia e Intervenção Precoce na instituição que freqüenta até hoje. Apresentou déficit no processo de aprendizagem e desenvolvimento, sem distúrbio neuropsicomotor. Segundo a mãe, o parecer médico foi o de que a rubéola só afetou a visão. Nunca apresentou à instituição os exames neurológicos apesar de inúmeras solicitações dos profissionais. Encaminhamento psicológico aos três anos: mãe com dificuldades na interação com a criança.

\footnotetext{
25 Doença infecciosa causada por vírus (classificado como um togavirus do gênero Rubivirus), que acomete crianças e adultos, embora esteja entre as que os médicos comumente denominam como próprias da infância. Trata-se de doença comumente benigna que cursa com febre, "rash" (manchas tipo "urticária" na pele) que dura aproximadamente 3 dias e aumento de gânglios linfáticos (linfonodomegalias para os médicos e ínguas para os leigos) embora possa apresentar-se de forma "subclínica" (quando o paciente praticamente não sente nada). Pode tornar-se potencialmente grave quando acomete mulheres grávidas, pois pode causar mal-formações no feto, sobretudo quando contamina gestantes no primeiro trimestre. (http://www.abcdasaude.com.br/artigo.php?372)
} 
Contexto familiar: pai, mãe e duas irmãs de 20 e 16 anos (à época do nascimento de Vivian elas estavam com 14 e 8 anos respectivamente). Os comportamentos dela desorganizam a família que reage fazendo tudo que solicita, com muita dificuldade em impor limites. Mãe sente muita pena dela não enxergar. Pai é bastante presente na vida da família, incluindo Vivian. Relacionam-se bem com parentes.

História de aprendizagem e desenvolvimento: Aos cinco meses, levava objetos à boca, mas não fazia alcance manual por meio de pista sonora. Manteve-se muito tempo fixada à boca para exploração dos objetos e satisfação libidinal. Não mostrava interesse no ambiente. Virava-se quando estimulada corporalmente e emitia sons guturais. Seguiu o desenvolvimento motor sem atrasos significativos. Aos dois anos começou o andar independente. Ainda não explorava o ambiente, não explorava objetos tatilmente, falava "mamãe" e repetia algumas palavras. Não aceitava contato à exceção da mãe. Muito irritada, chorava sem consolo e sem motivo aparente, jogava os brinquedos e não gostava de ser solicitada, só acalmando com movimentos repetitivos no "pula-pula", na rede ou com canções. Mostrava-se também passiva e resistente à movimentação corporal para realização de ações e algumas vezes aceitava movimentos co-ativos (fazer junto). Até os quatro anos fazia manipulação do objeto quase sem interagir com ele ou usá-lo em sua função. Nessa idade começou a se comunicar pelo toque e às vezes oralmente com algumas palavras adequadas ao contexto. Mas a comunicação até hoje é pobre, não mantendo diálogo e ainda mantendo repetição de palavras e aparentemente sem sentido. Aprendeu a discriminar objetos e situações pela percepção tátil e auditiva. Tem independência na locomoção nos ambientes internos conhecidos, tem noção de sequiência dos eventos, concentra-se para ouvir histórias e fazer lição, conhece sua rotina. Conhece as partes de seu corpo. Está sendo alfabetizada, mostrando memorização dos caracteres Braille e compreensão na formação de seu nome e de palavras simples. Não toma iniciativa e fala bem pouco.

Vivência escolar e comunitária: Foi para a escola aos quatro anos e adaptou-se, realizando as atividades propostas, participando de festas, algumas vezes voltando ao padrão de irritação e agressividade até a idade que se encontra. Além da escola e da rotina de casa, costuma ir à igreja e pede para ir.

Quadro clínico: Apresenta rompantes de irritabilidade e agressividade, mordendo e beliscando as pessoas, jogando os objetos e resistindo ao contato físico (à exceção da mãe) ou atividades propostas. Chora muito e quase não interage e não mantém diálogo. Fala para expressar alguma necessidade em um tom de exigência e irritação. Tem dificuldades com 
limites. Mostra capacidade para executar as atividades da vida diária, mas não as realiza, sendo quase tudo feito por sua mãe. Não aceita situações novas que quebrem a rotina. Tem dificuldades com alimentação e não aceita alimentos fora de casa. Era vista na família como incapaz e sem condições de desenvolvimento. Hoje está mais incluída na vida familiar. Teve muita dificuldade para aceitar crianças e até hoje quase não interage com elas por iniciativa própria.

Atividades freqüentadas na instituição: Pedagogia, Atividades recreativas, funcionais e motoras, Oftalmologia e Grupo de Apoio Psicossocial à família.

\section{ANÁLISE DAS OBSERVAÇÕES: A CRIANÇA EM ATO - DADOS LEVANTADOS NA OBSERVAÇÃO PARTICIPATIVA : DESCRIÇÃO}

Nesta seção apresentamos os dados referentes à Vivian nas atividades observadas pela pesquisadora. A estrutura das atividades foi mostrada em três quadros seguidos das descrições da situação de observação participativa.

Quadro 7: primeiro encontro com Vivian

\begin{tabular}{|c|c|c|c|c|c|}
\hline DATA & AMBIENTES & ATIVIDADES & PARTICIPANTES & TEMPO & MATERIAIS \\
\hline 2004 & $\begin{array}{l}\text { - Sala de } \\
\text { atividades } \\
\text { pedagógicas } \\
\text { - Parque }\end{array}$ & $\begin{array}{l}\text { - Saudação e Roda } \\
\text { de conversa } \\
\text { - Brincadeiras } \\
\text { dirigidas de } \\
\text { estimulação } \\
\text { - Higiene e lanche } \\
\text { - Parque } \\
\text { - Fechamento }\end{array}$ & $\begin{array}{l}\text { - } 4 \text { crianças } \\
\text { - } 4 \text { mães } \\
\text { - } 3 \text { educadoras } \\
\text { - pesquisadora }\end{array}$ & 2 horas & $\begin{array}{l}\text { - Brinquedos } \\
\text { de estimulação } \\
\text { sensorial } \\
\text { - Brinquedos } \\
\text { de parque } \\
\text { infantil }\end{array}$ \\
\hline
\end{tabular}

\section{Descrição:}

Nesta ocasião a pesquisadora acompanhou Vivian em um grupo de crianças com múltipla deficiência (na designação da instituição). Vivian chegou à sala agarrada à mãe e 
durante a roda de conversa permaneceu em seu colo, sem participar. A qualquer tentativa de contato ela ficava muito brava, expressando isso por meio de gritos e até jogando-se no chão. Rejeitou contato com os brinquedos e quando os segurava, não tinha interesse em explorá-los nem em brincar com eles. Também não aceitou nada que lhe foi oferecido no lanche, empurrando e emitindo sons de descontentamento. Já no parque, Vivian soltou-se um pouco, caminhando pelo espaço, sem bengala, mas com certa segurança, sempre sozinha ou chamando muito pela mãe que sempre a atendia. Em um dado momento, Vivian foi até uma "casinha de boneca". Ficou do lado de fora abrindo e fechando a janela, pondo e tirando a cabeça pra dentro e pra fora dela, em um movimento repetitivo, porém de exploração. Nesse momento a pesquisadora se aproximou, dizendo: “olá, Vivian! É a Eliana. Posso ficar aqui com você?" Vivian nada respondeu e continuou com seu "jogo". A pesquisadora entrou na casinha e começou a encenar algo entrando em um personagem com voz e tudo. Conseguiu chamar a atenção de Vivian que esboçou um leve sorriso e parou com seus movimentos repetitivos, estabelecendo por instantes um contato com a pesquisadora, abandonando seu estado solitário e ensimesmado. Já era hora de encerrar a atividade e a pesquisadora despediu-se de Vivian que aceitou seu abraço, ainda que com rigidez corporal.

Quadro 8: segundo encontro com Vivian

\begin{tabular}{|c|c|c|c|c|c|}
\hline DATA & AMBIENTES & ATIVIDADES & PARTICIPANTES & TEMPO & MATERIAIS \\
\hline $18 / 8 / 05$ & $\begin{array}{l}\text { - Sala de } \\
\text { atividades } \\
\text { pedagógicas } \\
\text { - Vestiário } \\
\text { - Piscina }\end{array}$ & $\begin{array}{l}\text { - Saudação e Roda } \\
\text { de conversa } \\
\text { - Orientação e } \\
\text { Mobilidade } \\
\text { - Atividades da } \\
\text { Vida Diária } \\
\text { - Atividades } \\
\text { Aquáticas } \\
\text { - Fechamento }\end{array}$ & $\begin{array}{l}\text { - } 4 \text { crianças } \\
\text { - } 4 \text { mães } \\
\text { - profissional de } \\
\text { Educação Física } \\
\text { - pesquisadora } \\
\text { - câmera }\end{array}$ & $\begin{array}{l}1 \text { hora e } \\
\text { trinta } \\
\text { minutos }\end{array}$ & $\begin{array}{l}\text { Brinquedos e } \\
\text { bóias }\end{array}$ \\
\hline
\end{tabular}

\section{Descrição:}

Vivian era do mesmo grupo de Augusto nesse ano. Durante toda primeira parte da atividade do dia: a chegada, a saudação e a canção de entrada, a roda de conversa, Vivian se 
mostrou calada. Seguiu as orientações dadas, mas não expressou nenhuma fala ou gesto. À hora de ir para a piscina, foi até o vestiário usando a bengala com cuidado e às vezes chamando a mãe tendo seu retorno como uma referência segura. Já no vestiário, Vivian perguntou à mãe: - Posso tirar o chinelo? - Pode. Vivian sentou-se e esperou pela professora. Enquanto isso batia uma mão na outra e apertava o ouvido. A professora chegou e chamou para entrar na piscina. Vivian chamou novamente a mãe: - Mãe! - Oi! - A professora chegou! - Pode ir lá! A mãe foi orientando: "em frente, direita...” A mãe a deixou encontrar o caminho só auxiliando no que precisava. Desceu as escadas que a levaram para dentro da piscina e na água ela ficou independente. A mãe se retirou para o curso de Braille e Vivian ficou bem. Procurou a professora e aceitou a aproximação de outra mãe que estava na piscina. Mas se não era procurada, ela não tinha iniciativa de fazê-lo. Aceitou brincar de roda para depois mergulhar. Quando a professora propôs a brincadeira de jogar bolas na água, encontrálas e guardá-las na cesta, Vivian não se interessou e largou a cesta. Professora fez com ela. Vivian mostrou ter uma boa coordenação motora, mas a professora segurava a cesta pra ela. A próxima atividade - atravessar de uma borda à outra batendo as pernas - Vivian realizou sem problemas, assim como pulou dentro da piscina, pôs a cabeça embaixo da água, usou a prancha conforme a professora ensinava. Mostrou sentir-se muito à vontade nesse meio e já estava quase nadando. Soltou a prancha, a professora lhe perguntou sobre isso, mas ela nada respondeu. A mãe de outra criança indicou onde estava a prancha e ela buscou e a encontrou. Vivian não interagiu com as crianças. Sua mãe mostrou-se bem atenta, quando voltou da aula de Braille foi até a borda da piscina várias vezes para limpar-lhe o nariz que escorria por causa do resfriado. Hora de boiar sobre o "espaguete" e Vivian continuou a fazer tudo com independência e com muito prazer. A professora começou a antecipar o final da aula e Vivian se recusou a sair. Disse "não" e resistiu muito: chorou e gritou intensamente. Puxou a touca da cabeça da professora e mordeu o "espaguete". A mãe interveio e começou a ficar muito nervosa com a situação: "Vivian, vamos conversar! Pára senão você não virá mais!”. Vivian não teve consolo, nem pôde se organizar internamente e a professora também não conseguiu acalmá-la. Foi tirada praticamente à força da piscina e saiu chorando. A mãe disse: "to muito chateada! Você fez feio e a professora ficou chateada." Seguiram para o vestiário e a mãe continuou falando firme com ela. No vestiário, no chuveiro, Vivian continuou chorando. A mãe foi lhe dando banho e ela ficava tentando consolar a si mesma pedindo: - Mãe, a música do cavalo... - Levanta o pé pra por calcinha... - Cavalinho, cavalão... (ela canta). A ambulância faz piuí, né, mãe?”. A mãe comentou que ela se desestrutura quando acaba algo de que ela gosta muito. A professora entrou no vestiário e a mãe logo disse: - Olha aí a 
professora, pede desculpa! - Desculpa. A Vivian chorô... A professora disse: "Dá cá um abraço! Você sabe que acaba e depois outro dia volta!" Vivian se acalmou um pouco, depois voltou ao choro e ao auto-consolo. Vestiu-se um pouco sozinha, um pouco com ajuda da mãe e continuou chorando. Mãe estava impaciente, ia arrumando tudo e mostrou-se descontente por não conseguir argumentos com a filha. A pesquisadora procurou também falar com Vivian, mas foi em vão. Acompanhou criança e mãe até a saída, quando Vivian respondeu ao "tchau", mas ainda foi embora chorando.

Quadro 9: terceiro encontro com Vivian

\begin{tabular}{|c|c|c|c|c|c|}
\hline DATA & AMBIENTES & ATIVIDADES & PARTICIPANTES & TEMPO & MATERIAIS \\
\hline 25/8/05 & $\begin{array}{l}\text { - Sala de } \\
\text { atividades } \\
\text { pedagógicas }\end{array}$ & $\begin{array}{l}\text { - Saudação e } \\
\text { Roda de } \\
\text { conversa } \\
\text { - Retomada da } \\
\text { história do } \\
\text { atendimento } \\
\text { anterior e } \\
\text { encenação } \\
\text { - Fechamento }\end{array}$ & $\begin{array}{l}\text { - } 4 \text { crianças } \\
\text { - } 4 \text { mães } \\
\text { - pedagoga } \\
\text { - pesquisadora } \\
\text { - câmera }\end{array}$ & $\begin{array}{l}\text { 1hora e } \\
\text { trinta } \\
\text { minutos }\end{array}$ & $\begin{array}{l}\text { - Livro de } \\
\text { história } \\
\text { adaptado } \\
\text { - Fantoches }\end{array}$ \\
\hline
\end{tabular}

\section{Descrição:}

Esse dia foi curto para Vivian, pois ela e sua mãe se atrasaram, chegando já à hora do banheiro e do lanche. Voltou do banheiro depois de lavar as mãos e sentou para o lanche, mas não aceitou nada do que as crianças do grupo lhe ofereceram de seus lanches. Ela empurrava e dizia “não!” A mãe disse que ela só come salgadinho, bolacha e suco, mas na instituição não. A pesquisadora fez uma tentativa e ela aceitou. Mãe ficou perplexa. Ao terminar, Vivian esperou. Enquanto esperava batia uma mão na outra e apertava os olhos. Mãe perguntou a ela como se escreve o "F" em Braille (porque a mãe de Augusto queria saber) e Vivian respondeu corretamente. As mães confabulavam sobre o Braille no corredor enquanto esperavam as crianças. Vivian estava quieta, não chamava ninguém, não interagia, só esperava. Ao término do lanche todas as crianças levaram seus pratos para a pia e depois foram orientadas a voltar para a roda. Como Vivian não havia localizado as atividades do dia no calendário de objetos de referência de cada uma dessas atividades, foi fazê-lo nesse momento com a pedagoga. 
Buscou a bolinha que se referia à hora da brincadeira de bola. (Nesse tipo de calendário, as crianças se remetem ao objeto de referência, ao mesmo tempo em que a pedagoga verbaliza o que vai acontecer. É utilizado como metodologia para antecipar os acontecimentos e localizálos na seqüência do dia e também para as crianças que ainda não têm uma comunicação verbal desenvolvida). Já na roda, antes do jogo de bola propriamente dito, a pedagoga começou a marcar o lugar de cada criança pedindo que uma de cada vez dissesse o nome e "Tô aqui!" E assim começaram o jogo. Cada criança que estivesse com a bola seguia a orientação da pedagoga de dizer "Vou jogar pra ... (dizendo o nome do amigo que escolhesse). Vivian participou da brincadeira seguindo todas as orientações. A pedagoga começou a antecipar o final do dia, foram se levantando, fazendo roda-roda a pedido de Augusto e se abraçaram ao final. Cantaram a música do "tchau" a qual entoa o nome de cada criança. Desta vez Vivian aceitou o final sem chorar. Eles têm uma lição de casa e a instrução foi dada às mães: trazer no caderno tátil uma atividade que realizariam durante a semana.

\subsection{Análise dos dados relativos à Vivian}

A consulta ao prontuário e as observações realizadas em dois períodos, com intervalo de um ano entre eles, levantou os dados referentes à história de vida e quadro clínico de Vivian, bem como os dados que a caracterizaram como uma criança cega com problemas na constituição subjetiva e no desenvolvimento. Tais dados foram organizados em temas a partir dos elementos que emergiram como significativos a este trabalho e que podem corroborar o Caso I. Os mesmos são apresentados no seguinte quadro:

Quadro10: temas e elementos significativos identificados nos dados do prontuário e nas observações

\begin{tabular}{|c|c|}
\hline TEMAS & ELEMENTOS SIGNIFICATIVOS \\
\hline $\begin{array}{l}\text { Formas de perceber, explorar, } \\
\text { relacionar-se compreender, e } \\
\text { expressar-se no mundo }\end{array}$ & $\begin{array}{l}\text { Expressava-se pelo choro quanto às suas necessidades; } \\
\text { Passividade quanto à exploração dos objetos apresentados a ela; } \\
\text { Não segurava os objetos, não tinha interesse; } \\
\text { Reconhecimento das pessoas pelas vozes e pelo tato, passando a } \\
\text { mão no rosto; aperta objetos para reconhecê-los; } \\
\text { Mostrava com o corpo quando queria sair do berço, segurando no } \\
\text { braço de quem se aproximava; } \\
\text { Compreende o que é dito e solicitado, mas responde pouco; } \\
\text { Grita e joga-se no chão quando contrariada (expressão da }\end{array}$ \\
\hline
\end{tabular}




\begin{tabular}{|c|c|}
\hline & $\begin{array}{l}\text { dificuldade da mãe em colocar pontos de "basta" e sustentar uma } \\
\text { posição); } \\
\text { Diante de cobranças, limites e mudança de rotina, fica irritadiça e } \\
\text { nervosa, morde, belisca, agride; } \\
\text { Conhece e nomeia as partes do próprio corpo e o corpo do outro; } \\
\text { É arredia na relação com as pessoas e desinteressada dos objetos; } \\
\text { Orienta-se e movimenta-se bem nos espaços internos da casa e da } \\
\text { escola. }\end{array}$ \\
\hline $\begin{array}{l}\text { Manifestações de } \\
\text { comprometimentos na } \\
\text { constituição subjetiva e no } \\
\text { desenvolvimento }\end{array}$ & $\begin{array}{l}\text { Passividade, não exploração do ambiente; Sem iniciativa; } \\
\text { Dificuldade na aceitação do contato físico; } \\
\text { Gritos e choros na expressão das demandas; } \\
\text { Enorme dificuldade com cortes e mudanças, desorganizando-se, } \\
\text { passando a agredir; } \\
\text { Linguagem pouco estruturada; } \\
\text { Apego e fusão na relação com a mãe; } \\
\text { Dificuldade na relação com o outro; agride (chuta, morde, belisca); } \\
\text { Não manipula e nem segura os objetos, mas joga-os (até a colher, } \\
\text { fazendo com que alguém a alimente); } \\
\text { Se algo cai, não pega; } \\
\text { Em geral, não vincula com as coisas; } \\
\text { Dificuldades na interação com adultos e crianças; } \\
\text { Mais voltada para si mesma; } \\
\text { Comunicaçãopobre, sem diálogo e ainda mantendo repetição } \\
\text { de palavras aparentemente sem sentido; } \\
\text { Dificuldade na resolução de problemas da situação prática; } \\
\text { Tem capacidades funcionais, mas não usa; } \\
\text { Brinquedos não lhe interessam, apenas uma boneca; } \\
\text { Fixação em objetos sonoros; Fixação em fase primitiva do } \\
\text { desenvolvimento (alimentação só amassada); Muito tempo fixada } \\
\text { à boca para explorar e ter prazer; } \\
\text { Formação inconsistente da imagem corporal e do "eu" (fala de si } \\
\text { como se fosse outro conversando com ela mesma). }\end{array}$ \\
\hline $\begin{array}{l}\text { Manifestações de pontos de } \\
\text { abertura para a constituição } \\
\text { subjetiva e o desenvolvimento }\end{array}$ & $\begin{array}{l}\text { Música; } \\
\text { Escola aos quatro anos; } \\
\text { Desde os cinco anos, começou a imitar uma cena com a boneca } \\
\text { dizendo que é o nenê e colocando-a para dormir; } \\
\text { Escrita: quer escrever; } \\
\text { Aos seis anos passou a responder seu nome quando perguntada, a } \\
\text { compreender conceitos do cotidiano e seguir instruções; } \\
\text { O modo como tentou consolar a si mesma ao deixar a piscina, } \\
\text { apesar de todo sofrimento; } \\
\text { Hoje pergunta tudo que se passa ao seu redor; quer saber. }\end{array}$ \\
\hline
\end{tabular}




\section{ANÁLISE DA ENTREVISTA: UMA “ANÁLISE DE DISCURSO” NO DISCURSO DA MÃE}

\subsection{Análise dos dados relativos à mãe de Vivian}

A entrevista com a mãe de Vivian evidenciou elementos significativos que foram arranjados por temas organizados no quadro abaixo para apresentação dos dados levantados neste caso.

Quadro 11: temas e elementos significativos identificados na entrevista com a mãe de Vivian

\begin{tabular}{|c|c|}
\hline TEMAS & ELEMENTOS SIGNIFICATIVOS \\
\hline $\begin{array}{l}\text { A reação ao diagnóstico, os } \\
\text { primeiros anos de vida de } \\
\text { Vivian e outras } \\
\text { contingências }\end{array}$ & $\begin{array}{l}\text { Conhecimento do diagnóstico aos } 15 \text { dias (antes disso, o pai já } \\
\text { sabia e a mãe percebia nele que algo estava errado e percebia que a } \\
\text { filha não abria o olho); } \\
\text { Choque levou a mãe ao hospital; O mundo tinha acabado; ele } \\
\text { parou; } \\
\text { Instituição especializada aos } 6 \text { meses; Nova expectativa de } \\
\text { diagnóstico contrário; Período de negação; } \\
\text { Não-aceitação, muita culpa (culpou o marido também), } \\
\text { autocomiseração; raiva, revolta; rejeição; depressão; } \\
\text { superproteção; sem crença no potencial de desenvolvimento da } \\
\text { filha; } \\
\text { Não querer saber das pessoas; não querer sair de casa; não ver } \\
\text { sentido nos brinquedos apara a criança que não enxerga, então } \\
\text { quebrava os brinquedos da filha; } \\
\text { Não responder ao chamado do marido; } \\
\text { Pai não aceita que a mãe se culpe. }\end{array}$ \\
\hline $\begin{array}{l}\text { Relação mãe-criança: } \\
\text { representação e sentimentos } \\
\text { em relação à filha e o que ela } \\
\text { diz dela }\end{array}$ & $\begin{array}{l}\text { Comparação com as outras filhas; pena; superproteção; } \\
\text { Desejo de normalidade: uma criança que enxergasse; sem } \\
\text { expectativas para Vivian; } \\
\text { Ela seria uma criança doente e não seria feliz; } \\
\text { Deixava a filha em casa, não saía com ela, evitava o social; nunca } \\
\text { foi de deixar Vivian com as pessoas; } \\
\text { Dificuldade para ver e validar o modo próprio da filha para } \\
\text { conhecer } \\
\text { o mundo, vendo apenas a cegueira e a incapacidade e dependência; } \\
\text { A filha é sua vida, seu objeto ainda; } \\
\text { Diferença em ser mãe de Vivian e das outras filhas que enxergam; } \\
\text { Passividade; tinha que levar tudo até ela; era triste e não se } \\
\text { expressava; não reagia; } \\
\text { Mãe não tinha prazer com Vivian; } \\
\text { Não via felicidade na filha; Não era capaz de ver nada do que a } \\
\text { filha fazia; } \\
\text { Só passou a explicar e significar as coisas para Vivian depois de }\end{array}$ \\
\hline
\end{tabular}




\begin{tabular}{|c|c|}
\hline & $\begin{array}{l}\text { dois anos, quando ela passou a eragir um pouco; } \\
\text { Desenvolvimento tardio: sentar, andar, tirar a fralda; } \\
\text { Quando Vivian começou a se desenvolver na parte motora, a mãe } \\
\text { começou a ver suas capacidades, porém não a deixava realizar suas } \\
\text { proezas, superprotegendo-a; } \\
\text { Todos na casa superprotegem, mimam e tratam Vivian como } \\
\text { bonequinha até hoje; } \\
\text { Mãe não esperava que ela expressasse necessidades, antecipava-se } \\
\text { sempre; } \\
\text { Mãe não colocava proibições e ainda tem essa dificuldade; } \\
\text { Vivian tem capacidade para fazer as coisas e não faz porque } \\
\text { sempre tem alguém que faça para ela; } \\
\text { Ela reconhecia e atendia as pessoas pelas vozes; } \\
\text { Mãe conversava e brincava com ela, cuidava; } \\
\text { Pobreza de experiências significativas; } \\
\text { Desde os seis anos mostra desenvolvimento de alguns núcleos de } \\
\text { inteligência (memória, conceitos do cotidiano, escrita) e lacunas } \\
\text { em } \\
\text { outros (raciocínio lógico); } \\
\text { Tem facilidade para aprender; boa memória. }\end{array}$ \\
\hline $\begin{array}{l}\text { Representação, sentimentos e } \\
\text { atitudes em relação à } \\
\text { cegueira }\end{array}$ & $\begin{array}{l}\text { Impossibilidade: nunca ver o mundo, não participar de muitas } \\
\text { coisas, não correr e não ir pra onde quiser, não brincar; } \\
\text { O mundo fica sem sentido sem a visão; } \\
\text { Dependência; isolamento em casa, pois não há sentido pra sair; } \\
\text { Sentimento de tristeza; } \\
\text { Criança cai, machuca, mas a cega não pode; } \\
\text { Na verdade, até hoje não aceita a cegueira e projeta nas pessoas } \\
\text { seus sentimentos sobre a cegueira. }\end{array}$ \\
\hline $\begin{array}{l}\text { Reação e sentimentos em } \\
\text { relação à agressividade da } \\
\text { filha }\end{array}$ & $\begin{array}{l}\text { Fica nervosa e envergonhada, mas passiva; } \\
\text { Não dá bronca com medo que as pessoas pensem que ela está } \\
\text { maltratando uma criança cega. }\end{array}$ \\
\hline $\begin{array}{l}\text { Como a mãe se mostrou - } \\
\text { lugar que ocupou, como se } \\
\text { sentiu }\end{array}$ & $\begin{array}{l}\text { Ocupou um lugar de culpada e vitimada; } \\
\text { Projeção de sua fantasmática de cegueira sobre a filha; } \\
\text { Não aceitação da explicação médica; } \\
\text { Sentiu-se paralisada; } \\
\text { Sentimento de culpa, nervosa; não sabia o que fazer; } \\
\text { desconhecimento; raiva; } \\
\text { Não queria uma filha cega; } \\
\text { Sentiu-se diminuída; } \\
\text { Isolou-se; } \\
\text { Não entendia o que a filha queria, a menos que se chorasse; } \\
\text { O olhar e as perguntas das pessoas ainda a incomodam; } \\
\text { Nervosa e triste com a passividade de Vivian; } \\
\text { Medo da filha se machucar quando começou a andar e brincar, }\end{array}$ \\
\hline
\end{tabular}




\begin{tabular}{|l|l|}
\hline & $\begin{array}{l}\text { então protegia, não dava liberdade (contradição: ficava nervosa } \\
\text { com sua passividade, depois reprimia sua expressão); } \\
\text { Ainda sente que algo a prende e não aceita, mesmo que já tenha } \\
\text { superado muitas coisas, mas é difícil; } \\
\text { Tem um bloqueio e acha que vai ser para sempre. }\end{array}$ \\
\hline \multirow{2}{*}{$\begin{array}{l}\text { A mudança de olhar da mãe e e } \\
\text { Vivian do lugar de deficiente: } \\
\text { a busca da instituição }\end{array}$} & $\begin{array}{l}\text { A instituição especializada a fez sair de casa; } \\
\text { a ver que ela seria cap̧az de se desenvolver; } \\
\text { especializada e a ince como uma criança normal e aprendeu isso com os anos } \\
\text { na instituição especializada; Ela só não enxerga e tem algumas } \\
\text { coisas que ela não faz ainda; } \\
\text { escolar } \\
\text { Hoje a Vivian vai à escola e a todos os lugares (a mãe vê as } \\
\text { possibilidades da filha a põe na circulação social); } \\
\text { Viu que Vivian começou a mudar quando ela, mãe, toda família e } \\
\text { a escola começaram a colocar limites e exigências; } \\
\text { Freqüenta escola comum, mas pensa que deveria ser escola } \\
\text { especial para poder ter mais atenção, classes com poucos alunos, } \\
\text { profissionais preparados. Podendo atender mais à Vivian, sem que } \\
\text { ela tenha sempre que esperar e ser a última. Na escola comum, não } \\
\text { faz nada. Está aprendendo, mesmo, é na Sala de Recursos; } \\
\text { Na escola comum há discriminação e não há recursos. }\end{array}$ \\
\hline
\end{tabular}

\section{ANÁLISE DOS DADOS RELATIVOS À INTER-RELAÇÃO DOS ELEMENTOS DO DISCURSO DA MÃE E AS MANIFESTAÇÕES DE VIVIAN}

No quadro abaixo é apresentado o cruzamento dos significantes que emergiram do discurso da mãe de Vivian na entrevista - indicadores da posição dela na rede discursiva da mãe - e suas manifestações que se apresentam como marcas do que é dito sobre ela pela mãe.

Quadro 12: a posição de Vivian na rede discursiva da mãe

\begin{tabular}{|c|c|c|c|}
\hline \multicolumn{2}{|c|}{ MÃE } & \multicolumn{2}{c|}{ CRIANÇA } \\
\hline O QUE A MÃE FALA & O LUGAR DADO & O QUE A CRIANÇA & MARCAS DO \\
DA CRIANÇA & À CRIANÇA NO & MOSTRA & DISCURSO \\
& DISCURSO DA MÃE & & DA MÃE NA \\
& & & CRIANÇA \\
\hline Doente e triste & Doença e Tristeza & Apatia & Deficiência encobrindo \\
Não iria fazer nada & Deficiente e incapaz & Passividade & lugar de criança \\
\hline
\end{tabular}




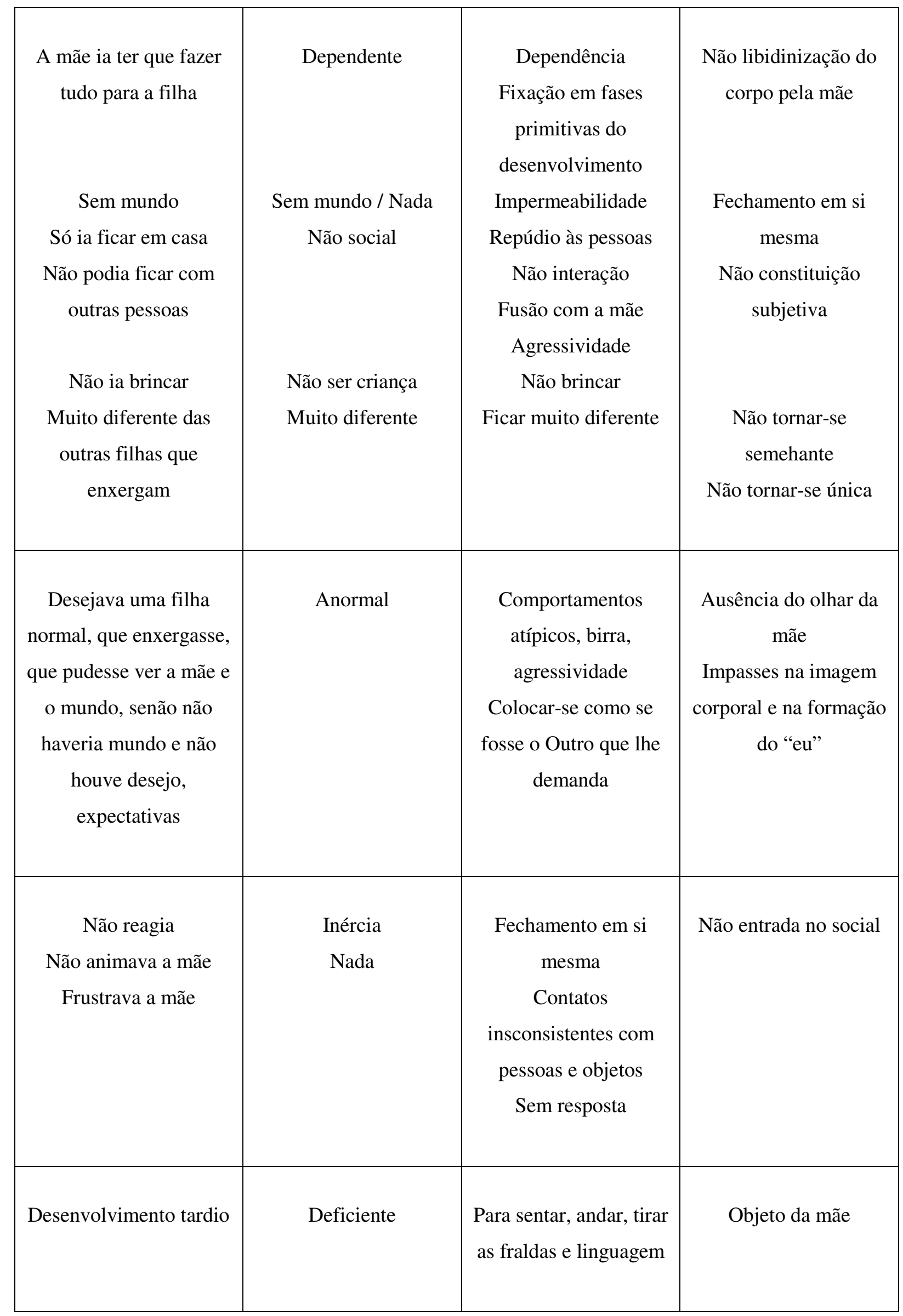




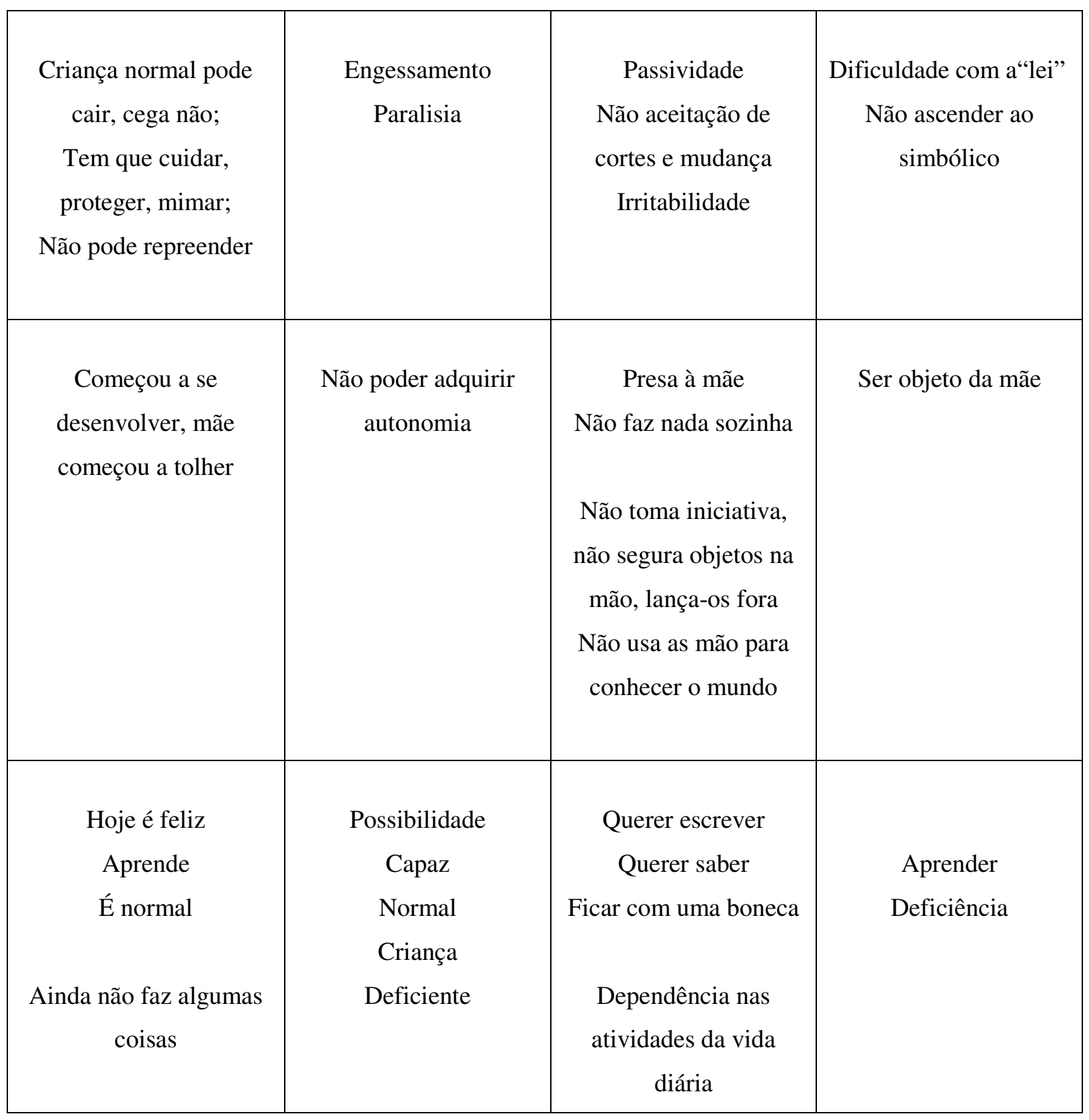


CASO III - RENAN

\section{DADOS LEVANTADOS NO PRONTUÁRIO}

Como nos outros dois casos, os dados coletados junto ao prontuário cumpriram o objetivo de identificação do sujeito nos aspectos do seu histórico de vida e históricos clínico, de aprendizagem e desenvolvimento, dados familiares, como também a etiologia de sua cegueira.

Idade: 7 anos no primeiro encontro e 9 anos no segundo

Sexo: masculino

Nível de escolaridade e profissão dos pais: pai ( $7^{a}$. Série do Ensino Fundamental - operário, mas está desempregado); mãe (Ensino Médio/Magistério - inspetora de alunos)

Situação sócio-econômica: baixa renda

Tipo, etiologia e tempo de ocorrência da deficiência visual: cegueira congênita, com percepção de luz. Nistagmo ${ }^{26}$ e Diagnóstico de Amaurose Congênita de Leber ${ }^{27}$.

História clínica (avaliações e diagnósticos psicológico, médico e pedagógico): Deficiência visual total diagnosticada aos nove meses. Foi encaminhado desde um ano e seis meses para atendimento de Oftalmologia e Intervenção Precoce na instituição que freqüenta até hoje. Apresentou déficit no processo de aprendizagem e desenvolvimento sem distúrbio neuropsicomotor. Encaminhamento psicológico aos quatro anos: dificuldades na interação mãe-criança.

Contexto familiar: pai, mãe e um irmão de 7 anos também cego com a mesma patologia de Renan. Pai está desempregado e tem histórico de alcoolismo. Pai é presente na vida dos filhos

\footnotetext{
${ }^{26}$ O termo nistagmo é usado para descrever os movimentos oculares oscilatórios, rítmicos e repetitivos dos olhos. É um tipo de movimento involuntário dos globos oculares, geralmente de um lado para o outro e que dificulta muito o processo de focagem de imagens. Os movimentos podem ocorrer de cima para baixo ou até mesmo em movimentos circulares e podem surgir isolados ou associados a outras doenças. (http://www.drvisao.com.br/conheca_doenca_detalhe.php?id=34)

27 A Amaurose Congênita de Leber (ACL) é a designação para um grupo de distrofias retinianas de acometimento precoce, de caráter hereditário, caracterizada por deficiência visual moderada a severa identificada nos primeiros meses de vida, nistagmo, respostas pupilares pobres e ERG extinto ou muito diminuído. A partir do locus alterado são descritas 5 formas da doença: Na maior parte dos caso a transmissão é de modo autossômico recessivo, apesar de casos descritos com transmissão dominante 6, e a heterogeneidade dos achados descritos na literatura reforça a impressão de que não de trata de uma entidade única. São descritos vários achados associados à ACL, oculares, renais e neurológicos entre outros. (Paschoalino, http://www.cbo.com.br/cbo/sociedades/subnormal/artigos/cmtrat08.htm)
} 
e sempre os acompanha à instituição. Mãe extremamente ansiosa por não saber o que fazer com ele e como brincar. Criança muito apegada ao pai. Este, por sua vez faz muita comparação com o irmão menor que teve um desenvolvimento sem bloqueios, apesar de ter a mesma patologia. Não se relacionam bem com parentes.

História de aprendizagem e desenvolvimento: Aos dezoito meses já andava. Seguiu o desenvolvimento motor sem atrasos significativos. Deixou de usar fraldas aos 2 anos. Sua forma de expressão era gritar. Jogava o que lhe era posto na mão e apertava muito os olhos. Até os dois anos chorava muito. Aos quase quatro anos rejeitava contato corporal, não interagia com as crianças do grupo, isolando-se, e não aceitava brincar. Falou somente nessa idade quando o irmão começou a falar. Linguagem pouco desenvolvida e ecolálica, quase não se comunicava, apesar de ter capacidade de fala. Ainda não explorava o ambiente, não explorava tatilmente os objetos. Irritadiço, muito nervoso e desorganizado internamente. Não aceitava manipulação dos objetos e texturas variadas, assim como ambientes e situações novas. Aos sete anos permanecia dependente totalmente da mãe nas atividades da vida diária apesar de ter capacidade para desempenhá-las. Continuava quase sem se comunicar verbalmente e quando o fazia era em casa com uma fala repetitiva, sempre com as mesmas perguntas respondidas incessantemente (sobre trens, carros, metrô, elevador). Nervoso, agredia. Ainda nessa idade preferia alimentar-se de comida pastosa. Hoje, aos nove anos, tem independência e segurança na locomoção nos ambientes internos e conhecidos, com boa noção na orientação e mobilidade e desenvoltura no uso da bengala, podendo já iniciar o trabalho em ambientes externos. Já sabe pedir, mostra boa memorização e noção de seqüência dos eventos. Não está alfabetizado, apenas conhece algumas letras, mas depende de muita mediação e incentivo para se interessar e compreender o que é ensinado. Não toma iniciativa e fala bem pouco e tem excelente memória. Tem ciúme das crianças, inclusive do irmão, e na escola e bate nelas.

Vivência escolar e comunitária: Foi para a escola aos cinco anos e teve dificuldades na adaptação. Recusava- se a ir e ainda hoje, diante de dificuldades como ser chamado de cego pelos colegas, não quer ir à escola e incomoda-se muito. Além da escola, hoje faz recreação e escola de futebol.

Quadro clínico: Não apresentou distúrbio neuropsicomotor e não há indícios de comprometimento neurológico. Apresenta muitas dificuldades nas atividades simples do cotidiano. Mostra capacidade para executar as atividades da vida diária, mas não as realiza, sendo quase tudo feito por sua mãe. Dificuldade para concentrar-se nas atividades, está 
sempre falando de outros assuntos fora do contexto, embora com sentido dentro do seu conhecimento de mundo. Mostra fixação em determinados assuntos e faz sempre as mesmas perguntas como para "ouvir o que ele já sabe" (sic mãe). Com pouca iniciativa, espera sempre a instrução verbal. Reage mal quando não pode fazer o que quer: fica muito irritado, nervoso, agride, inflexível, não sai do lugar, chora e fecha-se em si mesmo. A relação de Renan com a mãe é de muita recusa e provocação. Não aceita limites e a mãe se irrita muito com isso e mostra-se muito cansada de não saber lidar com ele.

Atividades freqüentadas na instituição: Pedagogia, Atividades recreativas, funcionais e motoras, Oftalmologia e Grupo de Apoio Psicossocial à família.

\section{ANÁLISE DAS OBSERVAÇÕES: A CRIANÇA EM ATO - DADOS LEVANTADOS NA OBSERVAÇÃO PARTICIPATIVA : DESCRIÇÃO}

Nesta seção apresentamos os dados das atividades de observação participativa da pesquisadora em relação a Renan. A estrutura dessas atividades foi mostrada em dois quadros seguidos das descrições das situações referidas.

Quadro 13: primeiro encontro com Renan

\begin{tabular}{|c|c|c|c|c|c|}
\hline DATA & AMBIENTES & ATIVIDADES & PARTICIPANTES & TEMPO & MATERIAIS \\
\hline 9/10/02 & $\begin{array}{l}\text { - Vestiário } \\
\text { - Piscina } \\
\text { - Sala de } \\
\text { atividades } \\
\text { pedagógicas }\end{array}$ & $\begin{array}{l}\text { - Recreação na } \\
\text { piscina } \\
\text { - Atividade de } \\
\text { leitura e escrita } \\
\text { - Fechamento }\end{array}$ & $\begin{array}{l}\text { - } 4 \text { crianças } \\
\text { - professora de } \\
\text { Educação Física } \\
\text { - pedagoga } \\
\text { - pesquisadora } \\
\text { - câmera-man }\end{array}$ & 2horas & $\begin{array}{l}\text { - Brinquedos e } \\
\text { bóias } \\
\text { - Reglete para } \\
\text { escrita Braille }\end{array}$ \\
\hline
\end{tabular}

\section{Descrição:}

A pesquisadora foi a uma atividade de Renan na piscina para conhecê-lo. No vestiário, a preparação de Renan para entrar na piscina foi toda feita por sua mãe. Ele ficou impassível. No percurso até a piscina mostrou autonomia na locomoção, sendo orientado verbalmente 
pela mãe. Durante a atividade mostrou-se tranqüilo, disponível e tendo prazer. Ele compreendia as instruções dadas e as seguia, mas não interagia com a professora, nem com os colegas e não disse uma palavra sequer. A professora disse que é sempre assim: "ele faz tudo, sabe falar, mas não se comunica com ninguém." Ao término da aula, a pesquisadora, que fora apresentada desde o início, dirigiu-se a ele e despediu-se com um "até logo", dando-lhe também a mão, já que ele, até então, na instituição, havia mostrado ausência de comunicação oral. Nesse instante ele respondeu oralmente: "não". Ficamos todos absolutamente surpresos e a pesquisadora continuou: _ Posso estar na sua próxima atividade com a ... (nome da profissional)? _ Não. Não vai! Depois de algum tempo a pesquisadora resolveu insistir e foi até à sala de atividades pedagógicas, bateu na porta, pediu licença anunciando seu nome, e perguntou à profissional e depois às crianças se podia estar na atividade. A pedagoga, já avisada, e as crianças responderam afirmativamente. Ele nada disse. A pesquisadora perguntou diretamente a ele desta vez e ele respondeu "sim" e então falou durante toda a atividade, compulsivamente, dirigindo-se só a ela com infindáveis perguntas sobre ela com seu assunto preferido: meios de transportes, em geral, até mesmo elevador, como ficamos sabendo pela mãe na saída. A pedagoga confessou que muito rara e minimamente ele falava com ela, mas como desta vez nunca ocorrera. Na atividade Renan mostrou-se disperso e com dificuldades na aquisição da escrita desde os conceitos e noções envolvidos nessa construção até dificuldades motoras na coordenação do uso dos instrumentos de escrita Braille. Ao término da atividade, Renan encontrou seus pais e ainda continuava fazendo, à pesquisadora que os acompanhou até a recepção do prédio, as mesmas perguntas sem fim: "você veio de carro? Não vem de trem, não? E de metrô? Você vai de elevador? Vai de escada?" A pesquisadora disse-lhe que aquelas perguntas ela já havia respondido e que agora iriam se despedir. Ele seguiu com seus pais ainda falando sobre o assunto.

Quadro 14: segundo encontro com Renan

\begin{tabular}{|c|c|c|c|c|c|}
\hline DATA & AMBIENTES & ATIVIDADES & PARTICIPANTES & TEMPO & MATERIAIS \\
\hline $22 / 9 / 05$ & $\begin{array}{l}\text { - Sala de } \\
\text { atividades } \\
\text { pedagógicas }\end{array}$ & $\begin{array}{l}\text { - Saudação e } \\
\text { Roda de } \\
\text { conversa } \\
\text { - Comunicação: } \\
\text { Jogo de Advinha } \\
\text { por meio da }\end{array}$ & $\begin{array}{l}\text { - } 6 \text { crianças } \\
\text { - pedagoga } \\
\text { - pesquisadora } \\
\text { - câmera-man }\end{array}$ & $\begin{array}{l}\text { 1hora e } \\
\text { trinta } \\
\text { minutos }\end{array}$ & $\begin{array}{l}\text { - Cartelas com } \\
\text { letras em } \\
\text { Braille }\end{array}$ \\
\hline
\end{tabular}




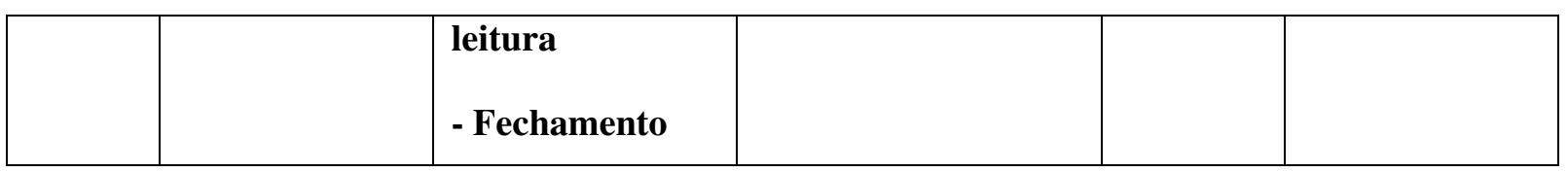

\section{Descrição:}

Depois de um período de três anos, Renan estava interagindo e comunicando-se mais com as pessoas, mostrando compreender o significado da escrita e sabendo as letras de seu nome. Ainda mostrou rigidez de pensamento com fixação ideativa, mas seu conhecimento de mundo se ampliou. Nesse dia, a atividade foi de exercícios de operações mentais simples: sequiências lógicas e pensamento associativo. Renan acompanhou a atividade com atenção, pensando, comentando, perguntando. Respondeu corretamente às primeiras proposições a serem completadas do tipo: $\mathrm{AA} B \mathrm{BB} C \mathrm{D}(\mathrm{D})$; $\mathrm{AB}$ AB $\mathrm{AB} A(\mathrm{~B})$. Quando começaram a se tornar mais complexas - $\mathrm{AB} \mathrm{AC} \mathrm{AD} \mathrm{A}(\mathrm{E})$ - ele levava mais tempo pensando, não desistia, mas não encontrava a resposta. Precisava mais tempo para o caminho de raciocínio que estava fazendo. A pedagoga mediava, mas as meninas do grupo ficavam ansiosas com o tempo e o "atropelavam" estranhando seu modo de raciocinar que não se apresentava linear. Era uma lógica toda própria. Possível sim, mas que não o levava ao resultado. Ele também demorava muito na leitura, o que o fazia esquecer a proposição. Renan ficou nervoso com a impaciência das suas colegas e começou a ficar agressivo. Quando a pedagoga pediu para eles dizerem o alfabeto para ver se sabiam a sequiência das letras e as meninas dispararam na frente em competição, ele disse que elas haviam esquecido $\mathrm{Y}, \mathrm{W}$ e $\mathrm{K}$. Elas responderam que a professora falou que essas letras saíram e que ela sabe. Ele retruca: "Se a professora erra, é burra! Se erra, é burra!" e sorri. Depois disso, todos começaram a falar ao mesmo tempo e ele gritou: "Cala boca!” As meninas reclamaram que só ele estava respondendo e ele disse: “Tá virando bagunça!" A pedagoga organizou o grupo e garantiu que todos tivessem a sua vez. Assim terminou a atividade, a pedagoga encerrou, as crianças foram saindo e Renan esperou parado, imóvel, pela mãe.

\subsection{Análise dos dados relativos a Renan}

$\mathrm{Na}$ consulta ao prontuário e as observações realizadas em dois períodos com intervalo de dois anos entre eles coletamos os dados que identificaram a história de vida e quadro clínico de Renan, bem como os dados que o caracterizaram como uma criança cega com 
problemas na constituição subjetiva e no desenvolvimento. Tais dados foram organizados em temas a partir dos elementos que emergiram como significativos a este trabalho e apresentados no seguinte quadro:

Quadro 15: temas e elementos significativos identificados nos dados do prontuário e nas observações

\begin{tabular}{|c|c|}
\hline TEMAS & ELEMENTOS SIGNIFICATIVOS \\
\hline $\begin{array}{l}\text { Formas de perceber, explorar, } \\
\text { relacionar-se, compreender, e } \\
\text { expressar-se no mundo }\end{array}$ & $\begin{array}{l}\text { Início das observações: boa percepção do ambiente, passividade, } \\
\text { pouca exploração, pouca busca de pessoas e objetos. poucas } \\
\text { respostas às solicitações; } \\
\text { Sabia falar, mas não falava. Mutismo. Até há pouco tempo só } \\
\text { falava em casa. } \\
\text { Observação atual: compreende o que é dito; } \\
\text { comunica-se bem melhor verbalmente, mas ainda permanece o } \\
\text { caráter de perseveração em um dado assunto; melhor interação; } \\
\text { Expressa necessidades e sentimentos e percebe sentimentos de } \\
\text { alegria e tristeza na voz da mãe. }\end{array}$ \\
\hline $\begin{array}{l}\text { Manifestações de } \\
\text { comprometimentos na } \\
\text { constituição subjetiva e no } \\
\text { desenvolvimento }\end{array}$ & $\begin{array}{l}\text { Fala vazia, repetitiva e perguntas incessantes com fixação em um } \\
\text { tema: transportes, particularmente trem; } \\
\text { Fala desconectada, aparentemente sem sentido; } \\
\text { Todo objeto que pega brinca de trem (desde } 2 \text { anos), mas quase } \\
\text { tudo que pega lança fora; } \\
\text { Não sabe brincar com o outro: agride e machuca; } \\
\text { Dificuldade na relação com o outro; } \\
\text { "Ilhas" de inteligência; } \\
\text { Tendência ao isolamento; } \\
\text { Até } 7 \text { anos não usava o pronome "eu". Depois disso o "eu" } \\
\text { sincrético (só para expressar necessidades). }\end{array}$ \\
\hline $\begin{array}{l}\text { Manifestações de pontos de } \\
\text { abertura para a constituição } \\
\text { subjetiva e o desenvolvimento }\end{array}$ & $\begin{array}{l}\text { A libidinização do corpo até os } 9 \text { meses; } \\
\text { O espelho "interrompido", mas recuperado com o irmão (também } \\
\text { cego) que nasce quando ele estava com três anos; o ciúme que } \\
\text { sentiu dele; } \\
\text { Nessa ocasião rejeitou a mãe e só queria o pai; } \\
\text { A identificação com o pai; } \\
\text { A partir dos quatro anos começou a desenvolver-se cognitivamente } \\
\text { Aos } 9 \text { anos: o raciocínio matemático é seu reconhecimento no } \\
\text { olhar da mãe e no espaço social da escola. } \\
\text { Alfabetização em processo; } \\
\text { Interesse em saber de sua história quando era bebê e da história da } \\
\text { família. }\end{array}$ \\
\hline
\end{tabular}




\section{ANÁLISE DA ENTREVISTA: UMA “ANÁLISE DE DISCURSO” NO DISCURSO DA MÃE}

\subsection{Análise dos dados relativos à mãe de Renan}

A entrevista com a mãe de Renan evidenciou elementos significativos que foram arranjados por temas organizados no quadro abaixo para apresentação dos dados levantados neste caso.

Quadro 16: temas e elementos significativos identificados na entrevista com a mãe de

Renan

\begin{tabular}{|c|c|}
\hline TEMAS & ELEMENTOS SIGNIFICATIVOS \\
\hline $\begin{array}{l}\text { A reação ao diagnóstico, os } \\
\text { primeiros anos de vida de } \\
\text { Renan e outras } \\
\text { contingências }\end{array}$ & $\begin{array}{l}\text { Com } 1 \text { mês, pediatra diagnosticou nistagmo. Não explicou o que } \\
\text { era e a mãe não perguntou. Não quis saber, pensou que melhoraria } \\
\text { quando usasse óculos. Foi encaminhada para oftalmologista - } \\
\text { protelou. } \\
\text { Aos } 9 \text { meses foi diagnosticado. O pai já desconfiava, mas a mãe } \\
\text { diz que não percebia até então (não queria aceitar). Não falava no } \\
\text { assunto. Não aceitava que seu filho fosse diferente: "Por que justo } \\
\text { comigo?" } \\
\text { Busca por outro especialista com esperança - Mesmo diagnóstico: } \\
\text { ela "perdeu o rumo de casa". } \\
\text { Negação; chorava sem saber o que fazer; parecia estar em outro } \\
\text { mundo; narcisismo ferido; revolta e autocomiseração; culpa, } \\
\text { angústia e desespero; não sabia o que fazer com ele; achava que } \\
\text { precisava estudar e aprender; começar do zero, pois nada do que } \\
\text { sabia sobre criança, servia; } \\
\text { Marido alcoólatra, perdeu o emprego, mas logo arrumou outro. } \\
\text { Mudaram-se mais perto de São Paulo; } \\
\text { Escondia seu filho das pessoas, pois os olhares e as perguntas a } \\
\text { incomodavam, ficava muito nervosa e respondia-lhes mal; } \\
\text { Desejo de um filho saudável - menino, para dar ao marido; } \\
\text { O casamento desmoronou. Muito ansiosa com o alcoolismo do } \\
\text { marido, pensa que passou isso para Renan. } \\
\text { O pai compara Renan com o irmão em termos de competências: } \\
\text { desvaloriza o primeiro e valoriza o segundo; } \\
\text { Pai ensina que ele não se deixe maltratar por ninguém; depois o } \\
\text { xinga e diz que é inútil. }\end{array}$ \\
\hline $\begin{array}{l}\text { Relação mãe-criança: } \\
\text { representação e sentimentos } \\
\text { em relação ao filho e o que ela }\end{array}$ & $\begin{array}{l}\text { Até } 9 \text { meses de vida de Renan, ela não sabia, então cuidava } \\
\text { normalmente dele: brincava, conversava, cantava, alimentava... } \\
\text { Era uma criança normal } \\
\text { Depois de saber da cegueira, ficou insegura e não interpretava seu } \\
\text { choro, não sabia o que ele queria e precisava, ficava nervosa e }\end{array}$ \\
\hline
\end{tabular}




\begin{tabular}{|c|c|}
\hline diz dele & $\begin{array}{l}\text { batia nele. Não conseguia mais ser mãe dele. } \\
\text { Criança que a desarrumou; não sabia por onde começar; } \\
\text { Criança passiva que não dava resposta que a animasse. Ela ficava } \\
\text { frustrada por não saber ajudá-lo. Ela se angustiava e ele também. } \\
\text { Desenvolvimento motor normal. Tinha capacidades, mas não as } \\
\text { usava. Ele passou para ela que não era capaz de nada sem ajuda; } \\
\text { Sentia pena dele e raiva; } \\
\text { É super inteligente, mas não mostra às pessoas, é muito fechado; } \\
\text { Ele é um desafio... como um trabalho. } \\
\text { Renan espera o reconhecimento do pai (sic mãe); } \\
\text { Até três anos era "grudado na mãe". Não ficava com ninguém. } \\
\text { Hoje é inteligente (memória, tem noção e tempo, causa e efeito, } \\
\text { brinca de faz-de-conta etc.) se desenvolveu muito depois do irmão; } \\
\text { Aceita limite, mas... quando algo não é permitido, ele bate no } \\
\text { irmão. }\end{array}$ \\
\hline $\begin{array}{l}\text { Representação, sentimentos e } \\
\text { atitudes em relação à cegueira }\end{array}$ & $\begin{array}{l}\text { Medo de uma senhora cega que conheceu na adolescência. Hoje vê } \\
\text { que tem criança que tem medo de seu filho; } \\
\text { Medo de não saber ajudar seu filho; } \\
\text { Imagem de cego como coitado, agressivo e pedinte; } \\
\text { A palavra cegueira incomoda muito, pois, para a sociedade (e para } \\
\text { ela) significa menosprezo, incapacidade, impossibilidade, } \\
\text { invalidez. }\end{array}$ \\
\hline $\begin{array}{l}\text { Reação e sentimentos em } \\
\text { relação à agressividade do } \\
\text { filho }\end{array}$ & Preocupação. \\
\hline $\begin{array}{l}\text { Como a mãe se mostrou - } \\
\text { lugar que ocupou, como se } \\
\text { sentiu }\end{array}$ & $\begin{array}{l}\text { Lugar de vítima; } \\
\text { Sentiu-se perdida, insegura, inútil, culpada, frustrada pela falta de } \\
\text { respostas dele; incapaz; fazia as coisas e não via resultado. } \\
\text { Sentia-se mergulhada no problema e não enxergava nada. }\end{array}$ \\
\hline $\begin{array}{l}\text { A mudança de olhar da mãe e } \\
\text { a possibilidade de saída de } \\
\text { Renan do lugar de deficiente: } \\
\text { a busca da instituição } \\
\text { especializada, o apoio } \\
\text { psicológico, o nascimento do } \\
\text { segundo filho e a inclusão } \\
\text { escolar }\end{array}$ & $\begin{array}{l}\text { Aos } 18 \text { meses é atendido em instituição especializada. No primeiro } \\
\text { Renan teve crise de choro, não conseguiu entrar e ela desesperou. } \\
\text { A psicóloga da instituição a ajudou muito. Sem isso, não teria } \\
\text { conseguido cuidar dele. Passou a conversar com ele, observá-lo, } \\
\text { ensiná-lo e, assim, ele ficou mais calmo. Ele percebeu a mudança } \\
\text { da mãe. } \\
\text { Conversar com outras mães e isso a animava; ficou fortalecida; } \\
\text { aprendeu muito; } \\
\text { Convivência dele com outras crianças; } \\
\text { O que a fez mesmo mudar o olhar sobre Renan: o segundo filho, } \\
\text { também cego, porém mostrou que o cego é capaz de desenvolver- } \\
\text { se; } \\
\text { Inclusão escolar: achava um absurdo. } \\
\text { Aos } 4 \text { anos entrou ma escola comum, mas sua opinião é a de que } \\
\text { deveria ser escola especial para que os professores fossem }\end{array}$ \\
\hline
\end{tabular}


preparados. Diz que se ela, mãe, ficou perdida, o professor tem direito de ficar. Não culpa o professor, mas o sistema de ensino. Para dar certo, é preciso trabalhar com os professores e os pais. Ainda fica no interesse de um professor com mais vontade.

\section{ANÁLISE DOS DADOS RELATIVOS À INTER-RELAÇÃO DOS ELEMENTOS DO DISCURSO DA MÃE E AS MANIFESTAÇÕES DE RENAN}

Apresentamos no quadro abaixo o cruzamento dos significantes que sugiram no discurso da mãe de Renan por ocasião da entrevista - indícios de sua posição na rede discursiva da mãe - e o que ele mostra como marcas do que foi dito sobre ele pela mãe.

Quadro 17: a posição de Renan na rede discursiva da mãe

\begin{tabular}{|c|c|c|c|}
\hline \multicolumn{2}{|c|}{ MÃ̂E } & \multicolumn{2}{|c|}{ CRIANÇA } \\
\hline $\begin{array}{c}\text { O QUE A MÃE FALA } \\
\text { DA CRIANÇA }\end{array}$ & $\begin{array}{c}\text { O LUGAR DADO } \\
\text { À CRIANÇA NO } \\
\text { DISCURSO DA MÃE }\end{array}$ & $\begin{array}{c}\text { O QUE A CRIANÇA } \\
\text { MOSTRA }\end{array}$ & $\begin{array}{c}\text { MARCAS DO } \\
\text { DISCURSO } \\
\text { DA MÃE NA } \\
\text { CRIANÇA }\end{array}$ \\
\hline $\begin{array}{l}\text { Criança normal } \\
\text { (até } 9 \text { meses - antes do } \\
\text { diagnóstico de cegueira) }\end{array}$ & Criança normal & $\begin{array}{l}\text { Mamava, chorava } \\
\text { expressando as } \\
\text { necessidades, sorria, } \\
\text { emitiu as primeiras } \\
\text { palavras }\end{array}$ & $\begin{array}{c}\text { Libidinização do corpo } \\
\text { Abertura para } \\
\text { subjetivação } \\
\text { Desenvolvimento }\end{array}$ \\
\hline $\begin{array}{l}\text { Passivo e sem resposta, } \\
\text { não reagia, } \\
\text { não a animava, } \\
\text { só a frustrava, } \\
\text { incapaz, } \\
\text { grudado na mãe }\end{array}$ & $\begin{array}{c}\text { Incapaz de reagir } \\
\text { Incapaz de realizar } \\
\text { coisas } \\
\text { Incapaz de satisfazer à } \\
\text { mãe e ao pai } \\
\text { Dependente }\end{array}$ & $\begin{array}{c}\text { Não respondia aos } \\
\text { estímulos dados } \\
\text { Não procurava objetos } \\
\text { e nem pessoas } \\
\text { Não falava }\end{array}$ & $\begin{array}{l}\text { Interrupção do curso } \\
\text { da libido } \\
\text { Fusão com a mãe }\end{array}$ \\
\hline
\end{tabular}




\begin{tabular}{|c|c|c|c|}
\hline (depois do diagnóstico) & & & \\
\hline $\begin{array}{c}\text { Desejo de um filho } \\
\text { menino e saudável para } \\
\text { dar ao marido, mas ele } \\
\text { nasceu cego }\end{array}$ & $\begin{array}{c}\text { Cego } \\
\text { Sem valor } \\
\text { Sem interpretação da } \\
\text { mãe }\end{array}$ & $\begin{array}{c}\text { Passividade } \\
\text { Não falava } \\
\text { Isolamento } \\
\text { Agressividade }\end{array}$ & $\begin{array}{c}\text { Impasses no olhar e no } \\
\text { desejo }\end{array}$ \\
\hline $\begin{array}{c}\text { Criança que a } \\
\text { desarrumou } \\
\text { Não sabia mais ser mãe } \\
\text { dele } \\
\text { Um desafio, como um } \\
\text { trabalho, um } \\
\text { aprendizado }\end{array}$ & $\begin{array}{c}\text { Caos } \\
\text { Estranho } \\
\text { Desafio e trabalho }\end{array}$ & $\begin{array}{l}\text { Chorava e se } \\
\text { angustiava } \\
\text { Passividade }\end{array}$ & $\begin{array}{c}\text { Criança sem mãe, sem } \\
\text { Outro, sem sustentação } \\
\text { Interrupção na } \\
\text { constituição da } \\
\text { imagem especular } \\
\text { Resgate }\end{array}$ \\
\hline $\begin{array}{l}\text { A mãe o escondia das } \\
\text { pessoas para que não o } \\
\text { olhassem ou fizessem } \\
\text { perguntas sobre a } \\
\text { deficiência } \\
\text { Tinha pena dele e raiva }\end{array}$ & $\begin{array}{c}\text { Não era para ser visto } \\
\text { Digno de pena }\end{array}$ & $\begin{array}{c}\text { Isolamento } \\
\text { Dificuldade na relação } \\
\text { com o outro } \\
\text { Agressividade }\end{array}$ & $\begin{array}{c}\text { Fora da circulação } \\
\text { social } \\
\text { Bloqueio na } \\
\text { constituição subjetiva e } \\
\text { no desenvolvimento }\end{array}$ \\
\hline $\begin{array}{c}\text { Criança tem loucura } \\
\text { pelo pai, espera seu } \\
\text { reconhecimento, mas } \\
\text { nunca consegue } \\
\text { Foi percebido pelo pai } \\
\text { Baixa-estima }\end{array}$ & $\begin{array}{c}\text { Ter que satisfazer as } \\
\text { expectativas do pai } \\
\text { Nunca conseguir }\end{array}$ & $\begin{array}{c}\text { Ansiedade } \\
\text { Auto-desvalorização } \\
\text { Agressividade } \\
\text { Hostilidade }\end{array}$ & $\begin{array}{c}\text { Pai presente } \\
\text { Identificação com o pai }\end{array}$ \\
\hline
\end{tabular}




\begin{tabular}{|c|c|c|c|}
\hline $\begin{array}{l}\text { Desenvolvimento motor } \\
\text { normal } \\
\text { Tinha capacidades, mas } \\
\text { não as usava } \\
\text { Isso irritava a mãe }\end{array}$ & Inútil & $\begin{array}{c}\text { Não usava as } \\
\text { capacidades funcionais } \\
\text { desenvolvidas: não } \\
\text { procurava os objetos, } \\
\text { não falava }\end{array}$ & $\begin{array}{c}\text { Saber, mas não fazer } \\
\text { Inutilidade }\end{array}$ \\
\hline $\begin{array}{l}\text { Desenvolveu-se quando } \\
\text { a mãe viu que o } \\
\text { segundo filho (cego } \\
\text { também) era capaz }\end{array}$ & Ser igual ao irmão & $\begin{array}{l}\text { Ciúme do irmão } \\
\text { Imitação } \\
\text { Fala } \\
\text { Interação } \\
\text { Brincar }\end{array}$ & $\begin{array}{c}\text { Corte na relação com a } \\
\text { mãe } \\
\text { Novoolhar da mãe } \\
\text { sobre ele } \\
\text { Identificação com o } \\
\text { irmão } \\
\text { Aprendizagem e } \\
\text { Desenvolvimento }\end{array}$ \\
\hline $\begin{array}{l}\text { Hoje é inteligente e as } \\
\text { pessoas não olham mais } \\
\text { com pena diante dessa } \\
\text { inteligência, mas } \\
\text { valorizam } \\
\text { É reconhecido na escola }\end{array}$ & $\begin{array}{c}\text { Inteligente } \\
\text { Tem valor } \\
\text { Reconhecimento }\end{array}$ & $\begin{array}{c}\text { Raciocínio matemático } \\
\text { Melhor comunicação e } \\
\text { interação com as } \\
\text { pessoas } \\
\text { Independente nas } \\
\text { atividades da vida } \\
\text { diária }\end{array}$ & $\begin{array}{l}\text { Resgate do que ficou } \\
\text { interrompido na } \\
\text { constituição de sujeito } \\
\text { Autonomia }\end{array}$ \\
\hline
\end{tabular}

Neste capítulo tratamos da apresentação dos dados dos casos estudados, com análise e interpretação do Caso I e análise preliminar dos casos II e III. Passamos, em seguida, às considerações finais, referências da bibliografia citada e consultada e anexos que compõem a pesquisa, finalizando, assim, este trabalho. 


\section{CONSIDERAÇÕES FINAIS}

Buscar conhecer a criança cega por ela mesma e por aqueles que ainda falam por ela, sem compará-la com a criança que enxerga, é a ética que pauta este trabalho. A análise dos casos apresentados, pela expressão de quem vive a realidade estudada, foi um caminho extremamente profícuo, ao revelar singularidades acerca da criança e da relação mãe-filho implicadas nas dificuldades que estas crianças mostraram para constituírem-se como sujeitos. Por outro lado, por descortinar a complexidade desta relação com elementos tão imbricados, foi um caminho difícil, no qual enfrentamos desafios teóricos e metodológicos, como também contradições e ambigüidades ao enveredarmos pela via da interpretação. Procuramos compreender aquilo que os discursos das mães apontaram, pois muitos dos significantes que emergiram deles, com seus múltiplos sentidos, remetiam a outros significantes que só poderiam ser abordados em um trabalho terapêutico.

O objetivo central - conhecer como se constituem os graves problemas no desenvolvimento global apresentados por algumas crianças cegas congênitas - traçou as diretrizes de investigação quanto ao registro e análise: do que a criança manifesta; do que a mãe diz; da interação criança-mãe.

Em relação ao que as crianças manifestam, a análise dos registros caracterizou-as como crianças cegas com comprometimentos na constituição subjetiva e no desenvolvimento, de acordo com o referencial teórico de Kupfer (1997) adotado neste trabalho, ou seja, crianças que não ascenderam ao registro simbólico, que apresentam falhas na rede da linguagem e dificuldades na relação com o outro. Tal formação psíquica se mostrou em Augusto, Vivian e Renan no uso das habilidades motoras, no desenvolvimento das estruturas cognitivas, linguagem pobre e ecolálica ou mutismo e perseveração; potencial de inteligência; comportamentos bizarros em forma de auto-agressão ou agressão aos outros; estereotipias (movimentos sem representação) e formas regredidas de contato com pessoas e objetos apenas para auto-erotização, com fixação da libido em fases primitivas da estruturaçãopsíquica; inconsistência na formação do "eu"; ausência da imitação e do brincar como formas de representar-se; dependência nas atividades da vida diária, entre outros. Estes comportamentos confirmam os estudos encontrados na literatura acerca do desenvolvimento de crianças cegas, principalmente os de Sandler (1963); Burlinghan (1965); Fraiberg e Freedman (1964); Wills (1970); Fraiberg e Adelson (1982) e Leonhardt (1992). Estes estudos 
marcam as dificuldades impostas ao desenvolvimento pela ausência da visão e apenas os de Leonhardt (1992) privilegiam as especificidades da cegueira e as dificuldades enfrentadas na relação mãe-bebê cego, causando problemas no desenvolvimento da criança cega, posição teórica que está mais de acordo com esta Tese.

Identificamos nos sujeitos estudados peculiaridades na forma de perceber, explorar, relacionar-se, compreender, e expressar-se no mundo. As crianças mostraram capacidades para usar os outros canais de percepção na apreensão do mundo e diferenciação das pessoas a audição e o tato, por exemplo - expressando-se por meio do sorriso quando ouviam as vozes das mães e das pessoas da casa, passando a mão no rosto das pessoas, andando pela casa para conhecer os espaços. Além disso, em relação à expressão deles vimos, em Augusto, o morder e o agredir; em Vivian, a passividade de um lado e a agressividade de outro; e em Renan, passividade, agressividade, choro e, mais tarde, sua perseveração nas perguntas incessantes versando sobre o mesmo tema. Observamos suas formas estereotipadas de relacionar-se com pessoas e objetos, como também interações sociais precárias. E outro aspecto que denuncia os problemas na constituição subjetiva é o não brincar, o não fazer-se representar nas brincadeiras e no jogo simbólico.

Cabe ressaltar que estas existências precisam ser compreendidas à luz das especificidades da cegueira e da qualidade da relação mãe-criança.

Ficaram também assinaladas as condições nas quais essas crianças, em suas singularidades, manifestaram pontos de abertura como possibilidades de constituição da subjetividade e de desenvolvimento, mostrando lances de enlaces no social: Augusto vê o mundo do portão e pede para ir à casa dos vizinhos; Vivian procura consolo "conversando" com a mãe, diante da falta insuportável, para ela, quando deixa a piscina e está lindamente descobrindo a escrita; e Renan tem ciúme do irmão, ao mesmo tempo em que se espelha nele e tem um raciocínio todo particular.

Consideramos que essa descoberta de pontos de abertura possa ser o caminho para inserir as crianças na cultura e no social se queremos vê-las na escola. Não encontramos essa postura nos casos relatados na literatura especializada em estudos sobre a cegueira.

É importante ressaltar que as três crianças deste estudo - Augusto, Vivian e Renan mostraram em suas experiências educacionais, desde a instituição especializada até a escola, que algo se transformou na direção de fazer um corte na relação mãe-filho, onde cada qual ocupava um lugar cristalizado. 
Embora não fosse objetivo deste trabalho investigar o papel desempenhado pela instituição especializada, constatamos, nos três casos, que ela funcionou como uma primeira inclusão educacional, entrando como um terceiro, na medida em que tirou a criança do circuito de gozo da mãe e da dinâmica familiar e a inseriu em um contexto sócio-educativo mais amplo, que foi capaz de antecipar um sujeito. Este achado está de acordo com os teóricos que defendem a função subjetivante da escola, por ser um lugar social e oferecer as manifestações da cultura. São eles: Mannoni (1977), Jerusalinsky (1997), Kupfer (1997, 2001) e Lajonquière (1997).

Passando à análise dos discursos das mães encontramos elementos significativos referentes a elas em relação a seus filhos, bem como à inter-relação mãe-criança, que elucidaram alguns aspectos das raízes dos problemas de desenvolvimento mostrados pelos sujeitos pesquisados.

Um dos temas levantados foi a reação das mães frente ao diagnóstico de cegueira e a vivência com seus filhos nos primeiros anos de vida deles. As experiências foram semelhantes: negação (a procura de confirmação do diagnóstico e a busca da cura), revolta, rejeição, sentimentos de auto-comiseração perguntando-se por que elas e por que seus filhos (vimos que a mãe de Vivian, até hoje, não elaborou esse sentimento e, mesmo sabendo a causa científica da cegueira da filha, ela desconfia e quer outra resposta), culpa, depressão profunda, o luto, pena, superproteção e elaboração. Para elas, cegueira estava associada às idéias de isolamento, dependência, incapacidade, agressividade, medo, tristeza, paralisação de tudo, não haver mundo sem a visão, impossibilidade de existir, desconhecido, necessidade de superproteção, não poder ver as coisas do mundo e a mãe nunca ser vista pelo filho, não ser igual aos outros filhos.

Esses dados confirmam o que foi apontado pelos estudos levantados na revisão bibliográfica acerca dos sentimentos provocados na mãe por ocasião do nascimento do bebê cego, bem como o significado da visão na estruturação psicossexual (Cf. LEONHARDT, 1992; LOWENFELD, 1981; WEST e LAMBERT, 1980).

É particularmente interessante notar que a mãe de Renan, antes do diagnóstico, fazia fluir naturalmente a relação com seu bebê, interpretando e respondendo às suas demandas, libidinizando seu corpo no toque, na carícia, no olhar e nas palavras, ou na canção de ninar, até o momento em que soube de sua cegueira. A partir daí vimos em seu relato que ela paralisou e já não compreendia o que ele queria, o que ele pedia ou precisava. Não sabia o que 
fazer com ele e ele deixou de ser normal para ela. Ele não a animava porque não lhe dava respostas e isso a frustrava muito.

A mãe de Augusto também relata que, até os nove meses, ele era normal. Esse fato chama nossa atenção por lembrar aos estudos de Sandler (1963), que afirmam que, até por volta de quatro-cinco meses os bebês cegos apresentam um desenvolvimento semelhante ao da criança que enxerga, mas que passam a ficar atrasados nas aquisições nesse momento de passagem da fase oral passiva para a ativa, na qual a visão passa a ter um papel importante na coordenação olho-mão. Nesse caso, fazemos alusão às dificuldades das mães para apoiar seus bebês, quando elas ainda estavam tão fragilizadas. Também lembramos os estudos de Fraiberg e Adelson (1982), que ressaltam que aos nove meses a formação do "eu" está se iniciando e muitas crianças cegas congênitas, sem comprometimentos de ordem neurológica, têm dificuldades de passar consistentemente por esse período. São momentos vulneráveis, certamente, como alerta Wills (1970), porque invocam uma presença e relação com a mãe fundamentais para o desenvolvimento do bebê cego e sua constituição como sujeito. Nesse momento da vida das crianças que estudamos nesta pesquisa, vimos que suas mães não estavam disponíveis para a relação, pois ainda estavam mergulhas na depressão e com muitas dificuldades para abandonar o filho imaginado e aceitar o filho que nascera.

Todas as mães mostraram que sua relação com seu filho cego ficou bastante perturbada pela presença da deficiência, pois não sabiam o que fazer com eles. Elas viram a deficiência antes de ver que ali estavam seus filhos.

Sobre o modo como as mães se mostraram, como se sentiram e o lugar que ocuparam, vimos que a mãe de Renan diz ter se sentido em outro mundo, a de Augusto não podia olhá-lo que perdia os sentidos; e a de Vivian sentiu que não tinha mundo, o fato de não ser vista pela filha e esta não poder ver o mundo é um fato que não aceita até hoje. A mãe de Renan, por sua vez, ao saber de sua cegueira, perdeu totalmente o contato com ele: não sabia brincar, não sabia mais nada sobre ele. As três mães mostraram-se extremamente afetadas com o nascimento de seus filhos cegos, ocupando o lugar de culpadas, coitadas, sentiam-se envergonhadas, sendo que as mães de Vivian e Renan se sentiam discriminadas e incomodadas pelos olhares das pessoas e chegavam a esconder as crianças. Quando saíram da depressão, entraram em um período de superproteção justificada ainda pela deficiência em primeiro lugar. Assim, continuavam não vendo seus filhos, mas a deficiência. Nesse aspecto, as idéias de Levin $(2002,2005)$, elucidam o fato das crianças deste estudo terem ficado à 
margem na constituição da imagem corporal, pois que a deficiência ocupou todo o lugar da criança.

Mais tarde, cada uma das mães, a seu modo, começou a sair desse lugar e mudar sua posição em relação à cegueira e à criança, favorecendo a abertura de seus filhos à constituição subjetiva. Assim, a mudança de olhar das mães e a possibilidade de saída dos filhos do lugar dado a eles - com a preocupação de educá-los, lançando-os ao mundo - iniciou-se na instituição especializada e com a inclusão escolar, mesmo que esta ainda não seja realizada efetivamente.

Nesta etapa, pareceu-nos que Augusto e Renan mostraram maiores possibilidades, pois suas mães parecem ter elaborado mais suas vivências e fantasmáticas acerca de seus filhos com cegueira. Vemos situações que funcionaram como pontos de cortes e disparadores do desejo da mãe para outra direção. O caso de Renan é ilustrativo de alguns pontos interessantes. A mãe teve um segundo filho e este, também cego, e com a mesma patologia de Renan, o "salvou", pois mostrou à mãe a possibilidade que têm as pessoas cegas para constituir-se e desenvolver-se plenamente. Porém, a mãe de Vivian não abriu mão da tristeza, não venceu a inconformidade e ainda vê a cegueira em primeiro lugar. Está presa a esse gozo. Assim, não solta Vivian para o mundo e ela, das três crianças, é a que se encontra mais fechada em si mesma. Mas quer escrever e por aí pode ser enlaçada no social.

Por todas essas implicações, chegamos ao nível de análise da inter-relação dos discursos das mães e as manifestações das crianças, encontrando marcas significativas que indicaram a posição dessas crianças na rede simbólica (de significantes das mães).

Nesse sentido, vimos que os significados atribuídos à cegueira na fantasmática das mães deu aos filhos o lugar de deficientes, cuja posição na rede da linguagem era de incapacidade de ter uma identidade própria, aquele que faria tudo mais tarde e que não precisava ser incentivado a desenvolver-se, pelo contrário, precisava ser protegido e a quem o "não" não poderia ser dito. O lugar de deficientes os encobriu como crianças, paralisando-as, já que ser cego significava, para as mães, não ter uma vida normal, ser dependentes delas para sempre, não sair de casa, causar medo nas pessoas e não haver mundo algum, as crianças permaneceram objetos de suas mães, fixadas a fases primitivas da vida psíquica, sem a libidinização do corpo e o desejo que engendram o psiquismo humano. A agressividade mostrada pelas crianças evidenciou uma forma de defesa à invasão de um mundo que não lhes foi possibilitado. A partir do momento em que as mães passaram a olhar para essas crianças 
com um olhar de possibilidades, elas começaram a desabrochar para o mundo e inscrever-se no simbólico, ensaiando uma circulação no social.

$\mathrm{Na}$ relação entre mãe e filho é preciso que haja reciprocidade constante nos atos de reconhecimento e investimento e estes podem claudicar, como indica Kupfer (2001) e como pudemos ver nos casos estudados nesta pesquisa. As crianças não foram olhadas por suas mães, o que significa que estas não lhes deram uma imagem, como um espelho, e tampouco lhes confirmaram a existência e a identidade. Assim as crianças não se reconhecem. As mães ficaram muito tempo presas à questão do ver e não investiram na voz e no toque que cumpririam a função do olhar na libidinização, pois a pulsão pode trilhar outros caminhos na constituição do sujeito, porque se trata do desejo (Cf. LAZNIK, 1998).

Retomamos, então, as questões que nortearam este trabalho, na realidade variações e ampliações de uma única:

- "o que ocorre com uma parcela significativa de crianças cegas congênitas que fica 'barrada' na possibilidade de tornar-se sujeito e desenvolver-se plenamente e quais os fatores imbricados nessa realidade?"

- "o que ocorre com a criança cega que fica paralisada nessa possibilidade se não há impedimento essencialmente proveniente da cegueira? E em que momento e dimensão da estruturação psíquica e do processo de desenvolvimento isso ocorre?"

- “de que maneira as relações iniciais ficam afetadas pela presença da cegueira na sua dimensão psicossocial, podendo impedir o acesso da criança ao simbólico e, portanto, à sua constituição de sujeito, levando-a a um desenvolvimento global prejudicado?”

A análise nos levou a apontar alguns resultados importantes, embora não conclusivos, pois o tema não poderia ser esgotado neste estudo.

Acreditamos que os dados recolhidos nesta pesquisa, e explicitados até aqui, permitiram apontar para algumas respostas acerca dessas questões, bem como apoiar fortemente as hipóteses de que os problemas graves de desenvolvimento, que encontramos em muitas crianças cegas congênitas, não são essencialmente provenientes da ausência da visão, mas dependem do que se passar no encontro de uma mãe com seu bebê cego. E se o período de luto for muito prolongado, no qual as necessidades psicológicas da mãe venham sobrepujar as do bebê, este corre todos os riscos de ter problemas pra constituir-se sujeito. 
Nos casos que estudamos vimos a primazia do significante cegueira remetido à cadeia vazio / nada / impossibilidade de ser / não-vida; a primazia do significante dificultando o olhar, o desejo e a palavra das mães para seus filhos, paralisando a constituição do corpoimagem que deixou lacunas no desenvolvimento do corpo-organismo. Esta constatação está de acordo com as idéias de Levin $(2002 ; 2005)$ a respeito da constituição da imagem corporal e da formação do "eu".

Também pensamos ser importante retomar a definição de Kupfer (1997), acerca das crianças com graves problemas no desenvolvimento, no ponto em que ela se refere a algumas crianças com deficiência como aquelas que estão propensas à instalação de falhas na inscrição do registro simbólico. Aqui queremos chamar atenção para o fato de que esta propensão está dada pela fantasmática da mãe, o que os casos que estudamos nesta pesquisa nos permitiram identificar.

Outras questões foram geradas neste estudo e abriram caminho ao objetivo de colaborar com os educadores, oferecendo subsídios ao seu trabalho com essas crianças na escola: o que é preciso saber, então, sobre elas para sua inclusão na escola? O que de sua existência é preciso conhecer e como elas nos mostram seu modo de perceber, compreender e relacionar-se com o mundo de coisas, pessoas e acontecimentos? Como interagem, como se expressam e como se movimentam no tempo e no espaço? Como organizam a libido, as emoções e a vida mental? Que significantes somos capazes de capturar diante de suas expressões tão singulares no mundo forjadas em cada história pessoal? E que possíveis sentidos somos levados a levantar para seus movimentos estereotipados, gritos, agressões, palavras soltas? Mesmo sabendo que o sentido escapa, perseguimo-lo para que algo enganche; fazemos de conta e criamos uma cena possível, na qual a criança venha a se reconhecer como parte deste universo onde estamos todos nós, seus semelhantes. Estas questões são proposições das quais todo educador deve partir na proposta de conhecer e traçar um plano de trabalho com crianças cegas e, particularmente, aquelas com comprometimentos na constituição subjetiva e no desenvolvimento.

Este estudo também viabilizou uma articulação teórica no sentido de considerar que as crianças cegas que apresentam problemas graves no desenvolvimento não se caracterizam exatamente como autistas ou psicóticas. Por exemplo, o balanceio e outras formas estereotipadas de condutas não significam necessariamente autismo nas crianças cegas. Para elas tais movimentos de corpo podem representar um modo de auto-estimulação na ausência de referentes relacionais humanos ou não. A cegueira implica especificidades, tanto em 
relação à forma da criança organizar internamente as experiências acerca do mundo vivido, como também o que vai representar no imaginário dos pais. Essa compreensão da questão é funamental.

Sabemos que uma criança com cegueira tem seu modo próprio de perceber o mundo e construir suas imagens e conceitos sobre ele, organizando-o internamente e tomando consciência das experiências vividas a partir de seus canais de percepção (Cf. MASINI, 1990; ORMELEZI, 2000). Suas formas de expressão muitas vezes parecem estranhas aos videntes por uma posição de cabeça, alguns maneirismos, uma atenção em coisas que não são muito perceptíveis àqueles que usam a visão como sentido predominante. São, porém, singularidades de uma criança diferente ainda em vias de estruturar-se.

Nesse sentido, as especificidades da cegueira são bem delineadas no pensamento de Vygotsky (1993) no qual encontramos uma referência que nos abre caminho para pensar o modo da criança cega construir o conhecimento e as estruturas cognitivas. Não se trata de uma criança como outra, apenas sem o sentido da visão, pois essa condição de não enxergar cria uma nova e singular organização que vai operar distintamente sobre ela. Portanto os sentidos de que dispõem não são compensatórios de sua cegueira, mas realidade única.

Se nos deslocássemos de nosso olhar de videntes, até onde nos fosse possível, conseguiríamos perceber que as formas como Augusto, Vivian e Renan lidam com o mundo são de outra natureza. E poderíamos começar nos perguntando sobre "o que é essa captura do mundo sem a visão". E, depois, poderíamos nos fazer uma segunda indagação: "como estar com eles e criar condições para que conheçam o mundo à sua maneira?". Desse modo nos aproximaríamos de cada um deles para conhecê-los em seu modo singular de estar no mundo e fazer parte dele.

O fato das mães pensarem que não ter a visão seja um horror, dificulta a descoberta do mundo por essas crianças. Dificulta-lhes a possibilidade de fazerem laço social, ou como diz Lajonquière (1997), de serem enlaçados pelo desejo do adulto e se colocarem na cultura.

Outra contribuição que pensamos ter trazido com esta investigação diz respeito à interdisciplinaridade, ao trabalharmos na trilha da Psicologia, da Medicina e da Psicanálise com dois eixos de entendimento sobre o ser humano: o da estrutura e o do desenvolvimento. Tratamos da criança que tem uma marca no real do corpo - a cegueira - e do que isso pode significar na constituição subjetiva e no desenvolvimento a partir do Outro (materno). 
Partimos de algumas premissas teóricas psicanalíticas que afirmam que o corpo não é o organismo somente, mas também uma imagem inconsciente que veicula o desejo do Outro (materno); as mães carregam representações inconscientes acerca da cegueira, assim como os professores também; o sujeito é sempre o sujeito do inconsciente e está além do organismo. Portanto, trabalhar com as imagens dos pais sobre o filho cego é abrir caminhos e criar pontes para que reconheçam a criança além da deficiência para construir possibilidades de subjetivação.

Da mesma forma, retornando à inclusão educacional e escolar, trabalhar com as imagens dos professores sobre seus alunos é abrir caminhos e criar pontes para que reconheçam a criança além da deficiência para construir possibilidades de subjetivação e interação.

A finalidade prática deste trabalho é apoiar os pais e os professores, fazendo-os falar de suas representações fantasmáticas. Encontramos nos relatos das mães entrevistadas nesta pesquisa dados sobre o que elas fizeram que estruturou as crianças do modo como elas estão. O trabalho do professor é entender essa dinâmica para conhecer melhor as crianças. Conhecer cada criança, pois a criança geral, a criança abstrata, não deixa ver o sujeito. Nesse sentido, esta pesquisa atingiu o objetivo de servir como referência e contribuição para os educadores no ponto em que a Psicanálise ilumina a Educação. Não se trata de uma metodologia que vá ensiná-los o como fazer, mas, antes os convoca a um olhar e uma leitura diferenciada dessa criança.

Pensamos que outra contribuição deste trabalho está em ter redefinido algumas idéias dos teóricos que estudam as crianças cegas na linha desenvolvimentista, que as comparam com as crianças videntes e concluem por seus atrasos ou distúrbios, sustentando a primazia da visão no desenvolvimento, convertendo-se em formas engessadas de ver a criança cega. Assim, tentamos desconstruir certas idéias prontas que amarram o sujeito, mesmo quando constatamos, nos relatos que ouvimos das mães nesta pesquisa, as dificuldades vividas por seus filhos para se tornarem sujeitos, ou a dificuldade do encontro mãe-filho com cegueira, por não poderem perceber os modos particulares deles viverem. Vimos que os sentimentos de culpa e pena em muito prejudicam esse encontro, assim como o tempo prolongado para elaboração do luto.

Este trabalho tentou atender à proposta de aprofundamento das discussões médica e psicológica, na via da Educação e na perspectiva do referencial psicanalítico, para a inclusão dessas crianças na escola. 
O referencial psicanalítico lacaniano aporta conceitos fundamentais acerca do que é uma criança, do que é educar, da dimensão do corpo e da deficiência além do organismo e do que somos feitos para nos tornarmos seres humanos. Somos feitos de linguagem e do olhar do Outro sobre nós. A primazia não é da visão, mas do significante, ou seja, daquilo que é dito sobre nós. Um dizer inconsciente que precede o sujeito e que o constitui, pois este é efeito de histórias particulares cunhadas no social. Portanto, sua constituição não vem de uma herança genética, mas simbólica, como diz Levin (2001). Estes dispositivos teóricos são confirmados pelas representações simbólicas que as mães desta pesquisa relataram acerca da cegueira e que as impediu de ver os seus filhos além delas no início de suas vidas.

Portanto, é um grande desafio lidar na escola com casos que apresentam tais singularidades para que o professor veja cada criança na individualidade e não todas as crianças de forma geral. Ver a cada uma dessas crianças cegas em seu modo próprio de existir; seu modo próprio de comunicar-se, pensar, aprender e agir. Conhecer seu estilo cognitivo como a relação peculiar de um sujeito com o objeto do conhecimento que carrega “as marcas de seu estilo como sujeito na relação com o Outro" (KUPFER, 2001, p. 129).

Esta pesquisa se insere, então, em um circuito de transmissão ao professor, uma vez que a Educação tem um papel importantíssimo, pois trabalha com o circuito de vida.

Em todas as crianças estudadas, constatamos o efeito terapêutico da escola, como vimos em Mannoni (1977), pelo impacto de sua entrada no espaço no qual elas foram reconhecidas como crianças. Mas ainda é preciso que haja um trabalho constante de construção de mais e mais significantes que enlacem essas crianças e as ajudem a fazer laço no social, que é o mesmo que dizer, constituírem sua subjetividade, colocarem-se no mundo como sujeitos de seu próprio desejo. A escola sozinha não dá conta desse trabalho, por isso a parceria com os profissionais especializados e as famílias.

Outra reflexão importante é que, embora em algumas passagens teóricas desta pesquisa, tenhamos abordado os problemas de desenvolvimento de algumas crianças cegas congênitas como falhas na constituição subjetiva - falhas nas funções materna e paterna gostaríamos de reposicionar essa questão não mais no sentido de um distúrbio ou falha a ser corrigida, mas a questão de um sujeito posto em jogo, porque é sobre este que nossas intervenções de educadores produzirão alguns efeitos.

Assim, passamos a falar em impasses para essas crianças cegas congênitas constituírem-se como sujeitos de linguagem e de desejo porque algo não se deu no espaço 
familiar; algo da ordem do olhar, do desejo e da palavra que deveria marcar presença para constituírem sua imagem corporal e todas as instâncias constitutivas do sujeito e estruturantes da vida psíquica, como vimos nos três casos estudados.

Quando assinalamos os impasses na constituição subjetiva ressaltamos, como diz Mannoni (1981), que algo da ordem da linguagem se encontra perturbado na relação mãebebê que não está representando essa criança para o mundo. Os casos que estudamos corroboram esta visão proposta por essa autora. Não queremos aqui fazer parecer que se trata de culpabilizar a mãe, mas sim falar de um encontro que não se deu quer tenha sido pela fantasmática parental acerca desse filho com cegueira, quer pelas dificuldades da própria criança.

Tratar dessa questão, para um possível entendimento do educador é importante, uma vez que concebemos educação como possibilidade de resgatar ou instituir algo da ordem da subjetivação que não se deu até o momento em que essa criança chega até nós. Esse mesmo sujeito do qual fala a Psicanálise é o sujeito que está no contexto educacional e escolar, pois é o sujeito que está na vida, e isso implica uma compreensão diferenciada por parte do educador no sentido de buscar em cada criança/aluno, uma criança/aluno em particular, com sua história única e seu modo próprio de funcionamento psíquico, estilo de aprender e formas próprias de perceber, conceber e agir no mundo.

Na proposta de educação das crianças cegas com transtornos graves na constituição subjetiva e no desenvolvimento, o que se busca é a possibilidade de que essa criança se constitua por algum fragmento de fala ou qualquer outra forma de expressão; a possibilidade de mergulhá-las na vida e na cultura, um banho libidinal, para submergir e tomar forma e lugar no mundo. É nesse aspecto que centramos ainda mais nossa preocupação ao defendermos a inclusão educacional e escolar e é também onde residem polêmicas, dissidências, negligências, inadequações, muitas dúvidas metodológicas e algumas experiências recentes. Se a inclusão das crianças apenas deficientes visuais na escola já não é de fácil execução, para as crianças com outros comprometimentos associados é grande um desafio. Exigirá muita maturidade dos profissionais envolvidos, muito estudo, capacidade de análise de situação e inovação na elaboração de propostas educativas de ruptura dos modelos pedagógicos; exigirá a participação efetiva da família em todos os processos de avaliação e análise que implicam tomadas de decisão em conjunto. $\mathrm{O}$ processo de inclusão das crianças com problemas graves de desenvolvimento não se dará se estas não forem acompanhadas “por 
um profissional, clínico ou educador, que esteja atento aos cuidados relativos à elaboração da posição da criança para seus pais" (LERNER, 1997 p. 70).

Neste estudo, a visão apresentada pelas mães acerca da inclusão de seus filhos na escola, foi a de que eles deveriam ir para a escola especial, pois nesta há especialistas que conhecem a deficiência, o que os faz preparados para trabalhar com eles e, além disso as classes são compostas por um número baixo de crianças, permitindo atendimento individual. Notamos nestas posições, a marca de um modelo médico de atendimento ao deficiente, como também a estampa de uma realidade da escola comum que ainda não atende às singularidades dos alunos. Porém, as mães de Augusto e de Renan, após a experiência na escola comum, julgaram que a convivência com as crianças que não têm deficiência vem sendo extremamente favorável ao desenvolvimento deles. Já a mãe de Vivian mantém, mais que uma posição racional, o desejo de que houvesse um atendimento escolar que só olhasse sua filha. Esse depoimento ainda traz a marca de uma superproteção.

Pensamos que a permanência dessas crianças na escola requer um monitoramento muito próximo e constante, a preparação de toda comunidade escolar e da família. Essas práticas não representam soluções e respostas acabadas. São artifícios ou respostas parciais, construções possíveis que vamos encontrando no espaço escolar e que beneficiarão a todas as crianças, porém não devem se converter em sistemas rígidos, que vão perdendo o sentido e se tornando mecânicos, meramente burocráticos e fator impeditivo da construção do conhecimento e da possibilidade da constituição dos sujeitos.

A crença na possibilidade da convivência e do entendimento entre as pessoas nessa aventura de conhecer e poder se tornar um sujeito orienta-nos no sentido de que a luta pela inclusão não é só política e a crítica à inabilidade da escola para fazer das crianças cidadãos críticos não é purista, mas é mais que tudo uma crença no potencial terapêutico que o ato educativo pode ter quando voltado para o sujeito (Cf. KUPFER, 1997).

Esta autora fala do papel da escola em nossa cultura como o da integração ou circulação social e que "ao darmos à criança um lugar na escola, está sendo feita uma atribuição imaginária de lugar social” (Ibid., p. 57). Essa é uma imagem que o adulto lhe emprestará à qual ela poderá responder buscando recursos para isso. É preciso que essa imagem se estabeleça com força e adquira o status simbólico. Por esse motivo, a escola pode buscar aparelhar-se para exercer sua função de dar à criança um lugar possível de sujeito. 
A concepção da constituição do sujeito pelo Outro possibilita pensar nas crianças cegas congênitas com problemas graves na constituição subjetiva e no desenvolvimento. Crianças que ficam paralisadas no lugar que foi dado a elas, bem como ficam as mães também paralisadas no papel que conferem a si mesmas nessa relação, como ressalta Mannonni (1981), apontando para algo de "perturbado ao nível da linguagem (na relação mãe-filho) que se exprime por uma via afastada" (Ibid., p. 40). A ética da Psicanálise está em indagar sobre isso e não em fechar diagnósticos encaixando as crianças neles. Por isso não fechamos, neste trabalho, diagnósticos de autismo ou psicose, mas nos referimos aos impasses na constituição subjetiva. Um dos motivos diz respeito ao fato de que ainda são crianças e estão se formando, e outro é o fato de que há a presença da cegueira e esta implica outros fatores de análise, como pudemos ver nos casos estudados.

Ainda assim, consideramos que neste aspecto aportamos a um limite nesta pesquisa, pois no capítulo em que tratamos dos problemas graves na constituição da subjetividade e abrimos uma seção para falar das estruturas psíquicas da psicose e do autismo, não nos foi possível abordar a relação com a cegueira, o que seria bastante importante. Esta lacuna neste trabalho constitui-se como tema para novas investigações.

Outro fator limitante a considerar foi que objetivamos a inclusão escolar, mas não pudemos abarcar esse espaço na coleta de dados, ouvindo os professores. Trabalhamos apenas com o que as mães trouxeram em seus discursos acerca das experiências escolares. Este limite também abre caminho para seguimento da pesquisa junto às escolas que estes sujeitos freqüentam.

Para finalizar, ressaltamos que a Educação Especial sempre postulou estimular para desenvolver competências e habilidades e então inserir no social, na cultura. O referencial teórico psicanalítico e os casos estudados nesta pesquisa propõem uma inversão: a inserção na cultura, o mergulho nas experiências significativas da vida, para a constituição do sujeito e para o seu desenvolvimento.

Augusto, a criança que melhor conhecemos neste trabalho, nos deu testemunho dessa possibilidade: a aposta em um trabalho que reuniu mãe, instituição especializada, o médico e o psicólogo (ambos cientes da função da educação) e a escola, todos supondo em Augusto uma criança em vias de constituir-se. Uma criança que vai à escola e, por isso, é uma criança, como enfatizaria Jerusalinsky (1997). 


\section{REFERÊNCIAS}

AMARAL, L.A. Conhecendo a deficiência: em companhia de Hércules. São Paulo: Robe Editorial, 1995.

AMARAL, L.A. Pensar a diferença/deficiência. Brasília: Corde, 1994.

AMIRALIAN, M.L.T.M. Compreendendo o cego: uma visão psicanalítica da cegueira por meio de desenhos-estórias. São Paulo: Casa do Psicólogo, 1997.

ARIÈS, P. História social da criança e da família. Rio de janeiro: LTC, 1981.

ASSOSCIAÇÃO AMERICANA DE PSIQUIATRIA (1994) Manual de diagnóstico e estatística de distúrbios mentais (DSM IV)

http://www.psicologia.com.pt/instrumentos/dsm_cid. Acesso em: 2 out. 2005.

ASSUMPÇÃO, F.B. Distúrbios globais do desenvolvimento. Estilos da Clínica: Revista sobre a infância com problemas - IPUSP, São Paulo, Ano II, n. 2, p. 103-110, $2^{\circ}$. Semestre 1997.

BACHA, M.N. Psicanálise e Educação: laços refeitos. Campo Grande: Universidade Federal do Mato Grosso do Sul e Casa do Psicólogo, 1998.

BALLONE, G.J. Autismo infantil. http://www.psiqweb.med.br/infantil/autismo.html. Acesso em: 02 out. 2005.

BARATTO, G. Da estruturação da imagem do corpo pela instância do olhar. In: KUPFER, M.C. (org.) Tratamento e escolarização de crianças com distúrbios globais do desenvolvimento. Salvador: Ágalma, 2000.

BARRÈS, P. Imagem do corpo e psicanálise. Terapia Psicomotora - Periódico do Sindicato Nacional de Reeducadores em Psicomotricidade. Paris: 1974. Trad. Priszkulnik, IPUSP.

BASTOS, A.B.B.I. A construção da pessoa em Wallon e a constituição do sujeito em Lacan. São Paulo: Editora Vozes, 2003.

BAUTISTA, R. Necessidades educativas especiais. Lisboa: Dinalivro, 1997.

BLANK, H.R. Psychoanalysis and blindness. Psychoanalytic Quarterly, New York, v. 26, p. $1-24,1957$.

BOURDIEU, P. O poder simbólico. São Paulo: Difel, 1989.

BRASIL. Ministério da Educação e do Desporto. Secretaria de Educação Especial. Projeto Escola Viva "Adaptações Curriculares" - Cartilhas 5 e 6 - Brasília: MEC, 2000.

BRASIL. Ministério da Educação e do Desporto. Secretaria de Educação Fundamental. Secretaria de Educação Especial. Parâmetros Curriculares Nacionais - Adaptações 
curriculares: estratégias para a educação de alunos com necessidades educacionais especiais. Brasília: MEC, 1999.

BRASIL. Ministério da Educação e do Desporto. Secretaria de Educação Especial. Política Nacional de Educação Especial. Brasília: MEC, 1994.

BRASIL. Presidência da República. Casa Civil. Subchefia para Assuntos Jurídicos. constituição da República Federativa do Brasil de 1988. http://www.presidencia.gov.br/CCIVIL/Constituicao/Constitui\%C3\%A7ao.htm. Acesso em 28 mai. 2006.

BROWN, R. et al. Are there "autistic-like" features in congenitally blind children? Journal Child Psychology and Psychiatry, Oxford, v. 38, n. 6, p. 693-703, 1997.

BRUNO, M.M.G. Escola inclusiva: problemas e perspectivas. Palestra proferida no III Encontro de Educação do Oeste Paulista. Políticas Públicas: Diretrizes e Necessidades da Educação Básica. UNESP-Marília, Ago. 2001.

BRUNO, M.M.G. O significado da deficiência visual na vida cotidiana: representações dos pais, dos alunos e dos professores, 1999. Dissertação (Mestrado em Educação) Universidade Católica Dom Bosco. Campo Grande. Mato Grosso.

BURLINGHAM, D. Some problems of ego development in blind children. Psychoanalitic Study of the Child, New York, v. 20, p. 194-208, 1965.

CALligARIS, C. A escrita do sintoma social. Anuário Brasileiro de Psicanálise, Rio de Janeiro, n.1, p. 11-22, 1992/1993.

CALLIGARIS, C. Introdução a uma clínica diferencial das psicoses. Porto Alegre: Artes Médicas, 1989.

CANTAVELLA, F. La primera relación. In: LEONHARDT, M. La intervención en los primeros años de vida del niño ciego y com baja vision: un enfoque desde la atención temprana. Barcelona: ONCE, 2002.

CONSELHO BRASILEIRO DE OFTALMOLOGIA (2002). http://www.cbo.com.br/publicacoes/jotazero/ed90/comunicado.htm. Acesso em: 11 nov. 2005.

CROMER, R. F. Conservation by the congenitally blind. British Journal of Psychology, Leicester, v. 64, n. 2, p. 241-50, mai. 1973.

CUTSFORTH, T.D. Personality and social adjustment among the blind. New Jersey: Zahl, P. Blindness, Princenton University Press, 1950.

DECLARAÇÃO DE SALAMANCA: PRINCÍPIOS, POLÍTICA E PRÁTICA EM EDUCAÇÃO ESPECIAL (1994). http://www.mec.gov.br/seesp/pdf/salamanca.pdf. Acesso em: 11 mai. 2005.

DEUTSCH, F. The sense of reality in person born blind. In: El bebé ciego: primera atención - 
un enfoque psicopedagógico. Barcelona: Masson / ONCE, 1992.

DIDEROT, D. Carta sobre os cegos para uso dos que vêem. Tradução e notas de J. Guinsburg. s/l, s/d

DOLTO, F. A imagem inconsciente do corpo. São Paulo: Editora Perspectiva, 1984.

DOLTO, F. No jogo do desejo. Rio de Janeiro: Zahar Editores, 1984.

DOLTO, F.; NASIO, J.D. A criança do espelho. Porto Alegre: Artes Médicas, 1991.

DUBET, F. O que é uma escola justa? Cadernos de Pesquisa, Fundação Carlos Chagas. São Paulo, v. 34, n. 123, p. 539-555, set/dez 2004.

FERREIRA, A. B. H.; Novo dicionário Aurélio. Rio de Janeiro: Editora Nova Fronteira, 1986.

FILIDORO. N.S. El lugar de los aprendizajes en los niños con problemas graves en constituición subjetiva.

http://www.xpsicopedagogia.com.ar/contenido/escritos/filidoro_aje_nee.htm. Acesso em: 30 set. 2005.

FILIDORO. N.S. O gravador que gravava tudo o que lhe dava vontade. Estilos da Clínica. Revista sobre a infância com problemas - IPUSP. São Paulo, ano II, n. 2, p. 120 - 137, $2^{\circ}$. Semestre, 1997.

FRAIBERG, S. Insights from the blind: comparatives studies of blind and sighted infants. Nova York: Basic Books, 1977.

FRAIBERG, S.; ADELSON, E. Auto-representacion en el lenguaje y en el juego. In: FRAIBERG, S. Niños ciegos: la deficiencia visual y el desarrollo inicial de la personalidad. Madrid: Instituto Nacional de Servivios Sociales / Ministerio de Trabajo y Seguridad Social, 1982. p.275-296.

FRAIBERG, S.; FREEDMAN, D. A. Studies in the ego development of the congenitally blind children. Psychoanalitic Study of the Child, New York, v. 19, p. 113-169, 1964.

FREUD, S. O ego e o id (1923). Obras Completas. v. XIX:23. Rio de Janeiro: Imago, 1980.

FREUD, S. Sobre o narcisismo: uma introdução (1914). Obras completas v. XIV:89. Rio de Janeiro: Imago, 1980.

GREGORY, R. L. Olho e cérebro: psicologia da visão. Rio de Janeiro: Zahar Editores, 1979.

GUINDIS, B. Vygotskty's vision: reshaping the pratice of special education for the $21^{\text {st }}$ century. Remedial and Special Education, Austin, v. 20, n. 6, p. 333-340, nov/dec. 1999.

GUINÉ, C. As adequações curriculares e o projeto educativo do centro. In: COLL, C. et al. (org.). Desenvolvimento psicológico e educação: Necessidades educativas especiais e aprendizagem escolar. Vol. 3. Porto Alegre: Artes Médicas, 1995. 
GUIRADO, M. Psicanálise e análise do discurso: matrizes institucionais do sujeito psíquico. São Paulo: Summus Editorial, 1995.

HADDAD, M. A. O. et al. Avaliação e recursos para baixa visão na infância. São Paulo: Laramara, 2001.

IDE, S.D. Pessoas com necessidades educativas especiais: do currículoao programa de intervenção educativa. Revista temas sobre desenvolvimento. São Paulo, v. 7, n. 42, p. 5-14, 1999.

INSTITUTO BENJAMIN CONSTANT. Biografia de José Álvares Azevedo. http://www.ibc.gov.br. Acesso em: 9 abr. 2006.

JAPIASSU, H. Interdisciplinaridade e patologia do saber. Rio de janeiro: Imago, 1976.

JARDIM, G. Do corpo ao desejo: um olhar sobre o sujeito. Estilos da Clínica. Revista sobre a infância com problemas - IPUSP. São Paulo, Ano I, n. 1, p. 68-77, 2º Semestre, 1996.

JERUSALINSKY, A. et al. A escolarização de crianças psicóticas. Estilos da Clínica. Revista sobre a infância com problemas - IPUSP. São Paulo, ano II, n. 2, p. 72 - 95, 2 . Semestre, 1997.

JERUSALINSKY, A. et al. Psicanálise o desenvolvimento infantil: um enfoque transdisciplinar. Porto Alegre: Artes Médicas, 1989.

KANNER, L. Distúrbios autísticos do contato afetivo. http://www.ama.org.br/download/kanner-completo.doc. Acesso em: 28 abr. 2006.

KAUFMANN, P. Dicionário enciclopédico de psicanálise: o legado de Freud e Lacan. Rio de Janeiro: Jorge Zahar Editor, 1996.

KHUN, T.S. A estrutura das revoluções científicas. São Paulo: Perspectiva, 1978.

KUPFER, M.C. (org.)Tratamento e escolarização de crianças com distúrbios globais do desenvolvimento. Salvador: Ágalma, 2000.

KUPFER, M.C. Educação para o futuro: psicanálise e educação. São Paulo: Escuta, 2001.

KUPFER, M.C. Educação terapêutica: o que a psicanálise pode pedir à educação. Estilos da Clínica. Revista sobre a infância com problemas - IPUSP. São Paulo, Ano II, n. 2, p. 53-61, $2^{\circ}$. Semestre, 1997.

KUPFER, M.C. Notas sobre o diagnóstico diferencial da psicose e do autismo na infância. Psicologia USP, São Paulo, vol. 11, n. 1, p.85-105, 2000.

KUPFER, M.C. Travessias: inclusão escolar - a experiência do grupo ponte Pré-escola Terapêutica Lugar de Vida. São Paulo: Casa do Psicólogo, 2005.

LACADÉE, P. Lá onde estão as crianças, CIEN, o social no singular - CIEN e seus laboratórios: encontros e resultados. Trad. Vera Avellar Ribeiro In: Documento de Trabalho 
n. 1 para a Jornada do CIEN (Centro Interdisciplinar de Estudos da Criança). Barcelona, 1998.

LACAN, J. A esquize do olho e do olhar. In: O seminário - Livro 11: os quatro conceitos fundamentais da psicanálise. Rio de janeiro: Jorge Zahar Editor, 1985.

LACAN, J. A tópica do imaginário. In: O seminário - Livro 1: os escritos técnicos de Freud. Rio de Janeiro: Zahar Editores, 1983.

LACAN, J. Escritos. São Paulo: Ed. Perspectiva, 1978.

LACAN, J. O Seminário - Livro 5: as formações do inconsciente. Rio de Janeiro: Zahar Editores, 1999.

LACAN, J. Os complexos familiares. Rio de Janeiro: Jorge Zahar Editor, 1987.

LAING, R.D. O eu dividido: estudo sobre a loucura e a sanidade. Rio de Janeiro: Zahar Editores, 1963.

LAJONQUIÈRE, L. A escolarização de crianças “com dgd”. Estilos da Clínica. Revista sobre a infância com problemas - IPUSP. São Paulo, ano II, n. 3, p. 116-129, $2^{\circ}$. Semestre, 1997.

LAJONQUIÈRE, L. Dos "erros" e em especial daquele de renunciar à educação. Estilos da Clínica. Revista sobre a infância com problemas - IPUSP. São Paulo, ano II, n. 2, p. 27-46, $2^{\circ}$. Semestre, 1997.

LAJONQUIÈRE, L. Duas notas psicanalíticas sobre crianças com necessidades educativas especiais. Pro-posições, Campinas, v. 12, n.2/3 p. 47-59, jul/nov 2001.

LAMBERT, R.M.; WEST, M. Parenting style and depressive syndrome in congenitally blind individuals. Journal of Visual Impairment and Blindness, New York, v. 74, n. 9, p. 333-337, nov. 1980.

LAPLANCHE, J. e PONTALIS, B. Vocabulário da psicanálise. São Paulo: Martins Fontes, 1985.

LAZNIK-PENOT, M.C. (org.) Do fracasso da instauração da imagem do corpo ao fracasso da instauração do circuito pulsional: quando a alienação faz falta. In: $O$ que a clínica do autismo pode ensinar aos psicanalistas. Salvador: Ágalma, 1998.

LEMOS, E.R. A educação de cegos no Brasil: aspectos históricos. Revista Contato: conversas sobre deficiência visual. São Paulo:Laramara, ano 4, n. 6, Set. 2000.

LEONHARDT, M. El bebé ciego: primera atención - un enfoque psicopedagógico Barcelona: Masson / ONCE, 1992.

LEONHARDT, M. La escuela integradora. Cuadernos par la education Del deficiente sensorial. Barcelona: s/e, 1984. 
LEONHARDT, M. La intervención en los primeros años de vida del niño ciego y com baja vision: un enfoque desde la atención temprana. Barcelona: ONCE, 2002.

LEONHARDT, M.; CANTAVELLA, F. e TARRAGÓ, R. Iniciacion del lenguaje en niños ciegos: un enfoque preventivo. Madrid: ONCE, 1999.

LERNER, R. Escolarização de crianças portadoras de distúrbios globais do desenvolvimento: dados e reflexões a respeito dos aspectos envolvidos. Revista sobre a infância com problemas - IPUSP. São Paulo, n. 2, p. 62-71, 1997.

LEVIN, E. A clínica interdisciplinar em crianças com transtornos na estrutura e no desenvolvimento. Amarelinhas 3. Curitiba: Biblioteca Freudiana de Curitiba, 1996.

LEVIN, E. A função do filho: espelhos e labirintos da infância. Petrópolis: Editora Vozes, 2002.

LEVIN, E. Clínica e educação com as crianças do outro espelho. Petrópolis: Editora Vozes, 2005.

LIMA, A.J.T. Encontros e desencontros na escola e na família. http://psicopedagogia.com.br/artigos/artigo.asp?entrID=733. Acesso em: 5 out. 2005.

LIPPI, J.R.S. Autismo e transtornos invasivos do desenvolvimento: revisão histórica do conceito, diagnóstico e classificação. http://www.autismo.med.br/pdf/autismo/AUTISMO\%20e\%20Transtornos\%20Invasivo.

Acesso em: 2 out. 2005.

LOPES, E.M.T. (ORG) A Psicanálise escuta a Educação. Belo Horizonte: Autêntica, 2001.

LOWENFELD, B. Berthold Lowenfeld on blindness and blind people: Selected papers. New York: American Foundation, 1981.

LOWENFELD, B. Psychological Foundation of Special Methods In: Teaching blind children. Zahl, P. A. (eds.) Blindness. New Jersey: Princenton University Press, 1950.

MANACORDA, M.A. História da educação. São Paulo: Cortez Editora, 10a . ed., 2002.

MANNONI, M. A criança atrasada e a mãe. São Paulo: Moraes Editores,1981.

MANNONI, M. Educação impossível. Rio de Janeiro: Francisco Alves Editora, 1977.

MANTOAN, M.T.E. et allit. A integração de pessoas com deficiência: contribuições para uma reflexão sobre o tema. São Paulo: Memnon/SENAC, 1997.

MARTIN, M.B. e BUENO, S.T. Deficiência visual: aspectos psico-evolutivos e educativos. São Paulo: Santos Livraria e Editora, 2003.

MASINI, E.F.S. (org.) Ação psicopedagógica. II Ciclo de Estudos de Psicopedagogia Mackenzie. São Paulo: Memnon/Ed. Mackenzie, 2000. 
MASINI, E.F.S. (org.) Do sentido, pelos sentidos, para o sentido: sentidos das pessoas com deficiência sensorial. São Paulo: Intertexto/Vetor, 2002.

MASINI, E.F.S. (org.) O ato de aprender. São Paulo: Memnon e Ed. Mackenzie, 1999.

MASINI, E.F.S. A educação do portador de deficiência visual: as perspectivas do vidente e do não-vidente. In: Tendências e desafios da Educação Especial. Série Atualidades Pedagógicas. Brasília: MEC - Secretaria de Educação Especial, 1984. p. 82-103.

MASINI, E.F.S. A inclusão responsável. Palestra proferida no evento "Saber 2004: o saber em busca da identidade educacional brasileira" realizada pelo Sindicato dos Estabelecimentos de Ensino do Estado de São Paulo (SIEEESP). São Paulo, 23 de setembro de 2004.

MASINI, E.F.S. Aprendizagem totalizante. São Paulo: Memnon e Ed. Mackenzie, 1999.

MASINI, E.F.S. et al. Conceituando deficiência: The concept of disability. Revista Saúde Pública, São Paulo, v. 34, n. 1, p. 97-103, 2000.

MASINI, E.F.S. O perceber e o relacionar-se do deficiente visual: orientando professores especializados, 1990. Tese (Livre Docência em Educação) Universidade de São Paulo. São Paulo.

MASINI, E.F.S. O perceber e o relacionar-se do deficiente visual: orientando professores especializados. Brasília: CORDE, 1994.

MASINI, E.F.S. Psicopedagogia e inclusão: o papel do profissional e da escola. Revista Psicopedagogia, São Paulo, v. 20, n. 61, p. 2-6, 2003.

MAZZOTTA, M.J.S. Escola inclusiva e Educação Especial: estratégias para a educação da diversidade. Palestra realizada no II Ciclo de Palestras "Educação Inclusiva - Enfrentando desafios: Alfabetização Urgente", promovido pela Prefeitura do Município de São Paulo DREM-7 - Nov 2000.

MAZZOTTA, M.J.S. Fundamentos da Educação Especial. São Paulo: Ed. Pioneira, 1982.

MERLEAU-PONTY, M. O visível e o invisível. São Paulo: Perspectiva, 1971.

MIGUELEZ, M. M. Criterios para la superación del debate metodológico "cuantitativo/cualitativo". II Congresso Ibero americano de Psicologia. Madrid Universidad Simon Bolivar, 1998.

MRECH, L.M. Educação inclusiva: realidade ou utopia. Trabalho apresentado no evento do LIDE - Laboratório Interunidades sobre Deficiência - Seminário Educação Inclusiva: realidade ou utopia? Faculdade de Educação da USP, 5 de Maio de 1999.

MRECH, L.M. O mercado de saber, o real da Educação e dos educadores e a escola como possibilidade, 2001. Tese (Livre Docência em Educação). Universidade de São Paulo. São Paulo.

MRECH, L.M. Psicanálise e educação: novos operadores de leitura. São Paulo: Pioneira, 
1999.

NAGERA, H. e COLONNA, A B. Aspects of the contribution oh sigth to ego na drive development. Psychoanalytic study of the child, New York, v. 20, 1965.

NIRJE, B. The normalization principle and it's human managements implications. In: KUGEL, R. e WOFENSBERGER, W. (eds.), s/l, 1969.

OBIAKOR, F. E. e STILE, S. W. The self-concepts of visually impaired and normally sighted school children. The Journal of Psychology, v. 124, n. 2, p.199-206, 1989.

OCHAITA, E.; ROSA, A. Percepção, ação e conhecimento em crianças cegas. In: COLL, C.; PALACIOS, J.; MARCHESI, A. (org.) Desenvolvimento psicológico e educação: Necessidades educativas especiais e aprendizagem escolar. v. 3. Porto Alegre: Artes Médicas, 1995.

OGASAWARA, M.M. et al. Microftalmia pura - relato de caso

http://www.abonet.com.br/abo/664s/casosclin01.htm. Acesso em 28 mai. 2006

OLIVEIRA, L.G.M. A transferência no trabalho com os pais na instituição. Estilos da Clínica. Revista sobre a infância com problemas - IPUSP. São Paulo, ano I, n. 1, p. 34-45, $2^{\circ}$. Semestre, 1996.

OLIVEIRA, M.K. et al. (org.) Psicologia, Educação e as temáticas da vida contemporânea. São Paulo: Moderna, 2002.

OLIVEIRA, M.K. In: LA TAILLE, I. (org.) Piaget, Vygotsky e Wallon. São Paulo: Summus Editorial, 1992.

OLIVEIRA, M.K. Three issues on conceptual development. s/l s/d.

OLIVEIRA, M.K. Vygotsky: Aprendizado e desenvolvimento um processo sócio-histórico. São Paulo: Editora Scipione, 1995.

OMWAKE, E.G. e SOLNIT, A. J. It isn't fair: the treatment of a blind child. In: El bebé ciego: primera atención - un enfoque psicopedagógico. Barcelona: Masson / ONCE, 1992.

ORGANIZAÇÃO MUNDIAL DA SAÚDE (1993) Classificação Estatística Internacional de Doenças e Problemas Relacionados à Saúde - Décima Revisão (CID-10). v. 3. São Paulo: Edusp, 1999.

ORGANIZAÇÃO MUNDIAL DA SAÚDE (2003) Classificação Internacional de Funcionalidade, Incapacidade e Saúde (CIF). Lisboa, 2004.

ORMELEZI, E.M. Os caminhos de aquisição do conhecimento e a cegueira: do universo do corpo ao universo simbólico, 2000. Dissertação (Mestrado em Psicologia e Educação). Universidade de São Paulo. São Paulo.

ORMELEZI, E.M. Psicopedagogia em pauta para a Educação Especial: uma busca de instrumentos para lidar com o aprender e o não-aprender. In: MASINI, E. F. S. Ação 
Psicopedagógica. II Ciclo de Estudos de Psicopedagogia Mackenzie. São Paulo: Memnon/Mackenzie, 2000.

PASCHOALINO,F. G.S. Amaurose congênita de leber. http://www.cbo.com.br/cbo/sociedades/subnormal/artigos/cmtrat08.htm, Acesso em 28 mai. 2006.

PATTO, M.H.S. A produção do fracasso escolar: histórias de submissão e rebeldia. São Paulo: T.A. Queiroz, 1990.

PATTO, M.H.S. A questão da Psicopedagogia como profissão. In: MASINI, E.F.S. (Org.) Ação Psicopedagógica. II Ciclo de Estudos de Psicopedagogia Mackenzie. São Paulo: Memnon/Mackenzie, 2000.

PERAITA, H. et al. Representatión de categorías naturales en los niños ciegos. Madrid: Ed. Trotta, 1992.

PORTAL DR. VISÃO http://www.drvisao.com.br/conheca_doenca_detalhe.php?id=34. Acesso em 28 mai. 2006.

ROCHA, H. Ensaio sobre a problemática da cegueira. Belo Horizonte: Fundação Hilton Rocha, 1987.

ROMANELLI, O.O. História da Educação no Brasil. São Paulo: Vozes, 1978.

SALOMON, S. M. Deficiente visual: um novo sentido de vida - proposta psicopedagógica para ampliação da visão reduzida. São Paulo: LTr, 2000.

SANDLER, A.M. Aspects of passivity and ego development in the blind infant. Psychoanalitic Study of the Child, New York, v. 18, p. 352-360, 1963.

SASSAKI, R.K. Inclusão: construindo uma sociedade para todos. Rio de Janeiro: WVA, 1997.

SEVERINO, A.J. Metodologia do trabalho científico. São Paulo: Cortez Editora, 2000.

SHIRAHIGE, E.E. Psicopedagogia na escola. In: MASINI, E.S.F. (org.) Ação psicopedagógica. II Ciclo de Estudos de Psicopedagogia Mackenzie. São Paulo: Mennon-Ed. Mackenzie, 2000.

SIAULYS, M.O.C. Brincar para todos. São Paulo: Laramara, 2005.

SILVA, O.M. A epopéia ignorada: a pessoa deficiente na história do mundo de ontem e de hoje. São Paulo: SBSC/CEDAS/FASC, 1987.

SPINELLI, M. O médico, o deficiente auditivo e sua família. In: MASINI, E.S.F. (org.) Do sentido, pelos sentidos, para o sentido: sentidos das pessoas com deficiência sensorial. São Paulo, Vetor-Intertexto, 2002.

STAINBACK, S. e STAINBACK, W. Inclusão: um guia para educadores. Porto Alegre: 
Artmed, 1999.

STERN, D. El sentido del si-mismo emergente. In: El mundo interpersonal del infante. Paidós, s/l, s/d.

STEVENS, A. A clínica psicanalítica em uma instituição para crianças. Estilos da Clínica. Revista sobre a infância com problemas. IPUSP. São Paulo, ano I, n. 1, 2º Semestre, 1996.

TEDESCO, J.C. Igualdad de oportunidades y política educativa. Cadernos de Pesquisa, Fundação Carlos Chagas, São Paulo, v. 34, n. 123, 557-572, set/dez 2004.

TORELLY, A. Rubéola, http://www.abcdasaude.com.br/artigo.php?372. Acesso em 28 mai. 2006.

VÁSQUEZ, A.; OURY, F. Hacia uma pedagogia institucional. Madrid: Editorial Popular, 2001 .

VEITZMAN, S. O oftalmologista frente à pessoa deficiente visual e sua família. In: MASINI, E.S.F. (org.) Do sentido, pelos sentidos, para o sentido: sentidos das pessoas com deficiência sensorial. São Paulo, Vetor-Intertexto, 2002.

VOLTOLINI, R. Psicanálise e inclusão escolar: direito ou sintoma. Estilos da Clínica. Revista sobre a infância com problemas. IPUSP. São Paulo, ano IX, n. 16, 1. Semestre, 2004.

VYGODSKAYA, G. Vygotsky and problems of special education. Remedial and Special Education, Austin, vol. 20, n. 6, p.330-332, nov/dec. 1999.

VYGOTSKY, L.S. The fundamentals of defectolog ( abnormal psychology and learnig disabilities). In: The collected works. Trabalhos escritos entre 1920 e 1930. New York: Plenum Press, 1993.

WILLS, D. Vulnerables periods in the early development of blind children. The psychoanalytic study of the child, New York, vol. 25, 1970. 
ANEXOS 


\section{ANEXO 1 - ROTEIRO DA ENTREVISTA}

1) Fale-me sobre a história de (o nome da criança). Como foi quando nasceu? Quem é e como é (o nome da criança) pra você?

(investigar que tipo de sentimentos: raiva, culpa, rejeição, negação... e que tipo de reação: paralizou, estimulou, deprimiu, procurou ajuda educacional, procurou a cura...)

2) Quando foi dado o diagnóstico?

3) Antes do diagnóstico, o que percebia no seu bebê? E depois? Teve diferença?

4) O que foi o nascimento desse(a) filho(a)? Qual o significado?

5) O que pensava sobre cegueira?

6) Esperava/imaginava outro filho?

7) Quanto tempo levou para assimilar o impacto do nascimento desse(a) filho(a)?

8) Quem foi esse(a) que nasceu?

9) Você acha que foi diferente com seu(s) outro(s) filho(s)? (se tiver)

10) Como você o(a) via?

11) O que percebia nele(a)?

12) O que ele(a) fazia / dizia?

13) O que ele(a) fazia que você percebia que ele(a) estava presente?

14) O que ele(a) fazia que te mostrava que ele(a) sabia que você estava presente?

15) O que fazia com ele(a)? (falava, cantava, oferecia coisas...)

16) Se ele(a) não a olhava, ficava parado(a), não sorria pra você, não respondia... $O$ que você fazia frente a essa situação?

17) Como mostrava a ele(a) coisas como encorajamento, prazer, expectativa?

18) O que sentia em ser mãe dessa criança? (orgulho, prazer, raiva, vergonha...)

19) Seu sorriso e expressões faciais eram substituídas pelo quê na comunicação com seu (sua) filho (a)?

\section{Dados mais específicos sobre a criança:}

20) Você pode me contar como foi o desenvolvimento de (o nome da criança)?

21) Você se lembra como eram suas reações e movimentos com o corpo?

22) Como se comunicava pelos outros sentidos e motoramente? (chorava, ria, buscava objetos e pessoas com as mãos, fazia força pra levantar o corpo ou se virava na direção dos sons) 
23) Procurava o peito ou a mamadeira com a boca? Sugava? Sugava as mãos? Fazia movimento de sucção mesmo na ausência da mamadeira? Segurava a mamadeira?

24) Como era/é o contato com objetos? (relaciona-se com função e significado ou usa para satisfazer as suas necessidades e se auto-estimular levando à boca, batendo, jogando...)

25) E com pessoas? (aceitava/aceita toque; aperta, belisca, morde, agarra, arranha, bate...)

26) Quais os seus objetos e pessoas favoritos?

27) Como eram/são os momentos de alimentação? Onde e com quem?

28) Aceitou o peito, a mamadeira, os alimentos sólidos?

29) Como você percebia/percebe fome e sede? Como ele (a) mostra?

30) Como ele (a) percebia/percebe o mundo com os outros sentidos?

31) Mostrava/mostra compreendê-lo?

32) Era/é uma criança ativa ou passiva? Como?

33) Explorava/explora o ambiente? Como? E vocês o que faziam/fazem nesse sentido?

34) Percebe a distinção entre si e os outros? Tem consciência do mundo fora dele (a)? Como? Desde quando?

35) Distingue pessoas e objetos? Como? Desde quando?

36) Percebe quando uma pessoa ou objeto desaparecem... saem da situação ou ambiente em que está? Desde quando? Como você observa isso?

37) Sabe pra onde foi? Procura? Pede?

38) Nesses casos, mostra saber que a pessoa ou objeto continuam a existir mesmo que não estejam na sua presença?

39) Percebia/percebe o que se passa à sua volta ou é alheio(a)?

40) Mostrava/mostra entender o que ocorre e o que é dito? Como?

41) Você dava/dá significado aos sons e ações que ele (a) fazia/faz? Como?

42) Quando começou a emitir sons? Você entendia/entende o significado? Quais?

43) Quando começou a falar? Como é sua fala? Do que fala? (pergunta, nomeia, usa sons, palavras, frases...)

44) Compreende os significados das palavras?

45) Compreende frases? Como mostrava/mostra o que quer, gosta e sente?

46) Como você respondia/responde?

47) Compreende quando se fala de tempo e seqüência de eventos? 
48) Compreende o que e por que aconteceu algo?

49) Quando ele (a) provoca um evento, sabe que foi o (a) responsável? Percebe que consegue provocar um acontecimento? Percebe que sua ação sobre um objeto ou pessoa produz resultados?

50) Sabe as diferenças e semelhanças entre as coisas?

51) Sabe pra que servem os objetos, suas características e classes?

52) Conhece sua rotina? (o que vai acontecer e fazer...)

53) O que faz sozinho (a)? Desde quando? Gosta de fazê-lo? (alimentação, higiene, vestir-se, banho, dentes, dormir...)

54) Quando sustentou a cabeça, sentou, engatinhou, andou, pulou, subiu e desceu escadas, rolou, chutou, carregou objetos entregando-os ou pegando-os...?

55) Localiza pessoas e objetos no espaço?

56) Percebe seus deslocamentos?

57) Conhece as partes do corpo em si e no outro? (nomeia, aponta...)

58) Como é o contato com o próprio corpo e o corpo no espaço? (auto-estimulação, movimentos repetitivos, maneirismos...)

59) Quando tirou a farlda? Ou ainda usa? Como se relacionou/relaciona com isso? (mãe e criança).

60) Como expressa a agressividade? Em que situação? (intencional, defesa, ansiedade...)

61) Brinca? Como? Com que? Com quem? Como isso se deu desde o começo?

62) O que você fazia/ faz em relação a isso?

63) Brinca de faz-de-conta? Como? Você ensina?

64) Chama-se de eu? Usa pronomes que se refiram a si mesmo (a)? (me, mim, meu)

65) Como é a relação com adultos e crianças?

66) Imita algo ou alguém? Como?

67) Como responde aos afetos das pessoas? E aos limites?

68) Como reage a situações, pessoas e objetos desconhecidos?

69) Como expressa os sentimentos? (amor, raiva, dor, carinho, aborrecimento, cansaço, frustração, angústias, ansiedades, medos...)

70) Você compreende? O que faz?

71) Como ele (a) aprende? Quais seus pontos fortes e suas dificuldades?

72) Mudou o quadro clínico com o tempo? 
73) Qual o significado dos comportamentos de (o nome da criança) pra você?

74) Descreva a rotina de (o nome da criança): hábitos, rituais religiosos e festivos, lazer, etc.

75) Como seu (sua) filho (a) é visto (a) na família e na comunidade?

76) Qual sua opinião sobre (o nome da criança) estar em uma escola comum? 


\section{ANEXO 2 - AS ENTEVISTAS COM AS MÃES}

\section{Entrevista 1}

\section{ENTREVISTADA: Sra. M. - mãe de Augusto}

Entrev. - Por favor, vou pedir que conte a história do Augusto. Como foi quando ele nasceu...

M. - Ele nasceu de... cesárea... porque, assim, como eu tenho mais outros filhos, eu optei em fazer cesárea, pra mim já operar pra não ter mais bebê, entendeu? Mas, assim: ... a gestação foi nervosa, devido... problemas com o pai. Mas até então era só discussão, não houve, assim, nada assim de grave... Que nenhum médico tenha descoberto, entendeu? O porquê da cegueira do Augusto. Mas foi um parto assim normal, não teve problema nenhum, mas eu vim descobrir bem depois que era um problema hereditário, que tem parente assim na família do... pai, que... tem bastante gente. Tem tias que nasce com visão e depois perde e tem tias também que... já nascem cegas, como o Augusto. Eu não sabia...

A gestação foi normal, de nove meses, tudo, mas eu percebi que tinha algo diferente assim no olhinho dele desde a primeira mamada que ele foi...

Entrev. - No hospital ainda?

M. - É, no hospital. Mas as médicas acharam que não. Por ser pequenininho, a retina tava normal. Aí, conforme ele foi desenvolvendo, o olhinho não foi desenvolvendo, ele continuava do mesmo tamanhinho. Tem um que é menorzinho, tem um outro que é um pouquinho maior. Mas a retina não foi formada, entendeu? Então, assim: ele nasceu com baixa visão e depois, aos poucos, foi perdendo... o pouco que tinha. Ele vê, assim, uma luz, mas muito longe. Não consegue distinguir de onde vem... entendeu?

Entrev. - Só percebe a luz?

M. - É, mas é bem pouquinho... Tem esse diagnóstico aqui... no último que eu passei.

Entrev. - E quando você soube? Você disse que logo na primeira mamada achou que havia alguma coisa estranha e... 
M. - Aí, como foi cesárea e eu sou meio molenga pra andar, com trinta dias o levaram pra mim no oftalmo e falaram que tava normal... Foi depois de uns dois, três meses que eu comecei a buscar mesmo, sabe? Fui na Faculdade de Medicina de São Paulo... procurei tudo que era de oftalmo aqui em São Paulo, e... vários lugares o diagnóstico era o mesmo, que ele tinha... má formação na retina... foi feita uma operação também no olho, entendeu? Então foi isso. Eu corri atrás, tentei... Foi difícil no começo pra mim, viu? Eu não conseguia entender...! A gente nunca acha que vai acontecer com a gente, sempre acha que é só com o outro, ou nunca acha que a gente merece, mas é aquele negócio, né?! Se Deus me deu ele assim, é porque eu tinha que cuidar dele assim. Foi difícil no começo... Fiquei dois anos depressiva, aí, depois consegui superar tudo. Porque foi logo... parte da visão do Augusto e depois eu tive também o problema com o meu exmarido, aí foi tudo junto, eu não agüentei... Aí, depois eu superei. Hoje eu tô muito bem, tô aí com ele, entendeu?

Entrev. - E foi nesse período de dois meses, mais ou menos que veio o diagnóstico?

M. - Isso! Nós andamos... Mas não foi só um diagnóstico. Nós andamos em vários oftalmos, escutamos a mesma coisa, o mesmo diagnóstico, entendeu? Aí, quando... aí tipo eu ia atrás, entendeu?

Entrev. - Antes do diagnóstico, o que você percebia no seu bebê?

M. - Ele ficava muito quietinho... entendeu? É... não dava trabalho, ele só chorava quando mamava, quando tinha fome pra mamar. Então, fora isso, então... hora do banho que ele gostava... até hoje ele gosta bastante de água, tomar banho... Se deixar ele toma mais de cinco banhos por dia, porque ele gosta muito de tomar banho. Então foi assim... Foi normal, não tinha dor, nem nada. Às vezes, o olhinho dele ficava ramelando muito, sujando muito, toda hora eu tinha que limpar. Então, nisso, eu... comecei a me preocupar também. Eu achei que era até a... quando ele nasceu, a médica achava que era até uma conjuntivite... mas não era. Aí foi indo, normalizou, não... não suja tanto, com tanta freqüência. É bem pouquinho... e ele não reclama mais. Toma a medicação, entendeu? Pra controlar, porque ele é um pouco nervoso, né?!

Entrev. - E antes do diagnóstico, que tipo de reações você percebia nele? Você disse: ele só chorava pra mamar... Ele era quietinho, mas...

M. - É... mas ele brincava, tudo, né, se desse brinquedo, a reação dele era a de uma criança normal. Ele só não conseguia distinguir onde estavam as pessoas, entendeu? De onde tava 
vindo a voz, né? Sem me vê... entendeu? Mas, quando a gente conversava com ele, ele ria, ele escutava tudo direitinho.

Entrev. - E depois do diagnóstico de deficiência visual, houve diferença na sua percepção do Augusto?

M. - Teve diferença em que sentido?

Entrev.. - Antes você percebia que quando falava com ele, ele ria, ele reconhecia você, ele fazia contato. Mas, depois que você soube do diagnóstico, mudou alguma coisa nele ou em você?

M. - Ah! A gente muda no momento. A gente não tá preparada... Se eu soubesse... que tinha parente na família do meu... do pai que tinha esse problema, talvez eu tivesse outra reação, entendeu? Mas, como na minha família não teve nenhum tipo de deficiência, nenhuma, então foi difícil no começo. Mas, assim, mudança não houve não. Houve mais é ... proteção. Acho que foi o meu erro. Proteger ele demais... por achar que ser deficiente, né?! Sabe? Eu sobrecarreguei ele... assim: eu protegi demais, demais. Tudo era ele... então tudo o que ele fazia de errado eu achava que era por ser deficiente, eu tinha que concordar. Foi um dos meus erros... Entendeu? E isso influencia, porque se tu tem uma criança, só porque é deficiente tem que falar palavrão, tem que bater? Eu acho que não. Eu acho que educação ela é normal pra todos. Mas, aí, foi o meu erro, entendeu? Por achar que ser deficiente, tinha que deixar fazer o que queria, e não era bem assim...

Entrev. - E você falou que ficou dois anos deprimida. Como que foi isso?

M. - Só chorava, olhava pra ele e passava mal...

Entrev. - Mal como?

M. - Às vezes faltava a visão, escurecia, caía a pressão, eu tinha que ir pro pronto socorro, entendeu? Aí, tinha que ligar pra família do... do pai dele, às vezes eu tinha que tomar... medicamento, às vezes eu passava três, quatro, cinco dias sem conseguir dormir, só chorando... Ficou assim durante muito tempo.

Entrev. - Você disse que olhava pra ele e se sentia mal. Quando você...

M. - Eu achava que ele ia sofrer, eu achava que ele não ia ter uma vida normal como a nossa, eu achava que ele ia sentir falta da visão. Mas depois que eu fui percebendo que ele já nasceu assim, que o mundo dele é o mundo normal. Mas foi difícil no começo, entendeu?. 
Entrev. - Sim... nesses primeiros dois anos?

M. - Foram. Foi meio complicado...

Entrev. - Ok. E o que significou o nascimento do Augusto pra você?

M. - Ah, mais um filho, né?! Uma benção pra mim. Mas, assim.... é ... Eu não tava... não foi planejada a gestação dele, entendeu? Eu tive três meninas, eu ia fazer cesárea da terceira... aí meu ex-marido falou assim: "Não, deixa que eu faço a vasectomia”. Aí eu fui na onda dele, no fim ele não fez, aí nós tivemos uma crise, ele saiu de casa, foi pra mãe dele, que eu pedi, depois disso ele voltou, foi só uma transa só, à noite, foi suficiente pra engravidar do Augusto. Então, assim... não tô falando pra você que ele não foi um filho bem-vindo. A hora que eu soube da gestação, tudo bem. Tratei a gestação como se fosse a primeira. Fiz prénatal, tudo direitinho, sem problema nenhum. Então, é isso, é... né? Ele foi o quarto filho, daí depois eu falei basta, independente do... antes do diagnóstico, eu tinha tomado essa decisão, entendeu? Aí eu procurei um médico, ele queria desistir uma semana antes... queria que eu desistisse. Eu acho que eu estaria até com mais filhos, se não houvesse feito. Porque eu já andei até tendo recaída, assim, com o próprio pai dele. Então eu falei: "Não, chega, vou dar um basta, eu não quero...”. Assim: se eu não fui esposa, eu não quero ser amante dele, entendeu? Fui eu mesma quem deu um basta e tô muito bem. Vai fazer cinco anos que eu tô sozinha e tô muito bem. Não quero ele, por enquanto, e nem um outro...

Entrev. - E nos dois anos de depressão, que tipo de sentimento você tinha?

M. - Ah... tudo! Porque, assim: tinha raiva, né, do pai, de ter feito o que fez, né? Me traído. Aí ele é problemático, ele é doente, aí ele se afastou das crianças. A raiva que a gente tinha um do outro, ele descontou nas crianças, foi se afastar. Eu também tinha raiva dele, por não ser um pai tão presente, entendeu? Então é isso, é... no momento assim que você tá meio desanimada, você pensa muita bobagem, né?

Entrev. - E em relação ao Augusto e à deficiência?

M. - Não... em relação ao Augusto, quando eu estava deprimida, eu cuidava dele normal, eu não tentava passar pra ele a minha angústia. Mas, eu creio que, de alguma forma, ele acabou percebendo. Porque eu chorava muito... entendeu?

Entrev. - E a angústia...

M. - É, mas eu não chegava a gritar, nem maltratar, nem ele nem nenhuma das minhas filhas, não. A minha angústia era só de chorar, não querer sair, ficar isolada, não conseguia 
dormir, tinha falta de ar constante, entendeu? Aí, quando vinha aquela falta de ar muito forte que eu achava que eu ia desmaiar, aí minha filha mais velha ia, ligava e me levava pro Pronto Socorro. Não sei se o Augusto conseguiu guardar alguma coisa... dessa fase baixa aí que eu passei, mas, maltratar ele ou alterar o tom de voz, não sei... nunca... não... nunca passei isso pro Augusto.

Entrev. - E o que você pensava sobre a cegueira?

M. - Que que eu pensava? Nossa! Eu achava que ele ia viver num mundo escuro! Toda hora, só via essa imagem na minha cabeça, assim, sabe? Achava que ele não ia ter uma vida normal, como eu já te falei... Achava que ele ia ficar uma criança... que ia depender de mim assim, que ia ficar dentro de casa... Falava: “Meu Deus!" Mas, não, depois que eu fui percebendo aos poucos que não é nada disso. É tudo paranóia (risos)...

Entrev. - E você esperava, imaginava um outro filho durante a gravidez?

M. - Durante a gravidez do Augusto?... se eu imaginava, planejava...

Entrev. - Um outro filho, que não era esse?

M. - Não. Eu não parava pra... desejar um filho de olho azul, um filho branquinho, pretinho... Não! Achava que era um filho que eu tava tendo e... ia ter todo o meu carinho, como teve as outras... independente do... sexo, da cor, entendeu? Eu não cheguei a.... a imaginar, não... a desejar ele de outra forma? Não...

Entrev. - É comum ouvir de mães de crianças com deficiência que elas imaginaram uma outra criança...

M. - Não, não, não, não... não me passou... Eu nunca... parei pra... desejar... A gente pede que venha pelo menos com saúde e com perfeição, mas se Deus deu, se Deus me deu ele assim, é porque eu tinha que ter ele assim, entendeu? Então... Foi difícil, porque eu acho assim: se o pai tivesse do meu lado, talvez eu não tivesse passado por tanta dificuldade, né? Mas aí já superei, faz tempo.

Entrev. - Quanto tempo você levou para assimilar essa idéia de um filho cego?

M. - Foi no... Porque assim, eu não assimilei não o fato por ele ter nascido deficiente, e sim por tudo, entendeu? Não foi a cegueira do Augusto. Ajudou bastante? Ajudou, porque eu até então não tava preparada. Mãe nenhuma tá preparada, né? Mas, quando você começa a sair, a ver outras pessoas e ver que a vida não é... só tem você que tá passando por aquele problema, que tem outras pessoas que às vezes têm até pior, aí foi quando eu passei a mais 
aceitar o Augusto, a ver que ele anda, ele fala, ele escuta. Então... e tem crianças que, infelizmente, você vê, que há uma certa dificuldade, paraplégico, às vezes fica em cima de uma cama vegetando, às vezes tem uma doença contagiosa... Então, assim, eu falei: "Ah, não, meu filho é perfeito, tem saúde”, entendeu?

Entrev. - Foi depois dos primeiros dois anos?

M. - Foi... devido eu ter ficado depressiva, eu não passei a raciocinar melhor, né? Tava com uma certa dificuldade. Depois que eu acordei. Aí eu trouxe ele pro Laramara... Houve um período que eu trouxe ele pro Laramara, quando bebê, né? Mas ele era tão bebezinho, né? E aí, surgiu uma vaga lá na Faculdade de Guarulhos, aí o Laramara falou: "Pode, você pode continuar levando ele lá, o efeito vai ser o mesmo”. Aí eu levei. E devido à depressão que eu tive, eu não agüentei, comecei a faltar. Aí, ele perdeu a vaga lá, entendeu? Ele fez muitas amizades, inclusive com o psicólogo de lá... ele montou uma clínica... não... olha, ele quer que eu continue levando o Augusto, e eu, agora, não tá dando tempo, porque eu tenho minhas outras filhas em casa, tá numa fase muito difícil. Aí, eu não tô podendo... só venho pra cá, mas eu dou graças a Deus à Laramara, porque a Laramara tem me dado muito suporte. Muito bom a Laramara.

\section{(Pausa)}

Entrev. - Você acha que foi diferente com seus outros filhos?

M. - Se eu fui diferente na criação, desenvolvimento? É.... é o meu erro, né? Por ser deficiente você acha que... deixar ele bater, deixar ele agredir, é porque é deficiente, entendeu? Na educação, no início, foi o meu erro.

Entrev. - Como você via o Augusto? O que você percebia nele? O que ele fazia, o que ele falava...

M. - Ele fala muitas coisas, assim, repetitivas. Às vezes fala coisas... ele cria nomes que às vezes eu desconheço. Ele pega um brinquedo, ele coloca um nome naquele brinquedo que não existe, só ele cria, entendeu?

Entrev. - Por exemplo...

M. - Por exemplo? (riso) Tem uma pecinha do... prendedor de cabelo da minha filha, ele é um formato igual a uma flor e ele é duro, o plástico, e aquilo é "izilo"... e fica "izilo", e se eu perder o "izilo", eu tenho que pegar e comprar outro lacinho de corta, entendeu? Então... Tem uma parte da vassoura, que é aquela parte de fora, azul, que é de plástico, ele 
desencaixa e fala que aquilo é “duiuiu”, e é “duiuiu”... Então são palavras que a gente não encontra e nem é, entendeu? Ele dá o nome nos brinquedos, e só sabe quem convive com ele... Ele põe nomes, assim, absurdos, e tem hora que até eu esqueço, entendeu? Agora que eu tô começando...

Entrev. - Ele inventa outro código?

M. - Inventa. Aí, agora, aos poucos, eu tô explicando pra ele, tal... Ele sabe tudo. O que ele pôr a mão... telefone, coisas assim... utensílios domésticos, tudo o que ele pôr a mão, a maioria, acho que noventa e cinco, noventa e nove vírgula nove ele sabe. Só alguma coisa que ele não pôs a mão mesmo, que ele nunca... é... ouviu.... E ele agora, tudo ele quer saber: o que que passa. Se passa uma moto, ele pára: que que é isso? Aí eu vou e falo: "É o barulho da moto". Aí ele vai memorizando. Quando eu saio com ele, ele sabe o que é que tá passando. Só no som ele já fala: “É o ônibus, é a moto”, entendeu? Ele consegue, já, distinguir já os sons...

Entrev. - Pensando nele bebê, o que ele fazia que você percebia que ele estava lá, presente? Como é que ele chamava a sua atenção?

M. - Como é que ele me chamava? Porque assim... por eu descobrir a deficiência cedo, eu não esperava... ele nunca ficava só... ele nunca... devido a ter outras irmãs, ter tios por perto, ter a avó... Então ele nunca estava só. Então, assim... Nunca, nunca deixei ele num local sozinho por muito tempo, pra ele precisar e me chamar, entendeu? Sempre tinha alguém.

Entrev. - E como ele chamava a sua atenção? O que ele fazia, que você olhava pra ele?

M. - Normal. Ele jogava um brinquedo, ele levantava do berço, em pé... tudo o que uma criança normal fazia, ele faz. Faz até hoje, entendeu? Mas, assim... ele não fazia nada anormal, pra você achar que era um deficiente. O problema dele era só que ele não via... entendeu? Aí eu busquei a ajuda da Laramara quando bebê por isso: pra o engatinhar dele, entendeu? Pra ele não se machucar. Então, eu não deixava tempo pra ele se machucar... É... por exemplo: às vezes eu deslocava os sofás, deixava ele protegido, né? ...com brinquedos... Então ele sentava, quando endureceu as costinhas, sentava normal, eu forrava cheio de almofada, ele ficava no centro brincando com um monte de brinquedo. Era normal como uma criança na idade dele, entendeu? Aí, depois, eu vim naquela preocupação: o engatinhar e o primeiro passo. Aí eu comecei a comprar andador, pra ele se proteger, pra não bater, porque é muito pequenininho, entendeu? Saber de coordenação motora, essas coisas... Assim... Eu nunca trabalhei, né?! Então me dedicava a ele e minhas filhas. 
Entrev. - E ele percebia quando você estava no mesmo local que ele?

M. - Devido a ele escutar a voz, ele ria, você vê as reações do bebê, entendeu? "Mamãe tá aqui!” Então a hora que ele escutava a minha voz, ele já se jogava em direção a minha voz, pra vir pra mim... entendeu?

Entrev. - Você disse que falava com ele... o que mais? Que coisas você fazia com esse bebê?

M. - Conversar, passear, tomar solzinho... Um hábito normal como uma criança.... entendeu? Tinha a hora do banho, tinha a hora das mamadas...

Entrev. - Isso desde bebezinho?

M. - $\operatorname{Sim} \ldots$

Entrev. - Mesmo naqueles dois primeiros anos?

M. - O banho dele era sempre no mesmo horário... quando eu ultrapassava, atrasava dez minutos, ele já chorava, porque já sabia que já passou do horário... Ele sempre... ele sempre foi assim: danado...(risos)

Entrev. - Se ele não olhava pra você, se ele não via, o que você fazia pra estimulá-lo, e pra chamar sua atenção?

M. - Com sons, né? Por eu ter vindo aqui, aí o Laramara me orientou, né? Sons... E ele tinha baixa visão; ele usava um óculos de vinte graus... aí ele tinha que fazer estimulação com papéis brilhantes, apagar todas as luzes e trabalhar esse lado de estimular dele com papéis que brilham, com.... Como é que chama, meu Deus?... Um negocinho que você acende e joga luz... é um... É lanterna. Comprei lanterna... então eu trabalhava esse lado dele, aí. Às vezes eu jogava a luz pra um lado, ele entortava o olhinho, olhava... Que dizer, aos poucos ele foi crescendo e foi perdendo o pouquinho de visão que tinha, entendeu?

Entrev. - Até que idade?

M. - Até que idade eu trabalhava esse lado dele? Acho que até uns... três anos, no máximo. E, aí, aos pouquinhos, ele foi... perdendo.

\section{(Pausa bem longa)}

Entrev. - Como era sua relação com seu filho, na parte de encorajá-lo a fazer algo... de incentivá-lo a brincar...?

M. - Ah, o brincar era normal, né? Como eu já falei... 


\section{Entrev. - Como você fazia?}

M. - Ah, a gente ficava junto, eu comprava muito brinquedos com sons, que saía musiquinha, aí eu ia ensinando com a mãozinha pra ele... saber tocar, brincar... Mais coisas de som: chocalhos, né? As irmãs tinham uns brinquedos, assim, de coordenação motora, com formas, né? ... quadrados, e tal... Então era mais esses lados, assim... mais de coordenação motora e

som... musiquinha mais tranqüila... É que minhas filhas foram crescendo e foram querendo ouvir samba, né? ...axé... então são músicas barulhentas que, no começo, ele ficava agitado, daí ele não conseguia assimilar o som muito alto e também nem... muito assim, o som muito... Músicas muito agitadas deixava ele nervoso... Até hoje. Hoje ele tá conseguindo mais querer ouvir música, eu ainda falo que tipo de música ele quer ouvir; se é forró, eu ponho forró; se é axé, eu ponho axé. E ele sabe: eu ponho um tipo de música, ele sabe que música que tá tocando: se é rap.. Rap eu já não gosto, porque fala tanto de violência e eu acho que isso não é bom pra ele, entendeu? Aí eu não deixo ele ouvir muito. Como tem colegas da minha filha que escutam de tudo, ele acaba escutando também, de tudo, entendeu? Mas ele opta o que ele quer ouvir no dia: “eu não quero, quero ouvir televisão, deixa eu no quatro”... então deixa... Tem uma novela das Chiquititas, que ele gosta de ouvir, da voz das crianças, e ele pede: “deixa nas Chiquititas”... e sempre ficou escutando. E antes não. Antes, quando eu ligava a televisão, podia ser o que fosse: um som barulhento ou mais tranqüilo, ele não agüentava... Desligou... ele quebrou muitos sons em casa, ele não agüentava assimilar, né?!

Entrev. - Antes até que idade?

M. - Até mais ou menos um ano, um ano e meio atrás. Aí, depois que eu passei a levar ele na psicóloga e... na neuro... acho que na neuro eu demorei pra ir, né?! A neuro, eu acho que eu devia ter ido mais cedo, porque ele sempre teve convênio. E aí eu... fui lá, conversei com ela, ele tava auto-agredindo, se mordendo, dando cabeçada. Falei: "Não, ele tá precisando de ajuda, né?" Aí... ela passou uma medicação e agora eu acho que ele... Nossa! Ele não agride mais... ele demora a agredir, mas tá reduzindo em noventa por cento, né? Eu acho que ele melhorou noventa ou mais. Ele tá bem melhor, bem melhor mesmo! Já consegue sentar, escutar televisão, saber o que tá passando, entendeu? Então é assim: se ele escuta um som, ele sabe qual é o cantor que tá cantando, principalmente o lado sertanejo. A maioria, ele acerta todos... sem eu precisar perguntar, ele fala quem tá cantando. E se eu tiro, ele pede pra mim deixar. Aí eu vou e volto, né, entendeu?

Entrev. - Como você se sentia em ser mãe do Augusto? 
M. - Ah, não, assim... o ser mãe é igual à primeira, como eu já te falei, entendeu? Não é por ele ser deficiente ou ser uma criança normal. A gente que é mãe, a gente... eu tenho quatro filhos e todos, pra mim que sou mãe, o amor de mãe é um só, pra mim. Mas, nenhum filho substitui o outro, nenhum, entendeu? Você pode ter dez filhos, nenhum substitui. A perda de um vai fazer falta a vida inteira. Então, pra mim, são tudo o que eu tenho, entendeu? Não é por ele ser deficiente ou minha filha mais velha ser normal. Todos, o amor pra mim é igual, entendeu?

\section{(Pausa)}

Entrev. - Você disse que ele sorria quando você falava com ele...

M. - É, ele sempre foi brincalhão, sempre foi risonho...

Entrev. - E as expressões faciais de Augusto?

M. - Você percebe o choro quando é de manha, né? A gente que é mãe, quando é a primeira viagem, é uma coisa. Mas já é o quarto filho, então você percebe quando é choro de manha, quando é choro de dor, quando a criança quer colo, entendeu?

Entrev. -Tudo isso você percebia nele desde bebezinho?

M. - Ele e as outras, normal.

Entrev. - Desde bebê?

M. - Desde bebê.

Entrev. - Agora eu vou lhe fazer perguntas mais específicas do desenvolvimento do Augusto. Como foi o desenvolvimento dele no geral?

M. - Normal. Agora, você fala nos primeiros passos, no andar, ou comer, tudo?

Entrev. - Tudo que você lembrar...

M. - Até... não, assim, normal... Começou a dar os primeiros passos, então eu, com medo, comecei a superproteger...

Entrev. - Que idade?

M. - Dos primeiros passos dele? Foi na FIG, na faculdade de Guarulhos, né? Lá estava estimulando pra ele dar os primeiros passos, foi lá que ele começou a dar os primeiros passos, lá...

Entrev. - Que idade? 
M. - Acho que um ano ou um ano e dez... um ano e um mês, creio eu. Não foi muito tarde, não.

Entrev. - Como é que ele reagia com o corpo? Que tipo de movimentos ele fazia?

M. - Que tipo de movimentos?

Entrev. - É. Você já falou, por exemplo, que ele ficava em pé no berço quando você falava...

M. - ... isso quando bebê, normal...

Entrev. - E ele se jogava pra você...

M. - Tá. Mas é quando ele começou a andar, você fala?

Entrev. - É.

M. - Normal. Engatinhava, queria subir escadas, ia pra cozinha. Eu tinha que ficar sempre atenta pra ele não se machucar, entendeu? Aí ele ia, quando encontrava a geladeira, colocava a mão na geladeira, ficava em pezinho na geladeira, entendeu? O que uma criança na idade dele fazia, ele também fazia.

Entrev. - Como ele se comunicava? Por exemplo: chorava, ria, buscava as coisas, as outras pessoas com as mãos, fazia força pra levantar o corpo, se virava na direção dos sons?

M. - Em direção dos sons ele sempre... se chegava assim perto da gente, ele colocava o apoio, ele ficava em pé, entendeu? Engatinhava... Como eu tinha carrinho, às vezes eu colocava um som baixinho, deixava ele no carrinho, quando ele... ele ainda dava pra ficar no carrinho, porque ele sempre foi grandão. Às vezes eu tava lavando a louça, eu começava a conversar com ele, dava um brinquedo, o mordedor, quando tava saindo os dentes... Então, assim, o que eu tratava ele, eu tratei as outras, era igual. Não houve diferença. A diferença foi assim: eu achava que por ele ser... por ele não ter visão, eu superprotegia demais. Por eu não ter deixado ele ser mais independente, até hoje ele não come sozinho, já é um hábito: eu sento, e o Laramara tá puxando muito a minha orelha, porque já era para ele estar comendo só. Muita coisa... lanche, refrigerante... muita coisa ele toma e come sozinho. É só a comida que eu levo a colher na boca. E ele quer aprender, às vezes ele pede, e o hábito, o medo dele se sujar, tudo o local onde ele tá, eu acabo... fazendo, e tô errada... Eu dava pra ele... ele sabe o que é colher. Muita coisa ele toca a mão e sabe o que é que é... mas...

Eliana: Você não o deixava fazer por si...? 
M. - Não. Eu achava que, devido à deficiência, eu tinha que cuidar, proteger ele. Foi um dos meus erros...

Entrev. - Essa proteção a que você se refere era em relação à independência de Augusto, por exemplo, em relação à alimentação?

M. - Sim... sim.

Eliana: É o que chama de proteção?

M. - É uma delas, porque...

\section{(Interrupção para trocar a fita e a frase ficou cortada)}

Entrev. - Como foi a amamentação de Augusto? Ele mamou no peito?

M. - Mamou.

Entrev. - Como foi?

M. - Ah, ele só faltava comer o meu seio. Mamou bastante. Não sei se... o pessoal tem aquele hábito de falar que, quando é homem, a fome é maior... quando é menina enche... Mas isso era bobagem. Mas o Augusto comia muito, mamava muito, chegava uma hora que não... eu apertava assim, não saía mais leite. Ele sugava, sugou até... até seis meses, era só o seio. Até que o pediatra dele brigou comigo, porque eu optei em não tirar do seio. Eu reduzi, eu dava o seio à noite, cedo, e durante o dia eu fui dando... porque com seis meses eu comecei a dar... com três, quatro meses, eu comecei a dar papinha pra ele, suquinhos, suco de fruta, suco de laranja, fui alternando. Mas o seio ele mamou acho que até um ano... um ano e dois meses mais ou menos, ele mamou.

Entrev. - Ele sugava as mãos?

M. - Sugava... Sim, quando ele tava coçando... a gengiva. Tava nascendo os dentes, ele levava assim.

Entrev. - Depois quando foi pra mamadeira, ele segurava a mamadeira?

M. - Sim...

Entrev. - E na ausência da mamadeira, ele fazia o movimento de sugar?

M. - Não. Quando saciava a fome dele, ele ficava quietinho porque ele não pegou chupeta, então... Não, mas a hora que dava a fome, ele já começava a chorar e aí... a hora que eu pegava ele no colo que ele procurava o seio, eu já sabia que era fome, entendeu? 
Entrev. - Como que era o contato dele com os objetos e como é ainda hoje?

M. - Com os objetos?... Bom, de que idade? A idade...

Entrev. - Desde cedo, quando você lhe dava um brinquedinho...

M. - Ele pegava, brincava normal. Se era chocalho, ele balançava, se era mordedor, ele levava à boquinha, muita coisa ele levava à boca. Toda criança na idade dele, primeiro leva a boca, né... Então sempre tinha esse cuidado de olhar se não tinha caído no chão, tudo, entendeu? Pra dar na mãozinha dele, pra ele num... Que a maioria das coisas ele leva à boca. Mas é normal...

Entrev. - Ele ainda faz isso?

M. - Algumas coisas ele leva à boca e morde.. algumas coisas ele brinca, fica esfregando, né? Embaixo do queixo, em cima do queixo, vai até assim no nariz assim e desce, sobe, e fica gesticulando esse gesto durante mais de meia hora. Se você deixar, ele senta, cruza as perninhas e fica fazendo esse movimento, esse gesto de debaixo do queixo até o nariz, ele fica descendo até... tem até um... tem até um pouquinho escuro embaixo assim do queixo, de tanto que ele faz assim esse movimento. Eé tudo, é tudo, era um brinquedo, um pano, um papel... o que ele encontrar, ele pega o papel dobra em vários tamanhozinhos e fica fazendo esse mesmo movimento. Aí, aos poucos eu fui tirando, né? Chamando ele pra brincar, pra cantar uma musiquinha, pra ouvir um som, aí aos poucos, ele tá diminuindo mas, de vez em quando, ele ainda senta e faz esse movimento de novo...

Ele só não faz com bola. Bola, ele senta com a perninha, aí a outra irmã senta um pouquinho longe dele, abre a perna também, aí joga rolando, ele vai e pega. Mas na hora de jogar, ele não joga rolando, ele joga pra baixo pra bola pular, acho que pra ouvir o som.

Entrev. - E o contato dele com as pessoas desde bebê até agora?

M. - Hã... assim: bebê não deu muito problema, né? Ele era muito gorduchinho, todo mundo queria pegar, todo mundo tinha prazer em tirar foto com ele, todo mundo gostava demais dele. Todo lugar, no ônibus, queria pegar ele no colo, essas coisas, né, normais. Aí, quando ele começou a ter os dentes dele, começou a morder, essa fase de morder, eu achava que era normal, por ele ser cego... Foi aí um dos meus erros, também. Eu não soube... eu não soube assim... corrigir na hora que eu devia, fui deixando, ele foi mordendo, foi ficando agressivo...

Entrev. - Ele se mordia...

M. - Não, ele mordia só os outros... as pessoas. 
Entrev. - Até que idade isso?

M. - Ele começou na hora que é a fase que começou a sair os dentes... uns seis... O primeiro dentinho saiu com cinco meses, o primeiro. Aí parou, aí começou a nascer o segundo, em diante os outros. Com sete, oito meses começou a vim em seqüência. E... aí começou (riso). Foi aí meus erros, porque se eu tivesse tratado ele como uma criança normal, talvez ele não me desse tanto trabalho como ele deu esses últimos anos, porque ele quebrou muito a minha casa, quebrou muita coisa, muito nervoso, devido eu ter que trabalhar... eu trabalhei quase dois anos, não, mais, dois anos e dois meses, que ele foi orientado por outras crianças, e eu muito cansada, acordava quatro horas da manhã pra ir trabalhar. Então, aí, foi o.... a fase que ele precisou de mim e eu não tava próxima a ele para orientar, pra ver onde tava errado. E mesmo, acho, que eu próxima, eu errei muito nos erros, né? Porque, quando eu fui normal, ah, isso não é certo, ah, isso é errado. Então você corrige. E por ser deficiente, eu achava que tudo pra ele tinha que ser daquele jeito, entendeu? Então foi o meu erro.

Entrev. - Você achava que o deficiente fazia daquele jeito?

M. - É, por ser deficiente, eu não tinha que corrigir, entendeu? Eu achava que, conforme o tempo, ia acabando... mas, não! Foi o meu erro. E ele tem uma força enorme. O tapa dele, dependendo do local que ele atinge, ele derruba um adulto. Ele bateu num rapaz, o rapaz lá vizinho nosso sabe que às vezes ele chega a agredir as pessoas, pegou ele assim sem esperar, bateu na parte íntima dele e o cara caiu no chão. Foi tão forte a pancada, que ele caiu. Ele tem o braço forte. O tapa dele machuca. Ele dá cabeçadas. Se você segurar a mão ele dá cabeçadas. Eu cheguei já a corrigir de uns dois anos pra cá, mas eu acho que, não é que foi tarde, é que ele já se habituou naquela rotina de agredir e eu achava que era normal...

Entrev. - E ele faz isso em que situações? Você disse que o contato dele com as pessoas é por essa forma...

M. - É, tá diminuindo, né...

Entrev. - Ele começou mordendo, depois passou a bater?

M. - ... e o pai, que no início ajudou muito, né? O pai morava próximo à gente... e sempre que o pai, quando ele era bebê, o pai fechava a mãozinha, começou a ensinar ele a dar socos, começou a ensinar a dar o dedinho do meio, e eu corrigia, corrigia, e o pai ensinando ele a ser agressivo. Não foi muito tempo. Não sei se isso ajudou ele a ser... mas era o pai falando que não... o pai falando que sim e eu falando que não, e eu pedindo, então eu não sei se isso ajudou. Mas isso já faz muito tempo... 
Entrev. - Que idade ele tinha?

M. - Ah, ele tinha um aninho, mais ou menos, um ano e dois meses. Isso foram meses e meses o pai ensinando a dar socos...

Entrev. - Por que você acha que isso era importante pro pai? O que ele dizia?

M. - Não sei! O pai começava a brincar: “ah, é macho, ah, é homem”, entendeu? E ele é meio... eu acho que até o pai tá precisando de um psicólogo... porque eu não vejo normal nisso, nunca achei normal, por ser homem ou por ser mulher ter esse lado agressivo. Cê tem que ter autodefesa, mas quando houver necessidade e... quando criança não, porque essa fase de criança logo passa, cê tem que dar carinho, tem que saber aproveitar essa fase. O pai, no começo, né? Tanto é que a minha filha de doze anos, a psicóloga que eu tô levando ele quis conhecer minhas filhas e a avó, porque ele tá sempre falando da avó. Levamos lá, e a minha filha de doze anos, eu não abri a minha boca, e a minha filha de doze anos falou a mesma coisa que eu tô te falando, que acha que o pai influenciou muito. E aí junta a agressividade dele, que já deve ser por natureza, já deve ser um pouquinho nervoso, e o fato de não enxergar, de não conseguir distinguir de onde vinha os sons antes, quando ele era um pouco menor, hoje não; o pai ensinando agressividade, né?! Eu discutia muito com o pai, era só gritos e discussão. Ele também presenciou muito isso. Aí junta o pai ensinando, a gente discutia muito, aí som ligado, tudo, eu não sei se isso ajudou muito, contribui com que ele... Aí junta a agressividade dele, e eu achando que era correto, fui deixando, deixando... Ele tá reduzindo bastante, tá tomando medicação, eu tô no pé corrigindo os erros dele... se ele fala palavrão eu falo que não pode, mas, às vezes, ele tá no portão, na minha garagem, passa alguém na rua e fala um palavrão, infelizmente a gente tá sujeita a isso... fala certos palavrões, ele escuta, entra lá dentro de casa, porque ele sabe, ele já se locomove a casa inteira sozinha sem precisar de ajuda, chega e fala: "Mamãe, isso...", e fala, repete o palavrão. Aí eu falo que é palavrão, que é feio, que não é pra repetir. Aí ele não repete. Aí sai de novo, e se já chega um outro e fala, ele já torna a repetir de novo, entendeu? Mas eu falo pra ele que não pode, e ele sabe que não pode, porque às vezes quando eu contrario ele, ele quer, por exemplo... eи dou água pra ele, ele quer bater o copo no chão pra quebrar o copo, e eu falo: "Não pode quebrar o copo", e eu tomo o copo da mão dele. Primeiro eu peço, quando ele não dá, aí eu pego o copo dele, aí ele fala palavrão. Então ele sabe o que é palavrão, ele sabe que não pode, entendeu?

Entrev. - E usa na hora certa... 
M. - Na hora certa. E às vezes ele me mata de vergonha, às vezes no ônibus ele fala palavrão. Às vezes você senta com ele e é assim... quando ele cisma de querer sentar sozinho e eu tenho que ficar do lado dele. Eu já tenho medo. Eu ando vinte e quatro horas com medo de ele agredir as pessoas. Eu ando, assim, assustada. Então, tá assim: eu tenho que sentar do lado dele, e você sabe que às vezes no ônibus tem alguém idoso que precisa mais do que eu... e se eu ceder o lugar e ele machucar um idoso? Aí eu fico com esse medo e acabo sentando. Aí, se senta um casal na frente e começa a conversar e incomoda ele, ele... ou quer avançar nas pessoas que tá na frente ou que tá atrás, ou começa a falar palavrão. E eu morro de vergonha porque na minha casa, às vezes, uma das minhas filhas, às vezes de nervoso, acaba escapando, mas elas não têm o hábito de falar palavrão e eu também não gosto de falar. Às vezes eu chamo de gorda, de baleia, brincando, e tudo. Aí ele vai e fala: "Ô Ninha” - Ninha é a Bruna - "sua baleia” (rindo), ele repete, mas até então isso eu ainda deixo, mas quando é palavrão mesmo, pesado, eu não gosto. Eu acho que é muito feio, independente se é normal se não é. Não é porque é deficiente que tem que falar palavrão, tem que ter má educação. Eu não gosto. Eu acho feio demais.

Entrev. - Quais são os objetos e as pessoas favoritas do Augusto?

M. - As pessoas favoritas... ah... a gente mesmo, entendeu? Ele tem facilidade de conversar com as pessoas lá. Às vezes, ele repete o que as pessoas falam e às vezes ele consegue ter, tá começando a ter um diálogo, entendeu? Fazer perguntas, pedir alguma coisa. Passa vizinhos, chega no portão: “Oi, Augusto, bom dia!” e ele repete, entendeu, conversa. Ele... pela voz, a maioria das vezes, ele acerta as pessoas que são, fala os nomes, pede pra pessoa segurar no portão, porque segurar no portão ele apóia a mão dele em cima e não deixa a pessoa ir embora. Pra ele, todo mundo que chega próximo, ele dá a mão e ele fala: "Dá a mão pro Augusto". Não é pra mim, é pro Augusto e puxa a pessoa e segura aqui, e ele fala: "Segura aqui, eu quero assim”. E segura, e segura a mão dele por cima das mãos das pessoas, pras pessoas não irem embora, pra ficar lá com ele, entendeu? Mas eles, engraçado que, quando o portão tá fechado, ele segurando, conversa, tudo bem. Algumas vezes ele tem reação de agredir, quando o portão tá fechado. Com o portão aberto, ele já não agride ninguém. Eu não sei o porque que ele faz isso. Qualquer pessoa. Vai um vendedor, um menor, qualquer coisa, se aproximou muito, se não souber, ele agride com o portão fechado. Com o portão aberto, se você chamar: “vamos passear?”, ele vai com a pessoa. Pra onde a pessoa levar ele vai. Meu portão é fechado vinte e quatro horas. Quando eu vou passear com ele, só no som da chave, ele já vai correndo no portão, já põe a mão, já fica esperando: "Augusto quer 
ir pra rua!” Eu fiz uma balancinha de madeira com corda em frente à minha casa, que tem várias árvores, aí ele fala: "Quero ir pra balança”. Aí eu vou e levo, ele balança um pouco. Às vezes ele fala: "Eu quero dar uma voltinha na praça”. Aí eu vou na pracinha de árvores, fico sentada, tomando solzinho. Às vezes eu mando uma das irmãs ir, entendeu?

Entrev. - E os objetos? Tem algum objeto que ele goste mais, que ele sempre queira?

M. - Tem: esse "duiuiu” aí... é um plástico que fica embaixo, encaixado assim na... na... na parte assim, que desencaixa, sabe? Não é aquele plástico que é grudado na madeira, a parte de baixo próxima às cerdas... que desencaixa... E tem esse "izilo”, que é o do negócio, do lacinho do cabelo, e tem um outro, que é aquela bonequinha gessinho, da Estrela, que vem um gessinho na mão e vem um gessinho no pé. Então ele pega o gessinho que vai no pezinho da boneca, desencaixa e fica horas e horas com aquele...

Entrev. - Sempre passando no rosto...

M. - Hã, hã... E às vezes segurando, às vezes dá uma mordidinha de vez em quando, mas a maioria das vezes é fazendo esse movimento que eu te falei: passando no queixo.

Entrev. - Onde e com quem ele era alimentado depois do peito?

M. - Comigo... em casa.

Entrev. - Em que lugar da casa?

M. - Na cozinha, enquanto tinha cadeira, porque depois ele quebrou todas as cadeiras, agora ele faz a refeição na sala (rindo). Ele faz na sala. O correto seria na mesa sozinho, mas não dá. Ele quebrou tudo e eu não compro outra com medo dele quebrar de novo. Eu penso que essa fase vai passar logo... quando ele for aos poucos eu vou... Aqui no Laramara tem onde sentar, tem mesa, porque eu sei que, quando ele vem, tem uns dias que é duas horas de atendimento com uma pessoa só, que é a $C$. (a profissional), aí ele senta à mesa, do meu lado. Às vezes, até na mesa lá de casa, ele quer subir na mesa, quer deitar em cima da mesa. Eu falo: “A mesa não foi feita pra deitar, aqui é o local onde a gente come”. Mas ele quebra tudo. Então, assim, pratos... pratos eu tô com poucos em casa, tô sempre comprando, sempre repondo, porque se tiver um prato aí fácil, às vezes, né, ele... “mamãe acabou”. Aí ele me dá o prato, na minha mão, eu falo: "Vamos levar na pia”. Eu levo. Aí ele tá lavando louça junto comigo, né, lava copo, prato e algumas coisas que não é cortante. Mas algumas vezes, quando você descuida, deixa ele sozinho, o que tiver de quebrar, ele joga tudo no chão.

Entrev. - Ele sabe que quebra? 
M. - Sabe, e se machucar... e se chegar e machucar o pezinho, ele fala: "Está sangrando o meu pé". Só que ele não sente dor, ele não chora e fala: "Ah, tá doendo”, né? Pra ele sentir uma dor, chorar mesmo, é preciso o negócio ser feio mesmo. Aí...

Entrev. - Que tipo de dor que é feia e o faz chorar?

M. - Que tipo de dor? Um tombo que ele não esteja esperando, que ele machuque mesmo...

Entrev. - Aí ele chora?

M. - É. Ele já chegou a cair duas vezes da escada, rolou a escada, foi só o susto, mas aí... chorou também...

Entrev. - Mas quando quebra...

M. - ... ele fica quieto. Ele fica assim, sabe que é medo, ele sabe que é errado... Ele fala: "O Augusto quebrou um prato". Então ele sabe que fez errado... mesmo assim, continua fazendo errado. Aí eu vou brigar com ele, conversando, eu falo que o caco de vidro entra no pé e machuca, entendeu?

Entrev. - Ele aceitou o alimento sólido, a comida em pedaço quando saiu da papinha?

M. - Normal.

Entrev. - Como é que você percebia ou percebe que ele tem fome? Como é que ele mostra isso?

M. - Tanto ele pede o que ele quer comer, como ele fala, né?

Entrev. - Como é que ele pede?

M. - Primeiro, se tá com sede, ele fala: "Eu quero água”. Às vezes ele fala: “O Augusto quer água”.

Entrev. - Ele fala "eu"?

M. - Às vezes. Muito raro. É mais: “o Augusto quer”.

Entrev. - Ele pede, então?

M. - Pede. Água, quando ele tá com sede. E agora só quer água gelada. "Augusto quer água com gelo". Se eu dou água natural, ele dá um gole, primeiro ele tenta devolver o copo na minha mão. Se eu não tô muito próxima, se eu tô em outro cômodo da casa, ele, bravo, joga o copo, Por que? Porque ele pediu com gelo e eu dei natural.

Entrev. - E antes, quando ele era nenê, como é que você percebia que ele tinha fome? 
M. - Com fome, ele chora, né? Sempre chorou, quando bebê. E a sede... eu via ele pondo a lingüinha pra fora, ou então eu via que a boquinha tava um pouco seca, mas eu nunca esperava ele ter muita sede. Eu sempre dava líquido, né, de hora em hora, cada quarenta minutos eu dava, ou um chazinho, ou um suco, ou um pouquinho de água.

Entrev. - Como que ele percebe, ou percebia, desde bebê, o mundo das coisas, dos acontecimentos e das pessoas? Como é que você percebia ele percebendo, captando o mundo?

M. - Quando bebê... não. Quando bebê eu acho que ele teve muita dificuldade. Era muito som ao mesmo tempo, ele não conseguia distinguir de onde vinha. Era pessoas que chegavam, pessoas que iam embora. Eu acho que ele não tinha muito essa percepção, não, né? Mas, assim, das irmãs, que é as pessoas que tem um contato diariamente dentro de casa, ele sabia. Porque, pelo som, ele se jogava pra pessoa. Mas só as pessoas que ele via pouquíssimas vezes, ele segurava em mim, na minha mão, e não ia, entendeu? Como se percebesse que aquela pessoa era uma pessoa estranha, entendeu? Mas, os tios, que tinham contato com ele, a avó, ele se joga...

Entrev. - Mais pelo som do que pelo tato, ou pelo olfato...

M. - Tato ele buscava quando ele queria se locomover, né? Balançava alguma coisa, algum som longe, ele escutava, ia até lá, pegava com a mãozinha, aí ele realmente sabia que era aquele som que eu fiz, entendeu?

Entrev. - E como é que ele mostra que ele compreende as coisas?

M. - Como é que ele mostra que ele compreende? Que ele sabe que é aquilo, mas insiste em fazer? Porque, às vezes, ele dá aquela risada, entendeu? Você percebe que ele sabe que é errado e quer continuar errando. Não sei se é pra chamar a atenção ou por algum outro motivo, mas que, às vezes... Hoje tá muito mais fácil de você compreender, porque ele sabe que é errado, mas insiste, entendeu? Só quem convive que percebe que ele é safado. Ele sabe que é errado e insiste.

Entrev. - Você fala muito em erro... fala dos erros dele e fala também que você errou. Por que essa preocupação com o erro?

M. - Por que essa preocupação com o erro? Porque eu acho assim: se a gente erra, como eu errei, né? Tudo... chega a prejudicar o desenvolvimento dele. Não físico, não mental. $O$ desenvolvimento que eu falo é ele ser mais independente, ter mais coordenação motora... Eu acho que eu prejudiquei nesse sentido. 
Entrev. - Você fala do erro dele também... que ele sabe que é errado...

M. - É errado... o errado pra mim nele é quando fala palavrão, quando quebra algo, entendeu? Ele se comporta... ele sabe distinguir o que pode e o que não pode, o certo do errado. Ele sabe. Ele já compreende. Às vezes ele faz ou pra chamar a atenção ou quando ele você... quando ele quer algo que você não atende naquela hora. Por exemplo, às vezes a comida... só no refogar do alho, ele já sabe que é comida. "Augusto quer papá”, "Augusto quer almoçar”, ele fala. Aí eu falo: "Eu estou fazendo, você aguarda?!”. Ele: "Tá bom, eu aguardo". Aí ele vai e senta. Aí eu falo: "Você aguarda só um pouquinho que já tá quase pronto". Aí, de repente, ele quer um Danone, uma bolacha. Aí eu falo: "Eu dou depois da comida, primeiro a gente vai almoçar”. Aí, às vezes, ele sabe, entendeu?

Entrev. - Ele entende tudo isso que você fala?

M. - Sim. Aí ele se joga, começa a fazer birra, quer bater na geladeira que ele já amassou, porque eu já falei, eu pus a mão dele e expliquei que ele amassou toda a minha geladeira. Aí ele vai em lugares que ele sabe que é errado, que não é pra ser feito. Ele vai lá e faz, só porque eu falei não pra ele naquele momento, entendeu? Às vezes ele se joga, às vezes as perninhas dele ficam toda roxa de ele ficar se jogando no chão, fazendo birra, porque eu falei não pra ele naquele momento. Mas, quando eu ando com ele no metrô, no ônibus, que ele fala: "Eu quero" ou "O Augusto quer um... uma coxinha”, porque ele come muito lanche, aí eu falo: “você espera chegar na estação”... aí falo o nome da estação e ele espera quietinho, não dá trabalho nenhum. Mas algumas vezes em casa ele faz aquilo que não é pra fazer só pra chamar a atenção, porque ele quer naquele momento, você entendeu? E eu percebo que ele já sabe... Uma coisa é quando a criança não compreende, e ele já compreende.

Entrev. - Pelo que você conta, ele foi um bebê, uma criança mais ativa do que passiva...

M. - Muito ativa, muito...

Entrev. - Muito, por que?

M. - Porque, assim: minhas filhas sempre viram um bibelozinho em algum certo lugar, colocava a mão pra saber e colocava de volta. Ele não: tudo dele era, tanto era jogar, quebrar tudo, destruir... Televisão: se você deixar ele só ele que jogar a televisão no chão, ele quebrou três TV minha. Quebrou quase tudo, assim, os eletrodomésticos meu. Tive que comprar algumas coisas que tava nas minhas condições, eu comprei, outras que não tava eu não comprei... 
Entrev. - M., e como você se sente com isso? Quando ele faz essas coisas, qual o seu sentimento?

M. - Na hora em que ele destrói algo? O meu sentimento? Hoje eu não me incomodo mais com bem material. Antes eu queria ter a casinha arrumadinha, tudo no seu devido lugar, tudo arrumadinho. Depois que o Augusto nasceu, que ele começou a ter... quebrar tudo e eu precisei trabalhar, e aí foi que começou a quebrar... Se ele vê uma porta dessa aí antes... hoje eu não sei, né, porque ele... eи não dou mais tempo pra ele destruir nada, mas... se antes ele visse uma porta assim no guarda-roupa, ele tenta abrir e força ela ao contrário, até soltar a porta do guarda-roupa. Então, assim, tudo o que você possa imaginar, ele tenta assim, de alguma forma, tirar do local, modificar, eu não sei o porquê ele age desse jeito, entendeu?

Entrev. - E o seu sentimento?

M. - O meu sentimento? Ah, eu explico pra ele o porquê que ele quebrou, que não podia...

Entrev. - Mas o que você sente?

M. - Não sei! Que tipo de sentimento você acha... ah.... a minha reação de momento? Ah, eu penso que vai passar, eu penso que depois eu vou poder arrumar minha casa aos poucos de novo...

Entrev. - Você não fica brava, não tem raiva...

M. - Raiva? Não. Eu já cheguei a dar uns tapinhas na mão dele, no bumbum, explicar pra ele que não podia, que não pode, que é errado, fecho, mostro o lado...

Entrev. - Mas uma criança destruir três televisões...

M. - ... é que não foi comigo em casa, né? A televisão tava uma no quarto das crianças... elas lá na cama, conversando... ele vai, é de repente, é sem esperar, que ele vem e joga. Eu chego e falo: “Ai, meu Deus, mais uma”. Aí falo: "Filho, não pode, você quebrou mais outra, entendeu?”. Vou conversando. E eu falo, eu cobro das minhas filhas, porque uma tinha doze e a outra tinha dez. Eu falo: "Filha, pelo amor de Deus, deixa a casa do jeito que tá, suja, só cuida dele, só dá atenção pra ele. Quando a mãe chegar, a mãe limpava”, entendeu? Mas elas dormiam tarde, acordavam tarde e ele, sem enxergar, acordava e saía destruindo tudo o que via pela frente.

Entrev. - Ah, tá. Ele ficava sozinho? 
M. - Algumas horas ficava, porque... eu ia chorar, eu ia trabalhar chorando, porque eu pensava: "eu preciso trabalhar, né?” (choro) Difícil... (chorando muito) Eu precisava ir trabalhar, né, pra dar as coisas assim pra elas... O pai não soube me compreender (chorando). Foi difícil essa fase. Graças a Deus, agora já passou... No começo foi... eu não tinha ódio, nem nada, nem descontava nele, no Augusto, não, nunca. Eu só falava: “Ai, meu Deus, quebrou mais outra coisa", e pronto. Hoje eu não compro nada, assim. O tempo que sobra, as minhas economias, eu guardo um pouco, pra quem sabe, daqui a alguns anos, quando o Augusto ficar menos agressivo, eu conseguir de novo. E pra completar, a minha filha mais velha hoje, eu cheguei até atrasada, que eu tava conversando com ela, que a minha filha mais velha dormiu na casa da avó ontem, e ela se relacionou com um cara que eu acho que não serve pra ela e eu tô com suspeita de que a minha filha de quatorze anos já tá grávida. Cê imagina, pra mim. O pai tá com a maior raiva de mim, porque acha que eu tinha que aceitar ele de volta, que eu tinha que perdoar ele. Não é assim, eu não consigo mais. Prefiro ficar só, com minhas filhas e o Augusto. Hoje eu tô bem, né? Não preciso trabalhar, nem nada, o pai ajuda, assim, paga o convênio, tudo, mas foi difícil no começo da separação e com o nascimento do Augusto. Essa fase já passou.

Entrev. - Você disse que saía pra trabalhar e ficava pensando...

M. - ... no que ele poderia quebrar pra se machucar. Porque teve uma hora que eu liguei pra casa, porque antes lá tinha telefone, e o Augusto tinha o hábito de abrir a torneira da pia, tampar a pia com alguma coisa, pra água cair da pia e encher a casa d'água, né? A parte de baixo: sala, cozinha, a parte de baixo. E às vezes quebrar as coisas. Aí teve uma hora que eu liguei e minha filha de dez anos falou: "Mãe, o Augusto encheu a casa d'água e entrou dois cacos de vidro no pezinho dele”. Aí eu tive que ligar pra família do meu ex-marido, aí foi todo mundo lá. E eu trabalhando. Era pertinho onde eu trabalhava, mas eu não podia sair do local, porque não tinha quem ficasse no meu lugar, entendeu? Eu trabalhava na sala vip da Varig e o movimento é muito grande lá. Aí chama vôo, entre vôo, aeroporto não tem como... não tinha como eu sair pra mim ir lá. E isso era, eu ia trabalhar preocupada, sabe? Entregava na mão de Deus e ia... Aí, quando eu vi que não agüentava mais, que não dava mais certo, que a minha filha mais velha tava saindo muito de casa, judiando do Augusto, não dava a refeição nada correta, né? Deixava ele dormir na hora errada, também. Ele não tinha horário pra acordar com ela, né? Às vezes eu chegava três horas do serviço, o Augusto já tava dormindo. Aí eu falei: "Não, preciso sair". Aí eu fui e conversei com a pessoa 
responsável, que é minha vizinha, e pedi que me mandasse embora. Eu fui obrigada a sair. Porque, nos dias de hoje, muitos querem trabalhar e eu não posso.

Entrev. - Você já disse que ele explorava o ambiente andando, subindo, passando a mãozinha, era isso que ele fazia... Qual sua atitude em relação a isso? Você deixava, tirava, ou deixava ele conhecendo as coisas?

M. - Coisas que eu achava que ia... que ele ia se machucar, eu tentava subir pra não quebrar, pra não se machucar mais. Na escada, assim, pra ele não subir pra escada, com medo dele se machucar, eu coloquei um portãozinho, improvisei um portão. Primeiro foi de madeirinha, aí ele destruiu tudo, não durou uma semana. Aí, meu cunhado trabalha num local onde ele faz... utilizam um material aí que eu não sei direito o nome, não sei se é aço, se é ferro, não me recordo, ele fez um portãozinho bem bonitinho, bem decoradinho. Aí ele veio e colocou o portão, mas o portão também tá meio... porque ele tem uma força enorme. Primeiro colocou com as travinhas, daqui a pouco começaram a destruir... Agora eu amarro com corda, pra ele não subir nas escadas. Porque, às vezes, a de doze anos fica responsável em limpar a parte de cima da casa, os quartos, a área, aí... pra pôr um limite nele, tem que ser assim, porque, se você fala: "Augusto, não pode, agora não vai", ele espera a gente distrair, quando você menos espera ele tá lá em cima. Aí eu vou e falo: "Augusto, desce!", aí ele vai e desce. Aí, quando você vira as costas, ele sobe de novo, porque ele quer ir lá pra cima. Aí, pra você pôr um limite, você tem que pôr uma barreira, senão... (rindo) senão ele não escuta. Quando ele quer fazer um negócio, tem que ser aquilo, entendeu?

Entrev. - Ele percebe a diferença que existe entre ele e os outros? Quer dizer, ele tem consciência de que há um mundo fora dele, que ele é ele e que os outros são os outros?

M. - Se ele consegue...

Entrev. - ... saber que ele é ele mesmo...

M. - Aí você me pegou! Se ele consegue saber que ele é o Augusto? Eu acho que sim, porque às vezes ele fala: "O Augusto quer isso”, entendeu? Às vezes ele pega um... uma mochila, aí ele fala: "Essa mochila é da Letícia”, da irmã dele, entendeu? Às vezes ele pega um certo objeto e ele fala de quem é o objeto, entendeu? Então, creio eи que sim.

Entrev. - Desde quando? 
M. - Desde quando? Que ele começou a falar, perceber os objetos de quem são? Há mais ou menos um ano. Mais ou menos com cinco anos ele começou a.... eu comecei já a passar isso pra ele, né?

Entrev. - E ele se chamar de Augusto? Desde quando ele fala "o Augusto" pra ele mesmo?

M. - Desde sempre. Desde pequenininho.

Entrev. - Quantos anos?

M. - Que ele começou a pronunciar que ele era o Augusto? Acho que de uns dois anos pra cá que ele começou a usar.

Entrev. - Então, a partir de quatro anos, mais ou menos?

M. - Não. O “Augusto" com dois anos.

Entrev. - E não passou a falar "eu”?

M. - “Eu”... por a gente falar tudo era "o Augusto”, ele começou a escutar só "o Augusto”, entendeu? Passa alguém na rua: “Oi, Augusto!”... “Bom dia, Augusto!” É... se eu vou falar com uma das minhas filhas, eu falo: "Filha, não mexe, é do Augusto". Então, ele, pra ele, ele usa não “eu”, ele usa “o Augusto”, entendeu? Aos poucos eu vou corrigindo. Às vezes ele fala: "O Augusto está com sede”. Aí eu falo: "Então fala: eu estou com sede”. Aí ele vai e repete, entendeu? Mas geralmente ele usa “o Augusto”.

Entrev. - Ele percebe quando uma pessoa ou um objeto não estão mais no lugar?

M. - Percebe. As pessoas ele corre. Se a irmã vai na ponta dos pés brincando de escondeesconde com ele, se desloca na ponta dos pés, ele pára, escuta e vai correndo...

Entrev. - Até onde ela foi?

M. - Às vezes ele acerta pelas risadas e às vezes ele... dá um cheiro (ruído de cheirar) assim... se ela tá de perfume, ele corre atrás e consegue localizar ela.

Entrev. - Desde quando?

M. - O cheiro ele sempre usou. Tudo o que ele vai pegar, ele cheira primeiro. Antes passa a mão pra ver o que que é e depois cheira. Acho que um ano e meio pra cá ele começou já.

Entrev. - Desde os quatro...

M. - Por aí.

Entrev. - Então ele sabe pra onde as coisas foram? Ele procura, pergunta e vai... 
M. - Sim, ele brinca de esconde-esconde.

Entrev. - E se, por exemplo, tem uma bola, um brinquedo, também ele identifica? Se a coisa saiu e tá guardada em outro lugar, ele sabe? Se você fala bola...

M. - Sim. Às vezes... tem uma caixa cheia de bugiganga, cheia de brinquedo, cheia de brinquedo. Ele vira, ele quer um brinquedo lá que ele escolheu naquele dia. Ele passa a mão em tudo; se não tá, ele fala: “O Augusto quer tal brinquedo”. Eu olho no chão e ele não tá lá, entendeu? Ele procura o brinquedo que ele quer e se não tá lá... às vezes tá na sala, às vezes tá num dos quartos. Aí eu vou lá e falo pra ele onde tava e pergunto se é esse, ele fala quéé.

Entrev. - E se você fala: "Augusto, vai buscar a bola", por exemplo...

M. - Se ele escutar o som da bola, pra onde ela correu, ele começa a buscar. Na maioria das vezes ele encontra.

Entrev. - Desde quando ele é capaz disso?

M. - A procura do brinquedo que ele deseja, em busca do que caiu... (pausa) Eu creio eu que foi do ano passado pra cá, porque eu tô em casa, aí tô me dedicando mais a ele. Até então... entendeu? Do ano passado pra cá. Não sei se é tarde...

Entrev. - Então ele sabe que a pessoa ou o objeto continuam existindo, mesmo que não estejam lá com ele? Ele tem essa consciência?

M. - Sim. Às vezes a gente sai, às vezes passa tempo sem o pai dar um telefonema, e aí ele fala, às vezes a gente passa... desce do ônibus e passa num local, ele escuta alguém falando no telefone, ele fala: “Augusto quer ligar pra alguém”. Então, às vezes, ele pede pra telefonar, entendeu? Ou pro pai, ou pra tia, quer ir visitar. Às vezes ele pede pra ir pra casa...

Entrev. - Se você fala: "Vai buscar o meu chinelo que está lá no meu quarto... ou qualquer coisa dele... você fala a palavra e ele sabe o que é?

M. - Ó, eu tranquei o portão, porque tem que varrer a frente da casa lá. Aí eu falei: “Augusto, vai em direção à mamãe e me traz a vassoura, está próxima à porta da cozinha, na garagem. Não é pra entrar". Ele foi reto, pôs a mão na porta da cozinha. Aí eu falei: "Então, tá do outro lado”. Aí ele foi, pegou a vassoura e me trouxe.

Entrev. - Então ele sabe e percebe o que se passa à volta dele. Ele não é uma criança alheia... 
M. - Alheio... o que é alheio pra você?

Entrev. - Indiferente ao que está acontecendo ao redor.

M. - Não, ele percebe os sons, tudo. Passa um cachorrinho, algum conhecido assim, ele fala quem é e... sempre. Pela voz, ele percebe tudo em volta.

Entrev. - Ele entende o que tá acontecendo e o que é dito pra ele?

M. - Sim. Quando eu passo a conversar com ele, sim.

Entrev. - Você lembra, quando ele era bebê, se você dava significado pras coisas que aconteciam? Você explicava pra ele? Você dava nome pras coisas?

M. - Quando bebê, não. Só o chocalho... é, o chocalho e o pianinho, né? Eu falava o que que era que dava sons, falava pra ele o que que era e ele ficava brincando, né? Mas na maioria das vezes ele quebrava... (voz de dó, risada) Brinquedo não dura muito na mão dele, não. E não tem que tá inteiro. O brinquedo tem que tá aos pedaços. Às vezes, aos pouquinhos, eu vou me desfazendo de algumas coisas e jogando fora, coisas que eu sei que ele não vai perceber, porque se eu vejo que um pedacinho de um negocinho lá, de um brinquedo, que ele tá sempre brincando e deu um nome praquele brinquedo, então não posso jogar aquele lixinho fora. E ele quebra. O brinquedo pra ele não pode ficar inteiro, tem que sair destruindo os brinquedos. E eu falo, eu explico pra ele: “Ó, você quebrou”, e eu passo a mão... E pra ele tem que tá aos pedaços. Uma carreta que tava guardada lá há dois anos, a psicóloga falou: "Mãe, ele vai passar a fase de brincar e não vai brincar. Mesmo que ele quebre, é pra dar”. Eu dei e não durou duas horas. (voz amargurada e uma risada). Ele quebrou todinho, arrancou as rodas... ele brinca com as rodas soltas, mas no carro ele não brinca. Senta em cima, entendeu?

Entrev. - E esse brincar, como que é? Se ele pega essa roda, qual é o jeito de brincar?

M. - O brincar tanto é assim, que eu te falei, o mesmo gesto passando no rosto. Ás vezes eu sento junto com ele, mostro pra ele que é de rodar, tudo. O brincar dele é mexendo, procurando e sempre gesticulando o mesmo gesto...

Entrev. - Ele não inventa uma brincadeira de faz-de-conta?

M. - Não, não. Às vezes ele fala: “Augusto quer ir pra escola”. Aí, quando eu sei que ele quer escrever, eu dou papel e caneta e ele fica: rabisca, rabisca, rabisca a folha até... daqui a pouco, quando eu penso que ele tá... ou também ele se risca ou ele começa a amassar, dobra, dobra, dobra, quando tá fininho, começa a esfregar de novo... 
Entrev. - Se estimular no rosto...?

M. - Novamente.

Entrev. - E com que idade ele começou a emitir sons pra falar?

M. - Meses....

Entrev. - E palavras?

M. - Palavra... foi mamãe, mamãe, papai, com a mesma idade das outras, com seis, sete meses já começou. "Que papá”, "papá”, entendeu? Ou então "cocô”. Cocô ele me deu um pouquinho de trabalho pra sair das fraldas. Mas ele sempre falou assim. Não um diálogo, né? Ou: "Eu quero tal coisa”. Geralmente eram palavras, assim, picadas, uma palavra por vez.

Entrev. - E você entendia?

M. - Sim. A gente que convive, entende. Não tem o que não entender.

Entrev. - E a fralda, por que você disse que deu trabalho?

M. - Porque, assim: eu não conseguia tirar ele da fralda. Mesmo deixando ele sem fralda, ele aprontou bastante. Ele saiu das fraldas com cinco anos.

Entrev. - Quando você começou a fazer o treino?

M. - O treino? Desde os dois... é, por aí. Mas antes disso, com um aninho, eu já comprava, já tinha comprado piniquinho, tudo, mas ele não avisava, não falava "eu quero xixi”, “eu quero fazer cocô". Não avisava, entendeu? Aí, aos poucos, até hoje às vezes ele quer fazer xixi e fala que não. Eu falo: "Você tem certeza? Tá, bom, então. Então vem cá. Vamos ali com a mamãe só pra ver”. Aí ele senta e às vezes ele faz. Eu não sei se é preguiça, não sei se ele não quer sair daquele local, entendeu?

Entrev. - Mas hoje...

M. - Ele já tem controle. Às vezes eu tô no metrô e ele fala: "Eu quero fazer cocô". Aí eu falei: "Então você vai esperar chegar no local”, ou no Laramara, ou no banheiro mais próximo, e ele sabe esperar tanto cocô, que é o meu pavor, que eu tenho medo dele fazer na roupa, às vezes eu saio desprevenida e não trago roupinha pra ele, e o xixi. Os dois ele controla e espera chegar no local e faz. Ele só não se limpa sozinho. Eu ainda limpo ele. Não sei se eu tô errando, ainda, né?

Entrev. - Você tá ensinando? 
M. - Não. (risos) O cocô eu ainda limpo. O xixi eu já peço pra ele... normal de homem, né? Balançar e dobrar assim o papel, ele vai...

Entrev. - Ele fica em pé pra fazer o xixi?

M. - Fica, e às vezes fica sentado, porque a minha filha ensinou a fazer sentado. Aí eu falo que homem tem que fazer pipi em pé. Aí ele vai e, às vezes, fica em pé.

Entrev. - A maior parte das coisas com o Augusto você disse ter feito igual com as outras filhas. Mas tem algumas coisas que você não fez igual...

M. - Porque eu pensei que, por ele ser deficiente.... eu não precisaria me preocupar em ensinar tão cedo. Eu achei que eu ia tá ajudando ele, que era tudo pra... tudo o que eu iria ensinar, por ser deficiente, eu achei que era assim. Eu achei que eu deveria retardar o ensinar, entendeu? Em vez de eu ensinar o mais cedo pra ele ser mais independente, eu retardei tudo.

Entrev. - Por que você achou que com o deficiente tem que retardar? O que é deficiente pra você?

M. - Deficiente pra mim é uma pessoa que depende do outro. Eu achava que era isso. Eu achava que o deficiente dependia, né? Por ele não enxergar, é... lógico, a gente tem como passar a ensinar coisas. Quando você enxerga, você tem estimulação da visão, cê tá vendo o que certo e o que é errado. Quem não enxerga, você tem que passar a ensinar e a falar a usar o tato. E eu achava que não, que quanto mais cedo era bobagem, que eu poderia esperar mais, pra não judiar... tudo bobagem da minha cabeça. Tudo bobagem... pelo contrário, eu tava prejudicando ele. Acho que se eu tivesse pego com ele normal... Não, o Augusto tá normal pra mim, entendeu? Talvez ele hoje fosse uma criança bem mais calma e bem mais independente.

Entrev. - Por que você diz isso?

M. - Sei lá... Pela deficiência, eu fui colocando fralda, fralda... "Ah, ele é deficiente. Enquanto eu tiver saúde e Deus me der saúde, eи vou cuidar dele. Ele não precisa se preocupar em ir no banheiro tão cedo, por ser deficiente”. Eu achava que, quanto mais tarde, melhor pra ele. Então foi aonde eu falo muito do meu erro, porque eu sei que eu errei bastante, mas... (rindo) nesse sentido, entendeu?

Entrev. - Você já disse que o Augusto compreende o significado das palavras, as frases que você usa... mas como é que ele mostrava ou mostra o que ele quer e o que ele gosta? 
M. - Ele pede. Hoje ele pede.

Entrev. - E quando ele mostra o que ele sente? Quando era bebê, você disse que ele chorava quando era fome, por exemplo... Enfim, ele mostra o sentimento dele?

M. - Sim, às vezes ele passa a mão no meu rosto e fala: "O Augusto ama a mamãe", entendeu? Eu tenho o hábito de sempre, ao dormir, pegar a Bíblia. É só eu deitar com ele, que ele dorme comigo (hã, hã), ele já fala: “Lê a Bíblia. O Augusto quer escutar a Bíblia”. Aí eu vou... às vezes eu vou repetindo frases da Bíblia, uns salmos, ele repete tudinho junto comigo. Às vezes, ele só deita e eu fico lendo a Bíblia pra ele, entendeu? Ele gosta muito. Então, quando ele quer algo, ele pede.

Entrev. - E se ele tem dor, se ele fica triste...

M. - ... ele chora, se tá doendo, ele fala que tá doendo. Eu nunca vi o Augusto triste. No canto, triste, eu não sei o que é triste, pro Augusto. E eu acho que ele não sabe. Porque, ou ele tá com dor, ou ele tá feliz e, geralmente, noventa por cento, feliz. Ou ele tá sentindo alguma dor... com essa medicação que ele tá tomando, que às vezes, o efeito colateral dá uma dorzinha, mas é uma coliquinha tão fraquinha, que ele fala: “Dá um beijo”. Aí, quando eu dou um beijo, ele fala: “Sarou”. Aí já sai pra brincar, entendeu? Então, é assim. Dor, mesmo, é muito raro. Só quando ele se machuca mesmo, pega algo cortante, que eu tô sempre de olho, né?

Entrev. - Como você responde ao que ele mostra sentir e querer?

M. - Como é que eu respondo? Se ele...Se ele pede uma água, eu falo: "Aguarda um momento" e vou buscar...

Entrev. - Você sempre dá uma resposta?

M. - Sim, eu tenho que dar. Se ele pediu, eu vou ter que dar, ou sim, ou não, mas alguma resposta pra ele eu tenho que dar.

Entrev. - E quando ele era bebê e você percebia alguma reação nele, o que você fazia?

M. - Reações, vocêfala, de sorriso, de choro?

Entrev. - É, por exemplo...

M. - Ah, de choro eu sempre ia ver. Olhava, tava sequinho, normal. Se tava com a barriguinha cheia, né? Não é fome. Então, assim, eu apertava a barriguinha, o ouvidinho, 
não alterava, o choro não modificava... a hora que eu pegava no colo, parava, falava, então a gente que é mãe, a gente percebe quando é choro de manha, quando é choro de fome.

Entrev. - Você falava com ele?

M. - Aí, às vezes, eu pegava um pouco no colo e, às vezes, eu falava: "Você quer colo?" E aí ele já sorria e me abraçava, quer dizer sim, entendeu? E algumas vezes, quando eu estava ocupada, que eu não tinha como segurar, eu colocava no andador, no carrinho, não tinha como você deixar uma criança chorado. Não é porque ele é cego.

Entrev. - Você ia falando com ele...

M. - Sim

Entrev. - Ele tem noção de tempo, da seqüência dos acontecimentos?

M. - Como no Laramara, antes... eu não passava pra ele o que a gente ia fazer durante o dia, né? Mas aí o Laramara me ensinou a fazer um calendário e passar pra ele o que vai ser feito durante o dia, qual vai ser a rotina dele naquele dia, pra ele não ficar... é... como é que eu vou te explicar... pra ele não ficar perdido, pra ele não saber, o que vai ser aquele dia não ser uma surpresa pra ele. Então, pra rotina dele ser: “Bom dia, Augusto, vamos escovar os dentes, depois a gente vai fazer a refeição"... e assim vai indo, eu vou passando pra ele, eu antecipo pra ele tudo. Eu antecipo pra ele o que vai ser feito durante o dia, o que vai vim depois, entendeu? Até escovar os dentes dele eu escovo ainda, você acredita nisso? Por que? Porque ele segura a escova e balança a cabeça. Aí eu fico agoniada...

Até escovar os dentes dele, eu escovava (rindo). Não é mais um erro meu, entendeu? (rindo) Porque eu tinha preocupação com os dentes do fundo, e como ele só fica nos da frente, eu abro a boquinha dele. Quando eu vou dar banho nele, a maioria das vezes quando ele toma banho, eu dou a buchinha, dou o sabonete, ele passa a buchinha, já tem um pouco de coordenação motora...

Entrev. - Como é que você fazia com as suas filhas para ensinar a escovar?

M. - É... por ser pequena e ter a visão, junto com ela, as primeiras vezes eu... escovava e falava como que é, e depois eu ia escovando junto e ela ia fazendo junto. Com o Augusto, por ele não ver, eu acho mais fácil eu escovando, entendeu? Mas aí é pior, porque quando ele entrar na escolinha, ele não vai nem saber nem comer direito, nem escovar, entendeu? Aí, agora eu tenho esse mês de janeiro e fevereiro para eu corrigir ele nisso aí tudo. 
Entrev. - É o que se costuma fazer: deixar a criança fazendo sozinha e depois vamos lá e terminamos... como no banho...

M. - É o que eu tô fazendo agora, tanto no banho como na escovação também. A meia eu coloco até na metade, depois ele puxa, tem que ser assim, devagar.

Entrev. - Voltando à questão do tempo... Ele sabe o que é ontem, hoje, amanhã?

M. - Ah, o amanhã ele sabe, porque eu preparo ele na véspera, né? "A gente vai em tal lugar, e agora a gente vai dormir, Augusto, porque amanhã cedo...” e ele já sabe. Na primeira vez. que eu chamo cedo, ele já pula, senta e já sabe que vem pro Laramara. Ele gosta muito daqui. A hora que ele sair daqui ele vai sentir muita falta.

Entrev. - Ele compreende o que aconteceu e porque aconteceu algo?

M. - Se de repente cair algo, eu falo. Sim, ele sabe que caiu.

Entrev. - Ele sabe que caiu. E ele sabe porquê caiu?

M. - Sim, se eu falar e, algumas vezes, dependendo se ele faz, ele sabe.

Entrev. - E quando é ele que provoca o acontecimento, ele sabe?

M. - Sabe.

Entrev. - Se ele joga alguma coisa, ele sabe que jogou?

M. - Sim, sabe.

Entrev. - Ele sabe então que foi ele que provocou?

M. - Sim. Ele sabe.

Entrev. - Ele sabe a diferença as semelhanças entre as coisas? Por exemplo, se você dá uma maçã e uma laranja, ele sabe que uma é maçã e a outra é laranja?

M. - Sim, ele tanto cheira e fala o que que é, como na mordida, no começo, sem você precisar falar. Batata frita, tem gente que diz que tem cheiro, tem gente que diz que não. E eu só no cortar a batata e por no óleo, ele já chega e já fala: "Hum, Augusto quer batata frita", entendeu?

Entrev. - E ele sabe que laranja e maçã são frutas? Apesar de serem diferentes ele sabe que são frutas? 
M. - Sim, ele põe a mão em cima e fala. Ele só se atrapalha um pouquinho, por exemplo, na laranja com o limão, que são redondos. Pra ele, só diminui o tamanho, e aí quando eu corto e ele passa a língua, aí ele já sabe que é azedo, e aí já sabe.

Entrev. - E ele sabe pra que servem os objetos? Por exemplo, se ele pega um copo ele sabe pra que é?

M. - Ele sabe que é pra beber água.

Entrev. - Se ele pega uma colher, uma toalha, um sabonete...

M. - Sim, sabe que é pra banho. Sim, sabe. Não sei se ele vai poder se expressar, ele tem dificuldade no diálogo. Mas, assim que ele sai do banho eu falo: "Augusto, pega a toalha e se seca”. Então ele já sabe, tem noção.

Entrev. - E ele conhece a rotina? Ele mesmo a antecipa?

M. - Se ele fala algo... às vezes ele fala o que gostaria de fazer, mas não o que deve ser feito.

Entrev. - Que já está na hora...

M. - Não, às vezes eu falo: "Augusto, bom dia, nós vamos tomar café”. Aí ele vai, desce, às vezes ele não quer, mas ele não tem fome na hora que levanta. Ele fica sentadinho, às vezes ele quer ouvir televisão, ele pede. O que ele quer naquele momento, ele pede, e ele sabe. Aí depois eu falo: vamos por o tênis que a gente vai tomar um solzinho, vamos sentar na balança. Aí ele já adora, já sorri, entendeu?

Entrev. - Ele sabe se vestir sozinho?

M. - Mais fácil pra ele é tirar. Ele tira tudo que tem no corpo. Pôr, ele talvez, ah... oh... ele tem certa dificuldade, mas ele tá conseguindo agora vestir a camiseta e a calça. Às vezes coloca as duas perninhas de um lado só, e ele fala: "Está errado". Aí ele mesmo tira e coloca do lado certo.

Entrev. - Bem, você já falou da higiene, da alimentação, do que ainda ele não faz sozinho...

M. - E ao dormir, às vezes a gente acha que é hora de ele dormir e ele não quer. Então a gente deita, às vezes eu começo a ler a Bíblia, tudo, e ele começa a inventar: "Eu quero fazer xixi”. E eu: “Augusto, você não quer”. "Eu quero". "Então tá, Augusto, desce lá e vai fazer xixi no banheiro". Às vezes ele vai até o banheiro, levanta a tampa do vaso e faz xixi. Às vezes ele finge que não quer, finge que quer, e fala pra mim que quer, mas não quer, eu sei que não quer, entendeu? Aí ele desce, senta na sala e as minhas filhas falam: "Ó, mãe, o 
Augusto tá sentado aqui. Não é hora dele dormir?". Aí eu falo: "Augusto, sobe". Aí ele vai e sobe. Quando ele deita de novo, ele fala: “Augusto quer fazer xixi”. Ele fica me enrolando pra não ir pra cama, entendeu? E eu percebo que o modo de ele sair, se deslocar da cama, é mentindo pra mim e falando que ele quer ir ao banheiro, quando ele não quer. E ele é assim. Tem horas que ele finge.

Entrev. - Você já falou do desenvolvimento motor... coisas como sustentar a cabeça, sentar, engatinhar, andar, pular, subir e descer, rolar, chutar, carregar, pegar e dar objetos... tudo isso...

M. - Normal.

Entrev. - Que ele localiza as pessoas e objetos no espaço, percebe que as coisas se deslocam...

M. - Sim.

Entrev. - Ele conhece as partes do corpo dele... nomeia?

M. - Todas.

Entrev. - E nos outros?

M. - Sim, porque eu ensinei.

Entrev. - E como é o contato dele com o próprio corpo?

M. - Às vezes ele quer ficar sempre sem roupa, sempre. Chega em casa, vai tirando tudo. Às vezes tira até a cueca. Aí eu falo pra ele que o pipi não pode ficar de fora, ele põe pelo menos a cueca, quando ele tá com muito calor, né? Ele não gosta muito de ficar de tênis, porque eu achava mais fácil pôr a papete ou o tênis dele, nunca havaiana. Eu comprei havaiana tá com meses, a primeira havaiana dele. Era só papete, tênis, papete, tênis. Eu achei até que ele não ia conseguir andar. Mas, o que! Durante a semana, ele já começou a andar com o chinelinho havaiana e tudo. Mas ele é mais descalço em casa e com o pipi de fora. Toda hora você tem que tá pedindo pra ele pôr a roupinha, entendeu?

Entrev. - Ele se masturba, fica se estimulando?

M. - Fica. Mexendo no pipi? Fica.

(Pausa) 
Entrev. - Você já falou sobre os movimentos repetitivos de roçar os objetos no rosto, mais popriamente no queixo... E sobre quebrar tudo... Ele quebra independente de ter acontecido alguma coisa?

M. - É... ele quebra, porque se, de repente, ele quer aquela rodinha pra ele, ele começa a bater o carrinho, até soltar aquela peça que ele quer.

Entrev. - Você chama isso de agressividade?

M. - Não, né?

Entrev. Ele parece quebrar com a intenção de obter o pedaço...

M. - Isso.

Entrev. - Agora, se ele tá bravo, ele reage com agressividade?

M. - Reage. Ele fica nervoso, faz assim, trava os dentes e se de repente a irmã tá próxima e ele sabe que tá ali, ele desconta nela, ele quer bater nela, ou então ele vai na geladeira. Uma coisa que eu acho que não...

Entrev. - Aí a agressividade é intencional?

M. - Sim.

Entrev. - Quando ele está ansioso, também ele faz isso?

M. - Não, não. Quando ele quer algo, quando ele tá ansioso, que ele deseja algo, eu sento com ele, e só falo: "Augusto, você espera". Quando eu posso, eu tenho condições, eu falo. Ontem eu saí com ele, eu só fui da minha casa ao... no mesmo bairro, só comprar algo no supermercado, e ele já queria vim pro Laramara. Eu falei, expliquei: "Nós vamos no supermercado. Mamãe te trocou falando que a gente ia no supermercado”. Aí ele desceu e falou: "Tá bom. Você me compra...", só que ele não pede. É assim, ele fala: "O Augusto quer Danone”. Só que antes ele pediu bolacha. Eu fui lá, comprei a bolacha, expliquei pra ele, dei pra ele, passamos no caixa, pagamos. Aí eu falei: "Cê pediu a bolacha, a mamãe deu porque pôde comprar a bolacha”. Quando entramos no ônibus ele pediu Danone. Eu falei: "Mas você pediu pra mamãe a bolacha, você não pediu Danone. Então você vai comer a bolacha”. Ele ficou quietinho e comeu a bolacha, entendeu? Nem sempre eu posso fazer o que ele pede, na hora que ele quer, também.

Entrev. - Com quem ele brinca?

M. - Com as irmãs... e comigo. 
Entrev. - Como é essa brincadeira?

M. - Com bola.

Entrev. - Ele aceita?

M. - Na boa! Às vezes, pra mim ficar mais próximo dele, ele fica na minha frente e fala que quer "assim". Aí ele quer que eu ponha as mãos por trás dele, segurando nos braços deles, pra na hora que a bola vir, eu já direcionar ele a agarrar a bola, entendeu? E ele ri pra caramba, quando a gente brinca assim. Ele gosta.

Entrev. - Ele brinca com criança da idade dele?

M. - Brinca...

Entrev. - Como é a relação dele com crianças?

M. - Da idade dele não. Ele brinca... com as coleguinhas...

Entrev. - Ele se relaciona com elas, procura, chama, interage?

M. - Chama, chama. Às vezes canta a musiquinha do "tchau, tchau" ou aquela que a gente inicia o trabalho, com o nome de cada uma delas. Ele pede, mas a V. (profissional da instituição) falou pra mim que eu tenho tanto medo da agressividade, que quando chega uma criança próxima a ele, eu tô sempre com meio... tiro ele de perto. Eu preciso trabalhar esse lado meu. Tudo... o medo dele machucar é tamanha, que eu acabo entrando no meio. Não sei se ele vai agredir ou não, mas eu já vou logo me prevenindo, me precavendo, não deixando ele se aproximar, entendeu? (rindo). Quando eu sei que a criança é uma criança como nós, que tem autodefesa, tudo, eu deixo, porque eu aviso, eu deixo. Porque a criança já sabe que ele em esse lado dele... de repente, assim, do nada, ele agredir. Mas quando é uma criança que tem um certo problema mental ou tem uma certa deficiência que não tem como perceber que ele vai agredir, eu tenho que entrar no meio. Ou então eu aviso a mãe. Aí, cabe à mãe ou não. Mas que eu tô sempre ali protegendo, com medo, eu tenho (rindo). Não sei se é exagero, mas infelizmente eu sou assim.

Entrev. - Você disse que ele não brinca de faz-de-conta...

M. - Ele gosta de ouvir historinha...

Entrev. - Você ensina a brincar de faz de conta?

M. - Não. Ensinar... Não. Não ensino. Eu precisava sentar com ele, pra incentivar esse lado dele, né? Mas eu já cheguei já, carrinhos a fazer som, tudo, mas ele já toma e fala que não, 
bate, quer arrancar as rodinhas. O modo dele brincar é diferente. Motoca eu empurro, falo pra ele que é de brincar, tudo. Ele gosta de gangorra, coisas de parquinho. Aí ele gosta.

Entrev. - Mas inventar uma brincadeira criativa em cima daquele objeto, não?

M. - Não, não.

Entrev. - A criança pode, por exemplo, pegar um pedaço de pau, subir e fazer de conta que é um cavalinho: "Olha o meu cavalo! Eu vou passear a cavalo!". Ou pegar uma boneca e falar: "Ó o nenê, vamos fazer o nenê dormir..."

M. - Se eu deito no tapete, ele: "Vira, mamãe, vira”, aí eu viro. Quando eu viro, ele monta e fala: "Agora vamos, vamos brincar de cavalo". Aí eu começo a andar no tapete de quatro e ele morre de rir em cima de mim, entendeu? Assim ele brinca.

Entrev. Mas se pegar um bichinho, um ursinho, fazer de conta que é o nenezinho dele... "dorme, nenê..."

M. - ... fazer de conta que é... os sons, não...

Entrev. - E você não tem feito com ele?

M. - Não.

Entrev. - Já vimos que ele não se chama de "eu", ou raramente ele se chama de "eu". Ele usa a expressão: "pra mim"?

M. - Sim. A maioria...

Entrev. - Não é "pro Augusto”?

M. - Ele tá agora: "Dá pra mim" e "pro Augusto", aí ele tá usando "mim”, tá usando bastante agora.

Entrev. - O “me dá”, "isso é meu”... Ou: "Isso é do Augusto”?

M. - Sim. Às vezes ele fala: "Isso é meu” e às vezes ele fala: "Dá pra mim" também.

Entrev. - Está começando a aparecer agora?

M. - Está.

Entrev. - Fale um pouquinho mais especificamente como é a relação dele com os adultos e com as crianças. 
M. - Ah, com os adultos, sempre que ele fala: "Dá a mão", às vezes eu saio na rua, tá a vizinha lá, ele escuta o som, ele já quer, ele já fala o nome da pessoa e ele já quer ir na casa e vai, ele se desloca até a cada daquela pessoa...

Entrev. - Ele diz “Oi!”, quando chega? Como é que ele se dirige às pessoas?

M. - Ele já chega e fala: "Izilda!”, o nome da pessoa. Ele pronuncia o nome da pessoa que ele tá ouvindo a voz, ele já fala quem é, entendeu? Aí, assim que ele fala o nome da pessoa, ele fala: "O Augusto quer a Izilda”. Ou então: "O Augusto quer entrar na casa da Izilda". Ele não usa "eu quero". A maioria das vezes, quando ele se desloca, assim, que ouve algum adulto, passa alguém na rua, ele vai e fala: "O Augusto quer passear com a Izilda. Vamos, Izilda, passear com ele, vamos, Izilda?”. Aí, a Izilda vai, pega na mãozinha e começa a rir, e fala: “O que que você quer, Augusto?”. "Ah, Augusto quer passar com a Izilda. Sai de perto, mamãe, sai de perto!”. Aí, quando tem alguém assim, ele manda eu embora, ele quer que eu saia de próximo dele. Aí eu vou e saio. Por que? Pra não pôr ele pra dentro de casa.

Entrev. - E com as crianças? Ele as chama pelo nome?

M. - Chama o nome delas, chama. Se ele escutar a voz, ele já sabe quem é, ele chama e quer brincar com ela. Às vezes eu coloco dentro da garagem, brinca, coloco o tapete lá, ele brinca com as crianças, mas da idade da minha outra filha (maiorzinha). Dá idade dele não.

Entrev. - Ele imita alguém ou alguma coisa?

M. - Ele imita som de bichos, né? Como é que o gatinho faz? Porque, às vezes, eu conto historinha da Branca de Neve, tudo. Então, eu fiz muitos sons pra ele, né? Então ele conseguiu memorizar bem, o som dos bichinhos, tudo.

Entrev. - Ele aceita contato físico como beijo e abraço?

M. - Sim.

Entrev. - Aceita quando você diz "não", ou seja, quando você põe limite?

M. - Quando eu saio com ele, eu ponho limites, ele sabe e fica quietinho, não dá trabalho nenhum.

Entrev. - Como ele reage nas situações ou com pessoas e objetos desconhecidos?

M. - Ele pergunta: "O que que é isso?” Eu ri pra caramba anteontem, porque o tempo fechou e veio o trovão. Aí ele olhou e falou: "Mamãe, o que que é isso?" E eu tava com a TV ligada, não consegui escutar muito. Aí eu falei assim: "O que que você quer saber, 
Augusto?". Aí, de novo, veio mais forte. "Que que é isso, mamãe?”. Eu falei: “É o trovão”. Aí, ele abriu a porta da cozinha, saiu pra garagem, pra escutar de novo. A hora que veio mais forte, ele correu, mas ficou entre a cozinha e o outro pé na garagem, com medo de... Do barulho. Aí eu falei: "É a chuva e esse som, Augusto, é o trovão. Cê tá com medo?” Ele disse: "Tô". Falei: "Então fecha a porta”. Aí fecho. Mas ele insistia em abrir, foi até lá fora. Aí ontem choveu de novo, fez o trovão, ele não teve mais medo (rindo).

Entrev. - E as pessoas estranhas, você diz que ele não ia...

M. - Não. Qualquer pessoa estranha que chegar lá... “quem é?”... ele quer saber o nome. Sabe, ele tenta puxar assunto, mas é aquele negócio: ele puxa, puxa, se a pessoa se aproximar muito, assim muito próximo. Sabe aquelas evangélicas que chegam, às vezes, nas horas que a gente tá mais ocupada, aquelas Bíblias na mão, o Augusto deu um soco numa, lá, muito próximo, sangrou a boca dela. Nunca mais ela se aproximou perto do meu portão (rindo). Eu expliquei pra ele que não podia, tudo, entendeu?

Entrev. - Voltando a falar de como ele expressa os sentimentos... amor, raiva, dor, carinho, aborrecimento, cansaço, satisfação...

M. - Quando ele tá cansado, ele quer colo. Ele fala: “Eu quero o meu colo”.

Entrev. - ... Angústia, frustração, ansiedade, medo...

M. - Ah, eu não sei. O medo ele fala: “Eu estou com medo”. Agora ele tá falando. Ansiedade é... é mais assim o pedir, entendeu? Quando ele quer muito ir pro Laramara, ele começa a ficar ansioso, porque ele gosta muito daqui, ele pede. Aí eu explico pra ele que tal dia a gente vai e ele deita quietinho e espera mesmo naquele dia, entendeu?

Entrev. - Ele tem medo do que?

M. - No caso aí do trovão, ele teve medo.

Entrev. - E de outras coisas?

M. - Só. Às vezes eu me apavoro, porque a minha janela é alta, a parte de cima, e ele quer sentir o vento. Então ele abre a janela e eu tô lá fora, eu chamo uma delas, elas vão correndo, aí elas falam que se machuca, mas ele quer ficar com o rosto... e lá embaixo e ele fica só sentindo o vento. Aí... quer sentir o vento. E ele sabe que é o vento que tá batendo no rosto dele, entendeu? Mas tô sempre de olho nele nesse sentido, pra ele não se machucar.

Entrev. - Como é que ele aprende? 
M. - Como é que ele aprende? Às vezes ele pergunta, se é alguma coisa nova, ele pergunta o que que é, ou o que é isso, ou como... não sei. De alguma forma ele pergunta, né? Se é um objeto, ele chega e fala: “O que que é isso?”, pra mim falar o nome. Se é comida, ele põe na boca e fala: "O que que é isso?” Aí eu falo pra ele o que que é. Se é uma salada de cebola com tomate. Quando ele não gosta, ele fala assim: "Não gostei”, né? Com a boca cheia, aí eu vou e pego, vamos pôr no lixo, quando ele não gosta, entendeu?

Entrev. - Quais são os pontos fortes do Augusto?

M. - Pontos fortes?

Entrev. - Coisas positivas...

M. - Positivas nele? Eu acho que ele tem assim, uma facilidade muito boa de memorização. Ele escuta e ele consegue memorizar muito fácil... ele já teve um lado agressivo. Hoje, eu acho que ele já está bem mais carinhoso, bem mais amoroso, né....

\section{(Pausa)}

Entrev. - E as dificuldades do Augusto?

M. - Maior dificuldade dele? Que eu acho é acabar esse lado dele agressivo, que eu queria que acabasse. Dele querer agredir uma pessoa que quer dar carinho, e ele querer retribuir com agressão, que eu não consigo saber o porque que ele agride. A minha dificuldade é só essa, com ele. Fora isso, ele é um filho maravilhoso.

Entrev. - E em relação à escola? Vc. me disse antes da entrevista que ele nunca foi pra escola. Por que?

M. - Eu achava que... quanto mais tarde ir pra escola, melhor, devido a essa agressividade dele. Eu tava esperando ele diminuir esse lado agressivo dele, com receio dele ir pra escola e agredir outras crianças, entendeu? Eu comecei a esperar, retardar um pouco a ida pra escola por esse motivo.

Entrev. - E você também disse que está querendo por numa escola especializada...

M. - O Laramara pediu que eu colocasse ele numa escola normal... no EMEI. Só que tô com uma certa dificuldade, porque tá assim: o bairro onde eu resido, o EMEI não está preparado pra aceitar o Augusto, porque a sala tem mais de vinte e oito crianças. Disse que a professora não está nem preparada e nem vai poder se dedicar ao Augusto, porque a escrita 
do EMEI é mais na lousa. E eles falaram que eu não posso pôr o Augusto numa escola, numa sala especial, porque o Augusto fala, anda e escuta. Estou com uma certa dificuldade...

Entrev. - Mudou o quadro clínico dele com o passar dos anos?

M. - Quadro clínico que você fala em que sentido? Da reação dele?

Entrev. - Como ele estava, como ele está hoje?

M. - Ah, depois que eu passei a buscar esse lado psicológico dele e mais a neuro, com a medicação, porque ele não tomava medicamento nenhum antes, aí melhorou bastante. $O$ medicamento está ajudando muito pro comportamento dele. Tá deixando ele menos tenso, menos agressivo, entendeu? E eu espero que, mais pra frente, na escola, ele consiga se adaptar melhor e ter, assim, uma vida mais tranqüila e consiga parar, não precise dessa medicação pra ter uma vida mais saudável, entendeu?

Entrev. - Há mais alguma coisa, M, que você ache importante falar?

M. - Se tem algo?

Entrev. - É. Além do que foi falado, tem mais alguma coisa que você gostaria de falar?

M. - Não. Eu acho que o que foi dito aqui, já foi feito um resumo de toda a vida do Augusto, entendeu? Agora é correr atrás do atraso, como eu já te disse, pra adaptar ele pra ter uma vida normal, porque ele é uma criança normal, entendeu? Simplesmente ele não vê. Fazer o que! Tem uma boa audição, uma boa memória... Então, tá tudo ok, tudo normal.

Entrev. - Ele já adquiriu os conceitos de grande, pequeno, liso, áspero, alto, baixo, em cima, embaixo?

M. - Alto, baixo, que tá em cima, que tá embaixo, ele já tem noção, também. Agora, assim, o que é áspero e liso eu não sei se ele... porque eu nunca cheguei a perguntar, né? Mas eu acho que, se ensinar, ele vai pegar fácil, fácil, também.

Entrev. - M., eu agradeço muito sua colaboração nesta pesquisa! Um trabalho que contribuirá também com o Augusto na instituição.

M. - Imagina... Eu já entendi. Vai ajudar também pra cá, pro Laramara.

Entrev. - Como é que foi pra você essa entrevista? Como é que você se sentiu?

M. - Eu já sabia o que era mais ou menos... Bem à vontade, falei aquilo que foi verdade, porque eu não gosto de falar o que não é verdadeiro, entendeu? Falei aquilo que me deu vontade, mas dentro da verdade. E eu acho que eu não deixei, assim, faltar nada, esconder 
nada do Augusto. O que eu falei aí é tudo, realmente, de fato, ou aconteceu ou acontece, tá bom? Fiquei à vontade.

Entrev. - Uma última coisa... Você falou pouco do seu marido em relação ao Augusto. Como é que foi pra ele o nascimento do Augusto, uma criança com deficiência visual?

M. - Olha, no começo assim, porque, devido as nossas brigas, ele quis me culpar, né? Primeiro ele falou pra mim que eu não era capaz de dar um filho perfeito pra ele, porque o sonho dele era ter um menino. Aí, depois que ele descobriu do Augusto, tudo... e veio descobrir que a causa veio dele mesmo, né? É hereditário, como eu já tinha te dito, é... foi dele mesmo a causa da cegueira, né? Pelo que foi constatado, entendeu? Aí ele passou a me pedir perdão, e passou a aceitar mais o Augusto, né? Falou que o Augusto, pra ele, é uma criança normal, que não tinha problema nenhum, tudo. Mas, devido a nossa crise dentro de casa e até fora, ele acaba descontando nas crianças um problema que é nosso. É onde eu acho que é o erro dele. Hoje, ele só tem falha como pai, entendeu? Eu não queria mais ele como marido, só queria que ele fosse bom pai. Nunca é tarde pra ele mudar. Mas ele não se conscientiza que tá precisando de ajuda e não sou eu que vou ajudá-lo, porque ele já tem outra mulher e tem mais um filhinho, entendeu? Mas sempre que ele vê o Augusto, ele chora muito. Chora que nem uma criança e, assim, de soluçar.

Entrev. - Na frente do Augusto?

M. - Na frente, longe...

Entrev. - E ele fala o que?

M. - Ele escreve, ele só chora.

Entrev. - O que ele escreve?

M. - Ele escreve falando que ama muito ele. Aí eu leio pro Augusto. Mas o Augusto não chama mais o pai, não lembra mais dele. Eu também não fico lembrando. Não sei se eu tô errada.

Entrev. - Ele não convive?

M. - Não. É porque é assim: deixa eu te explicar só um pouquinho. Vou resumir só um pouquinho. Ele fala que me ama, que eu falhei como esposa, tá? Eu reconheço, cheguei a falar. Quando eu falei, ele quase passou mal, porque eu reconheci o meu erro. E foi difícil pra mim reconhecer. Eu tive falhas como esposa. Isso fez ele buscar mulher fora. Quando eu descobri da traição, eu não quis aceitar e pedi que ele fosse embora. Ele foi. Foi, mas tentou 
voltar e eu não consegui aceitar. Quer dizer, em vez de eu tentar ver o meu erro e tentar salvar meu casamento, eu achei mais fácil mandar ele embora. Passou essa fase, tudo. Depois disso, a gente tinha certas recaídas, né? Porque, se eu não consegui me relacionar com nenhum homem até hoje, é porque eu ainda sinto alguma coisa por ele. Mas eu fico na minha. Eu nem busco, nem telefono, nem nada. Se eu lutasse pra reconquistar ele, talvez houvesse a possibilidade dele voltar pra minha casa. Mas eu não sei se eu tô preparada pra aceitá-lo de volta, porque minhas filhas já foram criadas só comigo. Quem determina tudo na minha casa sou eu, hora de entrar, hora de dormir, tudo sou eu. Então, eu não sei se mais uma segunda pessoa, que é o pai delas, inclusive elas falam que não têm pais mais, hoje, se elas tão preparadas pra aceitar de volta. Às vezes, eu converso com elas, pergunto, elas não querem mais o pai de volta na minha vida, elas...

Entrev. - Mas ele não convive, não visita...

M. - Não visita por esse motivo. Por ele achar que ainda gosta de mim. Sempre que ele vem ele quer dar palpite. Tudo o que eu falo, faço, ele revista todas as minhas coisas pra saber se eu tenho foto de homens se eu tenho telefone. Ele tem uma paranóia, que acha que eu tenho outros homens, e eu não tenho ninguém. Mas eu não posso provar isso pra ele. E ele tem outra mulher e não consegue se libertar disso, tá me entendendo? Aí houve algumas recaídas, andei dormindo com ele, tudo de novo. Depois eu parei: "O que é que eu tô fazendo da minha vida? Eu não quero isso pra mim”. Ele fica duas semanas comigo e um ano com a outra. Eu dei um basta nisso. Falei: "Se você me quiser, você vai ter que largar da sua mulher”. E nem ele sabe se tá preparado pra largar da outra, também, que tá tendo crise constante também lá, pra voltar. Ele acha que eu também não vou conseguir aceitá-lo de volta como antes, ele acha que vai ser pior. Por eu não aceitar ele na cama, por eu não dar carinho pra ele em casa, ele não vem ver os filhos. Ele não fala isso pra ninguém... É difícil pra mim. Eu queria que ele viesse em casa, ele podia dormir lá... como pai. Ele quer misturar as coisas. Ele pode não misturar no primeiro dia, no segundo, mas é só dormir, que eu olho, acordo, ele tá lá do meu lado, dormindo, às vezes só me olhando dormir, às vezes fazendo carinho, chora, diz que me ama... Mas que amor é esse? Não é difícil pra gente, que é mulher, aceitar? Eu tô super bem hoje. Eu vejo ele, não tenho mais ciúme dele com ninguém, porque eu tinha um ciúme doentio dele, não tenho mais. Foi difícil? Foi orando, dobrando o joelho, pedindo pra Deus, acho que Deus me libertou dessa doença. Porque eu não amava, eu tinha uma doença por ele. Ele não podia olhar pros lados, que eu achava que tinha mulher. E realmente, de tanto eu falar, ele acabou mesmo arrumando. Eu tenho consciência de que eu fui culpada, mas hoje eu 
tô bem, entendeu? Mas é difícil. Eu queria que ele fosse pai e ele vai se arrepender disso um dia, só que vai ser muito tarde, porque a fase agora que as filhas tão precisando dele, ele não tá junto. Minha filha perdeu a virgindade e eu soube através de outra colega, porque ela não teve coragem de me falar. Eu não posso expulsar ela de casa, nem vou bater, espancar, nem nada. Sentei, conversei com ela, com medo de doença, com medo de gravidez...

\section{ENTREVISTA 2}

\section{Entrevistada: Sra. M. - mãe de Vivian}

Entrev. - Nesta pesquisa estou estudando crianças que nasceram cegas ou que perderam a visão bem no comecinho da vida. É o caso da Vivian, né?

M. - Não. A Vivian já nasceu cega.

Entrev. - Gostaria de começar pedindo pra você me contar a história da Vivian...

M. - Como assim? Como ela nasceu?

Entrev. - A história dela, como você quiser contar. Fale-me da sua filha, da história de vida dela...

M. - Ah, quando a Vivian nasceu, no começo, eu não sabia, né? Durante uns quinze dias que ela nasceu eu não sabia que ela era deficiente visual. Depois que eu voltei no oftalmo, que ele falou pra mim que era. Aí encaminhou para o Hospital São Paulo... Eu fiz todos os exames lá no Hospital São Paulo, quando ele determinou que ela não enxergava nada. Aí encaminhou pra aqui, pro Laramara... Com seis meses de idade eu comecei aqui. No começo era difícil, né? Porque... Sei lá... Eu tinha duas meninas e elas enxergavam. Aí, de repente, vem uma que não enxerga, você não... Foi difícil pra mim bem no começo. Aí depois não! Depois eu fui... Sei lá... Como ela foi crescendo, né, foi desenvolvendo... Aí eu fui me acostumando, também, com aquilo. Aqui mesmo, no Laramara, que eu aprendi muito aqui também. Aí eu fui me acostumando com... Aceitar a gente não aceita, né? Até hoje mesmo, assim... Mas hoje mesmo, a Vivian, pra mim, é uma vida! Se você for fazer mais... as perguntas, pra mim fica mais fácil...

Entrev. - Fala um pouquinho dessa aceitação. Você disse: "Aceitar mesmo, a gente não aceita..." 
M. - Ah, porque é difícil, né? É difícil você... Ah, sei lá... Tem muitas coisas que a gente aceita, assim... Mas, você pensar, a maneira de você viver, você vê seus outros filhos e você saber que ela nunca vai fazer aquilo... assim... enxergar, né? Que nem as minhas outras meninas: uma tem o que... vinte anos, a outra tá com quinze. Então, depois você tem uma pequenininha, tá com oito... vai fazer sete anos... não, tá com sete. Aí... é difícil! Você vê aquilo, por exemplo, o mundo, né? Você saber que ela nunca vai... Ah, que nem... muitas coisas que ela nunca vai participar, né?

Entrev. - Por exemplo?

M. - Ah, por exemplo, assim... Não sei. Não ver o mundo assim que nem a gente vê...

Entrev. - Com os olhos?

M. - Com os olhos. Entendeu? Isso me deixa triste. Às vezes eu fico observando as outras meninas, o que elas fazem... E eu imaginar que tem coisas que a Vivian não vai fazer e você sente que ela tem vontade de fazer. Por exemplo, assim que nem... dirigir carro, né? Ela gosta muito de carro. Então, ela, pra ela, ela acha que um dia... Aí você vai saber que ela não vai fazer aquilo. Então isso entristece a gente, né? Muitas coisas que não dá pra aceitar. Tem que aceita, mas... é complicado.

Entrev. - Você disse: "No começo foi difícil”. O que era mais difícil no começo?

M. - Era você aceitar ter um filho ser deficiente visual. Porque... "Por que eu?" Eu me perguntava, né? Porque que nem... na minha família mesmo eu fui a primeira pessoa que tive uma criança deficiente visual. Então eu via os meus sobrinhos tudo... dos meus irmãos... Que nem na época em que a Vivian nasceu, acho que nasceu... três sobrinhos, tudo normal, né? E por que a Vivian deficiente visual? Então, foi difícil. Pra mim aceitar, foi complicado.

Entrev. - Que sentimentos que você tinha sobre isso?

M. - Ah, eu tinha... sentimento de culpa...

Entev. - ... culpa...

M. - Eu sempre achava que eu era culpada. Por que? Por que a Vivian nasceu daquele jeito? Porque eu via as outras crianças em todos os lugares onde você andava... No médico... todas as crianças enxergavam. Por que a Vivian não? Aí eu ficava me perguntando... que seria por minha culpa, né?

Entev. - Culpa de que?

M. - Ah, não sei... Alguma coisa de errado que você fez. O pessoal tem mania de falar assim, que você faz alguma coisa de errado e... e... como é que fala... assim...? Por exemplo: Deus deu um filho deficiente pra pagar alguma coisa que você fez, ou então... Sei lá! É complicado! Até hoje, às vezes, eu me pergunto... 
Entrev. - Você ainda sente isso? Você ainda se acha culpada?

M. - Às vezes eu acho. É... Às vezes, sim. Assim: quando eu vejo a Vivian brincando, feliz, aí não. Mas tem vez que você tá sozinha, que você vai parar pra pensar, aí eu me sinto ainda... Eu choro... Não pra ela perceber, nem o pai dela, porque o pai dela também não aceita que eu... Que eu me sinta culpada. A gente já fez exame, fez tudo! Foi... Foi detectado que ela tinha tido rubéola, né? Na minha gravidez, eu tinha pegado rubéola. Então, que nem ele fala pra mim... Eu não tive culpa! Mas, às vezes, quando eu tô sozinha, eu me sinto ainda culpada. Eu começo a pensar assim. Às vezes ele sai com ela pra passear, eu fico em casa só, aí eu começo... ainda a me fazer pergunta. Eu queria, assim, que ela fosse igual às outras, né? Que corresse, brincasse, saísse pra onde ela quisesse... Que nem, ela tá com... sete anos, então já dá pra ela fazer muita coisinha sozinha. Que as minhas meninas, as outras, com sete anos já iam pra escola, não sozinhas, mas já iam pra escola, assim... Eu só levava lá e ia buscar. A Vivian, não! A Vivian eu vou levar, vou buscar, cê tem que ficar ali sempre atento, né? E tudo... É totalmente diferente... Entendeu?

Entrev. - E quando você pensa nessa culpa e vem esse sentimento, essa idéia, tem alguma coisa específica que você pense?

M. - Não, não vem, porque na gravidez mesmo... Às vezes alguém me pergunta assim: “Ah, mas vocêfez pré-natal, vocêfez isso, vocêfez aquilo, você usava droga”, né? Não, eu usava... na época eu fumava. Só que eu fumava, mas... Durante a minha gravidez eu enjoava do cigarro, todas as minhas gravidez. Quando eu ficava grávida, eu enjoava do cigarro, né? Mas, às vezes, vinham as perguntas. Muita gente chega pra você e fala assim: "Ah, por que a sua filha nasceu cega? Você usava droga? Você fumava?” Assim... Eu falava: poxa! Eu não bebia, eu nunca bebi, eu nunca fumei. Cigarro eu fumava, mas durante a minha gravidez sempre... Então, sempre fica com aquela... Por que? Porque sempre tem o por quê, né? Sempre! Esse “por quê??” Eu não sei porque esse "porquêe” existe.

Por que onde você anda, é tudo... "Por que isso? Por que aquilo? Por que a sua filha..?." Poxa! Por que a minha filha não enxerga? Eu gostaria também de saber, né? O porquê eu não sei. Os médicos falaram que tinha sido por causa da rubéola, né? Fez exame, na época eu fiz. exame, meu marido fez exame, não tinha nada a ver. Mas... existe sempre o "por quê??". Aí... Não dá pra entender. Até hoje, assim, eu... Não consegui entender por que... por que...

\section{Silêncio}

Entrev. - Você falou do momento do diagnóstico... como foi?

M. - Não... logo no começo? Ah, eu... a Vivian nasceu em São Bernardo... eu fiquei... foi cesárea, eu fiquei lá os três dias... Os médicos sabiam que a Vivian não enxergava, né? Eles 
sabiam, eles falaram pro meu marido... Eles já sabiam tudo. O diagnóstico, tudo. Só que pra mim eles não falaram... nem o meu marido. Só que eu percebi, assim... eu perguntava pro meu marido: "Por que a Vivian não abre o olho?". Eu percebia que o olhinho dela era fechado, né? Aí ele falava assim: “Ah! Não, né? Às vezes as crianças, né?”. Mas, as crianças, geralmente, tem uma horinha que elas abrem o olhinho. Mas eu ficava naquilo... Foi pouco tempo, também. Foi dez dias que eu fiquei naquela expectativa. Por que a Vivian não abria o olhinho? Só que aí, eu já fui desconfiando, porque às vezes eu pegava ele triste. Uma vez eu peguei ele no banheiro e ele tava chorando, né? Mas acho que ele também não tinha coragem de falar, porque eu tava... era cesárea, né? Ele não tinha... Aí foi, o médico do convênio mesmo, em Santo André. Aí quando chegou lá, ele fez os exames, assim mesmo... examinou só por examinar, porque ele sabia que eu havia feito no Hospital São Paulo o final, né? Aí o médico já falou pra mim, já. Ele falou: "Não, mas a sua filha não enxerga. Aqui no convênio nós não podemos fazer nada, né? Porque você tem que fazer o tratamento, mas você tem que ir pro Hospital São Paulo”. Ah, aquilo ali, tá louco! Eu fui parar no hospital! Eu fiquei... por causa da pressão baixa, né? Eu tive que tomar remédio, fiquei um dia em observação. Ah, pra mim, o mundo tinha acabado! Tinha acabado! Eu não queria nem sair mais do hospital, voltar pra casa... Chegava ali, eu olhava pra ela, assim... eu não queria aceitar, né?

Entrev. - Você olhava pra ela e...

M. - Eu não queria aceitar... não que eu não aceitasse ela. Eu não queria aceitar que ela fosse deficiente, né? Eu não queria aceitar! Mas, mesmo assim, a gente fez tudo, né? Fomos pro Hospital São Paulo. Fizemos mais ou menos... trinta dias de tratamento. Fez os exames, fez tudo. Aí, lá mesmo ele já falou que não tinha... que a Vivian não tinha como enxergar. Mas sempre nós tínhamos aquela esperança, né? Que ela ia enxergar, que ela ia enxergar. Até quando chegou no último dia que ele deu os papéis tudo, falou: “Ó, a Vivian... a sua filha não enxerga”. Aí eu falei: “Ah, mas faz uma cirurgia, alguma coisa”. Ele falou: "Não, não tem, a Vivian não...” - nessa época não tinha ainda, assim, não falava Vivian, né? - "A sua filha não tem...” - aí falou uma coisa lá do olho, né? - “... e não adianta, não tem como. A única coisa que eu posso fazer é encaminhar vocês pro Laramara”. Mas até mesmo quando eu vim pra aqui, eu tinha uma esperança que aqui eu ia conseguir, né? Eu ia chegar no Laramara, eu ia fazer outros exames, tudo. Mas não... ainda hoje eu fico nessa expectativa, né? Que ela possa vir... eu sei que... que nem, os médicos já falaram pra mim que ela não vai enxergar, né? Ele falou assim... como... esse negócio de médico ser muito avançado, né? O tempo, né? Mas não vai... ele falou que no caso da Vivian não tinha como.

Entrev. - Você disse que na época o médico não falava Vivian. Ela não tinha nome ainda? 
M. - Tinha nome... Quero dizer assim... que o médico não saberia falar Vivian... Ele falava: "A sua filha”, né? Mas ela já tinha nome. Quando ela saiu do hospital, a primeira coisa quando meu marido foi... ele já registrou... Só que nós falávamos Vivian, mas os médicos geralmente falam "A sua filha".

Entrev. - E o que significava pra você a defiiciência visual? Ser cego... não enxergar?

M. - Ah, no momento pra mim era... Sei lá! Ser cego pra mim era uma pessoa que ia ficar dentro de casa, né? Era uma pessoa, assim... que não... tanto ela quanto eu, naquele momento, pra mim, era só em casa mesmo. Sair pra quê? Entende? Às vezes, eu me perguntava assim: “Ah, sair pra quê? Ah... vamos em tal lugar...” Meu marido me chamava: “Ah, vamos!” Eu falava: "Eu vou pra onde? Eu vou levar a Vivian pra onde? Ela não enxerga! Eu vou sair de casa com a menina...”. Eu nem saía de casa mesmo pra não... Depois comecei a sair de casa. Mas, mesmo assim, foi difícil. Porque eu saía de casa, mas eu pensava assim: "Eu vou sair, eu vou ver as coisas. A Vvian não vai ver nada!” Às vezes, eu chegava em casa, via o lugarzinho, o berço dela todo cheio de bonequinha, arrumadinho... As meninas arrumavam... Ah! Eu espatifava tudo aquilo ali! "Pra que isso aqui? Ela não vai brincar!” Eu falava, né? "Ela não vai brincar, ela não vai ver esses brinquedos!” Então, pra mim, ela nunca ia ser o que ela é hoje. Hoje, não. Hoje é diferente. Hoje eu já vejo a Vivian... uma criança normal. Pra mim, ela, minha filha, é uma criança que... só mesmo não enxerga, né? Mas a única coisa que ela não faz, assim, igual às outras crianças, ela não é muito de correr, né? E... andar de bicicleta. Essas coisas ela não faz ainda. Mas tem muitas coisas que ela faz, que eu vejo crianças que não fazem. Então pra mim, hoje, a deficiência é... é normal. Mas... depois da Laramara, né? Porque muita coisa... muita coisa não, tudo. Tudo que eu aprendi hoje, eu aprendi na Laramara, eu devo à Laramara. Porque a Vivian, quando ela veio para aqui, ela tinha um mês, só que ela era muito pequenininha. Aí nós ficamos... Era pra voltar no final do ano. Eu sei que a gente viajou... eu sei que eu voltei com seis meses. Ela já tinha seis meses quando chegou aqui. Hoje ela tá com sete anos. Então, aqui, foi a segunda casa. Tinha a casa dela e a segunda casa. Mas eu vejo a deficiência hoje diferente do que eu via antes, né?

Entrev. - Você acha que foi diferente ser mãe das outras duas e ser mãe da Vivian?

M. - É, porque eu tenho duas, mas uma é... Então eu só tenho uma de quinze anos... Ah, em algumas coisas, assim, sobre a deficiência, foi, né? Porque a Ana nasceu... a Débora nasceu de sete meses, também, mas não tinha problema nenhum, né? Ela ficou... eu vim embora e ela ficou acho que uns quatro dias... só porque ela tinha problema de icterícia, essas coisas, né? Tinha que ficar. Aí, logo em seguida, eu fui buscar. Então, eu vi uma diferença porque ela não 
enxergava, né? Então, eu nem imaginava que um dia eu ia passar por essa outra experiência, né? É totalmente diferente você ter um filho que enxerga e um filho deficiente...

Entrev. - Qual é a diferença?

M. - Agora, se eu tivesse hoje uma outra filha deficiente visual, hoje, aí pra mim seria... você entendeu? Pra mim já seria igual, né? Eu já teria uma experiência.

Entrev. - O que você faria hoje diferente do que você fez?

M. - Ah, eu acho que eu não ficaria mais como eu fiquei: nervosa como... Sei lá! Me isolar do mundo, não queria saber de nada. Ah! Teve uma época mesmo que marido, filho, pra mim não existia... os outros. Eu não queria nem saber, né? Eu culpava ele, também, né? Muitas vezes eu culpei ele, também, que ele poderia ser o culpado. Então, depois que você vai parar pra ver, né? Que você vai ver que você tava errada, entendeu? Mas, hoje, se eu tivesse uma filha hoje, aí era muito diferente. Eu já sabia como lidar com a deficiência, né? Eu ia olhar pra ela, eu ia lembrar da Vivian, eu ia ver: no começo, a Vivian, pra mim, era uma criança que não ia... mas só que hoje não. Hoje a Vivian já vai pra escola, ela freqüenta um monte de lugares...

Entrev. - ... Era uma criança que não ia...?

M. - Não ia sair... não ia sair de casa. O que que eu ia fazer com a Vivian, se eu não conhecesse aqui, seu eu não tivesse tido essa experiência aqui, como que era, né? Eu ficava pensando o que que eu ia fazer com ela? Vou sair de casa pra onde? Eu vou levar ela pro pessoal ficar todo mundo te olhando, te fazendo pergunta, né? Então, eu já tava preparada mesmo pra ficar em casa, de casa pro médico, né? E do médico pra casa. Eu não queria sair. Às vezes, nem pra fazer compra no mercado eu não queria ir. Se eu fosse, eu deixava ela, eu não levava ela. Então, eu era totalmente diferente. Hoje, não. Hoje...

Entrev. - Você está dizendo que é diferente...

M. - É, eu acho que é diferente pelo seguinte: você olhar pra uma criança que enxerga, você... não passa nada pela sua cabeça, assim... como vai ser a vida dela, né? Como que vai ser a vida dela? Não, ela enxerga, ela vai pra escola, ela vai brincar, ela vai correr... Então, você não tem o que... Já um deficiente, não. Você quer saber como vai ser aquela vida, porque ele... Poxa! Você fecha seu olho assim e... né?

Entrev. - O que acontece quando você fecha seu olho?

M. - Eu fecho meu olho assim e pra mim o mundo parou, né? Então, pra mim, aquela criança também não tinha mundo. Se ela não via nada, nada. Você colocava a mamadeira na boca, né? A chupeta na mão... Você tinha que levar tudo... Então, você... eu achava que ia ser sempre assim, né? Porque quando a criança enxerga, você pega a chupetinha, você dá pra ela, ela... quando ela tá grande, ela mesma já leva, ela já demonstra o que ela quer. A Vivian a gente não 
sabe o que ela queria. Só se chorasse. Se ela chorasse, aí eu ia ver que tava, né... tinha algum problema... Eu acho que tem diferença quando a pessoa... quando a criança enxerga e quando ela não enxerga, principalmente quando a gente não conhece a deficiência. Porque eu não conhecia... Não conhecia mesmo! Já tinha visto... nem mesmo na rua, né? Porque naquela época você nem saía de casa, assim, pra ver. Eu já tinha visto, assim, as pessoas mais velhas, que tinham perdido. Que nem lá no norte, mesmo, já tinha as pessoas que enxergavam e perdiam, né? Então eu... mas um bebê mesmo eu não conhecia... Um bebê cego. A Vivian foi a primeira criança que eu vim conhecer, porque eu não conhecia. Então eu não sabia como fazer.

\section{Silêncio}

Entrev. - Você disse o que pensava sobre o fato dela não enxergar. E o que você percebia nela, no jeito dela, nas reações dela? O que você via nela?

M. - Eu... Não sei. Eu olhava pra ela assim, eu via um bebê, mas pra mim um bebê triste, né? Às vezes sorrindo, era um sorriso... eu achava um sorriso triste. Pra mim, tudo nela era triste, você entendeu? Pra mim, tudo o que a Vivian vazia, tudo que ela era... ela era triste. Era uma coisa, assim, que você via... era uma doença, né? Você não via uma deficiência... hoje você vê aquilo, né? Pra mim era uma doença, era uma criança que... seria uma criança doente, não seria uma criança feliz. Eu não achava que a Vivian fosse feliz, entendeu? Pra mim ela não ia ser. Ela ia ser sempre uma criança triste. Sorria, sempre eu via um sorrisinho nela, mas era um sorriso triste. Eu pensava assim. Que ela seria sempre uma criança triste.

Entrev. - E o que ela fazia?

M. - Como assim?

Entrev. - Ela bebê... que coisas ela fazia?

M. - É... Esse é o problema, porque eu não via ela fazer nada, você entendeu? Ela fazia o que eu fazia. Por exemplo, eu colocava no berço, eu deixava um monte de brinquedo, um monte de coisinha perto dela, no começo, né? Ela não reagia. Ela ficava... olhava as coisas... você percebia que ela tava olhando, mas ela não enxergava. Então, ela não reagia. Tudo o que você colocasse próximo dela, ficava. Você não... não tinha como ela reagir pra... não demonstrava pra mim alguma coisa que me deixasse feliz, quando ela era pequenininha, né? Depois que ela começou a se mexer, a engatinhar, aí sim, eu já ficava mais, que nem, eu já pensava: "Ah, não, a minha filha não é aquilo que eu pensava que ia ser”. Mas eu pensei mais isso quando ela começou já a engatinhar, né? já fazia algum barulho, algum... aí sim.

Entrev. - E que idade ela tinha? Quantos meses ela começou a sentar, engatinhar, fazer algum barulho? 
M. - Ah, demorou. Ela demorou. A sentar, mesmo, acho que ela começou com quase um ano, ela já tinha mais de... É, ela já tinha uns oito, nove meses quando ela...

Entrev. - Fala um pouco do desenvolvimento dela nessa parte.

M. - Aí, pra mim lembrar... Porque, assim... que nem, eu mesmo protegia, né? Eu não deixava ela ficar muito engatinhando, porque eu tinha medo dela bater nas coisas, se machucar, né? Então, a Vivian foi muito protegida, muito protegia. Às vezes, até mesmo brincar... igual... as outras crianças brincavam no chão, né? Era o medo. Eu tinha medo dela bater a cabeça na parede, dela ir andando. Então, a Vivian foi uma criança que não teve muito... não teve muita, assim, liberdade de brincar. Ela foi criada mais no mimo, na proteção, você entendeu? Então, quando ela começou mesmo a andar, andava, começava a andar, você saía correndo atrás, pensando que ia bater, né? Sei lá, se encostasse na mesa, na parede... Então, ela foi uma criança muito protegida.

Entrev. - Que idade ela tinha quando começou a andar?

M. - Andar sozinha, mesmo, acho que ela tinha uns dois anos. Vivian sempre foi molinha pra tudo. Ela veio sair da fralda, ela tinha quase quatro anos, né? Ela veio sair da fralda, mesmo... Então, ela foi muito protegida. A gente... Não era igual à outra menina. A outra não, a outra ela brincava, ela se jogava no chão, andava, ela fazia... né? Vivian não. A Vivian parecia uma bonequinha, não só por mim, mas pelo pai, pelas outras meninas também. Quando a Vivian se mexia, tinha sempre alguém pra proteger a Vivian, entendeu? Com medo da Vivian cair: "A Vivian vai cair, a Vivian vai pegar alguma coisa e colocar na boca”. Então, tinha sempre alguém em volta da Vivian. Ela nunca tava sozinha. Porque o meu medo, também, era mais ela pegar alguma coisa que não devia e colocar na boca, né? Porque, como ela não enxergava, eu tinha medo... Porque a criança que enxerga coloca, né... Aí ela era muito protegida. Não teve muita liberdade. Não teve mesmo de... assim, em casa, de andar, de brincar, de engatinhar. Sempre que ela ia fazer alguma coisa: “A Vivian vai fazer, a Vivian vai se machucar, pega a Vivian, põe a Vivian no berço!” Então, ela foi muito... tolhida. Às vezes, hoje mesmo, isso aí complica pra ela, hoje. Você percebe hoje mesmo que ela... tem muitas coisas que ela tá sempre precisando de alguém, ela... Tem coisa que a Vivian quer fazer sozinha, mas ela não faz, porque ela já sempre teve alguém pra fazer pra ela.

Entrev. - Ela percebia quando vocês estavam perto, ela reagia, mostrava saber quem era?

M. - Ah, acho que sim.

Entrev. - Como ela mostrava isso?

M. - É... Se fosse tudo na direção dela, né? Se chamasse ela, ela vinha, conhecia... assim, que nem... a mãe, o pai... A gente percebia que ela conhecia, né? Na maneira do sorriso. Então, ela 
demonstrava, às vezes, sim, muitas coisas que a gente... Era totalmente diferente, né? Porque... Assim... pra você saber o que a Vivian queria, você tinha que ficar sempre em volta da Vivian, sempre. Mas ela sempre demonstrava. As meninas, mesmo, ela gostava quando elas chegavam no berço, ela ria... Só que... você percebia que ela tava se manifestando pra alguma coisa, né? Mas muitas vezes você não sabia o que era que ela queria. Mas você percebia. Você percebia. Se você chegasse no berço, mesmo, você percebe quando a criança quer. Ela começa, né? Que ela quer o braço, às vezes ela quer sair dali. Então, percebia muita coisa na Vivian.

Entrev. - E o que vocês faziam?

M. - Ah, sempre... como eu te falei, sempre protegia, sempre tava com nós.

Entrev. - Você falava com ela?

M. - Como assim?

Entrev. - Você conversava com ela? Ou você ficava mais quieta? Na hora de trocar, na hora de alimentar...

M. - Não, brincava, conversava igual a uma criança normal, mesmo. Fazia as brincadeiras, conversava com a vozinha de cri... mesma coisa. Não tinha... na maneira de cuidar, assim, não tinha diferença. Eu só achava diferença na parte da visão, assim... quando era a parte de ver, né? Aí, num bebê normal, num bebê que só percebia na parte de enxergar. Tudo o que era de ela ver, isso que eu achava diferença. Mas na maneira de cuidar, assim... isso pra mim era igual, né? Um bebê normal. Você brincava com ela, você conversava com ela, ela gostava...

Entrev. - Ela reagia...

M. - Reagia. Tudo normal. Pra mim, a diferença era só na visão, mesmo.

Entrev. - Costumamos encorajar as crianças a andar, a engatinhar, e sentimos prazer nisso, temos uma expectativa... Como era pra você?

M. - É, você tinha, você queria ver ela andar, ela engatinhar, mas o medo... Sempre tinha o medo, né? Sempre existia o medo que a gente tinha dela se machucar, porque a Vivian, a gente nunca queria que ela se machucasse. As outras podiam se machucar, mas a Vivian, porque... A Vivian não podia se machucar.

Entrev. - Por que?

M. - Eu não sei. Ela não podia cair.

Entrev. - Por que?

M. - Não sei. Porque a gente não queria deixar, né? Sei lá, pra nós, se a gente deixar... se a Vivian não enxerga, você tem que cuidar dela. Então, se ela não enxerga, porque que você vai deixar ela... tem que proteger pra ela não cair. As outras, às vezes caem, porque criança, você sabe, cai... Mas, a Vivian, se ela levou três quedas até hoje foi muito, esse tempo todo. Mas, 
porque: você vê que toda criança cai, se rala, bate na parede, né? Ela não! A Vivian não podia se ralar, assim, nem nada, porque a gente não deixava mesmo! Quando você via o perigo ali, com alguma coisinha que corresse, que você percebesse que era um perigo, você já corria, já tava ali, entendeu? Então, não tinha como. A gente não... nós não deixávamos mesmo ela...

Entrev. - O que você sentia em ser mãe dessa criança?

M. - Ah... hoje?

Entrev. - Na época.

M. - Ah, na época, ser mãe dessa criança, por que? Aí eu me pergunto: por que eu? Você entendeu? Eu não sei... Eu me perguntava, assim... Eu queria uma criança normal, né? Ah, eu não queria ter uma criança cega. È difícil! Você tá esperando um bebê nove meses... Talvez até durante a gravidez, se você soubesse, fosse mais fácil. Se houvesse uma maneira da gente saber que o seu bebê... Tem muitas deficiências que não dá pra você saber, né? Porque se o bebê fosse cego enquanto estivesse... talvez fosse mais fácil. Porque o bebê ia nascer, você já sabia que ela tinha aquele problema, que ela ia nascer com aquele problema. Então, eu acho... Agora, pra você esperar nove meses, aquela expectativa que você tá, né? Você não vê a hora daquele bebê nascer, aí depois do bebê nascer, você trazer pra casa uma criança cega, né? É difícil, entendeu? Eu achava, pra mim, que eu não deveria ter aquela criança cega. Por que as minhas cunhadas, na época, tiveram todos os bebês normais? - eu me perguntava. Nasceram três sobrinhos meus, na época, tudo na idade da Vivian, diferença de trinta dias, alguns dias. Aí, eu ia visitar... Teve um mesmo... um sobrinho meu que eu nem quis... nem fui visitar. Às vezes... "Por que eu vou? Os bebês tudo enxergam!” E a Vivian não enxergava, você entendeu?

Entrev. - Quanto tempo você levou pra superar esse impacto?

M. - Ah, eu... Pra ser sincera, eu acho que ainda hoje, eu não superei. Eu aceito tudo, assim, tudo que for no meu alcance, pra Vivian, eu faço. Ela é minha filha. Até as meninas falam assim: “Ah! A Vivian é a sua filha preferida!” Realmente, a Vivian, pra mim, hoje, ela é uma filha... é a minha filha preferida, assim, que eu quero sempre - não que as outras não sejam mas eu quero sempre estar perto, sempre estar próximo. Mas agora, pra mim chegar e falar assim pra você: "Eu aceitei..." Não, ainda não. Existe ainda... uma coisa que te prende, ainda...

Entrev. - Prende o que?

M. - Ah, não sei! É dentro de mim mesmo, assim... Pra mim... eu não me libertei ainda nisso... Eu não aceitei aquela filha mesmo que... Que nem, tem muita gente que eu falo assim:. Não! Eu aceito a Vivian, claro, eu faço tudo pela Vivian... Tudo que estiver ao meu alcance, e o que 
não tiver eu vou atrás, mas... Ah, eu aceitei tudo! Eu tenho uma filha deficiente, mas, pra mim, não, ainda tem... ainda tem um bloqueio... Assim: dentro de mim mesmo, que tá... Bloqueou, ainda não saiu. Eu acho que vai ser pra sempre. Vai ser sempre assim.

Entrev. - Mas já mudou...

M. - Já... Bastante...

Entrev. - Mas é diferente daquele momento que você esperava um filho e nasceu outro...

M. - Com certeza! Claro! Não, é uma coisa que a gente... mães, eu penso, não sei se são todas iguais, mas eu acho que a mãe que teve um filho deficiente, sempre tem aquilo dentro dela mesmo, entendeu? Sempre existe. Porque você vê que... "ah, mas a sua filha tem capacidade pra fazer tudo!” Tudo bem, eu concordo que ela tem, mas ela tá sempre precisando de alguém. Eu acho que ela sempre vai precisar. Às vezes eu me pergunto, assim: "E quando eu for embora?" né? Eu vou ter que deixar ela. E aí? E se ela precisar de mim? Então, eu sempre me pergunto assim, né? Então, eu não me libertei... Assim... pra você dizer: "A preocupação que eu tenho com a Ana é a mesma que eu..." Não. Porque eu sei que a Ana, ela tá uma mocinha, tem quinze anos. Então, se hoje eu for embora, ela se vira sozinha. Ela sabe fazer comida, ela sabe... então, ela vai ter a ajuda do pai e vai... Mas a Vivian, não. A Vivian, ela sempre vai precisar de alguém. Eu penso assim. Ela vai crescer... Hoje, é de mim. Amanhã ela pode casar, mas ela vai sempre precisar do marido, de um filho, você entendeu? Sempre ela tá precisando de alguém. Nós todos precisamos, né? Nós todos precisamos de um marido, de um filho, mas eu acho que a Vivian é diferente, assim... no caso de ela não enxergar... Não sei, eu acho que eu não me acostumei ainda com a idéia. Eu já aceitei, né? Mas, me acostumar mesmo...

Entrev. - Você lembra como ela se movimentava?

M. - A Vivian era molinha pra se movimentar. Ela demorava pra se virar, assim. Às vezes, na época, nós passávamos com a... Ai, esqueci o nome dela... (nome de uma profissional fisioterapeuta). Então, a gente colocava brinquedo, assim, tudo pra ela, e aí até chegar... ela demorava bastante.

Entrev. - A Vivian tem algum comprometimento neurológico?

M. No começo, ela... foram feitos os exames nela e tudo, não deu... Fez exame... esse aí, fez o de ouvido, não deu problema nenhum. Só que, ultimamente, agora, eu tô percebendo a Vivian muito nervosa. Agora... quando ela começou a freqüentar as escolas. Aí eu comecei... ela começou a agredir, ela começou a não aceitar. Quando ela não aceita uma coisa ela querer beliscar, morder. Depois que ela começou... a cobrança, né? Porque, antes, ela fazia tudo o que ela queria. Não tinha cobrança. E agora vem a cobrança. Tem a escola. Em casa tem a cobrança de casa, mesmo. Então, ela não aceita. Aí ela fica um pouco nervosa. Mas isso não 
quer dizer... não sei se ela pode ter vindo com, assim, algum problema, ou que seja mesmo porque ela não... o fato de ela ser criada daquele jeito e agora a gente mudar a rotina da vida dela, né? Porque, do ano... que nem esse final de ano mesmo, muita coisa mudou na vida dela. E ela, tem coisas que ela não aceita.

Entrev. - Por exemplo...

M. - Assim, ó... que nem... a Vivian sempre foi... pra se arrumar, sempre eu que arrumei ela, que vesti, que calcei, pra ir no banheiro, tomar banho... Então, não tinha cobrança. Falava: "Vamos tomar banho", aí ela vinha, eu ia no banheiro, eu dava banho nela, lavava a cabeça, penteava o cabelo dela, secava, colocava a calcinha, a meia, e tudo. Então... aí, hoje, já tem a cobrança: "Vivian, aqui tá a sua meia, você vai colocar, vai pegar sua roupa”. Leva ela lá no guarda-roupa: “olha, a sua gaveta...” Então, aquilo já deixa ela irritada. Aí ela chega na escola e tem cobrança da professora, entendeu? Porque antes ela chegava na escola, pra ela, ela ia só pro parquinho, o negócio dela era brincar. Ela achava que era sempre parquinho, que no primeiro é mais brincar, né? No prézinho. Aí, agora, ela passou pra primeira série, então tem a cobrança da professora. Chega aqui na Laramara, tem a cobrança da professora da piscina e da pedagoga. Então, aquilo tá deixando ela nervosa. Agora, eu quero fazer esse exame de novo. Até tava falando, que eu ia passar ela no médico, pra mim tirar a dúvida, né? Se tem... se ela vai ter algum problema depois que ela começou a crescer, porque quando ela era menor ela não tinha.

Entrev. - Como ela se comunicava com as pessoas pra mostrar o que ela sentia ou o que ela queria? Como era o jeito de ela mostrar que tinha fome, ou que tinha sono, ou que não estava bem...

M. - Ela chorava... Ela tinha mais mania de chorar. Quando ela chorasse, podia perceber que alguma coisa ela queria. Aí, depois, ela começou a pedir, né?

Entrev. - Como?

M. - Dá, dá... água...

Entrev. - Com que idade?

M. - Ah, a Vivian começou assim acho... com um ano, um ano e pouco ela já pedia alguma coisa. Água mesmo ela já começou... Porque a fala dela não atrasou, a Vivian. Ela sempre foi... ela não gostava muito de conversar. Mas em casa ela conversava. Quando ela saía, ela se trancava. Quando ela saía de casa, você podia perguntar o que quisesse pra ela, que ela não falava nada. Mas ela, assim, em casa, ela sempre se comunicava. Ela nunca foi, também, de se comunicar com as pessoas lá fora... Se alguma pessoa chegasse nela e começasse a falar, ela não respondia, ela nunca foi... Ela veio começar a responder o nome pra alguém depois de seis 
anos, que ela veio começar. "Vivian, como é que é o seu nome?” Daí ela fala. Você pergunta: “Como é o seu nome?” Aí, hoje, ela fala: "Vivian”. Ela fala tudo. Se você perguntar, levar ela na pergunta, você consegue muita coisa. Mas pra ela chegar em você e já ir conversando, ela não é de conversar.

Entrev. - E como ela usava o corpo - mãos, audição - pra conhecer o mundo?

M. - Ah, sempre... ela sempre usa a mão, né? Sempre no tato, assim, apertando... Ela gosta muito de apertar as pessoas, conhecer, passar a mão na cabeça. Ela tem uma observação, também, que ela observa se usa óculos. Ela sempre que vai com a mão assim, no seu rosto, ela já... “Ah, não é igual o pai, né? Não usa o óculos”, porque o pai dela usa óculos, né? Mas, ela observa muito com a mão. Careca... eu tenho um irmão que ele é careca e quando ele chega em casa, ela não vai muito pela voz dele, ela passa a mão no cabelo. Ela fala: "É o tio careca, né?" Então, ela conhece muito através da mão. Os meninos, ela... tudo ela identifica sempre com alguma coisa, com a voz, com o falar alto, né? Tem um irmão, mesmo, que fala bastante alto, então ela já sabe quem é. Quando ele chega, ela já sabe: “É o tio Paulo”. Porque ela já... por causa da voz dele, mesmo.

Entrev. - Ela punha muito a mão na boca? Porque o bebê, ele leva muito as coisas na boca, até descobrir a mão. Pra conhecer as coisas, tudo é muito com a boca, né? Estimula muito a boca... M. - É, mas ela não foi muito de levar, não, nada, assim... a mão na boca, não. Não foi muito não.

Entrev. - E pra pegar as coisas...

M. - Sempre teve dificuldade. Ela sempre teve dificuldade de ficar com as coisas na mão. Ela pegava alguma coisa, aí, ali, enquanto ela interessasse ali... mas sempre jogando fora. Ela não era muito de ficar muito tempo segurando alguma coisa. Até mesmo um brinquedo ela não gostava de segurar ele muito tempo. Se ela pegasse numa coisa, era questão de alguns minutos, ela já... aquilo pra ela... Hoje ela fica mais um pouquinho, mas não é muito. Com algum, assim... com algum brinquedo que interessa a ela... Que nem, ela tem uma boneca, mesmo, que ela gosta... O brinquedo que interessa a ela, ela fica bastante. Mas, quando ela pega um brinquedo que não interessa..., qualquer coisa que não interessa a ela, ela joga, ela não é muito de segurar, não.

Entrev. - E quando era bebê?

M. - Também. Ela não gostava muito de segurar. Tinha aquele chocalhinho, aqueles brinquedos lá, mas ela não gostava muito, não.

Entrev. - E a amamentação? 
M. - Ela não mamou. Num tinha... durante o tempo em que eu fiquei no hospital, ela não amamentou, os três dias ali. Mas ela... não tinha leite, também... nunca foi muito de... Ali ela já amamentou mesmo na mamadeira.

Entrev. - E ela aceitou?

M. - Aceitou. Logo nos primeiros dias mesmo, que chegou em casa, ela já foi na mamadeira. Ela sempre aceitou na mamadeira.

\section{Silêncio}

Entrev. - Ela procurava, sugava?

M. - Sugava...

Entrev. - ... já ia procurando o bico da mamadeira?

M. - Da mamadeira.

Entrev. - Ela segurava a mamadeira?

M. - Não. Só quando... aí já tinha uns... oito meses, mais ou menos. Quando ela era menor, ela não segurava a mamadeira. Ela não tinha muito interesse por nada, a Vivian. Ela era uma criança sem interesse. Ela não tinha interesse de pegar as coisas. Você vê, mamadeira, de segurar... aquilo que as crianças têm, né? Ela nunca teve. Até hoje, tudo dela é mais... que dê pra ela, assim...

Entrev. - Ela não procura?

M. - Não.

Entrev. - Não tem iniciativa de ela pegar...

M. - Ela tem, quando interessa a ela. Alguma coisa que... que nem eu te falei, assim, que chama a atenção dela, aí ela vai atrás. Mas, por exemplo, a colher pra almoçar, essas coisas, ela não tem interesse. Ela quer que você leve pra ela na boca, entendeu? Ela não é muito de...

Entrev. - Ela ainda não come sozinha?

M. - Não, agora que a gente tá trabalhando, mesmo. Já come sozinha, sim, mas não... não tem muito movimento. Isso a gente tá trabalhando agora, mesmo, pra ela comer sozinha.

Entrev. - Ela usava os objetos pela função que eles têm?

M. - Não. Ela, pra ela, ela usava se... qualquer coisa. Não tinha essas funções. A única função que ela sabia, assim, era... um brinquedo que tocasse uma musiquinha. Aí ela procurava, até aprender ali aonde que apertava, aquilo ali, pra ela, tinha uma função. Aí ela sabia, né, que aquilo ali tocava e ela queria aquilo, mas... pra ela pegar uma coisa que... não interessasse, assim, que não... ela não tinha... A té hoje, o brinquedo que interessa a ela é um brinquedo que toca musiquinha, é uma boneca que chore... tudo dela tem que... faça barulho. Se você der alguma coisa que não tenha muito valor, assim, pra... a não ser uma bola. Sempre bola ela fica 
bastante, porque ela gosta. Mas, se não tiver muito barulho, pra ela não interessa, não. Ela, até hoje, se não chamar a atenção dela... ela não fica com ele.

Entrev. - Ela tem hábitos repetitivos de balançar o corpo, ou de apertar os olhos, ou de ficar passando alguma coisa na boca, rodar, bater objetos?

M. - Não. Ela tem, assim, quando ela tá feliz, ela tem um movimento na mão dela que ela... assim... se tiver alguma coisa que ela esteja feliz, você percebe que ela tá feliz, ela quiser falar pra você o que ela tá sentindo, ela movimenta assim, o jeitinho dos dedos, aquela... ansiedade, né? Mas, esse negócio de esfregar o olho, de...

Entrev. - Você disse que ela aceitava melhor as pessoas de casa e menos as pessoas de fora...

M. - É. Ela não é muito de aceitar as pessoas. Ainda hoje, ela não é, mesmo. Tem pessoas que ela aceita fácil. Ó, os tios, mesmo, por parte de pai, ela gosta de um tio só. Os outros podem chegar nela, ela não tá nem aí, ela nem dá atenção. Brinca, dá beijo, "Vivian, vem aqui". Não, não vai! E o Tião, ele chega e fala... só a voz dele ela já conhece. Aí ela já gosta dele. Tem um tio e uma tia que ela gosta. Ele tem o que... uns dez irmãos. Só tem dois irmãos que ela... E não é falta de contato, porque ele leva ela na casa deles, tudo, mas ela não gosta. Quando ela não gosta de uma pessoa, aí não adianta.

Entrev. - Ela aceita que alguém se aproxime e a toque, abrace, beije?

M. - Se for uma pessoa que ela conheça. Se for uma pessoa estranha, ela não gosta, não. Hoje mesmo ela já pergunta, né? Se for uma pessoa que ela não tenha, assim, ela já pergunta: “Quem é? Seu nome?”. Aí, se você conseguir levar ela na palavra, conversando, muitas vezes ela responde alguma coisa, se chega assim. Mas quando não, ela nem... Não dá nem bola.

Entrev. - No contato com as pessoas ela se manifestava batendo ou mordendo?

M. - Ela beliscava, mordia. Ela teve essa fase. Inclusive agora... tá menos, mas, agora, quando a gente cobra muito dela, ela ainda faz isso. Quando ela era pequenininha não. Começou quando ela era... depois que ela começou a ir pra escola, mesmo... quatro anos, porque aí ela começou a ficar mais agressiva. Quando começou as cobranças, tudo, aí ela começou... é a maneira de ela... de ela se vingar. Que nem, ela tá aqui conversando com você, se você falar alguma coisa que não tá interessando ela, aí ela vai e te dá um chute. Aí ela chuta você por baixo, mesmo. Quando não interessa alguma coisa que ela tá... Acho que é a cobrança. Depois que ela começou a ir pra escola, que veio a cobrança pra ela, aí ela começou a morder, a beliscar...

Entrev. - E ela se interessa pelo quê?

M. - Agora ela tá se interessando mais pelo Braile, a máquina de escrever, né? Ela tá se interessando bastante. Antes, não. Antes ela só queria ir porque ela queria ir brincar. Ela 
sabia que no parque ela tinha tudo os brinquedos. Agora hoje, não. Nessa escola mesmo, onde ela tá, tá difícil. Porque as professoras não tão sabendo como trabalhar com a Vivian. Eles estão perdidos, né? Mas ela tá numa sala de... numa Sala de Recurso em Santo André, que a professora sabe trabalhar, tudo, né? Então ela tá gostando. Ela tá gostando mais de ir lá, que fica duas horas, do que ir na escola. Porque, na escola, ela chega lá, ela não tem muito o que fazer. Ninguém sabe o que fazer com ela. Então aquilo ali deixa ela nervosa, né? Acho que ela escuta as professoras falando: “Ah, fulano, pega um lápis, pega isso, pega aquilo...” Ela além de não ver, não tem nada pra ela fazer. Então aquilo deixa ela nervosa. A professora chega e fala: “Ah, mas a Vivian hoje ficou nervosa e queria morder ...” A professora dela, da Sala de Recurso, foi lá na escola e falou: "Tem alguma coisa pra Vivian fazer, porque se você der alguma coisa que interesse a Vivian pra ela fazer, ela não vai fazer isso. Ela fica nervosa, porque você fica conversando com os outros alunos: 'Faz isso, faz aquilo', e ela não faz nada?”. Então, ela tá ficando nervosa na escola. Bastante nervosa, mesmo.

Entrev. - Quais as pessoas favoritas, quais os objetos favoritos dela?

M. - Ah, eu acho... pessoas favoritas, mesmo, em casa? Em casa é o pai... comigo ela também... antes não era muito, não. Depois que ela começou a sair, ela grudou muito em mim, né? Mas, acho que se for parar, mesmo, acho que é o pai. Sempre. Desde que ela era pequenininha, sempre ela teve que ficar com ele, até hoje.

Entrev. - E objetos? Você falou de uma boneca...

M. - É. Objetos, ela gosta de uma bola que ela tem e uma boneca.

Entrev. - Ela brinca com a boneca como?

M. - Ah, ela senta numa cadeira, assim, aí põe a boneca aqui na frente, né? Deita a boneca, bate os pés, bate as mãos, né? Aí coloca em cima da cama. Depois: "Tá dormindo, o nenê, lá, ela dormiu...” Depois ela volta, pega aquela boneca, volta lá pra balança, porque ela tem uma balança, põe a boneca na balança, balança... Sempre ela tá com essa boneca...

Entrev. - Desde quando ela passou a brincar desse jeito?

M. - Com a boneca... acho que ela começou a brincar já com uns quatro anos. Uns quatro ou cinco anos, já...

Entrev. - De fazer de conta?

M. - Ela não gosta muito de fazer de conta. Não, hu, hu. Ela não gosta mesmo. Ela, pra ela, o que ela tá brincado ali, se você: "Ah, Vivian, vamos fazer de conta que a boneca é um bebê, você vai dar de mamar...”, não. Não adianta. Se você começar, aí aquele brinquedo pra ela, ela já deixa ele lá e já vai procurar um... Ela gosta muito de brincar sozinha. Ela não gosta muito que você interfira no brinquedo... na brincadeira... 
Entrev. - E com as outras crianças?

M. - Não gosta de brincar... Ela é assim: quando a criança começa a brincar com ela e pára, aí ela não gosta. Ela quer que brinque até quando ela não quiser mais. Então, ela não é muito de brincar com criança. Às vezes, quando aparece assim alguma lá em casa, ela já não inventa de brincar, porque é pra não pegar nos brinquedos dela. Ela não aceita que aquela outra criança vá lá e pegue uma boneca dela. O brinquedo dela, é dela. Se brincar com um brinquedo que não faça barulho, e brincar longe, onde ela não escuta, até ela deixa. Mas se for um brinquedo que liga, alguma coisa, ela já vai atrás, já toma logo. Ela não gosta de dividir as coisas, assim, com as outras crianças, não.

\section{Silêncio}

Entrev. - Vamos voltar a falar um pouco da alimentação dela depois que ela saiu da mamadeira...

M. - A Vivian saiu cedo da mamadeira. Ela não toma leite. Ela tomava... ela tomou mamadeira até um ano e meio, mais ou menos. Aí, depois, não quis. Ela enjoou do leite, não quis mais. Aí começou a comer comida, comer papinha, essas coisas, né?

Entrev. - E ela aceitou bem a comida?

M. - Aceitou bem.

Entrev. - Em pedaço?

M. - Não, ela não come carne. A verdura, pra ela, tem que ser bem amassadinha. Se tocar na boca um pedaço de verdura pra ela, ela já não quer. Carne ela só come em churrasco. Se você estiver assando, assim, pra ela sentir o cheiro da carne, aí ela vai lá e ela come. Mas, na comida também, ela não gosta de comer carne cozida. Ela come feijão, arroz... ela gosta de ovo, né? Se você cozinhar o ovo, assim, ela gosta de ovo, e verdura ela come bastante, mas você tem que machucar, assim, bem machucadinha...

Entrev. - Onde ela comia... com quem?

M. - Ela sempre tinha uma mesinha. Hoje, não. Hoje ela já come na mesa normal, mesmo, grande. Ela tinha uma mesinha quando ela era menor, né? E uma cadeirinha e sempre ela comia ali, assim, no cantinho. Agora, hoje não. Hoje ela já almoça, na hora do almoço, todo mundo junto, né? Na mesa, cadeira, assim... normal.

\section{Silêncio}

Entrev. - Como é que você percebia que ela tinha fome, sede...?

M. - Ah, os horários. Eu já marcava o horário que ela tinha que comer. A sede sempre ela teve, né? Quando ela era bebezinho, não, né? Sempre eu marcava, sempre eu ia dando água. Mas, quando ela começou a falar, logo que ela começou a pedir água, então ela mesma pedia 
água, né? Mas a comida, sempre eu marcava a hora. Eu sabia que aquela hora ela estava com fome. Aí eu dava comida, assim, na hora certa, e ela não sentia fome. Hoje, não. Hoje ela pede. É hora de almoço, janta... E se você demorar um pouquinho da hora, ela já fala: "Eu não vou jantar, não?" Então, hoje ela já pede tudo o que ela quer. Aí já é mais fácil, né? Ela veio pedir... faz pouco tempo que a Vivian começou a pedir as coisas. Não faz muito tempo, não. Seis anos... seis e pouco. Ela demorou... faz pouco tempo que ela começou. Quando eu te falei: depois que a gente começou a colocar o limite, né? Explicar pra ela o que... aí foi que ela começou... Muitas coisas ela veio aprender agora mesmo.

Entrev. - Ela entende o que você fala? Entende como o mundo funciona, como são as coisas? Ela compreende quando vocês conversam, enfim...?

M. - Ah, eu acho que tem muitas coisas que ela não aceita, não. Ela compreende alguma coisa...

Entrev. - Ela entende o que é falado?

M. - Entende, entende. Nem sempre ela entendeu. Principalmente quando ela quer uma coisa, que você não dá, né? Quando ela quer comprar uma coisa que ela vê, ou um barulho, ou um brinquedo, alguma coisa que você: "Não, Vivian, não vai dar pra comprar. A mãe não tem dinheiro pra comprar”, essas coisas ela não entende.

Entrev. - Ela não aceita, mas ela entende o que é falado?

M. - Entende. Ela entende que você não tem dinheiro. Se você explicar pra ela: "Olha aqui, a mamãe não tem dinheiro pra comprar isso aqui. Isso aqui tá caro”, ela entende.

Entrev. - Ela sabe o que é dinheiro?

M. - Sabe. Sabe o que é dinheiro e gruda nele (rindo).

Entrev. - Se você dá uma instrução, ela faz?

M. - Isso tudo tá começando agora, né? Acho que um ano... não tem nem um ano pra cá. Ela... eu falo: "Vivian, vai buscar isso". Qualquer coisa que eu mandar ela ir buscar, ela vai.

Entrev. - Você diz que ela espera mais as pessoas fazerem. Ela é uma criança mais passiva? Ela não toma muito iniciativa?

M. - Toma. Quando ela quer, ela toma. Ela espera muito, assim, fazer... as coisas assim que nem comida, trocar ela. Ela espera que você... você vista a roupa nela. Ela não quer vestir. Mas não é que ela não tem capacidade. É que ela não quer fazer, né? Mas agora a gente tá cobrando mesmo pra ela fazer. É o que ela não tá aceitando. Tem hora que ela não quer fazer. Ela fica nervosa mesmo. Que nem, pentear o cabelo mesmo, ela não aceita que ela penteou o cabelo dela. Tem muitas coisas que ela não quer aceitar, né? Mas que ela tem capacidade de 
fazer! Mas ela não quer. Por isso é que eu falo, a maneira que sempre a gente fez. Aí agora ela fala: "Por que não vão fazer mais?"

Entrev. - Ela percebia quando as coisas se deslocavam de um lugar a outro no ambiente?

M. - Percebe...

Entrev. - Ela percebia?

M. - A mudança, assim... você mudava alguma coisa na casa, por exemplo, uma mesa, assim, sei lá, ela percebe. Às vezes alguma coisa dela, mesmo, se ela guardar num lugar, ela vai direto naquele lugar que ela guardou, ela vai lá. Se não tiver.... Mas também é uma coisa, que ela procura na casa toda... ela procura. "Vivian, o que que você quer?”, ela não fala pra você o que ela tá procurando. Quando ela encontra.... Às vezes, eu até percebo o que ela tá procurando, aí eu coloco mais fácil pra ela, né? Eu vou colocando, sem ela perceber, eu coloco mais próximo dela. "Vivian, o que você tá procurando?”. "Nada!”. "Vivian, o que você...”. “Nada!”. Quando ela encontra, ela fala: “Achei!”. Mas ela não fala pra você o que ela tá procurando. Eu facilito, quando eu percebo que ela tá procurando uma boneca, uma coisa que é... do interesse, que ela tá procurando e não tá encontrando, aí eu vou devagarinho, né? aí eu facilito. "Vivian, você tá procurando que?". Mas ela não admite ajuda pra essas coisas. Mas... ela quer mais ajuda pra parte de comida, de... trocar de roupa, de dar banho, essas coisas ela não quer fazer sozinha.

Entrev. - Ela se chama de eu? Ela diz: "eu quero", "eu vou”, "eu faço".

M. - Não, ela inverte.

Entrev. - Como é?

M. - Ela fala assim... ah: "Você". Por exemplo, ela quer uma coisa, ela quer referir a ela, que é como ela tá falando comigo, né? Por exemplo: "Você quer jantar?", ela fala isso, né? ”Mãe, você quer jantar?”. E a gente fala: “Não, não é você. É: Eu quero!” Aí, agora, ela tá começando também agora. Mas ela troca as coisas, mesmo. Ela refere a ela como a outra pessoa que estivesse conversando com ela.

\section{(Silêncio longo)}

Entrev. - Se ela procura o objeto quando não está perto é 'porque ela sabe que o objeto continua a existir... Ela percebe o que acontece à volta dela?

M. - Percebe.

Entrev. - Ela percebia isso quando era bebê?

M. - Não. Eu acho que ela começou a perceber mesmo com uns dois anos, porque, aí, ela começava a perceber que... A perceber que chegou alguém, sempre ela percebia, né? Ficava dando risada. Você percebia que ela tava na escuta, que ela tinha ouvido algum barulho, né? 
Aí, depois que ela foi começando a falar, que ela começou a perguntar quem era. Chegava alguém, e ela: "Quem é?” Mas aí você percebia que ela tava sempre atenta a alguma coisa, a uma risada, a alguém que chegava. Se ela estivesse naquele silêncio, aí você entrasse num lugar... ela percebia que alguém chegou. Mas ela só veio demonstrar isso pra gente quando ela começou mesmo a falar.

Entrev. - Você disse que ela falou cedo...

M. - Ela começou a falar cedo, a Vivian. Em casa sempre foi de conversar. Agora, quando sai, não. Adora todas as conversas quando ela sai. Quando eu falo pra ela: "Vivian, você conversa até demais quando eu saio na rua”. Menina, ela quer saber tudo. Tudo, tudo, tudo. O barulho do céu, o barulho do carro, se é o barulho de uma moto, se é de um fusca. "Mãe, o barulho do fusca parece o barulho da moto”. O caminhão, se é do ônibus. Tudo. Tudo o que acontece na rua...

Entrev. - Está descobrindo o mundo...

M. - Descobrindo o mundo! É... quando ela entra, ela fala: "Ah, nós não vamos de ônibus, nós vamos de perua, né?”. Ela sabe que é a perua, ela sabe que é o ônibus. Tudo ela, na rua, ela sabe. Sabe quando ela vai no carro do pai. Quando ela vai no carro do tio dela, ela sabe.

Entrev. - Você explicava as coisas pra ela quando ela era bebezinha, pequenininha, você ia mostrando...?

M. - Não. Não. Eu vim começar a explicar isso aí, também, já depois de grande. Eu... porque eu passava, na época, com a pedagoga, né? Eu sempre falava pra ela: “Ah, por que eu saio na rua e a Vivian não quer saber de nada. Passa barulho e ela não tava nem aí”. Ela falava pra mim: “Ah, quando você for sair, você tem que falar pra ela: 'Ó, o barulho é disso, disso...”." Aí eu comecei... depois de dois anos, que... quando a Vivian começou a se interessar pelas coisas, aí que eu comecei a explicar pra ela, né? “Ó, filha, hoje nós vamos de ônibus”. Aí, hoje ela sabe quando ela vai de ônibus e quando ela vai de perua pra algum lugar.

Entrev. - Quando ela passou a reagir, você reagiu também?

M. - Isso! Ela começou, assim, a mostrar o interesse pelas coisas e eu também comecei a explicar pra ela. Antes não. Antes eu achava que ela também não queria saber. Ela não perguntava nada, né? Às vezes, eu saía pra cá, eu saía pra outro lugar, tudo, aí... Mas ela não me perguntava nada. Eu conversava com a pedagoga. Eu falav pra ela: "A Vivian não pergunta nada, não fala nada?”. "Espera, dá um tempo. Vai chegar uma hora que você vai mandar a Vivian calar a boca”. E é verdade. Hoje eu saio com a Vivian: "Vivian, pára de conversar! Você conversa demais!”. Aí ela pára. Aí depois começa tudo de novo! Tudo ela quer saber. Se ela passa em frente a uma escola, ela quer saber que escola que é: "Mãe, esse 
barulho de criança é uma escola, né? Que escola que é? Como é o nome da escola?’. Aí eu falo. Tudo, tudo que ela vê... que ela percebe, ela quer saber o que é que tá acontecendo. Hoje ela já é bem espertinha.

\section{(M. parece esperar mais uma pergunta)}

Entrev. - Ela tem noção de tempo? Por exemplo, ontem, hoje, amanhã; manhã, tarde, noite...

M. - Tem. Na quinta-feira, mesmo, ela já sabe que segunda... Ela já sabe os dias da semana, tudo, ela sabe. Se é manhã, se é tarde. É... ontem... De manhã ela vai pra escola, aí, à tarde... à tarde ela sempre fica em casa. Ela não vai pra escola. Tudo de manhã. Aí, à noite, pra dormir, ela sabe, quando eu saio pro colégio, né? Aí eu falo: "Vivian, a mamãe vai pra escola, você vai ficar...”. Mas, também, ela só dorme quando eu chego. Enquanto eu não chegar... ela fica deitada lá e tudo, mas não dorme. Mas ela sabe. Ontem mesmo foi engraçado, meu irmão chegou e falou: "Eu vou tirar um sono, eu vou dormir ali na sua cama”. Aífalou assim: "Vou lá pro seu quarto, tá?”. Aí ela lá sentada, quieta. Aí ele falou: “Boa noite, tá, Vivian?” “Boa noite, não. É boa tarde, tio". E era à tarde, né? Ela tinha terminado de almoçar, tinha chegado da escola. "Boa noite, Vivian" (ontem ela foi na Laramara) "Não, não é boa noite, tio. É boa tarde". E ela não aceita que ele entre no quarto dela pra dormir, não. Ela não gosta. "Você vai dormir? É boa tarde”, querendo dizer que, à tarde, não era pra ele dormir (rindo). Ela não gosta, não.

Entrev. - Ela entende o que acontece com as coisas? E porque acontece? Se uma coisa cai, como foi...?

M. - ... quando cai um copo, assim, de vidro, né? aí ela sabe a diferença, porque quebrou. Quando cai um copo de plástico, ela sabe que aquele copo não quebra, né? porque é plástico. Então, essas coisas, a diferença, assim, ela conhece.

Entrev. - Ela sabe quando é ela que provoca um acontecimento?

M. - Sabe, quando foi ela... Porque, quando não é ela... Quando é ela, ela fica quietinha. Quando foi as outras, ela casca o bico, começa a dar risada. Se acontecer de você quebrar um copo, um prato, aí ela começa... De onde ela tá, ela escuta o barulho, fala: “Quebrou?” Ela começa a rir. Mas quando é ela, ela não ri, ela fica assustada, né?

Entrev. - Ela sabe diferenças e semelhanças entre as coisas? Pra que servem os objetos? O que é fruta, o que é brinquedo, o que é móvel...?

M. - Tá aprendendo agora, também... a aprender todas essas coisas, ela tá começando... Ela sabe o que é uma fruta, só que ela não sabe diferenciar que fruta que é, né? Assim, por exemplo, se eu der uma maçã, aí se eu falar pra ela que é uma maçãa, aí ela vai e sabe, né? Aí depois que ela começa a mastigar... Mas diferenciar uma laranja e uma mexerica, aí ela não 
sabe diferenciar, assim, porque é na casca tudo, assim. Só se eu explicar pra ela, aí ela vai ficar sabendo, né? Mas uma banana ela conhece, ela sabe o que é uma banana, essas frutas, mas... Só quando elas são muito parecidas, aí ela não... não fala, não.

Entrev. - Você diz que ela não come sozinha, não se veste sozinha, não toma banho sozinha... ... não escova os dentes sozinha...

M. - ... não...

Entrev. - Dorme sozinha?

M. - Dorme sozinha. Tá tudo aprendendo agora, depois dessa médica aí, da Laramara, aí nós estamos... A gente vai chegar lá. Até o final do ano, se Deus quiser...

Entrev. - Ela conhece as partes do corpo?

M. - Tudo. Pode começar a perguntar daqui até...

Entrev. - Dos outros também?

M. - Tudo... é, conhece. Se você perguntar dos outros, também, dela, em cima, em baixo, se você perguntar, ela fala o que é.

Entrev. - Ela tem contato com o próprio corpo...

M. - Tem.

Entrev. - O corpo dela no espaço, ela explora as coisas, ela caminha...?

M. - É... dentro de casa ela sabe, né? tudo, assim, na escola, tudo ela conhece. Quando ela sai, não. Ela tem sempre dificuldade pra... lá fora, né? Ainda tem bastante dificuldade. Mas em casa, não. Em casa ela conhece tudo, ela sabe o espaço, tudo, da casa, aonde ela vai, se ela vai no quarto, no banheiro, no quintal, na escada, na garagem... Ela sabe onde ela tá, tudo.

Entrev. - Ela imita alguém ou alguma coisa?

M. - Não... assim... Ela imita a voz, né? Assim, quando você fala errado alguma coisa, aí ela lhe corrige. Ela gosta de corrigir, mesmo que ela corrige errado, que esteja errado. E ela gosta de imitar, assim, os meninos falando. Por exemplo, se você falar alguma coisa interessante, aí ela gosta de ficar imitando.

Entrev. - E na ação... naquilo que as pessoas fazem...?

M. - Não. Assim, onde ela estiver, eu falar: "Eu vou fazer”, ela não... lavar o copo, essas coisas. Só se eu chamar, assim: "Vivian, vem aqui na pia, vem ajudar a mãe”, aí ela vai.. Mas pra ela imitar, mesmo, sozinha, assim, não vai não.

Entrev. - E sobre a boneca, você diz que ela fala: "O nenê tá dormindo..."

M. - É, ela fala. Ela... assim...

Entrev. - De onde é essa experiência dela? É uma imitação. A criança imita o adulto nas coisas da vida... 
M. - Eu acho que é através dos meninos. Que nem, a minha cunhada, de fim de semana, ela ia muito em casa. Agora, não, que ele cresceu mais, e tudo. Mas, aí, a gente falava: “Ah, o Vinícius vai dormir. Ele é bebê. Ele tá dormindo”. Então, acho que isso aí fez com que ela soubesse que um nenê ia dormir, né? Que era a boneca, essas coisas assim. E, às vezes, a irmã dela também fala pra ela: “Ah, vamos colocar o nenê pra dormir? Ó, o bebê é a boneca, ela vai dormir”. Então, às vezes, assim, alguma brincadeira, quando ela tá de bom humor com a Ana, que a Ana vai brincar, ela aceita. Aí ela brinca. Mas é questão, também, de alguns segundos... Ela não é muito de... O negócio dela é ela sozinha. Sozinha, você pode deixar ela lá, que ela brinca. Enquanto ela quiser, ela vai brincando. Chegou alguém: "Vamos fazer isso", aí ela desinteressa daquilo... Ela não tem interesse...

Entrev. - E como que ela expressa os sentimentos? De amor, de raiva, de dor, de carinho, de cansaço, de ansiedade, de medo, de frustração...

M. - Ah... eu acho que, assim, ela demonstra pra nós, assim, a parte de amor, ela dá carinho, né? Ela dá carinho, passa a mão, dá beijo, né? Agora, de raiva, é ficar nervosa, mesmo. Quando ela tá nervosa, que ela tá com raiva, ela não quer papo com ninguém... Se você chegar perto dela, não adianta, que ela não quer mesmo.

Entrev. - E ela explica?

M. - Não.

Entrev. - Vocês entendem por quê?

M. - Ah, porque a gente vê o dia-a-dia, o que aconteceu, né? Porque muitas vezes, que ela tá assim nervosa, que... às vezes não sabe por que ela ficou. Muitas vezes não dá pra saber porquê. Porque ela chega da escola, às vezes ela chega da escola, ela vem nervosa, né? Então, a gente não sabe muitas vezes o que aconteceu. Ela não conta. Se você fizer alguma coisa com ela, se você der uma bronca pra ela, ela chega em casa e não conta. Às vezes eu saio e deixo ela com a Ana, a Ana briga com ela porque ela quer o som e a Ana quer assistir televisão, aí ela chega, ela fala: “Mãe, a Ana brigou”. Muitas vezes ela fala: “A Ana bateu”, mas aí, a Ana fala que não bateu. Aí ela fala. Mas lá fora, o que acontecer, pra ela chegar em casa e contar, assim, o que aconteceu, ela não... Da escola, se perguntar bastante, assim, ela... Nessa escola, que é lá na Sala de Recurso, aí ela fala. Você chega: "Ah, foi você que fez?”. "Ah, eu fiz o Braile, eu fiz a letra P de pai”, aí ela fala. Mas na outra escola, mesmo... A única coisa que ela chega e fala mesmo, assim: "Vivian..., todos os dias, o que você fez na escola?" "Toquei a campainha e brinquei com a mochila de rodinha do Henrique”. Todo dia a mesma coisa, a mesma coisa. Então, eu pergunto pra Isabel: “Mas por que...”, ela fala que o Jaime desce com eles pro lanche, né? Aí, quando chega lá, ele que toma conta das crianças, aí ele vai tocar a 
campainha, que é o sinal, aí ele leva ela com ele. Aí por isso que ela chega e a única coisa que ela conta é isso. Aí o Jaime leva ela, aí fala: “Vamos tocar o sinal pros meninos também?”. Aí ela chega: "Mãe, toquei o sinal e brinquei com a mochila de rodinha do Henrique!”, do coleguinha dela. Essas coisas ela fala, mas o que ela fez... se fez lição, essas coisas... Eu acho que também isso aí é incentivo da professora, né? Ela devia dar uma folha pra ela e falar: “Ah, , vamos fazer isso aqui... Leva pra sua mãe, ó, o que você fez!”. Aí, eu acho que ela ia chegar... porque na outra escola ela falava o que ela fez... Na outra ela falava. Então, eu acho que uma parte dessa é interesse... né? Porque eles alegam pra mim que não sabem o que fazer... o que trabalhar com ela, como fazer. "Como que nós vamos trabalhar com ela se a gente não tem material pra deficiente visual? Não sei nem como fazer!" Então... agora que a outra escola falou, que ia ensinar eles como eles fazerem. Aí isso, talvez, ajude ela a me falar o que aconteceu na escola. Porque quando toca a campainha lá ela fala, né?

Entrev. - Como ela aprende as coisas?

M. - Ah, a Vivian é muito inteligente. Ela tem uma inteligência... Todos os professores... as pessoas, assim, que... ela tem capacidade de aprender, ela aprende as coisas rápido. Tudo o que você falar pra ela pra ela aprender, pra ela fazer, ela aprende rápido, rapidinho. Ela tem facilidade pra aprender. Ela... falta oportunidade pra ensinar ela, né? Aqui mesmo, você vê, ela aprende a fazer bolo, quando chega em casa ela fala que fez bolo, quantos ovos ela colocou no bolo, quantas colheres de margarina... Ela fala tudo! Então ela tem facilidade. Mas é...

Entrev. - Ela memoriza...

M. - Memoriza. E ela não esquece...

Entrev. - E quando você dá um problema pra ela pensar, que ela que tem que raciocinar e descobrir a resposta...

M. - ... eu acho que não... Não. Aí ela não faz mesmo. Enquanto você tá com ela ali, ela tá fazendo. Aí você sai e fala: "Vivian, vai fazer isso aqui que eu vou ali...”. Aí, ela já... Aquilo lá pra ela já parou, né?

Entrev. - Se acontece algo que precisa ser resolvido... Por exemplo: "Ai, a chave não está aqui, a porta está fechada! E agora? Como é que a gente vai resolver esse problema? O que nós vamos fazer?"

M. - "Vamos esperar o pai chegar”, ela fala. Isso já aconteceu uma vez com a porta. Eu saí, eu levei a chave, só que quando eu cheguei, quando eu fui abrir a porta, a porta não conseguia ir, a chave não abria, né? E o pai tava lá embaixo, na garagem. E eu: "Vivian, eu não consigo 
abrir a porta". "Vamos esperar o pai chegar". Aí ficamos esperando ele chegar pra abrir a porta.

Entrev. - Como é a rotina dela? Os hábitos... o que ela faz no dia-a-dia?

M. - Ah, os hábitos... não tem muito, assim... Em casa? Ah, é normal... Ela acorda sempre... a gente acorda cedo, né? Seis e meia. Ela acorda, ela toma banho... eu dou um banho, né? Aí a gente sai por volta das sete horas, sete e dez. Aí nós vamos pra escola em Santo André, chega lá oito horas, fica das oito às nove e meia, né? Aí, volta pra casa. Ela almoça, aí eu levo na outra escola, aí lá ela fica uma hora e meia, né? Quando é duas e meia eu vou buscar. Aí, chega em casa, aí ela aquele tempo sempre... ela não gosta de dormir de dia. Aí aquele tempo dela é pra bagunça, mesmo, pra brincar, né? Aí ela inventa as brincadeiras, brinca. Aí gosta de assistir televisão, também, os programas de televisão, não todos... e ouvir música, também, ela gosta bastante de ouvir música. Aí chega a noite, quando é umas... seis e meia, sempre gosta de tomar banho. Tem vez, se deixar, é dois, três banhos por dia. Ela adora um chuveiro. Agora mesmo, ela pede... ela tá aprendendo ela mesmo a tirar... Esses dias, mesmo, ela fez, porque tava só de shortinho e uma blusinha. Quando é roupa fácil, ela mesma tira. Só que, aí, ela ficava embaixo do chuveiro, ela não sabia ligar. Ela esperava que se ela entrasse debaixo do chuveiro a água ia cair, né? (rindo) E eu lá embaixo: "Vivian, onde você tá?". Quando eu cheguei lá, ela tava debaixo do chuveiro. Tirou a calcinha e tava lá, né? Aí eu peguei e expliquei pra ela: “Ó, filha, quando chega aqui, tem que ligar, né?”. Aí, agora ela já sabe que tem que ligar o chuveiro. Mas... à noite, eu saio pro colégio, umas sete horas, aí ela ficou jantada, já, né? Fica com o pai, bagunçando com ele, porque, aí, pronto: quando eu chego, às vezes a casa ta caindo, porque é eles dois que ficam em casa, e a minha outra menina estuda à noite também. Aí ficam me esperando, quando é umas onze horas e pouco vamos dormir. Essa é a rotina de sempre, de todo dia, quase.

Entrev. - E fim de semana? O que vocês fazem?

M. - Ah, fim de semana a gente varia, assim. Eu não sou muito de sair. Eu gosto muito de... eu não sou muito de ir pra casa de parente, né? Ele sempre sai na casa dos irmãos dele, leva ela, né? Eu não sou muito, não. Eu gosto de ir muito assim pro clube, porque a gente é sócio do meu clube, né, o clube dos bancários, no Riacho Grande. Aí eu gosto. Assim, quando ele tá em casa no sábado, aí a gente vai no sábado. Lá tem casa, né? A gente, quando dá pra gente alugar casa, a gente fica lá no sábado e no domingo. É o único programa mais que eu gosto de fazer. Eu gosto de levar ela na igreja, também, que ela gosta muito de igreja. Aí no domingo à noite, eu levo sempre ela na igreja. Mas sou mais de ficar em casa, também. É que às vezes 
não tem mais condições de andar, você sabe, todo fim de semana, né? Aí tem que esperar receber, né?... pra depois. Então, não dá muito pra você sair todos os fins de semana.

Entrev. - Quando você sai de casa com a Vivian, como você sente o olhar das pessoas sobre a deficiência...?

M. - Isso incomoda. Porque, quando a Vivian era pequena, eu mesmo, muitas vezes, eu não saía, né? Porque às vezes você fala assim: “Ah, as pessoas lá!”. Só que tem gente da sua própria família que você percebe mais diferença do que mesmo das outras pessoas. Porque, às vezes, eu gosto muito também de ir pra Campinas de fim de semana. Sempre quando dá, eu tenho dois irmãos que moram lá, e tem os primos e tudo, então eu gosto de ir lá. Só que eu noto, às vezes, não... às vezes de uma cunhada, assim, de um primo, assim, eu noto mais frieza com ela. Porque as pessoas estranham. Então, às vezes eu noto isso na minha própria família, mesmo, eu noto muita diferença. Mas eu não ligo. Еu vou... eи vou...

Entrev. - O que incomoda?

M. - Assim: porque a maneira como o pessoal te olha. Eles te olham... eles não olham pra você, assim, como... uma criança deficiente. Se fosse uma criança loirinha, bonitinha, sabe, com os olhos lindos, as pessoas te olhavam com aquele olhar de admiração, né? "Olha que criança linda!”. Mas você não chega na pessoa pra perceber que ele te olhou com admiração, porque... “Ó que legal! Aquela mulher tem uma criança deficiente visual!” Eles não falam isso. Eles falam... olham assim com aquela cara de espanto, como quem falasse: "O que essa mulher tá fazendo aqui?”, né? "O que que essa mulher tá fazendo aqui com essa criança? Ela não enxerga!" (sussurrando). Você percebe nas pessoas aquele ar de espanto, assim.

Entrev. - Que era como você disse que se sentia também quando ela nasceu......

M. - Isso! É, é... Isso mesmo. Então, muitas vezes eu me fiz essa pergunta: "Pra onde eu vou? Como é que eu vou sair pra um casamento?" Que nem, na época em que a Vivian nasceu, ela era bebezinho, nessa época casou um sobrinho do meu marido. “Ah, mas vamos!”. "Mas eu vou fazer o que no casamento, com essa criança no colo? Eu vou deixar ela com quem?”. Porque eu sempre tive isso de não querer deixar com ninguém. Se o filho era meu, então eu que protegesse, eи que cuidasse. Porque eu ia ter que pedir pra uma irmã, pra um primo, pra uma prima, pra alguém pra ficar... Não! Então, se eu vou, eu vou ter que levar, né? Então, muitas vezes eu não ia, né? Muitas vezes eu não ia. Eu vim começar a sair mais quando eu percebi que a Vivian, ela tinha interesse em sair, ela gostava de sair, né? Você percebia que... “Ah, vamos em tal lugar?”. Você percebia que ela queria, que ela se sentia bem. Mas... esse negócio aí do pessoal ficar te olhando, te criticando, isso aí eu acho que não vai acabar nunca. Porque... sei lá! Eu não sei, também. Às vezes, também, eu me pergunto: "Será que se fosse 
comigo, eu também...” (rindo), não é verdade? Eu não iria olhar aquela pessoa: "aquela criança não enxerga...” Hoje não. Hoje eu vejo as crianças que não enxergam, pra mim... é uma criança normal. Eu nem olho. Às vezes eu encontro no metrô, no ônibus, uma mãe com uma criança deficiente, não só que não enxerga, mas com outros problemas. Então, às vezes eu nem olho, assim... Porque, se eu me sinto mal, aquela pessoa também, né? devei se sentir. Então, muitas vezes até eu nem olho, eu evito, pra não ficar aquela pessoa também constrangida. Mas eu acho que isso aí nunca vai acabar, porque todo lugar que você vai, sempre tem um curioso. E quando não vem as perguntas, né? "Por que ela nasceu cega?", "Por que ela...". Se eu soubesse porque, minha filha... né? Eu também gostaria de saber. Mas sempre existe...

Entrev. - Mas você sabe. Você teve rubéola.

M. - Não, eu não sabia... Assim, hoje eu sei. Porque a rubéola, na época, eu não tive rubéola, porque eu fiz pré-natal, fiz tudo, mas não estourou. Então, eu perguntei pro médico: "O que é rubéola?”. Porque eu não sabia nem o que era. Ele falou que no caso da Vivian foi bem fraquinha e foi dentro... assim, não estourou... Que nem no caso da Vivian, atacou só a visão, porque... ele falou assim: "A Vivian atacou só a visão, porque foi bem fraquinha”. Porque ele falou que tem gente que ataca a visão, a audição e ainda mexe com o cérebro da criança, né? Então, eu mesma vim saber depois de todos os exames... Mas eu não sabia também. É, hoje eu sei... Mas essa explicação, pra mim... não resolve... Eu também quero saber...

Entrev. - Você quer saber o que aconteceu com você...

M. - É! Por que a Vivian nasceu cega, ela poderia enxergar, ela é uma menina bonita, linda, mas por que ela não enxerga? Eu não vejo como foi a rubéola. Eu vejo a deficiência, né? Mas, pra mim... assim: por que foi a rubéola que fez isso? Pra mim, eu não entendo, eu não sei porquê. Eu só quero saber... eu só quero buscar uma solução. Mas a rubéola, pra mim, eu não entendi ainda que foi isso, entendeu?

Entrev. - O fato de ser uma causa física não te responde, que tipo de resposta você espera?

M. - Ah, não sei. Confesso pra você que eu não sei. Eu não... eu sei que o médico falou que foi a rubéola, mas quando alguém faz essa pergunta: “Por que ela nasceu cega?”, eu me pergunto: "Por que ela nasceu cega?". Eu não me lembro do fato que seria de ter sido a rubéola, né? Eu também falo assim: “Ah, mas isso é verdade. Por que ela nasceu cega?” Já tem uma explicação, mas pra mim ela não responde... ela não responde. Só que eu vou... o pessoal pode ficar olhando... Por mim, não, eu não tô nem aí. Eu também não sou muito de dar resposta. Que nem, aquela menina moreninha da escola: "Ah, eu fecho a cara, já dou uma resposta mal...”. Não! Eu respondo pras pessoas. Se ele tá perguntando, é uma curiosidade 
dele. Às vezes eu... eu não sou muito de... de maltratar as pessoas. Às vezes, na época em que a Vivian começava, assim, a... fazer as coisas, mas... eu tenho medo... na rua, de falar assim: "Vivian, não faz isso, filha” e vir alguém e falar assim: "Ah, mas a menina não enxerga, né? E a mãe tá gritando, falando alto com a menina...”. Então, eu evito ao máximo isso. Eu sempre trato a Vivian numa boa, pra ela não ficar nervosa, pra mim não ter que... pro pessoal... porque eles ficam falando, mesmo. Eles não querem saber... se a criança enxerga e faz uma birra na rua, você dá uma bronca, tudo, eles passam e não tão nem aí, né? Nem ligam. Muitas vezes passam e nem olham. Aí falam: “Ah, a mãe tá com a razão”. Mas, pelo fato dela não enxergar, se você der uma bronca, eu falo assim... o pessoal já te olha, assim. Porque eles falam assim: “Puxa, a criança não enxerga e a mãe tá...”, né? Eles já olham você, assim, com aquele olhar que você vê que a pessoa não gostou. Então, eu mesma já evito. Mas se me perguntarem, eu respondo... eu respondo. "Ah, mas ela é...”, tem uns que ficam insistindo. “Ela não enxerga?”. "Não, ela não enxerga. Não, ela tá dormindo, né?”. "Ah, mas ela tá com o olhinho fechado”. "Tá com o olho fechado”. "Ela não enxerga?”. "Não, ela não enxerga”. “Ela nasceu assim?. Eu falo: "Nasceu, ela nasceu assim”. Até aquela pessoa se cansar e aí ela pára. E tem uns que não param (rindo). Tem uns que vai até no lugar que você vai. Mas eu faço questão. Eu não gosto de maltratar as pessoas. Porque tem gente que fala assim: "Ah, eu fecho a cara quando me perguntam”. Não! Eu acho que a pessoa se sente curiosa, porque muitas vezes eu fiquei curiosa também, mesmo eu tendo um filho deficiente. Eu chegava aqui, eu via aquelas outras mães, eu queira saber qual que era a deficiência. Às vezes, a Vivian pequenininha e eu via uma mãe já com a criança grande. Então, muitas vezes eu tinha curiosidade. Eu não ia perguntar, mas eu tinha aquela curiosidade de eu saber, de eu chegar para aquela mãe e perguntar assim: "Como a senhora fez pra chegar o seu filho desse tamanho?”, né?. “Como você fez?” Assim... eu tinha, muitas vezes aqui mesmo, eu tinha curiosidade, mas eu não ia perguntar. Às vezes a pessoa não gosta. Mas não me incomoda, não, o fato de eu sair com a Vivian... Eu vou, eu viajo.. todo final de ano eu vou pra Bahia, ela adora viajar pra Bahia, né? Meus pais moram lá. Quando chega lá, meu pai pega ela, vai andar de cavalo, porque ela gosta de cavalo. Ele passeia de cavalo com ela... ele faz questão de andar com a Vivian e mostrar. Porque lá no Norte é assim: uma criança deficiente visual? Menina! É um bichinho, você entendeu? Você chegou com uma criança deficiente visual, deixa ali... Pra eles... acho que lá é assim: que lá tinha, antigamente, aquele pessoal do Norte, tinha pessoa que nunca saiu de casa, não sabe nem o que é. Então, eu chego lá, e o pessoal fica bobo com a Vivian. Pai pega ela dali onde ela tá e sai andando, e o pessoal corre atrás: "Ai, ela vai cair! Pelo amor de Deus, segura essa menina!". O pai morre de dar risada. Porque o pai já 
conhece ela. Ele viaja... todo mês ele vem pra cá, ele passa no máximo dois, três meses... Mas, daí, quando chega aqui, ele conta as coisas que a Vivian faz pro pessoal lá, ele fala que o pessoal não acredita. Aí, então, ele faz questão. Ele monta no cavalo, aí põe ela na frente, aí sai com ela. Aí, quando pensa que não, ele já pegou uma bicicleta. E o pessoal: "Gente, essa menina não enxerga! Essa menina vai cair dessa bicicleta!”. Então... ela adora isso aí. Ela gosta. Todo final de ano, a gente já faz uma economia pra todo final de ano a gente sempre viajar, né? Sempre viaja. Faz... dois anos que eu viajo sozinha. O meu pai e a minha mãe moram lá, e o meu avô, ele é bem velhinho. Então, eu gosto de ir lá ver ele, né? Ele tá com noventa e seis anos. Aí eu gosto de ir lá ver ele. Aí, às vezes, não dá pra ir a família toda, eu viajo com a Vivian. Sempre eu viajo. A minha filha gosta de ir pra Campinas, pra casa do meu irmão, a outra... Aí eu viajo sempre com a Vivian. Esse ano, não. Esse ano eu vou viajar com todo mundo. Já estamos programando de viajar com todo mundo. Mas eu gosto quando chega lá. Sorte minha e da Vivian. Aí lá eu me sinto bem! Porque lá, o que a Vivian faz, o pessoal acha que não seria capaz da Vivian fazer, né? Eles não acreditam que uma criança deficiente visual andar sozinha...

Entrev. - Ela já está usando a bengala?

M. - Não. Isso aí, quando ela começar, que vai ser um... Porque ela... eu já comprei, tudo. Ela vai começar a trabalhar com ela, já. Aí, quando eles virem ela, aí pronto, é que vão ficar aí. E lá não fica esse monte de pergunta. Porque devia ficar, né? Porque o Norte, né? Eu acho que o pessoal... de não sazer. Mas não sei se é porque todo mundo na Bahia é assim... lá no interiorzão mesmo, eles são mais... Então, é diferente da cidade grande. Eles não ficam naquela pergunta: "Por que ela nasceu assim?"

Entrev. - Eles aceitam?

M. - Aceitam! Eles admiram!

Entrev. - Integram...?

M. - Integram! Eles admiram o fato do que ela faz, você entendeu? Eles não ficam... Aqui não. Aqui, eles não querem saber. Eles querem saber porquê, porquê, porquê, né? Lá não.

Entrev. - E na sua casa o que vocês pensam da Vivian estar numa escola comum?

M. - Ah, eu penso assim: que deveria existir uma escola só pra deficiente visual. É, porque eu acho que eles são muito discriminados nas escolas assim. Porque... eu acho que o fato daquelas crianças... deles enxergarem, que nem... quando eles são pequenininhos, não. Quando eles são pequenos, eu acho que eles aceitam mais, né? Eles perguntam menos. Mas eu acho que deveria existir, assim, uma escola só pro deficiente mesmo. Eu acho que deveria. Porque, eu... não sei. Que nem no caso da, mesmo, é só a Vivian na escola, deficiente visual. É 
só ela. Então, tem muita dificuldade. Eu acho que se existe uma sala ou, não fosse uma escola, mas fosse uma sala só pra deficiente visual, eles tinham mais facilidade de aprender.

Entrev. - Isso é o que sempre foi feito, né? Da década de setenta pra frente... sessenta, setenta, é que as crianças começaram a estar na escola comum. Então você acha que deveríamos voltar àquele modelo?

M. - ... com certeza! Eu acho que seria bem... seria melhor pra eles. Eu acho que o fato deles conviverem numa sala com, digamos... oito, nove ou dez, que seja, alunos iguais eles são, deficientes, pra eles seria mais fácil eles aprenderem, eles aceitarem, do que ter aqueles outros que enxergam.

Entrev. - E pra se integrar à sociedade, se ela fica sempre separada?

M. - Ah, eu acho que eles conseguiam, eu acho que eles conseguem. Eu acho que eles conseguem diferenciar a sala de aula da sociedade. Eu acho que sim. Porque, lá, você vai ensinar pra eles... Ó, eu vejo na escola que a Vivian tá, em Santo André, eles têm uma Sala de Recurso, né? E eles são integrados em uma sala normal. Aí, o que eu acontece: aquela professora tá passando uma prova, aí passa a prova pra todos aqueles alunos que enxergam. Então, para aquele aluno, já tem dificuldade. Ela vai passar aquela prova, aquela prova vai para outra professora, professora vai passar toda aquela prova em Braile. Então, aquilo ali pra eles, né? Eles são sempre os últimos. Até aquela professora passar aquela prova em Braile, voltar pro aluno fazer... Eu percebo que eles tão sempre sendo os últimos. E se fosse tudo igual, a prova seria uma prova só. Então, o que acontece: "Vamos fazer prova de português”. Todos os deficientes estavam com a sua prova. Não tinha aquela de: "Ah, já acabei, professora”; “Ó, aqui, a minha”. E ele já tá esperando, lá, sentadinho aquela prova vir de uma outra professora pra ele fazer. Ou então eles deviam programar tudo junto, né? Porque... quando eu chego lá, às vezes eu tô na sala, aí os alunos já tão fazendo uma prova e aquele aluno tá descendo com aquela pasta pra professora lá na sala dela, passar aquela prova dele pra Braille. Entendeu? Ele vai responder aquela prova... Então, por que já não deixa tudo prontinho? Porque ele vai ter capacidade de responder a prova dele, porque, se ele sabe Braille, né? Ele vai ter responsabilidade... assim, na hora de todo mundo fazendo a prova, ele vai lá fazendo a dele.

Entrev. - E a Vivian, nessa parte, já está sendo alfabetizada?

M. - É... na Sala de Recurso... Tá tudo começando agora... Na sala de... na escola, mesmo, ela não tá fazendo nada! Agora que ela tá começando a letra do nome dela. Ela não sabe nada de Braille, a Vivian. 
Entrev. - Já estamos no final. Tem mais alguma coisa que você gostaria de falar que não tenha falado, que você acha que é o mais importante de tudo sobre a Vivian?

M. - Não. Acho que tudo já foi falado. Assim... o começo.... A única coisa que eu queria falar é assim: tudo aquilo que eu, no começo, eu falei, hoje já é diferente, né? Porque, às vezes, pode falar assim: “Não, mas é...”. Não! No começo, realmente... Agora, não. Agora, pra mim, eu já vejo a Vivian uma outra criança, né? Que a Vivian era triste, eu sentia no começo que ela era triste. Hoje, não. Hoje eu sei que a minha filha é feliz! Eu saio com ela, alguém fala assim: “Ah, mas... tadinha...”. Não! Tadinha por que? Muitas vezes eu falo: “Tadinha por que?”. Ela é feliz! Às vezes as pessoas olham assim pra você, assim: "Por que será que ela tá falando isso?”. Não, mas ela é feliz! Do jeito dela, né? É o mundo dela. Porque, você enxergar e perder a visão, eu acho que é uma coisa. E você já nascer deficiente visual, eu acho que é outra coisa, né? Então, hoje eu sinto, eu sei que ela é feliz. Pode até que lá na frente...

Entrev. - Já nascer cega é diferente de perder a visão depois?

M. - Ah, eu acho, sim. Porque você enxergar... Que nem, no caso, nós estamos aqui, ó, nó estamos vendo tudo. Eu saio daqui eu sei o que eu tenho que fazer, por onde eu tenho que passar, pra mim chegar no metrô, né? Então, eu acho que quando ele enxerga, quando ele não enxerga, ele não sabe o percurso. Ele vai aprender do jeito dele. Como que é, né? As ruas, tudo. E quando você enxerga, você vai ter mais dificuldade... em se perder. Você tem dificuldade, assim... Puxa! Você sabe o que é uma cor, você sabe o que é... ler, por exemplo. Você vai ter mais dificuldade por saber que você sabia ler...

\section{ENTREVISTA 3}

\section{Entrevistada: Sra. E. - mãe de Renan}

Entrev. - Eu queria pedir pra você falar um pouco do Renan: quem é ele pra você, que imagem você tem do seu filho, o que ele representa, como foi o nascimento dele... Enfim... me conte um pouco da história do Renan.

E. - O Renan teve um nascimento normal, né? E... até aí, tudo bem. De repente, eu levei ele na primeira consulta com a pediatra. Então, a pediatra falou: "Olha, seu filho tem um nistagmo”. Na verdade, eu não sabia o que era nistagmo. Então, eu... Hoje eu me sinto assim... um pouco assim até receosa, porque a médica falou que... nistagmo... Só que, daí, ela não explicou pra mim o que era nistagmo. Aí, assim... minha família perguntava: "O que é que seu filho tem?”. Eu falava: “É nistagmo”. Só que, como eu, nem as outras pessoas 
entendiam, né? Aí eu falava: “Ah, depois põe os óculos e ele vai ver normal, vai melhorar”. Eu entendi isso. Aí, eu continuei levando ele na pediatra, e a pediatra falou: "Olha, eu acho melhor você marcar uma consulta com o oftalmo". Inclusive me deu até o nome de um médico. Aí, tudo bem. Aí fui, eu tinha convênio e marquei a consulta com o oftalmo. E... daí... aconteceu que... eu tive que pedir a minha conta. Eu trabalhava no Extra nessa época. Daí eu tive que pedir a minha conta, porque eu não tinha quem olhasse o Renan. Então, daí, eu perdi o convênio. Então, aquela consulta que eu tinha marcado já não... Aí... tá. Aí, eu fiquei lutando pra ver se eu conseguia um médico público. Aí eu consegui no Juqueri. Nisso o Renan já estava com nove meses. Aí eu peguei... falei... Aí eu levei ele, né? Aí, o médico examinou. Aí, falou: “Olha, seu filho tem uma lesão na retina e ele não enxerga”. Aí eu falei... Aí ele falou assim: "Só que eu... eu te dei esse diagnóstico...”. Quer dizer, ele examinou tudo, direitinho, e ele viu o que é que era, né?

Entrev. - ... o oftalmologista?

E. - É. Ele fez o exame de fundo de olho, tudo... Só que ele pediu o seguinte: "Olha, aqui tem um especialista em retina. Então gostaria que você tal dia trouxesse ele pra confirmar o que realmente eu tô vendo”. Aí eu falei: “Tá, tudo bem!”. Aí, eu saí dali, eu não achava o rumo de casa. Luciano (pai) tava trabalhando, eu fui parar no serviço de Luciano, chorando. Só que Luciano já desconfiava, e eu não. Assim... Sei lá! Eu acho que eu não queria aceitar, né? Aí, Luciano pegou e... calmo, ele...: "Vamos pra casa”. Aí fomos pra casa, aí conversamos sobre isso. Ele calmo...: "Ainda tem uma chance, né? Ainda tem um médico que vai falar o resultado final”. Aí eu falei: “Tá bom!". Aí, no dia marcado eu levei o Renan, e o médico de retina, o especialista, confirmou que ele tinha amaurose congênita de Leber... E... daí, esse próprio médico me encaminhou para eu ir numa instituição, que se chamava Luis Braille, em Jundiaí, né? E eu cheguei nessa instituição com o Renan, chorando, sem saber o que fazer... Eu cheguei nessa instituição lá... sabe... Eu vi crianças cegas lá, e... eu... eu... parece que eu tava assim em outro mundo, sabe? Eu não queria aceitar. Aí eu entrei, comecei a conversar com a moça que tinha de assistente, lá. Aí ela me explicou como funcionava a instituição. Aí ele ficou passando com a psicóloga e com a terapeuta ocupacional.

A psicóloga ficou assim: ela ficou observando, né? E com a terapeuta ocupacional também, né? Porque também ela é uma pessoa muito legal. Aí ficou conversando muito. Só que, daí, Luciano tava fazendo bico lá em Franco da Rocha, e acabou. Daí, a gente se viu sem nada, sabe? Foi um sufoco! Porque eu tinha a minha família lá, só que minha família era assim, do tipo de pessoa... eles ajudam, sabe? Mas o mundo inteiro fica sabendo. Daí... eu tenho uma 
irmã que mora em Itapevi. Daí eu falei: "Olha, Luciano, é o seguinte: eu vou pra Itapevi conversar com minha irmã, ver se ela consegue algum serviço pra você, daí você vai”. Tá bom. Daí eu fui, conversei com minha irmã e no mesmo dia que eu conversei com minha irmã, minha irmã conseguiu um serviço pra Luciano. Foi rapidinho, sabe? Ela conversou com uns amigos dela, e daí ela arrumou. Aí, tá, Luciano começou a trabalhar nessa firma. Aí, nós fomos pra lá. Aí, chegando lá... E foi tudo tão rápido, que eu não me desliguei da instituição. Aí eu fui, liguei lá na instituição, lá em Itapevi, né? Liguei na instituição e falei que eu precisava saber se tinha alguma instituição próxima, né? Porque eu tava em Itapevi... Aí falei o que aconteceu. Aí ela me indicou a Laramara... Aí... inclusive... quando a Laramara tava mudando pra aqui, eu fui lá... na Lapa...

Aí eu cheguei lá, mais Luciano, aí o rapaz falou: "Mudaram”. Aí deu o endereço daqui, né? Aí eu vim, conversei com a assistente social, que me tratou super bem, né? Vim, conversei com ela, e... Tá, tudo bem! Aí ficou certo pra eu vir conhecer a Laramara. Só que, no dia em que eu vim conhecer a Laramara, você acredita que eu não consegui entrar?

Entrev. - Por que, E.?

E. - Por causa do Re... [E. diminuiu a voz]

Entrev. - Por que?

E. - Foi assim. Na hora que... engraçado, eu vinha muito bem com ele. Quando eu cheguei na porta da Laramara, Renan deu uma crise de choro, que não fazia cristão entrar aqui.

Entev. - Ele estava com quanto tempo?

E. - Ah... um ano e pouco. Um ano e meio, mais ou menos... Aí começou a chorar, chorar, chorar... E, daí, quando ele começou a chorar, eu comecei a ficar angustiada, angustiada, porque eu não conseguia fazer ele parar. E eu não sabia o porquê que ele tava chorando. E daí eu comecei a ficar angustiada, angustiada... Aí eu comecei a chorar, também. Aí, inclusive, uma profissional, que trabalhou aqui, né? ela virou pra mim e falou bem assim: “Eu posso te ajudar em alguma coisa?”. Eu falei: “Nem eu tô entendendo, porque ele tá chorando desesperadamente, eu não sei por quê!!”.

Entrev. - Você estava sozinha?

E. - É, eu e o Renan. Aí a assistente social me chamou, aí falou pra mim assim: "Olha... pode ir pra casa, fica calma, vai pra casa, que a vaga do Renan já é dele. Então, vamos marcar 
pra tal dia, pra ele já começar”. Aí, assim eu fiz. Aí eu fui pra casa e daí eu comecei o atendimento no Laramara.

Entrev. - Você falou do momento que a médica deu pra você um primeiro diagnóstico de nistagmo... e que você não entendeu e achou que, depois, usando óculos, ele ia ficar bem...

E. - (risada)

Entrev. - ... Você disse que, no fundo, você sabia, mas não queria aceitar?

E. - Não, eu não sabia.

Entrev. - Não sabia?

E. - Ó, assim: eu cheguei um dia pra levar Renan numa consulta. Só que não era a mesma médica, era outra. Então a médica ficou investigando com a luzinha. Eu percebi alguma coisa estranha. Aí eu comecei a perguntar pra ela "Por que a senhora tá fazendo isso?”. Aí ela falou: “Não, não é nada, não”. Ela não quis falar pra mim. Mas, assim: eu percebia alguma coisa estranha, né? Hoje eu sei o que é nistagmo. Nistagmo é o mexer dos olhos, né? Sem controle... Né? Mas pra mim, naquele tempo, eu não sabia o que é que era.

Entrev. - E foi essa mesma médica que investigou com a luzinha, que falou do nistagmo?

E. - Não.

Entrev. - Ah, não?! Depois foi a oftalmologista?

E. - Do nistagmo? Não. Foi a primeira consulta que eu fiz, na pediatra, que falou pra mim...

Entrev. - ... já logo ao nascimento?

E. - É. A primeira consulta... ela diagnosticou por causa do mexer dos olhos, né?

Entrev. - E depois, antes da primeira consulta com o oftalmologista, você não percebia que ele não acompanhava você, não acompanhava os objetos, não procurava...?

E. - Não. Não. Eu não percebia. Eu acho... Sabe, esses dias eu tava pensando: eu acho que se eu morasse, assim, num lugar... Porque tem aqueles municípios que as mulheres têm filho em casa, né? Não... Eu acho que eu nunca teria levado ele no médico pra saber... Não sei... Eu acho que eu iria perceber só depois que ele estivesse grande, que eu iria perceber... Porque eu não percebi.

Entrev. - Você disse que o pai percebia? 
E. - É. Luciano achava diferente. Mas eu, não. Eu não sei por quê.

Entrev. - Ele comentava com você... ou não?

E. - Não, porque eu não dava oportunidade...

Entrev. - Como assim?

E. - Assim: se ele tocasse no assunto, aquilo me afetava... me machucava. Eu não queria aceitar... que meu filho era diferente. Ah, que... Sei lá! Que era impossível isso acontecer. Por que comigo, entendeu? Por que justo comigo? (pausa longa) Então, eu não queria acreditar. Não é possível, né? (pausa longa)

Entrev. - Você imaginava alguma coisa?

E. - (pausa longa) Como assim?

Entrev. - Nesse período, até você ter esse diagnóstico, e aí chegar no trabalho do Luciano, e depois ir pra mais um oftalmologista... Era nesse período que você pensava isso?

E. - Era. Até procurar o segundo oftalmologista. Porque eu tinha uma esperança de chegar lá, sabe? A esperança é a última que morre. Então eu tinha a esperança de chegar, e ele: “Não, foi um engano”. Sei lá! De repente, né? Mas, não. Ele falou pra mim: "Olha, ele tem...”. Inclusive, sabe, o Renan... Eu saí de lá, eu fiquei mais nervosa foi com o médico, acho, do que com o diagnóstico dele. Porque ele foi super grosso comigo, sabe? O Renan tava se mexendo, então eu fui tentar segurar. E se eu fosse segurar como o médico queria, eu ia acabar machucando o Renan. "Não, mãe, você não sabe segurar o seu filho”. Sabe? Na maior grosseria! Ah, eu saí toda chateada de lá. Mas... foi o que ele falou pra mim, né? É uma realidade, ele não enxerga.

Entrev. O que significava pra você ser cego, não enxergar...?

E. - Antes de ter meu filho? Antes... eu via como uma pessoa... uma coitada! Assim, vamos supor: eu não tinha na minha família! Então, eu... pra te falar a verdade, eu tinha uma colega que a avó dela era cega e eu tinha medo! Eu morria de medo da avó dela!

Entrev. - Que idade você tinha?

E. - Ah, mais ou menos, eu tinha uns quinze, dezesseis anos. Eu morria de medo! Eu chegava lá, eu lembro que ela ficava agachada, né? Ela ficava agachada, e a gente passava e ela ficava passando a mão, assim, pra pegar na gente, né? Nossa! Eu tinha pavor daquilo! E ela, 
eu lembro que ela ficava muito nervosa, porque a gente tinha medo dela, né? E ela queria até agredir a filha dela. E, daí, aquilo me apavorava! Eu morria de medo. Agora, depois, hoje, eu vejo como... Ó, vou dar o conceito das pessoas. A gente vem no trem, sabe, e tem aquelas pessoas que... aqueles deficientes visuais que ficam pedindo. Se fosse a um tempo atrás, eu... se eu não tivesse filho, eu daria. Mas, como eu tenho um filho e eu sei que eles têm que se valorizar, então eu não dou...

Entrev. - Hum, hum... E o seu filho que não podia ver, enxergar, o que representou pra você? E. - (pausa) Olha, foi difícil, viu?! Eu... vou ser sincera: eu escondia das pessoas, sabe? Eu procurava pegar Renan, sempre pôr ele pra dormir no trem, pra não ver as pessoas ficarem olhando, perguntando. Se eu fosse no mercado, eu levava ele, mas eu colocaria ele, sabe? com o rostinho, assim, do lado do pescoço... Eu tentava esconder ele. Porque me incomodava, as pessoas; me incomodava.

Entrev. - Você lembrava da avó da sua amiga nessa ocasião?

E. - Não. E... ficou, assim, uma história marcante, né? Porque eu tinha medo! Não sei. Não, não sei, eu tinha... Tanto, que... agora eu me lembrei de uma coisa: tem uma criança que... não, no momento agora eu não tô lembrada, mas que eu já percebi que tem medo de meu filho). É como eu também não sei falar por quê... É como eu também não sei falar porque que eu tinha medo dessa mulher que não enxergava. Eu não sei se era porque eu via ela, assim, muito nervosa, eu tinha medo dela me agredir. Mas eu tinha medo.

Entrev. - Vou insistir: o que é que você imaginava da cegueira? Que imagem você tinha do seu filho quando você soube que ele não enxergava. Porque você falou das pessoas e falou que você tinha...

E. - ... medo...

Entrev. - Você falou, também, que escondia o Renan...

E. - Não... pelas pessoas... Talvez eu, assim, eu aceitasse a cegueira dele, mas... é... assim, me incomodava o que as pessoas iam ficar me perguntando. É como assim: uma ferida, né? Se você não mexe, não toca nela, então ela não vai doer, ela vai permanecer ali e, talvez, cicatrizar. Então, cada vez que as pessoas me perguntavam, eu me magoava. Então, eu acabava ficando nervosa, entendeu? Tentava até responder mal, pra cortar pela raiz, entendeu? Mas... é... quanto a mim, a cegueira não me incomodava tanto. Eram as pessoas. 
Entrev. - A palavra "cegueira", incomoda?

E. - Incomoda. Agora, nem tanto, mas... é assim: me incomoda ainda. Inclusive, esses dias, um coleguinha do Renanl tava chamando ele na escola, né? Mas, só que, assim: eu vi por um lado, porque o Renan, ele é uma criança fechada. Ele não fala, assim, o que acontece na escola, entendeu? Então, conversando bastante, eu descobri que esse menino era amiguinho dele e, de repente, ficaram de mal, tipo assim: de mal, e daí o menino ficou tirando tipo um sarro... chamando ele de cego. Mas esse cego, eu não senti, assim... como a palavra "cego". Eu senti como se fosse assim... um sarro... Entendeu? Tipo assim, querendo menosprezar...

Entrev. - E o que pega nessa palavra pra você, que incomoda?

E. - Ah, não sei. Eu sei que me incomoda. Não tem jeito! Eu já tentei... às vezes eu falo... Mas, não sei... Sabe por que? Porque é diferente: quando você fala cego, você não tem o filho cego, então não te dói tanto. Mas quem tem, dói! A palavra... É como se essa palavra menosprezasse... Assim, vamos supor: você é cego, você não pode pegar essa caneta. Eu posso. Eu vejo, entendeu? Não sei. Eu acho que é isso.

Entrev. - E antes dele nascer, que filho esperava?

E. - ...Ah, esperava um filho saudável, porque Luciano era louco pra ter um filho, principalmente menino. Então, eu queria dar esse filho pra ele. Eu também tinha desejo, né?

Entrev. - Quem foi esse filho que nasceu?

E. - Renan... (pausa)

Entrev. - E quem é o Renan?

E. - Meu filho! (risada). Foi assim: uma criança que me desarrumou... entendeu? Eu não sabia por onde começar... não sabia... Assim... parece que ele... bagunçou tudo. Eu... uma vez que tava conversando com uma psicóloga, e... eu estudei, eu fiz magistério, né? E... eu tava falando pra ela, que parece que tudo o que eu estudei, parece que alguém pegou uma borracha e apagou... E a partir daquela criança, eu iria começar do zero, eu ia começar a estudar... Porque eu parei ali.

Entrev. - O que você sabia sobre criança, não servia pra esta criança?

E. - Não, não, não... eu não sabia por onde começar. Eu não sabia por onde começar, eu tava sem rumo! 
Entrev. - Começar o que?

E. - A cuidar! Eu não sabia como poder ajudar!

Entrev. - E nos primeiros nove meses, antes de saber que ele não enxergava, como foi? Como é que você cuidava nesse tempo?

E. - Ah, normal. Mas você vê a diferença... Quando você... Eu não sabia, eu cuidava normal. Depois que eu descobri, aí sim, como diz o outro, caiu minha ficha. Então eu me senti, assim, insegura. Eu não sabia como poder ajudar... Entendeu? E... foi difícil pra mim! O pior que... Renan, ele... ele era assim: ele não... não fazia nada, assim, pra me... animar... eu me sentia... cada dia que passava, eu me sentia frustrada por não conseguir ajudar. Porque ele chorava, ele ficava angustiado. Se ele... Vamos supor, se ele perdesse o chinelo, ele não procurava aquele chinelo. Então, o que acontecia? O que acontecia? Eu ficava nervosa, eu batia no Renan porque eu não sabia o que ele queria, sabe? E a psicóloga que me... ela que me ajudou, sabe? E até hoje eu agradeço o Laramara, sabe? Porque eu tava no fundo do poço. Meu casamento desmoronou. Luciano me batia, sabe?

Entrev. - E antes não?

E. - Não. Ele bebia muito. Cada ida dele no bar, eu ficava em casa ansiosa. Eu não sei se eu passava isso também pro meu filho, né? essa insegurança também no casamento. Daí ele tinha essas atitudes que... não sei...

Entrev. - Quem?

E. - Renan.

Entrev. - Que atitudes?

E. - Assim, de... não ter atitude, de não procurar... Vamos supor: ele perdeu o chinelo, ele ter a atitude de procurar o chinelo, entendeu? Vamos supor: se Renan se batesse em algum lugar, ele me batia, sabe? Então, daí, quando ele fazia isso, eu sentia assim: "Meu Deus, ele não enxerga, eu tô responsável pra ver por ele!’. Então, era assim uma forma, parece... ele não me falava, mas eu me sentia assim, parece... Ele não falava, mas eu me sentia assim...

Entrev. - Quando ele se machucava, batia em você?

E. - É. Entendeu? Ele batia, assim, numa forma de dizer... Eu que percebia. Não sei se realmente ele tava passando isso pra mim, mas eu percebia que ele queria dizer assim: "Você 
enxerga por mim, não deixa eu me machucar”. Então isso me deixava mais angustiada, mais angustiada... Aí, graças a Deus, a psicóloga começou a falar bastante, conversar bastante comigo. Ela falou: “E., fica calma, não bate nele, porque isso tá frustrando ele mais ainda. Aí que ele vai ficar mais angustiado. Porque ele quer te passar uma mensagem chorando. Ele quer te falar alguma coisa, e você não tá entendendo; você tá respondendo com outra coisa. com tapa”.

Entrev. - Antes você conseguia ser mãe dele?

E. - É. Depois eu não conseguia... Eu não conseguia ser mais aquela mãe. Eu. por isso que, sabe, eu liguei lá... no Luis Braille e pedi, pelo amor de Deus, pra me falar de alguma instituição. Porque, sinceramente, eu não conseguiria cuidar dele... Aquilo bagunçou a minha cabeça...Sabe, assim, é a mesma coisa de você tá dirigindo, né? Você tá dirigindo numa linha reta, de repente vem um carro e bate em você, você fica... perdida, sem saber... Ele não me animava. Então esse... essa falta de estímulo dele, assim, de atitude, entendeu? Isso me fazia, como diz o outro, perder o rumo... Era como se eu estivesse fazendo uma coisa inútil, porque... eu não tinha resultados. Parece que eu tava andando pra trás. Mais ou menos isso.

Entrev. - Hã, hã. E você fazia o que?

E. - Tô tentando fazer uma volta... (rindo) ao passado. Não, não... Ah... não lembro.

Entrev. - Hum, hum. Hã... então me fala um pouquinho do desenvolvimento dele de bebê; Ele mamou no peito... como é que foi esse comecinho?

E. - Mamou até três meses. Três meses ele não quis mais. Aí, um dia, eu fui dar de mamar pra ele, né? Eu tava na casa da minha tia. Ele não quis, não quis, não quis... de repente, assim. Eu falei: “Ai, tia, ele deve tá doente, né, porque ele não quis”. Aí tia falou: "Espera aí”. Aí foi lá, fez uma mamadeira de Maisena, Renan tomou (rindo) e não quis mais saber.

Entrev. - E ele tomou mamadeira até quanto tempo?

E. - Ah, até um ano e pouco.

Entrev. - E como foi pra tirar a mamadeira?

E. - (pausa grande) Ai... não lembro. A chupeta eu lembro que, quando eu entrei aqui, né? com um ano e pouquinho, a físio falou: "Olha, E., vamos tirar?”. "Vamos”. Aí, Renan só chupava de um tipo de chupeta e onde eu moro, no bairro, não tinha essa chupeta, só no centro de Barueri. Aí, eu cheguei em casa e falei: "Luciano, a gente vai ter que tirar essa 
chupeta”. Luciano: “Mas, E...”. Eu falei: “Vamos”. Aí, um belo dia, ele pegou e rasgou a chupeta. De repente, ele pegou e rasgou. Aí eu falei: "Pois a partir de hoje, eu não vou comprar mais pro Renan”. Aí ele ficou meio tristinho, assim, um dia, dois. Aí Luciano: "E aí, E.?”. Eu falei: “Ah, Luciano, eu acho que eu vou ter que comprar outra”. Aí depois eu falei: “Não! Quer saber? Eu não vou comprar”. E não comprei, e ele esqueceu (rindo). Eu achei até que ele esqueceu rápido, porque ele... Renan nunca foi assim de conversar. Foi difícil ele conversar. Tanto que, até hoje, sabe, tem coisas que ele não fala. Acontece e ele não fala.

Entrev. - Como ele se comunicava com você? Não era falando?

E. - Não.

Entrev. - Como é que ele ia te mostrando o que ele queria, o que ele sentia? Você conseguia perceber isso nele?

E. - É, eu consegui... foi depois desse toque da psicóloga, de mandar eu ter mais calma, de eu tentar compreender ele. Como ele não falava, era assim: eu tinha que tentar compreender ele assim... aos poucos...

Entrev. - Como foi o desenvolvimento dele até nove meses: a criança mama, desmama, normalmente sai do peito, segura a cabecinha, senta, engatinha, começa a fazer os primeiros sons até falar alguma palavra...

E. - Isso aí foi normal.

Entrev. - É? Como foi? Essas coisas todas, como aconteceram?

E. - Ah, assim... na minha concepção, eu acho que ele teve assim... de uma criança normal, o desenvolvimento de uma criança normal.Sentou, engatinhou, começou a andar com um ano e seis meses. Falar, era "mamãe”, "papai”... com um ano e pouco... Agora, assim... entender ele, era só expressão, mesmo. Na minha concepção, Renan foi difícil de ser entendido. Entendeu? Porque, era isso: ele não ajudava, ele não falava, porque ele sabia falar, e ele não falava, entendeu? Ele poderia procurar as coisas, e ele não procurava... Entendeu? Então ele foi, realmente, uma pessoa difícil de ser compreendida. Eu não sei se era porque, também, eu tava angustiada, como eu te falei e isso eu passava pra ele. Então ele se tornava... eu achava se... uma concepção que eu tenho, também... da deficiência, da cegueira... Renan, de imediato, me passou o que: que ele não era capaz de fazer nada sem a ajuda de outra pessoa. Agora, eu seria aquela pessoa que iria ajudar. Mas como, se eu não tinha experiência nenhuma? De não saber onde começar, como eu poderia ajudar ele. Entendeu? Então, a 
instituição foi um ponto fundamental pra mim poder ajudar ele. Acho que, se eu não tivesse essa instituição, eu não sei o que seria de mim.

Entrev. - E nesse comecinho da vida de Renan você falava com ele? Cantava...

E. - Ah, eu cantava pra ele dormir. Ele era uma criança calma.

Entrev. - E nesse tempo você entendia ele?

E. - Entendia... ele não fazia nada. Mas, do mesmo jeito ele não fazia nada e... quer dizer, não fazia... hã...

Entrev. - Ele era bebê e não falava, mas você entendia...

E. - É... (pausa longa). É como se... é... eu compreendesse que, como ele era bebê ele não era capaz de fazer, assim, coisas extraordinárias, entendeu? Eram coisas normais. Então, depois que eu soube da cegueira, aí foi... diferente. Eu já vi de uma outra forma... Como poder ajudar? Eu queria ler livro, sabe... eu queria... Sei lá! Pesquisar, fazer alguma coisa pra eu poder ajudar. Porque eu me sentia incapaz. Aí eu pensava comigo: "Onde tá o meu magistério que eu fiz, se eu não sou capaz nem de cuidar de meu filho, de saber como ajudar?".

Entrev. - dos nove meses até um ano e meio, quando você chegou na instituição foi o tempo que ficou mais perdida?

E. - É. A instituição foi a porta pra mim, entendeu? Aí eu comecei mais... é... ter mais consciência das coisas, né? Aí eu comecei a ler, né? E conversava com as mães aqui, e isso me animava, mais, entendeu? Eu aprendi a ser mais forte, que eu não era, sabe? Teve uma vez, eu me lembro, eu entrei aqui no Laramara e eu vi um menino deformado. Ah, foi o ponto de eu ir pro banheiro, mas eu chorei, chorei, chorei, eu saí arrasada do Laramara, sabe? Naquele dia, eu achava que Deus não existia, porque não era possível de ver uma criança daquele jeito. Me deu mais... isso, hoje eu vejo como um fortalecimento, entendeu? Mas que é difícil, é. É como assim: as outras pessoas da rua vêem os meus filhos. Eu sei que todos no mundo tomam choque de cara, como eu já tomei com as crianças que eu já vi, né? Então é isso. Era assim: a primeira impressão, olha pra um, olha pra outro, aí... Entendeu? Só que o que aquelas pessoas que viram, vamos supor, uma ou duas vezes no trem, não vão se fortalecer, porque foi uma só vez que viram. E nós, não. Nós tamos convivendo. Porque, assim, é diferente. Como... assim: eu tinha medo daquela mulher, porque eu não convivia com ela, não era da minha família. Então, é diferente, é totalmente diferente. 
Entrev. - Em algum momento você teve medo do seu filho?

E. - Não.Mas é como eu te falei: eu acho que o meu medo era porque ela ficava nervosa e acabava agredindo quem passava por perto dela, assim. Ela agachava, assim, ela... Então, eu acho que era aquilo que eu tinha medo dela. É, mas meu filho, não!

Entrev. - O Renan expressa a agressividade dele de algum jeito?

E. - Assim, quando ele tá... Na realidade, Renan até hoje, eu acho que ele não sabe brincar. Sabe... o jeito de Renan brincar é, assim, tipo... ele acha que tá brincando, mas, na verdade, ele é machucando...

Entrev. - Como assim?

E. - Assim, vamos supor: ele tá ali com o irmão, dali a pouco ele vai lá, dá um tapa no irmão. Ele acha que aquele tapa não doeu, mas na realidade doeu. Com outras crianças também. É tanto que... ele foi uma criança assim: minhas colegas, minhas irmãs iam lá pra casa, Renan nunca ficava na sala, nunca ficava junto com a gente. Se a gente fizesse um churrasco, Renan não tava ali no meio. Ele sempre se isolava no quarto. Ele trancava a porta do quarto, porque ele queria ficar lá sozinho.

Entrev. - Você disse que o escondia das pessoas. É isso?

E. - É. Mas é assim... eu escondia pelo fato das pessoas ficarem me... me interrogando e eu não tava com vontade... Eu achava assim: eu já tenho, assim, muita coisa do meu dia a dia, muita coisa pra eu aprender, entendeu? Então, as pessoas ficam me interrogando, então eu tenho que ficar explicando, falando de coisas que eu já expliquei pra um monte de gente. Então isso me deixava irritada. Aí, depois, Renan deu pra fazer isso. Aí eu comecei... Então, aqui no Laramara, ele também aprendeu a conviver com outras crianças, também foi um ponto assim muito bom, entendeu? Agora hoje, não. Chegam as minhas irmãs, a gente faz churrasco, minhas colegas... ele vem pra sala, ele brinca... Mas eu ainda sinto que ele não é aquela criança assim que faz amizade rápido... Ele não é de... ele é superinteligente, o Renan, só que ele não demonstra. Olha, ele faz cada conta, assim, bárbara, de matemática, só que ele não demonstra pra ninguém... Um dia desses, né, a professora dele... eu cheguei na escola e a professora dele falou assim: "Nossa, E., eu não sabia que o Renan sabia tanto matemática! Ele deu uma aula aqui para os coleguinhas”. Aí eu falei assim: "Ah, é? Então, Renan, vamos mostrar o que você sabe”. Aí, comecei a fazer perguntas, né? de matemática, 
que ele responde, né? Nossa, os colegas dele ficaram tudo... Aí a professora falou: "É, ele não demonstra o que ele sabe. Ele guarda pra ele”. É assim.... E assim é o Renan (rindo)...

Entrev. - R outras coisas no desenvolvimento dele? Tirar a fralda, como foi?

E. - Foi difícil também... Porque ele fazia xixi, fazia cocô na roupa e eu conversava com ele...

Entrev. - Até que idade?

E. - Até três anos. Foi muito difícil tirar ele da fralda. Ele ia dormir, eu conversava com ele bastante, tentava passar pra ele, né, que tinha que ir no banheiro e tudo. E ele ia dormir, e sempre acordava de xixi e de cocô.

Entrev. - E durante o dia?

E. - Não. Durante o dia eu controlava, né? Ia levando...

Entrev. - Ele pedia, você antecipava...

E. - Eu que antecipava... Como ele não falava... E eu sabia. E o que eu ficava mais assim era porque ele sabia falar, e não falava. Eu perguntava as coisas a ele, Renan não respondia... Então ele era assim: muito fechado...

Entrev. - Algumas crianças que não enxergam... permanecem muito tempo levando brinquedos ou outros objetos na boca. Usam mais a boca pra conhecer o mundo do que a própria mão. Isso aconteceu com ele? Ficar agarrado em algum objeto específico...?

E. - Não.

Entrev. - Ele usa as coisas com a função que têm? Por exemplo, ele pega um objeto, ele usa pra fazer alguma coisa. Ou ele usa só pra ficar batendo, balançando, batendo no corpo dele...?

E. - Engraçado, uma coisa que você me lembrou bem. Ele... quando ele era menor, assim, uns dois anos, por aí, ele sempre pegava o chinelo do pai pra brincar. Hoje ele pega sabe o que? Um pente. Eu tenho um pente aí, ele chega, vai lá, pega o pente, brinca. A pá de lixo ele quer brincar, só que eu já expliquei pra ele. Eu falei: "Renan, a pá de lixo é pra tirar, pra pegaro lixo. Não pode, né, porque tem sujeira”. Aí, não, ele acaba indo, pegando...

Entrev. - E brinca como?

E. - Assim, tipo um trem. Tipo como se ele estivesse dirigindo. Ele fica balançando a pá e fica como se ele estivesse num trem... faz o barulho de trem. 
Entrev. - E ele fala alguma coisa acompanhando a brincadeira?

E. - Fala, fala...

Entrev. - E com o chinelo do pai? Também era assim?

E. - Era. O trem. Ele é apaixonado pelo trem. Ele sabe estações, ele... e faz o jeito quando abre as portas do trem, do metrô, ele sabe. Então, o trem é tudo pra ele.

Entrev. - E ele tem trenzinho de brinquedo?

E. - Não. Eu nunca achei assim pra comprar. Engraçado você falar isso, mas eu nunca vi, assim... Também, eu vou te falar, é tão difícil de eu sair, assim, porque eu trabalho a semana inteira; sábado e domingo eu fico em casa, fazendo o serviço de casa, né? Então, é difícil! Pra te falar a verdade, eu nem saio pra ir em loja. Eu não tenho...

A pedagoga, ele passou um bom tempo sem conversar com ela. Então, ela descobriu esse ponto fraco dele de trem. Então, a máquina em Braille, ela começou a conversar que era o trem, sabe? Mas, assim, no fundo, ela foi mostrando também que era uma máquina, entendeu? E daí ele foi se interessando mais. Ele adora a máquina, sabe?

Entrev. - Ele se alfabetizou?

E. - Ainda não. Mas, assim, o que ele aprende aqui, o que eu sei um pouquinho, eu tô ensinando pra ele em casa... Mas na escola, não. Ele não lê, ainda. Ele faz as letrinhas.

Entrev. - Ele decora o código de cada letra?

E. - Decora. Decora rapidinho. Eu falo uma vez, e ó... Ele ensina pro irmão. É. E ele fala os nome e escreve...

Entrev. - Palavras?

E. - Escreve palavras.

Entrev. - O que ele escreve?

E. - Assim: eu tenho um joguinho lá em casa, que forma palavras, que foi dado até aqui no Laramara... forma palavras em Braille. Aí, nós vamos... Eu falo: "Renan, que palavra você quer aprender?". Eu deixo pra ele falar. Aí ele vai falando as palavras, e aí eu falo: "Que letra que tem?”. Aí ele vai falando a letrinha e aí nós vamos fazendo aquela palavra.

Entrev. - Você que monta? 
E. - Não. . Ele encontra a letra...

Entrev. - Então ele lê? Pra encontrar a letra, ele tem que reconhecer qual é a letra, pelo tato...

E. - Não, assim... É porque o joguinho é assim: tem uma rodinha, e é colocado aquele... é que eu não lembro o nome do joguinho. Então é colocada a palavra, aí ele sabe, tem as seis...

Entrev. - A palavra escrita em Braille?

E. - Braille. É pra você formar as letras... é aquela "rodinha”...

Entrev. - É pra encaixar...?

E. - ... é. E ele sabe. Aí eu vou falando... e ele vai montando. Aí eu falo assim: "IRê,, que palavra você quer que eu faço?”. Aí ele fala. Por exemplo, bola. Aí, quais os números (pontos) da bola? Aí ele fala.

Entrev. - Aí você dá a "rodinha" pra ele...?

E. - Não. Ele mesmo pega e monta.

Entrev. - E depois?

E. - Ele passa a mão...

Entrev. - ... e consegue saber onde está cada letra...?

E. - Ele consegue.

Entrev. - Então, ele já está começando a ler?

E. - $E$.

Entrev. - E se você faz o contrário? Se você escreve uma palavra e pede pra ele descobrir qual é a palavra?

E. - Não, isso eu nunca fiz, não.

Entrev. - ... você sabe Braille?

E. - Um pouquinho...

Entrev. - Ele escreve na máquina?

E. - Escreve.

Entrev. - E na escola, como é? 
E. - A professora não sabe... Entendeu? E eu acho assim: não tem interesse, também, a escola, entendeu? Só a inclusão mesmo... só pôr lá...

Entrev. - E o que você acha da inclusão? Ou seja, o que você acha de uma criança com deficiência estudar junto com as outras numa escola comum, numa classe comum?

E. - Eu vou te falar uma coisa... assim, inclusão, em primeiro lugar, eu acho que... minha opinião era assim... Esses dias eu pensei comigo: eu acho que foi um louco que fez isso. Só que... um louco, porque pra não colocar pessoas preparadas pra receber as crianças... Porque, inclusive, aconteceu com Renan. O primeiro dia de aula dele, a professora dele não sabia nem que ele era deficiente visual. A diretora não teve a capacidade de passar isso pra ela, pelo menos. Então, ela se sentiu perdida. Ela queria que eu ficasse o dia inteiro na aula, entendeu? E eu não tiro a razão dela, porque quando eu fui também ter meu filho, quando eu descobri também, eu me senti perdida, eu não sabia como cuidar. Então ela teve medo de não ajudar, de não poder... sei lá, não conseguir ficar com ele, ele cair, sei lá! Ela não sabia como ajudar. A verdade foi essa.

Entrev. - Que idade ele tinha?

E. - Sete.

Entrev. - Ele entrou na escola com sete ou ele já tinha estado antes em escola?

E. - Não, com quatro anos ele foi pro prezinho, pra primeira fase, a segunda e a terceira fase. Ele saiu com sete anos de lá. Sim, daí... tá. Só que, daí, eu vi que não tava funcionando com Renan. Aí, eu chamei a psicopedagoga de um grupo de apoio que tem lá e falei assim: "Me explica uma coisa: o que é inclusão? Eu não entendi até agora, porque eu acho que quem fez isso foi um louco! Pôr pessoas despreparadas! Eu acho que não ia adiantar em nada”. Aí ela veio me contar a verdadeira história, né? Que as pessoas que eram deficientes eram menosprezadas, eram pessoas que não podiam aparecer, e que hoje a gente tem o livre arbítrio, né, pra incluir essas pessoas. Então, a gente tem que, pelo menos na sociedade, ter oportunidade. Então, agora, eu penso assim: tá certo essa pessoa que fez, que determinou a inclusão... que autorizou? Porque, a escola, é obrigada a receber a criança...!

Entrev. - E o que você acha disso?

E. - Eu acho errado. Eu acho errado pelo seguinte: porque eles tão sendo obrigados a receber aquela criança. Tá, até aí, tudo bem! Mas, pra eles receberem as crianças, eles precisavam de... não precisavam ser capacitados de alfabetizar, mas ter assim uma noção. 
Não existem os primeiros socorros? Então, ter uma noção de alguma coisa: como lidar, como cuidar. Porque, no prezinho mesmo, as professoras do L. (irmão mais novo também deficiente visual)... ou do Rê, já vieram aqui, entendeu? E elas se... tem uma professora lá, sabe, que ela é superinteressada. Se a diretora não deixasse ela vir, sabe o que ela fazia? Ligava pra supervisora e falava: “Olha, eu preciso ir”. A supervisora ligava pra diretora e ela autorizava a ir. Então, quer dizer: a professora tinha interesse.

... E eu tava lendo aqui nesse livro, né, que em Roma.. ah, eu não lembro a data, os deficientes eram jogados em esgotos... Você vêe!!! Mas, assim... e outra coisa também: eu acho que deveria estar passando isso também para os pais, sabe? Porque eu, na realidade, eu não sabia porquê inclusão. Eu não sabia mesmo. Se eu não tivesse conversado com essa psicopedagoga, até hoje eu não saberia.

Entrev. - Na Laramara você nunca acompanhou esse debate?

E. - ... não... É porque é assim como eu tô falando: minha vida... eu trabalho, né? Então, minha vinda aqui pro Laramara também é limitada. É como assim: eu venho na terça-feira, é o único dia que eu posso vir, entendeu? Então, na realidade, eu não participo muito daqui... Bem que eu gostaria, mas tem coisas que...

Entrev. - Retomando um pouco sobre o início de vida do Renan... Você disse que quando ele não respondia e ficava parado você batia nele e que depois você parou. O que passou a fazer?

E. - Observar mais ele, né? Como assim: eu precisei, como eu te falei, eu precisei do toque de alguém, porque... como assim: quando a gente tá com um problema, parece que o problema da gente é o maior do mundo. Às vezes, a gente precisa de alguém pra dar um toque. Aí, você... né? E eu precisei de alguém pra... Daí eu comecei a conversar mais com ele, entendeu? E ele percebeu isso. Então, foi daí que a gente começou a se entender.

Entrev. - Você sentiu mudança nele quando você começou a mudar?

E. - Sinto, senti. Aí eu comecei a cobrar também mais dele. No caso de perder o chinelinho: “Rê, vamos procurar o chinelinho?”, pegava a mãozinha dele, entendeu? Aí foi que eu comecei a me entender... E ele começou a responder. E aí ele já ficava mais calmo, né? Porque, junto com ele a gente tentava resolver, né?

Entrev. - E o que você sentia em ser mãe dessa criança? 
E. - Não sei, sabe... Parece que... parece que Deus me deu esse desafio... e eu não tinha resposta. Porque, assim... eu não tinha resposta pelo fato dele não me dar retorno nenhum. É a mesma coisa de você estar fazendo um trabalho e... não tá tendo resultado com aquele trabalho. Nunca! Então, chega um ponto que você se desespera e fala: "Espera aí, tô fazendo e não tô vendo resultado?! Tá inútil?”. Eu me sentia inútil, incapacitada.

Entrev. - E quando foi que isso mudou, que ele começou a te dar resposta?

E. - Posso falar mesmo... ?

Entrev. - Sim, claro!

E. - Até antes do L. nascer, eu... eu... quando engravidei do L. irmão), eu tinha esperança de que fosse normal. Aí, tá. O L. nasceu e foi uma fase muito difícil, porque Renan começou com ciúmes de mim. No dia que eu fui ter o L., ele... eu fui pro hospital, ele ficou com L. (pai). Então, eu acho que ele viu assim: como eu dormi fora e ele ficou com o L. (pai), como se fosse um abandono. No dia em que eu cheguei com L. (irmão), ele não queria ficar junto de $\operatorname{mim}$.

Entrev. - Ele tinha que idade?

E. - Três anos. Ele não queria ficar perto de mim, ele chorava. Se o pai dele tivesse assim... de repente falava: "Ah, eu vou ali”, ele queria ir junto. Ele nunca queria ficar comigo. Ele me rejeitou. Mas eu via assim, como... como se ele sentisse assim: que eu fui embora, entendeu? E abandonei ele com o pai...

Então... e daí eu fiquei grávida do L. e tal. Aí depois, tudo bem. Tive o L. Eu olhava pro L., mas eu não sei. Eu não via deficiência no L. Eu acho que a minha esperança era tão grande, que eu não via. O L. (pai) via... Teve uma vez que quase eu brigo com ele. Veio falar pra mim: “Ô, E., parece que o L. também não enxerga”. Ah, aquilo pra mim, eu queria morrer, eи queria matar ele.

Essa entrevista tá fazendo... como se eu estivesse revivendo tudo da minha vida, entendeu?

Entrev. - E como é reviver isso?

E. - Tudo bem... até me deu a idéia... de escrever um livro. Eu já tava querendo, né? E isso me deu mais uma idéia ainda. 
Entrev. - Então poderia falar mais um pouco sobre os nove meses de Renan quando você diz que não tinha percebido que ele era cego, mas o seu marido sim. Por que você acha que você não via a cegueira do Renan até os nove meses?

E. - Eu acho que eu não via porque eu nunca tive experiência, entendeu? Então eu era marinheira de primeira viagem, né? Eu não tinha experiência nenhuma com criança. Então, eи não... Ou eu não quis perceber... Não sei. Sei que eu não percebi.

Entrev. - Tudo era normal até os nove meses?

E. - É, era.

Entrev. - E o desenvolvimento dele? Nesse tempo ele era uma criança passiva ou ativa?

E. - Ah, ele era ativo.

Entrev. - Por que? O que ele fazia?

E. - Nossa! Ele se movimentava bastante! Eu lembro que ele gostava de pular. Pulava, pulava, pulava, sabe? E, assim, na minha opinião, ele era ativo.

Entrev. - E com as coisas, objetos, o que fazia?

E. - Pegava.

Entrev. - Como?

E. - Eu dava.

Entrev. - Que tipo de objetos?

E. - Assim, brinquedinho, assim: ursinho, aqueles brinquedinhos que apertam, assim... brincava, levava na boca, né? Ele ficava mordendo... E também, uma coisa também, que Renan... ele jogava muito. Sabe, a gente dava na mãozinha dele, ele brincava. Aí, geralmente ele jogava. Uma coisa, assim, que eu percebo em Renan, ele tem isso até hoje. Ele pega as coisas e joga... Eu já conversei com ele sobre isso e até hoje eu não consegui tirar isso dele. Ele... Por exemplo: ele vê isso aqui... Não sei se é maldade, não sei. Eu sei que ele "vê", ele pega isso aqui, né? Ele chega ali na janela e joga. E eu já conversei com ele bastante, eu falei que não pode jogar, que ele não sabe pra que que serve, que ele primeiro tem que me perguntar pra que que serve, se pode jogar, se não, entendeu?

Entrev. - Qualquer coisa? 
E. - Das coisas dele ele tem ciúmes, sabe? A bolsa dele ninguém toca. Às vezes eu vou pegar, ele: “Não! Não, mãe! Ela é minha!’. E pega da minha mão. Ele não quer saber que ninguém toque. Inclusive, coisa de comer, ontem na escola, ele pegou e levou uma bolacha recheada, né? Aí, diz que tinha um moleque que queria pegar a bolacha dele. Aí ele pegou e falou que não, que não, e daí começou a chorar. Aí a merendeira, que cuida dele super bem, aí chegou e me chamou, né, e me falou: "Olha, ali". O menino tava brincando, querendo tomar, e Renan começou a chorar. A orientadora chamou o menino e falou que aquilo não era brincadeira, né? Aí eu perguntei pra ele, ele também não quis me falar. Porque Renan é assim: pode acontecer o que for na escola, ele não é de comentar pra mim, entendeu? Então ele não comenta. Aí, se eu percebo alguma coisa, eu chego e falo pra ele, eu pergunto, até ele chegar e me falar. E, então, ontem eu perguntei. Aí ele falou: "É, o menino queria tomar, mãe, mas eu não deixei ele tomar, mãe!”. Aí, inclusive acho que de tanto L. (pai) ficar falando pra ele que ele não pode deixar as crianças maltratar ele, né, e tal, aí ele: "Mãe, fala pro pai que eu não deixei". Sabe... como se aquilo... "Fala pro pai que eu não deixei o meu colega tomar de mim! Viu, mãe?”. Eu falei: “Tá, filho”. Aí eu falei pro L. (pai) e Renan ficou todo feliz.

Entrev. - Ele ficou feliz poruqe você falou pro pai?!

E. - É. E eu percebo uma coisa, também, viu? Ele... assim: o L. (pai) fala muita besteira. Besteira assim, coisas que eu já li, sabe? e eu sei que não é o correto. Às vezes, Renan, como aconteceu esse dia na escola, que ele pegou, e... uma criança entrou no banheiro e riscou no bumbum dele. Então, eu tava trabalhando, L. foi dar banho nele e percebeu. Daí chegou e falou pra mim. Eu cheguei, chamei Renan e perguntei. Aí, pronto, L. já começou: "É, porque você é uma idiota", entendeu? "Porque você é um mocoronga". Então, palavras assim que machucam, entendeu? Então, daí, eu percebo que Renan fica muito triste, ele começa a chorar, e é o contrário. Ele tem que falar o contrário pra incentivar, né?

Entrev. - E sempre foi assim, E.?

E. - Sempre. E eu converso tanto com L., eu falo: “L., pelo amor de Deus! Não é assim! Você tem que falar o contrário, pra ele ser incentivado a fazer as coisas boas. Porque, quanto mais você falar coisas que deixam ele com uma baixa-estima, é pior, porque aí que ele vai dizer: 'Bom, eu sou um inútil, mesmo'!”. Porque ele fala, ele fala: "Mãe, eu sou um inútil, mesmo!’. Ai, o L., eu não entendo...

Entrev. - O pai fala isso? 
E. - Fala: "Renan, você é um inútil, Renan. O L. (irmão) não!". Ainda fica comparando, uma coisa que não pode, né? Eu aprendi isso, que não pode. Assim, porque eu leio muitos livros, sabe? Eu tento me informar de tudo o que eu posso. Então, ele pega e fica: “Ah, o L., o L., não, o L. não deixa ninguém mexer com ele! Você não, você é um inútil! Você...”, entendeu? Quando foi outro dia eu falei pra ele: “L., eu vou ter que conversar com um profissional sobre isso, porque não é correto o que você tá fazendo"... Não é correto. Às vezes, sabe... Agora, eu percebo que ele faz isso mais, sabe, quando ele bebe. Mas mesmo bebendo, com o L. ele não faz isso. É com o Renan. Acho que porque, assim, na verdade eu percebo que, acho que ele queria que Renan fosse mais ativo. Então, como Renan não é, sabe, aquela criança ativa, como ele iguala os dois, entendeu? Então, isso frustra ele. Então, ele fica nervoso e fica falando o que não deve. E é complicado.

Entrev. - Renan o frustra?

E. - Eu acho.

Entrev. - Por que?

E. - Ah, ele esperava um filho normal, jogador de futebol, porque ele adora jogo, L... Ele diz que aceita, mas eu percebo que não... Ele diz uma coisa e... e age de outra forma, entendeu? Então, assim, na verdade eu acho que isso influencia muito na educação deles... Porque, ele quando bebe, ele é uma outra pessoa. Eu já conversei tanto com L. pra parar com essa bebida, sabe? Pra gente, ao contrário, a gente poder se unir pra poder cuidar deles, porque eles precisam muito de nós, entendeu? Eu mesma, eu vinha ali pensando, agora, né? Tudo o que eu queria na minha vida, sabe, era não trabalhar fora, pra eu poder... Eu sei que eu iria ser muito útil para os meus filhos, sabe? Mas, a vida é assim, né?

Entrev. - Como é que Renan se comunicava com as pessoas?

E. - Ele rejeitava. Inclusive, o meu cunhado, né, gostava... Gostava não: gosta muito dele. Então, ele pegava o Renan... Nossa! Eu ficava tão nervosa, porque ele tava quietinho no meu colo e dali a pouco, meu cunhado vinha pegar ele, ele começava a chorar, sabe? E ficava angustiado, eu percebia isso. Aí eu falava: "Pô, o menino tá quieto! Por favor, deixa ele comigo”. Eu não gostava que ele pegasse o menino, o Renan, porque você via que Renan não gostava. Era rejeição mesmo. Eu acho assim: talvez, pelo fato de não ver...

Entrev. - Como é que ele pedia as coisas? 
E. - Ah, eu tinha que adivinhar... Assim, eu ia oferecendo as coisas, né, pra ver o que que era realmente... que ele queria.

Entrev. - Quais os objetos e as pessoas favoritas dele quando era bebê, depois, quando foi crescendo e até hoje?

E. - Acho que favorita era eu (rindo). E o objeto, assim, ele gostava muito de brincar com o tênis do pai. E eu queria tirar aquilo e não, sabe? Parece que ele tinha prazer de brincar com o tênis do pai, como falei antes.

Entrev. - E como foi que ele passou do peito para a mamadeira e para o alimento em pedaço? Ele aceitou essa passagem?

E. - Aceitou bem. Assim: ele mamou até os quatro meses e ele próprio decidiu não querer mais. Depois a comida eçe aceitou bem.

Entrev. - E explorar o ambiente: sair andando pela casa, subir nas coisas... como foi?

E. - Ele ficava sentadinho... É como eu falei: ele perdia as coisas, vamos supor, se ele estivesse com um objeto e ele perdesse, ele chorava, porque ele não sabia o que é que era...

Entrev. - Você consegue pensar desde quando ele mostrou ter noção de que ele era ele, você era você, o mundo era o mundo?

E. - Renan demorou.

Entrev. - Por que você diz isso?

E. - Porque ele era tão grudado em mim, sabe? Parece que só existia eu e ele.

Entrev. - Como assim?

E. - Ah, ele chorava muito. Por exemplo: se ele estivesse aqui e eu precisasse sair pra ir ao banheiro, ele chorava muito, ele não ficava com ninguém.

Entrev. - Até que idade?

E. - Até os três anos mais ou menos. Eu vinha aqui pro Laramara, ele chorava muito, não queria ficar com ninguém, era só no meu colo. Depois eu percebi que ele foi percebendo... Depois também do nascimento do L., daí ele foi percebendo também que ele teria que dar um espaço pro irmão.

Entrev. - Você acha que o nascimento do irmão mostrou que tinha um outro? 
E. - É. Daí foi que eu percebi que Renan, ele desenvolveu muito, muito, muito sabe?

Entrev. - O que que você acha que aconteceu?

E. - Bom, na verdade, é como eu digo: o L., pra mim, veio pra me mostrar que, apesar da deficiência, ele é capaz e me dar forças pra incentivar Renan, entendeu? Não foi por acaso. Não foi por acaso que ele veio. Eu acho que ele veio passar essa mensagem pra mim.

Entrev. - O Renan se chama de eu?

E. - Sim, mas não faz muito tempo... com sete anos. Antes ele se chamava pelo nome: Renan. Agora ele fala “eu quero, eи vou”...

Entrev. - Ele percebia quando alguém saía do ambiente ou quando ele tinha algum objeto que desaparecia, saía de perto? Porque, agora, ele percebe, né?

E. - É como eu te falo: eu acho que, perceber, ele percebia, mas só que ele não tinha iniciativa... de procurar como hoje ele faz. E quando ele não acha, ele pede ajuda: "Mãe, me ajuda a procurar tal coisa?". Aí eu vou lá e procuro. Ou pede pro L. (irmão). Antes ele chorava muito, muito, muito, sabe? E aquilo, como eu ficava muito nervosa, eu não sabia o que Renan queria, eu acabava batendo nele. Foi uma fase muito difícil... até uns quatro anos. Foi muito difícil, porque... Ah, eu tava perdida, sabe?

Entrev. - O L. nasceu quando o Renan tinha que idade?

E. - Três. É, dois anos e dez meses.

Entrev. - Quando ele fazia algum som, mostrando alguma coisa que ele queria, você dava um nome pra isso ou só pegava a coisa e dava pra ele?

E. - Eu não dava, não. Não falava o que era. Eu compreenda e dava.

Entrev. - Quando ele começou a falar?

E. - Ah, um ano e meio.

Entrev. - E como é que era essa fala dele?

E. - “Mamãe”, "papá”. Primeiro ele falou "papá”, “mamãe”... e... “água”. "Aga” ele falava. Até hoje a gente brinca, né? Ele fica... aí eu fico lembrando como que ele falava, ele cai na risada (rindo).

Entrev. - Hoje ele compreende os significados das palavras? 
E. - Compreende. E se ele não entende, ele chega pra mim e pergunta.

Entrev. - Como é a fala dele, hoje?

E. - Ah, fala super bem. Não fala errado. Se tiver um adulto ele quer consertar...

Entrev. - Ele falas as frases completas, com sentido?

E. - Fala. É como eu falei. Ele passou um ano... Ó, ele falava com a peadgoga aqui. De repente, ele se trancou, ele passou um ano sem falar... Pode perguntar. Passou um ano sem falar com ela, entendeu? Aí, de repente, ele começou a conversar bastante comigo, e tal. Falei, inclusive, que eu não vinha mais no Laramara. Por que eu viria, se a pedagoga não enxergava e precisava que ele falasse pra poder ajudar ele, que eu não podia ajudar sozinha, que precisava de profissional. Aí, foi indo, foi indo, a pedagoga também, do jeitinho dela... e depois ele começou a falar... mais ou menos de sete pra oito anos. Com outras pessoas ele conversava... com a professora da piscina também não. Com a gente em casa ele falava. Era assim...

Entrev. - Percebi que ele repete alguns assuntos com insistência, como a questão do elevador, por exemplo. Sempre que ele me encontra, ele pergunta do elevador.

E. - É, ele... interesse dele. Como trem, jogos de futebol... Nossa! Ele sabe estádio, ele sabe jogador de não sei das quantas (rindo), tudo ele sabe. E daí, ele... Não sei, acho que ele acaba perguntando pra se informar, assistindo televisão e o pai, ele pergunta, ele quer assistir jogos. Tem debate de bola, ele assiste, tudo. Ele é muito assim, por bola... É. Agora, é assim: eu percebo, também, que, pelo pai, o pai é vidrado no São Paulo, um time de futebol, e ele também. Se alguém fala pra ele que ele é de outro time, ele chora. Ele não gosta...

Entrev. - Tem que ser o do pai?

E. $-\dot{E}$

Entrev. - Ele tem noção de tempo: ontem, hoje, amanhã, semana que vem, hoje é segunda, amanhã é terça?

E. - Hum, hum. Inclusive, até horas. Eu falo: “Rê, que horas aí?”. Ele diz. Não sei como ele sabe. Até hoje, eu não percebi.

Entrev. - Ele compreende porque algo aconteceu? Se ele provoca um acontecimento, ele sabe que foi ele que provocou aquilo? 
E. - Compreende.

Entrev. - Ele sabe a diferença e a semelhança entre as coisas?

E. - Sabe.

Entrev. - Sabe pra que que servem os objetos? Sabe que uma coisa é fruta, outra é brinquedo, a outra é... móveis?

E. - Sabe.

Entrev. - O que ele faz sozinho?

E. - Olha, ele vai no banheiro sozinho, ele toma banho sozinho, veste a roupa sozinho...

Come sozinho...

Entrev. - Ele conhece bem a rotina dele? Ele tem uma rotina: acorda, faz isso, depois faz aquilo...

E. - ... tem...

Entrev. - Ele se organiza?

E. - Hum, hum.

Entrev. - Ele conhece as partes do corpo dele?

E. - Conhece.

Entrev. - Como é que ele expressa a agressividade?

E. - Olha, quando eu reclamo com ele de alguma coisa, eu falo: "Não pode!", sabe? Ele bate no L., eu falo: "Não pode", ele sai correndo. Meu quintal é bem grandão, assim, sabe? É o jeito dele: ele sai correndo...

Entrev. - E ele bate no L. em que situação?

E. - Ah, se o L. fica mexendo com ele. Assim, vamos supor, fica: "Rê, você não vai pra tal lugar”, "Rê, você...”, aí ele fica nervoso, aí ele... vai bater... Provocou, ele vai lá, bate, briga com o irmão.

Entrev. - Como é o contato dele com o próprio corpo? 
E. - (pausa) Assim... como ele usa? Ai... Antes ele ficava balançando..., mas eu comecei a conversar com ele bastante, ficava pegando no pé. A única coisa que até hoje eu não consegui é a mão no olho. Agora, balanço ele tinha... ele ficava balançando... até uns dois anos atrás. Hoje, assim, às vezes, eu percebo que ele tá nervoso, ele fica assistindo o jogo, aí eu percebo que ele fica andando na casa, pra lá e pra cá. Aí: "Renan, senta pra você assistir. Não precisa você ficar assim”. Aí ele vai e senta.

Entrev. - Ele brinca de faz-de-conta?

E. - Brinca. Agora eles inventaram de brincar de basquete. Ele é um jogador de basquete. Ou, senão... é assim tipo uma narração, eles fazem. Eu fico lá percebendo. Tem o Rogério Ceni, né, o goleiro do São Paulo, e daí o L. joga a bola, e ele... Eles mesmos ficam narrando.

Entrev. - Atualmente, a relação dele com os adultos e as crianças é boa?

E. - É boa. Antes ele rejeitava. Agora ele aceita mais os adultos... ele aceita mais. Só que é assim: até hoje eu não sei... eu acho que eu já falei sobre isso, que eu percebo em Renan, assim... tipo assim: parece que... ele acha que tá brincando, mas na verdade ele tá machucando.

Entrev. - E com as crianças na escola, por exemplo, ele interage?

E. - ... interage... Na escola, na realidade, eu nunca fui, nunca passei um dia na escola. Eu não sei te falar... como é, porque eu sempre pergunto pra professora... mas quando você... ela nunca sabe.

Entrev. - E quando você o vê com outras crianças?

E. - Então, isso, eu observo assim, vamos supor: ele pega, agarra, assim, sabe? Eu acho que, na realidade, tá machucando, mas ele acha que tá brincando.

Entrev. - E as crianças reagem como?

E. - “Pára, Rê! Pára, Rê!”. Aí, eu: “Renan, pára!”. Aí ele pára.

Entrev. - Ele imita o que as pessoas fazem?

E. - Não. Assim, eu percebo que o L. (irmão) monta bicicleta muito bem. Então, o pai dele: “Ah, Rê, vai, monta como o L.”, e tal. Então eu percebo também que ele monta na bicicleta: “Tá vendo, mãe! Tá vendo!”, sabe, mostrando, também.

Entrev. - Ele mostra pra você ou mostra pro pai? 
E. - também mostra pro pai.

Entrev. - Ele sempre tem que ser igual ao irmão?

E. - É. Eu acho que... o pai dele passa alguma coisa que... entendeu? Talvez nem seja igual. Sei lá, acho que pra ele, um pouquinho já é o suficiente.

Entrev. - Pra quem?

E. - Pro Renan. Assim, de alguma ação. Vamos supor: ele monta a bicicleta. Dá pra ver que o pouco que ele monte, não precisa ele fazer o que o L. faz. Um pouco que ele monte, ele acha que já é o suficiente.

Entrev. - Pro pai, é suficiente?

E. - Eu percebo que não.

Entrev. - E pra você?

E. - Pra mim? Ah, eu queria mais, né? Mas, eu percebo que ele... não... não sei. Eu queria mais. Ele tem capacidade de ser melhor, mas eu percebo que ele não... Eu tenho que incentivar: "Rê, você pode ser melhor! Faz isto! Presta atenção!", converso, entendeu? Mas eи percebo que ele não...

Entrev. - Como é que ele mostra os sentimentos?

E. - Mostra quando gosta, quando não gosta, ou ta triste, alegre...

Entrev. - Ele fala disso?

E. - Fala. E eu, também, nossa, ele percebe logo na minha voz quando eu tô triste. Ele fala: "Mãe, porque você tá triste?”. "Rêe, eu não tô triste”. "Tá, mãe, eu percebi que você tá”.

Entrev. - Ele aceita os afetos das pessoas?

E. - Aceita.

Entrev. - Como ele reage ao limite e à frustração, se ele quer alguma coisa que não tem, que não vai dar?

E. - Renan é... Se ele falar: "Mãe, eu quero isso", e eu falo: "Samuel, eu não tenho, a mamãe não tem dinheiro", eu explico pra ele, numa boa ele aceita.

Entrev. - Quais são os pontos fortes dele e quais as dificuldades? 
E. - Como assim? Ah, o que eu percebi nele, mesmo, assim, é... gravar. Sabe, ele grava coisas... É... a memória... Matemática. Engraçado, eu nunca ensinei matemática e Renanl sabe matemática. E a dificuldade? Iniciativa. Às vezes, a gente tem que ficar incentivando: "Vai, Rê, vai, vai, vai”. Aí, ele vai (rindo).

Entrev. - Como é que o Renan é visto na família? Como as pessoas o vêem?

E. - Ah, é difícil falar... Ah, de início... assim, de início, as pessoas ficam com dó. A gente percebe assim, sabe... Mas, depois, ele começa a falar de jogo e as pessoas vêem a inteligência dele, entendeu? Então, as pessoas tiram outra conclusão.

Entrev. - A família de vocês segue alguma religião, tradição...?

E. - Eu sou católica, só que eu não sou de estar direto em igreja. Eu, sabe, eu prefiro ficar na minha casa, fazendo o meu serviço. E... festas, assim, o Natal, o Ano Novo, sabe, a gente comemora... aniversário de primo...

Entrev. - Vocês contam história da família para os filhos?

E. - Conta. Nossa! E ele quer saber tudo: “Mãe, como você era assim...”.Inclusive, minha mãe tá aí, né, e ele fica perguntando pra minha mãe. Ele quer saber de mim (rindo). "Vó, como que minha mãe falava tal coisa?"

Entrev. - Você conta dele, também, quando ele era pequeno. Você fala: "Ah, quando você era pequenininho, quando você era nenê...”?

E. - Nossa, é o que eu mais falo! E como ele falava, né? Como ele falava, o L. Aí a gente começa tudo a dar risada (rindo)... de como eles falavam...

Entrev. - Bom, E., eu agradeço muito sua participação...

E. - Foi bom... 


\section{ANEXO 3 - GLOSSÁRIO DE TERMOS PSICANALÍTICOS}

GUIRADO, M. Psicanálise e Análise do Discurso: matrizes institucionais do sujeito psíquico. São Paulo: Summus Editorial, 1995.

Discurso: “... discurso enquanto lugar e cena... cena enunciativa... instâncias de enunciação em termos de lugares, visando enfatizar a preeminência e preexistência da topografia social sobre os falantes que aí vêm se inscrever. Um conceito de lugar cuja especificidade repousa sobre esse traço essencial segundo o qual cada um alcança sua identidade a partir e no interior de um sistema de lugares que o ultrapassa... e, segundo Foucault (in: Guirado, 1995, p. 27), trata-se de determinar "qual é a posição que pode e deve ocupar cada indivíduo para dela ser o sujeito” “... lugares sociais que só podem existir através de uma rede de lugares discursivos...” a cena "não é uma máscara do 'real', mas uma de suas formas, estando este real investido pelo discurso...” (p.28). E quando alguém fala, a possibilidade da “identificação de angústias, sintomas, defesas, palavras vazias, desejo imaginário, lembranças possivelmente encobridoras, condensações, deslocamentos e transferências" (p.12). O discurso “... não é uma teoria do sujeito antes que se enuncie, mas uma teoria da instância de enunciação...” (p.28). Distanciando-se de Foucault agora: “... a significação como operador analítico...” (da análise de discurso)... “... é isso que abre as portas para as fronteiras com a Psicanálise” (p.48). “... texto, conversação diária, múltiplos sentidos, enunciado e enunciação, ambigüidade, polissemia...” (p.49). O caráter de “... heterogeneidade mostrada do discurso funda-se na suposição de várias 'vozes' possíveis (polifonia) numa mesma fala, sinaliza as condições de sua ocorrência e, com isto, radicaliza a relação dentro/fora do discurso. É nele mesmo que dois sentidos se anunciam” (p.50). As várias vozes indicam os lugares, as posições ocupadas pelos sujeitos.

Pensar o discurso em análise é pensá-lo “como uma montagem legitimamente instituída, onde lugares reconhecidos e desconhecidos produzem seus efeitos" (p. 106).

Enunciado: $o$ dito...

Enunciação: $o$ não 'dito', o dizer... “... a a mesmo tempo e intrinsecamente, um efeito de enunciado “... não é uma cena ilusória onde seriam ditos conteúdos elaborados em outro lugar, mas um dispositivo constitutivo da construção do sentido e dos sujeitos que aí se reconhecem” (p.29). “... um discurso que vai além, e em direção diferente, ao conteúdo do 
enunciado... a posição em que o sujeito é colocado pelo seu discurso revela mais do que o conteúdo daquilo que diz sobre si mesmo” (Vallejo, 1979, apud Guirado, 1995, p. 72)

Sujeito psíquico da Psicanálise: “... é o sujeito do e no discurso... um sujeito singular... de representações e afetos, nas malhas ou nas redes das relações que se instituem concretamente...” (p. 18) “... que se reconhece a partir de seu lugar na ordem discursiva...” (p.30) “... supostamente dividido entre a consciência e o inconsciente... um sujeito psíquico, afetivo-emocional...” (p.51). “... o sujeito do inconsciente, da sexualidade, do sentido e do desejo. Traduzido no discurso enquanto representações...” (p.68) “... sujeito-efeito de relações sociais...” (p. 128).

“... configuração de um sujeito/subjetividade, assim efeito, por hipótese, estende-se aos processos de educação ou práticas de criação infantil, aos vínculos familiares, instituiçãomatriz da sexualidade, do desejo e, porque não dizer do sentido” (82). “...sede das instituições e rachaduras do discurso que vai além dele...” (p.97)

Inconsciente: “... o modo de operar esse inconsciente... é na história pessoal (mais ou menos remota, mais ou menos atual e, sempre na suposição de transferências) que se buscam motivos e sentidos que se 'esqueceram' (por efeito de repressão/recalque) e que se devem desesquecer... história pessoal... como a história dos sentidos construídos pelas pessoas nas relações que constituem vida adentro” (p.68). O inconsciente também se constrói no discurso. Para Lacan, é estruturado como linguagem.

Desejo: “... nos diferentes caminhos dos sentidos, das significações, das fantasias se deixaria surpreender pela análise, nas armadilhas da Associação Livre” (p.68). É inconsciente.

Escuta/Leitura: ... marcada pela “...constante atenção às ambigüidades da palavra e ao lugar em que se pões o sujeito do discurso, bem como o lugar que, então, atribui ao outro, interlocutor imaginário ou simbólico de sua fala...” (p.14) “... a atenção aos equívocos da fala, ao emprego especial de algumas delas, ao seu lugar na ordem da fala, à recorrência de termos a certas adjetivações, à seqüência de falas... à significação geral do arranjo discursivo, à entrada do discurso indireto livre, das ironias...” (p. 94) “... necessário ir além do sujeito e do conteúdo do enunciado” (p.51). “... atenção voltada para o como estes que falam se posicionam nas cenas que descrevem: que lugares ocupam, que expectativas desenvolvem, que inevitabilidade reconhecem para suas ações relatadas... o que importa é que assim se vejam: sujeitos em seus atos"(p. 87).

Análise: “...perspectiva dos recortes que ela permite, as "amarrações” ou as reconstruções a que se chega, que acabam falando ao mesmo tempo dos autores das cenas enunciativas e das condições de enunciação...” (p. 89). 
“... rastrear o lugar que se vê ocupando aquele que nos fala, ainda que disto não fale, traça ao mesmo tempo o mapa desse discurso e as auto-representações. Na estrutura discursiva, portanto, o desenho dos afetos" (p.94). Análise da subjetividade que se constitui... marcada pelas reconstruções e movimentos do indivíduo em torno de suas fantasias, de desejo imaginário ou simbólico, romances familiares e tragédias” (p.93).

Interpretação: “... identificar na fala... resistência, fantasia inconsciente... naturaliza-se uma invenção; uma tentativa para explicar 'mistérios do humano’ (p.118).

“Tornar a inventar efeitos de significado...” (Miller, 1995, p.7).

Transferência: “... a reedição, numa relação atual, de protótipos de relações infantis... articulada a outros termos como inconsciente, desejo, sexualidade, interpretação” (p. 117).

MRECH, L. M. Psicanálise e Educação: novos operadores de leitura. São Paulo: Pioneira, 1999.

Sujeito - "Para Lacan, a noção de sujeito remete sempre ao sujeito do inconsciente, ao sujeito cindido, e não a indivíduo ou a uma pessoa completa e total. Com isso Lacan revela que o sujeito não tem plena consciência dos seus atos (...) o sujeito é o falasser, o sujeito é cindido... ente consciente e inconsciente” (p.139).

Gozo - "Modalidade de funcionamento do sujeito. O gozo no sentido lacaniano não é gozo do prazer que se obtém através do orgasmo (sentido tradicional da cultura). É o gozo obtido através da linguagem e da palavra. O gozo é uma outra satisfação... obtida através do inconsciente... da linguagem e da fala, frente a algo onde o sujeito não deveria estar sentindo prazer. É por isso que Lacan fala de uma outra satisfação... que não serve para nada, mas que mantém o sujeito atado às suas cadeias. Onde o sujeito goza, goza, sem parar. Um prazer inconsciente que emerge na manutenção da inércia. Um prazer inconsciente que se encontra vinculado à libido fixada, fazendo com que o sujeito repita sempre os mesmos contextos, as coisas da mesma forma. Ou que queira sempre mais e acabe obtendo o pior. O gozo enquanto libido fixada está ligado à pulsão de morte” (p.132).

Desejo de Saber - "Para Lacan, o desejo de saber só é alcançado plenamente através da análise. Não se trata apenas de um querer saber ou ter vontade de saber. Mas do desejo de saber se tecer a partir do sujeito superar o seu próprio horror de saber, que atua paralizando-o, fazendo com que ele não queira saber algo que realmente necessite saber. $O$ desejo de saber se estrutura através da ultrapassagem daquilo que nós temos medo de saber, 
mas que precisamos saber. Para o sujeito, é ir em busca da sua verdade, doa o que doer" (p.130).

Fantasmática - O conceito de fantasma é fundamental para desvelar a realidade psíquica da criança e dos pais, pois possibilita uma aproximação do modo como se constituíram, dos sentidos que foram atribuídos às suas ações, o que foi visto, vivido e ouvido nas relações.

Real - Para Lacan o registro do real é distinto da realidade material, concreta, diz respeito ao real do inconsciente, o qual não é passível de apreensão direta, mas somente por meio do simbólico.

KAUFMANN, P. Dicionário enciclopédico de psicanálise: o legado de Freud e Lacan. Rio de Janeiro: Jorge Zahar Editor, 1996.

Símbolo - Para Lacan o símbolo é compreendido como significante (p. 476).

Significante e Significado - Na lingüística de Saussure "o significante é a representação psíquica do som tal como nossos sentidos o percebem, ao passo que o significado é o conceito a que ele corresponde." Lacan subverteu essa relação significante/significado afirmando a supremacia do significante sobre o significado. Assim, "o significado do significante não é um conceito delimitável no interior do campo lingüístico propriamente dito, ele é o desejo. Lacan, nos Escritos, refere que 'o significante vai consistir na estrutura sincrônica do material da linguagem' e o significado vai regêe-lo 'historicamente'. Um significante remete sempre a outro significante, formando a cadeia de significantes que se desdobra no tempo e engendra o sujeito. Lacan postulou que 'o significante representa o sujeito para outro significante' e "será num outro tempo que poderemos ter acesso ao significado" ( p. 472;473).

Sentido - é o que é dado na interpretação que o Outro faz da demanda da criança. Quando esta demanda algo de sua necessidade, o Outro lê, interpreta, dá sentido e lhe devolve seus próprios significantes. $O$ que o sujeito demanda assume sentido para o Outro. O sujeito estará ligado ao desejo do Outro. Além da satisfação da necessidade, põe o sujeito em posição de desejar. A necessidade entra na rede simbólica de comunicação por meio do imaginário e este dá consistência ao sentido. A emergência do sentido se realiza como nomeação e é o imaginário que tem essa função. A particularidade do sentido é colocar "o que isso quer dizer dizendo isso?” Pela interpretação que o Outro faz da necessidade da 
criança é que esta entra no campo do desejo que se inscreve entre a necessidade e a demanda (p. 464).

Fantasma - "um roteiro imaginário em que o sujeito está presente e que figura, de maneira mais ou menos deformada pelos processos defensivos, a realização de um desejo inconsciente. O fantasma se constitui a partir das coisas vistas e ouvidas” (p. 196).

LAPLANChe, J. e PONTAlis, J.B. Vocabulário da Psicanálise. São Paulo: Martins Fontes Editora, 1985.

Simbólico - um dos registros do aparelho psíquico, é usado por Lacan em duas direções diferentes e complementares: a) para designar uma estrutura cujos elementos discretos funcionam como significantes ou, de um modo mais geral, o registro a que pertencem tais estruturas (a ordem simbólica); b) para designar a lei que fundamenta esta ordem: assim Lacan, pela expressão pai simbólico ou Nome-do-Pai, tem em vista uma instância que não é redutivel às metamorfoses do pai real ou imaginário que promulga a lei (...) o significante lingüístico tomado isoladamente não possui qualquer ligação interna com o significado; não remete para uma significação senão por estar integrado num sistema significante caracterizado por oposições diferenciais” (p. 624-625).

Objeto - "A noção de objeto é encarada em psicanálise sob três aspectos principais: A) Enquanto correlativo à pulsão, ele é aquilo em que e por que esta procura atingir o seu alvo, isto é, um certo tipo de satisfação. Pode tratar-se de uma pessoa ou de um objeto parcial, de um objeto real ou de um objeto fantasmático. B) Enquanto correlativo do amor(ou do ódio), a relação em causa é então a da pessoa total, ou da instância do ego, com um objeto visado também como totalidade (pessoa, entidade, ideal etc.). C) No sentido tradicional da filosofia e da psicologia do conhecimento, enquanto correlativo do sujeito que percebe e conhece, é aquilo que se oferece com características fixas e pensamentos, reconhecíveis de direito pela universalidade dos sujeitos independentemente dos desejos e das opiniões dos indivíduos” ) p. 407).

Relações objetais - As relações objetais consistem no modo de relação do sujeito com o mundo de pessoas e coisas, resultado complexo da organização psíquica e da apreensão fantasmática do mundo.

Falo - "Lacan tentou recentrar a teoria psicanalítica em torno do da noção de falo como 'significante do desejo'. O complexo de Édipo, tal como por ele é reformulado, consiste numa 
dialética cujas principais alternativas são: ser ou não ser o falo, tê-lo ou não o ter - e cujos três tempos se centram no lugar ocupado pelo falo no desejo dos três protagonistas” (p. 227). 
ANEXO 4 -

\section{CARTA DE INFORMAÇÃO AO RESPONSÁVEL PELO SUJEITO DA PESQUISA}

O presente estudo se propõe a analisar crianças cegas congênitas com outros comprometimentos em seu desenvolvimento entre as idades de cinco a nove anos. Os dados para estudo serão coletados através de uma entrevista com a mãe da criança, contendo perguntas abertas e observação da criança nas atividades das quais participa na instituição especializada que freqüenta. A entrevista e as observações serão realizadas pela pesquisadora responsável. Esse material será gravado em fita cassete e em vídeo e posteriormente analisado. Será garantido o sigilo absoluto sobre as questões respondidas, sendo resguardado o nome dos sujeitos da pesquisa. A divulgação dos resultados terá finalidade acadêmica, esperando contribuir para um maior conhecimento do tema estudado.

Aos participantes cabe o direito de retirar-se do estudo em qualquer momento, sem prejuízo algum.

Os dados coletados serão utilizados na Tese de Doutorado da psicóloga Eliana Maria Ormelezi, vinculada ao Programa de Doutorado em Psicologia e Educação da Faculdade de Educação da Universidade de São Paulo.

Eliana Maria Ormelezi

Pesquisadora responsável
Profa. Dra. Elcie F. Salzano Masini

Orientadora

\section{TERMO DE CONSENTIMENTO LIVRE E ESCLARECIDO}

Pelo presente instrumento, que atende às exigências legais, o (a) senhor (a) responsável pelo sujeito da pesquisa, após leitura da CARTA DE INFORMAÇÃO AO SUJEITO DA PESQUISA, ciente dos procedimentos aos quais será submetido, não restando quaisquer dúvidas a respeito do lido e do explicado, firma seu CONSENTIMENTO LIVRE E ESCLARECIDO de concordância em participar da pesquisa proposta.

Fica claro que o sujeito da pesquisa pode, a qualquer momento, retirar se CONSENTIMENTO LIVRE E ESCLARECIDO e deixar de participar da pesquisa e fica ciente que todo trabalho realizado torna-se informação confidencial, guardada por força do sigilo profissional e só terá finalidade acadêmica de produção de conhecimento científico. 


\section{ANEXO 5 - PARECER DA PROFA. DRA. MERCÈ LEONHARDT DA ONCE (ORGANIZAÇÃO NACIONAL DOS CEGOS ESPANHÓIS - MADRID / ESPANHA)}

\section{----- Original Message -----}

From: "Ferran" < sanleon@ pangea.org>

To: "eormelezi" <eormelezi@uol.com.br>

Sent: Sunday, November 14, 2004 6:35 PM

Subject: Re: Brasil/Laramara

Estimada Eliana,

Me alegra tener noticias tuyas $y$ saber de tu tesis. Me parece sumamente interesante. De hecho no hay libros sobre ceguera y formación del yo. Quizás podrías encontrar elementos de reflexión en el libro de Selma Fraiberg, "Niños ciegos" y en el mío del "El bebé ciego", pero pensando que son elementos que ayudan a pensar en cómo se construye el "yo". Otros libros que sin ser sobre niños ciegos dan elementos para poder pensar, son "El mundo interpersonal del Infante" de D. Stern y el de Leon Grinberg y Rebeca Grinberg, "Identidad y Cambio" de Paidos. Siento no poder informarte sobre bibliografía más concreta, pero ya sabes que en nuestro campo hay todavía muchos aspectos por estudiar. Quedo a tu disposición en todo aquello que yo pueda facilitarte. Un fuerte abrazo

Mercè Leonhardt 